UNIVERSIDADE DE SÃO PAULO

FACULDADE DE ECONOMIA, ADMINISTRAÇÃO E CONTABILIDADE DEPARTAMENTO DE ADMINISTRAÇÃO PROGRAMA DE PÓS-GRADUAÇÃO EM ADMINISTRAÇÃo

\title{
INVESTIGAÇÃO DO IMPACTO DA PROPRIEDADE FAMILIAR EM EVENTOS DE AQUISIÇÕES NO BRASIL
}

Pedro Issao Takenouchi Orientador: Prof. Dr. Eduardo Kazuo Kayo 
Prof. Dr. João Grandino Rodas Reitor da Universidade de São Paulo

Prof. Dr. Reinaldo Guerreiro

Diretor da Faculdade de Economia, Administração e Contabilidade

Prof. Dr. Adalberto Américo Fischmann

Chefe do Departamento de Administração

Prof. Dr. Lindolfo Galvão de Albuquerque

Coordenador do Programa de Pós-Graduação em Administração 


\section{INVESTIGAÇÃO DO IMPACTO DA PROPRIEDADE FAMILIAR EM EVENTOS DE AQUISIÇÕES NO BRASIL}

Dissertação apresentada ao Departamento de Administração da Faculdade de Economia, Administração e Contabilidade da Universidade de São Paulo, como requisito para obtenção do título de Mestre em Administração de Empresas.

Orientador: Prof. Dr. Eduardo Kazuo Kayo

Versão Corrigida

(Versão original disponível na Faculdade de Economia, Administração e Contabilidade)

SÃO PAULO 
FICHA CATALOGRÁFICA

Elaborada pela Seção de Processamento Técnico do SBD/FEA/USP

Takenouchi, Pedro Issao

Investigação do impacto da propriedade familiar em eventos de aquisições no Brasil / Pedro Issao Takenouchi. -- São Paulo, 2013. 249 p.

Dissertação (Mestrado) - Universidade de São Paulo, 2013. Orientador: Eduardo Kazuo Kayo.

1. Empresas familiares 2. Fusão e aquisição de empresas 3. EmpresasAquisição.

I. Universidade de São Paulo. Faculdade de Economia, Administração e Contabilidade. II. Título.

CDD -658.041 
A Deus;

Aos meus pais (Masaaki e Inês) e irmãos (Marcos Masashi e Evandro Kendi);

À minha namorada, Denise; Aos meus familiares e antepassados; Aos amigos. 


\section{AGRADECIMENTOS}

Agradeço a Deus pela finalização desta Dissertação, por cada dia na Terra, e por colocar em minha vida cada um dos familiares e amigos que fiz.

Dedico todo meu trabalho e agradeço incondicionalmente aos meus pais e aos meus irmãos. Não tenho palavras para agradecer por tudo, a cada um de vocês. Pai e Mãe, este, e todos os outros trabalhos que puder vir a fazer em vida, dedico a vocês! Fico contente em ainda poder lhes agradecer pessoalmente a cada dia!

Agradeço à minha namorada, Denise, pela força e apoio dado.

Agradeço aos meus familiares e antepassados, em especial, minha madrinha Adélia, padrinho Alekisho, e aos meus avós in memoriam.

Agradeço ao Prof. Dr. Eduardo Kazuo Kayo, meu orientador, pela paciência, compreensão, oportunidade de aprendizado, sugestão do foco do tema de pesquisa, e por seus ensinamentos e críticas, sem os quais, não seria possível o desenvolvimento deste trabalho.

Agradeço, também, com grande respeito, ao eterno, orientador e professor, Prof. Dr. Rubens Famá, com quem pude aprender muito ao longo destes anos.

Agradeço à estimada Prof ${ }^{\mathrm{a}}$. Dr ${ }^{\mathrm{a}}$. Rosana Tavares, pelo grande apoio e pelas orientações que, sobretudo, deram-me bases e força para concluir este trabalho. Sou e sempre serei-lhe muito grato, pelos ensinamentos e pela motivação/apoio a mim transmitidos.

Agradeço, com grande apreço, admiração e respeito, ao Prof. Dr. Abraham Yu, pela oportunidade de aprendizado e ensinamentos através de sua disciplina, monitoria e pelo excelente grupo de pesquisa - Núcleo Decide.

Agradeço ao Prof. Dr. Roy Martelanc, pelos ensinamentos e incentivos dados.

Agradeço ao Prof. Dr. José Roberto Securato, também pelos ensinamentos e incentivos dados. Agradeço à Prof ${ }^{\mathrm{a}}$. Dr ${ }^{\mathrm{a}}$. Alessandra de Avila Montini, pelos ensinamentos transmitidos em suas aulas.

Agradeço à Prof ${ }^{\mathrm{a}}$. Dr ${ }^{\mathrm{a}}$. Bernadete de Lourdes Marinho, pelos ensinamentos e, sobretudo, pela motivação sempre dada e transmitida.

Agradeço ao Prof. Dr. Antonio Carlos Aidar Sauaia pela oportunidade de aprendizado dado pelo grupo de pesquisa SIMULAB - Laboratório de Gestão.

Agradeço ao amigo, e sempre professor, Dr. Pedro Lucas de Resende Melo, pela valorosa amizade, e incentivos sempre dados.

Aos amigos Denis Yuque e Leandro Doi, amigos e irmãos de consideração, obrigado pela amizade. 
Agradeço aos amigos que fiz durante o mestrado, e espero que o nosso contato seja mantido. Agradeço pela amizade, aos amigos: Tania Amaral, Milton Sanches, Luis Pérez Espinola, Bastos, Bruna Losada Pereira, Igor Bária, Cecília Galante, Cristina Lau Chu, ao professor Willy Hoppe, Nelson Yoshida, Alcides Carlos de Araújo, Sandra Petho, Maria Isabel, Edison Simoni da Silva, Clovis Galdino, Bruno Cals de Oliveira, Douglas de Almeida Ribeiro, e a todos os amigos do grupo de pesquisa Núcleo Decide.

A todos os amigos que fiz nas disciplinas, onde pude conhecer pessoas de outras áreas, como em estatística e metodologia de pesquisa. Aos amigos, em especial, Mariana Sutter, Lívia Tiemi Bastos, Leandro Pongeluppe, Bassiro Só, Silvye, Marina Begalli, Fernanda Figueiredo, Simone Barakat, Alessandra Quishida, Ivan Ferraz, Anderson de Almeida, Leonel Ferreira, Keysa Manuela, Elaine Mandotti, Tomé Bambo e Andrea Rodrigues Vasconcelos. Minhas sinceras desculpas se esqueci de alguém, mas vamos marcar o $\mathrm{HH}$, Mariana!

Agradeço ao excelente corpo de colaboradores da Biblioteca da FEA USP, Secretaria de PósGraduação (tanto no corredor C, como no FEA5 - segundo andar).

Agradeço à Fernanda Lopes Bornia, Heloisa Lopes Bornia, Rita de Cássia Giorno, Aparecida Costa Rodrigues, Elaine Lopes Gadelha da Symposion, e à Adriana Bauer e José Roberto Jared da JRJ Informática, pelo profissionalismo e serviços prestados em revisões ortográfica, ABNT e impressões das versões original e corrigida desta dissertação. 


\section{RESUMO}

Este trabalho investiga os impactos provenientes da propriedade familiar em eventos de aquisições. Foram analisados 355 anúncios concluídos de eventos de aquisições, realizados por 122 empresas públicas no período de 2009 a 2013. Os dados foram obtidos do banco de dados da Thomson Reuters SDC Platinum e também da Thomson Reuters Eikon. Foi utilizada a metodologia de estudos de eventos (MacKinlay, 1997; McWilliams \& Siegel 1997), para aferir os retornos anormais em aquisições de empresas familiares e não familiares. Para analisar os dados obtidos, foram empregadas análises univariadas, bivariadas e regressões multivariadas reportadas com erros-padrão robustos por Hubber-White Sandwich, e técnica não paramétrica estatística de resampling Bootstrap. Foram empregados, ainda, testes de robustez para a variável explicativa, grau de concentração acionária e de benchmark de retorno de mercado. Outrossim, foram adotadas variáveis específicas de empresas familiares, para melhor mensurar o impacto da propriedade familiar sobre os retornos anormais analisados. Como principais achados da dissertação, foram encontrados evidências de que empresas familiares geram valor em aquisições. Encontrou-se, também, que não há evidências de que empresas familiares tenham maiores retornos anormais positivos que empresas não familiares. Reporta-se, ainda, que o retorno anormal está relacionado positivamente à empresa familiar cujo gestor é membro da família controladora. Por outro lado, não se encontraram evidências de que os retornos anormais em aquisições de empresas estejam relacionados positivamente às empresas de primeira e segunda gerações familiares. Por fim, relata-se que não há evidências de que haja relação positiva entre o grau de concentração acionária detida pela família controladora e retornos anormais em aquisições.

Palavras-chave: Empresas Familiares; Fusão e Aquisição de Empresas. 


\section{ABSTRACT \\ INVESTIGATION OF THE IMPACT OF FAMILY OWNERSHIP ON EVENTS OF MERGERS AND ACQUISITIONS IN BRAZIL}

This study investigates the impact of family ownership on acquisitions of enterprises. On this purpose, we analyzed 355 acquisitions made by 122 public firms during the sample period 2009 to 2013. The data on acquisitions of enterprises were obtained from Thomson Reuters SDC Platinum and Thomson Reuters Eikon database. This study employs the Methodology of Event Study (MacKinlay, 1997; McWilliams \& Siegel 1997) in order to obtain the performance on acquisitions measured by the abnormal return. Furthermore, were employed univariate, bivariate statistical analysis and multivariate regression analysis. Those regressions were reported with robust standard errors by Hubber-White Sandwich. Additionally, as a robustness test, this study reported the non parametric robust statistical test; yclept, Bootstrap. Besides, were applied further robust techniques, due to better measure the impact of the variable family firms on the dependent variable abnormal return. Our findings suggest that there is evidence that family firms generate value on acquisitions of enterprises. Moreover, this study founded that there is no evidence that family firms have higher abnormal returns than non-family firms. This research, withal, sheds lights on the fact that abnormal return it is positively related to family firms which has a family member as a director, vice president or CEO of the company. On the other hand, it is founded on this research that there is no evidence that abnormal returns are associated to the first and second generations. Ultimately, it is reported that there is no evidence that exists positive relation among the variable power concentration (stake owned by the controlling family) and abnormal returns on acquisitions of enterprises.

Keywords: Family Firms; Mergers and Acquisitions. 


\section{SUMÁRIO}

LISTA DE ABREVIATURAS E SIGLAS

LISTA DE FUNÇÕES MATEMÁTICAS

LISTA DE TABELAS $\quad 12$

LISTA DE QUADROS E FIGURAS $\quad 15$

1. INTRODUÇÃO 16

1.1 Problema de Pesquisa e Justificativa 18

1.2 Objetivos 19

1.3 Principais Temas Abordados na Pesquisa 20

1.4 Delimitação da Pesquisa $\quad 21$

1.5 Contribuições da Pesquisa 21

1.6 Estrutura da Pesquisa $\quad 22$

2. FUNDAMENTAÇÃO TEÓRICA 23

2.1 Teoria da Firma 23

2.2 Empresa Familiar 29

2.2.1 Conceitos, Definições e Características

2.2.2 Erros de Definição de Empresa Familiar

2.2.3 Empresa Familiar no Exterior e Desempenho 33

2.2.4 Empresa Familiar no Brasil e Desempenho

2.2.5 Ciclo de Vida da Empresa Familiar

2.2.6 Sucessão na Empresa Familiar 37

2.2.7 Vantagens e Desvantagens das Empresas Familiares 39

2.2.8 Concentração Acionária, Poder, Influência e Hubris em Empresas Familiares 41

2.2.9 Controle e Gestão da Empresa Familiar pela própria Família 42

2.2.9.1 Controle e Gestão da Empresa Familiar pelo próprio Fundador e/ou de seu Herdeiro Direto de Segunda Geração

2.2.9.2 Controle e Gestão da Empresa Familiar pelos Familiares de Terceira ou mais Gerações do Fundador

2.2.10 Relação com Investidores Institucionais, Grupos de Negócios, Agentes Financeiros, Governo, entre outros eventuais Blockholders $\quad 47$

2.3 Aquisições de Empresas

2.3.1 Conceito, Características e Classificação dos tipos de Aquisições de Empresas

2.3.2 Motivações para a realização de Operações de Aquisição de Empresas 49

2.3.3 Aquisições de Empresas no Exterior 53

2.3.4 Aquisições de Empresas no Brasil

2.3.5 Estratégias em Aquisições de Empresas

3. METODOLOGIA DA PESQUISA

3.1 Modelo Conceitual da Pesquisa

3.2 Modelo Diagramático Relacional dos Constructos da Pesquisa 62

$\begin{array}{ll}3.3 \text { Hipótese da Pesquisa } & 62\end{array}$

3.3.1 Hipóteses 1 e $2 \quad 63$

3.3.2 Hipóteses 3 , 4 e $5 \quad 63$

4. PROCEDIMENTOS METODOLÓGICOS E A PESQUISA 65

4.1 Dados e Fontes de Informação

4.2 Metodologia de Estudo de Eventos $\quad 67$

4.3 Definição Operacional das Variáveis da Pesquisa $\quad 72$

4.3.1 CAR (Cumulative Abnormal Return)

4.3.2 Empresas Familiares 73

4.3.3 Concentração de Propriedade Acionária 75 
4.3.4 Empresa Familiar de Primeira e Segunda Gerações 76

4.3.5 Oportunidade

4.3.6 Administração Familiar

4.3.7 Poder dos Controladores no Conselho 77

$\begin{array}{ll}\text { 4.3.8 Indústria Manufatureira } & 78\end{array}$

$\begin{array}{ll}\text { 4.3.9 Idade } & 78\end{array}$

4.3.10 Tamanho da Adquirente $\quad 78$

4.3.11 Diferença de Stake dos Acionistas Controladores e Demais Blockholders 78

4.3.12 Diferença entre remuneração variável e por ações / Remuneração Total 79

4.3.13 Investidores Institucionais

4.3.14 Alavancagem Financeira da adquirente $\quad 79$

4.3.15 Folga Financeira $\quad 80$

4.3.16 CAPEX (Capital Expenditure) $\quad 80$

4.3.17 Governança Corporativa (Novo Mercado e Nível 2) 80

4.3.18 Adquirente Serial $\quad 81$

4.3.19 Aquisição Internacional $\quad 81$

5. RESULTADOS

5.1 Análise Descritiva $\quad 82$

5.1.1 Descrição Amostral dos Dados da Pesquisa

5.1.2 Estatística Descritiva - Análise Univariada do CAR de Todas Empresas, Empresas Familiares e Empresas Não Familiares

5.1.2.1 Estatística Descritiva - CAR - Análise de desempenho e criação de valor em aquisições de empresas - Todas Empresas da Amostra

5.1.2.2 Estatística descritiva - CAR - Análise de desempenho e criação de valor em aquisições de empresas - Empresas Familiares da Amostra

5.1.2.3 Estatística descritiva - CAR - Análise de desempenho e criação de valor em aquisições de empresas - Empresas Não Familiares da Amostra

5.1.3 Estatística Descritiva - Análise Univariada do CAR de Todas empresas, Empresas Familiares e Empresas Não Familiares - Inserida a estratificação por grau de concentração acionária

5.1.3.1 Análise CAR - Todas Empresas - Estratificadas por Concentrações Acionárias

5.1.3.2 Análise CAR - Empresas Familiares - Estratificadas por Concentrações Acionárias

5.1.3.3 Análise CAR - Empresas Não Familiares - Estratificadas por Concentrações Acionárias

5.1.4 Estatística Descritiva - Análise Univariada das demais variáveis da pesquisa

5.2 Análise Comparativa (bivariada) das Variáveis da Pesquisa - Correlação Pairwise

5.3 Análise dos Resultados das Regressões Multivariadas

5.3.1 Modelos Gerais - Regressão com todas as empresas (com teste de robustez para grau de concentração acionária, benchmark de retorno de mercado e técnicas de análises estatísticas mencionadas anteriormente).

5.3.2 Modelos Específicos - Regressão apenas com empresas familiares para medir relação de variáveis específicas das empresas familiares (com teste de robustez para grau de concentração acionária, benchmark de retorno de mercado e técnicas de análises estatísticas mencionadas anteriormente).

5.3.3 Resultados das regressões pelo método de mínimos quadrados ordinários (MQO) utilizando erros-padrão robustos - Hubber-White Sandwich - Benchmark - Ibovespa. 


\section{LISTA DE ABREVIATURAS E SIGLAS}

$\%$ : Porcentagem

ACAR: Average Cumulative Abnormal Return

al.: Alii

ANBID: Associação Nacional dos Bancos de Investimentos

BM\&F BOVESPA: Bolsa de Mercadorias e Futuros - Bolsa de Valores de São Paulo

CAPEX: Capital Expenditure

CAR: Cumulative Abnormal Return

CAR_1: Janela de evento 1 dia (Dia do anúncio dos eventos de F\&A)

CAR_3: Janela de evento 3 dias

CAR_11: Janela de evento 11 dias

CAR_21: Janela de evento 21 dias

CEO: Chief Executive Officer

CVM: Comissão de Valores Mobiliários

F\&A: Funções e Aquisições

FDI: Foreign Direct Investment

FINEP: Financiadora de Estudos e Projetos

IBOVESPA: Índice da Bolsa de Valores de São Paulo

KPMG: Klynveld, Peat, Marwick e Goerdeler

MQO: Mínimos Quadrados Ordinários

$p$ : Nível de significância

SDC: Securities Data Company

SIC: Standard Industrial Classification

$t: t$-student

VIF: Variance Inflation Factor 


\section{LISTA DE FUNÇÕES MATEMÁTICAS}

\section{Modelos de Regressões Econométricas}

$\mathrm{AR}_{i t}=\mathrm{R}_{i t}$ - ERit (Metodologia de Estudo de Eventos: Retorno anormal)

$\mathrm{R}_{\mathrm{it}}=\alpha_{\mathrm{i}}+\beta_{\mathrm{i}} \mathrm{R}_{\mathrm{mt}}+\varepsilon_{\mathrm{it}}$ (Metodologia de Estudo de Eventos)

Modelo de regressão múltipla 1 - Modelo Geral:

Modelo de regressão múltipla 2 - Modelo Geral:

Modelo de regressão múltipla 3 - Modelo Geral:

Modelo de regressão múltipla 4 - Modelo Geral:

Modelo de regressão múltipla 5 - Modelo Geral:

Modelo de regressão múltipla 6 - Modelo Geral:

Modelo de regressão múltipla 7 - Modelo Geral:

Modelo de regressão múltipla 8 - Modelo Geral:

Modelo de regressão múltipla 9 - Modelo Geral:

Modelo de regressão múltipla 10 - Modelo Geral:

Modelo de regressão múltipla 11 - Modelo Geral:

Modelo de regressão múltipla 12 - Modelo Geral:

Modelo de regressão múltipla 13 - Modelo Geral:

Modelo de regressão múltipla 14 - Modelo Específico:

Modelo de regressão múltipla 15 - Modelo Específico:

Modelo de regressão múltipla 16 - Modelo Específico:

Modelo de regressão múltipla 17 - Modelo Específico:

Modelo de regressão múltipla 18 - Modelo Específico:

Modelo de regressão múltipla 19 - Modelo Específico:

Modelo de regressão múltipla 20 - Modelo Específico:

Modelo de regressão múltipla 21 - Modelo Específico:

Modelo de regressão múltipla 22 - Modelo Específico:

Modelo de regressão múltipla 23 - Modelo Específico:

Modelo de regressão múltipla 24 - Modelo Específico:

Modelo de regressão múltipla 25 - Modelo Específico:

Modelo de regressão múltipla 26 - Modelo Específico: 


\section{LISTA DE TABELAS}

Tabela 1 - Descrição Amostral - Composição da Amostra por Segmentos de Negócios/Atividade Industrial

Tabela 2 - Descrição Amostral - Composição da Amostra por Adoção de Padrão de Governança Corporativa

Tabela 3 - Descrição Amostral - Composição da Amostra de Aquisições por País-alvo

Tabela 4 - Descrição Amostral - Composição da Amostra Total das Empresas

Tabela 5 - Painel A. CAR (Cumulative Abnormal Returns) - Todas Empresas da Amostra Proxy do modelo de mercado: IBOVESPA

Tabela 6 - Painel B. CAR (Cumulative Abnormal Returns) - Todas Empresas da Amostra Proxy do modelo de mercado: IBRX50

Tabela 7 - Painel C. CAR (Cumulative Abnormal Returns) - Empresas Familiares da Amostra - Proxy do modelo de mercado: IBOVESPA

Tabela 8 - Painel D. CAR (Cumulative Abnormal Returns) - Empresas Familiares da Amostra - Proxy do modelo de mercado: IBRX50

Tabela 9 - Painel E. CAR (Cumulative Abnormal Returns) - Empresas Não Familiares da Amostra - Proxy do modelo de mercado: IBOVESPA

Tabela 10 - Painel F. CAR (Cumulative Abnormal Returns) -Empresas Não Familiares da Amostra - Proxy do modelo de mercado: IBRX50

Tabela 11 - Testes de Comparação de Desempenho entre Empresas Familiares e Não Familiares

Tabela 12 - Painel G. CAR (Cumulative Abnormal Returns). Todas Empresas da Amostra com Propriedade Concentrada Superior a 50\% - Proxy do modelo de Mercado: Ibovespa e IBRX50

Tabela 13 - Painel H. CAR (Cumulative Abnormal Returns). Todas Empresas da Amostra com Propriedade Concentrada Superior a 20\% - Proxy do modelo de Mercado: Ibovespa e IBRX50

Tabela 14 - Painel I. CAR (Cumulative Abnormal Returns). Todas Empresas da Amostra com Propriedade Concentrada Superior a 10\% - Proxy do modelo de Mercado: Ibovespa e IBRX50

Tabela 15 - Painel J. CAR (Cumulative Abnormal Returns). Todas Empresas da Amostra com Propriedade Concentrada Baixa - Proxy do modelo de Mercado: Ibovespa e IBRX50

Tabela 16 - Painel K. CAR (Cumulative Abnormal Returns). Todas Empresas da Amostra com Propriedade Concentrada Média - Proxy do modelo de Mercado: Ibovespa e IBRX50

Tabela 17 - Painel L. CAR (Cumulative Abnormal Returns). Todas Empresas da Amostra com Propriedade Concentrada Alta - Proxy do modelo de Mercado: Ibovespa e IBRX50

Tabela 18 - Painel M. CAR (Cumulative Abnormal Returns). Todas Empresas da Amostra com Propriedade Concentrada Superior a 50\% - Proxy do modelo de Mercado: Ibovespa e IBRX50

Tabela 19 - Painel N. CAR (Cumulative Abnormal Returns). Todas Empresas da Amostra com Propriedade Concentrada Superior a 20\% - Proxy do modelo de Mercado: Ibovespa e IBRX50

Tabela 20 - Painel O. CAR (Cumulative Abnormal Returns). Todas Empresas da Amostra com Propriedade Concentrada Superior a 10\% - Proxy do modelo de Mercado: Ibovespa e IBRX50

Tabela 21 - Painel P. CAR (Cumulative Abnormal Returns). Todas Empresas da Amostra com Propriedade Concentrada Baixa - Proxy do modelo de Mercado: Ibovespa e IBRX50 
Tabela 22 - Painel Q. CAR (Cumulative Abnormal Returns). Todas Empresas da Amostra com Propriedade Concentrada Média - Proxy do modelo de Mercado: Ibovespa e IBRX50

Tabela 23 - Painel R. CAR (Cumulative Abnormal Returns). Todas Empresas da Amostra com Propriedade Concentrada Alta - Proxy do modelo de Mercado: Ibovespa e IBRX50

Tabela 24 - Painel S. CAR (Cumulative Abnormal Returns). Todas Empresas da Amostra com Propriedade Concentrada Superior a 50\% - Proxy do modelo de Mercado: Ibovespa e IBRX50

Tabela 25 - Painel T. CAR (Cumulative Abnormal Returns). Todas Empresas da Amostra com Propriedade Concentrada Superior a 20\% - Proxy do modelo de Mercado: Ibovespa e IBRX50

Tabela 26 - Painel U. CAR (Cumulative Abnormal Returns). Todas Empresas da Amostra com Propriedade Concentrada Superior a 10\% - Proxy do modelo de Mercado: Ibovespa e IBRX50

Tabela 27 - Painel V. CAR (Cumulative Abnormal Returns). Todas Empresas da Amostra com Propriedade Concentrada Baixa - Proxy do modelo de Mercado: Ibovespa e IBRX50

Tabela 28 - Painel W. CAR (Cumulative Abnormal Returns). Todas Empresas da Amostra com Propriedade Concentrada Média - Proxy do modelo de Mercado: Ibovespa e IBRX50

Tabela 29 - Painel X. CAR (Cumulative Abnormal Returns). Todas Empresas da Amostra com Propriedade Concentrada Alta - Proxy do modelo de Mercado: Ibovespa e IBRX50

Tabela 30 - Painel I. Todas as Empresas da Amostra

Tabela 31 - Painel II. Empresas Familiares da Amostra

Tabela 32 - Painel III. Empresas Não Familiares da Amostra

Tabela 33 - Matriz de Correlação Pairwise - Todas as Empresas da Pesquisa

Tabela 34 -Matriz de Correlação Pairwise - Subamostra: Variáveis da amostra| Empresas Familiares

Tabela 35 - Matriz de Correlação Pairwise - Subamostra: Variáveis da amostra | Empresas não Familiares.

Tabela. 36 - Resultados Regressões Multivariadas: CAR_1_IBOV - Porcentagens de Concentração Acionária Baseadas em legislação societária - Painel A. Todas Empresas da Amostra - MQO com erros-padrão robustos

Tabela. 37 - Resultados Regressões Multivariadas: CAR_1_IBOV - Porcentagens de Concentração Acionária Baseadas em legislação societária - Painel B. Empresas Familiares da Amostra - MQO com erros-padrão robustos

Tabela. 38 - Resultados Regressões Multivariadas: CAR_1_IBOV - Porcentagens de Concentração Acionária Baseados em ranqueamento da amostra - Painel A. Todas Empresas da Amostra - MQO com erros-padrão robustos

Tabela. 39 - Resultados Regressões Multivariadas: CAR_1_IBOV - Porcentagens de Concentração Acionária Baseados em ranqueamento da amostra - Painel B. Empresas Familiares da Amostra - MQO com erros-padrão robustos

Tabela. 40 - Resultados Regressões Multivariadas: CAR_3_IBOV - Porcentagens de Concentração Acionária Baseadas em legislação societária - Painel A. Todas Empresas da Amostra - MQO com erros-padrão robustos 
Tabela. 41 - Resultados Regressões Multivariadas: CAR_3_IBOV - Porcentagens de Concentração Acionária Baseadas em legislação societária - Painel B. Empresas Familiares da Amostra - MQO com erros-padrão robustos

Tabela. 42 - Resultados Regressões Multivariadas: CAR_3_IBOV - Porcentagens de Concentração Acionária Baseados em ranqueamento da amostra - Painel A. Todas Empresas da Amostra - MQO com erros-padrão robustos

Tabela. 43 - Resultados Regressões Multivariadas: CAR_3_IBOV - Porcentagens de Concentração Acionária Baseadas em ranqueamento da amostra - Painel B. Empresas Familiares da Amostra - MQO com erros-padrão robustos

Tabela. 44 - Resultados Regressões Multivariadas: CAR_11_IBOV - Porcentagens de Concentração Acionária Baseadas em legislação societária - Painel A. Todas Empresas da Amostra - MQO com erros-padrão robustos

Tabela. 45 - Resultados Regressões Multivariadas: CAR_11_IBOV - Porcentagens de Concentração Acionária Baseadas em legislação societária - Painel B. Empresas Familiares da Amostra - MQO com erros-padrão robustos

Tabela. 46 - Resultados Regressões Multivariadas: CAR_11_IBOV - Porcentagens de Concentração Acionária Baseadas em ranqueamento da amostra - Painel A. Todas Empresas da Amostra - MQO com erros-padrão robustos

Tabela. 47 - Resultados Regressões Multivariadas: CAR_11_IBOV - Porcentagens de Concentração Acionária Baseadas em ranqueamento da amostra - Painel B. Empresas Familiares da Amostra - MQO com erros-padrão robustos

Tabela. 48 - Resultados Regressões Multivariadas: CAR_21_IBOV - Porcentagens de Concentração Acionária Baseadas em legislação societária - Painel A. Todas Empresas da Amostra - MQO com erros-padrão robustos

Tabela. 49 - Resultados Regressões Multivariadas: CAR_21_IBOV - Porcentagens de Concentração Acionária Baseadas em legislação societária - Painel B. Empresas Familiares da Amostra - MQO com erros-padrão robustos

Tabela. 50 - Resultados Regressões Multivariadas: CAR_21_IBOV - Porcentagens de Concentração Acionária Baseadas em ranqueamento da amostra - Painel A. Todas Empresas da Amostra - MQO com erros-padrão robustos

Tabela. 51 - Resultados Regressões Multivariadas: CAR_21_IBOV - Porcentagens de Concentração Acionária Baseadas em ranqueamento da amostra - Painel B. Empresas Familiares da Amostra - MQO com erros-padrão robustos 


\section{LISTA DE QUADROS E FIGURAS}

Quadro 1 - Classificação dos Processos de aquisições de Empresas $\quad 48$

Quadro 2 - Motivação para a realização de Operações de Aquisições de Empresas

Quadro 3 - Coleta, Operacionalização dos Dados da Pesquisa e Classificação em Empresas Familiares e não Familiares.

Figura 1 - Modelo conceitual de avaliação e comparação de modelos $\quad 60$

$\begin{array}{ll}\text { Figura 2 - Modelo conceitual da pesquisa } & 61\end{array}$

Figura 3 - Modelo Diagramático Relacional dos Constructos da Pesquisa. $\quad 62$

Figura 4 - Esquematização da Metodologia de Estudo de Eventos 69 


\section{INTRODUÇÃO}

De acordo com a ASSOCIAÇÃO DAS EMPRESAS FAMILIARES (2013) e SEBRAE (2013) são empresas familiares aquelas em que uma ou mais famílias detém o controle da empresa, em termos de propriedade e influência na gestão.

Empresas familiares sempre tiveram relevante representatividade sobre os mais diversos segmentos de negócios e setores da economia (LA PORTA, LÓPEZ e SHLEIFER, 1999; CLAESSENS, DJANKOV e LANG, 2000; VILLALONGA e AMIT, 2010).

Para Gorgati (2004) e Rocha (2012), o fato de as empresas familiares sempre existirem, desde os primórdios da sociedade, e a tendência de que sempre serão um dos alicerces para o desenvolvimento econômico das nações, contribuem para a importância do tema.

Segundo SEBRAE (2013), as empresas familiares são a base de sustentação da economia, pois todas as empresas nascem a partir da iniciativa de algum membro de uma família. A instituição anteriormente citada, ainda afirma que a primeira geração da empresa familiar é ágil, rápida e eficiente, devido sobretudo à gestão centralizada e ao menor grau de burocracia interna na tomada de decisão. A partir das demais gerações, a quantidade de pessoas envolvidas na gestão, a descentralização da tomada de decisão, entre outros fatores, torna a gestão menos eficiente.

Gorgati (2004) e Rocha (2012) destacam também como característica das empresas familiares a agilidade e a flexibilidade, permitindo maior eficácia operacional necessária para o desempenho superior.

Para SEBRAE (2013), outra característica das empresas familiares é a estrutura da máquina administrativa da empresa, na média, mais enxuta do que em empresas não familiares. À medida que as gerações vão passando, a empresa se profissionaliza e os gestores se especializam, resultando em aumento da estrutura da máquina administrativa da empresa.

Segundo Mello et al. (2008), em pesquisa realizada no Brasil, somente 30\% das empresas familiares sobrevivem para a segunda geração e apenas 5\% sobrevivem para a terceira geração. Como hipóteses de explicação deste fenômeno (alta taxa de mortalidade de empresas familiares) são levantados dois fatores:

i) risco de sucessão, causado pela possibilidade de insucesso da gestão dos sucessores nas gerações seguintes ao do fundador; 
ii) maior possibilidade de ocorrência de não distinção entre pessoa física e pessoa jurídica - ferindo-se o axioma contábil da entidade. Esse problema é decorrente da alta concentração de poder e acionária pela família, que faz com que o gestor familiar atue visando aos interesses familiares em detrimento da pessoa jurídica. Ao se ferir esse postulado da contabilidade, gera-se maior risco de não continuidade da empresa.

Por outro lado, Schuman, Stutz \& Ward (2010) afirmam que as empresas familiares, nos dias de hoje, têm maior expectativa de vida, devido à melhoria significativa na capacidade de gestão e à adoção de melhores práticas existentes no mercado.

Outrossim, a legislação pertinente à governança corporativa tem provido maior segurança aos investidores, o que contribui para o maior desenvolvimento de empresas familiares.

Frugis (2007) cita outros fatores que potencializam as empresas familiares, como por exemplo, cultura organizacional mais estável, maior visão de longo prazo, estratégia corporativa mais clara e melhor definida advinda do fundador, que resultam melhor desempenho em relação às empresas não familiares. Evidencia-se que esses argumentos serão aprofundados na seção fundamentação teórica, em específico, no subitem: Vantagens e Desvantagens das Empresas Familiares.

O desenvolvimento e as vantagens intrínsecas da empresa, corroborados à conjuntura econômica mais competitiva e globalizada, incentivam as empresas no Brasil a focar ações estratégicas que envolvam a realização de aquisições, alianças, abertura de capital e, sobretudo, à obtenção de recursos para competir nos mercados doméstico e internacional. (PRICEWATERHOUSECOOPERS, 2011).

O foco principal deste estudo é analisar o desempenho/resultado de empresas familiares adquirindo empresas no Brasil.

O desempenho/resultado em aquisições de empresas será mensurado pelo retorno anormal, utilizando a metodologia de estudo de eventos de Mackinlay (1997) e McWilliam e Siegel (1997).

Segundo Nardi (2012), o retorno anormal é a diferença entre o retorno real diário e o retorno diário esperado. Adota-se, neste trabalho, da mesma forma que Kayo, Patrocínio e Martin (2009) e Nardi (2012), o modelo de mercado para estimar o retorno diário esperado, pois afirmam que o retorno anormal calculado contempla os fatores risco e mercado. 
Segue sucintamente, de acordo com Nardi (2012), a metodologia para cálculo de retorno anormal, que será detalhado posteriormente em seção própria do presente trabalho:

i) Definir o evento e a data de anúncio do evento estudado, estabelecer o período analisado e calcular o retorno real diário para cada período definido;

ii) Efetuar o cálculo do retorno anormal diário para cada empresa da amostra da pesquisa;

iii) Calcular o retorno anormal médio diário de todas as empresas da amostra;

iv) Acumular o retorno anormal médio diário calculado em (ii), obtendo o retorno anormal médio acumulado para o período estudado.

v) Analisar e reportar os resultados encontrados.

Evidencia-se também que neste trabalho serão analisados apenas aquisições de empresas, excluindo-se as outras operações como fusões, cisões, entre outras.

\subsection{Problema de Pesquisa e Justificativa}

Segundo Schuman, Stutz \& Ward (2010), há trinta anos, o tema empresas familiares era praticamente negligenciado. As escolas de negócio desenvolviam "gestores profissionais" para aquelas companhias que possuíam propriedade separada de sua administração, e não se observava que as necessidades de uma empresa familiar são distintas das necessidades das empresas não familiares.

O tema obtém cada vez mais notoriedade na academia, pois grande parte da economia global é formada por empresas familiares que operam em diversos setores econômicos, pertencentes a todos os portes e classificações de pessoa jurídica. (LA PORTA, LÓPEZ e SHLEIFER, 1999; CLAESSENS, DJANKOV e LANG, 2000; VILLALONGA e AMIT, 2010).

Outrossim, evidencia-se ainda que o estudo do tema Empresas Familiares é relevante, devido à escassez e ao recente interesse de seu estudo, em âmbitos global e doméstico, (SCHUMAN, STUTZ e WARD, 2010; MCCONAUGHY, MATTHEWS e FIALKO, 2001), e à necessidade de pesquisas que propiciem a seus administradores um melhor conhecimento dos fatores que possam contribuir para a otimização do desenvolvimento e desempenho das empresas familiares.

Segundo Rocha (2012), um tópico promissor na academia em relação às empresas familiares é o estudo sobre o desempenho das estratégias de crescimento das empresas familiares, pois, em decorrência da globalização e acirramento da disputa de mercados interno e externo, as 
empresas familiares brasileiras, cada vez mais, utilizam aquisições para a obtenção de diferenciais, a fim de competirem com empresas estrangeiras e não familiares (PRICEWATERHOUSECOOPERS, 2011).

Os resultados sobre o desempenho de operações corporativas de empresas familiares versus empresas não familiares ainda são contraditórios e inconclusivos para a academia. Há autores que afirmam que empresas familiares têm pior desempenho, e outros autores, afirmam que têm melhor desempenho em determinadas operações.

Em concordância com o parágrafo acima, Rocha (2012) também afirma que é incipiente, inconclusiva e contraditória a literatura sobre o desempenho de empresas familiares em operações diversas, inclusive, em eventos de aquisições, quando comparadas à empresas não familiares. Salienta ainda que, mesmo com algumas pesquisas realizadas no Brasil e no exterior, permanecem sem resposta na literatura as seguintes arguições adotadas, inclusive para o presente trabalho:

- Qual o impacto da propriedade familiar sobre eventos de aquisições?

- Há diferença de retornos anormais entre empresas familiares e não familiares em eventos de aquisições?

Em decorrência dos fatores comentados anteriormente, este trabalho é justificado pela necessidade de maior estudo, pela academia, do tema empresa familiar e sua estratégia de crescimento inorgânico.

\subsection{Objetivos}

Este trabalho irá analisar o desempenho de empresas familiares e não familiares, no Brasil, em eventos de aquisições. Os desempenhos são mensurados pelo ACAR (average cumulative abnormal return), utilizando a metodologia de Estudo de Eventos que mede a geração ou destruição de valor da empresa em determinados eventos analisados (MACKINLAY,1997; MCWILLIAM e SIEGEL, 1997).

O objetivo geral desta dissertação é investigar os impactos oriundos da variável propriedade familiar sobre os retornos anormais em eventos de aquisições.

Objetivo secundário: Verificar e analisar possível existência de diferença de retornos anormais entre empresas familiares e empresas não familiares em eventos de aquisições. 


\subsection{Principais Temas Abordados na Pesquisa}

São abordados três importantes áreas de estudo, no campo da administração e da economia, a saber:

- empresa familiar;

- aquisições de empresas;

- teoria da firma.

Salienta-se que os três temas possuem caráter multidisciplinar. Com relação à empresa familiar, serão abordados, principalmente, o aspecto de sua definição operacional para esta pesquisa; a análise de desempenho de empresas familiares no Brasil e no exterior; o ciclo de vida da empresa familiar; o processo sucessório; as vantagens e desvantagens competitivas das empresas familiares; e outras características intrínsecas do referido tema, como por exemplo; o fator concentração acionária e influência de gestão da família em empresa familiar; diferença de gestão e performance da empresa entre distintas gerações da empresa familiar.

Quanto ao tema aquisições, serão abordados, principalmente, a análise histórica de aquisições de empresas, no Brasil e no exterior, seu desempenho e estratégias que buscam criação de valor nesses tipos de operações.

Por fim, abordar-se-á sobre a teoria da firma, que é o alicerce conceitual tanto para empresas familiares quanto para aquisições de empresas, pois, essa teoria estuda, sobretudo, as ações e motivações que as levam a produzir bens para a sociedade, otimizando a utilização dos fatores de produção para atender à função oferta-demanda e, sobretudo, atingir a maximização do valor da empresa e da riqueza dos seus acionistas. 


\subsection{Delimitação da Pesquisa}

A presente dissertação sujeita-se às delimitações temática, amostral e temporal. Em relação ao âmbito temático, esta dissertação pertence à temática empresas familiares, mais especificamente, sobre o desempenho de empresas familiares em eventos de aquisições.

Referente à delimitação da amostra da pesquisa, utilizou-se apenas empresas adquirentes brasileiras de capital aberto que realizaram eventos de aquisições, no período de 2009 a 2013. Acusam-se as seguintes limitações de pesquisa:

i) limitam-se as conclusões oriundas dos resultados desta pesquisa para empresas de capital aberto;

ii) o período amostral pode conter viéses e ruídos, devido às crises econômico-financeiras e mudanças relevantes nas searas político, institucional e legal no país. Neste último aspecto, evidencia-se o advento da Lei 11.638/2007 - Adequação da BR-GAAP (Brazilian Generally Accepted Accounting) aos padrões internacionais IFRS (Intenational Financial Reporting Standards), que podem ocasionar diferenças em algumas rubricas nas evidenciações contábeis de determinadas empresas e setores. Não faz parte do escopo deste trabalho o aprofundamento e exame das diferenças nas rubricas ocasionadas pela lei.

\subsection{Contribuições da Pesquisa}

Em consonância com Sharma et al (1997) e Rocha (2012), a pesquisa comparativa entre empresas familiares e não familiares (grupo de controle) permitirá a verificação de quais fatores afetam em maior magnitude um tipo de empresa em relação a outra. Outrossim, corroborando com a visão de Sharma (2004) e Rocha (2012), a contribuição maior desta pesquisa é o melhor entendimento sobre empresas familiares e, consequentemente, a melhoria na prática em gestão corporativa, e na realização de aquisições por empresas familiares.

Entretanto, salienta-se que não se esgotarão as necessidades de aprimoramento da literatura sobre empresas familiares. Segundo Zahra e Sharma (2004) e Rocha (2012), ainda há muito o que se contribuir e aprimorar à literatura sobre empresas familiares, para melhor entendimento da sua natureza, especificidades e necessidades que resultem melhor desempenho e otimização de resultados. 


\subsection{Estrutura da Pesquisa}

A dissertação está estruturada em capítulos. O primeiro capítulo introduz o tema e organiza a dissertação. Apresenta a problemática do trabalho, a justificativa, os objetivos que se almeja atingir e as metodologias de pesquisa. Explica-se também a estrutura do trabalho, para melhor compreensão e didática da apresentação do conteúdo da dissertação.

No segundo capítulo, apresentam-se a fundamentação teórica da pesquisa, e o conceito da empresa familiar e aquisições de empresas, com o desenvolvimento do arcabouço teórico necessário para a elaboração deste trabalho.

No capítulo 3, apresenta-se a metodologia da pesquisa, onde se relata os procedimentos de pesquisa realizados e detalhamento da pesquisa com informações de como foi planejado e executado.

No capítulo 4, relatam-se os resultados da pesquisa e, em seguida, finaliza-se a dissertação com as considerações finais e seus elementos pós-textuais (referências, apêndices e anexos). 


\section{FUNDAMENTAÇÃO TEÓRICA}

Segue abaixo a revisão literária que aborda o arcabouço teórico necessário e pertinente ao trabalho proposto. Este capítulo versa sobre a empresa familiar, aquisições de empresas e seus conceitos correlatos.

\subsection{Teoria da Firma}

Segundo Camargos e Coutinho (2008), Gogati (2004) e Rocha (2012), a teoria geral de aquisições e de empresas familiares não está devidamente definida e explicada pela literatura. O embasamento teórico dos temas aquisições e empresas familiares é originado principalmente do arcabouço da teoria da firma.

Para Camargos e Coutinho (2008), a teoria da firma fundamenta o surgimento e evolução da empresa, e também das atividades de aquisições de empresas, como ferramentas utilizadas pela motivação da empresa, para o seu crescimento e desenvolvimento (PENROSE, 1959).

Logo, a teoria da firma é o alicerce conceitual para a fundamentação do tema empresas familiares e aquisições de empresas (CAMARGOS e COUTINHO, 2008; GORGATI, 2004; SILVEIRA, 2006).

De acordo com Camargos e Coutinho (2008), com base na teoria da firma, existem diversos motivos para a existência de empresas familiares e de realizações de operações de aquisições de empresas. Seja qual for o motivo, encontra-se suporte teórico, principalmente na teoria de maximização de riqueza ao acionista (JENSEN E MECKLING, 1976); na teoria de crescimento da firma (PENROSE, 1959); e na teoria da agência e da governança corporativa. (JENSEN E MECKLING, 1976; KAYO E FAMA, 1997).

Segundo Saito e Silveira (2008), a teoria da firma estabelece que a entidade é apenas uma alocação de capital entre seus acionistas, onde a empresa é um mero contrato legal, que visa à maximização de riqueza. (JENSEN E MECKLING, 1976).

De acordo com Camargos e Coutinho (2008), Adam Smith pode ser considerado o precursor dos estudos sobre a empresa, cujo desenvolvimento originou a teoria da firma. Segundo esta teoria, a empresa é um mecanismo ou agente para a obtenção de objetivos pré-estipulados pelos seus proprietários. 
Na teoria da firma, os estudos de Coase (1937), Alchian e Demsetz (1972) e Jensen e Meckling (1976) originaram importantes debates sobre a propriedade da empresa e a teoria dos contratos. Conceitos, estes, essenciais para o tema empresa familiar e aquisições de empresas (SAITO E SILVEIRA, 2008).

De acordo com Veblen (1967), a propriedade é o embasamento para a existência da empresa, onde a corporação existe com o objetivo principal de gerar riqueza aos acionistas beneficiários. Estes, podem ser constituídos por pessoas físicas, uma ou mais unidades familiares, ou mesmo outros tipos de acionistas beneficiários, como por exemplo, investidores institucionais e governo. Evidencia-se que o tipo de acionista pode influenciar significativamente no modelo de gestão da empresa e afetar, porventura, os resultados.

A combinação do modo como a empresa é gerenciada, a vigilância sobre os agentes administradores (custo de agência), o poder do(s) acionista(s) controlador(es) sobre a administração da empresa e o perfil de comando resultam diferentes ações e desempenhos da empresa.

Knight (1921), Coase (1937), Penrose (1959), Alchian e Demsetz (1972), Williamson (1975), Jensen e Meckling (1976), Klein, Crawford e Alchian (1978), North (1978), Marshall (1982), Veblen (1967), Schumpeter (1982), entre outros, de distintas escolas econômicas, têm fundamentado a teoria da firma. Entretanto, para Hart (1996), mesmo com o extenso estudo sobre a natureza da empresa, ainda há necessidade de se desenvolver o entendimento da existência e evolução das empresas, sobretudo, conectando seu desenvolvimento com a utilização de métodos de crescimento inorgânico (aquisições de empresas); e verificando como a estrutura de propriedade pode interferir no desempenho da empresa familiar ou não.

A teoria da firma, para Camargos e Coutinho (2008), fornece base conceitual para o entendimento do comportamento da empresa, bem como para análise das motivações das tomadas de decisões corporativas, como por exemplo, decisões de crescimento e expansão da empresa, decisões de concentração acionária e decisões de financiamento. 
Evidencia-se que outras teorias coadunam com os propósitos da teoria da firma, como por exemplo, a teoria da decisão e a teoria dos jogos, que buscam o entendimento e a análise das ações da empresa e o comportamento entre agentes para a maximização dos resultados e o desenvolvimento da entidade. Como grandes precursores dessas teorias mencionadas, citamse Cournot (1897), Bertrand (1883); e modernamente, Von Neumann e Morgenstern (1944); Nash (1950) e Kahneman e Tversky (1979), entre outros.

Todas essas teorias visam à otimização dos resultados, seja por meio de melhor utilização dos recursos escassos (utilidade esperada dos recursos), maximização do lucro aos acionistas, crescimento e perpetuidade da corporação (PENROSE, 1959; ALCHIAN e DEMSETZ, 1972; WILLIAMSON, 1975; JENSEN e MECKLING, 1976; SCHUMPETER,1982).

Knight (1921) afirma ainda que é precípua e profícua a otimização da alocação dos recursos estratégicos da empresa, pois os bens naturalmente se movem em direção aos agentes de maior demanda pelos recursos escassos. Em outras palavras, caso a empresa não utilize seus recursos de forma adequada, incorre-se, em médio e longo prazos, na possibilidade da perda de seus recursos, pois, outra empresa, com melhores condições de aproveitamento dos recursos escassos indubitavelmente não perderá essa oportunidade.

Esse fenômeno econômico supracitado por Knight (1921) faz analogia à teoria da evolução de Darwin, em que apenas as melhores e mais capacitadas empresas continuam a se desenvolver no mercado, e as empresas menos aptas tendem a não sobreviver no horizonte de médio e longo prazos e/ou serem adquiridas.

Em outra analogia ao aludido fenômeno econômico de Knight (1921), a partir de Isaac Newton - Lei da atração das massas / Lei da gravitação universal, "matéria atrai matéria na razão direta do produto das massas e na razão inversa do quadrado da distância". Em outras palavras, na visão de mercado, empresas maiores são atraídas pelo crescimento, pois visam à economia de escala e escopo, e, desse modo, atraem e adquirem empresas menores. Entretanto, empresas conglomeradas, que adquirem sistematicamente empresas de outros segmentos de negócios, podem sofrer desvalorização pelo mercado, decorrente de operação de aquisição de empresa não relacionada ao principal segmento econômico da holding.

De acordo ainda com Coase (1937), o crescimento da empresa gera menores custos operacionais para a organização, como a redução no custo de obtenção de fatores de produção para empresas de maiores portes. Devido à vantagem do fator tamanho da organização, as 
empresas buscam no crescimento inorgânico auferir maiores vantagens competitivas. (CAMARGOS E COUTINHO, 2008).

Evidencia-se ainda que com o aumento do tamanho das empresas, os agentes administradores passam a desempenhar um papel mais efetivo nas corporações, sobretudo, em decorrência das exigências do mercado credor e acionistas minoritários, instituindo padrões de governança corporativa, em que empresas familiares, quando adotam por exemplo, o padrão Novo Mercado da BOVESPA (Bolsa de Valores de São Paulo), devem optar pelo não acúmulo de funções, seja na diretoria executiva ou no Board (conselho de administração), na tentativa de gerar menor concentração de poder dos acionistas controladores, e menor assimetria de informação entre o mercado e os acionistas controladores.

Outro fator positivo que coaduna com os esforços de melhoria do sistema de governança corporativa no Brasil, na tentativa de separação de poder acionário e poder de gestão da empresa, são as evidências encontradas por Mussnich (1979). O referido autor verificou um maior crescimento das empresas administradas por agentes, que em relação às empresas administradas pelos próprios controladores. Segundo o autor supracitado, o fator conhecimento técnico, que o agente possa ter trazido para a empresa, talvez tenha resultado em desempenho superior.

Por outro lado, Jensen e Meckling (1976) afirmam também que há diversos fatores que possam diminuir a magnitude dos resultados da empresa, em decorrência da utilização de agentes, como por exemplo, gastos excedentes, que visam mitigar a possibilidade de oportunismo do agente administrador da empresa, chamados de custo de agência ou também chamados de perdas residuais. (KAYO e FAMÁ, 1997).

Adventa-se assim dois tipos de propriedade empresarial: 1. a propriedade ativa, cujo acionista controlador detém o poder e/ou influência na administração; 2. propriedade passiva, onde a administração é desempenhada por agentes terceiros (administradores profissionais), e cuja propriedade acionária é pulverizada, separando-se a propriedade do seu controle, resultando em pouca ou nenhuma influência de um acionista mais representativo na gestão da empresa (CAMARGOS E COUTINHO, 2008).

Esse último tipo de propriedade empresarial supracitada, a propriedade passiva, é mais comum em países como os Estados Unidos da América, onde também conta com melhor sistema de governança corporativa, ordenamento e sistema jurídico mais eficiente e maior compliance das empresas às legislações pertinentes (SILVEIRA, 2006). 
Referente ainda à modalidade de propriedade passiva, Camargos e Coutinho (2008) colocam que os proprietários, nessa modalidade, deixam de exercer o controle direto sobre a empresa. Os acionistas seriam apenas emprestadores e detentores de direitos financeiros da entidade (DEMSETZ, 1967). Em outras palavras, os acionistas possuem direitos apenas à parte do lucro oriundo das operações da empresa, mas não possuem a corporação em si.

De acordo com Saito e Silveira (2008) e Kayo e Famá (1997), o trabalho de Jensen e Meckling (1976) é considerado seminal quanto à contribuição para os temas estrutura de capital da empresa, custo de agência, governança corporativa, e inclusive, em concordância com um novo conceito da empresa, conforme relatado no parágrafo anterior, por Camargos e Coutinho (2008) e Demsetz (1967).

Camargos e Coutinho (2008) afirmam que denominações como governança corporativa e estrutura de capital são apenas enfoques dentro do amplo estudo da teoria da firma.

Williamson (1975) cita ainda uma outra possibilidade de ocorrência de oportunismo; a dos integrantes da cadeia de negócio (stakeholders). Com base na teoria de equilíbrio dos interesses dos stakeholders, deveria ser maximizado e repartido o lucro entre todos os elos da cadeia (FREEMAN, 1984; DONALDSON e PRESTON, 1995; PHILLIPS, 2003).

Entretanto, essa teoria é criticada por Jensen (2001a) e Silveira (2006), pois, segundo esses autores, tal teoria está fadada ao insucesso, pois é inviável atender a todos os interesses de cada elo participante da cadeia. Em um certo instante, haverá um trade-off que envolverá os elos. Portanto, é profícuo para a empresa focar e ter apenas um único objetivo, a maximização do valor total de mercado da empresa. Em outras palavras, visar a outros fatores pode diminuir os resultados da empresa e, por conseguinte, haver menor atendimento ao pressuposto da função-objetivo da empresa, ou seja, a maximização da riqueza aos acionistas.

Como exemplo, Jensen (2001a) afirma que quando há múltiplos objetivos e equilíbrio dos interesses dos stakeholders, não há objetividade da função objetivo da empresa, pois gera trade-off entre decisão de maximização do lucro da empresa e da participação de mercado, por exemplo. Assim, o gestor deverá decidir a faixa que estabelecerá as variáveis avaliadas dentro de uma amplitude determinada, perdendo oportunidade de maximizar a variável mais importante da empresa, ou seja, o valor total da empresa, pois o ponto máximo global não é o mesmo do ponto máximo local. Em outras palavras, ao maximizar um conjunto de objetivos, torna a maximização dos objetivos individuais menos otimizada, pois, em geral, há conflitos e 
divergências entre os objetivos, ao conciliá-los, perde-se eficiência na otimização e maximização do ponto máximo global.

Dessa forma, segundo Jensen (2001a), é impróprio haver mais de uma dimensão/objetivo ao mesmo tempo, e a melhor variável a ser maximizada é o valor total da empresa - que é a soma do valor de mercado da empresa aos passivos com terceiros. Essa é a única variável que deve ser focada como função-objetivo da empresa.

Em síntese, evidencia-se que a função-objetivo da empresa é o principal motivo empresarial para o aumento do poder de mercado, aumento da taxa de lucro, mas, nunca o oposto.

Referente ainda à otimização da empresa e à busca por eficiência, Williamson (1975) prega que a integração vertical da empresa, obtida por meio de expansão inorgânica da empresa, mitiga o oportunismo e a divisão do lucro com outros elos da cadeia, o que maximiza o lucro da empresa verticalizada.

Outros motivos para as empresas realizarem expansões inorgânicas, com foco no crescimento da empresa, são a maior oportunidade de mercado, lucros e poder hegemônico, conforme prega a teoria da firma e os modelos econômicos de Cournot (1897), Bertrand (1883), Nash (1950), Seth (1990b), Pindyck e Rubinfeld (2006), entre outros.

Em concordância com os autores supracitados, Robbins (1945) e Penrose (1959) colocam que as empresas e as pessoas físicas buscam maximizar a utilidade dos recursos escassos, portanto, esta escassez de recursos estratégicos, muitas vezes, é a explicação e a motivação intrínseca para utilização de ferramentas, como aquisições de empresas, mesmo que tais ferramentas resultem em destruição de valor momentâneo para empresa, mas em perspectiva macro e estratégico, o potencial de geração de valor futuro pode cobrir eventuais perdas de valor de mercado no presente.

Se utilizado o raciocínio da argumentação precedente, isto também ocorre quando uma empresa adota mecanismos de controle de seus executivos para conter eventuais possibilidades de oportunismo e problema de agência, pois, embora sejam despesas e ônus incorridos, na visão estratégica de longo prazo, os ganhos e/ou prejuízos potenciais são maiores que as despesas presentes com controle e vigilância dos agentes administrativos.

Outro exemplo de estratégia que visa à aquisição de recursos que viabilizem a otimização dos resultados e operações da empresa, mas com possível perda de valor presente e/ou acréscimo de despesas correntes extras, é a alavancagem financeira e financiamento, em que a empresa incorre em despesas e ônus financeiros. Entretanto, o potencial ganho futuro com o 
financiamento e a alavancagem financeira pode suplantar os ônus presentes com os juros e riscos da operação.

Esses argumentos, com base na ampla teoria da firma, são algumas explicações para a utilização de mecanismos / ferramentas corporativas, que serão analisados no presente trabalho, com o foco na análise de desempenho de empresas familiares em operações de aquisições.

\subsection{Empresa Familiar}

\subsubsection{Conceitos, Definições e Características}

A definição de empresa familiar tem sido objeto de debate acadêmico há décadas. Lansberg et al. (1988) levantaram a emblemática questão: O que é uma Empresa Familiar?, e que permanece até hoje sem resposta única e objetiva. (WERNER, 2004; ROCHA, 2012).

Sharma (2004) evidencia a importância de se estabelecer uma definição própria e majoritária para o tema, com o intento de comparabilidade dos resultados da pesquisa, e criação de massa crítica do tema. Essa falta de definição consensual de empresas familiares tem gerado limitação do avanço dessa linha de pesquisa (WINTER et al., 1998; ROCHA, 2012).

Salienta-se que ao definir empresa familiar deve-se enquadrá-la em termos do grau de concentração acionária e envolvimento da família com a empresa. Outras variáveis que devem também ser observadas são a geração gestora da família proprietária e o ciclo natural do negócio. (TSANG, 2002; SHARMA, 2004; ROCHA, 2012).

Para Chua, Chrisman e Sharma (1999) há dois critérios de classificação de empresas familiares. Um baseado no conceito de propriedade, e o outro no conceito de gestão. Entretanto, com base em Anderson, Reeb \& Zhao (2012), a propriedade é o principal fator para classificação da empresa, a gestão é apenas uma variável de explicação de performance da empresa; portanto, este último conceito - gestão, não seria variável para classificação e definição de empresa familiar ou não.

De acordo com Anderson, Reeb \& Zhao (2012), a empresa familiar deverá haver uma ou mais pessoas físicas e/ou unidade(s) familiar(es) e/ou instituição que a represente, com relevante influência nas decisões da empresa. Esta influência é dada, por meio do direito econômico, ou seja, propriedade/direito a votos. 
Salienta-se que a empresa gerida ou não pela própria família apenas aumenta a concentração de poder por meio de influência de gestão. Podendo esse fator afetar a performance da empresa em situações diversas, como por exemplo, em eventos de aquisições de empresas (ASTRACHAN, 2010; ROCHA, 2012).

Referente à classificação e definição de empresa familiar, não é necessário que haja um administrador da família, para que seja classificada como empresa familiar, mas é necessário que a propriedade pertença a uma família, pessoa física ou instituição que a represente, para ser classificada com empresa familiar.

Ainda referente à classificação de empresas familiares, para Neubauer e Lank (1998), será empresa familiar apenas se o controle societário da empresa estiver $100 \%$ (cem por cento) nas mãos da família. Entretanto, Gorgati (2004) salienta que devem ser analisados outros fatores que determinam influência de certa família ou pessoa física na corporação. Evidencia-se que não é condição necessária que a família ou controlador possua capital majoritário, para que a empresa tenha características de empresa familiar.

Salienta-se que este modo de analisar, por fatores de influência na administração da empresa, mitiga o erro de classificação de empresa familiar.

Para este trabalho, a empresa familiar é toda empresa que tem estrutura de propriedade semelhante a de uma empresa familiar, com estrutura de capital próprio concentrado, gerando concentração de poder e influência sobre a organização. (BERNHOEFT, 1987; MARTINS, MENEZES e BERNHOEFT, 1999).

Segundo Lanzana \& Costanzi (1999) pode ser definido como grau relevante de concentração da propriedade, como 5\%, desde que a família ou o controlador da empresa tenha possibilidade de interferir ativamente na empresa.

De acordo com essa argumentação supracitada, Anderson, Reeb \& Zhao (2012) argumentam que 5\% de controle acionário, associados a outros fatores como a quantidade de familiares na administração e no conselho, podem influenciar significativamente nas decisões tomadas pela empresa e, por conseguinte, no desempenho dessa.

Coadunam-se ainda às afirmações anteriores, a Lei 6.404/76 e suas alterações, em diversas disposições. Como, por exemplo, o $\S 1^{\circ}$ do Art. 157; $\S 4^{\circ}$ do Art. 159; $\S 2^{\circ}$ do Art. 161; $6^{\circ}$ do Inciso VIII do Art. 163; alínea b do Inciso II do Art. 206; alínea a do $§ 1^{\circ}$ do Art. 246; caput do Art. 277; Art. 105 e $\S 3^{\circ}$ do Art. 124, que atribuem ao acionista que represente 5\% (cinco por cento) ou mais do capital social, relevância para a empresa. 
Entretanto, salienta-se que a referida Lei 6.404/76, e suas leis que a derrogam, estabelecem outras porcentagens e parâmetros para classificação de influência sobre a empresa. Como exemplo, o $\S 5^{\circ}$ do Art. 243 estabelece que é presumido influência significativa, quando o investidor deter $20 \%$ (vinte por cento), ou mais, do capital votante da investida.

Outrossim, a referida Lei $6.404 / 76$ e suas leis que a derrogam; nos $\S 1^{\circ}$ e $\S 4^{\circ}$ do Art. 243 , estabelecem que não existe uma porcentagem correta para inferir se há influência na administração. Apenas, considera-se que há influência significativa, quando o investidor detém, ou exerce, poder nas decisões de política financeira ou operacional na empresa. Salienta-se ainda, que inclusive na lei das S.A.s, o parâmetro para medir e definir a influência na gestão da empresa é objetivo - o grau de propriedade acionária.

Dessa forma, visando à operacionalização conceitual do termo empresa familiar, para esta pesquisa, a empresa familiar será tratada como a empresa que tem acionista, pessoa física, que detém pelo menos $5 \%$ (cinco por cento) das ações ordinárias da empresa-objeto de análise, conforme já argumentado por Anderson, Reeb \& Zhao (2012); Lanzana \& Costanzi (1999); Martins, Menezes e Bernhoeft, (1999); e as disposições da Lei 6.404/76, e as leis que a alteram.

Evidencia-se ainda que o fator concentração acionária é relevante para empresas familiares e não familiares. Desse modo, aplicar-se-ão algumas classificações de concentração societária, em modelos distintos, verificando como a concentração impacta em empresas familiares e não familiares, em eventos de aquisições de empresas.

Referente à operacionalização e à classificação das variáveis empresa familiar e concentração acionária, salienta-se que serão ainda mais discutidas e definidas na seção: Definição Operacional das variáveis da pesquisa.

Por ora, apenas se informa que são consideradas relevantes para este trabalho as seguintes concentrações acionárias que podem influir no desempenho de empresas familiares ou não familiares, em eventos de aquisição aqui estudados:

i) Serão consideradas concentração acionária relevante empresas que tiverem como acionistas, pessoas físicas que detêm $10 \%$ (dez por cento), ou mais, de ações ordinárias da empresa-objeto de análise desta pesquisa;

ii) Serão consideradas empresas familiares as que tiverem como acionistas, pessoas físicas, que detêm $20 \%$ (vinte por cento), ou mais, de ações ordinárias da empresa-objeto de análise desta pesquisa; 
iii) Serão consideradas empresas familiares, em sua definição mais conservadora, e clássica, conforme Neubauer e Lank (1998), as que tiverem como acionistas, pessoas físicas, controladores que detenham mais de $50 \%$ (cinquenta por cento) das ações ordinárias da empresa-objeto de análise desta pesquisa.

Outrossim, reporta-se que é comum empresas familiares de grande porte, e listadas, mascarar, intencionalmente ou não, a concentração societária na empresa, por meio de estrutura piramidal de propriedade e/ou dispersão das ações ordinárias, não possuídas pelo agente controlador; seja por motivo de mercado, contábil-fiscal, societário, entre outras eventuais motivações.

Salienta-se, portanto, que serão verificadas, para as empresas da amostra, as estruturas piramidais de controle de propriedade, pois é bastante comum, no Brasil, famílias terem o controle de instituições que são proprietárias de outras empresas. Assim, passam a exercer influência indireta e significante, nessas empresas.

Neste trabalho, a classificação se pautará na variável propriedade societária. Foram estabelecidas, conforme a literatura apresentada, algumas porcentagens que indicam que a empresa é familiar e/ou que tem influência significativa de uma família e/ou pessoa física.

Outrossim, será verificado, conforme Astrachan (2010) e Rocha (2012), se a gestão familiar gera maior desempenho da empresa em eventos de aquisições de empresas.

\subsubsection{Erros de Definição de Empresa Familiar}

Segundo Rocha (2012), existem erros de definição de empresa familiar comumentes praticados pela academia e pelo mercado, representado por pesquisadores e consultores profissionais. Visando a não incorrer em erros de definição de empresa familiar na presente pesquisa, apresenta-se os principais erros na definição de empresa familiar, segundo o autor anteriormente citado:

i) Associar empresa familiar à empresa de capital fechado; pois, a classificação de empresa familiar independe se a empresa é de capital fechado ou listada em bolsa de valores;

ii) Associar empresa familiar à classificação jurídica de empresa limitada; pois, a classificação de empresa familiar independe da quantidade de acionistas;

iii) Associar empresa familiar à empresa de micro, pequeno ou médio portes. Evidencia-se que existem, proporcionalmente, empresas familiares em todas as classificações de porte de empresas. Inclusive, empresas familiares têm relevante participação em qualquer classificação de tamanho da empresa. 
Nesta pesquisa mitiga-se os erros anteriormente citados, ao restringir a amostra coletada às empresas familiares e não familiares listadas na Bolsa de Valores de São Paulo (BOVESPA), visando, também, a maior transparência na obtenção dos dados secundários, pois empresas listadas têm maior disclosure de suas informações, e há melhor evidenciação e histórico do valor de mercado das empresas listadas em bolsa.

\subsection{3 - Empresa Familiar no Exterior e Desempenho}

Empresas familiares dominam diversos segmentos de negócios no mundo inteiro. Como exemplo, a indústria global de bebidas, que é controlada por diversas empresas internacionais familiares como a InBev-Anheuser-Busch, a SABMiller, a Heineken, a FEMSA, a Carlsberg, entre outras empresas familiares menores (VILLALONGA e AMIT, 2010).

Segundo La Porta, López e Shleifer (1999), empresas familiares representam significativa porcentagem das empresas de médio (45\%) e grande (30\%) portes, em 27 países pesquisados.

Nos EUA, são diversas as famílias que controlam setores importantes da economia, como por exemplo, a indústria de editoração, mídia e radiodifusão, onde quinze das dezessete maiores empresas de capital aberto nos EUA são empresas familiares (VILLALONGA e AMIT, 2010).

Outrossim, Forbes (2009) cita diversas famílias que dominam segmentos de negócios nos EUA, como por exemplo, as famílias: Rockefeller, Bloomberg, Walton, Du Pont, Ford, Kennedy, Carnegie, Vanderbilt, Astor, Trump, Gates e Buffet.

Com ênfase à importância das empresas familiares norte-americanas, Rocha (2012) evidencia que, a pesquisa feita pelo IFERA (The International Family Enterprise Research Academy), em 2003, levantou que 95\% das empresas estado-unidenses eram familiares, e que essas empresas representavam $40 \%$ do produto nacional bruto nos EUA.

A Europa também cresceu com diversas famílias que dominam inúmeros segmentos de negócios, como por exemplo, as famílias: Rothschild, Arnault, Ortega, Albrecht, Kamprad, Persson, Bettencourt, Otto, Ferrero, Lisin, Prokhorov, Rausing, Fridman, Grosvenor, Abramovich, Klatten, Deripaska, Alekperov, Del Vecchio, Potanin, Bertarelli, Rausing e Berlusconi.

De acordo com Rocha (2012), uma pesquisa de 2003, do IFERA (The International Family Enterprise Research Academy), evidenciou que no continente europeu, países como França, 
Alemanha e Itália possuem uma porcentagem de empresas familiares, na economia, que varia de $60 \%$ a $85 \%$.

A Ásia, inclusive, foi adotada como modelo estratégico de crescimento nacional,com o patrocínio dos governos locais às empresas familiares (Zaibatsu e Chaebol), como ocorreu no Japão e Coreia do Sul, e de forma um pouco distinta, com a China e a Índia. Segundo a publicação da CNBC (2011) e Forbes (2012), existem diversas famílias que dominam inúmeros setores econômicos na região, como por exemplo, Wang, $\mathrm{Ng}$, Hartono, Hee, Kuok, Mittal, Kwok, Ka-shing, Ambani, Toyoda, Yamauchi, Mori, Takei, Itoyama, Yanai, Ito, Fukuda, Kinoshita e Takenaka.

Referente ao desempenho de empresas familiares no exterior, Sraer e Thesmar (2007) evidenciam que em sua pesquisa sobre empresas familiares listadas na bolsa da França, no período de 1994 a 2000, dois terços das empresas abertas eram familiares. Como resultado da pesquisa, encontrou-se que empresas familiares têm melhor performance que empresas não familiares. Outrossim, que esse resultado é significante, inclusive, a pesquisa analisou outros fatores de influência para a performance, como por exemplo, o controle da empresa pelo fundador; gestão profissional; e gestão por descendentes do fundador. Segundo os autores supracitados da pesquisa, em todos os casos, suporta-se que a empresa familiar tem melhor resultado que a empresa não familiar. Salienta-se ainda que, como variável de desempenho das empresas, foram utilizados múltiplos como ROA (Return on Asset), ROE (Return on Equity), Market to Book, entre outros.

Sraer e Thesmar (2007) afirmam também que encontraram que a variável gestão profissional tem pior desempenho em relação à gestão realizada pelo próprio fundador e seus descendentes, pois, na média, o gestor profissional arrisca menos, e tem um perfil mais conservador em relação aos gestores integrantes da família.

Por outro lado, Pérez-González (2006) afirma que, em sua pesquisa, analisando 335 empresas familiares norte-americanas, foi encontrado que a gestão por descendentes do fundador gera menor desempenho da empresa, pois, o nepotismo em empresas familiares acarreta grande ineficiência administrativa. Salienta-se que também foram utilizados como variáveis de performance ROA (return on asset), market to book, gastos com pesquisa e desenvolvimento, entre outros.

Referente ainda à performance de empresas familiares no exterior; Adams, Almeida e Ferreira (2009); Palia e Ravid (2003); Villalonga e Amit (2006) afirmam que empresas que têm suas 
famílias fundadoras ainda no comando, têm melhor valoração pelo mercado. Fahlenbrach (2009) evidencia ainda que $11 \%$ das maiores empresas norte-americanas ainda têm seu fundador como CEO (Chief Executive Officer), e que é significativo e robusto o maior desempenho da empresa com o fundador gerindo a própria empresa. Foi ainda encontrado na pesquisa de Fahlenbrach (2009) que fundadores-gestores investem mais em pesquisa e desenvolvimento, realizam mais aquisições de empresas e têm maior gasto em CAPEX (capital expenditure).

Já para Maury (2006), que analisou 1672 empresas do Oeste Europeu não financeiras, afirma que empresas familiares têm melhores índices de lucratividade, comparativamente às empresas não familiares. Outrosssim, evidencia que empresas que a própria família administra são ainda mais lucrativas.

\subsection{4 - Empresa Familiar no Brasil e Desempenho}

Empresas familiares no Brasil têm significativa importância para a economia nacional, pois representam 94\% das trezentas maiores empresas brasileiras. (GORGATI, 2004)

Segundo Mello et al. (2008), o desenvolvimento da economia brasileira está diretamente relacionado ao fortalecimento e desenvolvimento das empresas familiares nacionais. Em análise histórica, o Brasil teve seu desenvolvimento relacionado a iniciativas familiares, como por exemplo, cita-se Irineu Evangelista de Sousa (Barão e Visconde de Mauá), um dos grandes empreendedores brasileiros, que desenvolveu suas empresas de forma verticalizada, e, dessa maneira, estruturou diversos setores da economia brasileira.

Outrossim, juntamente com a iniciativa do imperador Dom Pedro II; o Barão de Mauá foi grande incentivador e patrocinador do ensino sobre comércio e registro contábil no país. Evidenciam-se, ainda, outras famílias de grande influência para o desenvolvimento do país, como por exemplo, as famílias Penteado, Matarazzo, De Moraes, entre outros.

A Forbes (2012) cita diversas famílias relevantes no Brasil, que dominam diversos segmentos de negócios no país, como por exemplo, as famílias: Batista, Safra, Lemann, Branco, Villela, Marinho, Telles, Sicupira, Diniz, Esteves, Faria, Seabra, Civita, Steinbruch, Setubal, Mello, Saverin, Rocha, Bueno, Moreira Salles, Parisotto, Horn, Leal, Queiroz, Grandin, Bozano, de Souza, Aguiar, Garfinkel, Schincariol, Cavalcanti, Paulus, Goldfarb, Johannpeter, Auriemo, Zarzur, Grendene Bartelle, Carneiro, Rolim Amaro, Molina, dos Santos, Birman, Klein, Bertin, Resende, Mattar, Terpins e Jereissati. 
Referente ao desempenho de empresas familiares, no Brasil, ainda é escasso na academia o estudo sobre esse assunto. As maiores fontes de informações sobre empresas familiares no país ainda são oriundas do mercado, como exemplo, de acordo com a pesquisa da PriceWaterHouseCoopers (2011), as empresas familiares brasileiras obtiveram desempenho superior ao resultado global das empresas mundiais em 2012. A referida pesquisa inclusive evidencia mudanças na visão dos gestores de empresas familiares brasileiras, para os próximos anos, onde as empresas familiares tendem a focar na competição globalizada, nos mercados doméstico e internacional. Desta forma, a aquisição de empresas pode vir a ser uma ferramenta útil, visando ao aumento de competitividade e inserção como player global.

\subsection{5 - Ciclo de Vida da Empresa Familiar}

Segundo Gorgati (2004), os ciclos de vida na empresa familiar não são tão distintos do ciclo de vida das empresas não familiares, a não ser pelo fato de que as relações e laços familiares afetam no desenvolvimento do ciclo empresarial. Isto pode evidenciar que há diferenças significativas no desempenho das empresas em diferentes gerações familiares.

Ao analisar o ciclo de vida da empresa familiar, é preciso equilibrar o trinômio: desenvolvimento da empresa, da família e da propriedade, que passa por um processo de três fases: início, expansão e maturidade. (GERSICK et al., 1997).

De acordo com os autores supracitados, o início da empresa familiar é geralmente marcado pelo viés do excesso de otimismo, determinação, gosto pelo risco, e pela proatividade.

São diversas as motivações para a formação de uma empresa, como exemplo, citam-se: a incapacidade do empreendedor de adequar-se a papéis nos sistemas já existentes, experiências anteriores, falta de oportunidade econômica (necessidade de sobrevivência), oportunidade gerada pelo mercado, entre outras motivações. (GERSICK et al. , 1997; GERA, 2011).

Entretanto, o início/abertura de negócios no Brasil está geralmente relacionado à necessidade de sobrevivência. Enquanto que, em países mais desenvolvidos, a motivação dada pela oportunidade gerada pelo mercado é observada com mais frequência. (GERA, 2011).

Para Gorgati (2004), o início da empresa, geralmente é caracterizado por concentração total de propriedade e gestão, na figura do empreendedor, que incutirá seus valores, sua visão, sua dinâmica de trabalho, e suas habilidades, que poderão ser diferenciais competitivos no mercado. 
Já na fase de expansão, os filhos do fundador geralmente encontram desafios, como por exemplo, manter o crescimento da empresa. Assim, buscam fontes de financiamento para promover a expansão empresarial e/ou a adequação da carteira de produtos para as novas necessidades do mercado. (GORGATI, 2004)

Na fase da maturidade, Gorgati (2004) salienta que é fundamental a formalização das políticas e processos internos da empresa para minimizar conflitos de interesses entre uma quantidade, nesta fase maior de acionistas. Vale citar que o grande desafio da empresa madura é a maior necessidade de renovação da carteira de produtos, pois, geralmente nessa fase, o mercado já mudou significativamente, e a empresa precisa se readequar para sobreviver a um mercado muito distinto da primeira e/ou segunda gerações.

Evidencia-se que as variáveis mais relevantes para o desempenho e perpetuidade da empresa familiar são: i) sucessão, ii) concentração acionária, iii) controle administrativo da empresa pela própria família e iv) obtenção de fonte de financiamento para as atividades corporativas. (DONNELLEY, 1967; FRUGIS, 2007; BERNHOEFT, 1987; GORGATI, 2004).

\subsection{6 - Sucessão na Empresa Familiar}

O processo de sucessão é um dos grandes riscos da empresa familiar. Desse modo, para que esta continue com crescimento elevado e perpetue, no mercado, esse processo é primordial. Assim, deve ser realizado com toda cautela e preparação possível. (DONNELLEY, 1967; FRUGIS, 2007; BERNHOEFT, 1987; GORGATI, 2004).

O entendimento da importância do processo sucessório em uma empresa familiar é essencial para a resolução de possíveis conflitos por ele gerados, já que as discussões dos processos sucessórios em empresas familiares têm se tornado cada vez mais frequentes e imprescindíveis. (GORGATI, 2004).

Enfatiza-se que, inevitavelmente, em um determinado tempo, será preciso haver sucessão, preparada adequadamente ou não. Salienta-se que, geralmente, o processo de sucessão é falho nas empresas familiares. Haja vista a enorme taxa de mortalidade que assola as empresas familiares, decorrente da preparação inadequada de sucessores, entre outras causas.

O processo sucessório é lento, a preparação dos sucessores depende do empenho e objetivos familiares, pois envolve as três dimensões da empresa familiar - a família, propriedade e gestão. (GORGATI, 2004). 
Para Bernhoeft (1987), o processo sucessório em empresas familiares não pode ser tratado apenas sobre os aspectos racionais, pois envolve pontos afetivos e emocionais, relacionados à própria estrutura familiar. Já, Lodi (1998) afirma que o êxito de um programa sucessório depende da maneira como os sucessores foram preparados para a gestão da empresa e a administração da riqueza.

Referente ao processo de sucessão, Lodi (1998) afirma que o sucessor deve ter um aprendizado profissional em outras empresas antes do início da dedicação total à empresa da família. Salienta-se que, ao iniciar na empresa familiar, deve-se começar por baixo, aprendendo as áreas- chave da empresa, para quando chegar ao posto de comando, tenha conquistado o conhecimento generalista importante para os cargos executivos. Deve-se ainda permitir e analisar a priori a completude do processo de aprendizagem do sucessor, para que possa, então, assumir as responsabilidades da direção estratégica.

Evidencia-se ainda um outro grande problema no processo sucessório, o duplo comando, que gera disputa de poder e prejudica o gerenciamento da empresa familiar. Como sugestão de resolução desse problema, são colocados alguns tópicos, como a importância do respeito mútuo, o correto funcionamento do conselho de administração e a clara passagem do bastão do fundador ao sucessor. É importante comentar que a raiz de vários problemas, durante o processo de sucessão, pode estar centrada na dificuldade do fundador em passar a gestão para o sucessor. (LODI, 1998; FREIRE, 2009b).

Essa dificuldade pode ser mitigada sobretudo pelo funcionamento correto do Conselho de Administração. $\mathrm{O}$ fundador ou o atual gestor da empresa familiar pode continuar na empresa como conselheiro, e minimizar gradualmente a saída do antigo gestor e, assim, fortalecer a "passagem do bastão" para seus sucessores.

Entretanto, enfatiza-se que há diversos fatores que podem prejudicar a sucessão dos gestores da empresa familiar. Dessa maneira, é comum a venda da propriedade da empresa para outras famílias, bem como a pulverização do capital social em bolsas de valores mobiliários, ou mesmo, a venda da empresa para agentes financeiros e/ou grupos de negócios. Esses são alguns cenários extremamente ordinários na realidade das empresas familiares com o passar das gerações.

Assim, ao unir o conceito de ciclo de vida das empresas familiares e processos sucessórios, reconhece-se a diversidade de conflitos possíveis originados das dinâmicas familiar e empresarial, que se sobrepõem e atuam concomitantemente, podendo causar problemas não 
sanáveis entre o elo familiar e o resultado pode ser a dissolução e/ou venda da sociedade. (GORGATI, 2004).

O motivo principal dos possíveis conflitos é que já há intrinsecamente um conflito préexistencial entre a instituição família e a instituição sociedade empresarial, na empresa familiar. (GORGATI, 2004) Está claro que são duas variáveis distintas, que estão intrinsecamente ligadas na empresa familiar, que devem ser otimizadas, e, de certa forma, o ponto máximo global é difícil de ser atingido.

Geralmente, uma das duas variáveis é afetada (pode haver desequilíbrio entre os pesos família e empresa) e, como consequência, o desempenho geral da empresa familiar é afetado. Em outras palavras, a empresa familiar é mais suscetível a problemas existenciais que a empresa não familiar, por isso ,tende-se, em longo prazo, a se tornar uma empresa não familiar.

Salienta-se então que este trabalho tem como premissa clarificar que, com o passar das gerações, a empresa vai se tornando menos familiar. Ou seja, a empresa pode passar a ser propriedade de outros agentes e/ou ter seu capital social pulverizado, em decorrência de erros de sucessão da família fundadora.

\subsection{7 - Vantagens e Desvantagens das Empresas Familiares}

Segue a argumentação das vantagens e desvantagens das empresas familiares em relação às empresas não familiares.

Segundo Frugis (2007), as empresas familiares têm diversas vantagens, como por exemplo:

i) Pensamento a longo prazo: empresas familiares costumam pensar, e agir, com propósito de longo prazo. Desta forma, tendem a ter melhores resultados do que empresas não familiares, que geralmente costumam agir a curto prazo, devido sobretudo, porque os executivos em empresas não familiares têm tempo determinado de gestão, e são pressionados constantemente pelos acionistas e pelo board, a terem resultados imediatos. Logo, este imediatismo, pode gerar resultados menos favoráveis às empresas não familiares.

Em harmonia com a vantagem ocasionada pelo maior pensamento a longo prazo das empresas familiares, citado anteriormente por Frugis (2007), De Visscher, Aronoff $e$ Ward (1995) afirmam ainda que empresas familiares consideram seu capital próprio como um capital paciente. Embora deseje um retorno imediato sobre seus investimentos no negócio, a família, geralmente é mais paciente com relação aos investimentos realizados, pois tem um olhar voltado para o futuro e para os retornos dos investimentos, e visa, principalmente, à 
continuidade da empresa, da tradição e da herança familiar. Este tipo de visão em longo prazo pode ter maior potencial de retorno que o imediatismo das empresas não familiares.

Frugis (2007) cita ainda outras vantagens das empresas familiares, como:

ii) Conhecimento: refere-se ao segredos empresariais, o modo particular de como é feita determinada função, a habilidade e conhecimento tácito que o fundador transfere expressamente ou tacitamente, para empresa; fatores estes, que muitas vezes, são determinantes para o sucesso da empresa;

iii) Flexibilidade: a empresa familiar, em geral, tem maior rapidez para tomadas de decisões corporativas. Ao contrário das empresas não familiares, que por conta do problema de agência, devido aos executivos poderem tomar decisões que não maximizem a riqueza dos acionistas, geralmente, adota-se estrutura burocrática mais bem-desenvolvida, com o intuito de controle sobre o agente administrador;

iv) Cultura: empresas familiares tendem a ter cultura organizacional mais estável, devido ao maior tempo de permanência dos seus gestores na administração da empresa. Ao contrário de empresas não familiares, que a cada gestão muda-se o estilo do gestor, como as tarefas são feitas, como a empresa é vista do ponto de vista estratégico.

v) Prestígio e liderança: refere-se aqui, ao sentimento de prestígio e liderança natural que o fundador, muitas vezes, tem em relação aos seus funcionários, fornecedores, clientes e parceiros comerciais. Este referido prestígio faz com que clientes possam se relacionar com empresas em que sua administração não estejam em constantes mudanças de políticas, cargos e regras.

Por outro lado, como desvantagens de empresas familiares, segundo ainda Frugis (2007) destaca:

a) Concentração de poder: este fato, muitas vezes pode prejudicar a empresa, pois, a concentração de poder, torna a empresa familiar mais frágil do que empresas com maior dispersão de poder. Para este trabalho, refere-se à concentração de poder, como concentração de participação acionária, que possa resultar significativa influência na gestão da empresa;

b) Sucessão: refere-se à passagem da empresa às gerações seguintes, que muitas vezes são falhas. Ocasionando maiores riscos de continuidade e desempenho à empresa familiar. O autor supracitado evidencia que menos de $30 \%$ das empresas, chegam à segunda geração, e somente, cerca de $10 \%$, chegam à terceira;

c) Questões emocionais: podem interferir significativamente nas ações, e nas tomadas de decisões da empresa familiar. Entretanto, salienta-se que não significa que este tipo de problema não possa ocorrer em empresas não familiares, mas evidencia-se, que o fator emoção é mais frequente em empresas familiares. Devido aos laços familiares e ligações afetivas que seus acionistas geralmente têm com a empresa.

Outra desvantagem e/ou vantagem de empresas familiares é que, segundo Forbes (2005), há relação significante entre fundadores de empresas familiares e o viéis de excesso de confiança. Observa-se que, embora as heurísticas obtidas por meio da experiência do fundador possam ser úteis na gestão da empresa, o excesso de confiança dado pela experiência passada também pode ocasionar sérios de erros sistemáticos e tomadas de decisões equivocadas (TVERSKY e KAHNEMAN, 1974; BAZERMAN e MOORE, 2010; RUSSO E SCHOEMAKER, 1991 e 1992; FORBES, 2005). Dessa forma, segundo Alvarez e 
Busenitz (2001), não há como definir se o viés de excesso de confiança e a utilização de heurísticas possam ser uma vantagem ou desvantagem empresarial.

\subsection{8 - Concentração Acionária, Poder, Influência e Hubris em Empresas Familiares}

De acordo com a teoria de que as empresas familiares têm maiores vantagens em relação às empresas não familiares, Toffler (1980 e 1998); Frugis (2007); Schuman, Stutz \& Ward (2010); Li \& Srinivasan (2011); Anderson, Reeb \& Zhao (2012) afirmam que a centralização de poder, associada à expertise e ao prestígio do seu fundador, podem resultar em decisões mais rápidas e eficientes, adaptando-se melhor às novas necessidades do mercado e, por conseguinte, maior potencial de desempenho da empresa.

Salienta-se, entretanto, que existe um hiato em relação às consequências dos fatores/variáveis: concentração de poder e empresas familiares. Assim, pode-se dizer que a expressão empresa familiar tem, no universo popular, conotação pejorativa, devido ao fator de concentração de poder estar associado, muitas vezes, ao nepotismo e à ineficiência (GORGATI, 2004; FRUGIS, 2007).

Outrossim, segundo Roll (1986), a concentração de poder pode desencadear no viés de excesso de confiança, chamado "Hubris hypothesis". Esse excesso de confiança, segundo o autor supracitado, pode resultar em retornos medíocres para a empresa.

Evidencia-se ainda que outros autores corroboram com as argumentações realizadas por Roll (1986). Como por exemplo, Bazerman e Moore (2010) e Tversky e Kahneman (1974) afirmam que a concentração de poder pode gerar para o tomador e/ou influenciador das tomadas de decisão da empresa o viés de excesso de confiança, que está associado a resultados negativos para a empresa.

Por outro lado, Gallo e Vilaseca (1998); Toffler (1998); Schuman, Stutz \& Ward (2010); Li \& Srinivasan (2011) e Anderson, Reeb \& Zhao (2012) defendem que os fatores concentração de poder e a maior participação ativa da família na empresa são significantes para o desempenho superior da empresa familiar. Segundo os autores supracitados, a concentração de poder mitiga os custos de agência, já que facilita o maior alinhamento entre os objetivos dos acionistas e do agente administrador, devido, sobretudo, ao fator vigilância do próprio proprietário na empresa. 
Ainda referente aos fatores concentração acionária e Hubris hypothesis, criticando a visão de Roll (1986), Sraer e Thesmar (2007) afirmam que há evidências de que o fator confiança que o gestor tem em si mesmo é na realidade importante alavanca para o resultado da empresa. $\mathrm{Ou}$ seja, a confiança do gestor em si próprio pode gerar maior desempenho para a empresa. Apenas salienta ainda que o fator concentração acionária pode aumentar o nível de confiança do gestor.

Portanto, conclui-se, com base nos argumentos anteriormente apresentados neste trabalho, que fatores, como expertise, experiência, prestígio, liderança, entre outros, podem influenciar no desempenho da empresa com característica familiar, bem como os fatores concentração acionária, poder, influência e hubris.

\subsection{9 - Controle e Gestão da Empresa Familiar pela própria Família}

Segundo Tàpies e Ward (2008); McConaughy, Matthews, e Fialko (2001); Rosenblatt et al. (1985); Kets de Vries (1993); McCounaughy et al. (1998), quando o controle e a gestão da empresa estão nas mãos da família há maior potencial de criação de valor do que em relação às empresas cujas famílias controladoras não as supervisionam e as gerenciam.

Outrossim, há evidências de que o Q de Tobin aumenta quando membros da família estão em posições privilegiadas no board da empresa, pois, a família tende a vigiar melhor as ações dos agentes administrativos da empresa e, como resultado, gera-se maior valor à empresa decorrente dos fatores controle e vigilância (MORCK, SHLEIFER e VISHNY, 1988; MCCONAUGHY, MATTHWES e FIALKO, 2001).

Em concordância ainda, com o contexto das afirmações acima, Zahra (2005); Fernández e Nieto (2005); Molly, Laveren e Jorisen (2012) afirmam que, quando novos membros da família se envolvem ativamente na gestão da empresa, aufere-se como resultado um significativo aumento de crescimento da empresa e renovação das estratégias corporativas.

Outrossim, segundo Molly, Laveren e Jorisen (2012), a entrada de novos membros da família na empresa está associada à maior inovação e à internacionalização da empresa. Desse modo, reitera-se que os fatores resultantes do input mencionado são o maior crescimento e geração de valor à empresa.

Referente ao controle e gestão da empresa familiar, sob a perspectiva de governança corporativa e estrutura de capital, a cada geração que passa, a empresa familiar se torna mais 
parecida com empresas não familiares, ou seja, com controle e gestão mais difusos (KELLERMANNS e EDDLESTON, 2004; BLANCO-MAZAGATOS, QUEVEDOPUENTE e CASTRILLO, 2007; MOLLY, LAVEREN e JORISEN, 2012).

De acordo com os autores supracitados, a desconcentração do capital social da empresa gera maior assimetria de informação entre os acionistas, o que resulta na necessidade de adoção de medidas contentoras, como por exemplo, o aumento do custo de agência, para maior controle das ações do gestor. Também, cita-se como outra alternativa, a contratação de agente administrativo externo com o intuito de mediar rivalidades, visões e interesses conflitantes entre um número maior de acionistas.

Esta inevitável profissionalização da administração, decorrente do crescimento da empresa e da desconcentração do capital acionário, gera menor eficiência e menor desempenho da empresa. (KELLERMANNS e EDDLESTON, 2004; BLANCO-MAZAGATOS, QUEVEDO-PUENTE e CASTRILLO, 2007; MOLLY, LAVEREN e JORISEN, 2012).

O resultado apresentado anteriormente é devido, sobretudo, à maior possibilidade de oportunismo, em que cada stakeholder tenta maximizar seu próprio interesse diminuindo a maximização do interesse dos acionistas, conforme já discutido na seção da teoria da firma. Outrossim, o agente contratado, muitas vezes, não tem todas as qualidades e interesses de um membro da família, sobretudo, quando comparado com o próprio fundador, ou descendente próximo.

Portanto, como inferência e conclusão dos argumentos apresentados nesta seção, coloca-se que, quanto maior a concentração acionária e a participação da família na gestão da empresa, maior o potencial de desempenho desta, sobretudo, quando o fundador ainda está na empresa e propaga suas qualidades diferenciadas, que a levaram a crescer e se desenvolver, como por exemplo, o expertise, experiência, prestígio, liderança intrínseca e empreendedorismo nato. Assim, evidencia-se que a maior vigilância da empresa pelo próprio proprietário corrobora ao maior desempenho da empresa.

Por outro lado, quanto menor o controle acionário e a participação da família na gestão da empresa, menor o potencial de desempenho desta, devido, sobretudo, a fatores, como: o aumento do custo de agência e maior conflitos de interesses (oportunismo). 


\subsubsection{1 - Controle e Gestão da Empresa Familiar pelo próprio Fundador e/ou de seu Herdeiro direto de segunda Geração}

Segundo Frugis (2007), mesmo que possa haver hubris por parte do fundador, este teria melhores condições de gestão da empresa que seus sucessores, sejam familiares ou agentes não familiares, já que suas qualidades como empreendedor nato, líder natural da empresa, prestígio, expertise e experiência, sobrepõem-se. Outrossim, seus sucessores, sejam familiares ou não, podem também ter viés de excesso de confiança (hubris) como parte de sua personalidade intrínseca. Nesse caso citado de possibilidade de existência de excesso de confiança, também por parte dos sucessores do fundador da empresa, resulta-se na equalização das potenciais ameaças geradas pelo fator hubris, mas não nas oportunidades decorrentes das qualidades mencionadas anteriormente referentes ao fundador.

O hubris (viés de excesso de confiança) para este trabalho é visto como uma ameaça, e não como um defeito. Vale ressaltar que arriscar é parte integrante da atividade empresarial, devido, sobretudo, à racionalidade limitada do homen (Simon, 1957). Salienta-se que as tomadas de decisões consideradas mais arriscadas podem também ser relacionadas a gestões de alto desempenho, tornando-se, muitas vezes, uma característica favorável (qualidade).

Evidencia-se também que autores como Bazerman e Moore (2010), e Russo e Schoemaker (1991) enfatizam a necessidade de mensurar os riscos e ter o máximo de informações possíveis antes da tomada de decisão. Entretanto, Forbes (2005) afirma que quanto maior a compreensão do problema, maior o viés de excesso de confiança.

Logo, o risco proveniente do viés de excesso de confiança (hubris) é uma variável que pode se tornar uma ameaça e/ou oportunidade para a empresa.

Coloca-se ainda que o laço emocional familiar, resultando esforço e devoção em prol da empresa, geralmente observado em sucessores arraigados ao legado e próximos ao fundador, pode gerar desempenho superior.

De acordo com Frugis (2007) e Bernhoeft (1987), a segunda geração ainda continua o crescimento anormal da empresa, sobretudo, porque o fundador, muitas vezes, ainda é muito presente no Conselho de Administração, e geralmente consegue treinar seu sucessor, transmitindo-lhe alguns conhecimentos tácitos e habilidades necessárias para a continuação do desenvolvimento da empresa. 
Donnelley (1967); Martins, Menezes e Bernhoeft (1999) afirmam que a expansão da empresa familiar ocorre, sobretudo, na segunda geração de dirigentes, pois, a primeira geração (fundador) abre caminhos para seus sucessores com uma ideia e atitudes que deram certo. Nessa primeira fase, obtém-se grande crescimento, mas geralmente, o problema de financiamento e a captação de recursos insuficientes acabam por dificultar o crescimento.

Segundo os autores supracitados, na segunda geração, a empresa consegue se capitalizar melhor internamente (capital próprio) devido ao fluxo de caixa mais elevado, o que propicia maior reinvestimento dos lucros. E, sobretudo, externamente (capital de terceiros) devido ao melhor relacionamento com instituições financeiras, decorrente do maior tempo de funcionamento e o maior tamanho e solidez da empresa, o que resulta no boom da expansão corporativa.

Entretanto, devido ao ritmo mais acelerado de desenvolvimento do mercado interno, do sistema financeiro, bancário, de crédito e do mercado de capitais, é comum observar empresas na primeira geração que já conseguem alta capitalização interna (capital próprio), e sobretudo, externa (capital de terceiros).

Essas empresas se desenvolvem, de tal forma, que rapidamente realizam IPOs (Initial Public Offers), na bolsa de valores de São Paulo (BOVESPA), e até mesmo, realizam aquisições no exterior, na busca por recursos estratégicos para seu crescimento e estruturação corporativa.

Portanto, como síntese desta seção, quanto ao crescimento da empresa e geração de valor aos acionistas, geralmente ocorrem, com maior vigor, na primeira e na segunda gerações da empresa.

\subsubsection{2 - Controle e Gestão da Empresa Familiar pelos Familiares de Terceiros ou mais de Gerações do Fundador}

Segundo Gorgati (2004), a estrutura societária na empresa de terceira ou mais gerações está geralmente mais diluída, em razão da entrada na sociedade de terceiros, associados aos filhos, netos do fundador, e/ou inclusive, pessoas fora do círculo familiar inicial. Entretanto, não perde as características de empresa familiar.

De acordo com Donnelley (1967); Martins, Menezes e Bernhoeft, (1999), Frugis (2007); Bernhoeft (1987) e Gorgati (2004), a terceira geração, geralmente, tem menor crescimento da 
empresa e menor geração de valor aos acionistas. Como fatores apresentados para o menor crescimento e geração de valor, segundo os autores supracitados têm-se:

i) menor centralização acionária, resultando menor influência e vigilância pessoal dos próprios proprietários na empresa;

ii) maior risco de sucessão, devido ao maior número de potenciais sucessores;

iii) maior dispersão e conflito de interesses dos acionistas para com a empresa, devido ao maior número de acionistas. Espera-se uma maior quantidade de pontos de vista distintos, resultando maiores conflitos entre os acionistas;

iv) maior custo de agência, pois, com o aumento de acionistas e a pulverização do controle, tende-se a exigir um maior controle dos gestores. Em alusão à administração pública, cria-se um maior sistema burocrático, inflexibilizando a gestão, visando a evitar eventual utilização do poder de gestão (discricionariedade) para fins próprios (prevaricação).

De acordo com Molly, Laveren e Jorissen, e em concordância com as afirmações anteriores, (2012) há diferenças significativas entre desempenho de empresas familiares de diferentes gerações, pois, quanto maior o grau de geração da empresa, mais conservadores tende a ser os gestores em relação às tomadas de decisão que envolvem risco. Assim, alteram-se, consideravelmente, as orientações institucionais de crescimento, desempenho e gerenciamento da empresa. Ou seja, geralmente, perdem-se significativamente as características intrínsecas, fundamentais da empresa, oriundas dos fundadores empreendedores.

Nesse sentido, Forbes (2005) afirma que quanto maior a idade da empresa, do gestor e da variável relação com investidores externos (bancos, por exemplo), menor é o viés de excesso de confiança do gestor. Dessa forma, pode haver menores desempenhos, pois há menores riscos tomados e menores possibilidades de ganhos anormais.

De acordo com as afirmações anteriores, McConaughy e Phillips (1999); Molly, Laveren e Jorisen (2012) encontraram que empresas familiares com geração mais afastada do fundador tendem a explorar menos novas tecnologias e mercados, o que resulta menor crescimento e geração de valor para a empresa. 


\subsubsection{0 - Relação com Investidores Institucionais, Grupos de Negócios, Agentes Financeiros, Governo, entre outros eventuais Blockholders}

Segundo Shleifer e Vishny (1986); Bertrand e Mullainathan (2000); Hartzell e Starks (2003); Cremers e Nair (2005); Edmans (2009); Edmans e Manso (2011); e Kim e Lu (2011), o fato de a empresa familiar ter relações com investidores institucionais, grupos de negócios, agentes financeiros, governo, entre outros eventuais blockholders, pode influenciar significativamente no desempenho da empresa, devido ao tráfico de influência ocasionado da relação com blockholders.

Conforme já citado, Forbes (2005) evidencia que empresas que têm relação com investidores externos, têm gestores com menores graus de viés de excesso de confiança. Dessa forma, os gestores tomam menos decisões com maiores riscos para a organização. Esse fato pode ocasionar menores desempenhos nos resultados obtidos.

Outrossim, blockholders podem agregar à empresa familiar maior expertise em gestão e monitoramento, o que gera maior potencial de desempenho para as empresas relacionadas aos blockholders.

Para este trabalho, não serão considerados como blockholders os insiders (administradores) e acionistas controladores (família), pois, os acionistas controladores ou família, são justamente o foco de análise da pesquisa, e serão classificados separadamente a posteriori.

\subsection{Aquisições de Empresas}

Esta seção abordará aquisições de empresas como parte da fundamentação teórica para o presente trabalho.

\subsubsection{Conceito, Características e Classificação dos tipos de Aquisições de Empresas}

As aquisições de empresas, principalmente a partir da década de 80, do século $\mathrm{XX}$, tiveram grande destaque no cenário econômico global. Esse período teve como grande fator impulsionador o intenso desenvolvimento tecnológico das telecomunicações, dos transportes, e da maior integração político, econômico e aduaneiro. (CAMARGOS e COUTINHO, 2008). Segundo Nardi (2012), os choques econômicos, tecnológicos e institucionais motivam ainda mais a ocorrência de eventos de aquisições de empresas em um determinado mercado e país. 
Como definição do conceito de aquisição de empresas, pertinente para o desenvolvimento da pesquisa empírica, cita-se Miranda e Martins (2000):

Aquisição é a compra de participação acionária de uma determinada empresa já existente, sem que isso implique necessariamente em mudança de seu controle gerencial por meio da propriedade total das ações, nem o desaparecimento de sua personalidade jurídica.

O quadro a seguir mostra as classificações de operações de aquisições de empresas existentes.

Quadro 1 - Classificação dos Processos de aquisições de Empresas

\begin{tabular}{|c|c|}
\hline Classificação & Definição \\
\hline Horizontal & Quando o processo envolve empresas atuantes no mesmo ramo de atividade. \\
\hline Vertical & $\begin{array}{l}\text { Quando o processo envolve empresas atuantes na mesma cadeia produtiva, } \\
\text { podendo ser a montante, em direção aos fornecedores; ou a jusante, em direção } \\
\text { aos clientes. }\end{array}$ \\
\hline Conglomerado & Quando o processo envolve empresas de ramos de atividades não relacionadas. \\
\hline Congênere & $\begin{array}{l}\text { Quando processo envolve empresas da mesma indústria, mas não no mesmo } \\
\text { ramo de atividade, não sendo fornecedor ou cliente. }\end{array}$ \\
\hline
\end{tabular}

Fonte: Adaptado de Camargos e Coutinho (2008).

Segundo Penrose (1959) e Wood (1971), os dois principais tipos de classificação estratégicas quanto à aquisição de empresas são a operação relacionada e a não relacionada. A primeira, relacionada ou concêntrica, em que a empresa adquirente adiciona atividades em comum a seu portfólio, e a segunda é a diversificação conglomerada - não relacionada, em que ocorre a entrada, em novas áreas de especialização não relacionadas com seu portfólio já existente.

Referente às aquisições relacionadas, há evidências de que podem resultar melhores desempenhos, devido às similaridades em sua cadeia produtiva e de suprimentos, obtendo maior economia de escala e foco para crescimento e expansão da empresa (LEMELIN, 1982; SCOTT, 1983; MACDONALD, 1985).

Para Penrose (1959), Guimarães (1982a, 1982b) e Teece (1982), as empresas realizam aquisições de empresas para maximizar seus excedentes, na procura pelo potencial de crescimento acima da média de mercado.

As transações de forma conglomerada, em função das restrições específicas de recursos internos, como por exemplo, a falta de conhecimento e habilidades necessárias para a entrada em outros segmentos, possibilidade de perda de foco e eficiência, escassez de recursos financeiros, para o contínuo reinvestimento em todas as áreas de negócios, acabam por limitar 
a quantidade de possibilidade de diversificação da empresa.

Abaixo segue um breve trecho de Penrose (1959), que versa sobre a limitação da empresa, devido à escassez de recursos.

Uma empresa pode entrar em diversos segmentos, mas para mantê-la competitiva, deverá estar preparada para sempre reinvestir em cada segmento atuado. Esta necessidade de re-investimento contínuo irá restringir sua diversificação em uma quantidade de segmentos suportáveis em qualquer período de tempo.

Evidencia-se ainda nessa seção que aquisições de empresas podem ser bons meios de obtenção de resultados superiores e busca de melhores recursos para a empresa. Entretanto, sua execução deve ser bem-planejada e executada, pois, a maior parte dos processos de aquisições de empresas têm resultados negativos, tanto para a empresa adquirida, quanto para a adquirente. Em geral, observa-se que a empresa adquirida perde sua cultura e sua visão corporativa, que muitas vezes eram os diferenciais para o sucesso da empresa. Enquanto que a empresa adquirente, geralmente, paga ágio na compra de uma empresa, e o mercado mal avalia a transação devida, sobretudo, aos riscos incorridos na operação (GUARITA, 2002).

\subsubsection{Motivações para a realização de Operações de Aquisição de Empresas}

Para Camargos e Coutinho (2008), os processos de aquisições de empresas decorrem naturalmente da origem e da evolução da empresa e de sua atividade empresarial. Dessa maneira, a origem geralmente é marcada por uma estrutura organizacional familiar de propriedade concentrada. Assim, à medida que a empresa evolui e cresce, inicia-se a necessidade de adoção de outras práticas administrativas, como por exemplo, a contratação de gestores profissionais e utilização da ferramenta de aquisição de empresa, com a finalidade de obter maiores e melhores resultados.

Conforme já abordado na seção Teoria da Firma, salienta-se que, embora as operações de aquisições de empresas sejam atividades comuns entre empresas familiares e não familiares, a teoria geral, que serve de suporte para os temas supracitados, não está totalmente consolidada na literatura. Na realidade, o que existe é um conjunto de explicações que se propõem a lhe conferir legitimidade e embasamento teórico, mas toda essa fundamentação deriva principalmente de aspectos da teoria da firma. (CAMARGOS e COUTINHO, 2008; GORGATI, 2004; ROCHA, 2012). 
Segundo Camargos e Coutinho (2008), as motivações para a realização de aquisições de empresas encontram suporte teórico nos diversos enfoques da teoria da firma, como por exemplo, a economia dos custos de transação de Coase (1937), e a teoria da economia dos custos de administração, de Alchian e Demsetz (1972), que explicam o surgimento, existência e crescimento da empresa. Enquanto que a teoria de monopólio de stigler (1950), a teoria de alocação de recursos, de Penrose (1959), a teoria de maximização da riqueza dos acionistas, de Jensen e Meckling (1976), a teoria do mercado de controle corporativo, de Manne (1965), entre outras teorias e autores, dão base para explicação de parte das motivações da realização de aquisições de empresas.

De acordo ainda com Camargos e Coutinho (2008), a teoria da firma fundamenta o surgimento e evolução da empresa, bem como as atividades de aquisições de empresas, como ferramentas utilizadas para o crescimento e seu desenvolvimento (PENROSE, 1959).

Existem diversos motivos para a realização de aquisições de empresas, que são suportados pela teoria da firma, principalmente na teoria do crescimento, de Penrose (1959), bem como na teoria da agência e da governança gorporativa. (CAMARGOS E COUTINHO, 2008).

Segundo Berkovitch e Narayan (1993), e Seth, Song e Pettit (2002), os principais motivos para a execução de aquisições de empresas são:

- Sinergia que pode haver entre adquirente e adquirida, resultado em ganhos econômicos decorrentes da união das empresas;

- Managerialism, cuja motivação para a realização de aquisição de empresas é que os gestores se atraem pela possibilidade de aumentar o tamanho de sua empresa visando a interesses pessoais de aumento de salário, prestígio e maior evidência no mercado;

- Hubris de Roll (1986), onde o excesso de confiança do gestor gera maior propensão na realização de operações de aquisições de empresas.

Segundo ainda Seth, Song e Pettit (2002), quando há combinação de sinergia e hubris são encontrados retornos totais positivos nas operações de aquisições de empresas. Entretanto, quando há a combinação de hubris e managerialism hypothesis, há evidências consistentes da existência de retornos totais negativos nas operações de aquisições de empresas.

Segundo (Seth, 1990a; Dawar \& Frost, 1999; Gubbi et al., 2010; Cuervo-Cazurra, Maloney \& Manrakhan, 2007; Uhlenbruck, Hitt \& Semadeni, 2006; Vermulen \& Barkema, 2001) existem diversas outras motivações complementares para a relização de aquisições de empresas, a saber: 
- O acesso a novos e diferentes mercados - ganhando novas experiências mercadológicas e podendo auferir ganhos com a diminuição de riscos sistêmicos (por estar atuando em mercados/conjunturas econômicas/países distintos), riscos idiossincráticos/específicos da empresa (que é diminuído naturalmente sempre que há diversificação de algumas variáveis da empresa);

- Aumento de poder de mercado - pode-se aumentar o market-share, apenas com a aquisição de concorrente em um mercado oligopolista, diminuindo a barganha dos compradores e fornecedores;

- Maior captação de crédito a juros menores - pois uma empresa maior consegue captar maiores recursos de financiamento à sua operação empresarial com menor taxa de juros. No caso de aquisição de empresa cross border, realizada por empresa brasileira e em país-target desenvolvido, salienta-se também que a empresa poderá se utilizar de financiamento com o custo ainda mais baixo, pois os juros praticados em países desenvolvidos são consideravelmente mais baixos que em países em desenvolvimento;

- Obtenção de tecnologia de ponta - a ferramenta de aquisição de empresa pode ser útil para a aquisição de tecnologia de ponta, quando realizadas em mercadotarget e/ou empresa-target, com maior desenvolvimento tecnológico;

- Aquisição de marcas globais - pode-se também entrar e crescer rapidamente no mercado onde se quer inserir, pois, pode-se adquirir marcas fortes e com boa reputação, sem precisar passar por todo o demorado processo de lançamento, desenvolvimento e maturação de uma marca. Evidencia-se ainda que outro ponto positivo de aquisição de marcas já conceituadas é a diminuição de risco operacional, havendo inclusive maior precisão na previsão futura de fluxo de caixa, pois há histórico de vendas. O maior risco, nesse caso, é coordenar a mudança de propriedade e gestão da marca;

- Internalização de conhecimentos e habilidades para fabricação de produtos superiores, bem como a obtenção de melhores práticas em marketing, cadeia de suprimentos, finanças e recursos humanos, entre outros - a realização de aquisição de empresa traz a possibilidade de se adquirir conhecimentos de práticas corporativas diversas;

- Ganho de economia de escala e de escopo - No caso da economia de escala, ao adquirir novos ativos, há possibilidade de aumento de produtividade, volume de produção, por exemplo, o que causa simultaneamente redução do custo médio de um determinado bem. Ou, inclusive, pode haver ganho de economia de escopo, que se caracteriza pelo ganho em redução de custo e aumento de produtividade, quando há combinação de produção de dois tipos distintos de produtos, que são de alguma forma relacionados;

- Possibilidade de arbitragem internacional por atuar em outros países - evidenciase que, quando uma empresa atua em mais de um país, pode ter a possibilidade de agir de forma mediadora nas necessidades de cada mercado, executando a chamada arbitragem. Esta é a simples, e sem risco de transação de compra e venda de um bem gerado pela diferença momentânea de preço, em diferentes mercados.

Referente aos benefícios que motivam a realização de aquisições de empresas, Shan \& Son (1997) afirmam que aquisições de empresas são puxadas / motivadas em decorrência do potencial da transação de se adquirir recursos, capacidades e habilidades provenientes da empresa target.

Abaixo segue o Quadro 2, que resume e evidencia as principais motivações para a realização de aquisições de empresas, de acordo com Camargos e Coutinho (2008). 
Quadro 2 - Motivação para a realização de Operações de Aquisições de Empresas

\begin{tabular}{|c|c|}
\hline $\begin{array}{l}\text { Motivação para a } \\
\text { realização de } \\
\text { operações de } \\
\text { aquisições de } \\
\text { empresas } \\
\end{array}$ & Descrição \\
\hline $\begin{array}{l}\text { Expectativas } \\
\text { Assimétricas }\end{array}$ & $\begin{array}{l}\text { Diferentes expectativas sobre o futuro levam os investidores a } \\
\text { atribuírem valores diferentes a uma mesma empresa, ocasionando } \\
\text { propostas de compra e venda. }\end{array}$ \\
\hline $\begin{array}{l}\text { Irracionalidade } \\
\text { Individual nas } \\
\text { Decisões de Dirigentes }\end{array}$ & $\begin{array}{l}\text { Justificativa hipotética para as aquisições de empresas, segundo a qual, } \\
\text { sob condições de incerteza, os indivíduos nem sempre tomam decisões } \\
\text { racionais. Irracionalidades estas, diluídas ou anuladas quando } \\
\text { consideradas de forma agregada na interação dos vários agentes } \\
\text { econômicos (Roll, 1986). }\end{array}$ \\
\hline $\begin{array}{l}\text { Aquisições de } \\
\text { empresas como uma } \\
\text { Alternativa a } \\
\text { Dividendos e } \\
\text { Recompra de Ações }\end{array}$ & Situação presente em empresas com fluxos de caixa livres \\
\hline $\begin{array}{l}\text { Compensações e } \\
\text { Incentivos } \\
\text { Tributários }\end{array}$ & $\begin{array}{l}\text { Advindos de créditos tributários, relativos a prejuízos acumulados por } \\
\text { uma das empresas envolvidas podendo ser compensados em exercícios } \\
\text { futuros pela outra empresa que venha apresentando lucros. }\end{array}$ \\
\hline $\begin{array}{l}\text { Custos de Reposição e } \\
\text { Valores de } \\
\text { Mercado }\end{array}$ & $\begin{array}{l}\text { Situação existente quando os custos de reposição dos ativos de uma } \\
\text { empresa forem maiores que o seu valor de mercado. Isto é, quando a } \\
\text { razão "Q de Tobin" de uma empresa for menor que a unidade. ("Q de } \\
\text { Tobin" < 1). }\end{array}$ \\
\hline $\begin{array}{l}\text { Sinergias Operacionais } \\
\text { e Gerenciais }\end{array}$ & $\begin{array}{l}\text { Advindas de possíveis reduções nos custos em função do aumento do } \\
\text { nível de produção, maior racionalização do esforço de pesquisa e } \\
\text { desenvolvimento, uso conjunto de insumos específicos não divisíveis e } \\
\text { transferência de tecnologia e conhecimento (know-how). }\end{array}$ \\
\hline $\begin{array}{l}\text { Efeitos } \\
\text { Anticompetitivos e } \\
\text { Busca } \\
\text { do Poder de } \\
\text { Monopólio }\end{array}$ & $\begin{array}{l}\text { Advindos de ganhos com o aumento da concentração de mercado e da } \\
\text { consequente redução da competição. }\end{array}$ \\
\hline $\begin{array}{l}\text { Redução do Risco de } \\
\text { Insolvência }\end{array}$ & $\begin{array}{l}\text { Advinda da união entre duas ou mais empresas com fluxos de caixa } \\
\text { sem correlação perfeita (aquisições conglomerados - cosseguro) }\end{array}$ \\
\hline Razões Gerenciais & $\begin{array}{l}\text { As aquisições de empresas podem ocorrer visando tanto ao aumento do } \\
\text { bem-estar dos diretores das empresas, mesmo que a operação cause } \\
\text { impacto negativo no valor de mercado de suas ações, como a } \\
\text { substituição de diretores que não estejam maximizando o valor de } \\
\text { mercado de suas empresas. }\end{array}$ \\
\hline
\end{tabular}

Fonte: Camargos e Coutinho (2008)

Segundo ainda Camargos e Coutinho (2008), ao simplificar e resumir ainda mais as motivações para a realização de aquisições de empresas apresentadas pela literatura, adventam-se em apenas duas principais macromotivações que, embora coadunem quanto à propensão para a utilização de operações de aquisições, têm objetivos específicos conflitantes, 
conforme evidenciados a seguir. Dessa forma, de acordo com Camargos e Coutinho (2008), citam-se a maximização do lucro aos acionistas e a maximização da utilidade gerencial como as duas principais motivações para a realização de aquisições de empresas, onde:

- A Teoria da Maximização do lucro e riqueza aos acionistas prega a corrida pela melhor utilização dos recursos existentes e fatores de produção, levando as empresas a buscar a utilização de operações de aquisições de empresas.

- A Teoria da Maximização da Utilidade Gerencial prega que os administradores buscam maximizar sua utilidade pessoal (aumento de salários e satisfação em trabalhar em empresa de maior porte), em detrimento da maximização do lucro e riqueza aos acionistas. Assim, motivam os agentes a utilizar a ferramenta de aquisição para o próprio gozo, levando em consideração, sobretudo, os benefícios de aumento do tamanho da empresa. Evidencia-se ainda que, geralmente, os agentes acabam atribuindo maiores pesos para as variáveis tamanho da empresa, quando deveriam focar, sobretudo, na variável maximização do lucro e riqueza dos acionistas, ao realizar eventos de aquisições de empresas.

Dessa forma, segundo Camargos e Coutinho (2008), as duas motivações supracitadas, teoria da maximização do lucro e teoria da maximização da utilidade gerencial, levam à utilização de operações de aquisições de empresas, entretanto, é latente a existência de um conflito de interesses entre os acionistas e os agentes administrativos, em que existe a possibilidade de ocorrência de expropriação de riqueza dos acionistas, por parte dos agentes administrativos.

Desta forma, esta pesquisa tem como princípio, que quando há membro da família controladora na diretoria executiva da empresa, há maior propensão para realização de operações pautadas em direcionadores de geração de valor e maximização da riqueza aos acionistas, pois mitiga-se a variável utilidade gerencial, já que o gestor membro da família é parte acionista, e também, tende a melhor vigiar e coibir a maximização da utilidade gerencial.

\subsubsection{Aquisições de Empresas no Exterior}

A ferramenta de aquisição de empresas, na década de 90 do século $\mathrm{XX}$, já era bastante utilizada nos países desenvolvidos. Nos EUA, por exemplo, as transações em aquisição de empresas já eram superiores a US\$ 1 bilhão.

Salienta-se, também, a existência de ondas de eventos de aquisições de empresas (MCNAMARA, HALEBLIAN e DYKES, 2008), cujas quedas de ocorrências desses eventos, geralmente são relacionadas a choques, como crises econômicas. Como exemplo, cita-se que, em 2001 e 2002, devido à crise mundial financeira causada pelo atentado terrorista de 11 de 
setembro, somada ao colapso da Argentina, ao escândalo do caso Enron e à concordata da WorldCom, havendo queda momentânea dos eventos de aquisições de empresas no mundo (GUARITA, 2002). Por outro lado, o aquecimento do mercado de aquisições de empresas ocorre concomitantemente com o aquecimento econômico, como por exemplo, cita-se o período de 2004 a 2007, em que houve crescimento em eventos de aquisições de empresas devido, sobretudo, à melhora da conjuntura econômica mundial e brasileira. Pode-se observar a evolução da quantidade de operações de aquisições nas tabelas dos Anexos 1 e 2.

Quanto aos resultados encontrados na literatura de aquisições de empresas no exterior, evidencia-se que Haleblian et al. (2009), em revisão bibliográfica, encontraram, de forma consistente na literatura, que adquirentes destroem valor. Como exemplo, os referidos autores citam os estudos de Asquith (1983); Dodd (1980); Jarrell e Poulsen (1989); Malatesta (1983); Agrawal, Jaffe e Mandelker (1992); Loderer e Martin (1992); Chatterjee (1992); Datta, Pinches e Narayanan (1992); King, Dalton, Daily e Covin (2004); Moeller, Schlingemann e Stulz (2003); Seth, Song e Pettit (2002).

Entretanto, para as adquiridas, a referida revisão bibliográfica encontra que, na média, há retornos anormais positivos. Os referidos autores do estudo bibliográfico sobre aquisições de empresas citam os trabalhos de Asquith \& Kim (1982); Datta, Pinches, \& Narayanan (1992); Hansen \& Lott (1996) e Malatesta (1983) para fundamentar a afirmação realizada.

Pode-se afirmar que em estudos de análise combinada do valor gerado pelas duas empresas (adquirente e adquiridas), em geral, segundo Haleblian et al. (2009), o resultado global é positivo para os eventos de aquisições de empresas. Os referidos autores citam os trabalhos de Bradley, Desai, \& Kim, 1988; Bruner, 1988; Carow, Heron, \& Saxton, 2004; Healy, Palepu, \& Ruback, 1992; Wright, Kroll, Lado, \& van Ness, 2002; Houston, James, \& Ryngaert, 2001 e Leeth \& Borg, 2000.

\subsubsection{Aquisições de Empresas no Brasil}

No Brasil, a melhora significativa da estabilidade e conjuntura econômica, como por exemplo, o controle da inflação, consolidação das políticas macro e microeconômicas, massiva entrada de investimentos estrangeiros e o desenvolvimento do mercado de capitais e do sistema bancário-financeiro, desencadearam os processos de aquisições de empresas no país.

Rocha, Iootty e Ferraz (2001) enfatizam que o movimento de aquisição de empresa teve seu estopim, no início da década de 90 do séculoXX, pois, houve forte ampliação da abertura 
econômica, em que se permitiu o acesso a melhores tecnologias, matérias-primas, máquinas e equipamentos, capital humano e financeiro. Esta abertura econômica, se melhor planejada e executada pelo governo e pela iniciativa privada, proporcionaria melhores condições para a evolução da produtividade, qualidade e competitividade de nossas empresas no mundo globalizado. Entretanto, o resultado obtido foi uma evolução da indústria nacional abaixo do seu potencial, o que causou, inclusive, o fechamento de diversas empresas nacionais devido à entrada massiva de empresas estrangeiras mais competitivas, seja pela estratégia de greenfields (estabelecimento de novas instalações no país/local) e/ou pela aquisição de empresas brasileiras por estrangeiros (utilizando a ferramenta de crescimento inorgânico vide tabela do Anexo 2).

Segundo ainda Rocha, Iootty e Ferraz (2001) e (KPMG, 2012b), foram diversos os motivos para o baixo desempenho das empresas brasileiras na época. A seguir, citam-se alguns problemas da década de 90 do século passado, que levaram ao fracasso das empresas nacionais, e ainda é feita uma ligação com a conjuntura atual brasileira:

- Falta de estratégia governamental e incentivo às empresas nacionais para diminuir o choque econômico e institucional decorrente da abertura econômica: apenas foi feita a abertura, mas careceu de planejamento na sua execução. Sobretudo, faltou incentivo às empresas nacionais para que se preparassem para a competição em uma nova economia globalizada. $\mathrm{O}$ resultado foi um grande descompasso entre a visão e a preparação obsoleta das empresas e as novas necessidades geradas;

- Baixa qualidade de mão de obra: outro problema crônico que assola o país e atrasa o avanço da economia brasileira, impedindo que se tenha um desenvolvimento interno de novas tecnologias que possam melhorar a competitividade das empresas brasileiras;

- Incipiente mercado consumidor interno, para bens de consumo com alto valor agregado: ainda hoje é preciso aumentar a renda do consumidor interno para alavancar a economia doméstica. Quanto mais desenvolvido o mercado interno e a demanda por bens de consumo com alto valor agregado, maior a necessidade de desenvolvimento de inovações, tecnologias e conhecimentos específicos para atender ao consumidor mais exigente. Essas necessidades estimulam maiores investimentos em educação, pesquisa e desenvolvimento, o que resulta o aumento na solicitação de patentes e direitos autorais de empresas brasileiras, mão-de-obra mais qualificada e desenvolvimento da nação;

- Falta de foco global das empresas e do governo: em uma economia aberta, em um mundo cada vez mais transfronteiriço, o foco global é essencial para a sobrevivência das empresas. Nos últimos anos, houve um aumento no foco das empresas e do governo, na internacionalização da economia brasileira, em comparação ao início da década de 90 do século passado. Entretanto, é possível evidenciar que, ainda hoje, é pequena a ocorrência de eventos de aquisições internacionais realizados por empresas nacionais.

A seguir, será realizada uma análise setorial do histórico de aquisições de empresas, no Brasil, apresentada na tabela da seção Anexos: Anexo 1 - Histórico setorial acumulado das transações de aquisições de empresas, no período de 1994-2012 a seguir, da KPMG (2012b), 
para melhor entendimento das ocorrências de aquisições de empresas no país.

É possível verificar, por meio da tabela do Anexo 1, que os setores que têm liderado historicamente as transações de aquisições de empresas, no Brasil, são das áreas de tecnologia de informação, alimentos, bebidas e fumo, telecomunicações e mídia, instituições financeiras, companhia energética, publicidade e editoras, entre outros.

Os setores de alimentos, bebidas e fumo lideraram as transações de aquisições de empresas até 2007, onde passou por uma redefinição constante no market-share dos principais players, no mercado brasileiro, com a entrada de novas empresas estrangeiras no país, e a concentração e consolidação das empresas já existentes.

Referente ao setor de tecnologia de informação (T.I.), que atualmente domina as transações de aquisições de empresas, no Brasil, pode-se dizer que as empresas brasileiras têm recebido bom incentivo governamental para inovar e se desenvolver no mercado. Observa-se ainda que, embora o desenvolvimento do país em T.I., nos últimos anos, seja profícuo, existe um problema conjuntural e crônico, pois, inclusive, nesse setor, empresas estrangeiras adquirem significativamente as empresas brasileiras (VIEIRA, 2008; KPMG, 2012b).

Em suma, o Brasil deve aumentar os gastos e investimentos com inovação, pesquisa e desenvolvimento e educação. Outrossim, melhor proteger a indústria nacional e evitar que os esforços passados se dissipem em longo prazo. Em outras palavras, impedir que seja tão facilmente transferido o conhecimento e desenvolvimento ao longo dos anos, com a venda de empresas brasileiras para estrangeiros, sobretudo, quando a empresa vendida para estrangeiros utilizou-se de recursos governamentais brasileiros para financiar tal desenvolvimento.

A tabela seguinte, evidenciada na seção Anexos: Anexo 2 - Aquisições de empresas, em 2012, no Brasil, discriminadas por setor, origem e destino do capital, mostra mais detalhadamente como as transações de aquisições de empresas são realizadas no Brasil. Foram estratificados os eventos de aquisições de empresas, em setor de atuação empresarial, a origem e o destino do capital.

Verifica-se no anexo 2, que a maior parte das aquisições de empresas realizadas, no Brasil, no período, foram de aquisições internacionais, sobretudo, de empresas estrangeiras fazendo investimentos e adquirindo empresas no Brasil ( $c b 1$ e 4). Os dados da KPMG evidenciam informações preocupantes ao país, pois, constata-se que, de forma geral, as empresas brasileiras pouco têm executado a ferramnenta de aquisição de empresas. Essa reatividade pode ocasionar em médio e longo prazos, inclusive, a perda de relevante participação de 
empresas brasileiras no mercado interno (como já se pode observar em diversos segmentos da economia doméstica), devido à massiva aquisição de empresas brasileiras por estrangeiros.

Quanto às pesquisas sobre aquisições de empresas no mercado brasileiro, segundo Camargos e Coutinho (2008) a academia brasileira tem seguido a tendência internacional, ao apresentar pesquisas com objetivos variados sobre o tema, como por exemplo:

- Motivações e as alterações econômicas e institucionais no mercado (HÉAU, 2001; ROSSETTI, 2001; MILMAN, D’MELLO, AYBER e ARBELAEZ, 2001);

- Concentração e efeitos anticompetitivos (CANO, 2002 e ANDRADE, 2002);

- Estratégia empresarial (PFIFFER, 2004);

- Desempenho operacional, desempenho econômico-financeiro, criação de valor para os acionistas e reação do mercado de capitais (PATROCINIO, KAYO e KIMURA, 2005; CAMARGOS e BARBOSA, 2005).

Para Camargos e Coutinho (2008), Gorgati (2004) e Rocha (2012), é fato a tendência atual das pesquisas em aquisições de empresas dar maior ênfase na teoria da firma e na estrutura societária, como alicerce teórico, na busca por um novo enfoque ao tema. Segundo Rocha (2012), a pesquisa no Brasil sobre empresas familiares e seu desempenho em aquisições de empresas ainda é praticamente inexistente.

\subsubsection{Estratégias em Aquisições de Empresas}

São as motivações corporativas (estrategicamente alinhadas à missão da empresa ou não) que instigam a empresa a executar aquisições de empresas. Essas motivações, muitas vezes, estão associadas à necessidade de crescimento, desenvolvimento e perpetuidade da empresa, conforme já discutido previamente na seção Teoria da Firma.

A seguir, Rocha, Iootty e Ferraz (2001) e Miranda \& Martins (2000) evidenciam algumas estratégias utilizadas na realização de aquisições de empresas, citam-se:

- Asset/resource seeking (busca por ativos/recursos) - Visa a buscar, no mercado, ativos/recursos estratégicos que possam gerar retorno à empresa, aumentando a riqueza e renda;

- Efficiency seeking (busca por eficiência) - Visa a otimizar operacionalmente o negócio, buscando empresas-alvo que tenham sinergia operacional e que agreguem valor à cadeia produtiva e/ou de suprimentos da empresa, possibilitando, por exemplo, auferir economia de escala e/ou escopo;

- Market seeking (busca por mercados) - Visa ao ganho de market-share ou à entrada em novos mercados por meio de aquisição de empresas. Muitas vezes, essa estratégia pode auferir outros benefícios, como por exemplo, a diversificação de mercados, hedgeando-se a contratempos oriundos de problemas conjunturais macro e/ou microeconômicos. Esta mitigação de risco ocorre apenas se os mercados não forem interdependentes ou houver pouca relação entre si. 
De acordo com Miranda \& Martins (2000), a globalização constitui forte motivação para as operações de aquisições de empresas, em que as empresa buscam incessantemente melhorar sua competitividade local e global. Entretanto, conforme já argumentado anteriormente, a atual conjuntura das empresas brasileiras mostra que historicamente há pouca utilização da ferramenta de aquisição de empresa, o que contribui para a perda de competitividade de nossa indústria e faz com que empresas estrangeiras entrem e comprem com maior facilidade as empresas nacionais, e, dessa forma, monopolizam o mercado interno.

Uma causa para a pouca utilização histórica da ferramenta de aquisição de empresa, no Brasil, é que relevante parte das empresas domésticas brasileiras, mesmo considerando as negociadas em bolsa de valores, são de pequeno porte comparadas às dos países mais desenvolvidos. Vale mencionar que apenas nos últimos anos, com o crescimento significativo do mercado de valores mobiliários, estruturação do sistema bancário e estabilização da economia brasileira, pôde-se notar maior crescimento e aumento no valor de mercado das empresas brasileiras, e, dessa forma, o Brasil começa a se destacar mundialmente no mercado de aquisições de empresas.

Munõz-Bullón e Sánchez-Bueno (2012) também afirmam que a robustez financeira da empresa e seu porte corroboram para a utilização das ferramenta de aquisição de empresa de forma mais expressiva.

A KPMG (2012b), igualmente, evidencia que as empresas brasileiras, familiares ou não, têm aumentado de forma gradual e significativa a utilização da ferramenta de aquisição de empresa relacionada com melhorias diversas ao cenário doméstico, conforme já relatado.

Chandler (1990) enfatiza que as aquisições de empresas podem resultar em ganho de vantagem competitiva, devido à busca de sinergias e otimização operacional das empresas. Outrossim, evidencia-se que também é utilizada a ferramenta de aquisição de empresa para se manter a capacidade de inovação de empresas maduras. Assim, coloca-se a importância das aquisições de empresas, a fim de promover desenvolvimento das empresas familiares e não familiares brasileiras nos cenários doméstico e internacional.

Reitera-se que eventos de aquisições de empresas neste trabalho serão utilizados como variáveis de mensuração e comparação de desempenho entre empresas familiares e não familiares, no Brasil. 


\section{METODOLOGIA DA PESQUISA}

Nesta seção, aborda-se os métodos de pesquisa para melhor contextualizar e dimensionar a questão metodológica. Barreto e Honorato (1998) afirmam que a etapa de metodologia de uma pesquisa define como a investigação será realizada, compreendendo as técnicas científicas e métodos executados, a fim de elaborar uma pesquisa, de modo que seja possível atingir os objetivos propostos, e atender aos critérios de custo baixo, eficácia, rapidez e confiabilidade nas informações.

Dessa forma, para alcançar os objetivos propostos pelo presente trabalho, será realizada uma pesquisa descritiva, pois visa-se descrever, analisar e obter variáveis que capturem o efeito de geração de valor das empresas familiares e não familiares brasileiras, em eventos de aquisições.

Quanto aos meios (VERGARA, 2011), esta pesquisa será quantitativa, de natureza empírica, com análise estatística de dados secundários e, ex post facto, utilizar-se-á a metodologia de estudo de eventos, que visa à avaliação, se houve geração ou destruição de valor, nos eventos de aquisição de empresas familiares e não familiares.

\subsection{Modelo Conceitual da Pesquisa}

Com base na fundamentação teórica, que provê bases conceituais dos constructos investigados nesta pesquisa, empresa familiar e aquisições, será elaborado um modelo com o propósito de associar e validar esses constructos, originando as hipóteses de pesquisa evidenciadas a posteriori.

O modelo conceitual da pesquisa tem como intuito melhor ilustrar e apresentar a relação entre os constructos da presente dissertação, para atingir os objetivos da pesquisa.

Para Kayo (2002), o modelo é definido como uma representação simplificada da realidade, a fim de evidenciar o relacionamento entre vários elementos de um sistema ou processo sob investigação.

Segundo Kayo (2002), ao se embasar em temas que se relacionam, é importante a simplificação da realidade e utilização de modelo conceitual, a fim de atender ao caráter explicativo da pesquisa. 
De acordo ainda com Kayo (2002), a formação dos modelos deve seguir um padrão sistemático, de modo que atinja os objetivos estabelecidos, e que se possibilite a validação dos resultados. $\mathrm{O}$ autor supracitado evidencia um modelo conceitual, que tem por objetivo avaliar e relacionar uma ou mais teorias ou modelos teóricos, em um ou mais modelos operacionais, como ilustrado na figura a seguir.

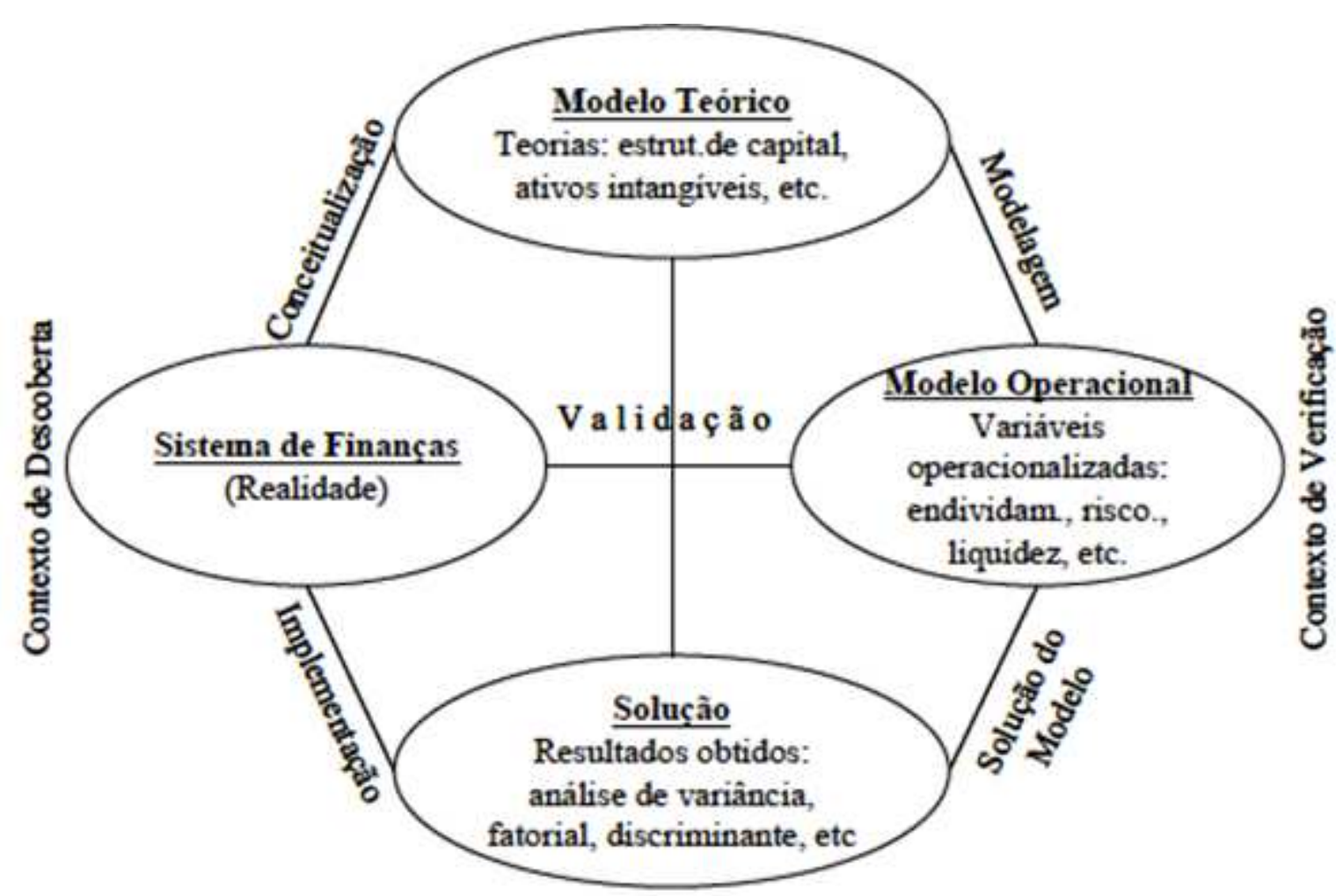

Figura 1 - Modelo conceitual de avaliação e comparação de modelos Fonte: Kayo (2002), baseado no modelo de Mazzon (1978).

Com o entendimento de que a ciência é um processo de testes de teorias que visa ao seu desenvolvimento, este trabalho desenvolve e testa um modelo teórico adaptando aquele utilizado por Kayo (2002). Apresenta-se o modelo conceitual da presente pesquisa, evidenciado pela figura a seguir. 


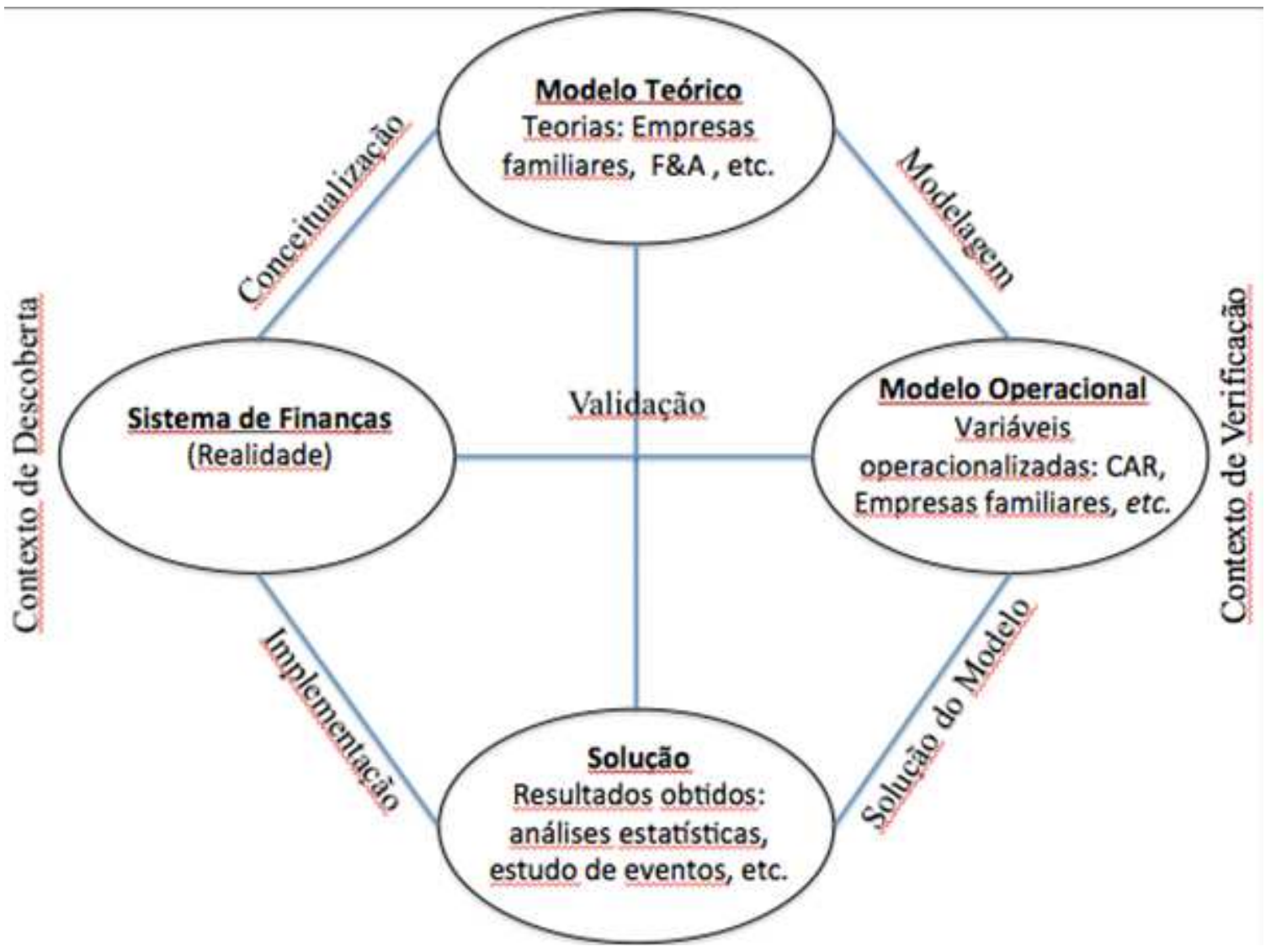

Figura 2 - Modelo conceitual da pesquisa

Fonte: Elaborado pelo próprio autor, adaptado do modelo de Kayo (2002).

Segundo Kayo (2002), com base na figura acima, ilustra-se a inter-relação entre o modelo teórico, o modelos operacional e a solução dos problemas propostos. No caso desta pesquisa, o modelo teórico aborda os temas empresas familiares, aquisições de empresas e teoria da firma.

Quanto ao modelo operacional, segundo ainda Kayo (2002), são construídas as variáveis utilizadas na investigação empírica, tendo como base o arcabouço teórico.

Como solução do modelo, as variáveis são analisadas estatisticamente e metodologicamente, formando o que Mazzon (1978) apud Kayo (2002) chamam de Solução do modelo.

Em outras palavras, para esta pesquisa, o Modelo Teórico foi abordado e fundamentado na seção de Revisão/Fundamentação Teórica, no Capítulo 2. O Modelo Operacional será apresentado no Capítulo 4, denominado Procedimentos Metodológicos e a Pesquisa. Por fim, a solução do modelo desta dissertação é apresentada no Capítulo 5, denominado Resultados. 


\subsection{Modelo Diagramático Relacional dos Constructos da Pesquisa}

A partir da fundamentação teórica e do modelo teórico proposto, evidencia-se a seguir, o modelo diagramático relacional dos constructos da pesquisa, visando ilustrar os fatores que podem influir no desempenho de empresas familiares em operações de aquisições.

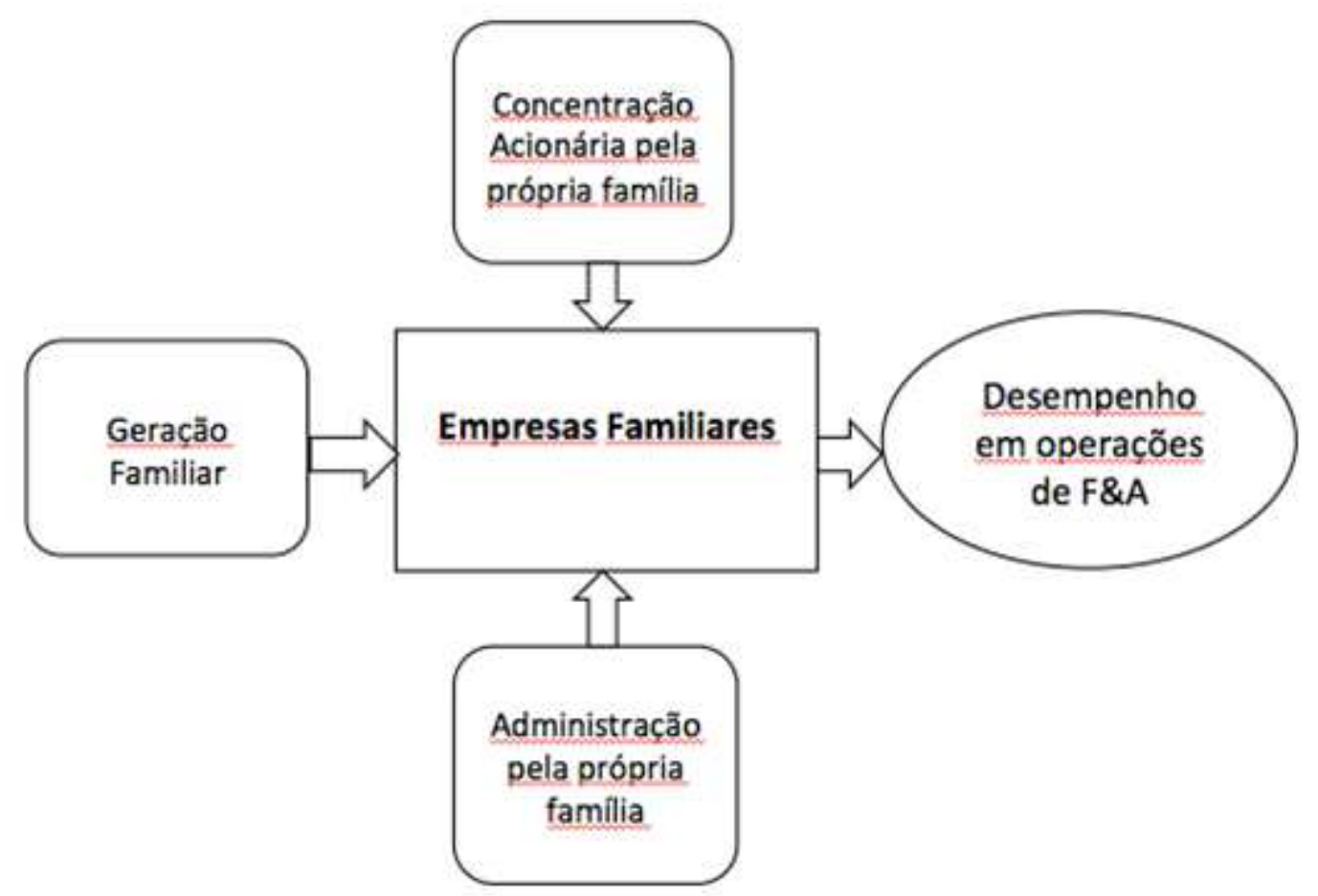

Figura 3 - Modelo Diagramático Relacional dos Constructos da Pesquisa. Fonte: Elaborado pelo próprio autor.

Conforme abordado na fundamentação teórica, salienta-se que as empresas familiares, ao realizarem operações de aquisições de empresas, podem ter como fatores de influência em seu desempenho, o grau de concentração acionária da propriedade, a administração pela própria família e a geração familiar que administra a empresa, abordado e devidamente fundamentado no capítulo 2 - Fundamentação Teórica.

\subsection{Hipótese da Pesquisa}

Com o propósito de atingir os objetivos desta dissertação, são formuladas as seguintes hipóteses de pesquisa: 


\subsubsection{Hipóteses 1 e 2}

Para esta pesquisa, seguindo a literatura evidenciada no capítulo fundamentação teórica, espera-se que empresas familiares tenham retornos anormais positivos em eventos de aquisições de empresas (MUNOZ-BULLON e SANCHEZ-BUENO, 2011).

Segundo Rocha (2012), o principal modo de se avaliar a geração de riqueza da empresa ao proprietário é por meio da análise do valor das ações. No caso de eventos de aquisições de empresas, calcula-se o retorno anormal medindo a diferença do retorno observado, e retorno esperado de uma determinada ação, em um determinado período.

Em concordância com os parágrafos anteriores, Maury (2006); Kozan, Oksoy e Ozoy (2012) afirmam que empresas familiares com gestão ativa estão associadas com melhor desempenho corporativo. Dessa forma, a primeira e segunda hipóteses da pesquisa propõem:

Hipótese 1. Empresas familiares geram valor em eventos de aquisições de empresas.

Hipótese 2. Empresas familiares têm maiores retornos anormais em aquisições de empresas do que empresas não familiares.

Salienta-se que a variável desempenho anormal refere-se neste trabalho à variável proxy CAR (cumulative abnormal return), utilizada em pesquisas de finanças (aquisições de empresas, por exemplo) como medida de mensuração de desempenho dos eventos estudados, conforme abordado anteriormente no presente trabalho. Evidencia-se ainda que será mais detalhada e discutida a variável CAR (mensuração de desempenho em aquisição de empresas) na próxima seção - Procedimentos Metodológicos e a Pesquisa, nas subseções Metodologia de Estudos de Eventos e Definição operacional das variáveis de pesquisa, no Capítulo 4.

\subsubsection{Hipóteses 3, 4 e 5}

Há evidências de que o controle (grau de concentração acionária) e gestão ativa da empresa pela própria família geram maior potencial de criação de valor para empresas familiares. 
Evidencia-se ainda que a família tende a vigiar melhor as ações dos agentes administrativos da empresa e, como resultado, gera-se maior valor à empresa decorrente dos fatores controle e vigilância (MORCK, SHLEIFER e VISHNY, 1988; MCCONAUGHY, MATTHWES e FIALKO, 2001).

Assim, infere-se que quanto maior a concentração acionária e a participação da família na gestão da empresa, maior o seu desempenho em aquisições de empresas. Logo, propõe-se as seguintes hipóteses de pesquisa:

Hipótese 3. Retornos anormais em aquisições de empresas estão relacionados positivamente às empresas familiares cujo gestor é membro da familia controladora.

Hipótese 4. Retornos anormais em aquisições de empresas estão relacionados positivamente às empresas familiares de primeira e segunda gerações.

Hipótese 5. Retornos anormais em aquisições de empresas estão relacionados positivamente ao grau de concentração acionária detida pela família controladora. 


\section{PROCEDIMENTOS METODOLÓGICOS E A PESQUISA}

Esta seção trata sobre o percurso metodológico da pesquisa e a sua execução.

Segundo Santos (1999), são procedimentos metodológicos as atividades práticas, necessárias para a aquisição dos dados com os quais se desenvolverão os raciocínios e a pesquisa empírica.

\subsection{Dados e Fontes de Informação}

Referente às variáveis empresas familiares, e não familiares; os dados históricos das ações, acionistas, dados financeiros, contábeis e de mercado, foram retirados das bases de dados Economática ${ }^{\circledR}$, Datastream Thomson Reuters Financial Data ${ }^{\circledR}$, sítio das próprias empresas Relações com Investidores, CVM, sítio eletrônico da Bloomberg®, para obter as informações das empresas listadas na Bolsa de Valores de São Paulo (BOVESPA).

Os dados em aquisições de empresas foram obtidos da base de dados da Thomson Reuters Platinum Financial SDC Database ${ }^{\circledR}$ e da Thomson Reuters Eikon Financial Database ${ }^{\circledR}$, do período de janeiro de 2009 a janeiro de 2013.

Conforme argumentado, o intuito é estratificar empresas familiares e não familiares, a fim de proporcionar comparação e análise do desempenho das empresas públicas listadas na Bovespa que executaram aquisições de empresas no período amostral.

Dessa forma, referente aos dados coletados sobre aquisição de empresas, serão considerados somente anúncios de aquisições realizadas por empresas brasileiras listadas na BM\&F BOVESPA, com status de "completadas/concretizadas."

Foi obtido o total de 650 aquisições completadas, entre familiares ou não. Para cada aquisição, a Thomson Platinum SDC Financial Database ${ }^{\circledR}$ e a Thomson Reuters Eikon Financial Database ${ }^{\circledR}$ proveram o nome da empresa adquirente, o nome da empresa adquirida, o país da adquirida, o país da adquirente (Brasil), data do anúncio do evento, entre outras informações.

Outrossim, foi realizada revisão e verificação dos dados no processo de identificação e seleção os eventos. Segue abaixo detalhamento do processo de coleta de dados, informando as bases de dados utilizadas para obter, analisar e revisar os dados da amostra de aquisições de empresas: 
1. A base de dados da Thomson Reuters Platinum SDC Financial Database ${ }^{\circledR} e$ Thomson Reuters Eikon Financial Database®;

2. Dados obtidos na CVM (Comissão de Valores Mobiliários) com todos os fatos relevantes anunciados após 2007 ;

3. Banco de dados da Economática;

4. Banco de dados da Thomson Reuters - Notícias;

5. Banco de dados da Datastream Thomson Reuters Financial Data®;

6. Relatórios sobre Aquisição de empresas da KPMG®;

7. Relatórios sobre Aquisição de empresas da PriceWaterHouseCoopers®;

8. Relatório sobre Aquisição de empresas da ANBID - Associação Nacional dos Bancos de Investimento;

9. Sítios de relacionamento com o investidor (R.I.) das próprias empresas listadas pela BOVESPA (Bolsa de Valores de São Paulo);

10. Banco de dados da BOVESPA (Bolsa de Valores de São Paulo);

11. Dados obtidos no sítio da Bloomberg®;

12. Jornais especializados, revistas especializadas, artigos especializados e científicos, relatórios anuais das empresas.

Salienta-se, ainda, que no processo de validação e verificação dos dados históricos das companhias, para coleta das informações necessárias para o estudo, ocasionaram-se dados faltantes, gerando, por fim, a base de 355 aquisições feitas por empresas brasileiras, entre familiares e não familiares, conforme apresentado inicialmente. Foram eliminados eventos, segundo os seguintes critérios:

1. Exclusão dos eventos cujas empresas adquirentes não eram listadas em bolsa;

2. Falta de dados históricos (preço ações, dados das companhias, dados contábeis, dados da administração, entre outros dados faltantes). 
Dessa forma, foram criadas algumas estratificações da amostra total: (i) completa com 355 eventos; (ii) empresas familiares com 225 eventos; (iii) empresas não familiares com 130 eventos.

Referente à metodologia a ser utilizada para a mensuração do cálculo de geração de valor em aquisições e análise de desempenho, dos eventos analisados, e de acordo com McConaughy, Matthews e Fialko (2001), MacKinlay (1997), McWilliams e Siegel (1997), a metodologia de estudo de eventos, possibilita pesquisadores a determinar se houve desempenho/retorno anormal no preço da ação avaliada pelo mercado.

A regressão por mínimos quadrados ordinários (MQO), por outro lado, possibilita verificar se as variáveis são significantes, e se ajudam a explicar a variável dependente do modelo.

Dessa forma, replicando em partes o modelo de pesquisa de McConaughy, Matthews e Fialko (2001), e utilizando a base teórica da metodologia de estudo de evento dada por (MacKinlay, 1997; McWilliams e Siegel, 1997), foram calculados os CARs (cumulative abnormal return) e testadas as hipóteses da pesquisa, com aplicação dos seguintes procedimentos:

1) Primeiramente, foi mensurada a performance individual de cada aquisição, e utilizada a metodologia de Estudo de Eventos;

2) Foram obtidos os ACARs (average cumulative abnormal return), ou retornos médios anormais acumulados, possibilitando, neste momento, a verificação da hipótese 1;

3) Os resultados da última etapa são regredidos nos modelos sobre as variáveis explicativas e de controle dos modelos, a fim de verificar quais variáveis influenciam os modelos estabelecidos.

\subsection{Metodologia de Estudo de Eventos}

Nesta subseção serão abordadas maiores informações sobre a difundida e bastante utilizada nas pesquisas em ciências sociais aplicadas, a Metodologia de Estudos de Eventos.

Segundo McConaughy, Matthews e Fialko (2001), MacKinlay (1997), McWilliams e Siegel (1997), a literatura de finanças tornou padrão a utilização de estudo de eventos para mensuração do impacto de determinado evento, em relação ao preço da ação de determinada empresa examinada. 
É uma técnica que se baseia nos retornos ao redor dos anúncios, que tem como base um "índice de mercado", que visa a verificar como o mercado precifica uma determinada informação (COSTA JR., 2008).

O estudo de evento permite ao pesquisador concluir se o evento teve efeito positivo ou negativo, em relação a uma base prefixada como modelo. Esta metodologia tem sido utilizada em diversas áreas do conhecimento, como por exemplo, nas áreas de finanças, contabilidade e direito. (MCWILLIAMS \& SIEGEL, 1997).

Segundo McWilliams and Siegel (1997) e Campbell, Lo e Mackinlay (1997), o estudo de eventos tem quatro premissas fundamentais:

i) O mercado é eficiente;

ii) Racionalidade do mercado;

iii) Não há assimetria de informação, portanto, não há antecipação de ações no mercado referente ao evento;

iv) Não há outros eventos que possam mascarar, confundir os resultados, ou gerar ruídos ao evento analisado.

Essa metodologia envolve três etapas (BROWN \& WARNER, 1985; MCWILLIAMS and SIEGEL, 1997):

i) Identificar qual evento será avaliado. Dessa forma, definir a janela do evento, a janela de estimação, e a janela pós-evento. Evidencia-se que para alguns casos, dependendo do pesquisador, não é necessária a utilização de janela pós-evento. Logo, nesta pesquisa, não será utilizada a janela pós-evento;

ii) Calcular o retorno anormal diário;

iii) Obter o ACAR (Average Cumulate abnormal returns) ou retorno anormal médio acumulado, e testar sua significância. Geralmente utiliza-se o teste paramétrico t de student para avaliar o nível de significância do ACAR.

A seguir, apresenta-se detalhadamente a execução às três etapas da Metodologia de Estudo de Evento:

i) Definição das Janelas de Estimação e Janelas de Evento:

Inicialmente, ilustra-se a Metodologia de Estudo de Eventos, com a esquematização de cada janela, conforme foi evidenciado anteriormente. 


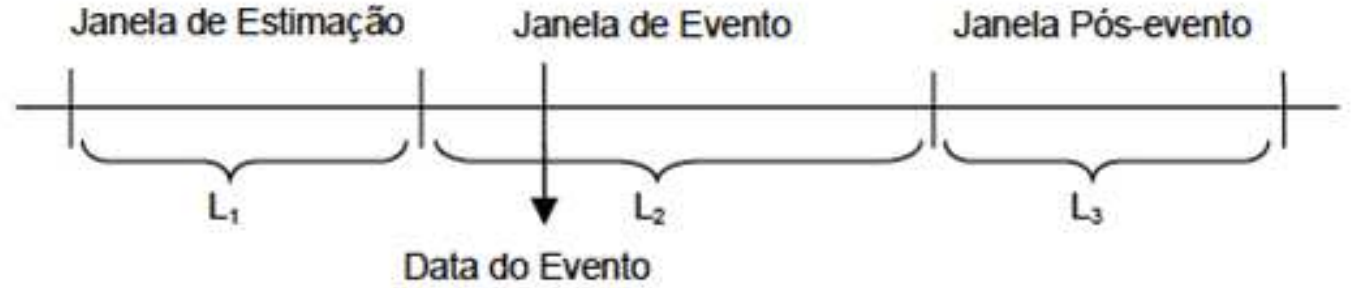

Onde $\mathrm{L}_{1}, \mathrm{~L}_{2}$ e $\mathrm{L}_{3}$ são o tamanho temporal atribuído a cada janela.

Figura 4 - Esquematização da Metodologia de Estudo de Eventos

Fonte: Costa Jr. (2008).

Com base na esquematização da Metodologia de Estudo de Eventos é importante ressaltar a importância do estabelecimento da amplitude temporal pertinente à janela de evento. Recomenda-se um tamanho temporal reduzido para melhor captar os efeitos do evento, e mitigar o ruído dos impactos de outros eventos, pois, segundo Mackinlay (1997), quanto menor a janela de evento, melhor a estimação do evento e a diminuição dos ruídos. Por outro lado, os autores supracitados afirmam que a janela de estimação deve ser temporalmente abrangente para estabilizar a estimação do retorno anormal.

Assim, evidencia-se que, neste trabalho, foi utilizada a janela de estimação, conforme Kayo, Patrocínio e Martin (2009); Nardi (2012), onde foi considerado um período de 180 dias, que começa 210 dias antes do anúncio da aquisição, e termina 31 dias antes dele, e para a janela de eventos, conforme Nardi (2012), serão adotadas as janelas de 1, 3, 11 e 21 dias, em torno da data do anúncio do evento.

ii) Calcular o retorno anormal diário.

Segundo Nardi (2012), o retorno anormal diário é a diferença entre o retorno real diário e o retorno diário esperado. 


$$
A R_{\mathrm{it}}=R_{\mathrm{it}}-E R_{\mathrm{it}}
$$

Onde,

$A R_{\text {it }}$ : retorno anormal (abnormal return) da ação da empresa adquirente no evento $i$, na data $t$. $R_{\mathrm{it}}$ : retorno real da ação da empresa adquirente no evento $i$, na data $t$.

$E R_{\text {it }}$ : Retorno esperado (expected return) da ação da empresa adquirente no evento $i$, na data $t$.

Segundo Nardi (2012), há benefícios em se calcular o retorno de forma contínua, pois a distribuição torna-se mais próxima a uma distribuição $t$ de student: RETcontínuo $=\ln ($ Preço $\tau)-\ln ($ Preço $\tau-1)$, e que o retorno real é obtido da simples negociação em bolsa dos preços reais das ações. Por outro lado, o retorno esperado, deve ser estimado.

Segundo Mackinlay (1997) há diversos modelos que podem ser empregados para estimar o retorno esperado, como por exemplo, a academia costuma adotar modelos como o Capital Asset Pricing Model (CAPM), Arbitrage Pricing Model (APT), modelo de mercado e o retorno de mercado.

Adota-se, neste trabalho, da mesma forma que Kayo, Patrocínio e Martin (2009) e Nardi (2012), o modelo de mercado para estimar o retorno diário esperado, pois afirmam que o retorno anormal calculado contempla os fatores risco e mercado.

Segundo Aybar \& Ficici (2009) e Nardi (2012), o modelo de mercado base assume relação linear com o retorno do ativo ou da carteira de ativos. Portanto, para cada ativo, o modelo de mercado assume que os retornos gerados são dados por:

$$
R_{i t}=\alpha_{i}+\beta_{i} R_{m t}+\varepsilon_{i t}
$$


Onde:

$R_{i t}$ é o retorno do ativo $(i)$ em determinado tempo $(t)$;

$R_{m t}$ é o retorno de mercado em um determinado período $(t) ;$

$\mathcal{E}_{i t}$ é o termo de erro aleatório para um determinado ativo $(i)$, em um determinado período $(t)$, sendo seu valor esperado igual a zero $\left(E\left(\varepsilon_{i t}\right)=0 ; \operatorname{var}\left(\varepsilon_{i t}\right)=\sigma^{2} \varepsilon_{i}\right)$;

$\beta_{i}$ é o coeficiente específico do ativo (i) (risco sistemático);

$\alpha_{i}$ é o intercepto do ativo $(i)$

Evidencia-se que foi utilizado o IBOVESPA como proxy/benchmark de mercado; e como teste de robustez, conforme Nardi (2012), o IBRX50, como índice de mercado comparável.

iii) Obter o ACAR (Average Cumulate abnormal return) ou retorno anormal médio acumulado, e testar sua significância. Geralmente utiliza-se o teste paramétrico t de student para avaliar o nível de significância do ACAR.

Segundo Nardi (2012), para obter o ACAR (Average Cumulate abnormal return), basta calcular o retorno anormal médio acumulado, considerando todos os " $\mathrm{N}$ " eventos " $i$ " e calcular também a variância do retorno médio acumulado, e por fim, realizar o teste de hipótese para avaliar a hipótese nula (Ho) de que o retorno anormal médio acumulado é nula por meio da estatística t de student, paramétrica, ou mesmo, testes de robustez não paramétricos que forem adequados.

Segundo Costa Jr. (2008), outros pressupostos básicos, necessários para rodar os modelos, são:

i) A ausência de correlação serial dos termos de erro, autocorrelação, que pode ser mitigado pelo procedimento de Newey-West;

ii) Homocedasticidade dos termos de erro, que podem estar comprometidos. Entretanto, a fim de mitigar o problema de heterocedasticidade, foram adotadas medidas como matrizes robustas para estimação dos parâmetros por Hubber-White Sandwich. Desse modo, evidencia-se que todos os resultados das regressões por MQO (mínimos quadrados ordinários), apresentados neste trabalho, estão reportados adotando os erros-padrão robustos de Hubber-White Sandwich;

iii) Normalidade ou amostra com distribuição normal. Segundo McWilliams \& Siegel (1997), o tamanho da amostra da pesquisa é suficientemente grande, para aceitar a assunção de normalidade. Mesmo assim, como teste de robustez, realiza-se o procedimento estatístico não paramétrico Bootstrap, que não necessita da premissa de normalidade, pois, funciona como a simulação de Monte Carlo, que replica "n 
vezes" a amostra, condicionando-se intrinsecamente à função distribuição característica da amostra.

Evidencia-se que, mesmo com a pressuposição de normalidade, abordada por McWilliams \& Siegel (1997), foram realizados testes de verificação de normalidade, como por exemplo, os testes de Shapiro-Wilk, Kolmogorov-Smirnov e Jarque-Bera. Informa-se que, em geral, para os modelos analisados, o resultado foi o de amostra com distribuição não normal.

Dessa forma, a utilização do teste não paramétrico Bootstrap torna-se relativamente importante teoricamente, mesmo que as pesquisas em aquisições de empresas pouco abordem a utilização do referido instrumento estatístico para mitigação do problema de não normalidade dos resíduos da amostra, sobretudo, quando os dados obtidos pela metodologia de estudo de eventos - CAR (cumulative abnormal return) são inseridos em análises de regressões estatísticas com a utilização do método de mínimos quadrados ordinários, que tem como pressuposição a distribuição normal dos resíduos da amostra.

Outrossim, utiliza-se o teste não paramétrico de Wilcoxon signed rank test (Teste de sinais de Wilcoxon - Rank Teste) para maior robustez às análises dos resultados obtidos.

\subsection{Definição Operacional das Variáveis da Pesquisa}

As definições operacionais das variáveis utilizadas na pesquisa são descritas a seguir.

Os autores relacionados às variáveis foram citados no capítulo da Fundamentação Teórica do presente trabalho, que deram base para a utilização da variável, em voga, nos modelos de pesquisa. Outrossim, esses autores, igualmente utilizaram e/ou fundamentaram as variáveis a seguir apresentadas.

\subsubsection{CAR (Cumulative Abnormal Return)}

A variável dependente nesta pesquisa será o CAR (cumulative abnormal return) que mede o desempenho em eventos de aquisições de empresas, na visão do mercado (ANDERSON, REEB e ZHAO, 2012; SILVEIRA e BARROS, 2012; MORCK, SHLEIFER e VISHNY, 1988; VILLALONGA e AMIT, 2006). 
O CAR (Cumulative Abnormal Return) mede o retorno anormal acumulado, para os eventos analisados, visando à comparação entre o desempenho de empresas familiares e não familiares, para atender ao teste das hipóteses da pesquisa.

Salienta-se que será utilizada a janela de estimação de 180 dias, que começa 210 dias antes do anúncio da aquisição, e termina 31 dias antes dele, e janelas de eventos de 1, 3, 11 e 21 dias, em torno da data do anúncio do evento, para maior robustez dos resultados da pesquisa (MACKINLAY, 1997; KAYO, PATROCINIO e MARTINS, 2009; NARDI, 2012).

\subsubsection{Empresas Familiares}

Conforme a literatura, a concentração acionária, em pelo menos $5 \%$ de ações ordinárias, já é considerada concentração acionária relevante (SHLEIFER \& VISHNY, 1986; LANZANA \& COSTANZI, 1999; MARTINS, MENEZES e BERNHOEFT, 1999; VILLALONGA \& AMIT, 2006; ANDERSON, REEB \& ZHAO, 2012), podendo-se considerar como empresa familiar, desde que existam outros fatores que corroborem com acúmulo de poder/influência na gestão da empresa.

Visando à operacionalização e classificação em empresa familiar e não familiar, evidencia-se que outras variáveis relacionadas às empresas familiares foram analisadas. Foi realizado um levantamento minucioso e detalhado sobre a propriedade da empresa, conforme é apresentado no quadro a seguir. 
Quadro 3 - Coleta, Operacionalização dos Dados da Pesquisa e Classificação em Empresas Familiares e não Familiares.

\begin{tabular}{|c|c|c|c|c|}
\hline \# & $\begin{array}{l}\text { Perguntas para Operacionalização da } \\
\text { Pesquisa - Classificações variáveis }\end{array}$ & Operacionalização da coleta dos dados & Fonte dos Dados Coletados & Literatura \\
\hline 1 & $\begin{array}{l}\text { Há pessoa(s) física(s), família(s) e/ou } \\
\text { pessoa(s) jurídica(s) (representando } \\
\text { pessoas físicas e/ou famílias) que detêm } \\
\text { mais de } 5 \% \text { de stake acionário? }\end{array}$ & $\begin{array}{l}\text { Verificação do stake de cada acionista informado pelas } \\
\text { empresas. Foi inclusive investigado a propriedade das } \\
\text { empresas que tinham propriedade acionária nas } \\
\text { empresas da amostra da pesquisa. }\end{array}$ & $\begin{array}{c}\text { Economática, Bloomberg, } \\
\text { Datastream, Thomson Reuters, } \\
\text { Site das empresas (RI), CVM, } \\
\text { Bovespa. }\end{array}$ & $\begin{array}{l}\text { ROCHA, 2012; SHLEIFER \& VISHNY, 1986; } \\
\text { LANZANA \& COSTANZI, 1999; MARTINS, } \\
\text { MENEZES e BERNHOEFT, 1999; VILLALONGA \& } \\
\text { AMIT, 2006; ANDERSON, REEB \& ZHAO, 2012; LI } \\
\text { \& SRINIVASAN, } 2011\end{array}$ \\
\hline 2 & $\begin{array}{l}\text { Quem são os acionistas controladores? } \\
\text { Qualificação do controlador. }\end{array}$ & Idem anterior & Idem anterior & $\begin{array}{l}\text { ROCHA, 2012; SHLEIFER \& VISHNY, 1986; } \\
\text { LANZANA \& COSTANZI, 1999; MARTINS, } \\
\text { MENEZES e BERNHOEFT, 1999; VILLALONGA \& } \\
\text { AMIT, 2006; ANDERSON, REEB \& ZHAO, 2012; LI } \\
\text { \& SRINIVASAN, } 2011 \\
\end{array}$ \\
\hline 3 & $\begin{array}{l}\text { Os acionistas controladores participam } \\
\text { diretamente e/ou têm representante no } \\
\text { board? }\end{array}$ & $\begin{array}{l}\text { A partir da identificação dos controladores, foram } \\
\text { levantadas a sua participação no board. }\end{array}$ & Idem anterior & LI \& SRINIVASAN, 2011 \\
\hline 4 & $\begin{array}{l}\text { Os acionistas controladores participam } \\
\text { diretamente e/ou têm representante na } \\
\text { diretoria executiva? }\end{array}$ & $\begin{array}{l}\text { A partir da identificação dos controladores, foram } \\
\text { levantadas a sua participação na diretoria executiva. }\end{array}$ & Idem anterior & $\begin{array}{l}\text { ANDERSON, REEB \& ZHAO, 2012; LI \& } \\
\text { SRINIVASAN, 2011; ASTRACHAN, } 2010\end{array}$ \\
\hline 5 & O fundador ainda permanece na empresa? & $\begin{array}{l}\text { Foi feita uma busca da história da empresa, e verificado } \\
\text { se o fundador ainda permanece. }\end{array}$ & $\begin{array}{c}\text { Sítio da empresa (Relações com } \\
\text { investidores) }\end{array}$ & $\begin{array}{l}\text { ANDERSON, REEB \& ZHAO, 2012; LI \& } \\
\text { SRINIVASAN, } 2011\end{array}$ \\
\hline 6 & $\begin{array}{l}\text { A família do fundador ainda tem relação } \\
\text { com a empresa? Seja por meio do Board, } \\
\text { Diretoria Executiva ou apenas } \\
\text { propriedade acionária. }\end{array}$ & $\begin{array}{l}\text { A partir da identificação da família dos fundadores das } \\
\text { empresas, foi levantado se os mesmos ainda têm } \\
\text { relação com a empresa fundada. }\end{array}$ & $\begin{array}{l}\text { Sítio da empresa, Economática, } \\
\text { Bloomberg, Reuters. }\end{array}$ & $\begin{array}{l}\text { ANDERSON, REEB \& ZHAO, 2012; LI \& } \\
\text { SRINIVASAN, 2011; ASTRACHAN, } 2010\end{array}$ \\
\hline 7 & Qual a geração familiar da empresa? & $\begin{array}{l}\text { A partir da identificação da família controladora, foi } \\
\text { levantado qual a geração familiar. }\end{array}$ & $\begin{array}{l}\text { Sítio da empresa (Relações com } \\
\text { investidores) }\end{array}$ & CAMARGOS E COUTINHO, 2008; GORGATI, 2004 \\
\hline 8 & $\begin{array}{l}\text { Qual o stake dos controladores da } \\
\text { empresa? }\end{array}$ & $\begin{array}{c}\text { Levantado o stake dos controladores de cada empresa } \\
\text { da amostra da pesquisa. Foi inclusive investigado a } \\
\text { propriedade das empresas que tinham propriedade } \\
\text { acionária nas empresas estudadas. }\end{array}$ & $\begin{array}{c}\text { Economática, Bloomberg, } \\
\text { Datastream, Thomson Reuters, } \\
\text { Site das empresas (RI), CVM, } \\
\text { Bovespa. }\end{array}$ & $\begin{array}{c}\text { SHLEIFER \& VISHNY, 1986; LANZANA \& } \\
\text { COSTANZI, 1999; MARTINS, MENEZES e } \\
\text { BERNHOEFT, 1999; VILLALONGA \& AMIT, 2006; } \\
\text { ANDERSON, REEB \& ZHAO, 2012;LI \& } \\
\text { SRINIVASAN, 2011 }\end{array}$ \\
\hline 9 & $\begin{array}{l}\text { Há outros blockholders? Qual a } \\
\text { participação acionária dos outros } \\
\text { blockholders? }\end{array}$ & $\begin{array}{l}\text { Levantada a existência de outros blockholders e sua } \\
\text { participação acionária. }\end{array}$ & $\begin{array}{c}\text { Economática, Bloomberg, } \\
\text { Datastream, Thomson Reuters, } \\
\text { Site das empresas (RI), CVM, } \\
\text { Bovespa. }\end{array}$ & $\begin{array}{c}\text { SHLEIFER \& VISHNY, 1986; LANZANA \& } \\
\text { COSTANZI, 1999; MARTINS, MENEZES e } \\
\text { BERNHOEFT, 1999; VILLALONGA \& AMIT, 2006; } \\
\text { ANDERSON, REEB \& ZHAO, 2012; LI \& } \\
\text { SRINIVASAN, 2011 }\end{array}$ \\
\hline 10 & $\begin{array}{l}\text { Quais são os tipos de classificação dos } \\
\text { outros blockholders? Investidores } \\
\text { institucionais, Governo, etc. }\end{array}$ & $\begin{array}{c}\text { A partir do levantamento de blockholders, foi feita a } \\
\text { classificação destes de acordo com a CVM (Comissão } \\
\text { de Valores Mobiliários). }\end{array}$ & $\begin{array}{l}\text { CVM (Comissão de Valores } \\
\text { Mobiliários) }\end{array}$ & $\begin{array}{c}\text { SHLEIFER \& VISHNY, 1986; LANZANA \& } \\
\text { COSTANZI, 1999; MARTINS, MENEZES e } \\
\text { BERNHOEFT, 1999; VILLALONGA \& AMIT, 2006; } \\
\text { ANDERSON, REEB \& ZHAO, 2012;LI \& } \\
\text { SRINIVASAN, 2011 }\end{array}$ \\
\hline
\end{tabular}

Fonte: Elaborado pelo autor. 
Informa-se, inclusive, que foram investigadas, analisadas e classificadas como empresa familiar, em que os controladores possuem ao menos 5\% de stake acionário e influência na gestão via Board e/ou diretoria executiva e/ou o sobrenome familiar tem história relevante no desenvolvimento da empresa.

Salienta-se também que foi aprofundada a busca sobre propriedade acionária de pessoas jurídicas, informadas nos relatórios, de composição/estrutura acionária das empresas da amostra desta pesquisa, mitigando-se o fator relativamente ordinário de estrutura de propriedade piramidal das empresas, em que, por exemplo, criam-se empresas de sociedade de propósitos específicos (SPE), para benefícios, como anonimato dos acionistas controladores das empresas de capital aberto, benefícios físcais e redução de riscos operacionais-financeiros.

Dessa maneira, os resultados da operacionalização dessa coleta de dados proveram informação robusta, para classificar as empresas da amostra em familiares e não familiares.

Por fim, para efeito de definição operacional da variável será utilizada a variável binária; 1, se for empresa familiar; e 0 , se não for empresa familiar.

\subsubsection{Concentração de Propriedade Acionária}

Com o objetivo de responder a quinta hipótese da pesquisa, a empresa será dividida em três grupos classificados por grau de concentração acionária. Com base nos argumentos desenvolvidos em seção própria - Fundamentação Teórica - Empresas Familiares - Capítulo 2, apresenta-se, a seguir, os três grupos de concentração acionária que serão operacionalizados nesta pesquisa.

O primeiro grupo de classificação de concentração acionária será formado por empresas que tenham concentração de propriedade de ações ordinárias em $10 \%$ ou mais, pelos acionistas controladores.

O segundo grupo de classificação de concentração acionária será formado por empresas que tenham concentração de propriedade de ações ordinárias em $20 \%$ ou mais, pelos acionistas controladores. 
O terceiro grupo de classificação de concentração acionária será formado por empresas que tenham concentração de propriedade de ações ordinárias em $50 \%$ ou mais, pelos acionistas controladores.

Evidencia-se ainda que, para maior robustez da pesquisa, foi proposto e adotado outro modo de classificação de concentração da empresa, ao invés de adotar somente medidas jurídicocontábil de relevância de concentração acionária.

Nesta outra classificação, evidenciada a seguir, utiliza-se o simples sistema de ranqueamento e agrupamento de stake acionário, classificando-o em outros três grupos de concentração acionária, conforme apresenta-se a seguir:

O primeiro grupo do teste de robustez de concentração acionária classificou as empresas da amostra cujos acionistas controladores detinham menos de $30 \%$ de stake acionário.

O segundo grupo do teste de robustez de concentração acionária classificou as empresas da amostra cujos acionistas controladores detinham entre 30\% a 70\% de stake acionário.

Por fim, o terceiro grupo do teste de robustez de concentração acionária classificou as empresas da amostra cujos acionistas controladores detinham acima de $70 \%$ de stake acionário.

Evidencia-se que, para efeito de definição operacional das variáveis discutidas neste tópico sobre concentração acionária, serão utilizadas variáveis binárias: 1, se os acionistas controladores detiverem o stake previamente estabelecido para o grupo de classificação, e 0 , caso contrário.

\subsubsection{Empresa Familiar de Primeira e Segunda Gerações}

Conforme já discutido na seção Fundamentação Teórica, empresas familiares de primeira e/ou segunda gerações tendem a ter maior taxa de crescimento e melhor desempenho, em relação às empresas familiares de terceira ou mais gerações (GERSICK et al., 1997).

Para efeito de definição operacional da variável será utilizada variável binária: 1, se for empresa familiar de primeira e/ou segunda geração; e 0 , se for empresa familiar de terceira ou mais gerações. 


\subsubsection{Oportunidade}

Segundo Bhagat, Malhotra \& Zu (2011) e Rocha (2012) há relação entre Q de Tobin alto, desempenho e realização de aquisições de empresas. Este trabalho utilizará a variável Q de Tobin, para mensurar a oportunidade de crescimento da empresa avaliada pelo mercado. Em outras palavras, quanto maior o quociente da variável, maior a expectativa do mercado em relação à determinada empresa.

Para efeito de definição operacional da variável, o Q de Tobin, de acordo com Rocha (2012), é a soma do valor de mercado das ações com o valor contábil da dívida, dividido pelo valor contábil do ativo total.

\subsubsection{Administração Familiar}

Segundo Anderson, Reeb e Zhao (2012) e Li e Srinivasan (2011), a empresa familiar que tem em sua gestão um membro da família, em posição privilegiada no comando da empresa, tende a ter melhor desempenho.

Para efeito de definição operacional da variável da pesquisa, será utilizada variável binária: 1, quando houver pelo menos um membro da família nos principais cargos executivos; e 0, caso contrário.

\subsubsection{Poder dos Controladores no Conselho}

Há evidências de bom desempenho de empresas quando os controladores exercem maior influência no conselho de administração (LI e SRINIVASAN, 2011). Dessa forma, a variável em voga neste subitem verifica a relação entre o desempenho da empresa em aquisições de empresas em relação ao poder/representatividade dos controladores no conselho de administração.

Para efeito de definição operacional da pesquisa, a representatividade dos controladores no conselho de administração será mensurada por meio da seguinte fórmula:

Poder dos Controladores no Conselho $=($ Representantes dos Controladores no Conselho $/$ Número de Cadeira no Board). 


\subsubsection{Indústria Manufatureira}

Essa variável consiste no fato de as empresas adquirentes classificadas como manufatureiras poderem ter diferentes desempenhos em aquisições de empresas (MARKIDES e ITTNER, 1994; SILVEIRA, 2006).

Será adotada, nesta pesquisa, a classificação SIC (Standard Industrial Classification) 20003999 - Indústria Manufatureira. A variável indústria manufatureira será definida como variável binária: 1 , caso a adquirente for da indústria manufatureira; e 0 , caso contrário.

\subsubsection{Idade}

Esta variável é baseada no fato de que a idade da adquirente pode influenciar no retorno anormal em eventos de aquisições de empresas (MOLLY, LAVEREN e JORISSEN, 2011). Para este trabalho, a idade da adquirente será a diferença entre o ano da aquisição e o ano de fundação da empresa.

\subsubsection{Tamanho da Adquirente}

Esta variável está baseada no fato de que o tamanho da adquirente influencia no retorno anormal em eventos de aquisições de empresas (MOLLY, LAVEREN E JORISSEN, 2011).

Essa variável será operacionalizada neste trabalho como o logaritmo natural do ativo total do exercício anterior ao anúncio de aquisição.

\subsubsection{Diferença de Stake dos Acionistas Controladores e Demais Blockholders}

A diferença da propriedade acionária entre os acionistas controladores e os demais blockholders, com base em Anderson, Reeb \& Zhao (2012) e Li \& Srinivasan (2011), gera maior concentração de poder sobre a empresa.

Esta variável verifica se há relação entre a diferença de stake entre os controladores e demais blockholders, e o desempenho das empresas analisadas.

A variável será operacionalizada como a divisão entre o stake dos controladores e o stake dos demais blockholders. 


\subsubsection{Diferença entre remuneração variável e por ações / Remuneração Total}

Verificar-se-á se a variável, diferença entre remuneração variável e por ações divididas pela remuneração total, tem relação com o desempenho das empresas analisadas. Infere-se que quando há a remuneração variável e por ações, em maior proporção em relação à remuneração total, os administradores tendem a buscar maiores retornos acima da média (LI e SRINIVASAN, 2011).

As variáveis remuneração variável, por ações e total, serão operacionalizadas como os valores informados das remunerações variáveis e por ações, constituídas por bônus, participação nos resultados, comissões e remunerações baseadas em ações. Quanto ao valor da remuneração total, soma-se ainda à remuneração fixa informada. Esta última é constituída pelo salário/prólabore, benefícios diretos e indiretos, entre outros.

\subsubsection{Investidores Institucionais}

Esta variável está baseada em que outros blockholders, em especial, investidores institucionais, podem influir positivamente no desempenho da empresa, devido, sobretudo, ao expertise que podem trazer à gestão da empresa, pois, tendem a vigiar melhor as ações dos agentes administrativos. Essa vigilância também pode ocasionar melhores resultados à empresa. (ANDERSON, REEB \&ZHAO, 2012; KIM \&LU, 2011).

Para este trabalho, investidores institucionais são fundos de investimentos, companhias seguradoras, entidades privadas de previdência complementar, entre outros, definidos pela CVM (Comissão de Valores Mobiliários). Dessa forma, esta variável será operacionalizada como 1, caso a empresa tenha entre seus acionistas investidores institucionais; e 0, caso contrário.

\subsubsection{Alavancagem Financeira da adquirente}

Esta variável é baseada em que a alavancagem financeira influencia o retorno anormal em operações de aquisições de empresas (HALEBLIAN, KIM e RAJAGOPALAN, 2006; ROCHA, 2012).

Para este trabalho, a variável alavancagem financeira será medida como a divisão da dívida de longo prazo pelo ativo total do ano anterior ao anúncio do evento. Inclui-se a variável baseada também na afirmação de Rocha (2012) de que a existência de dívida coíbe aos 
administradores de realizarem desenfreadamente investimentos e a se envolverem em aquisições de empresas de baixo benefícios ou destruidoras de valor.

\subsubsection{Folga Financeira}

A variável folga financeira, segundo Rocha (2012), é o resultado da divisão das disponibilidades e investimentos de curto prazo pelo ativo total da empresa "i", no ano "t". Onde também se baseia na ideia de que a existência de fluxos de caixa substanciais podem motivar aos administradores à realização de investimentos inadequados.

\subsubsection{CAPEX (Capital Expenditure)}

Esta variável é incluída tendo como base Rocha (2012), em que os esforços de crescimento inorgânico são relacionados aos esforços de crescimento orgânico. Verificar-se-á se há relação entre os gastos/dispêndios de capital, ou investimento em bens de capital, e o desempenho da empresa.

Outrossim, Fahlenbrach (2009) evidencia que encontrou relação positiva entre maiores gastos com CAPEX e desempenho da empresa.

Esta variável será operacionalizada como o logaritmo natural do CAPEX, do ano anterior ao anúncio do evento analisado.

\subsubsection{Governança Corporativa (Novo Mercado e Nível 2)}

Com base em Silveira (2006), empresas que aderem aos níveis diferenciados de governança corporativa da Bovespa devem se enquadrar aos padrões mais rígidos de transparência e governança corporativa, o que pode resultar em melhor valoração de suas ações pelo mercado. Evidencia-se ainda que sob escala de transparência, instituindo-se exigências de melhorias nas evidenciações contábeis, concessão de direito de tag along, obrigatoriedade de oferta pública de aquisição de ações, sendo no mínimo pelo valor econômico em função de fechamento ou saída do segmento, esta pesquisa classificou os padrões Novo mercado e Nível 2, como padrões de governança corporativa. 
Salienta-se que a variável governança corporativa será operacionalizada, adotando as nomenclaturas utilizadas pela Bovespa. Dessa forma, 1, para empresas que adotam o padrão Novo Mercado, e Nível 2; e 0, para os demais padrões/classificações.

\subsubsection{Adquirente Serial}

Esta variável está baseada em que adquirentes seriais podem ter melhores resultados decorrentes de acúmulo de experiências em aquisições, no período da amostra da pesquisa (VILLALONGA e MCGAHAM, 2005).

Para este trabalho, a variável adquirente serial será definida como variável binária: 1, caso a empresa adquirente tenha executado ao menos três eventos de aquisições de empresas, durante o período da amostra, e 0 , caso contrário.

\subsubsection{Aquisição Internacional}

Com base em Aybar \& Ficici (2009); Gubbi et. al (2010); aquisições internacionais podem resultar em desempenho anormal. Essa variável relacionará o desempenho das empresas da amostra, com aquisições internacionais e será operacionalizada como variável binária: 1, se a aquisição foi internacional; 0 , se a aquisição foi doméstica. 


\section{RESULTADOS}

Informa-se que para obtenção e cálculo dos resultados foram utilizados basicamente os softwares STATA 12 single-user 2-core e Microsoft Office 2010.

Relata-se neste capítulo os resultados encontrados nesta pesquisa, que serão apresentados em três seções.

Na primeira seção, reportar-se-á a análise descritiva, contendo a descrição amostral da pesquisa e estatísticas descritivas da amostra. Quanto às estatísticas descritivas da amostra, será analisada univariadamente cada uma das variáveis da amostra e, em especial, os CARs obtidos. Assim, serão verificadas as hipóteses da pesquisa pertinente, se há criação ou não de valor.

Na segunda seção, será reportada a análise comparativa (bivariada) das variáveis da amostra, evidenciando-se a matrix de correlação pairwise.

Por fim, na terceira seção, serão reportados os resultados das análises multivariadas das variáveis da amostra. Evidencia-se que foram reportados para todas as regressões os resultados com matrizes robustas, para estimação dos parâmetros por Hubber-White Sandwich, mitigando o problema encontrado de heterocedasticidade pelo teste de BreuschPagan.

Outrossim, aborda-se que, na primeira e terceira seções, apresentar-se-ão ainda os resultados estimados pelo teste não paramétrico Bootstrap, mitigando-se o problema encontrado de não normalidade da amostra, evidenciado pelos testes Shapiro-Wilk, Kolmogorov-Smirnov e Jarque-Bera.

\subsection{Análise Descritiva}

\subsubsection{Descrição Amostral dos Dados da Pesquisa}

Inicia-se o reporte dos resultados encontrados, com a evidenciação da descrição amostral dos dados da pesquisa por segmento de negócios. A distribuição da amostra, na tabela a seguir, são nomenclaturas fornecidas pela Economática®, para fins de classificação do segmentos/setor de negócios. 
Tabela 1 - Descrição Amostral - Composição da Amostra por Segmentos de Negócios/Atividade Industrial

\begin{tabular}{|c|c|c|}
\hline Setor|Economática ${ }^{\circledR}$ & $\begin{array}{c}\text { Números de } \\
\text { Eventos }\end{array}$ & Porcentagem \\
\hline Agropecuária e Pesca & 2 & $0.56 \%$ \\
\hline Alimentos e Bebibas & 33 & $9.30 \%$ \\
\hline Comércio & 8 & $2.25 \%$ \\
\hline Construção & 12 & $3.38 \%$ \\
\hline Eletroeletrônicos & 2 & $0.56 \%$ \\
\hline Energia Elétrica & 28 & $7.89 \%$ \\
\hline Finanças e Seguros & 31 & $8.73 \%$ \\
\hline Máquinas Industriais & 6 & $1.69 \%$ \\
\hline Mineração & 13 & $3.66 \%$ \\
\hline Minerais não Metálicos & 1 & $0.28 \%$ \\
\hline Outros & 120 & $33.80 \%$ \\
\hline Papel e Celulose & 5 & $1.41 \%$ \\
\hline Petróleo e Gás & 21 & $5.92 \%$ \\
\hline Química & 9 & $2.54 \%$ \\
\hline Siderúrgica \& Metalúrgica & 10 & $2.82 \%$ \\
\hline Software e Dados & 12 & $3.38 \%$ \\
\hline Telecomunicações & 6 & $1.69 \%$ \\
\hline Textil & 11 & $3.10 \%$ \\
\hline Transporte Serviço & 16 & $4.51 \%$ \\
\hline Veiculos e peças & 9 & $2.54 \%$ \\
\hline Total & 355 & $100 \%$ \\
\hline
\end{tabular}

Fonte: Elaborado pelo autor.

Pode-se observar, na tabela acima, que os segmentos econômicos que mais realizaram eventos de aquisições, no período da amostra no Brasil, foram as indústrias de alimentos e bebidas, energia elétrica, finanças e seguros, mineração, petróleo e gás e transportes, totalizando $40 \%$ do total dos eventos de aquisição da amostra da pesquisa.

Tabela 2 - Descrição Amostral - Composição da Amostra por Adoção de Padrão de Governança Corporativa

\begin{tabular}{lrr}
\hline Nível/Padrão de Governança Corporativa & Número de eventos & Porcentagem \\
\hline Novo Mercado & 220 & $61.97 \%$ \\
Nível 2 & 24 & $6.76 \%$ \\
Nível 1 & 57 & $16.06 \%$ \\
Tradicional & 50 & $14.08 \%$ \\
BDR3 & 4 & $1.13 \%$ \\
Total & $\mathbf{3 5 5}$ & $\mathbf{1 0 0 . 0 0 \%}$ \\
\hline
\end{tabular}

Fonte: Elaborado pelo autor. 
Na tabela acima, reporta-se a composição da amostra por adoção de padrão de Governança Corporativa. Evidencia-se que, no período da amostra, as empresas que efetuaram eventos de aquisições no Brasil adotaram, em sua maioria (61,97\%), o padrão Novo Mercado da Bovespa. É importante citar que parte relevante da amostra é de empresas recém-listadas na Bolsa de Valores de São Paulo, que aproveitaram a onda de IPOs (Initial Public Offering), que ocorreu entre 2005 a 2008, período de relativa exuberância econômica brasileira.

Observa-se também que parte relevante $(30,14 \%)$ das empresas que executaram aquisições de empresas, no Brasil, ainda adotam padrões considerados menos atrativos e transparentes; padrões Nível 1 e Tradicional, em que ainda há diferenças de tratamento entre acionistas minoritários e grupos de controle, como exemplo, a inexistência de direito de tag along, não há obrigação da empresa comunicar oferta pública de recompra, por pelo menos o valor econômico da ação; em caso de fechamento e/ou saída da empresa do segmento, e não há obrigação a se sujeitar a decisões da câmara de arbitragem do mercado.

Informa-se ainda que somente $1,13 \%$ dos eventos de aquisições, no Brasil, foram efetuados por empresas listadas na Bovespa como BDR3 (Brazilian Depositary Receipts - Nível 3). Os BDRs são certificados de depósito de valores mobiliários emitidos no Brasil por empresas que também têm emissão de valores mobiliários no exterior. Os BDRs também são classificados em níveis, entretanto, esses níveis não são relacionados às políticas/práticas de Governança Corporativa.

Dessa forma, para efetuar uma classificação mais acurada quanto à governança corporativa, foi pesquisada cada uma das três empresas da amostra com BDRs na Bovespa, a saber: GP investimentos, Tam S.A. e Wilson Sons Logística. Assim, em análise de fatores de governança, concluiu-se que as três empresas não se inserem nos níveis diferenciados da Bovespa, devido a fatores de composição acionária, acúmulo de cargos de pessoas-chave, entre outros.

Logo, para efeito de operacionalização da presente pesquisa, adotaram-se as empresas com BDRs da amostra como padrão de Governança Corporativa símiles aos demais níveis da Bovespa, ou seja, não sendo integrantes dos padrões de governança mais diferenciados e melhores, na visão dos investidores (Novo Mercado e Nível 2).

Em análise ainda das empresas da presente amostra com BDRs na Bovespa, constatou-se que, em sua totalidade, têm relevante histórico de atividade empresarial, no Brasil, cujas famílias fundadoras atuaram e têm atuado, por longo período. A Wilson Sons Logística, por exemplo, 
atua no Brasil desde o século 19, sendo uma das empresas ativas mais antigas, perdendo apenas para o Banco do Brasil, fundado em 1808, com a chegada da Família Real. Logo, as três empresas com BDRs da amostra são, na realidade, brasileiras, mesmo que tenham emissão de valores mobiliários e/ou sede no exterior, pois, ainda são extremamente atuantes no Brasil, e seus portifólios de negócios estão alocados com relevância domésticamente.

É relevante mencionar também que foi observado, na amostra da pesquisa, que não há relação entre ser classificada como familiar / não familiar para que a empresa adote ou não melhores padrões de governança corporativa. Na realidade, existe um movimento geral do mercado de exigir que todas as empresas adotem melhores práticas de governança corporativa.

Informa-se que quanto à relação do desempenho das empresas em eventos de aquisições, em decorrência da adoção ou não de melhores padrões de governança corporativa (Novo Mercado e Nível 2 da Bovespa), será apresentada posteriormente nas regressões estatísticas pertinentes.

Tabela 3 - Descrição Amostral - Composição da Amostra de Aquisições por País-alvo

\begin{tabular}{ccc}
\hline País-Alvo & Número de Eventos & Porcentagem \\
\hline Argentina & 12 & $3.4 \%$ \\
Bélgica & 2 & $0.6 \%$ \\
Benim & 1 & $0.3 \%$ \\
Brasil & 294 & $82.8 \%$ \\
Canadá & 2 & $0.6 \%$ \\
Chile & 2 & $0.6 \%$ \\
Colômbia & 3 & $0.8 \%$ \\
República Dominicana & 1 & $0.3 \%$ \\
Equador & 1 & $0.3 \%$ \\
França & 1 & $0.3 \%$ \\
Guernsey & 1 & $0.3 \%$ \\
México & 4 & $1.1 \%$ \\
Namíbia & 3 & $0.8 \%$ \\
Países Baixos & 2 & $0.6 \%$ \\
Portugal & 7 & $2.0 \%$ \\
Espanha & 1 & $0.3 \%$ \\
Reino Unido & 1 & $0.3 \%$ \\
Estados Unidos da América & 1 & $0.3 \%$ \\
Uruguai & 15 & $4.2 \%$ \\
Total & 1 & $0.3 \%$ \\
\hline
\end{tabular}

Fonte: Elaborado pelo autor. 
Evidencia-se que, conforme os dados apresentados anteriormente, na fundamentação teórica de aquisições de empresas, grande parte dos eventos de aquisições, no período da amostra, ocorreu domesticamente $(82.8 \%)$.

Observa-se ainda que os países, em que as empresas da amostra mais realizaram eventos de aquisições, foram aqueles com alto grau de desenvolvimento econômico, como os EUA (Estados Unidos da América) 4,2\%, em primeiro lugar. Outrossim, países com grande proximidade cultural, linguística e/ou geográfica, totalizando-se $9 \%$ dos eventos da amostra. 
Tabela 4 - Descrição Amostral - Composição da Amostra Total das Empresas

\begin{tabular}{|c|c|c|c|c|c|c|}
\hline Id. & Empresas Adquirentes & Número de Eventos & $\%$ & Empresas Familiares & Família & Stake Família (\%) \\
\hline 1 & Abril SA & 3 & $0.8 \%$ & $\operatorname{Sim}$ & Civita & 65.4 \\
\hline 2 & Guarani SA & 2 & $0.6 \%$ & Não & - & - \\
\hline 3 & Anhanguera SA & 9 & $2.5 \%$ & Sim & Carbonari e Poli & 62.3 \\
\hline 4 & AES ELPA & 1 & $0.3 \%$ & Não & - & - \\
\hline 5 & Brasilagro SA & 1 & $0.3 \%$ & Sim & Cresud - Elsztain & 35.75 \\
\hline 6 & Alpargatas Sa & 3 & $0.8 \%$ & Sim & Camargo Correa & 66.99 \\
\hline 7 & Aliansce SA & 5 & $1.4 \%$ & Sim & Renato Rique & 10.81 \\
\hline 8 & AmBev SA & 1 & $0.3 \%$ & Sim & Lemann, Telles, Sicupira e Sebastien & 91.11 \\
\hline 9 & Amil SA & 2 & $0.6 \%$ & Sim & Godoy Bueno & 14.39 \\
\hline 10 & Autometal SA & 1 & $0.3 \%$ & Não & - & - \\
\hline 11 & Brasil SA & 9 & $2.5 \%$ & Não & - & - \\
\hline 12 & Bradesco SA & 9 & $2.5 \%$ & Sim & Aguiar e Brandão & 73.98 \\
\hline 13 & Brasil Brokers SA & 6 & $1.7 \%$ & Não & - & - \\
\hline 14 & BTG Pactual SA & 2 & $0.6 \%$ & Sim & Andre Esteves & 65.3 \\
\hline 15 & Bardella SA & 1 & $0.3 \%$ & Sim & Bardella & 96.85 \\
\hline 16 & Minerva SA & 3 & $0.8 \%$ & Sim & Vilela de Queiroz & 37.45 \\
\hline 17 & BHG SA & 7 & $2.0 \%$ & Sim & Bonchristiano e Lambranho & 17.04 \\
\hline 18 & BIC SA & 1 & $0.3 \%$ & Sim & Bezerra e Menezes & 98.25 \\
\hline 19 & Bombril SA & 1 & $0.3 \%$ & Sim & Sampaio Ferreira & 34.64 \\
\hline 20 & Panamericano SA & 1 & $0.3 \%$ & Sim & Andre Esteves & 51 \\
\hline 21 & BR Foods SA & 3 & $0.8 \%$ & Não & - & - \\
\hline 22 & BR Insurance & 1 & $0.3 \%$ & Não & - & - \\
\hline 23 & Braskem SA & 4 & $1.1 \%$ & Sim & Odebrecht & 50.11 \\
\hline 24 & BR Malls SA & 16 & $4.5 \%$ & Não & - & - \\
\hline 25 & BR Properties SA & 5 & $1.4 \%$ & Não & - & - \\
\hline 26 & Camargo Correa SA & 5 & $1.4 \%$ & Sim & Camargo Correa & 66.11 \\
\hline 27 & Cyrela Commercial SA & 1 & $0.3 \%$ & Sim & Horn e Krakowiak & 70.91 \\
\hline 28 & CCR SA & 5 & $1.4 \%$ & Sim & Andrade Gutierrez, Camargo Correa e Soares Penido & 51.22 \\
\hline 29 & Cielo SA & 3 & $0.8 \%$ & Não & 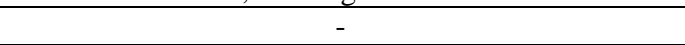 & - \\
\hline 30 & CEMIG SA & 6 & $1.7 \%$ & Não & - & - \\
\hline
\end{tabular}


Continuação da Tabela 4. Descrição amostral - Composição da amostra total das empresas.

\begin{tabular}{|c|c|c|c|c|c|c|}
\hline 31 & CPFL SA & 4 & $1.1 \%$ & Sim & Camargo Correa & 24.33 \\
\hline 32 & Cremer SA & 5 & $1.4 \%$ & Sim & Magalhães & 51.26 \\
\hline 33 & Cosan SA & 5 & $1.4 \%$ & Sim & Ometto Alterio & 66.4 \\
\hline 34 & CSN SA & 1 & $0.3 \%$ & Sim & Steinbruch & 51.85 \\
\hline 35 & Contax SA & 2 & $0.6 \%$ & Sim & Jereissati e Andrade Gutierrez & 53.3 \\
\hline 36 & Karsten SA & 1 & $0.3 \%$ & Sim & Karsten e Odebrecht & 54.45 \\
\hline 37 & Coteminas & 1 & $0.3 \%$ & Sim & Gomes da Silva e Rebello de Paula & 74.47 \\
\hline 38 & Cyrela Realty SA & 2 & $0.6 \%$ & Sim & Horn & 30.61 \\
\hline 39 & DASA SA & 2 & $0.6 \%$ & Sim & Godoy Bueno & 23.59 \\
\hline 40 & Duratex SA & 4 & $1.1 \%$ & Sim & Villela e Setubal & 60 \\
\hline 41 & Dixie Toga SA & 1 & $0.3 \%$ & Não & - & - \\
\hline 42 & Embratel SA & 2 & $0.6 \%$ & Sim & Slim Helú & 98.24 \\
\hline 43 & Ecorodovias SA & 3 & $0.8 \%$ & Sim & Almeida & 63.99 \\
\hline 44 & Eletrobras SA & 1 & $0.3 \%$ & Não & - & - \\
\hline 45 & EDP SA & 2 & $0.6 \%$ & Não & - & - \\
\hline 46 & Energisa SA & 2 & $0.6 \%$ & Sim & Botelho & 86.6 \\
\hline 47 & Equatorial SA & 1 & $0.3 \%$ & Não & - & - \\
\hline 48 & Estácio SA & 3 & $0.8 \%$ & Não & - & - \\
\hline 49 & Eternit SA & 1 & $0.3 \%$ & Não & - & - \\
\hline 50 & EZTEC SA & 1 & $0.3 \%$ & Sim & Zarzur & 58.31 \\
\hline 51 & Heringer SA & 1 & $0.3 \%$ & Sim & Heringer & 67.76 \\
\hline 52 & Fibria SA & 2 & $0.6 \%$ & Sim & Moraes & 29.42 \\
\hline 53 & Forjas Taurus SA & 1 & $0.3 \%$ & Sim & Estima & 43.8 \\
\hline 54 & Fleury SA & 3 & $0.8 \%$ & Não & - & - \\
\hline 55 & Gafisa SA & 1 & $0.3 \%$ & Não & - & - \\
\hline 56 & Gerdau SA & 3 & $0.8 \%$ & Sim & Gerdau Johannpeter & 50.02 \\
\hline 57 & Gol SA & 1 & $0.3 \%$ & Sim & Familia Constantino & 100 \\
\hline 58 & GP Invest. SA & 2 & $0.6 \%$ & Sim & Bonchristiano e Lambranho & 100 \\
\hline 59 & General Shop. SA & 2 & $0.6 \%$ & Sim & Poli e Veronezi & 59.41 \\
\hline 60 & HRT SA & 4 & $1.1 \%$ & Não & - & - \\
\hline
\end{tabular}


Continuação da Tabela 4. Descrição amostral - Composição da amostra total das empresas.

\begin{tabular}{|c|c|c|c|c|c|c|}
\hline 61 & Hypermarcas SA & 13 & $3.7 \%$ & Não & - & - \\
\hline 62 & Ideiasnet SA & 2 & $0.6 \%$ & Não & - & - \\
\hline 63 & Indusval SA & 1 & $0.3 \%$ & Sim & Ciampolini, Ribeiro e Cintra & 55.12 \\
\hline 64 & Iguatemi SA & 3 & $0.8 \%$ & Sim & Jereissati & 29.5 \\
\hline 65 & Cia. docas de Imbituba SA & 1 & $0.3 \%$ & Não & - & - \\
\hline 66 & International Meal SA & 4 & $1.1 \%$ & Não & - & - \\
\hline 67 & Inepar SA & 2 & $0.6 \%$ & Sim & Oms & 32.83 \\
\hline 68 & Itautec SA & 1 & $0.3 \%$ & Sim & Villela e Setubal & 94.01 \\
\hline 69 & Itau SA & 2 & $0.6 \%$ & Sim & Villela e Setubal & 72.41 \\
\hline 70 & ItauUnibanco SA & 6 & $1.7 \%$ & Sim & Villela, Setubal e Moreira Salles. & 89 \\
\hline 71 & JBS SA & 11 & $3.1 \%$ & Sim & Batista e Bertin & 43.6 \\
\hline 72 & Kroton SA & 6 & $1.7 \%$ & Sim & Galindo e Laffranchi & 10.32 \\
\hline 73 & Americanas SA & 1 & $0.3 \%$ & Sim & Lemann, Telles, Sicupira. & 59.62 \\
\hline 74 & Light SA & 4 & $1.1 \%$ & Não & - & - \\
\hline 75 & Le lis Blanc SA & 1 & $0.3 \%$ & Sim & Guida, Afrange, Lima, Russel e Camargo. & 47.1 \\
\hline 76 & Lopes SA & 5 & $1.4 \%$ & Sim & Lopes & 16.29 \\
\hline 77 & Lupatech SA & 2 & $0.6 \%$ & Sim & Perrini & 6.11 \\
\hline 78 & Mangels SA & 1 & $0.3 \%$ & Sim & Mangels & 90.92 \\
\hline 79 & MMX SA & 2 & $0.6 \%$ & Sim & Batista & 78.5 \\
\hline 80 & MPX SA & 4 & $1.1 \%$ & Sim & Batista & 28.99 \\
\hline 81 & Marfrig SA & 6 & $1.7 \%$ & Sim & Santos & 33.12 \\
\hline 82 & Multiplan SA & 3 & $0.8 \%$ & Sim & Peres & 32 \\
\hline 83 & IochpeMaxion SA & 5 & $1.4 \%$ & Sim & Iochpe & 31.92 \\
\hline 84 & Odontoprev SA & 1 & $0.3 \%$ & Sim & Cardodo e Zanetti. & 7.54 \\
\hline 85 & OGX SA & 3 & $0.8 \%$ & Sim & Batista & 60.7 \\
\hline 86 & Oi SA & 2 & $0.6 \%$ & Sim & Jereissati e Andrade Gutierrez & 21.84 \\
\hline 87 & Pão de Açúcar SA & 1 & $0.3 \%$ & Sim & Diniz e Casino Perrachon & 99.94 \\
\hline 88 & PDG Realty SA & 3 & $0.8 \%$ & Não & - & - \\
\hline 89 & Petrobras SA & 14 & $3.9 \%$ & Não & - & - \\
\hline 90 & Profarma SA & 1 & $0.3 \%$ & Sim & Birmarcker & 56.25 \\
\hline
\end{tabular}


Continuação da Tabela 4. Descrição amostral - Composição da amostra total das empresas.

\begin{tabular}{|c|c|c|c|c|c|c|}
\hline 91 & Marcopolo SA & 3 & $0.8 \%$ & Sim & $\begin{array}{c}\text { Bellini } \\
\end{array}$ & 49.35 \\
\hline 92 & Positivo SA & 1 & $0.3 \%$ & Sim & $\begin{array}{l}\text { Formighieri, Rotenberg, Vargas, Von Ridder, Lago e } \\
\text { Guimarães. }\end{array}$ & 72.65 \\
\hline 93 & Qualicorp SA & 1 & $0.3 \%$ & Sim & José Seripieri Filho & 25.4 \\
\hline 94 & Drogasil SA & 1 & $0.3 \%$ & Sim & Pipponzi, Zagottis e Dias. & 25.72 \\
\hline 95 & Irani SA & 1 & $0.3 \%$ & Sim & Druck & 90.98 \\
\hline 96 & Rodobens SA & 1 & $0.3 \%$ & Sim & Verdi & 46.01 \\
\hline 97 & Localiza Rent a Car & 2 & $0.6 \%$ & Sim & Mattar e Resende & 30.73 \\
\hline 98 & Renar SA & 1 & $0.3 \%$ & Sim & Frey & 24.77 \\
\hline 99 & Romi SA & 1 & $0.3 \%$ & Sim & Romi e Chiti & 50 \\
\hline 100 & São Carlos SA & 1 & $0.3 \%$ & Sim & Lemann, Telles, Sicupira. & 53.87 \\
\hline 101 & Sistema Educ. BR. SA & 1 & $0.3 \%$ & Não & - & - \\
\hline 102 & Sao Martinho SA & 2 & $0.6 \%$ & Sim & Ometto & 56.23 \\
\hline 103 & Sonae Sierra SA & 1 & $0.3 \%$ & Não & - & - \\
\hline 104 & Sul America SA & 1 & $0.3 \%$ & Sim & Ségur e Larragoiti Lucas. & 63.5 \\
\hline 105 & Suzano SA & 4 & $1.1 \%$ & Sim & Feffer & 97.3 \\
\hline 106 & TAESA SA & 1 & $0.3 \%$ & Não & - & - \\
\hline 107 & Tam SA & 1 & $0.3 \%$ & Sim & Rolim Amaro & 80.3 \\
\hline 108 & Tegma SA & 1 & $0.3 \%$ & Sim & Moreira Franco e Coser & 65.5 \\
\hline 109 & Tim SA & 1 & $0.3 \%$ & Sim & Fossati e Napolitano & 66.68 \\
\hline 110 & Telemar Norte Leste SA & 1 & $0.3 \%$ & Sim & Jereissati e Andrade Gutierrez & 21.84 \\
\hline 111 & Totvs SA & 6 & $1.7 \%$ & Sim & Cosentino e Haberkorn. & 17.66 \\
\hline 112 & TPI Triunfo SA & 2 & $0.6 \%$ & Sim & Carvalho, Garcia, Aguiar, Piovezan e Queiroz. & 64.72 \\
\hline 113 & CTEEP SA & 2 & $0.6 \%$ & Não & - & - \\
\hline 114 & TIVIT SA & 1 & $0.3 \%$ & Sim & Mattar e Paola & 54.7 \\
\hline 115 & Ultrapar SA & 2 & $0.6 \%$ & Sim & Aguiar Cunha, Igel, Andrade e Beltrão. & 23.67 \\
\hline 116 & UNIPAR SA & 1 & $0.3 \%$ & Sim & Geyer & 67.71 \\
\hline 117 & UOL SA & 3 & $0.8 \%$ & Sim & Frias e Queiroz & 100 \\
\hline 118 & Usiminas SA & 2 & $0.6 \%$ & Não & - & - \\
\hline 119 & Vanguarda Agro SA & 1 & $0.3 \%$ & Sim & Seibel, Pivetta e De Araújo & 45.63 \\
\hline 120 & Vale SA & 11 & $3.1 \%$ & Não & - & - \\
\hline 121 & Weg SA & 4 & $1.1 \%$ & Sim & Voigt, da Silva e Werninghaus & 64.57 \\
\hline 122 & Wilson SA & 1 & $0.3 \%$ & Sim & Salomon & 23.1 \\
\hline Total: & - & 355 & $100.0 \%$ & - & - & - \\
\hline
\end{tabular}

Fonte: Elaborado pelo autor 
Evidencia-se, na tabela acima, a descrição amostral das empresas, reportando-se a quantidade de empresas analisadas na pesquisa (122 empresas), o nome das empresas adquirentes, o número de eventos realizados e a sua participação relativa sobre a quantidade total de eventos da amostra, e a classificação da empresa em familiar ou não, a qualificação da família controladora e o stake acionário da família controladora.

\subsubsection{Estatística Descritiva - Análise Univariada do CAR de Todas Empresas, Empresas Familiares e Empresas Não Familiares}

Em análise univariada, primeiramente, será avaliada a variável que mensura o desempenho das empresas no Brasil, em eventos de aquisições, no período da amostra. Dessa forma, apresenta-se, a seguir, a tabela de análise dos CARs (cumulative abnormal return), que evidenciará se houve ou não criação de valor em decorrência dos eventos de aquisições analisados, podendo mensurar o desempenho das empresas familiares e não familiares, inclusive por grau de concentração acionária.

Evidencia-se ainda que foi reportado, nesta seção, o teste de robustez de bechmark/proxy de retorno de mercado - IBRX50, e, outrossim, o teste de robustez de concentração acionária, métodos por ranqueamento e agrupamento de stake acionário, conforme já relatado na seção de definição operacional das variáveis da pesquisa - Concentração de propriedade acionária Capítulo 4, do presente trabalho.

5.1.2.1 Estatística Descritiva - CAR - Análise de desempenho e criação de valor em aquisições de empresas - Todas Empresas da Amostra 
Tabela 5 - Painel A. CAR (Cumulative Abnormal Returns) - Todas Empresas da Amostra - Proxy do modelo de mercado: IBOVESPA

\begin{tabular}{|c|c|c|c|c|c|c|c|c|c|c|c|c|c|}
\hline 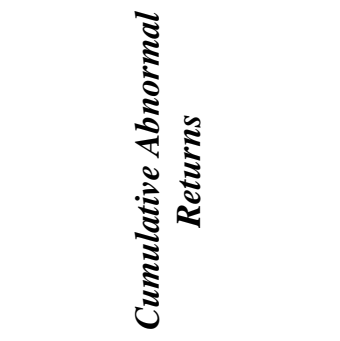 & 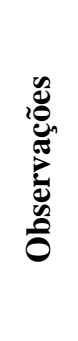 & 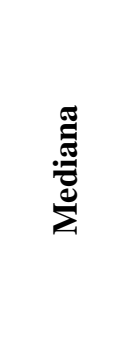 & 莺 & 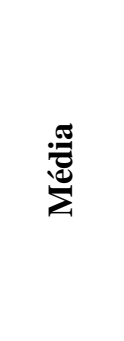 & 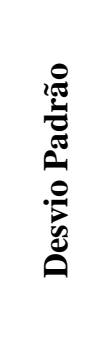 & $\begin{array}{l}\overrightarrow{0} \\
\stackrel{0}{0} \\
\stackrel{0}{*}\end{array}$ & & 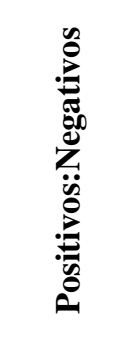 & 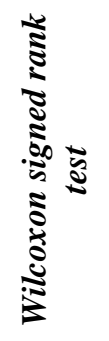 & 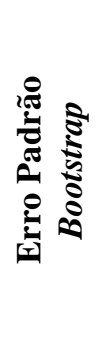 & $\begin{array}{l}\widehat{\mathrm{v}} \\
\text { s. } \\
\overline{5} \\
0 \\
0 \\
0\end{array}$ & & 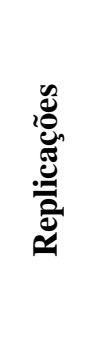 \\
\hline Dia Anúncio_Ibovespa & 355 & $-0.05 \%$ & $35.44 \%$ & $0.27 \%$ & $2.82 \%$ & 1.7928 & $*$ & 172:183 & 0.28 & 0.89 & 2.02 & $* *$ & 1000 \\
\hline CAR_3_Ibovespa & 355 & $-0.21 \%$ & $40.35 \%$ & $0.32 \%$ & $4.33 \%$ & 1.3776 & & $162: 193$ & 0.03 & 0.97 & 1.42 & & 1000 \\
\hline CAR_11_Ibovespa & 355 & $0.01 \%$ & $65.67 \%$ & $0.05 \%$ & $6.77 \%$ & 0.1424 & & 178:177 & -0.46 & 1.00 & 0.14 & & 1000 \\
\hline CAR_21_Ibovespa & 355 & $-0.88 \%$ & $63.73 \%$ & $-0.48 \%$ & $9.23 \%$ & -0.9876 & & $164: 191$ & -1.62 & 1.07 & -0.92 & & 1000 \\
\hline
\end{tabular}

CAR: cumulative abnormal return, onde o primeiro valor refere-se à janela de evento e a segunda nomenclatura ao benchmark de retorno de mercado utilizado; $* p<0,10, * * p<0.05$, *** $p<0.01$; em caso de diminuição do número de observações reportadas, salienta-se que é decorrente de missing values (dados faltantes).

Fonte: Elaborado pelo autor.

Evidencia-se, no painel A, o CAR (cumulative abnormal return) de todas as empresas da amostra, utilizando como benchmark do retorno de mercado o IBOVESPA.

Pode-se perceber que a maioria dos ACARs (average cumulative abnormal return) obteve resultados positivos, entretanto, apenas o CAR_1 (resultados anormais acumulados mensurados no dia do anúncio do evento; $0.27 \%$ de geração de valor) obteve significância estatística tanto pelo teste t de student $(\mathrm{p}<0.10)$, como no teste não paramétrico Bootstrap $(p<0.05)$. 
Tabela 6 - Painel B. CAR (Cumulative Abnormal Returns) - Todas Empresas da Amostra - Proxy do modelo de mercado: IBRX50

\begin{tabular}{|c|c|c|c|c|c|c|c|c|c|c|c|c|c|c|}
\hline 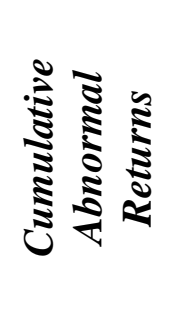 & 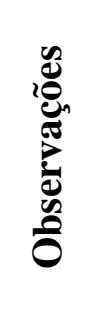 & 胥 & 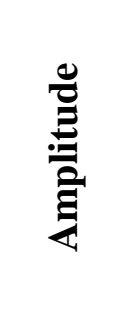 & 疍 & 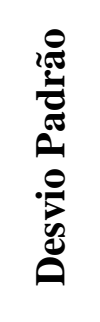 & $\stackrel{\omega}{\mathscr{E}}$ & & 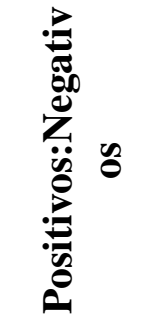 & 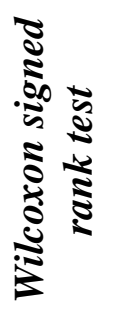 & & 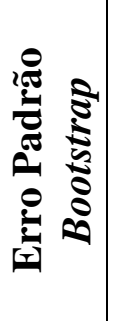 & 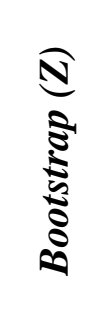 & & 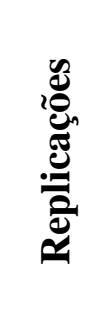 \\
\hline $\begin{array}{c}\text { Dia } \\
\text { Anúncio } \\
\text { IBRX50 }\end{array}$ & 355 & $\begin{array}{c}- \\
0.07 \%\end{array}$ & $35.8 \%$ & $0.28 \%$ & $\begin{array}{c}2.82 \\
\%\end{array}$ & 1.84 & $*$ & 169:186 & 0.16 & & 0.92 & 2.00 & $* *$ & 1000 \\
\hline $\begin{array}{l}\text { CAR_3_- } \\
\text { IBRX50 }\end{array}$ & 355 & $\begin{array}{c}- \\
0.23 \%\end{array}$ & $40.3 \%$ & $0.31 \%$ & $\begin{array}{c}4.37 \\
\%\end{array}$ & 1.34 & & $157: 198$ & -0.05 & & 0.97 & 1.38 & & 1000 \\
\hline $\begin{array}{l}\text { CAR_11_ } \\
\text { IBRX50 }\end{array}$ & 355 & $\begin{array}{c}- \\
0.06 \%\end{array}$ & $66.0 \%$ & $-0.05 \%$ & $\begin{array}{c}6.79 \\
\%\end{array}$ & $\begin{array}{c}- \\
0.12\end{array}$ & & $175: 180$ & -0.69 & & 0.99 & -0.13 & & 1000 \\
\hline $\begin{array}{l}\text { CAR_21_ } \\
\text { IBRX50 }\end{array}$ & 355 & $\begin{array}{c}- \\
0.90 \%\end{array}$ & $64.0 \%$ & $-0.69 \%$ & $\begin{array}{c}9.30 \\
\%\end{array}$ & $\begin{array}{c}- \\
1.39\end{array}$ & & 163:192 & -2.15 & $* *$ & 1.04 & -1.35 & & 1000 \\
\hline
\end{tabular}

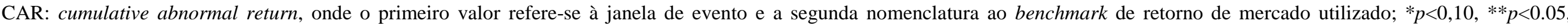
***p<0.01; em caso de diminuição do número de observações reportadas, salienta-se que é decorrente de missing values (dados faltantes).

Fonte: Elaborado pelo autor. 
No painel B, que é apenas um teste de robustez de retorno de mercado, utilizando o benchmark IBRX50, foram encontrados praticamente os mesmos resultados quando utilizado o retorno de mercado IBOVESPA. A única diferença a ser evidenciada é que o CAR_21_IBRX50 obteve significância estatística para o teste de sinais de Wilcoxon. Esse teste, cuja premissa é (hipótese zero - H.0), pressupõe que a mediana de determinada amostra seja igual a zero.

Dessa forma, como se rejeita H.0 a ( $<<0.05)$, há evidências estatísticas de que a mediana seja diferente de zero, ou seja, de que a maior parte dos resultados tem sinais negativos.

Por outro lado, o ACAR_1 (dia do anúncio; 0.28\% de geração de valor) ainda apresenta significância estatística de criação de valor, pelos testes t de student e bootstrap, ou seja, retornos anormais acumulados positivos na média.

Assim, para todas as empresas, verifica-se que para CAR_1 (dia do anúncio) há evidências estatísticas de criação de valor, nos eventos de aquisições de empresas da amostra.

5.1.2.2 Estatística descritiva - CAR - Análise de desempenho e criação de valor em aquisições de empresas - Empresas Familiares da Amostra 
Tabela 7 - Painel C. CAR (Cumulative Abnormal Returns) -Empresas Familiares da Amostra - Proxy do modelo de mercado: IBOVESPA

\begin{tabular}{|c|c|c|c|c|c|c|c|c|c|c|c|c|}
\hline 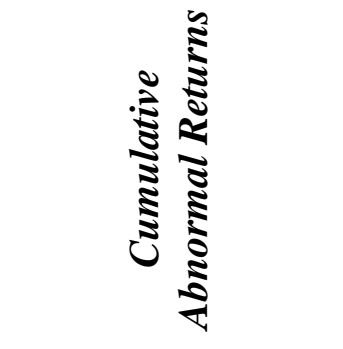 & 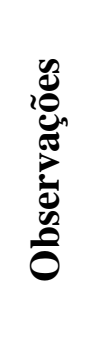 & 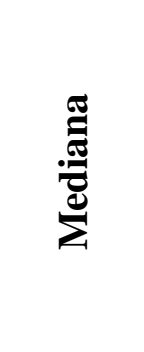 & 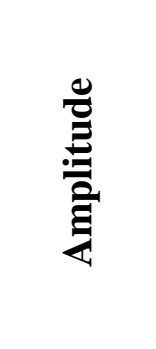 & 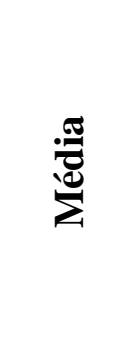 & 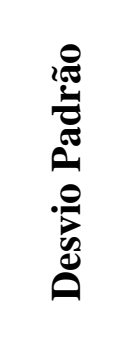 & $\underset{\mathscr{\theta}}{\stackrel{\mathscr{E}}{*}}$ & 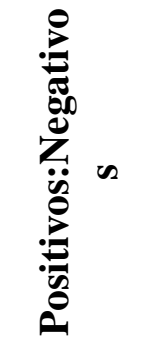 & 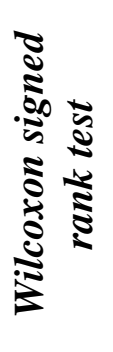 & 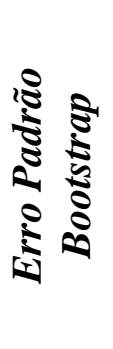 & 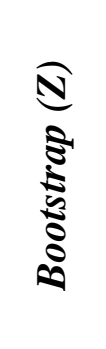 & & 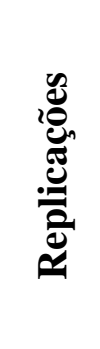 \\
\hline $\begin{array}{c}\text { Dia } \\
\text { Anúncio_Ibovespa }\end{array}$ & 226 & $-0.17 \%$ & $35.44 \%$ & $0.34 \%$ & $3.17 \%$ & 1.627 & 104:122 & 0.02 & 0.91 & 1.79 & $*$ & 1000 \\
\hline CAR_3_Ibovespa & 226 & $-0.33 \%$ & $40.35 \%$ & $0.33 \%$ & $4.51 \%$ & 1.1105 & $101: 125$ & -0.04 & 0.93 & 1.20 & & 1000 \\
\hline CAR_11_Ibovespa & 226 & $0.03 \%$ & $65.67 \%$ & $-0.02 \%$ & $6.88 \%$ & -0.0356 & 113:113 & -0.32 & 0.99 & -0.04 & & 1000 \\
\hline CAR_21_Ibovespa & 226 & $-0.48 \%$ & $59.25 \%$ & $-0.36 \%$ & $9.01 \%$ & -0.6019 & $104: 122$ & -0.67 & 0.99 & -0.61 & & 1000 \\
\hline
\end{tabular}

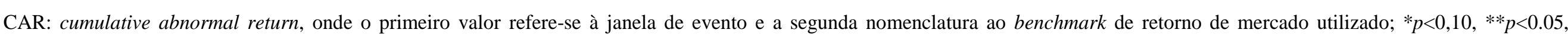
***p<0.01; em caso de diminuição do número de observações reportadas, salienta-se que é decorrente de missing values (dados faltantes).

Fonte: Elaborado pelo autor.

No painel C, apresentam-se os resultados CAR (cumulative abnormal return) das empresas familiares da amostra. É possível verificar que no ACAR_1 (dia do anúncio; 0.34\% de geração de valor) há significância estatística no teste não paramétrico Bootstrap $(p<0.10)$. 
Tabela 8 - Painel D. CAR (Cumulative Abnormal Returns) -Empresas Familiares da Amostra - Proxy do modelo de mercado: IBRX50

\begin{tabular}{|c|c|c|c|c|c|c|c|c|c|c|c|c|}
\hline 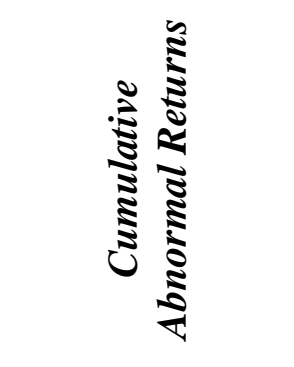 & 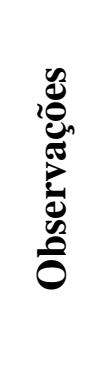 & 䒿 & 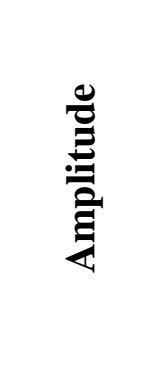 & 祸 & 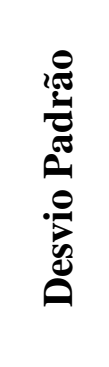 & 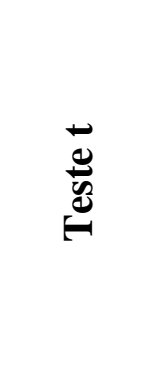 & 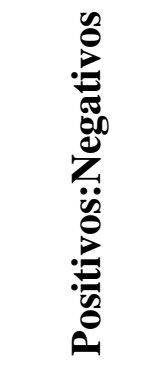 & 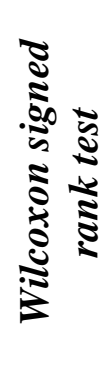 & 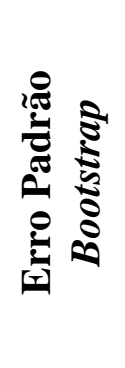 & 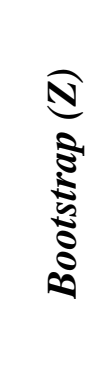 & & 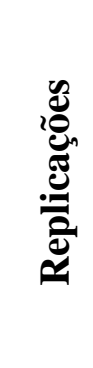 \\
\hline $\begin{array}{c}\text { Dia } \\
\text { Anúncio_IBRX } \\
50 \\
\end{array}$ & 226 & $-0.14 \%$ & $35.87 \%$ & $0.32 \%$ & $\begin{array}{c}3.21 \\
\%\end{array}$ & 1.5061 & $100: 126$ & -0.18 & 0.90 & 1.67 & $*$ & 1000 \\
\hline $\begin{array}{c}\text { CAR_3_IBRX5 } \\
0\end{array}$ & 226 & $-0.41 \%$ & $40.32 \%$ & $0.32 \%$ & $\begin{array}{c}4.56 \\
\%\end{array}$ & 1.0446 & $97: 129$ & -0.10 & 0.95 & 1.10 & & 1000 \\
\hline $\begin{array}{c}\text { CAR_11_IBRX } \\
50\end{array}$ & 226 & $-0.04 \%$ & $66.01 \%$ & $-0.09 \%$ & $\begin{array}{c}6.92 \\
\%\end{array}$ & -0.1902 & $111: 115$ & -0.46 & 0.99 & -0.19 & & 1000 \\
\hline $\begin{array}{c}\text { CAR_21_IBRX } \\
50\end{array}$ & 226 & $-0.71 \%$ & $59.26 \%$ & $-0.56 \%$ & $\begin{array}{c}9.12 \\
\%\end{array}$ & -0.9213 & $103: 123$ & -1.14 & 1.02 & -0.91 & & 1000 \\
\hline
\end{tabular}

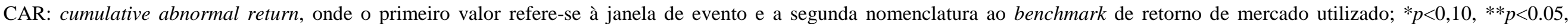
***p<0.01; em caso de diminuição do número de observações reportadas, salienta-se que é decorrente de missing values (dados faltantes).

Fonte: Elaborado pelo autor. 
No painel D, onde foi apenas relatado o teste de robustez de retorno de mercado - benchmark IBRX50, apresentam-se os mesmos resultados encontrados na tabela anterior, onde o ACAR_1 (dia do anúncio; $0.32 \%$ de geração de valor) apresenta significância estatística no teste não paramétrico Bootstrap $(p<0.10)$.

Dessa forma, verifica-se que, com base no teste não paramétrico Bootstrap, na média, houve criação de valor para empresas familiares em eventos de aquisições.

Desse modo, se obtém o resultado do teste da hipótese 1 da pesquisa, a seguir:

Hipótese 1. Empresas familiares geram valor em eventos de aquisições de empresas.

Informa-se que não se rejeita a hipótese 1, em que empresas familiares, na média, têm geração de valor em eventos de aquisições de empresas, quando análisado o CAR_1 (dia do anúncio), em que se resultou CAR positivo (geração de valor para empresas familiares) com significância estatística $(\mathrm{p}<0.10)$ em ambos benchmarks de retorno de mercado (Ibovespa e IBRX50) mensurados pelo teste não paramétrico Bootstrap.

5.1.2.3 Estatística descritiva - CAR - Análise de desempenho e criação de valor em aquisições de empresas - Empresas Não Familiares da Amostra 
Tabela 9 - Painel E. CAR (Cumulative Abnormal Returns) -Empresas Não Familiares da Amostra - Proxy do modelo de mercado: IBOVESPA

\begin{tabular}{|c|c|c|c|c|c|c|c|c|c|c|c|c|}
\hline 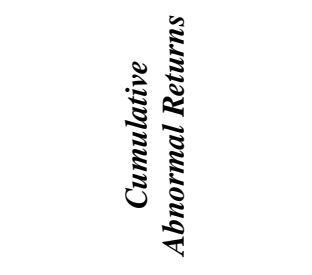 & 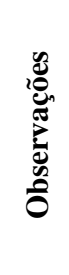 & 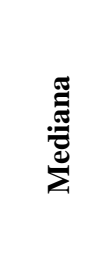 & 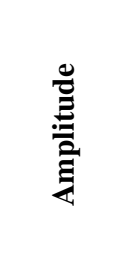 & 㞼 & 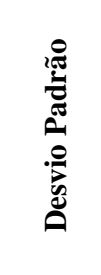 & & 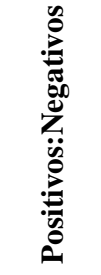 & 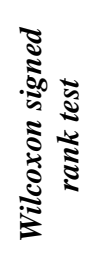 & & 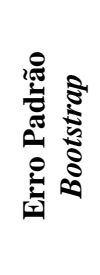 & 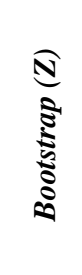 & 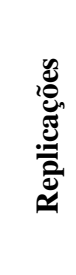 \\
\hline Dia Anúncio_Ibovespa & 129 & $0.24 \%$ & $13.10 \%$ & $0.14 \%$ & $2.05 \%$ & 0.7519 & $68: 61$ & 0.56 & & 0.98 & 0.77 & 1000 \\
\hline CAR_3_Ibovespa & 129 & $-0.10 \%$ & $32.32 \%$ & $0.29 \%$ & $4.00 \%$ & 0.8143 & $61: 68$ & 0.09 & & 0.99 & 0.83 & 1000 \\
\hline CAR_11_Ibovespa & 129 & $0.01 \%$ & $43.30 \%$ & $0.17 \%$ & $6.61 \%$ & 0.291 & $65: 64$ & -0.43 & & 1.00 & 0.29 & 1000 \\
\hline CAR_21_Ibovespa & 129 & $-1.31 \%$ & $59.56 \%$ & $-0.70 \%$ & $9.64 \%$ & -0.8244 & $60: 69$ & -1.78 & $*$ & 1.05 & -0.79 & 1000 \\
\hline
\end{tabular}

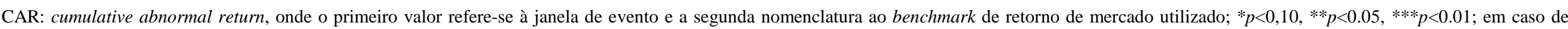
diminuição do número de observações reportadas, salienta-se que é decorrente de missing values (dados faltantes).

Fonte: Elaborado pelo autor.

No painel E, apresentam-se os resultados CAR (cumulative abnormal return) das empresas não familiares da amostra. Pode-se verificar que nenhum resultado teve significância estatística, tanto no teste t de student como no teste não paramétrico Bootstrap, ou seja, na média, não se pode afirmar que os retornos foram diferentes de zero.

Por outro lado, no teste de sinais de Wilcoxon, há evidências $(\mathrm{p}<0.10)$ de se rejeitar a hipótese nula de que a mediana é igual a zero, ou seja, pode-se verificar que os sinais negativos são em maior quantidade que os sinais positivos, podendo-se inferir que para o CAR_21, em geral, teve retornos negativos em decorrência de eventos de aquisições de empresas da amostra. 
Tabela 10 - Painel F. CAR (Cumulative Abnormal Returns) -Empresas Não Familiares da Amostra - Proxy do modelo de mercado: IBRX50

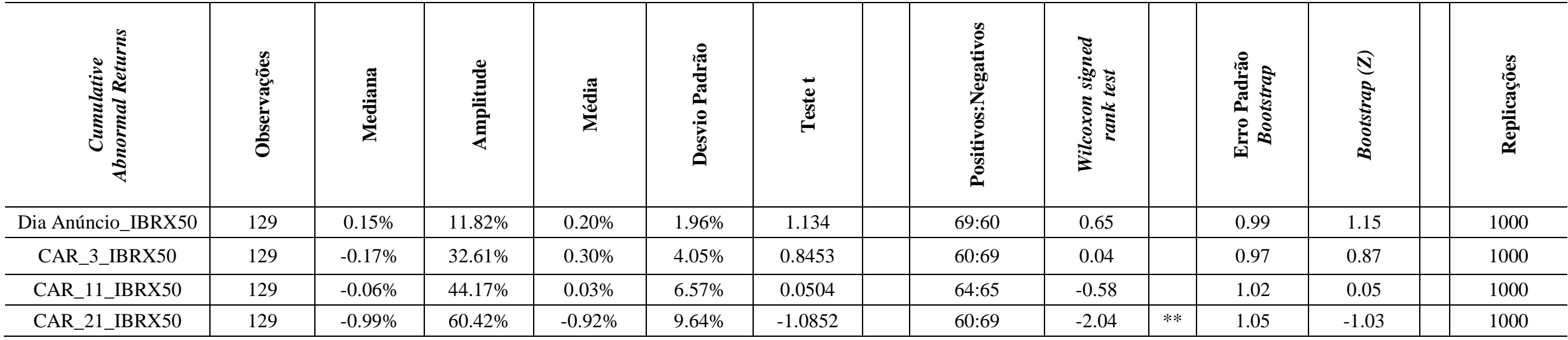

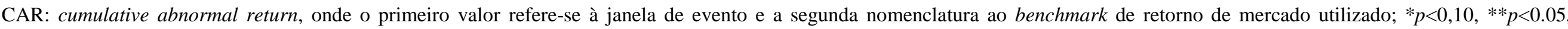
*** $p<0.01$; em caso de diminuição do número de observações reportadas, salienta-se que é decorrente de missing values (dados faltantes).

Fonte: Elaborado pelo autor.

No painel F, que apenas faz teste de robustez do retorno de mercado - benchmark IBRX50, não se evidenciou qualquer outro tipo de resultado encontrado pela tabela anterior. Apenas houve um maior grau de significância $(\mathrm{p}<0.05)$ para o teste de sinais de Wilcoxon no CAR_21.

É possível verificar que, para empresas não familiares, não foi encontrado significância estatística para informar se há criação ou destruição de valor decorrente de aquisições de empresas. Portanto, na média, empresas não familiares tiveram retorno anormal igual a zero nos eventos de aquisições de empresas da amostra analisada. 
Segue abaixo a tabela que compara por meio de análises estatísticas os desempenhos entre os CARs das empresas familiares e não familiares.

Tabela 11 - Testes de Comparação de Desempenho entre Empresas Familiares e Não Familiares

\begin{tabular}{c|c|c|c}
\hline $\begin{array}{c}\text { Comparação de } \\
\text { Desempenho }\end{array}$ & \multicolumn{2}{|c}{ Empresas Familiares versus Não Familiares } \\
\hline Técnicas Estatísticas & & t de student & U Mann Whitney $(p$-value $)$ \\
\hline Análise (H.0) & $\begin{array}{c}\text { Número de observações } \\
\text { base }\end{array}$ & EF=ENF & EF=ENF \\
\hline CAR_1_Ibovespa & 355 & 0.92 & 0.94 \\
\hline CAR_3_Ibovespa & 355 & 0.80 & 0.74 \\
\hline CAR_11_Ibovespa & 355 & 0.74 & 0.99 \\
\hline CAR_21_Ibovespa & 355 & 0.45 & 0.65 \\
\hline CAR_1_IBRX50 & 355 & 0.97 & 0.72 \\
\hline CAR_3_IBRX50 & 355 & 0.87 & 0.68 \\
\hline CAR_11_IBRX50 & 355 & 0.73 & 0.93 \\
\hline CAR_21_IBRX50 & 355 & 0.65 & 0.63 \\
\hline Todos os CARs & 2840 & 0.69 & 0.19 \\
\hline
\end{tabular}

A tabela apresenta os resultados do teste paramétrico t de student, em que foi estabelecido como hipótese nula (H.0), se o desempenho da empresa familiar (EF) é igual ao da empresa não familiar (ENF). Como teste de robustez, foi utilizado, ainda, o teste estatístico não paramétrico $U$ de Mann Whitney sob as mesmas prerrogativas de análise.

Fonte: Elaborado pelo autor.

Reporta-se que, em ambos os testes, $t$ de student e $U$ de Mann Whitney foram encontrados que não rejeita-se a hipótese nula (H.0) de que o desempenho da empresa familiar e empresas não familiares sejam iguais.

Desta forma, se obtém o resultado do teste da hipótese 2 da pesquisa:

Hipótese 2. Empresas familiares têm maiores retornos anormais em aquisições de empresas do que empresas não familiares.

Informa-se que, em análise geral, rejeita-se a hipótese 2, em que empresas familiares, na média, têm maiores retornos anormais em eventos de aquisições de empresas que empresas não familiares, pois em análise de comparação de diferenças entre médias, não acusou-se diferenças significativas estatisticamente, conforme reportado na tabela de comparações evidenciada anteriormente. Apesar da análise univariada do CAR da subamostra empresas familiares apontar evidências significantes pelo procedimento estatístico de bootstrap de que no dia do anúncio do evento (CAR_1) houve criação de valor. 


\subsubsection{Estatística Descritiva - Análise Univariada do CAR de Todas empresas, Empresas Familiares e Empresas Não Familiares - Inserida a estratificação por grau de concentração acionária}

Vale destacar que nessa subseção serão analisados os resultados dos CARs estratificados em empresas familiares, não familiares e todas as empresas da amostra, agrupadas por concentração acionária.

Evidencia-se ainda que, conforme já relatado anteriormente na seção de definição das variáveis de pesquisa, serão agrupadas as companhias por dois tipos de classificação de concentração.

O primeiro, mais tradicional, conforme já tratado na fundamentação teórica, é baseado principalmente na legislação societária, em que se utilizam os graus de concentrações à luz da legislação pertinente, que define direitos e poderes de influência na empresa aos acionistas que detêm ao menos uma determinada quantidade de concentração acionária, ora estipulada.

O segundo, é baseado em simples ranqueamento e agrupamento das empresas em níveis de concentração acionária. Esta segunda classificação é apenas um teste de robustez para a variável concentração acionária.

Assim, inicia-se a análise do primeiro tipo de classificação, com as porcentagens de concentrações acionárias definidas à luz da legislação societária brasileira de 10, 20 e 50\% conforme apresentados na seção Fundamentação Teórica. 


\subsubsection{Análise CAR - Todas Empresas - Estratificadas por Concentrações Acionárias}

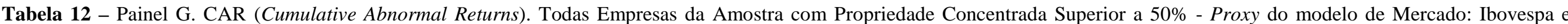
IBRX50

\begin{tabular}{|c|c|c|c|c|c|c|c|c|c|c|c|c|}
\hline 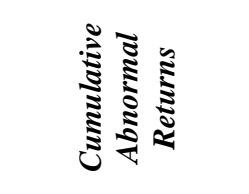 & 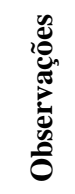 & 营 & $\frac{\stackrel{0}{\Xi}}{: \bar{E}}$ & 荧 & 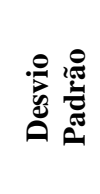 & $\begin{array}{l}\vec{g} \\
\vec{g} \\
\vec{H}\end{array}$ & 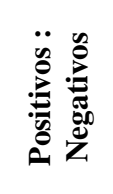 & 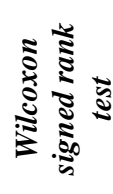 & & 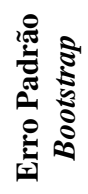 & 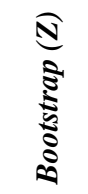 & 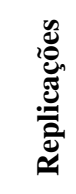 \\
\hline CAR_3_IBOV & 177 & $-0.47 \%$ & $32.19 \%$ & $-0.05 \%$ & $3.79 \%$ & -0.18 & $72: 105$ & -1.44 & & 1.04 & -0.17 & 1000 \\
\hline CAR_11_IBOV & 177 & $0.08 \%$ & $62.11 \%$ & $-0.21 \%$ & $7.06 \%$ & -0.39 & $89: 88$ & -0.60 & & 1.00 & -0.40 & 1000 \\
\hline CAR_21_IBOV & 177 & $-1.12 \%$ & $63.73 \%$ & $-0.55 \%$ & $9.40 \%$ & $\begin{array}{l}-0.77 \\
\end{array}$ & $76: 101$ & -1.47 & & 1.02 & -0.76 & 1000 \\
\hline CAR_1_IBOV & 177 & $-0.04 \%$ & $16.91 \%$ & $0.09 \%$ & $2.30 \%$ & 0.54 & $86: 91$ & 0.04 & & 0.99 & 0.55 & 1000 \\
\hline CAR_3_IBRX50 & 177 & $-0.44 \%$ & $32.29 \%$ & $-0.08 \%$ & $3.80 \%$ & -0.27 & $70: 107$ & -1.50 & & 1.03 & -0.27 & 1000 \\
\hline CAR_11_IBRX50 & 177 & $-0.06 \%$ & $63.09 \%$ & $-0.34 \%$ & $7.04 \%$ & -0.63 & $86: 91$ & -0.81 & & 1.01 & -0.63 & 1000 \\
\hline CAR_21_IBRX50 & 177 & $-1.74 \%$ & $64.05 \%$ & $-0.75 \%$ & $9.47 \%$ & -1.05 & $77: 100$ & -1.85 & $*$ & 1.03 & -1.02 & 1000 \\
\hline CAR_1_IBRX50 & 177 & $-0.07 \%$ & $15.61 \%$ & $0.11 \%$ & $2.25 \%$ & 0.65 & $85: 92$ & -0.11 & & 0.99 & 0.66 & 1000 \\
\hline
\end{tabular}

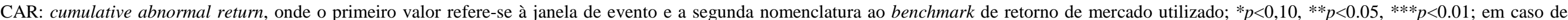
diminuição do número de observações reportadas, salienta-se que é decorrente de missing values (dados faltantes).

Fonte: Elaborado pelo autor.

Evidencia-se que para todas as empresas da amostra, com propriedade concentrada superior a 50\%, não se identificou significância estatística para os testes de média dos CARs. Desse modo, não se rejeita a hipótese nula dos testes estatísticos utilizados, de que a média é zero dos CARs. Em outras palavras, para todas empresas da amostra com concentração acionária superior a 50\%, os retornos anormais, na média, em aquisições, são estatisticamente iguais a zero.

Por outro lado, no teste de sinais de Wilcoxon, há evidências $(\mathrm{p}<0.10)$ de se rejeitar a hipótese nula de que a mediana é igual a zero, ou seja, é possível a verificação de que os sinais negativos são em maior quantidade que os sinais positivos, podendo-se inferir que para o CAR_21_IBRX50, em geral, houve retornos negativos, em decorrência de eventos de aquisições de empresas das empresas da amostra. 
Tabela 13 - Painel H. CAR (Cumulative Abnormal Returns). Todas Empresas da Amostra com Propriedade Concentrada Superior a 20\% - Proxy do modelo de Mercado: Ibovespa e IBRX50

\begin{tabular}{|c|c|c|c|c|c|c|c|c|c|c|c|c|c|c|}
\hline 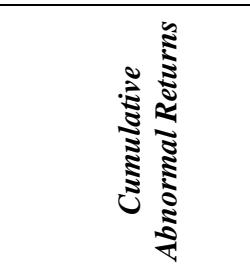 & 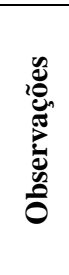 & 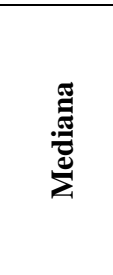 & 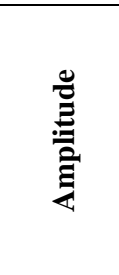 & 丞 & 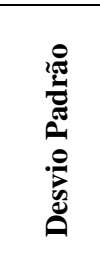 & $\begin{array}{l}\overrightarrow{0} \\
\stackrel{\vec{v}}{0} \\
\stackrel{\theta}{*}\end{array}$ & & 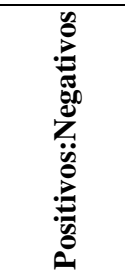 & 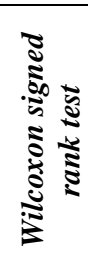 & & 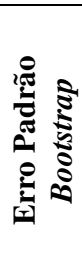 & 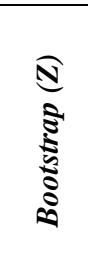 & & 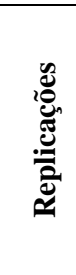 \\
\hline CAR_3_IBOV & 296 & $-0.17 \%$ & $34.30 \%$ & $0.29 \%$ & $4.08 \%$ & 1.20 & & $139: 157$ & 0.24 & & 1.00 & 1.20 & & 1000 \\
\hline CAR_11_IBOV & 296 & $-0.06 \%$ & $62.11 \%$ & $0.01 \%$ & $6.67 \%$ & 0.02 & & $147: 149$ & -0.48 & & 1.00 & 0.03 & & 1000 \\
\hline CAR_21_IBOV & 296 & $-0.88 \%$ & $63.73 \%$ & $-0.40 \%$ & $9.15 \%$ & -0.74 & & $136: 160$ & -1.46 & & 1.02 & -0.73 & & 1000 \\
\hline CAR_1_IBOV & 296 & $-0.02 \%$ & $19.47 \%$ & $0.29 \%$ & $2.52 \%$ & 2.00 & $* *$ & $147: 149$ & 0.91 & & 0.97 & 2.07 & $* *$ & 1000 \\
\hline CAR_3_IBRX50 & 296 & $-0.19 \%$ & $34.65 \%$ & $0.28 \%$ & $4.12 \%$ & 1.15 & & $133: 163$ & 0.14 & & 0.99 & 1.16 & & 1000 \\
\hline CAR_11_IBRX50 & 296 & $-0.34 \%$ & $63.09 \%$ & $-0.09 \%$ & $6.65 \%$ & -0.24 & & $142: 154$ & -0.72 & & 1.01 & -0.24 & & 1000 \\
\hline CAR_21_IBRX50 & 296 & $-0.79 \%$ & $64.05 \%$ & $-0.61 \%$ & $9.21 \%$ & -1.13 & & $136: 160$ & -1.96 & $*$ & 1.03 & -1.10 & & 1000 \\
\hline CAR_1_IBRX50 & 296 & $-0.06 \%$ & $19.71 \%$ & $0.30 \%$ & $2.52 \%$ & 2.04 & $* *$ & $145: 151$ & 0.69 & & 0.99 & 2.07 & *** & 1000 \\
\hline
\end{tabular}

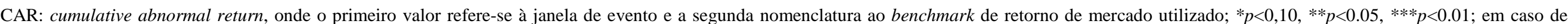
diminuição do número de observações reportadas, salienta-se que é decorrente de missing values (dados faltantes).

Fonte: Elaborado pelo autor.

É possível evidenciar que, para todas as empresas da amostra, com propriedade concentrada superior a 20\%, identificou-se significância estatística (p<0.05) para os CAR_1_Ibovespa e CAR_1_IBRX50 (Dia dos Anúncios), em que obtiveram geração de valor em 0.29\% e 0.30\% respectivamente.

Por outro lado, no teste de sinais de Wilcoxon, há evidências $(\mathrm{p}<0.10)$ de se rejeitar a hipótese nula de que a mediana é igual a zero, ou seja, verifica-se que os sinais negativos são em maior quantidade que os sinais positivos, podendo-se inferir que para o CAR_21_IBRX50, em geral, teve retornos negativos, em decorrência de eventos de aquisições de empresas, das empresas da amostra. 
Tabela 14 - Painel I. CAR (Cumulative Abnormal Returns). Todas Empresas da Amostra com Propriedade Concentrada Superior a 10\% - Proxy do modelo de Mercado: Ibovespa e IBRX50

\begin{tabular}{|c|c|c|c|c|c|c|c|c|c|c|c|c|}
\hline 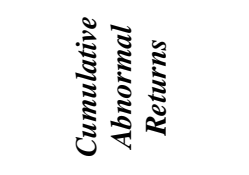 & 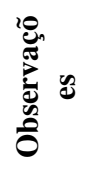 & 䔍 & 总 & 䄈 & 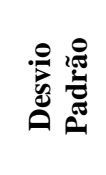 & 矛 & 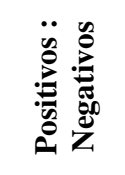 & 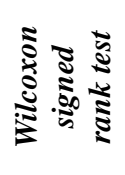 & & 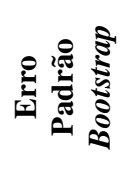 & 起 & 总 \\
\hline CAR_3_IBOV & 352 & $-0.21 \%$ & $34.30 \%$ & $0.24 \%$ & $4.08 \%$ & 1.1042 & 160:192 & -0.05 & & 0.98 & 1.13 & 1000 \\
\hline CAR_11_IBOV & 352 & $0.00 \%$ & $62.11 \%$ & $-0.03 \%$ & $6.55 \%$ & -0.079 & $176: 176$ & -0.50 & & 1.03 & -0.08 & 1000 \\
\hline CAR_21_IBOV & 352 & $-0.88 \%$ & $63.73 \%$ & $-0.59 \%$ & $9.08 \%$ & -1.2117 & 162:190 & -1.73 & $*$ & 1.01 & -1.20 & 1000 \\
\hline CAR_1_IBOV & 352 & $-0.06 \%$ & $19.47 \%$ & $0.19 \%$ & $2.45 \%$ & 1.4682 & 170:182 & 0.16 & & 0.95 & 1.55 & 1000 \\
\hline CAR_3_IBRX50 & 352 & $-0.23 \%$ & $34.65 \%$ & $0.24 \%$ & $4.13 \%$ & 1.0692 & $155: 197$ & -0.13 & & 0.95 & 1.13 & 1000 \\
\hline CAR_11_IBRX50 & 352 & $-0.06 \%$ & $63.09 \%$ & $-0.13 \%$ & $6.57 \%$ & -0.3614 & $173: 179$ & -0.74 & & 1.03 & -0.35 & 1000 \\
\hline CAR_21_IBRX50 & 352 & $-0.90 \%$ & $64.05 \%$ & $-0.79 \%$ & $9.15 \%$ & -1.6154 & 161:191 & -2.24 & $* *$ & 1.02 & -1.58 & 1000 \\
\hline CAR_1_IBRX50 & 352 & $-0.07 \%$ & $19.71 \%$ & $0.20 \%$ & $2.46 \%$ & 1.5281 & $167: 185$ & 0.04 & & 0.99 & 1.55 & 1000 \\
\hline
\end{tabular}

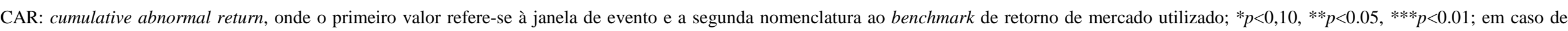
diminuição do número de observações reportadas, salienta-se que é decorrente de missing values (dados faltantes).

Fonte: Elaborado pelo autor.

É possível evidenciar que para todas as empresas da amostra, com propriedade concentrada superior a 10\%, não se identificou significância estatística para os testes de média dos CARs. Desse modo, não se rejeita a hipótese nula dos testes estatísticos utilizados, de que a média é zero dos CARs. Em outras palavras, para todas empresas da amostra com concentração acionária superior a 10\%, os retornos anormais, na média, em aquisições, são estatisticamente iguais a zero.

Por outro lado, no teste de sinais de Wilcoxon, há evidências $(\mathrm{p}<0.10$ e $\mathrm{p}<0.05)$ de se rejeitar a hipótese nula de que a mediana é igual a zero, ou seja, verifica-se que os sinais negativos são em maior quantidade que os sinais positivos, podendo-se inferir que, para os CAR_21_Ibovespa e CAR_21_IBRX50, em geral, houve retornos negativos, em decorrência de eventos de aquisições de empresas, das empresas da amostra. 
Evidencia-se agora, o segundo tipo de classificação de concentração acionária, utilizando o simples ranqueamento e agrupamento das empresas da amostra da pesquisa, em faixas de graus de concentração acionária, arbitrariamente, definidos nesta pesquisa. Assim, são citadas e testadas as concentrações acionárias estipuladas arbitrariamente, em faixas de concentração acionária dos acionistas controladores em até 30\% (denominados neste trabalho como baixa concentração acionária), de 30\% a 70\% (denominados neste trabalho como média concentração acionária) e acima de $70 \%$ (denominados neste trabalho como alta concentração acionária).

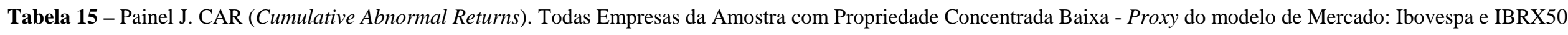

\begin{tabular}{|c|c|c|c|c|c|c|c|c|c|c|c|}
\hline 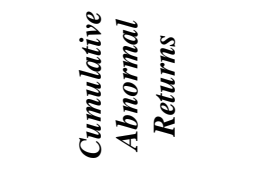 & 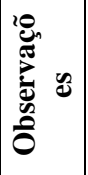 & 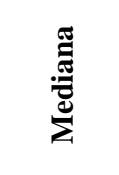 & 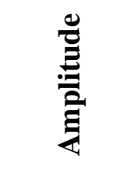 & 宽 & 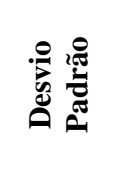 & 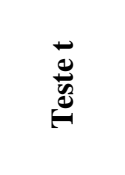 & 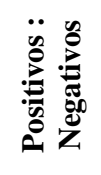 & 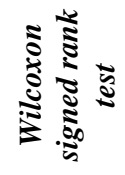 & 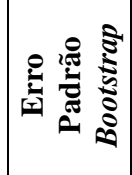 & $\frac{5}{5}$ & 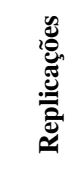 \\
\hline CAR_3_IBOV & 87 & $-0.29 \%$ & $40.35 \%$ & $0.62 \%$ & $5.37 \%$ & 1.0703 & $39: 48$ & 0.10 & 0.94 & 1.14 & 1000 \\
\hline CAR_11_IBOV & 87 & $0.07 \%$ & $50.08 \%$ & $0.26 \%$ & $7.06 \%$ & 0.3449 & $44: 43$ & 0.01 & 1.01 & 0.34 & 1000 \\
\hline CAR_21_IBOV & 87 & $0.30 \%$ & $56.95 \%$ & $-0.71 \%$ & $9.22 \%$ & -0.719 & $44: 43$ & -0.52 & 1.05 & -0.68 & 1000 \\
\hline CAR_1_IBOV & 87 & $-0.10 \%$ & $35.44 \%$ & $0.30 \%$ & $3.80 \%$ & 0.7384 & $41: 46$ & -0.57 & 0.96 & 0.77 & 1000 \\
\hline CAR_3_IBRX50 & 87 & $-0.40 \%$ & $40.26 \%$ & $0.60 \%$ & $5.43 \%$ & 1.0361 & $37: 50$ & -0.02 & 0.98 & 1.06 & 1000 \\
\hline CAR_11_IBRX50 & 87 & $0.46 \%$ & $50.44 \%$ & $0.20 \%$ & $7.14 \%$ & 0.2561 & $46: 41$ & -0.01 & 0.99 & 0.26 & 1000 \\
\hline CAR_21_IBRX50 & 87 & $-0.16 \%$ & $57.08 \%$ & $-0.92 \%$ & $9.31 \%$ & -0.9216 & $42: 45$ & -0.83 & 1.03 & -0.90 & 1000 \\
\hline CAR_1_IBRX50 & 87 & $-0.15 \%$ & $35.87 \%$ & $0.31 \%$ & $3.83 \%$ & 0.7455 & $40: 47$ & -0.47 & 0.97 & 0.77 & 1000 \\
\hline
\end{tabular}

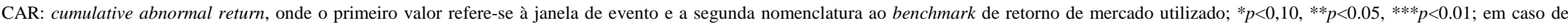
diminuição do número de observações reportadas, salienta-se que é decorrente de missing values (dados faltantes).

Fonte: Elaborado pelo autor. 
É possível evidenciar que, para todas as empresas da amostra, com baixa propriedade concentrada (concentração acionária dos acionistas controladores em até 30\%), não se identificou significância estatística para os testes de média dos CARs. Desse modo, não se rejeita a hipótese nula dos testes estatísticos utilizados, de que a média é zero dos CARs. Em outras palavras, para todas empresas da amostra com baixa concentração acionária, os retornos anormais, na média, em aquisições, são estatisticamente iguais a zero.

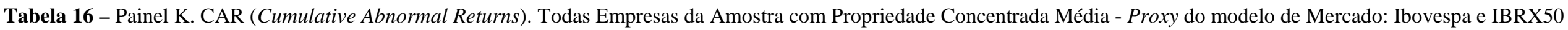

\begin{tabular}{|c|c|c|c|c|c|c|c|c|c|c|c|c|c|c|}
\hline 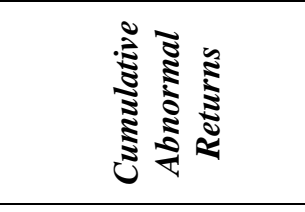 & 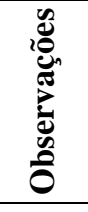 & 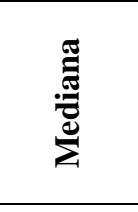 & 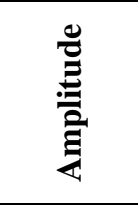 & 䍃 & 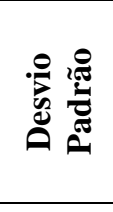 & 矛 & & 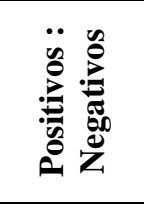 & 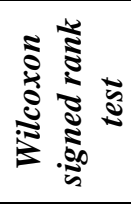 & & 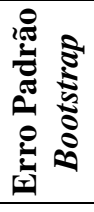 & 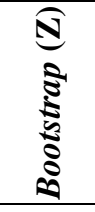 & & 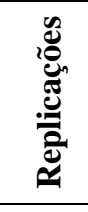 \\
\hline CAR_3_IBOV & 216 & $-0.11 \%$ & $34.06 \%$ & $0.27 \%$ & $3.99 \%$ & 0.98 & & 104:112 & 0.45 & & 0.98 & 1.00 & & 1000 \\
\hline CAR_11_IBOV & 216 & $-0.32 \%$ & $62.11 \%$ & $-0.10 \%$ & $6.92 \%$ & -0.20 & & 106:110 & -0.61 & & 1.04 & -0.20 & & 1000 \\
\hline CAR_21_IBOV & 216 & $-1.06 \%$ & $63.73 \%$ & $-0.40 \%$ & $9.35 \%$ & -0.63 & & $96: 120$ & -1.51 & & 1.01 & -0.63 & & 1000 \\
\hline CAR_1_IBOV & 216 & $0.09 \%$ & $16.73 \%$ & $0.34 \%$ & $2.39 \%$ & 2.10 & $* *$ & 111:105 & 1.18 & & 1.01 & 2.09 & $* *$ & 1000 \\
\hline CAR_3_IBRX50 & 216 & $-0.18 \%$ & $34.65 \%$ & $0.27 \%$ & $4.05 \%$ & 0.96 & & $102: 114$ & 0.43 & & 0.97 & 0.99 & & 1000 \\
\hline CAR_11_IBRX50 & 216 & $-0.44 \%$ & $63.09 \%$ & $-0.22 \%$ & $6.91 \%$ & -0.46 & & 101:115 & -0.88 & & 1.04 & -0.45 & & 1000 \\
\hline CAR_21_IBRX50 & 216 & $-1.04 \%$ & $64.05 \%$ & $-0.65 \%$ & $9.40 \%$ & -1.01 & & $97: 119$ & -1.94 & $*$ & 1.05 & -0.97 & & 1000 \\
\hline CAR_1_IBRX50 & 216 & $0.04 \%$ & $15.75 \%$ & $0.36 \%$ & $2.38 \%$ & 2.24 & $* *$ & 110:106 & 1.05 & & 0.96 & 2.35 & $* *$ & 1000 \\
\hline
\end{tabular}

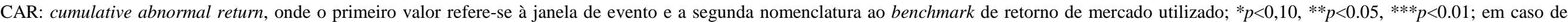
diminuição do número de observações reportadas, salienta-se que é decorrente de missing values (dados faltantes).

Fonte: Elaborado pelo autor. 
É possível evidenciar que, para todas as empresas da amostra, com média propriedade concentrada (empresas cujos acionistas controladores detêm de 30\% a 70\% do stake acionário), identificou-se significância estatística (p<0.05) para ambos os CAR_1_Ibovespa e CAR_1_IBRX50 (Dia dos Anúncios), em que obtiveram geração de valor em $0.34 \%$ e $0.36 \%$ respectivamente.

Tabela 17 - Painel L. CAR (Cumulative Abnormal Returns). Todas Empresas da Amostra com Propriedade Concentrada Alta - Proxy do modelo de Mercado: Ibovespa e IBRX50

\begin{tabular}{|c|c|c|c|c|c|c|c|c|c|c|c|}
\hline 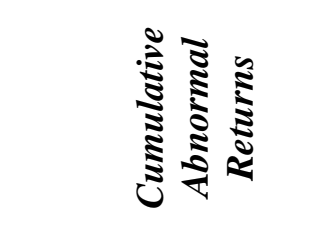 & 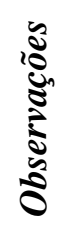 & 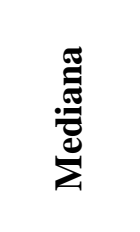 & $\frac{\stackrel{0}{E}}{\stackrel{:}{:}}$ & 苞 & 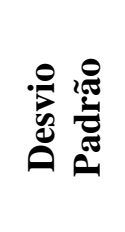 & 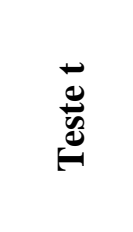 & 范总 & 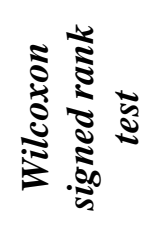 & 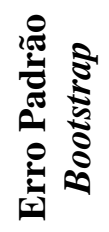 & $\frac{0}{0}$ & 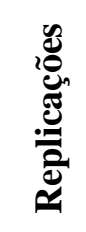 \\
\hline CAR_3_IBOV & 52 & $-0.59 \%$ & $20.18 \%$ & $0.02 \%$ & $3.72 \%$ & 0.0422 & 19:33 & -1.06 & 1.08 & 0.04 & 1000 \\
\hline CAR_11_IBOV & 52 & $0.33 \%$ & $27.11 \%$ & $0.32 \%$ & $5.67 \%$ & 0.4062 & $28: 24$ & -0.03 & 0.99 & 0.41 & 1000 \\
\hline CAR_21_IBOV & 52 & $-1.21 \%$ & $42.88 \%$ & $-0.44 \%$ & $8.93 \%$ & -0.3575 & $24: 28$ & -0.31 & 1.02 & -0.35 & 1000 \\
\hline CAR_1_IBOV & 52 & $-0.45 \%$ & $15.25 \%$ & $-0.10 \%$ & $2.53 \%$ & -0.272 & $20: 32$ & -0.90 & 1.05 & -0.26 & 1000 \\
\hline CAR_3_IBRX50 & 52 & $-0.52 \%$ & $19.54 \%$ & $0.01 \%$ & $3.69 \%$ & 0.024 & $18: 34$ & -1.14 & 1.07 & 0.02 & 1000 \\
\hline CAR_11_IBRX50 & 52 & $0.57 \%$ & $26.81 \%$ & $0.28 \%$ & $5.66 \%$ & 0.3535 & $28: 24$ & -0.07 & 1.05 & 0.34 & 1000 \\
\hline CAR_21_IBRX50 & 52 & $-1.05 \%$ & $42.66 \%$ & $-0.48 \%$ & $9.04 \%$ & -0.3825 & $24: 28$ & -0.42 & 1.05 & -0.36 & 1000 \\
\hline CAR_1_IBRX50 & 52 & $-0.57 \%$ & $15.48 \%$ & $-0.14 \%$ & $2.51 \%$ & -0.4028 & 19:33 & -1.06 & 1.01 & -0.40 & 1000 \\
\hline
\end{tabular}

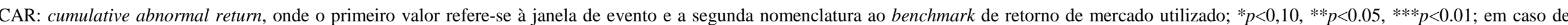
diminuição do número de observações reportadas, salienta-se que é decorrente de missing values (dados faltantes).

Fonte: Elaborado pelo autor.

Por outro lado, no teste de sinais de Wilcoxon, há evidências $(\mathrm{p}<0.10)$ de se rejeitar a hipótese nula de que a mediana é igual a zero, ou seja, verifica-se que os sinais negativos são em maior quantidade que os sinais positivos, podendo-se inferir que para o CAR_21_IBRX50, em geral, houve retornos negativos, em decorrência de eventos de aquisições de empresas, das empresas da amostra.

É possível evidenciar que para todas as empresas da amostra, com alta propriedade concentrada (empresas cujos acionistas controladores detêm acima de 70\% do stake acionário), não se identificou significância estatística para os testes de média dos CARs. Desse modo, não se rejeita a hipótese nula, dos testes estatísticos utilizados, de que a média é zero dos CARs. Em outras palavras, para todas empresas da amostra com alta concentração acionária, os retornos anormais, na média, em aquisições, são estatisticamente iguais a zero. 


\subsubsection{Análise CAR - Empresas Familiares - Estratificadas por Concentrações Acionárias}

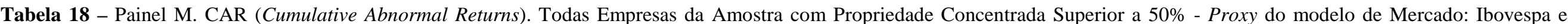
IBRX50

\begin{tabular}{|c|c|c|c|c|c|c|c|c|c|c|c|}
\hline 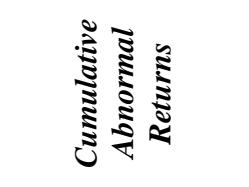 & 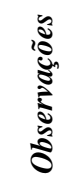 & 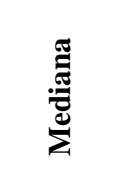 & 总 & 宽 & 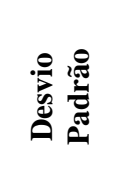 & $\begin{array}{l}\vec{y} \\
\stackrel{5}{0} \\
\vec{v}\end{array}$ & 范 & 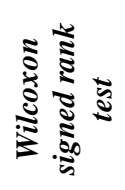 & 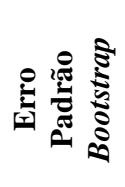 & 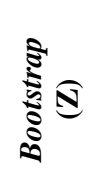 & 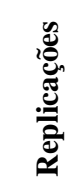 \\
\hline CAR_3_IBOV & 124 & $-0.40 \%$ & $23.26 \%$ & $0.05 \%$ & $3.49 \%$ & 0.14 & $53: 71$ & -0.60 & 1.00 & 0.14 & 1000 \\
\hline CAR_11_IBOV & 124 & $0.26 \%$ & $52.44 \%$ & $-0.18 \%$ & $6.96 \%$ & -0.29 & $66: 58$ & 0.00 & 1.03 & -0.29 & 1000 \\
\hline CAR_21_IBOV & 124 & $-1.00 \%$ & $55.57 \%$ & $-0.09 \%$ & $9.10 \%$ & -0.11 & $55: 69$ & -0.36 & 1.03 & -0.11 & 1000 \\
\hline CAR_1_IBOV & 124 & $-0.13 \%$ & $15.38 \%$ & $0.06 \%$ & $2.34 \%$ & 0.30 & $57: 67$ & -0.29 & 1.02 & 0.30 & 1000 \\
\hline CAR_3_IBRX50 & 124 & $-0.42 \%$ & $23.14 \%$ & $0.00 \%$ & $3.55 \%$ & 0.01 & $51: 73$ & -0.70 & 1.00 & 0.01 & 1000 \\
\hline CAR_11_IBRX50 & 124 & $0.11 \%$ & $52.61 \%$ & $-0.31 \%$ & $7.00 \%$ & -0.48 & $63: 61$ & -0.17 & 1.00 & -0.49 & 1000 \\
\hline CAR_21_IBRX50 & 124 & $-1.33 \%$ & $55.60 \%$ & $-0.32 \%$ & $9.21 \%$ & -0.38 & $55: 69$ & -0.66 & 1.01 & -0.38 & 1000 \\
\hline CAR_1_IBRX50 & 124 & $-0.11 \%$ & $15.61 \%$ & $0.04 \%$ & $2.35 \%$ & 0.18 & $54: 70$ & -0.47 & 1.02 & 0.18 & 1000 \\
\hline
\end{tabular}

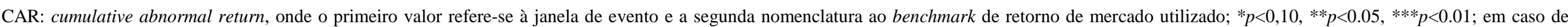
diminuição do número de observações reportadas, salienta-se que é decorrente de missing values (dados faltantes).

Fonte: Elaborado pelo autor.

É possível evidenciar que para as empresas familiares da amostra, com propriedade concentrada superior a 50\%, não se identificou significância estatística para os testes de média dos CARs. Desse modo, não se rejeita a hipótese nula, dos testes estatísticos utilizados, de que a média é zero dos CARs. Em outras palavras, para as empresas familiares da amostra com concentração acionária superior a 50\%, os retornos anormais, na média, em aquisições, são estatisticamente iguais a zero. 
Tabela 19 - Painel N. CAR (Cumulative Abnormal Returns). Todas Empresas da Amostra com Propriedade Concentrada Superior a 20\% - Proxy do modelo de Mercado: Ibovespa e IBRX50

\begin{tabular}{|c|c|c|c|c|c|c|c|c|c|c|c|c|c|}
\hline 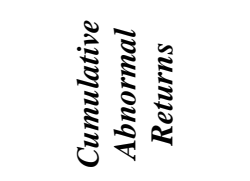 & 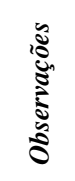 & 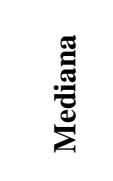 & 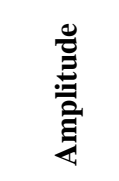 & & 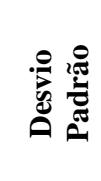 & $\begin{array}{l}\vec{y} \\
\vec{y} \\
\vec{y}\end{array}$ & & 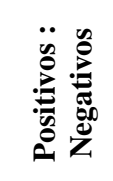 & 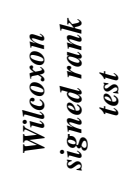 & 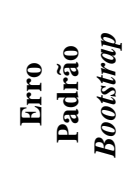 & $\frac{2}{8}$ & & 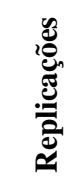 \\
\hline CAR_3_IBOV & 192 & $-0.21 \%$ & $28.90 \%$ & $0.42 \%$ & $4.16 \%$ & 1.3864 & & $90: 102$ & 0.56 & 0.96 & 1.44 & & 1000 \\
\hline CAR_11_IBOV & 192 & $0.08 \%$ & $52.44 \%$ & $-0.10 \%$ & $6.56 \%$ & -0.2055 & & $97: 95$ & -0.27 & 1.00 & -0.21 & & 1000 \\
\hline CAR_21_IBOV & 192 & $-0.48 \%$ & $55.57 \%$ & $-0.21 \%$ & $8.48 \%$ & -0.3477 & & 88:104 & -0.47 & 1.05 & -0.33 & & 1000 \\
\hline CAR_1_IBOV & 192 & $-0.05 \%$ & $19.47 \%$ & $0.41 \%$ & $2.75 \%$ & 2.0485 & $* *$ & 93:99 & 0.94 & 0.93 & 2.20 & $* *$ & 1000 \\
\hline CAR_3_IBRX50 & 192 & $-0.27 \%$ & $28.58 \%$ & $0.39 \%$ & $4.23 \%$ & 1.2911 & & $85: 107$ & 0.44 & 0.98 & 1.31 & & 1000 \\
\hline CAR_11_IBRX50 & 192 & $-0.04 \%$ & $52.61 \%$ & $-0.16 \%$ & $6.60 \%$ & -0.3372 & & $94: 98$ & -0.39 & 0.98 & -0.34 & & 1000 \\
\hline CAR_21_IBRX50 & 192 & $-0.68 \%$ & $55.60 \%$ & $-0.39 \%$ & $8.61 \%$ & -0.6215 & & 88:104 & -0.88 & 0.99 & -0.62 & & 1000 \\
\hline CAR_1_IBRX50 & 192 & $-0.08 \%$ & $19.71 \%$ & $0.38 \%$ & $2.79 \%$ & 1.8998 & $*$ & $90: 102$ & 0.71 & 0.97 & 1.96 & $* *$ & 1000 \\
\hline
\end{tabular}

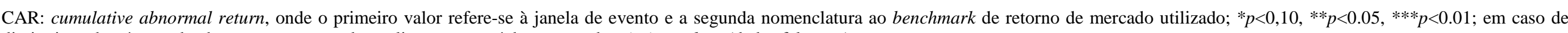
diminuição do número de observações reportadas, salienta-se que é decorrente de missing values (dados faltantes).

Fonte: Elaborado pelo autor.

É possível evidenciar que, para as empresas familiares da amostra, com propriedade concentrada superior a 20\%, identificou-se significância estatística $(\mathrm{p}<0.05)$ para os CAR_1_Ibovespa e $(\mathrm{p}<0.10)$ CAR_1_IBRX50 (Dia dos Anúncios), em que obtiveram geração de valor em 0.41\% e 0.38\% respectivamente. 
Tabela 20 - Painel O. CAR (Cumulative Abnormal Returns). Todas Empresas da Amostra com Propriedade Concentrada Superior a 10\% - Proxy do modelo de Mercado: Ibovespa e IBRX50

\begin{tabular}{|c|c|c|c|c|c|c|c|c|c|c|c|}
\hline 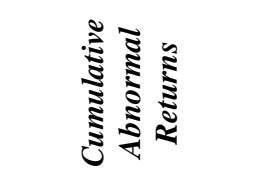 & 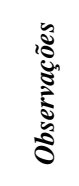 & 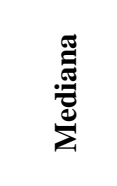 & 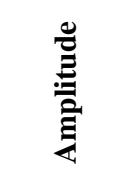 & 䒿 & 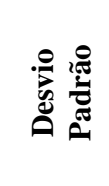 & & 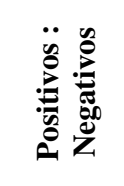 & 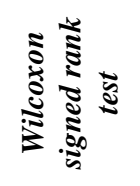 & 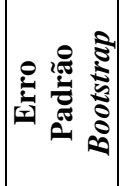 & 产 ब & 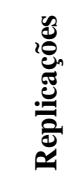 \\
\hline CAR_3_IBOV & 223 & $-0.34 \%$ & $28.90 \%$ & $0.21 \%$ & $4.13 \%$ & 0.7697 & $99: 124$ & -0.14 & 0.97 & 0.79 & 1000 \\
\hline CAR_11_IBOV & 223 & $-0.01 \%$ & $52.44 \%$ & $-0.14 \%$ & $6.53 \%$ & -0.3236 & $111: 112$ & -0.37 & 1.00 & -0.32 & 1000 \\
\hline CAR_21_IBOV & 223 & $-0.55 \%$ & $55.57 \%$ & $-0.52 \%$ & $8.77 \%$ & -0.8879 & $102: 121$ & -0.81 & 0.99 & -0.90 & 1000 \\
\hline CAR_1_IBOV & 223 & $-0.18 \%$ & $19.47 \%$ & $0.22 \%$ & $2.66 \%$ & 1.2593 & 102:121 & -0.14 & 0.98 & 1.29 & 1000 \\
\hline CAR_3_IBRX50 & 223 & $-0.41 \%$ & $28.58 \%$ & $0.20 \%$ & $4.19 \%$ & 0.7039 & $95: 128$ & -0.20 & 1.00 & 0.70 & 1000 \\
\hline CAR_11_IBRX50 & 223 & $-0.06 \%$ & $52.61 \%$ & $-0.22 \%$ & $6.59 \%$ & -0.4913 & 109:114 & -0.53 & 1.00 & -0.49 & 1000 \\
\hline CAR_21_IBRX50 & 223 & $-0.73 \%$ & $55.60 \%$ & $-0.71 \%$ & $8.88 \%$ & -1.1958 & $101: 122$ & -1.26 & 1.02 & -1.18 & 1000 \\
\hline CAR_1_IBRX50 & 223 & $-0.15 \%$ & $19.71 \%$ & $0.20 \%$ & $2.70 \%$ & 1.1171 & $98: 125$ & -0.33 & 1.00 & 1.12 & 1000 \\
\hline
\end{tabular}

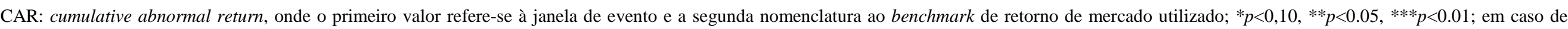
diminuição do número de observações reportadas, salienta-se que é decorrente de missing values (dados faltantes).

Fonte: Elaborado pelo autor.

É possível evidenciar que, para as empresas familiares da amostra, com propriedade concentrada superior a 10\%, não se identificou significância estatística para os testes de média dos CARs. Desse modo, não se rejeita a hipótese nula, dos testes estatísticos utilizados, de que a média é zero dos CARs. Em outras palavras, para as empresas familiares da amostra, com concentração acionária superior a 10\%, os retornos anormais, na média, em aquisições, são estatisticamente iguais a zero. 
Evidencia-se agora o segundo tipo de classificação de concentração acionária, utilizando o simples ranqueamento e agrupamento das empresas da amostra da pesquisa em faixas de graus de concentração acionária arbitrariamente definidos nesta pesquisa. Assim, são citadas e testadas as concentrações acionárias estipuladas arbitrariamente em faixas de concentração acionária dos acionistas controladores em até 30\% (denominados neste trabalho como baixa concentração acionária), de 30 a 70\% (denominados neste trabalho como média concentração acionária), e acima de 70\% (denominados neste trabalho como alta concentração acionária).

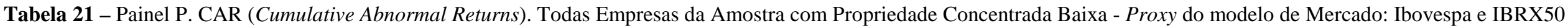

\begin{tabular}{|c|c|c|c|c|c|c|c|c|c|c|c|}
\hline 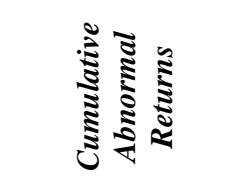 & 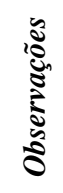 & 尝 & $\frac{\stackrel{0}{\Xi}}{:}$ & 蒠 & 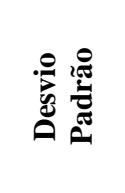 & $\begin{array}{l}\vec{y} \\
\vec{y} \\
\vec{y}\end{array}$ & 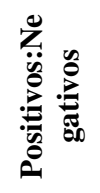 & 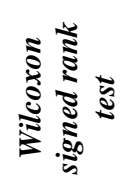 & 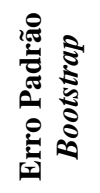 & 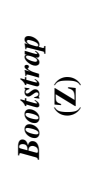 & 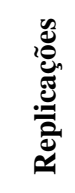 \\
\hline CAR_3_IBOV & 58 & $-0.32 \%$ & $40.35 \%$ & $0.22 \%$ & $5.68 \%$ & 0.2922 & $25: 33$ & -0.56 & 1.01 & 0.29 & 1000 \\
\hline CAR_11_IBOV & 58 & $-0.17 \%$ & $50.08 \%$ & $0.52 \%$ & $7.64 \%$ & 0.5208 & $27: 31$ & 0.11 & 1.00 & 0.52 & 1000 \\
\hline CAR_21_IBOV & 58 & $0.43 \%$ & $56.95 \%$ & $-0.49 \%$ & $10.25 \%$ & -0.3605 & $30: 28$ & -0.24 & 1.02 & -0.35 & 1000 \\
\hline CAR_1_IBOV & 58 & $-0.40 \%$ & $35.44 \%$ & $0.25 \%$ & $4.43 \%$ & 0.4351 & $24: 34$ & -1.25 & 1.08 & 0.40 & 1000 \\
\hline CAR_3_IBRX50 & 58 & $-0.48 \%$ & $40.26 \%$ & $0.15 \%$ & $5.64 \%$ & 0.2065 & $23: 35$ & -0.72 & 1.04 & 0.20 & 1000 \\
\hline CAR_11_IBRX50 & 58 & $-0.25 \%$ & $50.44 \%$ & $0.41 \%$ & $7.64 \%$ & 0.4108 & $28: 30$ & -0.01 & 1.02 & 0.40 & 1000 \\
\hline CAR_21_IBRX50 & 58 & $-0.13 \%$ & $57.08 \%$ & $-0.76 \%$ & $10.31 \%$ & -0.5644 & $28: 30$ & -0.61 & 1.02 & -0.55 & 1000 \\
\hline CAR_1_IBRX50 & 58 & $-0.35 \%$ & $35.87 \%$ & $0.21 \%$ & $4.45 \%$ & 0.3546 & $23: 35$ & -1.36 & 1.09 & 0.32 & 1000 \\
\hline
\end{tabular}

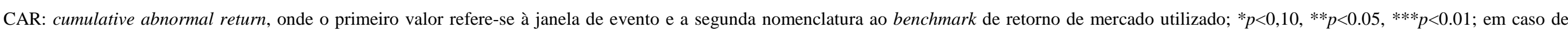
diminuição do número de observações reportadas, salienta-se que é decorrente de missing values (dados faltantes).

Fonte: Elaborado pelo autor.

É possível evidenciar que, para as empresas familiares da amostra, com baixa propriedade concentrada (concentração acionária dos acionistas controladores em até 30\%), não se identificou significância estatística para os testes de média dos CARs. Desse modo, não se rejeita a hipótese nula, dos testes estatísticos utilizados, de que a média é zero dos CARs. Em outras palavras, para as empresas familiares da amostra com baixa concentração acionária, os retornos anormais, na média, em aquisições, são estatisticamente iguais a zero. 
Tabela 22 - Painel Q. CAR (Cumulative Abnormal Returns). Todas Empresas da Amostra com Propriedade Concentrada Média - Proxy do modelo de Mercado: Ibovespa e IBRX50

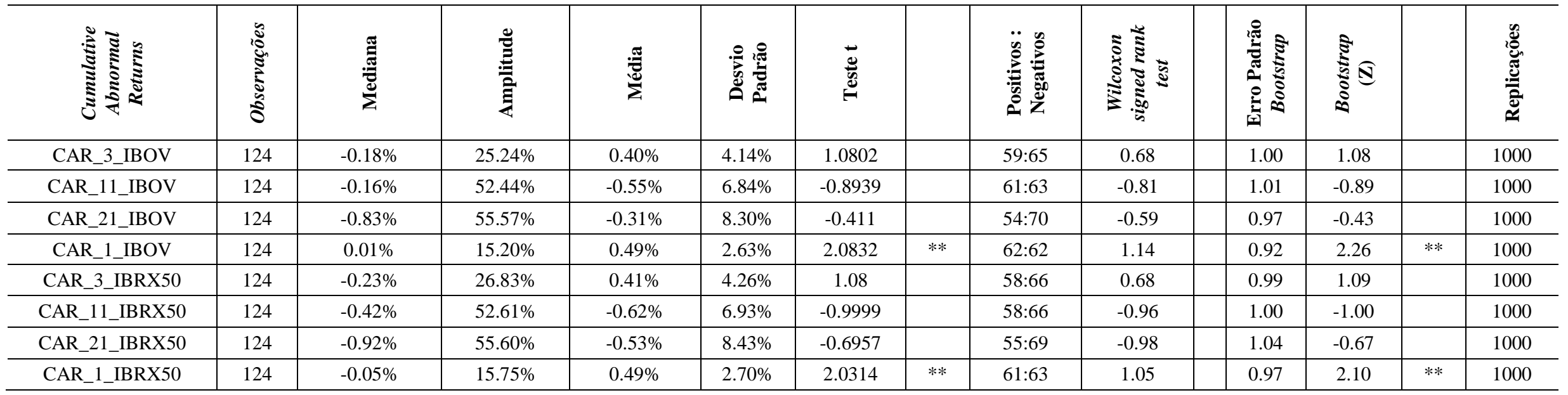

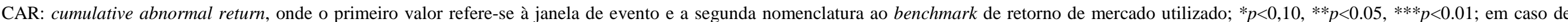
diminuição do número de observações reportadas, salienta-se que é decorrente de missing values (dados faltantes).

Fonte: Elaborado pelo autor.

É possível evidenciar que, para as empresas familiares da amostra, com média propriedade concentrada (empresas cujos acionistas controladores detêm de 30\% a 70\% do stake acionário), identificou-se significância estatística (p<0.05) para ambos os CAR_1_Ibovespa e CAR_1_IBRX50 (Dia dos Anúncios), em que ambos obtiveram geração de valor em $0.49 \%$. 


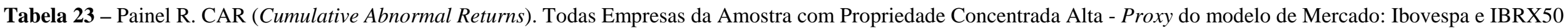

\begin{tabular}{|c|c|c|c|c|c|c|c|c|c|c|c|}
\hline 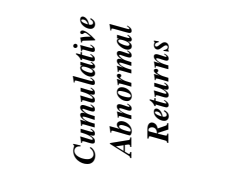 & 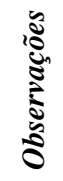 & 䔍 & 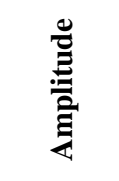 & 恶 & 。ْ & & 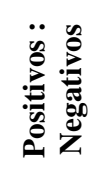 & 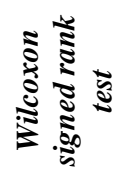 & 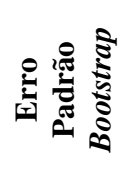 & $\frac{2}{8}$ & 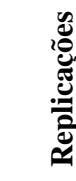 \\
\hline CAR_3_IBOV & 44 & $-0.59 \%$ & $20.18 \%$ & $0.29 \%$ & $3.83 \%$ & 0.5076 & $17: 27$ & -0.54 & 1.00 & 0.51 & 1000 \\
\hline CAR_11_IBOV & 44 & $1.17 \%$ & $27.11 \%$ & $0.78 \%$ & $5.86 \%$ & 0.8779 & $25: 19$ & 0.56 & 1.02 & 0.86 & 1000 \\
\hline CAR_21_IBOV & 44 & $-1.70 \%$ & $42.88 \%$ & $-0.35 \%$ & $9.43 \%$ & -0.247 & $20: 24$ & -0.21 & 1.02 & -0.24 & 1000 \\
\hline CAR_1_IBOV & 44 & $-0.26 \%$ & $15.25 \%$ & $0.04 \%$ & $2.59 \%$ & 0.1139 & $18: 26$ & -0.54 & 1.01 & 0.11 & 1000 \\
\hline CAR_3_IBRX50 & 44 & $-0.52 \%$ & $19.54 \%$ & $0.26 \%$ & $3.82 \%$ & 0.4538 & $16: 28$ & -0.65 & 0.99 & 0.46 & 1000 \\
\hline CAR_11_IBRX50 & 44 & $0.97 \%$ & $26.81 \%$ & $0.76 \%$ & $5.84 \%$ & 0.8643 & $25: 19$ & 0.54 & 1.02 & 0.85 & 1000 \\
\hline CAR_21_IBRX50 & 44 & $-1.65 \%$ & $42.66 \%$ & $-0.38 \%$ & $9.54 \%$ & -0.2641 & $20: 24$ & -0.30 & 1.00 & -0.26 & 1000 \\
\hline CAR_1_IBRX50 & 44 & $-0.37 \%$ & $15.48 \%$ & $-0.01 \%$ & $2.58 \%$ & -0.0205 & $16: 28$ & -0.71 & 1.06 & -0.02 & 1000 \\
\hline
\end{tabular}

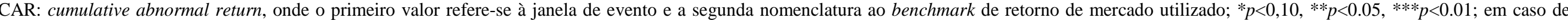
diminuição do número de observações reportadas, salienta-se que é decorrente de missing values (dados faltantes).

Fonte: Elaborado pelo autor.

É possível evidenciar que, para as empresas familiares da amostra, com alta propriedade concentrada (empresas cujos acionistas controladores detêm acima de 70\% do stake acionário), não se identificou significância estatística para os testes de média dos CARs. Desse modo, não se rejeita a hipótese nula, dos testes estatísticos utilizados, de que a média é zero dos CARs. Em outras palavras, para as empresas familiares da amostra com alta concentração acionária, os retornos anormais, na média, em aquisições, são estatisticamente iguais a zero. 
Dessa forma, após a análise univariada dos CARs, em empresas familiares, estratificadas por grau de concentração acionária de seus acionistas controladores, pode-se obter uma conclusão parcial sobre a relação entre o desempenho anormal em aquisições de empresas, e o maior grau de concentração acionária em empresas familiares, evocando-se a hipótese 5:

Hipótese 5. Retornos anormais em aquisições de empresas estão relacionados positivamente ao grau de concentração acionária detida pela família controladora.

Informa-se que como conclusão parcial a ser enrobustecida ou não pelas demais análises bivariadas e multivariadas ulteriores, os retornos anormais em aquisições de empresas têm relação positiva à variável de concentração acionária detida pela família controladora. Evidencia-se, inclusive, que foi encontrada uma possível relação quadrática de concentração acionária pela família controladora e o desempenho da empresa familiar em eventos de aquisições de empresas. Entretanto, reporta-se que não será medido esta possível relação neste presente trabalho, mas deixa-se como sugestão de escopo de pesquisa para futuros trabalhos.

Referente ainda aos achados sobre o grau de concentração acionária, encontrou-se que em baixa concentração de propriedade (concentrações acionárias menores de 30\%) e em alta concentração de propriedade (concentrações acionárias acima de 70\%), não há significância estatística nos retornos anormais mensurados nas análises univariadas reportadas anteriormente, desta forma, os CARs, nestas concentrações acionárias, em empresas familiares, são iguais a zero.

Por outro lado, em concentrações acionárias relevantes de 30 a $70 \%$ (denominado neste trabalho como concentração média), tiveram resultados positivos e estatisticamente significantes dos ACAR (average cumulative abnormal return). Assim, a concentração acionária de controladores de empresas familiares que detém de 30 a 70\% do stake acionário, criaram valor em eventos de aquisições de empresas.

Coaduna-se aos resultados encontrados o outro tipo de classificação de concentração de propriedade pelos acionistas controladores, em que os ACARs das concentrações superiores a $50 \%$ e a $10 \%$ não obtiveram significância estatística, inferindo que os ACARs nessas referidas concentrações em empresas familiares, são iguais a zero.

Por outro lado, em concentrações acionárias superiores a 20\%, tiveram resultados positivos e estatisticamente significantes dos ACAR (average cumulative abnormal return), a saber: CAR_1_Ibovespa e CAR_1_IBRX50 [dias dos anúncios, gerando criação de valor em 
$(0.41 \% ; \mathrm{p}<0,05)$ e $(0.38 \% ; \mathrm{p}<0.10)$, respectivamente]. Assim, a concentração acionária de controladores de empresas familiares que detém mais de $20 \%$ do stake acionário, criaram valor em eventos de aquisições de empresas.

Desta forma, caso houvesse apenas esta análise univariada, poderia tender a não rejeitar a hipótese 5, colocando que há relação positiva e significante entre o grau de concentração acionária média e superiores a $20 \%$ e os ACARs evidenciados nas tabelas anteriores. Entretanto, conforme mencionado anteriormente, esta conclusão parcial pode ser reavaliada a medida que são realizadas e reportadas no presente trabalho maiores análises ulteriores. 


\subsubsection{Análise CAR - Empresas Não Familiares - Estratificadas por Concentrações Acionárias}

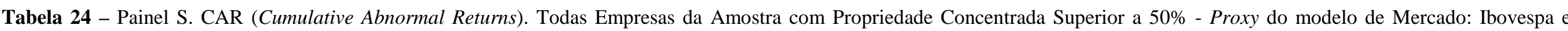
IBRX50

\begin{tabular}{|c|c|c|c|c|c|c|c|c|c|c|c|c|}
\hline 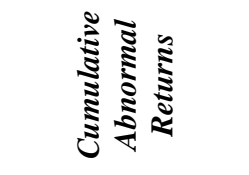 & 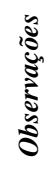 & & 总 & 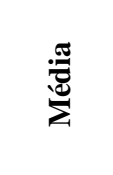 & 产 & & 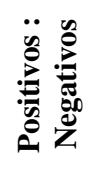 & 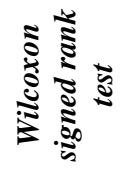 & & 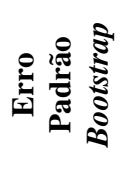 & 㺼 & 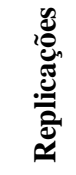 \\
\hline CAR_3_IBOV & 53 & $-0.50 \%$ & $29.00 \%$ & $-0.28 \%$ & $4.43 \%$ & -0.4569 & $19: 34$ & -1.66 & $*$ & 1.20 & -0.38 & 1000 \\
\hline CAR_11_IBOV & 53 & $-1.33 \%$ & $43.06 \%$ & $-0.27 \%$ & $7.36 \%$ & -0.2707 & $23: 30$ & -1.16 & & 1.09 & -0.25 & 1000 \\
\hline CAR_21_IBOV & 53 & $-1.48 \%$ & $54.72 \%$ & $-1.60 \%$ & $10.08 \%$ & -1.1575 & $21: 32$ & -2.16 & $* *$ & 1.30 & -0.89 & 1000 \\
\hline CAR_1_IBOV & 53 & $0.33 \%$ & $13.10 \%$ & $0.17 \%$ & $2.24 \%$ & 0.5403 & $29: 24$ & 0.45 & & 0.98 & 0.55 & 1000 \\
\hline CAR_3_IBRX50 & 53 & $-0.45 \%$ & $28.90 \%$ & $-0.27 \%$ & $4.38 \%$ & -0.4509 & $19: 34$ & -1.60 & & 1.20 & -0.38 & 1000 \\
\hline CAR_11_IBRX50 & 53 & $-1.20 \%$ & $43.28 \%$ & $-0.40 \%$ & $7.22 \%$ & -0.4047 & $23: 30$ & -1.30 & & 1.12 & -0.36 & 1000 \\
\hline CAR_21_IBRX50 & 53 & $-2.37 \%$ & $54.94 \%$ & $-1.76 \%$ & $10.07 \%$ & -1.273 & $22: 31$ & -2.48 & $* *$ & 1.33 & -0.95 & 1000 \\
\hline CAR_1_IBRX50 & 53 & $0.27 \%$ & $9.55 \%$ & $0.28 \%$ & $1.99 \%$ & 1.0168 & $31: 22$ & 0.57 & & 1.02 & 1.00 & 1000 \\
\hline
\end{tabular}

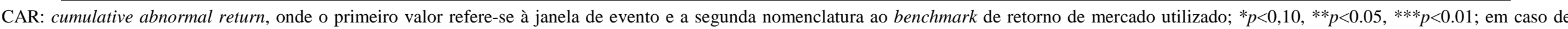
diminuição do número de observações reportadas, salienta-se que é decorrente de missing values (dados faltantes).

Fonte: Elaborado pelo autor.

É possível evidenciar que, para as empresas não familiares da amostra, com propriedade concentrada superior a 50\%, não se identificou significância estatística para os testes de média dos CARs. Desse modo, não se rejeita a hipótese nula, dos testes estatísticos utilizados, de que a média é zero dos CARs. Em outras palavras, para as empresas não familiares da amostra com concentração acionária superior a 50\%, os retornos anormais, na média, em aquisições, são estatisticamente iguais a zero.

Por outro lado, no teste de sinais de Wilcoxon, há evidências de se rejeitar a hipótese nula de que a mediana é igual a zero em ( $p<0.10$ e p $<0.05$ ), ou seja, verifica-se que os sinais negativos são em maior quantidade que os sinais positivos, podendo-se inferir que para os CARs: CAR_3_Ibovespa, CAR_21_Ibovespa e CAR_21_IBRX50, em geral, tiveram retornos negativos, em decorrência de eventos de aquisições de empresas, das empresas da amostra 
Tabela 25 - Painel T. CAR (Cumulative Abnormal Returns). Todas Empresas da Amostra com Propriedade Concentrada Superior a 20\% - Proxy do modelo de Mercado: Ibovespa e IBRX50

\begin{tabular}{|c|c|c|c|c|c|c|c|c|c|c|c|c|}
\hline 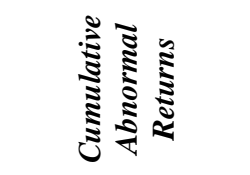 & 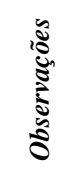 & 营 & 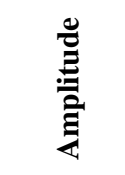 & 恶 & 产密 & & 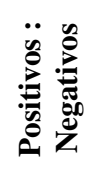 & 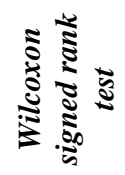 & & 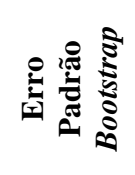 & 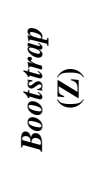 & 氖 \\
\hline CAR_3_IBOV & 104 & $-0.09 \%$ & $32.32 \%$ & $0.04 \%$ & $3.92 \%$ & 0.1136 & $49: 55$ & -0.39 & & 0.99 & 0.11 & 1000 \\
\hline CAR_11_IBOV & 104 & $-1.16 \%$ & $43.30 \%$ & $0.21 \%$ & $6.88 \%$ & 0.3078 & $50: 54$ & -0.54 & & 0.99 & 0.31 & 1000 \\
\hline CAR_21_IBOV & 104 & $-1.18 \%$ & $59.56 \%$ & $-0.74 \%$ & $10.30 \%$ & -0.731 & $48: 56$ & -1.67 & $*$ & 1.08 & -0.68 & 1000 \\
\hline CAR_1_IBOV & 104 & $0.15 \%$ & $13.10 \%$ & $0.08 \%$ & $2.04 \%$ & 0.4227 & $54: 50$ & 0.27 & & 1.03 & 0.41 & 1000 \\
\hline CAR_3_IBRX50 & 104 & $-0.18 \%$ & $32.61 \%$ & $0.06 \%$ & $3.91 \%$ & 0.1489 & $48: 56$ & -0.44 & & 1.07 & 0.14 & 1000 \\
\hline CAR_11_IBRX50 & 104 & $-0.89 \%$ & $44.17 \%$ & $0.03 \%$ & $6.76 \%$ & 0.0482 & $48: 56$ & -0.73 & & 1.05 & 0.05 & 1000 \\
\hline CAR_21_IBRX50 & 104 & $-2.18 \%$ & $60.42 \%$ & $-1.01 \%$ & $10.27 \%$ & -1.0062 & $48: 56$ & -2.03 & $* *$ & 1.08 & -0.93 & 1000 \\
\hline CAR_1_IBRX50 & 104 & $0.10 \%$ & $11.82 \%$ & $0.14 \%$ & $1.93 \%$ & 0.7669 & $55: 49$ & 0.24 & & 0.99 & 0.77 & 1000 \\
\hline
\end{tabular}

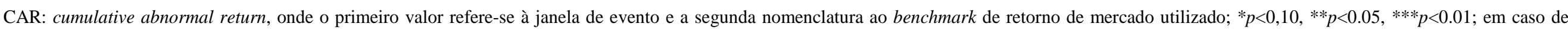
diminuição do número de observações reportadas, salienta-se que é decorrente de missing values (dados faltantes).

Fonte: Elaborado pelo autor.

É possível evidenciar que, para as empresas não familiares da amostra, com propriedade concentrada superior a 20\%, não se identificou significância estatística para os testes de média dos CARs. Desse modo, não se rejeita a hipótese nula, dos testes estatísticos utilizados, de que a média é zero dos CARs. Em outras palavras, para as empresas não familiares da amostra com concentração acionária superior a 20\%, os retornos anormais, na média, em aquisições, são estatisticamente iguais a zero.

Por outro lado, no teste de sinais de Wilcoxon, há evidências de se rejeitar a hipótese nula de que a mediana é igual a zero em (p<0.10 e p<0.05), ou seja, verifica-se que os sinais negativos são em maior quantidade que os sinais positivos, podendo-se inferir que para os CARs: CAR_21_Ibovespa e CAR_21_IBRX50, em geral, tiveram retornos negativos em decorrência de eventos de aquisições de empresas, das empresas da amostra. 
Tabela 26 - Painel U. CAR (Cumulative Abnormal Returns). Todas Empresas da Amostra com Propriedade Concentrada Superior a 10\% - Proxy do modelo de Mercado: Ibovespa e IBRX50

\begin{tabular}{|c|c|c|c|c|c|c|c|c|c|c|c|c|}
\hline 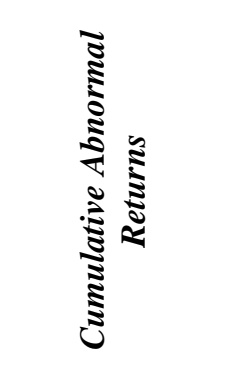 & 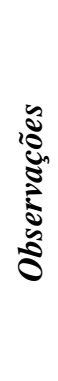 & 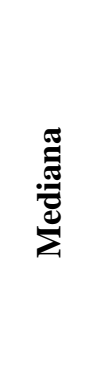 & 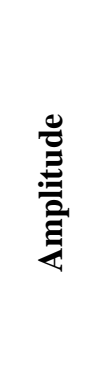 & 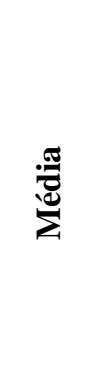 & 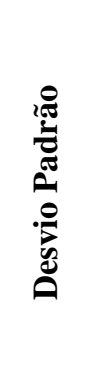 & 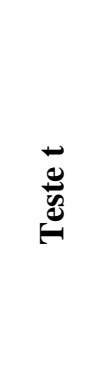 & 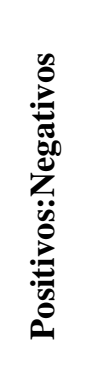 & 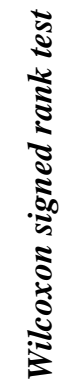 & & 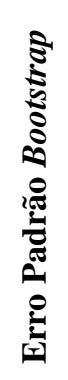 & 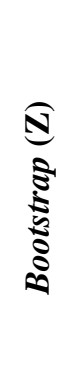 & 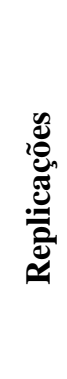 \\
\hline CAR_3_IBOV & 129 & $-0.10 \%$ & $32.32 \%$ & $0.29 \%$ & $4.00 \%$ & 0.8143 & $61: 68$ & 0.09 & & 0.97 & 0.84 & 1000 \\
\hline CAR_11_IBOV & 129 & $0.01 \%$ & $43.30 \%$ & $0.17 \%$ & $6.61 \%$ & 0.291 & $65: 64$ & -0.43 & & 1.01 & 0.29 & 1000 \\
\hline CAR_21_IBOV & 129 & $-1.31 \%$ & $59.56 \%$ & $-0.70 \%$ & $9.64 \%$ & -0.8244 & $60: 69$ & -1.78 & $*$ & 1.12 & -0.74 & 1000 \\
\hline CAR_1_IBOV & 129 & $0.24 \%$ & $13.10 \%$ & $0.14 \%$ & $2.05 \%$ & 0.7519 & $68: 61$ & 0.56 & & 0.99 & 0.76 & 1000 \\
\hline CAR_3_IBRX50 & 129 & $-0.17 \%$ & $32.61 \%$ & $0.30 \%$ & $4.05 \%$ & 0.8453 & $60: 69$ & 0.04 & & 0.94 & 0.90 & 1000 \\
\hline CAR_11_IBRX50 & 129 & $-0.06 \%$ & $44.17 \%$ & $0.03 \%$ & $6.57 \%$ & 0.0504 & $64: 65$ & -0.58 & & 1.01 & 0.05 & 1000 \\
\hline CAR_21_IBRX50 & 129 & $-0.99 \%$ & $60.42 \%$ & $-0.92 \%$ & $9.64 \%$ & -1.0852 & $60: 69$ & -2.04 & $* *$ & 1.14 & -0.95 & 1000 \\
\hline CAR_1_IBRX50 & 129 & $0.15 \%$ & $11.82 \%$ & $0.20 \%$ & $1.96 \%$ & 1.134 & $69: 60$ & 0.65 & & 0.99 & 1.15 & 1000 \\
\hline
\end{tabular}

CAR: cumulative abnormal return, onde o primeiro valor refere-se à janela de evento e a segunda nomenclatura ao benchmark de retorno de mercado utilizado; ${ }^{*} p<0,10,{ }^{*} p<0.05$, ***p $<0.01$; em caso de diminuição do número de observações reportadas, salienta-se que é decorrente de missing values (dados faltantes).

Fonte: Elaborado pelo autor.

É possível evidenciar que, para as empresas não familiares da amostra, com propriedade concentrada superior a 10\%, não se identificou significância estatística para os testes de média dos CARs. Desse modo, não se rejeita a hipótese nula, dos testes estatísticos utilizados, de que a média é zero dos CARs. Em outras palavras, para as empresas não familiares da amostra com concentração acionária superior a 10\%, os retornos anormais, na média, em aquisições, são estatisticamente iguais a zero.

Por outro lado, no teste de sinais de Wilcoxon, há evidências de se rejeitar a hipótese nula de que a mediana é igual a zero em $(\mathrm{p}<0.10$ e $\mathrm{p}<0.05)$, ou seja, verifica-se que os sinais negativos são em maior quantidade que os sinais positivos, podendo-se inferir que para os CARs: CAR_21_Ibovespa e CAR_21_IBRX50, em geral, tiveram retornos negativos, em decorrência de eventos de aquisições de empresas, das empresas da amostra. 
É possível evidenciar agora o segundo tipo de classificação de concentração acionária, utilizando o simples ranqueamento e agrupamento das empresas da amostra da pesquisa, em faixas de graus de concentração acionária arbitrariamente definidas nesta pesquisa. Assim, são citadas e testadas as concentrações acionárias estipuladas arbitrariamente em faixas de concentração acionária dos acionistas controladores em até 30\% (denominados neste trabalho como baixa concentração acionária), de 30 a 70\% (denominados neste trabalho como média concentração acionária), e acima de 70\% (denominados neste trabalho como alta concentração acionária).

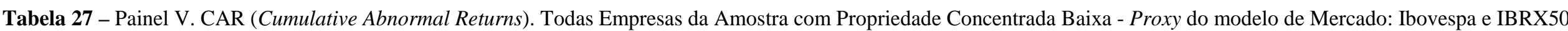

\begin{tabular}{|c|c|c|c|c|c|c|c|c|c|c|c|c|}
\hline 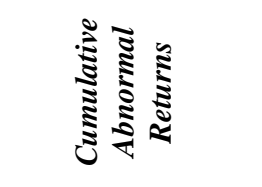 & 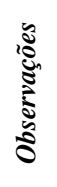 & 䒿 & 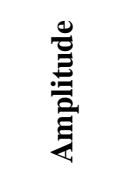 & 突 & 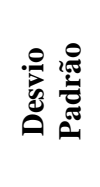 & $\begin{array}{l}\vec{y} \\
\stackrel{y}{0} \\
\end{array}$ & 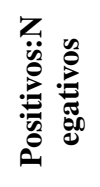 & 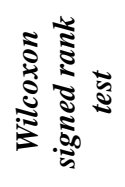 & 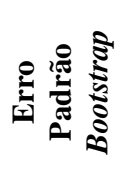 & $\frac{\sqrt{0}}{2}$ & & 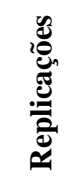 \\
\hline CAR_3_IBOV & 29 & $-0.29 \%$ & $18.36 \%$ & $1.41 \%$ & $4.68 \%$ & 1.62 & $14: 15$ & 1.07 & 0.92 & 1.76 & $*$ & 1000 \\
\hline CAR_11_IBOV & 29 & $0.69 \%$ & $22.46 \%$ & $-0.26 \%$ & $5.82 \%$ & -0.24 & $17: 12$ & -0.18 & 1.06 & -0.23 & & 1000 \\
\hline CAR_21_IBOV & 29 & $-1.53 \%$ & $31.46 \%$ & $-1.16 \%$ & $6.86 \%$ & -0.91 & $14: 15$ & -0.49 & 0.99 & -0.92 & & 1000 \\
\hline CAR_1_IBOV & 29 & $0.29 \%$ & $9.06 \%$ & $0.40 \%$ & $2.08 \%$ & 1.02 & $17: 12$ & 0.92 & 0.99 & 1.04 & & 1000 \\
\hline CAR_3_IBRX50 & 29 & $-0.02 \%$ & $19.25 \%$ & $1.50 \%$ & $4.95 \%$ & 1.63 & $14: 15$ & 0.98 & 0.94 & 1.74 & $*$ & 1000 \\
\hline CAR_11_IBRX50 & 29 & $1.04 \%$ & $22.89 \%$ & $-0.24 \%$ & $6.12 \%$ & -0.20 & $18: 11$ & -0.12 & 1.05 & -0.20 & & 1000 \\
\hline CAR_21_IBRX50 & 29 & $-0.90 \%$ & $32.83 \%$ & $-1.23 \%$ & $7.02 \%$ & -0.94 & $14: 15$ & -0.57 & 1.03 & -0.91 & & 1000 \\
\hline CAR_1_IBRX50 & 29 & $0.45 \%$ & $9.19 \%$ & $0.50 \%$ & $2.19 \%$ & 1.24 & $17: 12$ & 1.18 & 0.98 & 1.27 & & 1000 \\
\hline
\end{tabular}

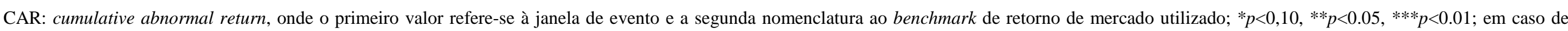
diminuição do número de observações reportadas, salienta-se que é decorrente de missing values (dados faltantes).

Fonte: Elaborado pelo autor.

É possível evidenciar que, para as empresas não familiares da amostra, com baixa propriedade concentrada (concentração acionária dos acionistas controladores em até 30\%), identificou-se significância estatística $(p<0.10)$ para ambos os CAR_3_Ibovespa e CAR_3_IBRX50, em que ambos obtiveram geração de valor em $1.41 \%$ e $1.50 \%$ respectivamente 
Tabela 28 - Painel W. CAR (Cumulative Abnormal Returns). Todas Empresas da Amostra com Propriedade Concentrada Média - Proxy do modelo de Mercado: Ibovespa e IBRX50

\begin{tabular}{|c|c|c|c|c|c|c|c|c|c|c|c|c|}
\hline 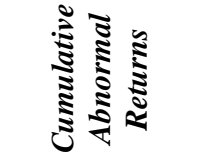 & 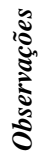 & 胥 & 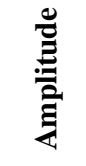 & 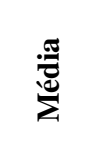 & 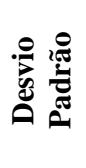 & 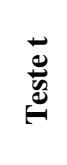 & 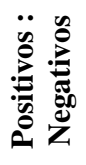 & 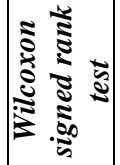 & & 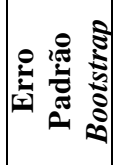 & 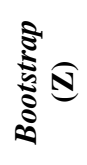 & n \\
\hline CAR_3_IBOV & 92 & $-0.05 \%$ & $32.3 \%$ & $0.08 \%$ & $3.8 \%$ & 0.21 & $45: 47$ & -0.03 & & 1.01 & 0.21 & 1000 \\
\hline CAR_11_IBOV & 92 & $-1.00 \%$ & $43.3 \%$ & $0.51 \%$ & $7.0 \%$ & 0.69 & $45: 47$ & -0.09 & & 0.98 & 0.71 & 1000 \\
\hline CAR_21_IBOV & 92 & $-1.40 \%$ & $59.5 \%$ & $-0.53 \%$ & $10.6 \%$ & -0.47 & $42: 50$ & -1.44 & & 1.06 & -0.45 & 1000 \\
\hline CAR_1_IBOV & 92 & $0.25 \%$ & $13.1 \%$ & $0.14 \%$ & $2.0 \%$ & 0.66 & $49: 43$ & 0.51 & & 1.00 & 0.66 & 1000 \\
\hline CAR_3_IBRX50 & 92 & $-0.16 \%$ & $32.6 \%$ & $0.07 \%$ & $3.7 \%$ & 0.16 & $44: 48$ & -0.13 & & 1.03 & 0.16 & 1000 \\
\hline CAR_11_IBRX50 & 92 & $-0.55 \%$ & $44.1 \%$ & $0.32 \%$ & $6.8 \%$ & 0.44 & $43: 49$ & -0.29 & & 0.99 & 0.45 & 1000 \\
\hline CAR_21_IBRX50 & 92 & $-2.45 \%$ & $60.4 \%$ & $-0.81 \%$ & $10.6 \%$ & -0.73 & $42: 50$ & -1.78 & $*$ & 1.09 & -0.68 & 1000 \\
\hline CAR_1_IBRX50 & 92 & $0.13 \%$ & $11.8 \%$ & $0.19 \%$ & $1.8 \%$ & 0.98 & $49: 43$ & 0.40 & & 0.96 & 1.03 & 1000 \\
\hline
\end{tabular}

CAR: cumulative abnormal return, onde o primeiro valor refere-se à janela de evento e a segunda nomenclatura ao benchmark de retorno de mercado utilizado; *p<0,10, **p<0.05, ***p<0.01; em caso de diminuição do número de observações reportadas, salienta-se que é decorrente de missing values (dados faltantes).

Fonte: Elaborado pelo autor.

É possível evidenciar que, para as empresas não familiares da amostra, com média propriedade concentrada (empresas cujos acionistas controladores detêm de 30\% a 70\% do stake acionário), não se identificou significância estatística para os testes de média dos CARs. Desse modo, não se rejeita a hipótese nula, dos testes estatísticos utilizados, de que a média é zero dos CARs. Em outras palavras, para as empresas não familiares da amostra com média propriedade concentrada, os retornos anormais, na média, em aquisições, são estatisticamente iguais a zero.

Por outro lado, no teste de sinais de Wilcoxon, há evidências de se rejeitar a hipótese nula de que a mediana é igual a zero em ( $\mathrm{p}<0.10)$, ou seja, verifica-se que os sinais negativos são em maior quantidade que os sinais positivos, podendo-se inferir que para o CAR_21_IBRX50, em maior parte da amostra, obteve retornos negativos, em decorrência de eventos de aquisições de empresas analisados. 
Tabela 29 - Painel X. CAR (Cumulative Abnormal Returns). Todas Empresas da Amostra com Propriedade Concentrada Alta - Proxy do modelo de Mercado: Ibovespa e IBRX50

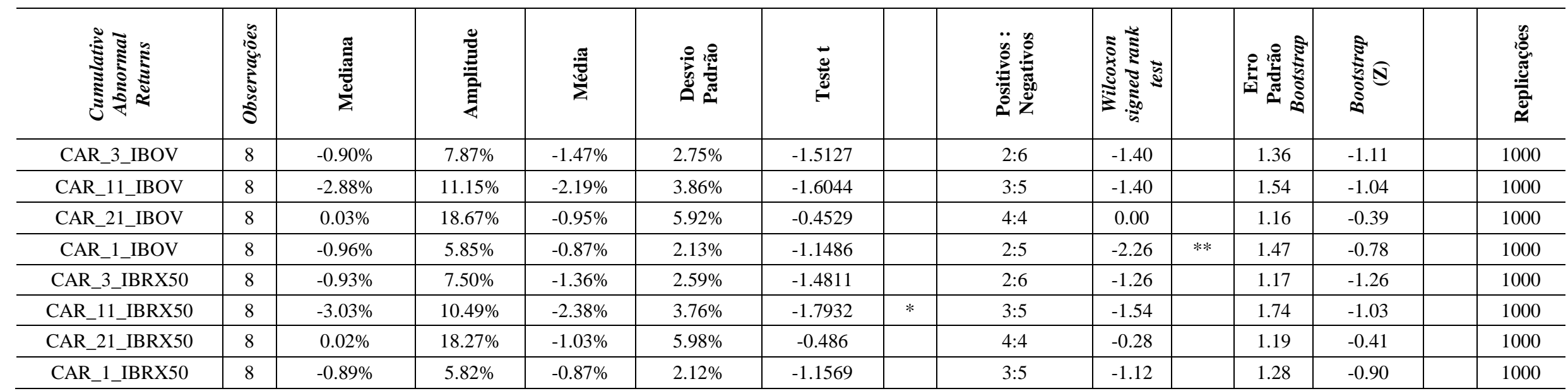

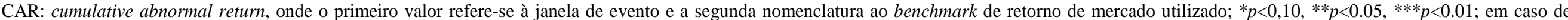
diminuição do número de observações reportadas, salienta-se que é decorrente de missing values (dados faltantes).

Fonte: Elaborado pelo autor.

É possível evidenciar que para as empresas familiares da amostra, com alta propriedade concentrada (empresas cujos acionistas controladores detêm acima de 70\% do stake acionário), identificou-se significância estatística (p<0.10) para o CAR_11_IBRX50, em que obteve destruição de valor em -2.38\%.

No teste de sinais de Wilcoxon, coadunam-se as evidências de destruição de valor por empresas não familiares, que têm alta concentração acionária por parte de seus acionistas controladores, pois, rejeita-se a hipótese nula de que a mediana é igual a zero em ( $\mathrm{p}<0.05$ ), ou seja, verifica-se que os sinais negativos são em maior quantidade que os sinais positivos, podendo-se inferir que para o CAR_1_Ibovespa (data do anúncio), em geral, tiveram retornos negativos, em decorrência de eventos de aquisições de empresas, das empresas da amostra. 


\subsubsection{Estatística Descritiva - Análise Univariada das demais variáveis da pesquisa}

Nesta seção serão analisadas univariadamente as demais variáveis desta pesquisa.

Relata-se que foi inserido apenas um dos CAR nesta análise univariada global dos dados, para apenas manter um parâmetro de desempenho como possível referência, embora, seja importante esclarecer que, neste trabalho, já foram realizadas previamente as análises dos CARs, univariadamente, de forma ampla e exaustiva.

Com base na tabela a seguir, reporta-se a estatística descritiva e a análise univariada das variáveis explicativas e de controle, quando apresentadas globalmente com os dados de todas as empresas da amostra da pesquisa.

Tabela 30 - Painel I. Todas as Empresas da Amostra

\begin{tabular}{|c|c|c|c|c|c|}
\hline & Observações & Média & $\begin{array}{l}\text { Desvio } \\
\text { Padrão }\end{array}$ & Mínimo & Máximo \\
\hline CAR_1_IBOV & 355 & 0.27 & 2.82 & -9.11 & 26.32 \\
\hline Empresas Familiares & 355 & 0.64 & 0.48 & 0 & 1 \\
\hline Stake Controladores & 355 & 47.45 & 23.86 & 6.11 & 100 \\
\hline Propriedade Concentrada $>50 \%$ & 355 & 0.50 & 0.50 & 0 & 1 \\
\hline Propriedade Concentrada $>20 \%$ & 355 & 0.83 & 0.37 & 0 & 1 \\
\hline Propriedade Concentrada $>10 \%$ & 355 & 0.99 & 0.09 & 0 & 1 \\
\hline Propriedade Concentrada_Alta & 355 & 0.25 & 0.43 & 0 & 1 \\
\hline Propriedade Concentrada_Média & 355 & 0.61 & 0.49 & 0 & 1 \\
\hline Propriedade Concentrada_Baixa & 355 & 0.15 & 0.35 & 0 & 1 \\
\hline Poder_Controladores_Conselho & 290 & 0.58 & 0.29 & 0 & 1 \\
\hline Índice_Stake_Controladores/Blockholders & 221 & 3.92 & 8.50 & 0.09 & 97.97 \\
\hline $\begin{array}{c}\text { Índice_remuneração_variável e por } \\
\text { ações/remuneração total }\end{array}$ & 327 & 0.53 & 0.24 & 0.03 & 0.98 \\
\hline Q de Tobin & 355 & 1.21 & 0.79 & 0.20 & 6.81 \\
\hline Indústria Manufatureira & 355 & 0.39 & 0.49 & 0 & 1 \\
\hline Idade & 355 & 43.02 & 39.80 & 1 & 204 \\
\hline Tamanho_LN(Ativo Total) & 355 & 16.12 & 2.01 & 12.21 & 20.85 \\
\hline Investidores Institucionais & 355 & 0.86 & 0.35 & 0 & 1 \\
\hline Alavancagem Financeira & 355 & 0.32 & 0.13 & 0.00 & 0.79 \\
\hline Folga Financeira & 355 & 0.32 & 0.91 & 0.00 & 11.55 \\
\hline $\mathrm{LN}(\mathrm{CAPEX})$ & 355 & 12.23 & 6.02 & -15.63 & 18.20 \\
\hline Novo Mercado e Nível 2 & 355 & 0.68 & 0.47 & 0 & 1 \\
\hline Adquirente Serial & 355 & 0.72 & 0.45 & 0 & 1 \\
\hline Aquisição Internacional & 355 & 0.17 & 0.38 & 0 & 1 \\
\hline
\end{tabular}

CAR: cumulative abnormal return, onde o primeiro valor refere-se à janela de evento e a segunda nomenclatura ao benchmark de retorno de mercado utilizado; em caso de diminuição do número de observações reportadas, salienta-se que é decorrente de missing values (dados faltantes).

Fonte: Elaborado pelo autor. 
Observa-se que no Painel I é reportada a estatística descritiva básica das variáveis da pesquisa, que são relacionadas a todas as classificações de empresas do presente trabalho (empresas familiares e empresas não familiares). Verifica-se que um percentual relevante dos eventos de aquisições da amostra, no período analisado, foi realizado por empresas familiares (64\% do total dos eventos da amostra).

Evidencia-se também que o grau de concentração acionária, pelos acionistas controladores das empresas da amostra, é elevado, bem como o grau de poder de influência dos controladores no conselho de administração. Este medido pela razão entre representantes dos controladores no conselho e o número de cadeiras existentes no board. Relata-se que a pesquisa evidencia que na média para todas as empresas, aproximadamente $60 \%$ dos assentos no board são representados pelos acionistas controladores.

Outrossim, salienta-se que $68 \%$ do total das empresas têm adotado os melhores níveis de governança corporativa, a saber: padrões Novo Mercado e Nível 2 da Bovespa. Esse dado traz diferença significativa quando comparado às empresas no Brasil, há alguns anos anteriores, pois é recente a onda de IPOs (Initial Public Offering), que alavancou empresas listadas na Bovespa que adotam atualmente o padrão de governança Novo Mercado.

Outro fator para a mudança no cenário da adoção de melhores práticas de governança corporativa, pelas empresas, no Brasil, é o fator exigência do mercado, em que se tem exigido cada vez mais que a empresa adote melhores padrões de governança, a fim de obter melhor qualificação para tomada de empréstimos, financiamentos e valoração das ações pelo mercado.

Evidencia-se ainda que $72 \%$ dos eventos de aquisições de empresas da amostra foram realizados por empresas consideradas, neste trabalho, como adquirentes seriais, e que a idade média de todas as empresas da amostra é de 43 anos.

Com base na tabela a seguir, reportam-se a estatística descritiva e a análise univariada das variáveis explicativas e de controle consideradas, neste painel, somente as empresas familiares da amostra da pesquisa. 
Tabela 31 - Painel II. Empresas Familiares da Amostra

\begin{tabular}{c|c|c|c|c|c}
\hline Cumulative Abnormal Returns & Observações & Média & $\begin{array}{c}\text { Desvio } \\
\text { Padrão }\end{array}$ & Mínimo & Máximo \\
\hline CAR_1_IBOV & 226 & 0.34 & 3.17 & -9.11 & 26.32 \\
\hline $1^{\text {a e 2 }{ }^{\text {a }} \text { Geração Familiar }}$ & 226 & 0.79 & 0.41 & 0 & 1 \\
\hline Família na Administração & 226 & 0.48 & 0.50 & 0 & 1 \\
\hline Stake Família & 226 & 50.35 & 25.14 & 6.11 & 100 \\
\hline Propriedade Concentrada>50\% & 226 & 0.55 & 0.50 & 0 & 1 \\
\hline Propriedade Concentrada>20\% & 226 & 0.85 & 0.36 & 0 & 1 \\
\hline Propriedade Concentrada>10\% & 226 & 0.99 & 0.11 & 0 & 1 \\
\hline Propriedade Concentrada_Alta & 226 & 0.26 & 0.44 & 0 & 1 \\
\hline Propriedade Concentrada_Média & 226 & 0.55 & 0.50 & 0 & 1 \\
\hline Propriedade Concentrada_Baixa & 226 & 0.19 & 0.40 & 0 & 1 \\
\hline Poder_Controladores_Conselho & 222 & 0.52 & 0.29 & 0 & 1 \\
\hline Índice_Stake_Controladores/Blockholders & 163 & 4.26 & 9.81 & 0.09 & 97.97 \\
\hline Índice_remuneração_variável e por & 204 & 0.51 & 0.24 & 0.03 & 0.98 \\
\hline ações/remuneração total & 226 & 1.20 & 0.82 & 0.20 & 6.81 \\
\hline Q de Tobin & 226 & 0.39 & 0.49 & 0 & 1 \\
\hline Indústria Manufatureira & 226 & 41.48 & 30.26 & 1 & 173 \\
\hline Idade & 226 & 15.75 & 1.81 & 12.21 & 20.68 \\
\hline Tamanho_LN(Ativo Total) & 226 & 0.79 & 0.41 & 0 & 1 \\
\hline Investidores Institucionais & 226 & 0.34 & 0.14 & 0.00 & 0.79 \\
\hline Alavancagem Financeira & 226 & 0.40 & 1.12 & 0.00 & 11.55 \\
\hline Folga Financeira & 226 & 11.55 & 6.43 & -15.63 & 18.19 \\
\hline LN(CAPEX) & 226 & 0.70 & 0.46 & 0 & 1 \\
\hline Adovo Mercado e Nível 2 & 226 & 0.66 & 0.47 & 0 & 1 \\
\hline Adquirente Serial & & 0.20 & 0.40 & 0 & 1 \\
\hline
\end{tabular}

CAR: cumulative abnormal return, em que o primeiro valor refere-se à janela de evento e a segunda nomenclatura ao benchmark de retorno de mercado utilizado; em caso de diminuição do número de observações reportadas, salienta-se que é decorrente de missing values (dados faltantes).

Fonte: Elaborado pelo autor.

Observa-se que no Painel II, é reportada a estatística descritiva básica das variáveis da pesquisa, que são relacionadas às empresas familiares do presente trabalho. Verifica-se, dessa forma, que um percentual relevante (79\%) dos eventos da amostra estratificada, analisada neste painel, foi executado por empresas familiares de primeira e segunda gerações.

Reporta-se também que em empresas familiares, na média, quase 50\% delas têm algum familiar na administração no ano da aquisição, e que a concentração de propriedade tende a ser um pouco mais elevada em relação às empresas não familiares.

Com base na tabela a seguir, reportam-se a estatística descritiva e a análise univariada das variáveis explicativas e de controle consideradas, neste painel, somente as empresas não familiares da amostra da pesquisa. 
Tabela 32 - Painel III. Empresas Não Familiares da Amostra

\begin{tabular}{c|c|c|c|c|c}
\hline Cumulative Abnormal Returns & Observações & Média & $\begin{array}{c}\text { Desvio } \\
\text { Padrão }\end{array}$ & Mínimo & Máximo \\
\hline CAR_1_IBOV & 129 & 0.14 & 2.05 & -7.23 & 5.87 \\
\hline Stake Controladores (Não Família) & 129 & 42.37 & 20.57 & 10.36 & 100 \\
\hline Propriedade Concentrada>50\% & 129 & 0.41 & 0.49 & 0 & 1 \\
\hline Propriedade Concentrada>20\% & 129 & 0.81 & 0.40 & 0 & 1 \\
\hline Propriedade Concentrada>10\% & 129 & 1.00 & 0.00 & 1 & 1 \\
\hline Propriedade Concentrada_Alta & 129 & 0.22 & 0.42 & 0 & 1 \\
\hline Propriedade Concentrada_Média & 129 & 0.71 & 0.45 & 0 & 1 \\
\hline Propriedade Concentrada_Baixa & 129 & 0.06 & 0.24 & 0 & 1 \\
\hline Poder_Controladores_Conselho & 68 & 0.76 & 0.24 & 0 & 1 \\
\hline Índice_Stake_Controladores/Blockholders & 58 & 2.97 & 2.02 & 0.88 & 11.36 \\
\hline Índice_remuneração_variável e por & 123 & 0.56 & 0.23 & 0.21 & 0.95 \\
\hline ações/remuneração total & 129 & 1.21 & 0.73 & 0.25 & 5.93 \\
\hline Q de Tobin & 129 & 0.39 & 0.49 & 0 & 1 \\
\hline Indústria Manufatureira & 129 & 45.71 & 52.52 & 1 & 204 \\
\hline Idade & 129 & 16.76 & 2.17 & 12.50 & 20.85 \\
\hline Tamanho_LN(Ativo Total) & 129 & 0.98 & 0.15 & 0 & 1 \\
\hline Investidores Institucionais & 129 & 0.30 & 0.11 & 0.03 & 0.56 \\
\hline Alavancagem Financeira & 129 & 0.17 & 0.19 & 0.01 & 1.65 \\
\hline Folga Financeira & 129 & 13.40 & 5.05 & -11.75 & 18.20 \\
\hline LN(CAPEX) & 129 & 0.66 & 0.48 & 0 & 1 \\
\hline Novo Mercado e Nível 2 & 129 & 0.83 & 0.38 & 0 & 1 \\
\hline Adquirente Serial & & 0.12 & 0.33 & 0 & 1 \\
\hline Aquisição Internacional & & & &
\end{tabular}

CAR: cumulative abnormal return, em que o primeiro valor refere-se à janela de evento e a segunda nomenclatura ao benchmark de retorno de mercado utilizado; em caso de diminuição do número de observações reportadas, salienta-se que é decorrente de missing values (dados faltantes).

Fonte: Elaborado pelo autor.

Observa-se que no Painel III, é reportada a estatística descritiva básica das variáveis da pesquisa, que são relacionadas às empresas não familiares do presente trabalho. Verifica-se, dessa forma que, na média, a concentração acionária das empresa não familiares também é elevada, mas, em geral, menor, em comparação à das empresas familiares.

Relata-se ainda que empresas não familiares, na média, tiveram maiores ocorrências de adquirentes seriais, realizando eventos de aquisições de empresas, que em comparação às empresas familiares.

Por fim, evidencia-se que empresas não familiares executaram, na média, menos aquisições internacionais que empresas familiares. 


\subsection{Análise Comparativa (bivariada) das Variáveis da Pesquisa - Correlação Pairwise}

A seguir, evidenciam-se as análises realizadas das matrizes de correlações pairwise, das variáveis da pesquisa. Relata-se que foram estratificadas em três subamostras, para análise mais aprofundada dos dados. A primeira com a correlação pairwise de todas as empresas da amostra. A segunda com a correlação pairwise de apenas empresas familiares. A terceira com a correlação pairwise de apenas empresas não familiares da amostra.

Tabela 33 - Matriz de Correlação Pairwise - Todas as Empresas da Pesquisa

\begin{tabular}{|c|c|c|c|c|c|c|c|c|c|c|c|c|c|c|}
\hline Variáveis & CAR_1_Ibovespa & & CAR_3_Ibovespa & & CAR_11_Ibovespa & & CAR_21_Ibovespa & & $\begin{array}{l}\text { Empresas } \\
\text { Familiares }\end{array}$ & & $\begin{array}{c}1^{\mathrm{a}} \text { e } 2^{\mathrm{a}} \\
\text { Geraçãa } \\
\text { Familiar }\end{array}$ & & $\begin{array}{c}\text { Família na } \\
\text { Administração }\end{array}$ & \\
\hline CAR_1_Ibovespa & 1.00 & & & & & & & & & & & & & \\
\hline CAR_3_Ibovespa & 0.67 & 米米米 & 1.00 & & & & & & & & & & & \\
\hline CAR_11_Ibovespa & 0.43 & 水决水 & 0.62 & ***** & 1.00 & & & & & & & & & \\
\hline CAR_21_Ibovespa & 0.33 & 米米 & 0.46 & 粎氺 & 0.76 & 米米米 & 1.00 & & & & & & & \\
\hline Empresas Familiares & 0.04 & & 0.01 & & $\begin{array}{l}-0.01 \\
\end{array}$ & & 0.02 & & 1.00 & & & & & \\
\hline $1^{\mathrm{a}} \mathrm{e} 2^{\mathrm{a}}$ Geração Familiar & 0.07 & & 0.03 & & 0.10 & & 0.13 & * & . & & 1.00 & & & \\
\hline Família na Administração & 0.07 & & 0.19 & **** & 0.06 & & 0.01 & & . & & -0.19 & **** & 1.00 & \\
\hline Stake Controladores & -0.05 & & -0.05 & & -0.01 & & 0.00 & & 0.16 & $* * *$ & 0.31 & ***** & -0.14 & ** \\
\hline Propriedade Concentrada $>50 \%$ & -0.06 & & -0.08 & & -0.04 & & -0.01 & & 0.13 & *** & 0.17 & *** & -0.25 & *** \\
\hline Propriedade Concentrada $>20 \%$ & 0.02 & & -0.02 & & -0.01 & & 0.02 & & 0.06 & & 0.35 & ***** & -0.22 & **** \\
\hline Propriedade Concentrada $>10 \%$ & -0.29 & 头米米 & -0.19 & $* * *$ & -0.13 & *** & -0.12 & ** & -0.07 & & 0.10 & & 0.03 & \\
\hline Propriedade Concentrada_Baixa & 0.01 & & 0.04 & & 0.02 & & -0.01 & & 0.04 & & -0.25 & * & 0.05 & \\
\hline Propriedade Concentrada_Média & 0.03 & & -0.01 & & -0.03 & & 0.01 & & -0.16 & $* * *$ & -0.04 & & -0.08 & \\
\hline Propriedade Concentrada_Alta & -0.05 & & -0.03 & & 0.02 & & 0.00 & & 0.18 & $* * * *$ & 0.32 & 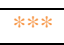 & 0.04 & \\
\hline Poder_Controladores_Conselho & 0.01 & & 0.08 & & 0.11 & $*$ & 0.07 & & -0.34 & $* * *$ & 0.08 & & -0.07 & \\
\hline $\begin{array}{c}\text { Índice_Stake_Controladores/Blockhol } \\
\text { ders }\end{array}$ & -0.04 & & 0.03 & & 0.08 & & 0.04 & & 0.07 & & 0.12 & & -0.20 & $* *$ \\
\hline $\begin{array}{c}\text { Índice_remuneração_variável e por } \\
\text { ações/remuneração total }\end{array}$ & -0.03 & & 0.11 & $* *$ & 0.02 & & 0.03 & & -0.11 & $*$ & 0.07 & & -0.05 & \\
\hline Q de Tobin & -0.02 & & -0.02 & & 0.00 & & -0.02 & & -0.01 & & -0.34 & ***** & 0.02 & \\
\hline
\end{tabular}


Continuação da Tabela 33 - Matriz de Correlação Pairwise - Todas as Empresas da Pesquisa

\begin{tabular}{|c|c|c|c|c|c|c|c|c|c|c|c|c|c|}
\hline Indústria Manufatureira & 0.03 & & -0.03 & & -0.06 & & -0.01 & 0.00 & & 0.32 & $* * *$ & -0.18 & $* * *$ \\
\hline Idade & 0.07 & & -0.02 & & 0.00 & & -0.01 & -0.05 & & 0.64 & $* *$ & 0.01 & \\
\hline Tamanho_LN(Ativo Total) & -0.02 & & 0.02 & & 0.03 & & 0.03 & -0.24 & **** & 0.43 & **** & -0.01 & \\
\hline Investidores Institucionais & -0.06 & & -0.10 & $* *$ & -0.03 & & -0.02 & -0.26 & **** & -0.03 & & -0.04 & \\
\hline Alavancagem Financeira & -0.13 & $* *$ & -0.08 & & -0.06 & & -0.06 & 0.16 & $* * *$ & 0.02 & & -0.05 & \\
\hline Folga Financeira & -0.04 & & -0.06 & & 0.00 & & 0.01 & 0.12 & $* *$ & 0.09 & & -0.06 & \\
\hline LN(CAPEX) & -0.04 & & -0.05 & & -0.06 & & -0.01 & -0.15 & $* * *$ & 0.00 & & -0.02 & \\
\hline Novo Mercado e Nível 2 & 0.04 & & 0.06 & & -0.09 & $*$ & -0.04 & 0.04 & & -0.42 & $* * *$ & 0.11 & \\
\hline Adquirente Serial & -0.07 & & -0.01 & & -0.05 & & -0.04 & -0.18 & $* * *$ & 0.11 & & 0.05 & \\
\hline Aquisição Internacional & -0.10 & $*$ & -0.08 & & 0.01 & & 0.04 & 0.10 & $*$ & 0.18 & $* * *$ & 0.01 & \\
\hline
\end{tabular}

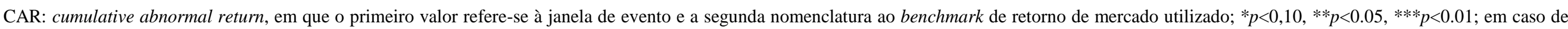

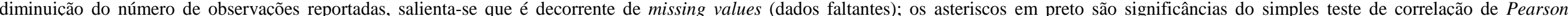

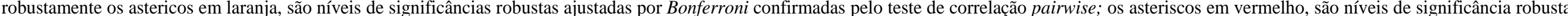

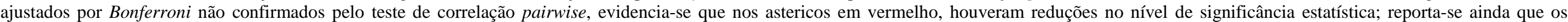
asteriscos em preto não são significantes na correlação pairwise com níveis de significância ajustados por Bonferroni.

Fonte: Elaborado pelo autor 
Reporta-se que, inicialmente, foi executado teste de correlação simples de Pearson, mas devido a diferenças significativas de output estatísticos, foi evidenciado também a correlação pairwise com nível de significância ajustado por Bonferroni, conforme se aborda na legenda da respectiva tabela.

Com a matriz de correlação das variáveis da amostra a todas as empresas, é possível a observação de que os CARs têm relação negativa e significante com a variável propriedade concentrada superior a 10\%. Outrossim, evidencia-se que o CAR_3_Ibovespa tem relação positiva e significante com a variável família na administração da empresa. 
Tabela 34 -Matriz de Correlação Pairwise - Subamostra: Variáveis da amostra| Empresas Familiares

\begin{tabular}{|c|c|c|c|c|c|c|c|c|c|c|c|c|}
\hline Variáveis & CAR_1_Ibovespa & & CAR_3_Ibovespa & & CAR_11_Ibovespa & & CAR_21_Ibovespa & & $\begin{array}{c}1^{\mathrm{a}} \text { e } 2^{\mathrm{a}} \text { Geração } \\
\text { Familiar }\end{array}$ & & $\begin{array}{c}\text { Família na } \\
\text { Administração }\end{array}$ & \\
\hline CAR_1_Ibovespa & 1.00 & & & & & & & & & & & \\
\hline CAR_3_Ibovespa & 0.69 & 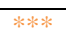 & 1.00 & & & & & & & & & \\
\hline CAR_11_Ibovespa & 0.43 & 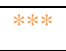 & 0.60 & 米隶* & 1.00 & & & & & & & \\
\hline CAR_21_Ibovespa & 0.38 & **** & 0.47 & 粰米 & 0.74 & 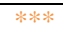 & 1.00 & & & & & \\
\hline $1^{\mathrm{a}}$ e $2^{\mathrm{a}}$ Geração Familiar & 0.07 & & 0.03 & & 0.10 & & 0.13 & $*$ & 1.00 & & & \\
\hline Família na Administração & 0.07 & & 0.19 & $* * *$ & 0.06 & & 0.01 & & -0.19 & $* * *$ & 1.00 & \\
\hline Stake Controladores & -0.05 & & 0.00 & & 0.01 & & 0.02 & & 0.31 & ***** & -0.14 & $* *$ \\
\hline Propriedade Concentrada $>50 \%$ & -0.10 & & -0.07 & & -0.03 & & 0.03 & & 0.17 & *** & -0.25 & *冰决 \\
\hline Propriedade Concentrada $>20 \%$ & 0.05 & & 0.04 & & -0.03 & & 0.04 & & 0.35 & *水* & -0.22 & $* * *$ \\
\hline Propriedade Concentrada $>10 \%$ & -0.32 & 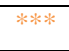 & -0.23 & **** & -0.16 & $* *$ & -0.15 & *** & 0.10 & & 0.03 & \\
\hline $\begin{array}{c}\text { Propriedade } \\
\text { Concentrada_Baixa }\end{array}$ & -0.02 & & -0.02 & & 0.05 & & -0.01 & & -0.25 & $*$ & 0.05 & \\
\hline $\begin{array}{c}\text { Propriedade } \\
\text { Concentrada_Média }\end{array}$ & 0.05 & & 0.02 & & -0.09 & & 0.01 & & -0.04 & & -0.08 & \\
\hline Propriedade Concentrada_Alta & -0.05 & & 0.00 & & 0.06 & & 0.00 & & 0.32 & 棣* & 0.04 & \\
\hline $\begin{array}{c}\text { Poder_Controladores_Conselh } \\
\text { o }\end{array}$ & -0.01 & & 0.10 & & 0.13 & $*$ & 0.11 & $*$ & 0.08 & & -0.07 & \\
\hline $\begin{array}{c}\text { Índice_Stake_Controladores/Bl } \\
\text { ockholders }\end{array}$ & -0.06 & & 0.03 & & 0.10 & & 0.04 & & 0.12 & & -0.20 & $* *$ \\
\hline $\begin{array}{c}\text { Índice_remuneração_variável e } \\
\text { por ações/remuneração total }\end{array}$ & -0.05 & & 0.08 & & 0.01 & & 0.03 & & 0.07 & & -0.05 & \\
\hline
\end{tabular}


Continuação da Tabela 34 -Matriz de Correlação Pairwise - Subamostra: Variáveis da amostra | Empresas Familiares

\begin{tabular}{|c|c|c|c|c|c|c|c|c|c|c|}
\hline Q de Tobin & -0.05 & & -0.03 & & -0.02 & -0.02 & -0.34 & ***** & 0.02 & \\
\hline Indústria Manufatureira & 0.09 & & 0.01 & & -0.02 & 0.06 & 0.32 & ***** & -0.18 & **** \\
\hline Idade & 0.15 & ** & 0.05 & & 0.10 & 0.08 & 0.64 & *** & 0.01 & \\
\hline Tamanho_LN(Ativo Total) & 0.00 & & 0.05 & & 0.00 & 0.07 & 0.43 & **** & -0.01 & \\
\hline Investidores Institucionais & -0.09 & & -0.14 & ** & -0.05 & -0.02 & -0.03 & & -0.04 & \\
\hline Alavancagem Financeira & -0.14 & ** & -0.07 & & -0.04 & -0.04 & 0.02 & & -0.05 & \\
\hline Folga Financeira & -0.05 & & -0.07 & & 0.02 & 0.02 & 0.09 & & -0.06 & \\
\hline LN(CAPEX) & 0.02 & & -0.01 & & -0.08 & -0.01 & 0.00 & & -0.02 & \\
\hline Novo Mercado e Nível 2 & 0.04 & & 0.04 & & -0.09 & -0.07 & -0.42 & *米米 & 0.11 & \\
\hline Adquirente Serial & -0.10 & & -0.04 & & -0.11 & -0.03 & 0.11 & & 0.05 & \\
\hline Aquisição Internacional & $\begin{array}{l}-0.09 \\
\end{array}$ & * & -0.08 & & 0.02 & 0.03 & 0.18 & **** & 0.01 & \\
\hline
\end{tabular}

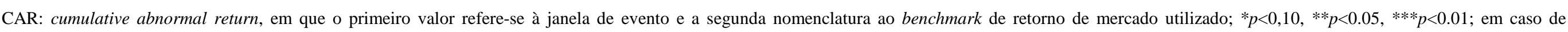

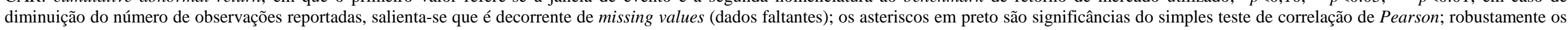

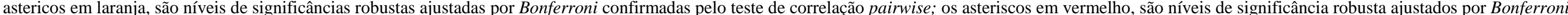

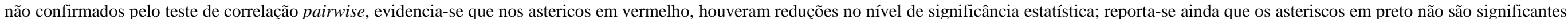
na correlação pairwise com níveis de significância ajustados por Bonferroni.

Fonte: Elaborado pelo autor. 
Reporta-se que, nessa tabela, também inicialmente, foi executado teste de correlação simples de Pearson, mas devido a diferenças significativas de output estatísticos, foi evidenciada também a correlação pairwise com nível de significância ajustado por Bonferroni, conforme aborda-se na legenda da respectiva tabela.

Com a matriz de correlação das variáveis da subamostra das empresas familiares, é possível observar que os CARs têm relação negativa e significante com a variável propriedade concentrada superior a $10 \%$. Outrossim, evidencia-se que o CAR_3_Ibovespa tem relação positiva e significante com a variável família na administração da empresa.

Reporta-se ainda que foi encontrada relação positiva e significante entre o CAR_21_Ibovespa e a variável $1^{\mathrm{a}}$ e $2^{\mathrm{a}}$ geração familiar. 
Tabela 35 - Matriz de Correlação Pairwise - Subamostra: Variáveis da amostra | Empresas não Familiares.

\begin{tabular}{|c|c|c|c|c|c|c|c|}
\hline Variáveis & CAR_1_Ibovespa & & CAR_3_Ibovespa & & CAR_11_Ibovespa & & CAR_21_Ibovespa \\
\hline CAR_1_Ibovespa & 1.00 & & & & & & \\
\hline CAR_3_Ibovespa & 0.67 & **** & 1.00 & & & & \\
\hline CAR_11_Ibovespa & 0.45 & *决水 & 0.66 & **** & 1.00 & & \\
\hline CAR_21_Ibovespa & 0.22 & *** & 0.45 & **** & 0.79 & **** & 1.00 \\
\hline Stake Controladores & -0.07 & & -0.17 & $*$ & -0.05 & & -0.04 \\
\hline Propriedade Concentrada $>50 \%$ & 0.01 & & -0.12 & & -0.06 & & -0.08 \\
\hline Propriedade Concentrada $>20 \%$ & -0.05 & & -0.12 & & 0.01 & & -0.01 \\
\hline Propriedade Concentrada $>10 \%$ & & & & & & & \\
\hline Propriedade Concentrada_Baixa & 0.07 & & 0.15 & * & -0.04 & & -0.03 \\
\hline Propriedade Concentrada_Média & 0.00 & & -0.08 & & 0.08 & & 0.03 \\
\hline Propriedade Concentrada_Alta & -0.13 & & -0.11 & & -0.09 & & -0.01 \\
\hline Poder_Controladores_Conselho & 0.18 & & 0.04 & & 0.06 & & 0.08 \\
\hline Índice_Stake_Controladores/Blockholders & 0.16 & & 0.03 & & -0.05 & & 0.04 \\
\hline $\begin{array}{c}\text { Índice_remuneração_variável e por ações/remuneração } \\
\text { total }\end{array}$ & 0.05 & & 0.19 & *** & 0.04 & & 0.04 \\
\hline Q de Tobin & 0.06 & & 0.00 & & 0.04 & & -0.02 \\
\hline Indústria Manufatureira & -0.12 & & -0.12 & & -0.12 & & -0.12 \\
\hline Idade & -0.02 & & -0.10 & & -0.10 & & -0.08 \\
\hline Tamanho_LN(Ativo Total) & -0.03 & & -0.04 & & 0.07 & & -0.01 \\
\hline Investidores Institucionais & 0.18 & ** & 0.06 & & 0.03 & & 0.00 \\
\hline Alavancagem Financeira & -0.12 & & -0.12 & & -0.11 & & -0.14 \\
\hline Folga Financeira & -0.04 & & -0.11 & & -0.17 & * & -0.14 \\
\hline LN(CAPEX) & -0.23 & ** & -0.14 & & -0.01 & & 0.00 \\
\hline Novo Mercado e Nível 2 & 0.01 & & 0.10 & & -0.10 & & 0.01 \\
\hline Adquirente Serial & 0.05 & & 0.07 & & 0.06 & & -0.03 \\
\hline Aquisição Internacional & -0.16 & * & -0.04 & & 0.00 & & 0.04 \\
\hline
\end{tabular}

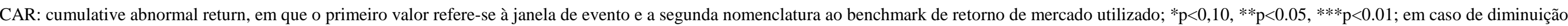

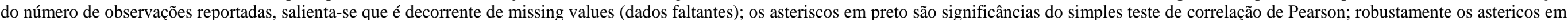

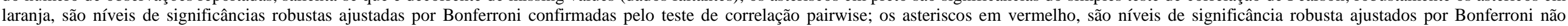

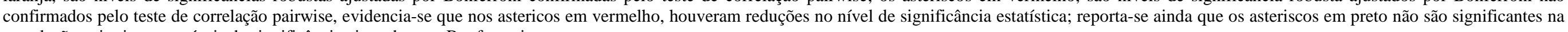
correlação pairwise com níveis de significância ajustados por Bonferroni.

Fonte: Elaborado pelo autor. 
Reporta-se também que nessa tabela inicialmente foi executado teste de correlação simples de Pearson, mas devido a diferenças significativas de output estatísticos, foi evidenciada também a correlação pairwise com nível de significância ajustado por Bonferroni, conforme legenda da referida tabela.

Com a matriz de correlação das variáveis da subamostra das empresas não familiares, é possível observar que não há nenhuma correlação significante pelo teste mais robusto de nível de significância de Bonferroni.

\subsection{Análise dos Resultados das Regressões Multivariadas}

Nesta seção serão analisadas multivariadamente as variáveis da pesquisa, com adoção de modelos de regressão por mínimos quadrados ordinários (MQO), utilizando medidas como matrizes robustas para estimação dos parâmetros, por Hubber-White Sandwich, para mitigar o problema encontrado de heterocedasticidade dos resíduos da amostra, evidenciados pelo teste de Breusch-Pagan.

Outrossim, informa-se que também foram encontrados problemas na amostra da pesquisa quando executados os testes de normalidade de Shapiro-Wilk, Kolmogorov-Smirnov e JarqueBera. Dessa forma, para mitigar os problemas de anormalidade da amostra, foi procedida também a evidenciação dos resultados das regressões realizadas sob o procedimento estatístico não paramétrico de resampling chamado Bootstrap. Esta ferramenta estatística não demanda de premissa de normalidade, funciona como uma simulação de Monte Carlo, que replica "n vezes" a amostra, condicionando-se à função distribuição de probabilidade característica da amostra analisada. Assim, informa-se que os resultados apresentados pela ferramenta estatística Bootstrap tendem a ser mais robustos.

Evidencia-se que, em todos os modelos de regressões, as variáveis dependentes serão os CARs (cumulative abnormal return) previamente definidos e reportados no presente trabalho. Informa-se ainda que o intuito da análise multivariada, utilizando regressões estatísticas, é de testar as hipóteses deste trabalho que ainda não obtiveram respostas com as análises univariadas e bivariadas. Outrossim, para corroborar com as análises dos testes das hipóteses de pesquisa já testadas e analisadas anteriormente.

É importante ressaltar que foi testado também se há colinearidade entre as variáveis da pesquisa. Assim, utilizou-se o método Variance Inflation Factor (VIF) para cada variável utilizada nos modelos. Os valores de VIF foram de 1.16 a 2.87, com VIF médio de 1.77. De 
acordo com Gujarati (2006), são considerados livres de multicolinearidades, VIFs abaixo de 5. Portanto, o fator multicolinearidade não representa um fator de risco que possa causar problemas aos achados desta pesquisa. Corroboram-se aos resultados deste teste os achados das análises anteriores - bivariadas, em específico, os testes de correlação pairwise das variáveis de pesquisa, em que também praticamente não foi encontrada forte relação e altos níveis de significâncias estatísticas entre as variáveis da presente pesquisa.

Por fim, processam-se os modelos das regressões para testar as hipóteses da pesquisa. Evidencia-se a seguir os modelos utilizados para as análises de regressões multivariadas. Vale citar ainda que todos os modelos, a seguir apresentados, foram duplamente regredidos visando à robustez da pesquisa por duas técnicas estatísticas distintas de regressão, a saber: regressões por MQO (mínimos quadrados ordinários com erros-padrão robustos - estimação dos parâmetros por Hubber-White Sandwich) e regressões utilizando a técnica estatística de resampling Bootstrap, que enrobustece também a estimação dos parâmetros das regressões, conforme já abordado anteriormente.

Referente à construção dos modelos de regressão, a seguir evidenciados, salienta-se que foram baseados na literatura apresentada na fundamentação teórica própria. Reporta-se ainda que a variável propriedade concentrada, que tem três classificações quanto ao grau de propriedade, e também tem um teste de robustez com outras três classificações, foi definido um modelo para cada classificação de grau de propriedade para a mitigação de problema de multicolinearidade.

Outrossim, aborda-se que, para responder às hipóteses de pesquisa, foram estabelecidos modelos específicos para empresas familiares, inserindo variáveis como primeira e segunda gerações familiares e família na administração.

Evidencia-se também o modelo 13, que insere a variável stake dos controladores (empresa familiar e não familiar), para a verificação da relação da variável nível de propriedade acionária como um todo, ou seja, não estratificada por grau de concentração acionária. Por motivos de mitigação de multicolinearidade, também foi definido um modelo de regressão para a variável mencionada. Apenas se informa que o modelo 13 não é reportado para as regressões das variáveis de robustez de concentração de propriedade acionária, pois os resultados encontrados são idênticos aos da regressão com as variáveis originais, de classificação de concentração de propriedade acionária. 
Por fim, salienta-se ainda que foram estabelecidos modelos distintos para determinadas variáveis de controles que evidenciaram importância tanto na literatura, abordada propriamente na fundamentação teórica, quanto na análise estatística, trazendo melhor especificação e maior poder de explicação aos modelos de regressão, a saber: i) Poder dos controladores no conselho; ii) Índice de stake dos controladores / stake dos demais Blockholders; e iii) Índice de remuneração variável e por ações / remuneração total.

Informa-se ainda que essas variáveis de controles supracitadas foram inseridas em modelos distintos, para melhor visualização de seus resultados e, sobretudo, para mitigar possíveis problemas de análises das regressões, devido aos missings values, pois com este procedimento de definição, de distintos modelos de regressão com a inclusão de variáveis, permite-se observar, em especial, os resultados obtidos sobre diferentes modelos e visualização da melhoria do poder explicativo da regressão, medido pelo coeficiente de determinação do modelo $\left(\mathrm{R}^{\wedge} 2\right)$.

Dessa forma, resultaram-se em 13 modelos utilizados nesta pesquisa, nas regressões multivariadas. É relevante a observação de que para esses 13 modelos citados, também foram regredidos testando-se as variáveis específicas para as empresas familiares, e não obstante ainda, do teste de robustez de retorno de mercado - IBRX50, do teste de robustez da classificação do grau de propriedade concentrada dos acionistas controladores, e dos testes estatísticos MQO com erros-padrão robusto e Bootstrap. Em resumo, para os 13 modelos foram ainda realizados os seguintes testes:

Benchmark do retorno de Mercado, utilizado para todos os 13 modelos evidenciados a seguir: Ibovespa e IBRX50;

Métodos e técnicas estatíscas, utilizadas para todos os 13 modelos evidenciados a seguir: MQO com erros-padrão robusto $e$ Bootstrap;

Teste de classificação de grau de concentração acionária do acionista controlador: teste original conforme legislação societária vigente e teste de robustez;

Geral e específico, em que o geral é para todas as empresas, e o denominado específico, são variáveis utilizadas somente para empresas familiares, conforme explicado anteriormente. Assim, evidenciam-se os 13 modelos utilizados: 


\subsubsection{Modelos Gerais - Regressão com todas as empresas (com teste de robustez para grau de concentração acionária, benchmark de retorno de mercado e técnicas de análises estatísticas mencionadas anteriormente).}

Modelo 1 - Conta com as variáveis explicativas Empresas Familiares, Propriedade Concentrada Superior a 50\% (ou seu teste de robustez correspondente) e variáveis de controle, regressadas sobre as variáveis dependentes CAR (cumulative abnormal return - 1 , 3, 11 e 21 dias de janelas de eventos);

Modelo de regressão múltipla 1 - Modelo Geral:

$\operatorname{CAR}\left(J_{1} ; J_{2}\right) i=\alpha i+\beta_{1}$ (Empresas Familiares) $i+\beta_{2}$ (Propriedade Familiar $>50 \%$ ou seu teste de robustez correspondente $) i+\beta_{3}(Q$ de Tobin $) i+\beta_{4}($ Indústria $) i+\beta_{5}($ Idade $) i+\beta_{6}$ $($ Tamanho $) i+\beta_{7}$ (Investidores Institucionais $) i+\beta_{8}($ Alavancagem Financeira $) i+\beta_{9}($ Folga Financeira $) i$ $+\beta_{10}(\operatorname{LN}($ CAPEX $)) i+\beta_{11}($ Novo Mercado e Nível 2$) i+\beta_{12}$ (Adquirente Serial) $i+\beta_{13}$ (Aquisição Internacional) $i+\varepsilon i$

Onde:

$C A R\left(J_{1} ; J_{2}\right) i$ é o retorno anormal acumulado de determinada janela de evento $(1,3,11$ e 21 dias) e janela de estimação [-210;-31] $\left(J_{1}\right)$, em que este último é único para todos os CARs analisados, por isso não foi evidenciado; e Benchmark de retorno de mercado $\left(J_{2}\right)$, de determinado evento $(i)$ em aquisição de empresas familiares e não familiares da amostra da pesquisa;

$\alpha i$ é o intercepto da regressão de determinado evento $(i)$ em aquisição de empresas familiares e não familiares da amostra da pesquisa;

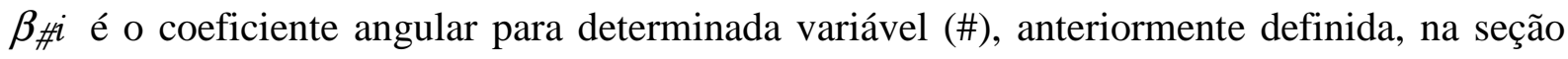
variáveis de determinado evento $(i)$ em aquisição de empresas familiares e não familiares da amostra da pesquisa; 
$\varepsilon i$ é o termo de erro aleatório para um determinado evento $(i)$ em aquisição de empresas familiares e não familiares da amostra da pesquisa.

Modelo 2 - Conta com as variáveis explicativas Empresas Familiares, Propriedade Concentrada Superior a 50\% (ou seu teste de robustez correspondente), Poder dos Controladores no Conselho e variáveis de controle, regressadas sobre as variáveis dependentes CAR (cumulative abnormal return - 1, 3, 11 e 21 dias de janelas de eventos);

Modelo de regressão múltipla 2 - Modelo Geral:

$\operatorname{CAR}\left(J_{1} ; J_{2}\right) i=\alpha i+\beta_{1}$ (Empresas Familiares) $i+\beta_{2}$ (Propriedade Familiar $>50 \%$ ou seu teste de robustez correspondente $) i+\beta_{3}$ (Poder dos Controladores no Conselho) $i+\beta_{4}(Q$ de Tobin $) i+\beta_{5}($ Indústria $) i+\beta_{6}($ Idade $) i+\beta_{7}($ Tamanho $) i+\beta_{8}($ Investidores Institucionais $) i+\beta_{9}$ $($ Alavancagem Financeira $) i+\beta_{10}($ Folga Financeira $) i+\beta_{11}(L N(C A P E X)) i+\beta_{12}$ (Novo Mercado e Nível 2) $i+\beta_{13}($ Adquirente Serial $) i+\beta_{14}($ Aquisição Internacional $) i+\varepsilon i$

Onde:

$C A R\left(J_{1} ; J_{2}\right) i$ é o retorno anormal acumulado de determinada janela de evento $(1,3,11$ e 21 dias) e janela de estimação [-210;-31] $\left(J_{1}\right)$, em que este último é único para todos os CARs analisados, por isso não foi evidenciado; e Benchmark de retorno de mercado $\left(J_{2}\right)$, de determinado evento $(i)$ em aquisição de empresas familiares e não familiares da amostra da pesquisa;

$\alpha i$ é o intercepto da regressão de determinado evento $(i)$ em aquisição de empresas familiares e não familiares da amostra da pesquisa;

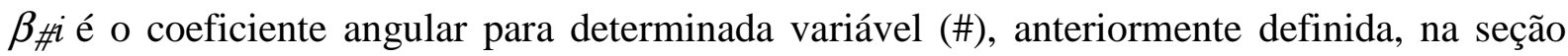
variáveis de determinado evento $(i)$ em aquisição de empresas familiares e não familiares da amostra da pesquisa;

$\varepsilon i$ é o termo de erro aleatório para um determinado evento ( $i$ ) em aquisição de empresas familiares e não familiares da amostra da pesquisa. 
Modelo 3 - Conta com as variáveis explicativas Empresas Familiares, Propriedade Concentrada Superior a $50 \%$ (ou seu teste de robustez correspondente), Poder dos Controladores no Conselho, Índice de Stake dos Controladores / demais Blockholders e variáveis de controle, regressadas sobre as variáveis dependentes CAR (cumulative abnormal return - 1, 3, 11 e 21 dias de janelas de eventos);

Modelo de regressão múltipla 3 - Modelo Geral:

$\operatorname{CAR}\left(J_{1} ; J_{2}\right) i=\alpha i+\beta_{1}$ (Empresas Familiares) $i+\beta_{2}$ (Propriedade Familiar $>50 \%$ ou seu teste de robustez correspondente) $i+\beta_{3}$ (Poder dos Controladores no Conselho) $i+\beta_{4}$ (Índice de Stake dos Controladores / demais Blockholders $) i+\beta_{5}(Q$ de Tobin $) i+\beta_{6}($ Indústria $) i+\beta_{7}$ $($ Idade $) i+\beta_{8}($ Tamanho $) i+\beta_{9}($ Investidores Institucionais $) i+\beta_{10}($ Alavancagem Financeira $) i+\beta_{11}$ $($ Folga Financeira $) i+\beta_{12}(L N(C A P E X)) i+\beta_{13}($ Novo Mercado e Nível 2$) i+\beta_{14}$ (Adquirente Serial) $i+$ $\beta_{15}$ (Aquisição Internacional) $i+\varepsilon i$

Onde:

$C A R\left(J_{1} ; J_{2}\right) i$ é o retorno anormal acumulado de determinada janela de evento $(1,3,11$ e 21 dias) e janela de estimação [-210;-31] $\left(J_{1}\right)$, em que este último é único para todos os CARs analisados, por isso não foi evidenciado; e Benchmark de retorno de mercado $\left(J_{2}\right)$, de determinado evento $(i)$ em aquisição de empresas familiares e não familiares da amostra da pesquisa;

$\alpha i$ é o intercepto da regressão de determinado evento $(i)$ em aquisição de empresas familiares e não familiares da amostra da pesquisa;

$\beta \# i$ é o coeficiente angular para determinada variável (\#), anteriormente definida, na seção variáveis de determinado evento $(i)$ em aquisição de empresas familiares e não familiares da amostra da pesquisa;

Ei é o termo de erro aleatório para um determinado evento $(i)$ em aquisição de empresas familiares e não familiares da amostra da pesquisa. 
Modelo 4 - Conta com as variáveis explicativas Empresas Familiares, Propriedade Concentrada Superior a $50 \%$ (ou seu teste de robustez correspondente), Poder dos Controladores no Conselho, Índice de Stake dos Controladores / demais Blockholders, Índice de remuneração variável e por ações / remuneração Total e variáveis de controle, regressadas sobre as variáveis dependentes CAR (cumulative abnormal return - 1, 3, 11 e 21 dias de janelas de eventos);

Modelo de regressão múltipla 4 - Modelo Geral:

$\operatorname{CAR}\left(J_{1} ; J_{2}\right) i=\alpha i+\beta_{1}$ (Empresas Familiares) $i+\beta_{2}$ (Propriedade Familiar $>50 \%$ ou seu teste de robustez correspondente) $i+\beta_{3}$ (Poder dos Controladores no Conselho) $i+\beta_{4}$ (Índice de Stake dos Controladores / demais Blockholders) $i+\beta_{5}$ (Índice de remuneração variável e por ações / remuneração Total $) i+\beta_{6}(Q$ de Tobin $) i+\beta_{7}($ Indústria $) i+\beta_{8}($ Idade $) i+\beta_{9}($ Tamanho $) i+\beta_{10}$ (Investidores Institucionais) $i+\beta_{11}$ (Alavancagem Financeira) $i+\beta_{12}$ (Folga Financeira) $i+\beta_{13}$ $(L N(C A P E X)) i+\beta_{14}($ Novo Mercado e Nível 2$) i+\beta_{15}$ (Adquirente Serial) $i+\beta_{16}$ (Aquisição Internacional $) i+\varepsilon i$

Onde:

$C A R\left(J_{1} ; J_{2}\right) i$ é o retorno anormal acumulado de determinada janela de evento $(1,3,11$ e 21 dias) e janela de estimação [-210;-31] $\left(J_{1}\right)$, em que este último é único para todos os CARs analisados, por isso não foi evidenciado; e Benchmark de retorno de mercado $\left(J_{2}\right)$, de determinado evento $(i)$ em aquisição de empresas familiares e não familiares da amostra da pesquisa;

$\alpha i$ é o intercepto da regressão de determinado evento $(i)$ em aquisição de empresas familiares e não familiares da amostra da pesquisa;

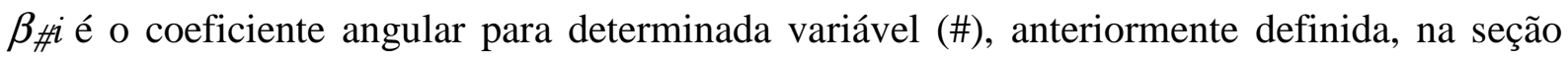
variáveis de determinado evento $(i)$ em aquisição de empresas familiares e não familiares da amostra da pesquisa;

$\varepsilon i$ é o termo de erro aleatório para um determinado evento $(i)$ em aquisição de empresas familiares e não familiares da amostra da pesquisa. 
Modelo 5 - Conta com as variáveis explicativas Empresas Familiares, Propriedade Concentrada Superior a $20 \%$ (ou seu teste de robustez correspondente) e variáveis de controle, regressadas sobre as variáveis dependentes CAR (cumulative abnormal return - 1 , 3, 11 e 21 dias de janelas de eventos);

Modelo de regressão múltipla 5 - Modelo Geral:

$\operatorname{CAR}\left(J_{1} ; J_{2}\right) i=\alpha i+\beta_{1}($ Empresas Familiares $) i+\beta_{2}$ (Propriedade Familiar $>20 \%$ ou seu teste de robustez correspondente $) i+\beta_{3}(Q$ de Tobin $) i+\beta_{4}($ Indústria $) i+\beta_{5}($ Idade $) i+\beta_{6}$ $($ Tamanho $) i+\beta_{7}($ Investidores Institucionais $) i+\beta_{8}($ Alavancagem Financeira $) i+\beta_{9}($ Folga Financeira $) i$ $+\beta_{10}(\operatorname{LN}($ CAPEX $)) i+\beta_{11}($ Novo Mercado e Nível 2$) i+\beta_{12}($ Adquirente Serial $) i+\beta_{13}$ (Aquisição Internacional $) i+\varepsilon i$

Onde:

$C A R\left(J_{1} ; J_{2}\right) i$ é o retorno anormal acumulado de determinada janela de evento $(1,3,11$ e 21 dias) e janela de estimação [-210;-31] $\left(J_{1}\right)$, em que este último é único para todos os CARs analisados, por isso não foi evidenciado; e Benchmark de retorno de mercado $\left(J_{2}\right)$, de determinado evento $(i)$ em aquisição de empresas familiares e não familiares da amostra da pesquisa;

$\alpha i$ é o intercepto da regressão de determinado evento $(i)$ em aquisição de empresas familiares e não familiares da amostra da pesquisa;

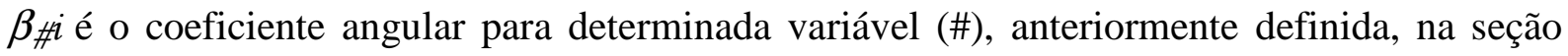
variáveis de determinado evento $(i)$ em aquisição de empresas familiares e não familiares da amostra da pesquisa;

$\varepsilon i$ é o termo de erro aleatório para um determinado evento $(i)$ em aquisição de empresas familiares e não familiares da amostra da pesquisa. 
Modelo 6 - Conta com as variáveis explicativas Empresas Familiares, Propriedade Concentrada Superior a $20 \%$ (ou seu teste de robustez correspondente), Poder dos Controladores no Conselho e variáveis de controle, regressadas sobre as variáveis dependentes CAR (cumulative abnormal return - 1, 3, 11 e 21 dias de janelas de eventos);

Modelo de regressão múltipla 6 - Modelo Geral:

$\operatorname{CAR}\left(J_{1} ; J_{2}\right) i=\alpha i+\beta_{1}$ (Empresas Familiares) $i+\beta_{2}$ (Propriedade Familiar $>20 \%$ ou seu teste de robustez correspondente $) i+\beta_{3}($ Poder dos Controladores no Conselho $) i+\beta_{4}(Q$ de Tobin $) i+\beta_{5}($ Indústria $) i+\beta_{6}($ Idade $) i+\beta_{7}($ Tamanho $) i+\beta_{8}($ Investidores Institucionais $) i+\beta_{9}$ $($ Alavancagem Financeira $) i+\beta_{10}($ Folga Financeira $) i+\beta_{11}(L N(C A P E X)) i+\beta_{12}($ Novo Mercado e Nível $2) i+\beta_{13}($ Adquirente Serial $) i+\beta_{14}$ (Aquisição Internacional $) i+\varepsilon i$

Onde:

$C A R\left(J_{1} ; J_{2}\right) i$ é o retorno anormal acumulado de determinada janela de evento $(1,3,11$ e 21 dias) e janela de estimação [-210;-31] $\left(J_{1}\right)$, em que este último é único para todos os CARs analisados, por isso não foi evidenciado; e Benchmark de retorno de mercado $\left(J_{2}\right)$, de determinado evento $(i)$ em aquisição de empresas familiares e não familiares da amostra da pesquisa;

$\alpha i$ é o intercepto da regressão de determinado evento $(i)$ em aquisição de empresas familiares e não familiares da amostra da pesquisa;

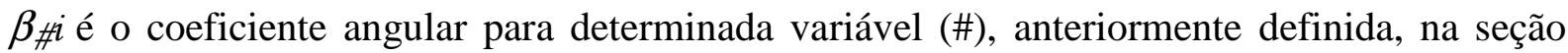
variáveis de determinado evento $(i)$ em aquisição de empresas familiares e não familiares da amostra da pesquisa;

Ei é o termo de erro aleatório para um determinado evento ( $i$ ) em aquisição de empresas familiares e não familiares da amostra da pesquisa. 
Modelo 7 - Conta com as variáveis explicativas Empresas Familiares, Propriedade Concentrada Superior a $20 \%$ (ou seu teste de robustez correspondente), Poder dos Controladores no Conselho, Índice de Stake dos Controladores / demais Blockholders e variáveis de controle, regressadas sobre as variáveis dependentes CAR (cumulative abnormal return - 1, 3, 11 e 21 dias de janelas de eventos);

Modelo de regressão múltipla 7 - Modelo Geral:

$\operatorname{CAR}\left(J_{1} ; J_{2}\right) i=\alpha i+\beta_{1}$ (Empresas Familiares $) i+\beta_{2}$ (Propriedade Familiar $>20 \%$ ou seu teste de robustez correspondente) $i+\beta_{3}$ (Poder dos Controladores no Conselho) $i+\beta_{4}$ (Índice de Stake dos Controladores / demais Blockholders $) i+\beta_{5}(Q$ de Tobin $) i+\beta_{6}($ Indústria $) i+\beta_{7}$ $($ Idade $) i+\beta_{8}($ Tamanho $) i+\beta_{9}($ Investidores Institucionais $) i+\beta_{10}($ Alavancagem Financeira $) i+\beta_{11}$ $($ Folga Financeira $) i+\beta_{12}(\operatorname{LN}($ CAPEX $)) i+\beta_{13}($ Novo Mercado e Nível 2$) i+\beta_{14}($ Adquirente Serial $) i+$ $\beta_{15}$ (Aquisição Internacional) $i+\varepsilon i$

Onde:

$\operatorname{CAR}\left(J_{1} ; J_{2}\right) i$ é o retorno anormal acumulado de determinada janela de evento $(1,3,11$ e 21 dias) e janela de estimação [-210;-31] $\left(J_{1}\right)$, em que este último é único para todos os CARs analisados, por isso não foi evidenciado; e Benchmark de retorno de mercado $\left(J_{2}\right)$, de determinado evento $(i)$ em aquisição de empresas familiares e não familiares da amostra da pesquisa;

$\alpha i$ é o intercepto da regressão de determinado evento ( $i$ ) em aquisição de empresas familiares e não familiares da amostra da pesquisa;

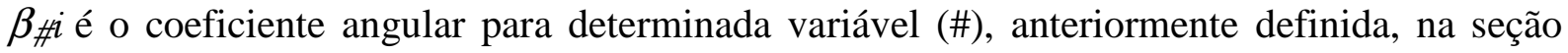
variáveis de determinado evento $(i)$ em aquisição de empresas familiares e não familiares da amostra da pesquisa;

$\varepsilon i$ é o termo de erro aleatório para um determinado evento ( $i$ ) em aquisição de empresas familiares e não familiares da amostra da pesquisa. 
Modelo 8 - Conta com as variáveis explicativas Empresas Familiares, Propriedade Concentrada Superior a $20 \%$ (ou seu teste de robustez correspondente), Poder dos Controladores no Conselho, Índice de Stake dos Controladores / demais Blockholders, Índice de remuneração variável e por ações / remuneração Total e variáveis de controle, regressadas sobre as variáveis dependentes CAR (cumulative abnormal return - 1, 3, 11 e 21 dias de janelas de eventos);

Modelo de regressão múltipla 8 - Modelo Geral:

$\operatorname{CAR}\left(J_{1} ; J_{2}\right) i=\alpha i+\beta_{1}$ (Empresas Familiares) $i+\beta_{2}$ (Propriedade Familiar $>20 \%$ ou seu teste de robustez correspondente) $i+\beta_{3}$ (Poder dos Controladores no Conselho) $i+\beta_{4}$ (Índice de Stake dos Controladores / demais Blockholders) $i+\beta_{5}$ (Índice de remuneração variável e por ações / remuneração Total $) i+\beta_{6}(Q$ de Tobin $) i+\beta_{7}($ Indústria $) i+\beta_{8}($ Idade $) i+\beta_{9}($ Tamanho $) i+\beta_{10}$ (Investidores Institucionais) $i+\beta_{11}$ (Alavancagem Financeira) $i+\beta_{12}$ (Folga Financeira) $i+\beta_{13}$ $(L N(C A P E X)) i+\beta_{14}($ Novo Mercado e Nível 2$) i+\beta_{15}$ (Adquirente Serial) $i+\beta_{16}$ (Aquisição Internacional $) i+\varepsilon i$

Onde:

$C A R\left(J_{1} ; J_{2}\right) i$ é o retorno anormal acumulado de determinada janela de evento $(1,3,11$ e 21 dias) e janela de estimação [-210;-31] $\left(J_{1}\right)$, em que este último é único para todos os CARs analisados, por isso não foi evidenciado; e Benchmark de retorno de mercado $\left(J_{2}\right)$, de determinado evento $(i)$ em aquisição de empresas familiares e não familiares da amostra da pesquisa;

$\alpha i$ é o intercepto da regressão de determinado evento $(i)$ em aquisição de empresas familiares e não familiares da amostra da pesquisa;

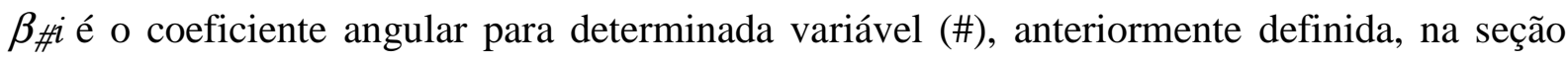
variáveis de determinado evento $(i)$ em aquisição de empresas familiares e não familiares da amostra da pesquisa;

$\varepsilon i$ é o termo de erro aleatório para um determinado evento ( $i$ ) em aquisição de empresas familiares e não familiares da amostra da pesquisa. 
Modelo 9 - Conta com as variáveis explicativas Empresas Familiares, Propriedade Concentrada Superior a $10 \%$ (ou seu teste de robustez correspondente) e variáveis de controle, regressadas sobre as variáveis dependentes CAR (cumulative abnormal return - 1 , 3, 11 e 21 dias de janelas de eventos);

Modelo de regressão múltipla 9 - Modelo Geral:

$\operatorname{CAR}\left(J_{1} ; J_{2}\right) i=\alpha i+\beta_{1}$ (Empresas Familiares) $i+\beta_{2}$ (Propriedade Familiar $>10 \%$ ou seu teste de robustez correspondente $) i+\beta_{3}(Q$ de Tobin $) i+\beta_{4}($ Indústria $) i+\beta_{5}($ Idade $) i+\beta_{6}$

$($ Tamanho $) i+\beta_{7}($ Investidores Institucionais $) i+\beta_{8}($ Alavancagem Financeira $) i+\beta_{9}($ Folga Financeira $) i$ $+\beta_{10}(\operatorname{LN}($ CAPEX $)) i+\beta_{11}($ Novo Mercado e Nível 2$) i+\beta_{12}($ Adquirente Serial $) i+\beta_{13}$ (Aquisição Internacional $) i+\varepsilon i$

Onde:

$C A R\left(J_{1} ; J_{2}\right) i$ é o retorno anormal acumulado de determinada janela de evento $(1,3,11$ e 21 dias) e janela de estimação [-210;-31] $\left(J_{1}\right)$, em que este último é único para todos os CARs analisados, por isso não foi evidenciado; e Benchmark de retorno de mercado $\left(J_{2}\right)$, de determinado evento $(i)$ em aquisição de empresas familiares e não familiares da amostra da pesquisa;

$\alpha i$ é o intercepto da regressão de determinado evento ( $i$ ) em aquisição de empresas familiares e não familiares da amostra da pesquisa;

$\beta_{\# i}$ é o coeficiente angular para determinada variável (\#), anteriormente definida, na seção variáveis de determinado evento $(i)$ em aquisição de empresas familiares e não familiares da amostra da pesquisa;

$\varepsilon i$ é o termo de erro aleatório para um determinado evento $(i)$ em aquisição de empresas familiares e não familiares da amostra da pesquisa. 
Modelo 10 - Conta com as variáveis explicativas Empresas Familiares, Propriedade Concentrada Superior a $10 \%$ (ou seu teste de robustez correspondente), Poder dos Controladores no Conselho e variáveis de controle, regressadas sobre as variáveis dependentes CAR (cumulative abnormal return - 1, 3, 11 e 21 dias de janelas de eventos);

Modelo de regressão múltipla 10 - Modelo Geral:

$\operatorname{CAR}\left(J_{1} ; J_{2}\right) i=\alpha i+\beta_{1}$ (Empresas Familiares) $i+\beta_{2}$ (Propriedade Familiar $>10 \%$ ou seu teste de robustez correspondente $) i+\beta_{3}$ (Poder dos Controladores no Conselho $) i+\beta_{4}(Q$ de Tobin $) i+\beta_{5}($ Indústria $) i+\beta_{6}($ Idade $) i+\beta_{7}($ Tamanho $) i+\beta_{8}($ Investidores Institucionais $) i+\beta_{9}$ $($ Alavancagem Financeira $) i+\beta_{10}($ Folga Financeira $) i+\beta_{11}(L N(C A P E X)) i+\beta_{12}($ Novo Mercado e Nível $2) i+\beta_{13}($ Adquirente Serial $) i+\beta_{14}$ (Aquisição Internacional $) i+\varepsilon i$

Onde:

$C A R\left(J_{1} ; J_{2}\right) i$ é o retorno anormal acumulado de determinada janela de evento $(1,3,11$ e 21 dias) e janela de estimação [-210;-31] $\left(J_{1}\right)$, em que este último é único para todos os CARs analisados, por isso não foi evidenciado; e Benchmark de retorno de mercado $\left(J_{2}\right)$, de determinado evento $(i)$ em aquisição de empresas familiares e não familiares da amostra da pesquisa;

$\alpha i$ é o intercepto da regressão de determinado evento $(i)$ em aquisição de empresas familiares e não familiares da amostra da pesquisa;

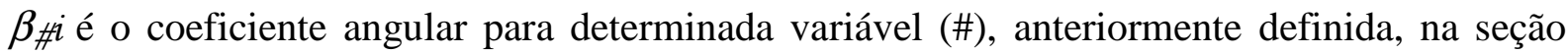
variáveis de determinado evento $(i)$ em aquisição de empresas familiares e não familiares da amostra da pesquisa;

Ei é o termo de erro aleatório para um determinado evento ( $i$ ) em aquisição de empresas familiares e não familiares da amostra da pesquisa. 
Modelo 11 - Conta com as variáveis explicativas Empresas Familiares, Propriedade Concentrada Superior a $10 \%$ (ou seu teste de robustez correspondente), Poder dos Controladores no Conselho, Índice de Stake dos Controladores / demais Blockholders e variáveis de controle, regressadas sobre as variáveis dependentes CAR (cumulative abnormal return - 1, 3, 11 e 21 dias de janelas de eventos);

Modelo de regressão múltipla 11 - Modelo Geral:

$\operatorname{CAR}\left(J_{1} ; J_{2}\right) i=\alpha i+\beta_{1}$ (Empresas Familiares) $i+\beta_{2}$ (Propriedade Familiar $>10 \%$ ou seu teste de robustez correspondente) $i+\beta_{3}$ (Poder dos Controladores no Conselho) $i+\beta_{4}$ (Índice de Stake dos Controladores / demais Blockholders $) i+\beta_{5}(Q$ de Tobin $) i+\beta_{6}($ Indústria $) i+\beta_{7}$ $($ Idade $) i+\beta_{8}($ Tamanho $) i+\beta_{9}($ Investidores Institucionais $) i+\beta_{10}($ Alavancagem Financeira $) i+\beta_{11}$ $($ Folga Financeira $) i+\beta_{12}(\operatorname{LN}($ CAPEX $)) i+\beta_{13}($ Novo Mercado e Nível 2$) i+\beta_{14}($ Adquirente Serial $) i+$ $\beta_{15}$ (Aquisição Internacional) $i+\varepsilon i$

Onde:

$C A R\left(J_{1} ; J_{2}\right) i$ é o retorno anormal acumulado de determinada janela de evento $(1,3,11$ e 21 dias) e janela de estimação [-210;-31] $\left(J_{1}\right)$, em que este último é único para todos os CARs analisados, por isso não foi evidenciado; e Benchmark de retorno de mercado $\left(J_{2}\right)$, de determinado evento $(i)$ em aquisição de empresas familiares e não familiares da amostra da pesquisa;

$\alpha i$ é o intercepto da regressão de determinado evento $(i)$ em aquisição de empresas familiares e não familiares da amostra da pesquisa;

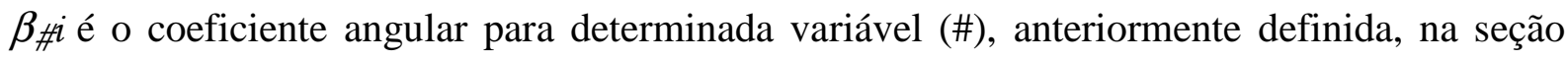
variáveis de determinado evento $(i)$ em aquisição de empresas familiares e não familiares da amostra da pesquisa;

Ei é o termo de erro aleatório para um determinado evento $(i)$ em aquisição de empresas familiares e não familiares da amostra da pesquisa. 
Modelo 12 - Conta com as variáveis explicativas Empresas Familiares, Propriedade Concentrada Superior a $10 \%$ (ou seu teste de robustez correspondente), Poder dos Controladores no Conselho, Índice de Stake dos Controladores / demais Blockholders, Índice de remuneração variável e por ações / remuneração Total e variáveis de controle, regressadas sobre as variáveis dependentes CAR (cumulative abnormal return - 1, 3, 11 e 21 dias de janelas de eventos);

Modelo de regressão múltipla 12 - Modelo Geral:

$\operatorname{CAR}\left(J_{1} ; J_{2}\right) i=\alpha i+\beta_{1}($ Empresas Familiares $) i+\beta_{2}$ (Propriedade Familiar $>10 \%$ ou seu teste de robustez correspondente) $i+\beta_{3}\left(\right.$ Poder dos Controladores no Conselho) $i+\beta_{4}$ (Índice de Stake dos Controladores / demais Blockholders) $i+\beta_{5}$ (Índice de remuneração variável e por ações / remuneração Total $) i+\beta_{6}(Q$ de Tobin $) i+\beta_{7}($ Indústria $) i+\beta_{8}($ Idade $) i+\beta_{9}($ Tamanho $) i+\beta_{10}$ (Investidores Institucionais) $i+\beta_{11}$ (Alavancagem Financeira) $i+\beta_{12}$ (Folga Financeira) $i+\beta_{13}$ $(L N(C A P E X)) i+\beta_{14}($ Novo Mercado e Nível 2$) i+\beta_{15}$ (Adquirente Serial) $i+\beta_{16}$ (Aquisição Internacional $) i+\varepsilon i$

Onde:

$C A R\left(J_{1} ; J_{2}\right) i$ é o retorno anormal acumulado de determinada janela de evento $(1,3,11$ e 21 dias) e janela de estimação [-210;-31] $\left(J_{1}\right)$, em que este último é único para todos os CARs analisados, por isso não foi evidenciado; e Benchmark de retorno de mercado $\left(J_{2}\right)$, de determinado evento $(i)$ em aquisição de empresas familiares e não familiares da amostra da pesquisa;

$\alpha i$ é o intercepto da regressão de determinado evento $(i)$ em aquisição de empresas familiares e não familiares da amostra da pesquisa;

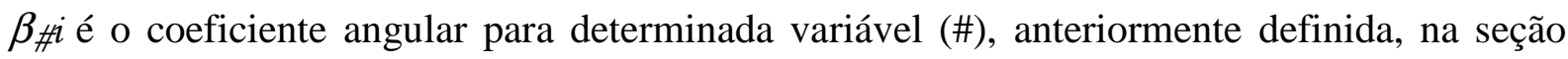
variáveis de determinado evento $(i)$ em aquisição de empresas familiares e não familiares da amostra da pesquisa;

$\varepsilon i$ é o termo de erro aleatório para um determinado evento ( $i$ ) em aquisição de empresas familiares e não familiares da amostra da pesquisa. 
Modelo 13 - Conta com as variáveis explicativas Empresas Familiares, Stake dos Acionistas Controladores (empresa familiar ou não) e variáveis de controle, regressadas sobre as variáveis dependentes CAR (cumulative abnormal return - 1, 3, 11 e 21 dias de janelas de eventos):

Modelo de regressão múltipla 13 - Modelo Geral:

$C A R\left(J_{1} ; J_{2}\right) i=\alpha i+\beta_{1}($ Empresas Familiares $) i+\beta_{2}($ stake dos acionistas controladores $) i+$ $\beta_{3}$ (Poder dos Controladores no Conselho)i $+\beta_{4}$ (Índice de Stake dos Controladores / demais Blockholders $) i+\beta_{5}$ (Índice de remuneração variável e por ações / remuneração Total $) i+\beta_{6}(Q$ de Tobin $) i$ $+\beta_{7}$ (Indústria) $i+\beta_{8}\left(\right.$ Idade) $i+\beta_{9}$ (Tamanho $) i+\beta_{10}$ (Investidores Institucionais) $i+\beta_{11}$ (Alavancagem Financeira) $i+\beta_{12}($ Folga Financeira $) i+\beta_{13}(L N(C A P E X)) i+\beta_{14}$ (Novo Mercado e Nível $2) i+\beta_{15}($ Adquirente Serial $) i+\beta_{16}($ Aquisição Internacional $) i+\varepsilon i$

Onde:

$C A R\left(J_{1} ; J_{2}\right) i$ é o retorno anormal acumulado de determinada janela de evento $(1,3,11$ e 21 dias) e janela de estimação [-210;-31] $\left(J_{1}\right)$, em que este último é único para todos os CARs analisados, por isso não foi evidenciado; e Benchmark de retorno de mercado $\left(J_{2}\right)$, de determinado evento $(i)$ em aquisição de empresas familiares e não familiares da amostra da pesquisa;

$\alpha i$ é o intercepto da regressão de determinado evento $(i)$ em aquisição de empresas familiares e não familiares da amostra da pesquisa;

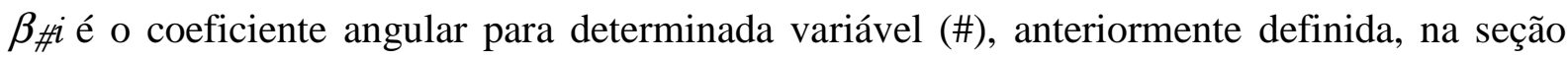
variáveis de determinado evento $(i)$ em aquisição de empresas familiares e não familiares da amostra da pesquisa;

$\varepsilon i$ é o termo de erro aleatório para um determinado evento ( $i$ ) em aquisição de empresas familiares e não familiares da amostra da pesquisa. 


\subsubsection{Modelos Específicos - Regressão apenas com empresas familiares para medir relação de variáveis específicas das empresas familiares (com teste de robustez para grau de concentração acionária, benchmark de retorno de mercado e técnicas de análises estatísticas mencionadas anteriormente).}

Modelo 1 - Conta com as variáveis explicativas Primeira e Segunda Gerações Familiares, Família na Administração, Propriedade Concentrada Superior a 50\% (ou seu teste de robustez correspondente) e variáveis de controle, regressadas sobre as variáveis dependentes CAR (cumulative abnormal return - 1, 3, 11 e 21 dias de janelas de eventos);

Modelo de regressão múltipla 14 - Modelo Específico:

$C A R\left(J_{1} ; J_{2}\right) i=\alpha i+\beta_{1}$ (Primeira e Segunda Gerações Familiares)i $+\beta_{2}$ (Família na Administração)i $+\beta_{3}$ (Propriedade Familiar $>50 \%$ ou seu teste de robustez correspondente) $i$ $+\beta_{4}(Q$ de Tobin $) i+\beta_{5}($ Indústria $) i+\beta_{6}($ Idade $) i+\beta_{7}$ (Tamanho $) i+\beta_{8}$ (Investidores Institucionais $) i+\beta_{9}($ Alavancagem Financeira $) i+\beta_{10}($ Folga Financeira $) i+\beta_{11}(L N($ CAPEX $)) i+\beta_{12}$ $($ Novo Mercado e Nível 2$) i+\beta_{13}($ Adquirente Serial $) i+\beta_{14}($ Aquisição Internacional $) i+\varepsilon i$

Onde:

$C A R\left(J_{1} ; J_{2}\right) i$ é o retorno anormal acumulado de determinada janela de evento $(1,3,11$ e 21 dias) e janela de estimação [-210;-31] $\left(J_{1}\right)$, em que este último é único para todos os $C A R s$ analisados, por isso não foi evidenciado; e Benchmark de retorno de mercado $\left(J_{2}\right)$, de determinado evento $(i)$ em aquisição de empresas familiares e não familiares da amostra da pesquisa;

$\alpha i$ é o intercepto da regressão de determinado evento $(i)$ em aquisição de empresas familiares e não familiares da amostra da pesquisa;

$\beta \# i$ é o coeficiente angular para determinada variável (\#), anteriormente definida, na seção variáveis de determinado evento $(i)$ em aquisição de empresas familiares e não familiares da amostra da pesquisa;

ci é o termo de erro aleatório para um determinado evento $(i)$ em aquisição de empresas familiares e não familiares da amostra da pesquisa. 
Modelo 2 - Conta com as variáveis explicativas Primeira e Segunda Gerações Familiares, Família na Administração, Propriedade Concentrada Superior a 50\% (ou seu teste de robustez correspondente), Poder dos Controladores no Conselho e variáveis de controle, regressadas sobre as variáveis dependentes CAR (cumulative abnormal return - 1, 3, 11 e 21 dias de janelas de eventos);

Modelo de regressão múltipla 15 - Modelo Específico:

$\operatorname{CAR}\left(J_{1} ; J_{2}\right) i=\alpha i+\beta_{1}$ (Primeira e Segunda Gerações Familiares) $i+\beta_{2}$ (Família na Administração)i $+\beta_{3}$ (Propriedade Familiar $>50 \%$ ou seu teste de robustez correspondente) $i$ $+\beta_{4}$ (Poder dos Controladores no Conselho $) i+\beta_{5}(Q$ de Tobin $) i+\beta_{6}($ Indústria $) i+\beta_{7}$ $($ Idade $) i+\beta_{8}($ Tamanho $) i+\beta_{9}($ Investidores Institucionais $) i+\beta_{10}($ Alavancagem Financeira $) i+\beta_{11}$ $($ Folga Financeira $) i+\beta_{12}(L N(C A P E X)) i+\beta_{13}($ Novo Mercado e Nível 2$) i+\beta_{14}$ (Adquirente Serial) $i+$ $\beta_{15}$ (Aquisição Internacional) $i+\varepsilon i$

Onde:

$C A R\left(J_{1} ; J_{2}\right) i$ é o retorno anormal acumulado de determinada janela de evento $(1,3,11$ e 21 dias) e janela de estimação [-210;-31] $\left(J_{1}\right)$, em que este último é único para todos os CARs analisados, por isso não foi evidenciado; e Benchmark de retorno de mercado $\left(J_{2}\right)$, de determinado evento $(i)$ em aquisição de empresas familiares e não familiares da amostra da pesquisa;

$\alpha i$ é o intercepto da regressão de determinado evento $(i)$ em aquisição de empresas familiares e não familiares da amostra da pesquisa;

$\beta \# i$ é o coeficiente angular para determinada variável (\#), anteriormente definida, na seção variáveis de determinado evento $(i)$ em aquisição de empresas familiares e não familiares da amostra da pesquisa;

Ei é o termo de erro aleatório para um determinado evento $(i)$ em aquisição de empresas familiares e não familiares da amostra da pesquisa. 
Modelo 3 - Conta com as variáveis explicativas Primeira e Segunda Gerações Familiares, Família na Administração, Propriedade Concentrada Superior a 50\% (ou seu teste de robustez correspondente), Poder dos Controladores no Conselho, Índice de Stake dos Controladores / demais Blockholders e variáveis de controle, regressadas sobre as variáveis dependentes CAR (cumulative abnormal return - 1, 3, 11 e 21 dias de janelas de eventos);

Modelo de regressão múltipla 16 - Modelo Específico:

$\operatorname{CAR}\left(J_{1} ; J_{2}\right) i=\alpha i+\beta_{1}$ (Primeira e Segunda Gerações Familiares) $i+\beta_{2}$ (Família na Administração)i $+\beta_{3}$ (Propriedade Familiar $>50 \%$ ou seu teste de robustez correspondente) $i$ $+\beta_{4}$ (Poder dos Controladores no Conselho)i $+\beta_{5}$ (Índice de Stake dos Controladores / demais Blockholders $) i+\beta_{6}(Q$ de Tobin $) i+\beta_{7}($ Indústria $) i+\beta_{8}($ Idade $) i+\beta_{9}($ Tamanho $) i+\beta_{10}$ (Investidores Institucionais) $i+\beta_{11}$ (Alavancagem Financeira) $i+\beta_{12}$ (Folga Financeira) $i+\beta_{13}$ $(\operatorname{LN}(C A P E X)) i+\beta_{14}($ Novo Mercado e Nível 2$) i+\beta_{15}$ (Adquirente Serial) $i+\beta_{16}$ (Aquisição Internacional $) i+\varepsilon i$

Onde:

$C A R\left(J_{1} ; J_{2}\right) i$ é o retorno anormal acumulado de determinada janela de evento $(1,3,11$ e 21 dias) e janela de estimação [-210;-31] $\left(J_{1}\right)$, em que este último é único para todos os CARs analisados, por isso não foi evidenciado; e Benchmark de retorno de mercado $\left(J_{2}\right)$, de determinado evento $(i)$ em aquisição de empresas familiares e não familiares da amostra da pesquisa;

$\alpha i$ é o intercepto da regressão de determinado evento $(i)$ em aquisição de empresas familiares e não familiares da amostra da pesquisa;

$\beta \not i$ é o coeficiente angular para determinada variável (\#), anteriormente definida, na seção variáveis de determinado evento $(i)$ em aquisição de empresas familiares e não familiares da amostra da pesquisa;

$\varepsilon i$ é o termo de erro aleatório para um determinado evento $(i)$ em aquisição de empresas familiares e não familiares da amostra da pesquisa. 
Modelo 4 - Conta com as variáveis explicativas Primeira e Segunda Gerações Familiares, Família na Administração, Propriedade Concentrada Superior a 50\% (ou seu teste de robustez correspondente), Poder dos Controladores no Conselho, Índice de Stake dos Controladores / demais Blockholders, Índice de remuneração variável e por ações / remuneração Total e variáveis de controle, regressadas sobre as variáveis dependentes CAR (cumulative abnormal return - 1, 3, 11 e 21 dias de janelas de eventos);

Modelo de regressão múltipla 17 - Modelo Específico:

$\operatorname{CAR}\left(J_{1} ; J_{2}\right) i=\alpha i+\beta_{1}$ (Primeira e Segunda Gerações Familiares) $i+\beta_{2}$ (Família na Administração) $i+\beta_{3}$ (Propriedade Familiar $>50 \%$ ou seu teste de robustez correspondente) $i$ $+\beta_{4}$ (Poder dos Controladores no Conselho)i $+\beta_{5}$ (Índice de Stake dos Controladores / demais Blockholders $) i+\beta_{6}($ Índice de remuneração variável e por ações / remuneração Total $) i+\beta_{7}(Q$ de Tobin $) i$ $+\beta_{8}($ Indústria $) i+\beta_{9}($ Idade $) i+\beta_{10}$ (Tamanho) $i+\beta_{11}$ (Investidores Institucionais) $i+\beta_{12}$ (Alavancagem Financeira) $i+\beta_{13}($ Folga Financeira $) i+\beta_{14}(L N(C A P E X)) i+\beta_{15}$ (Novo Mercado e Nível $2) i+\beta_{16}($ Adquirente Serial $) i+\beta_{17}($ Aquisição Internacional $) i+\varepsilon i$

Onde:

$C A R\left(J_{1} ; J_{2}\right) i$ é o retorno anormal acumulado de determinada janela de evento $(1,3,11$ e 21 dias) e janela de estimação [-210;-31] $\left(J_{1}\right)$, em que este último é único para todos os CARs analisados, por isso não foi evidenciado; e Benchmark de retorno de mercado $\left(J_{2}\right)$, de determinado evento $(i)$ em aquisição de empresas familiares e não familiares da amostra da pesquisa;

$\alpha i$ é o intercepto da regressão de determinado evento $(i)$ em aquisição de empresas familiares e não familiares da amostra da pesquisa;

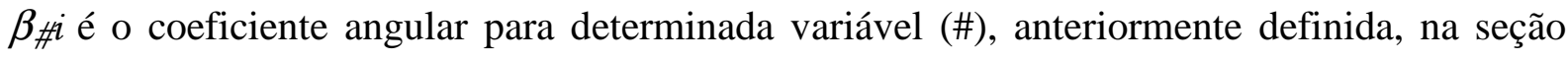
variáveis de determinado evento $(i)$ em aquisição de empresas familiares e não familiares da amostra da pesquisa;

$\varepsilon i$ é o termo de erro aleatório para um determinado evento ( $i$ ) em aquisição de empresas familiares e não familiares da amostra da pesquisa. 
Modelo 5 - Conta com as variáveis explicativas Primeira e Segunda Gerações Familiares, Família na Administração, Propriedade Concentrada Superior a 20\% (ou seu teste de robustez correspondente) e variáveis de controle, regressadas sobre as variáveis dependentes CAR (cumulative abnormal return - 1, 3, 11 e 21 dias de janelas de eventos);

Modelo de regressão múltipla 18 - Modelo Específico:

$\operatorname{CAR}\left(J_{1} ; J_{2}\right) i=\alpha i+\beta_{1}$ (Primeira e Segunda Gerações Familiares) $i+\beta_{2}$ (Família na Administração)i $+\beta_{3}$ (Propriedade Familiar $>20 \%$ ou seu teste de robustez correspondente) $i$ $+\beta_{4}(Q$ de Tobin $) i+\beta_{5}($ Indústria $) i+\beta_{6}($ Idade $) i+\beta_{7}($ Tamanho $) i+\beta_{8}$ (Investidores Institucionais $) i+\beta_{9}$ (Alavancagem Financeira $) i+\beta_{10}($ Folga Financeira $) i+\beta_{11}(L N(C A P E X)) i+\beta_{12}$ $($ Novo Mercado e Nível 2$) i+\beta_{13}($ Adquirente Serial $) i+\beta_{14}($ Aquisição Internacional $) i+\varepsilon i$

Onde:

$C A R\left(J_{1} ; J_{2}\right) i$ é o retorno anormal acumulado de determinada janela de evento $(1,3,11$ e 21 dias) e janela de estimação [-210;-31] $\left(J_{1}\right)$, em que este último é único para todos os CARs analisados, por isso não foi evidenciado; e Benchmark de retorno de mercado $\left(J_{2}\right)$, de determinado evento $(i)$ em aquisição de empresas familiares e não familiares da amostra da pesquisa;

$\alpha i$ é o intercepto da regressão de determinado evento $(i)$ em aquisição de empresas familiares e não familiares da amostra da pesquisa;

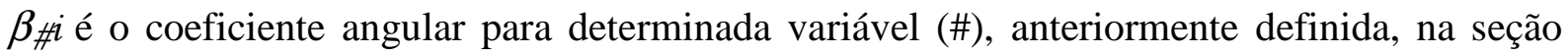
variáveis de determinado evento $(i)$ em aquisição de empresas familiares e não familiares da amostra da pesquisa;

$\varepsilon i$ é o termo de erro aleatório para um determinado evento $(i)$ em aquisição de empresas familiares e não familiares da amostra da pesquisa. 
Modelo 6 - Conta com as variáveis explicativas Primeira e Segunda Gerações Familiares, Família na Administração, Propriedade Concentrada Superior a 20\% (ou seu teste de robustez correspondente), Poder dos Controladores no Conselho e variáveis de controle, regressadas sobre as variáveis dependentes CAR (cumulative abnormal return - 1, 3, 11 e 21 dias de janelas de eventos);

Modelo de regressão múltipla 19 - Modelo Específico:

$\operatorname{CAR}\left(J_{1} ; J_{2}\right) i=\alpha i+\beta_{1}$ (Primeira e Segunda Gerações Familiares) $i+\beta_{2}$ (Família na Administração)i $+\beta_{3}$ (Propriedade Familiar $>20 \%$ ou seu teste de robustez correspondente) $i$ $+\beta_{4}($ Poder dos Controladores no Conselho $) i+\beta_{5}(Q$ de Tobin $) i+\beta_{6}($ Indústria $) i+\beta_{7}$ $($ Idade $) i+\beta_{8}($ Tamanho $) i+\beta_{9}($ Investidores Institucionais $) i+\beta_{10}($ Alavancagem Financeira $) i+\beta_{11}$ $($ Folga Financeira $) i+\beta_{12}(L N(C A P E X)) i+\beta_{13}($ Novo Mercado e Nível 2$) i+\beta_{14}$ (Adquirente Serial) $i+$ $\beta_{15}$ (Aquisição Internacional) $i+\varepsilon i$

Onde:

$C A R\left(J_{l} ; J_{2}\right) i$ é o retorno anormal acumulado de determinada janela de evento $(1,3,11$ e 21 dias) e janela de estimação [-210;-31] $\left(J_{1}\right)$, em que este último é único para todos os CARs analisados, por isso não foi evidenciado; e Benchmark de retorno de mercado $\left(J_{2}\right)$, de determinado evento $(i)$ em aquisição de empresas familiares e não familiares da amostra da pesquisa;

$\alpha i$ é o intercepto da regressão de determinado evento ( $i$ ) em aquisição de empresas familiares e não familiares da amostra da pesquisa;

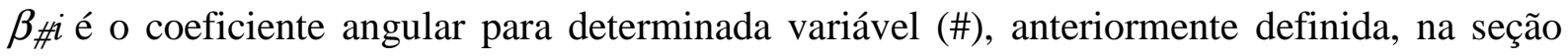
variáveis de determinado evento $(i)$ em aquisição de empresas familiares e não familiares da amostra da pesquisa;

Ei é o termo de erro aleatório para um determinado evento ( $i$ ) em aquisição de empresas familiares e não familiares da amostra da pesquisa. 
Modelo 7 - Conta com as variáveis explicativas Primeira e Segunda Gerações Familiares, Família na Administração, Propriedade Concentrada Superior a 20\% (ou seu teste de robustez correspondente), Poder dos Controladores no Conselho, Índice de Stake dos Controladores / demais Blockholders e variáveis de controle, regressadas sobre as variáveis dependentes CAR (cumulative abnormal return - 1, 3, 11 e 21 dias de janelas de eventos);

Modelo de regressão múltipla 20 - Modelo Específico:

$\operatorname{CAR}\left(J_{1} ; J_{2}\right) i=\alpha i+\beta_{1}$ (Primeira e Segunda Gerações Familiares) $i+\beta_{2}$ (Família na Administração)i $+\beta_{3}$ (Propriedade Familiar $>20 \%$ ou seu teste de robustez correspondente) $i$ $+\beta_{4}$ (Poder dos Controladores no Conselho)i $+\beta_{5}$ (Índice de Stake dos Controladores / demais Blockholders $) i+\beta_{6}(Q$ de Tobin $) i+\beta_{7}($ Indústria $) i+\beta_{8}($ Idade $) i+\beta_{9}($ Tamanho $) i+\beta_{10}$ (Investidores Institucionais) $i+\beta_{11}$ (Alavancagem Financeira) $i+\beta_{12}$ (Folga Financeira) $i+\beta_{13}$ $(\operatorname{LN}(C A P E X)) i+\beta_{14}($ Novo Mercado e Nível 2$) i+\beta_{15}$ (Adquirente Serial) $i+\beta_{16}$ (Aquisição Internacional $) i+\varepsilon i$

Onde:

$C A R\left(J_{1} ; J_{2}\right) i$ é o retorno anormal acumulado de determinada janela de evento $(1,3,11$ e 21 dias) e janela de estimação [-210;-31] $\left(J_{1}\right)$, em que este último é único para todos os CARs analisados, por isso não foi evidenciado; e Benchmark de retorno de mercado $\left(J_{2}\right)$, de determinado evento $(i)$ em aquisição de empresas familiares e não familiares da amostra da pesquisa;

$\alpha i$ é o intercepto da regressão de determinado evento $(i)$ em aquisição de empresas familiares e não familiares da amostra da pesquisa;

$\beta \not i$ é o coeficiente angular para determinada variável (\#), anteriormente definida, na seção variáveis de determinado evento $(i)$ em aquisição de empresas familiares e não familiares da amostra da pesquisa;

$\varepsilon i$ é o termo de erro aleatório para um determinado evento $(i)$ em aquisição de empresas familiares e não familiares da amostra da pesquisa. 
Modelo 8 - Conta com as variáveis explicativas Primeira e Segunda Gerações Familiares, Família na Administração, Propriedade Concentrada Superior a 20\% (ou seu teste de robustez correspondente), Poder dos Controladores no Conselho, Índice de Stake dos Controladores / demais Blockholders, Índice de remuneração variável e por ações / remuneração Total e variáveis de controle, regressadas sobre as variáveis dependentes CAR (cumulative abnormal return - 1, 3, 11 e 21 dias de janelas de eventos);

Modelo de regressão múltipla 21 - Modelo Específico:

$\operatorname{CAR}\left(J_{1} ; J_{2}\right) i=\alpha i+\beta_{1}$ (Primeira e Segunda Gerações Familiares) $i+\beta_{2}$ (Família na Administração) $i+\beta_{3}$ (Propriedade Familiar $>20 \%$ ou seu teste de robustez correspondente) $i$ $+\beta_{4}$ (Poder dos Controladores no Conselho)i $+\beta_{5}$ (Índice de Stake dos Controladores / demais Blockholders $) i+\beta_{6}($ Índice de remuneração variável e por ações / remuneração Total $) i+\beta_{7}(Q$ de Tobin $) i$ $+\beta_{8}($ Indústria $) i+\beta_{9}($ Idade $) i+\beta_{10}($ Tamanho $) i+\beta_{11}$ (Investidores Institucionais) $i+\beta_{12}$ (Alavancagem Financeira) $i+\beta_{13}($ Folga Financeira $) i+\beta_{14}(L N(C A P E X)) i+\beta_{15}$ (Novo Mercado e Nível $2) i+\beta_{16}($ Adquirente Serial $) i+\beta_{17}($ Aquisição Internacional $) i+\varepsilon i$

Onde:

$C A R\left(J_{1} ; J_{2}\right) i$ é o retorno anormal acumulado de determinada janela de evento $(1,3,11$ e 21 dias) e janela de estimação [-210;-31] $\left(J_{1}\right)$, em que este último é único para todos os CARs analisados, por isso não foi evidenciado; e Benchmark de retorno de mercado $\left(J_{2}\right)$, de determinado evento $(i)$ em aquisição de empresas familiares e não familiares da amostra da pesquisa;

$\alpha i$ é o intercepto da regressão de determinado evento $(i)$ em aquisição de empresas familiares e não familiares da amostra da pesquisa;

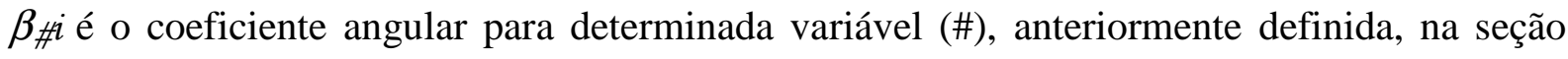
variáveis de determinado evento $(i)$ em aquisição de empresas familiares e não familiares da amostra da pesquisa;

Ei é o termo de erro aleatório para um determinado evento $(i)$ em aquisição de empresas familiares e não familiares da amostra da pesquisa. 
Modelo 9 - Conta com as variáveis explicativas Primeira e Segunda Gerações Familiares, Família na Administração, Propriedade Concentrada Superior a 10\% (ou seu teste de robustez correspondente) e variáveis de controle, regressadas sobre as variáveis dependentes CAR (cumulative abnormal return - 1, 3, 11 e 21 dias de janelas de eventos);

Modelo de regressão múltipla 22 - Modelo Específico:

$\operatorname{CAR}\left(J_{1} ; J_{2}\right) i=\alpha i+\beta_{1}$ (Primeira e Segunda Gerações Familiares) $i+\beta_{2}$ (Família na Administração)i $+\beta_{3}$ (Propriedade Familiar $>10 \%$ ou seu teste de robustez correspondente) $i$ $+\beta_{4}(Q$ de Tobin $) i+\beta_{5}($ Indústria $) i+\beta_{6}($ Idade $) i+\beta_{7}$ (Tamanho $) i+\beta_{8}$ (Investidores Institucionais $) i+\beta_{9}$ (Alavancagem Financeira $) i+\beta_{10}($ Folga Financeira $) i+\beta_{11}(L N(C A P E X)) i+\beta_{12}$ $($ Novo Mercado e Nível 2$) i+\beta_{13}\left(\right.$ Adquirente Serial) $i+\beta_{14}$ (Aquisição Internacional) $i+\varepsilon i$

Onde:

$C A R\left(J_{1} ; J_{2}\right) i$ é o retorno anormal acumulado de determinada janela de evento $(1,3,11$ e 21 dias) e janela de estimação [-210;-31] $\left(J_{1}\right)$, em que este último é único para todos os CARs analisados, por isso não foi evidenciado; e Benchmark de retorno de mercado $\left(J_{2}\right)$, de determinado evento $(i)$ em aquisição de empresas familiares e não familiares da amostra da pesquisa;

$\alpha i$ é o intercepto da regressão de determinado evento $(i)$ em aquisição de empresas familiares e não familiares da amostra da pesquisa;

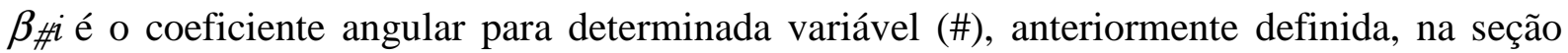
variáveis de determinado evento $(i)$ em aquisição de empresas familiares e não familiares da amostra da pesquisa;

$\varepsilon i$ é o termo de erro aleatório para um determinado evento $(i)$ em aquisição de empresas familiares e não familiares da amostra da pesquisa. 
Modelo 10 - Conta com as variáveis explicativas Primeira e Segunda Gerações Familiares, Família na Administração, Propriedade Concentrada Superior a 10\% (ou seu teste de robustez correspondente), Poder dos Controladores no Conselho e variáveis de controle, regressadas sobre as variáveis dependentes CAR (cumulative abnormal return - 1, 3, 11 e 21 dias de janelas de eventos);

Modelo de regressão múltipla 23 - Modelo Específico:

$\operatorname{CAR}\left(J_{1} ; J_{2}\right) i=\alpha i+\beta_{1}$ (Primeira e Segunda Gerações Familiares) $i+\beta_{2}$ (Família na Administração)i $+\beta_{3}$ (Propriedade Familiar $>10 \%$ ou seu teste de robustez correspondente) $i$ $+\beta_{4}$ (Poder dos Controladores no Conselho $) i+\beta_{5}(Q$ de Tobin $) i+\beta_{6}($ Indústria $) i+\beta_{7}$ $($ Idade $) i+\beta_{8}($ Tamanho $) i+\beta_{9}($ Investidores Institucionais $) i+\beta_{10}($ Alavancagem Financeira $) i+\beta_{11}$ $($ Folga Financeira $) i+\beta_{12}(L N(C A P E X)) i+\beta_{13}($ Novo Mercado e Nível 2$) i+\beta_{14}$ (Adquirente Serial) $i+$ $\beta_{15}$ (Aquisição Internacional) $i+\varepsilon i$

Onde:

$C A R\left(J_{1} ; J_{2}\right) i$ é o retorno anormal acumulado de determinada janela de evento $(1,3,11$ e 21 dias) e janela de estimação [-210;-31] $\left(J_{1}\right)$, em que este último é único para todos os CARs analisados, por isso não foi evidenciado; e Benchmark de retorno de mercado $\left(J_{2}\right)$, de determinado evento $(i)$ em aquisição de empresas familiares e não familiares da amostra da pesquisa;

$\alpha i$ é o intercepto da regressão de determinado evento $(i)$ em aquisição de empresas familiares e não familiares da amostra da pesquisa;

$\beta \# i$ é o coeficiente angular para determinada variável (\#), anteriormente definida, na seção variáveis de determinado evento $(i)$ em aquisição de empresas familiares e não familiares da amostra da pesquisa;

Ei é o termo de erro aleatório para um determinado evento $(i)$ em aquisição de empresas familiares e não familiares da amostra da pesquisa. 
Modelo 11 - Conta com as variáveis explicativas Primeira e Segunda Gerações Familiares, Família na Administração, Propriedade Concentrada Superior a 10\% (ou seu teste de robustez correspondente), Poder dos Controladores no Conselho, Índice de Stake dos Controladores / demais Blockholders e variáveis de controle, regressadas sobre as variáveis dependentes CAR (cumulative abnormal return - 1, 3, 11 e 21 dias de janelas de eventos);

Modelo de regressão múltipla 24 - Modelo Específico:

$\operatorname{CAR}\left(J_{1} ; J_{2}\right) i=\alpha i+\beta_{1}$ (Primeira e Segunda Gerações Familiares) $i+\beta_{2}$ (Família na Administração)i $+\beta_{3}$ (Propriedade Familiar $>10 \%$ ou seu teste de robustez correspondente) $i$ $+\beta_{4}$ (Poder dos Controladores no Conselho)i $+\beta_{5}$ (Índice de Stake dos Controladores / demais Blockholders $) i+\beta_{6}(Q$ de Tobin $) i+\beta_{7}($ Indústria $) i+\beta_{8}($ Idade $) i+\beta_{9}($ Tamanho $) i+\beta_{10}$ (Investidores Institucionais) $i+\beta_{11}$ (Alavancagem Financeira) $i+\beta_{12}$ (Folga Financeira) $i+\beta_{13}$ $(\operatorname{LN}(C A P E X)) i+\beta_{14}($ Novo Mercado e Nível 2$) i+\beta_{15}$ (Adquirente Serial) $i+\beta_{16}$ (Aquisição Internacional $) i+\varepsilon i$

Onde:

$C A R\left(J_{1} ; J_{2}\right) i$ é o retorno anormal acumulado de determinada janela de evento $(1,3,11$ e 21 dias) e janela de estimação [-210;-31] $\left(J_{1}\right)$, em que este último é único para todos os CARs analisados, por isso não foi evidenciado; e Benchmark de retorno de mercado $\left(J_{2}\right)$, de determinado evento $(i)$ em aquisição de empresas familiares e não familiares da amostra da pesquisa;

$\alpha i$ é o intercepto da regressão de determinado evento $(i)$ em aquisição de empresas familiares e não familiares da amostra da pesquisa;

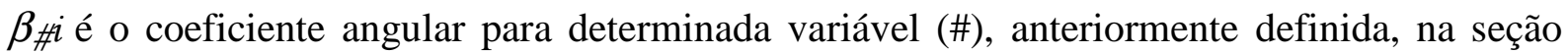
variáveis de determinado evento $(i)$ em aquisição de empresas familiares e não familiares da amostra da pesquisa;

$\varepsilon i$ é o termo de erro aleatório para um determinado evento $(i)$ em aquisição de empresas familiares e não familiares da amostra da pesquisa. 
Modelo 12 - Conta com as variáveis explicativas Primeira e Segunda Gerações Familiares, Família na Administração, Propriedade Concentrada Superior a 10\% (ou seu teste de robustez correspondente), Poder dos Controladores no Conselho, Índice de Stake dos Controladores / demais Blockholders, Índice de remuneração variável e por ações / remuneração Total e variáveis de controle, regressadas sobre as variáveis dependentes CAR (cumulative abnormal return - 1, 3, 11 e 21 dias de janelas de eventos);

Modelo de regressão múltipla 25 - Modelo Específico:

$\operatorname{CAR}\left(J_{1} ; J_{2}\right) i=\alpha i+\beta_{1}$ (Primeira e Segunda Gerações Familiares) $i+\beta_{2}$ (Família na Administração) $i+\beta_{3}$ (Propriedade Familiar $>10 \%$ ou seu teste de robustez correspondente) $i$ $+\beta_{4}$ (Poder dos Controladores no Conselho)i $+\beta_{5}$ (Índice de Stake dos Controladores / demais Blockholders $) i+\beta_{6}($ Índice de remuneração variável e por ações / remuneração Total $) i+\beta_{7}(Q$ de Tobin $) i$ $+\beta_{8}($ Indústria $) i+\beta_{9}($ Idade $) i+\beta_{10}$ (Tamanho) $i+\beta_{11}$ (Investidores Institucionais) $i+\beta_{12}$ (Alavancagem Financeira) $i+\beta_{13}($ Folga Financeira $) i+\beta_{14}(L N(C A P E X)) i+\beta_{15}$ (Novo Mercado e Nível $2) i+\beta_{16}($ Adquirente Serial $) i+\beta_{17}($ Aquisição Internacional $) i+\varepsilon i$

Onde:

$C A R\left(J_{1} ; J_{2}\right) i$ é o retorno anormal acumulado de determinada janela de evento $(1,3,11$ e 21 dias) e janela de estimação [-210;-31] $\left(J_{1}\right)$, em que este último é único para todos os CARs analisados, por isso não foi evidenciado; e Benchmark de retorno de mercado $\left(J_{2}\right)$, de determinado evento $(i)$ em aquisição de empresas familiares e não familiares da amostra da pesquisa;

$\alpha i$ é o intercepto da regressão de determinado evento $(i)$ em aquisição de empresas familiares e não familiares da amostra da pesquisa;

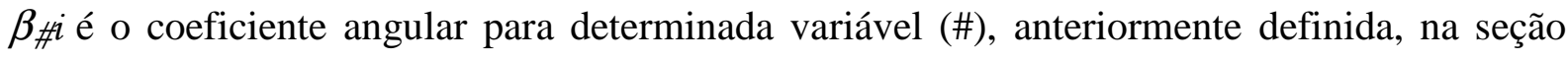
variáveis de determinado evento $(i)$ em aquisição de empresas familiares e não familiares da amostra da pesquisa;

Ei é o termo de erro aleatório para um determinado evento ( $i$ ) em aquisição de empresas familiares e não familiares da amostra da pesquisa. 
Modelo 13 - Conta com as variáveis explicativas Primeira e Segunda Gerações Familiares, Família na Administração, Stake dos Acionistas Controladores (empresa familiar ou não) e variáveis de controle, regressadas sobre as variáveis dependentes CAR (cumulative abnormal return - 1, 3, 11 e 21 dias de janelas de eventos);

Modelo de regressão múltipla 26 - Modelo Específico:

$\operatorname{CAR}\left(J_{1} ; J_{2}\right) i=\alpha i+\beta_{1}$ (Primeira e Segunda Gerações Familiares)i $+\beta_{2}$ (Família na Administração)i $+\beta_{3}$ (stake dos acionistas controladores) $i+\beta_{4}$ (Poder dos Controladores no Conselho)i $+\beta_{5}$ (Índice de Stake dos Controladores / demais Blockholders) $i+\beta_{6}$ (Índice de remuneração variável e por ações / remuneração Total $) i+\beta_{7}(Q$ de Tobin $) i+\beta_{8}($ Indústria $) i+\beta_{9}$ $($ Idade $) i+\beta_{10}($ Tamanho $) i+\beta_{11}($ Investidores Institucionais $) i+\beta_{12}($ Alavancagem Financeira $) i+\beta_{13}$ $($ Folga Financeira $) i+\beta_{14}(\operatorname{LN}($ CAPEX $)) i+\beta_{15}($ Novo Mercado e Nível 2$) i+\beta_{16}($ Adquirente Serial $) i+$ $\beta_{17}$ (Aquisição Internacional) $i+\varepsilon i$

Onde:

$C A R\left(J_{1} ; J_{2}\right) i$ é o retorno anormal acumulado de determinada janela de evento $(1,3,11$ e 21 dias) e janela de estimação [-210;-31] $\left(J_{1}\right)$, em que este último é único para todos os CARs analisados, por isso não foi evidenciado; e Benchmark de retorno de mercado $\left(J_{2}\right)$, de determinado evento $(i)$ em aquisição de empresas familiares e não familiares da amostra da pesquisa;

$\alpha i$ é o intercepto da regressão de determinado evento $(i)$ em aquisição de empresas familiares e não familiares da amostra da pesquisa;

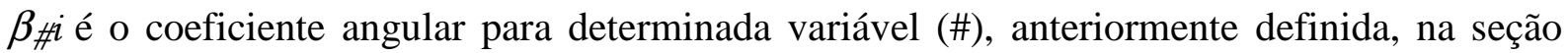
variáveis de determinado evento $(i)$ em aquisição de empresas familiares e não familiares da amostra da pesquisa;

$\varepsilon i$ é o termo de erro aleatório para um determinado evento $(i)$ em aquisição de empresas familiares e não familiares da amostra da pesquisa. 
As tabelas a seguir, inicialmente, apresentarão os resultados das regressões por MQO (mínimos quadrados ordinários com erros-padrão robustos - estimação dos parâmetros por Hubber-White Sandwich), para cada janela de eventos analisados, outrossim, para os trezes modelos de regressões anteriormente definidos, para ambos os benchmark de mercados (Ibovespa e IBRX50). Informa-se, ainda, que foi criado uma subamostra (empresas familiares), com o objetivo de regredir variáveis intrínsecas das empresas familiares, tornando possível a aferição das relações entre os CARs, e variáveis como, $1^{\text {a }}$ e $2^{\text {a }}$ geração familiares e família na administração.

\subsubsection{Resultados das regressões pelo método de mínimos quadrados ordinários (MQO) utilizando erros-padrão robustos - Hubber-White Sandwich -} Benchmark - Ibovespa.

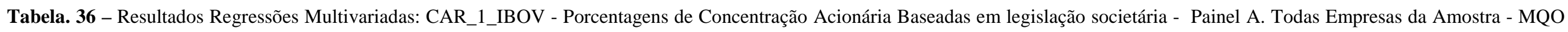
com erros-padrão robustos

\begin{tabular}{|c|c|c|c|c|c|c|c|c|c|c|c|c|c|c|c|c|c|c|c|c|c|c|c|c|c|c|c|c|c|c|c|c|c|c|c|c|c|c|c|}
\hline & & Iodelo & & & Iodelo 2 & & & Modelo : & & & Iodelo 4 & & & Modelo 5 & & & Todelo 6 & & & Modelo 7 & & & Iodelo 8 & & & Modelo 9 & & & Modelo 16 & & & Modelo 1 & & & Iodelo 12 & & & Modelo 1 & \\
\hline Variáveis & B & & $t$ & $B$ & & $t$ & B & & $t$ & $B$ & & $t$ & $B$ & & $t$ & B & & $t$ & $\mathbf{B}$ & & $t$ & B & & $t$ & $B$ & & $t$ & B & & $t$ & B & & $t$ & B & & $t$ & B & & $t$ \\
\hline $\begin{array}{l}\text { Empresas Familiares } \\
\text { Stake Controladores }\end{array}$ & 0,48 & & 1,29 & 0,52 & & 1,19 & $-0,21$ & & $-0,37$ & $-0,18$ & & $-0,28$ & 0,35 & & 1,00 & 0,50 & & 1,13 & $-0,18$ & & $-0,31$ & $-0,16$ & & $-0,26$ & $\begin{array}{ll}0,27 \\
\end{array}$ & & 0,88 & 0,55 & & 1,26 & $-0,12$ & & $-0,21$ & $-0,15$ & & $-0,25$ & $\begin{array}{l}-0,22 \\
-0,01\end{array}$ & & $\begin{array}{l}-0,36 \\
-0,74\end{array}$ \\
\hline $\begin{array}{l}\text { Propriedade } \\
\text { Concentrada }>50 \%\end{array}$ & $-0,89$ & ** & $-2,37$ & $-1,15$ & **** & $-2,82$ & $-0,61$ & & $-1,34$ & $-0,83$ & & $-1,59$ & & & & & & & & & & & & & & & & & & & & & & & & & & & \\
\hline $\begin{array}{c}\text { Propriedade } \\
\text { Concentrada }>20 \%\end{array}$ & & & & & & & & & & & & & 0,00 & & 0,00 & 0,00 & & 0,00 & 0,05 & & 0,05 & $-0,09$ & & $-0,09$ & & & & & & & & & & & & & & & \\
\hline $\begin{array}{c}\text { Propriedade } \\
\text { Concentrada }>10 \%\end{array}$ & & & & & & & & & & & & & & & & & & & & & & & & & $-9,40$ & & $-1,40$ & $-9,58$ & & $-1,40$ & $-10,28$ & & $-1,53$ & $-10,72$ & & $-1,61$ & & & \\
\hline $\begin{array}{l}\text { Poder_Controladores_ } \\
\text { Conselho }\end{array}$ & & & & 0,30 & & 0,43 & 0,31 & & 0,30 & 0,14 & & 0,13 & & & & 0,06 & & 0,09 & 0,23 & & 0,22 & 0,00 & & 0,00 & & & & 0,56 & & 0,86 & 0,93 & & 1,07 & 0,73 & & 0,81 & $-0,03$ & & $-0,03$ \\
\hline $\begin{array}{l}\text { Índice_Stake_Control } \\
\text { adores/Blockholders }\end{array}$ & & & & & & & $-0,01$ & & $-0,22$ & 0,00 & & $-0,10$ & & & & & & & $-0,01$ & & $-0,55$ & $-0,01$ & & $-0,45$ & & & & & & & $-0,01$ & & $-0,37$ & $-0,01$ & & $-0,22$ & 0,00 & & 0,12 \\
\hline Índice_remuneração_v & & & & & & & & & & & & & & & & & & & & & & & & & & & & & & & & & & & & & & & \\
\hline $\begin{array}{l}\text { ariável e por } \\
\text { ações/remuneração } \\
\text { total }\end{array}$ & & & & & & & & & & 0,80 & & 0,82 & & & & & & & & & & 0,55 & & 0,49 & & & & & & & & & & 1,12 & & 1,09 & 0,79 & & 0,76 \\
\hline Q de Tobin & 0,02 & & 0,13 & 0,17 & & 0,85 & $-0,03$ & & $-0,14$ & $-0,05$ & & $-0,19$ & $-0,03$ & & $-0,17$ & 0,06 & & 0,32 & $-0,08$ & & $-0,34$ & $-0,11$ & & $-0,41$ & 0,01 & & 0,05 & 0,11 & & 0,63 & $-0,08$ & & $-0,35$ & $-0,13$ & & $-0,54$ & $-0,10$ & & $-0,39$ \\
\hline $\begin{array}{l}\text { Indústria } \\
\text { Manufatureira }\end{array}$ & 0,31 & & 0,98 & 0,44 & & 1,21 & 0,24 & & 0,46 & $-0,03$ & & $-0,05$ & 0,27 & & 0,83 & 0,50 & & 1,30 & 0,21 & & 0,40 & 0,01 & & 0,01 & 0,18 & & 0,53 & 0,33 & & 0,85 & $-0,16$ & & $-0,28$ & $-0,60$ & & $-0,85$ & 0,01 & & 0,02 \\
\hline Idade & 0,01 & ** & 2,21 & 0,01 & *** & 2,39 & 0,02 & $* * *$ & 2,57 & 0,02 & $* *$ & 2,10 & 0,01 & & 1,53 & 0,01 & * & 1,73 & 0,02 & $* * *$ & 2,69 & 0,02 & ** & 2,26 & 0,01 & * & 1,66 & 0,01 & * & 1,95 & 0,03 & $* * *$ & 3,39 & 0,02 & $* * *$ & 3,00 & 0,02 & $* *$ & 1,98 \\
\hline $\begin{array}{c}\text { Tamanho_LN(Ativo } \\
\text { Total) }\end{array}$ & 0,08 & & 0,95 & 0,07 & & 0,72 & 0,16 & & 1,01 & 0,23 & & 1,24 & 0,06 & & 0,65 & 0,03 & & 0,29 & 0,17 & & 0,94 & 0,24 & & 1,13 & 0,07 & & 0,83 & 0,04 & & 0,46 & 0,32 & $*$ & 1,71 & 0,41 & $*$ & 1,84 & 0,25 & & 1,29 \\
\hline $\begin{array}{l}\text { Investidores } \\
\text { Institucionais }\end{array}$ & $-0,53$ & & $-0,97$ & $-0,42$ & & $-0,70$ & $-1,51$ & & $-1,63$ & $-1,95$ & ** & $-2,12$ & $-0,29$ & & $-0,53$ & $-0,12$ & & $-0,19$ & $-1,53$ & & $-1,61$ & $-1,87$ & * & $-1,90$ & $-0,51$ & & $-0,96$ & $-0,28$ & & $-0,48$ & $-1,52$ & * & $-1,67$ & $-2,16$ & ** & $-2,32$ & $-2,17$ & ** & $-2,12$ \\
\hline $\begin{array}{l}\text { Alavancagem } \\
\text { Financeira }\end{array}$ & $-2,96$ & * & $-1,73$ & $-3,13$ & ${ }^{*}$ & $-1,70$ & $-3,54$ & & $-1,08$ & $-3,39$ & & $-0,98$ & $-2,70$ & & $-1,63$ & $-3,00$ & ${ }^{*}$ & $-1,80$ & $-3,44$ & & $-1,09$ & $-3,24$ & & $-1,01$ & $-2,95$ & ${ }^{*}$ & $-1,91$ & $-3,23$ & * & $-1,93$ & $-4,09$ & & $-1,45$ & $-3,57$ & & $-1,29$ & $-3,21$ & & $-0,96$ \\
\hline $\begin{array}{l}\text { Folga Financeira } \\
\text { LN(CAPEX) }\end{array}$ & $\begin{array}{l}-0,15 \\
-0,03\end{array}$ & *** & $\begin{array}{l}-2,76 \\
-1,36\end{array}$ & $\begin{array}{l}-0,12 \\
-0,02\end{array}$ & ** & $\begin{array}{l}-2,06 \\
-0,68\end{array}$ & $\begin{array}{l}-0,13 \\
-0,03\end{array}$ & ** & $\begin{array}{l}-2,21 \\
-0,98\end{array}$ & $\begin{array}{l}-0,14 \\
-0,04\end{array}$ & $* *$ & $\begin{array}{l}-2,38 \\
-0,92\end{array}$ & $\begin{array}{r}-0,15 \\
-0,02\end{array}$ & ** & $\begin{array}{l}-2,47 \\
-0,99\end{array}$ & $\begin{array}{l}-0,11 \\
-0,01\end{array}$ & ** & $\begin{array}{l}-2,01 \\
-0,28\end{array}$ & $\begin{array}{l}-0,13 \\
-0,02\end{array}$ & *** & $\begin{array}{l}-2,07 \\
-0,66\end{array}$ & $\begin{array}{l}-0,13 \\
-0,03\end{array}$ & ** & $\begin{array}{l}-2,08 \\
-0,61\end{array}$ & $\begin{array}{l}-0,13 \\
-0,02\end{array}$ & ** & $\begin{array}{l}-2,28 \\
-1,13\end{array}$ & $\begin{array}{c}-0,09 \\
0,00\end{array}$ & & $\begin{array}{l}-1,51 \\
-0,23\end{array}$ & $\begin{array}{l}-0,09 \\
-0,02\end{array}$ & & $\begin{array}{l}-1,31 \\
-0,74\end{array}$ & $\begin{array}{l}-0,10 \\
-0,01\end{array}$ & & $\begin{array}{l}-1,51 \\
-0,35\end{array}$ & $\begin{array}{l}-0,11 \\
-0,03\end{array}$ & * & $\begin{array}{l}-1,65 \\
-0,74\end{array}$ \\
\hline $\begin{array}{c}\text { Novo Mercado e Nível } \\
2\end{array}$ & 0,09 & & 0,27 & $-0,16$ & & $-0,39$ & 0,59 & & 1,01 & 0,52 & & 0,76 & 0,39 & & 1,12 & 0,30 & & 0,74 & 0,84 & & 1,49 & 0,87 & & 1,38 & 0,25 & & 0,72 & 0,09 & & 0,23 & 0,58 & & 0,99 & 0,64 & & 0,98 & 0,68 & & 0,92 \\
\hline Adquirente Serial & $-0,38$ & & $-0,86$ & $-0,41$ & & $-0,87$ & $-0,67$ & & $-1,13$ & $-0,78$ & & $-1,10$ & $-0,32$ & & $-0,68$ & $-0,40$ & & $-0,76$ & $-0,72$ & & $-1,10$ & $-0,77$ & & $-0,96$ & $-0,03$ & & $-0,09$ & $-0,10$ & & $-0,26$ & $-0,20$ & & $-0,40$ & $-0,30$ & & $-0,58$ & $-0,84$ & & $-1,07$ \\
\hline $\begin{array}{c}\text { Aquisição } \\
\text { Internacional }\end{array}$ & $-1,13$ & $* * *$ & $-3,05$ & $-1,03$ & ** & $-2,49$ & $-1,53$ & ** & $-2,56$ & $-1,45$ & $* *$ & $-2,33$ & $-0,99$ & $* * *$ & $-2,68$ & $-0,86$ & $* *$ & $-2,07$ & $-1,41$ & ** & $-2,39$ & $-1,34$ & $* *$ & $-2,14$ & $-1,11$ & $* * *$ & $-2,77$ & $-0,99$ & ** & $-2,19$ & $-1,85$ & *** & $-2,70$ & $-1,71$ & ** & $-2,47$ & $-1,39$ & ${ }^{* *}$ & $-2,22$ \\
\hline $\begin{array}{c}- \text { cons } \\
\mathrm{N}\end{array}$ & 0,77 & 355 & 0,48 & 0,60 & 290 & 0,32 & 0,69 & 187 & 0,19 & $-0,03$ & 175 & $-0,01$ & 0,35 & 355 & 0,21 & 0,20 & 290 & 0,11 & 0,15 & 187 & 0,04 & $-0,67$ & 175 & $-0,18$ & 9,70 & 355 & 1,38 & 9,28 & 290 & 1,31 & 7,61 & 187 & 1,07 & 6,75 & 175 & 0,95 & 0,20 & 175 & 0,04 \\
\hline $\mathrm{F}$ & & 2,16 & & & 2,09 & & & 2,82 & & & 2,53 & & & 1,79 & & & 1,70 & & & 2,87 & & & 2,51 & & & 1,79 & & & 1,80 & & & 2,72 & & & 2,48 & & & 2,45 & \\
\hline$R^{\wedge} 2$ & & 0,07 & & & 0,08 & & & 0,14 & & & 0,15 & & & 0,05 & & & 0,05 & & & 0,14 & & & 0,14 & & & 0,14 & & & 0,15 & & & 0,28 & & & 0,29 & & & 0,14 & \\
\hline
\end{tabular}

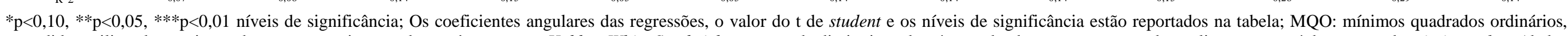

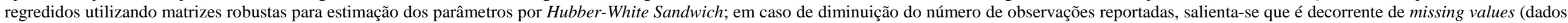
faltantes); CAR: cumulative abnormal return, em que o primeiro valor refere-se à janela de evento e a segunda nomenclatura ao benchmark de retorno de mercado utilizado.

Fonte: Elaborado pelo autor. 
Evidencia-se que, na tabela 36, são regredidas todas as empresas da amostra por mínimos quadrados ordinários, utilizando erros-padrão robustos, e tem como variável dependente o CAR_1_Ibovespa [cumulative abnormal return, da janela de evento de 1 dia (data do anúncio)], e, como benchmark de retorno de mercado, o Ibovespa.

Encontrou-se que a variável propriedade concentrada superior a 50\%, tem relação negativa com o CAR_1_Ibovespa, e significantes estatisticamente nos modelos 1 e 2 ( $p<0.05$ e p $<0.01$, respectivamente).

Reporta-se ainda que referente à variável empresa familiar, nesta tabela, não se pode concluir sobre sua relação com o CAR_1_Ibovespa, pois não foi encontrada significância estatística em nenhum dos modelos analisados.

É possível observar também que as variáveis folga financeira, aquisição internacional, alavancagem financeira e investidores institucionais têm relação negativa com o CAR_1_Ibovespa e, sobretudo, apresentam significâncias estatísticas reiteradas em modelos diversos analisados.

Por fim, como análise desta tabela, evidencia-se que as variáveis idade e tamanho da empresa têm relação positiva em relação ao CAR_1_Ibovespa e, sobretudo, apresentam significâncias estatísticas reiteradas em modelos diversos analisados.

A seguir, apresentam-se as regressões com estratificação da amostra, utilizando apenas empresas familiares, com o intuito de mensurar a relação entre o CAR_1_Ibovespa e variáveis específicas, da subamostra a seguir apresentada. 
Tabela. 37 - Resultados Regressões Multivariadas: CAR_1_IBOV - Porcentagens de Concentração Acionária Baseadas em legislação societária - Painel B. Empresas Familiares da Amostra MQO com erros-padrão robustos

\begin{tabular}{|c|c|c|c|c|c|c|c|c|c|c|c|c|c|c|c|c|c|c|c|c|c|c|c|c|c|c|c|c|c|c|c|c|c|c|c|c|c|c|c|}
\hline & & Iodelo & & & Modelo 2 & & & Iodel 03 & & & Modelo 6 & & & Modelo & & & Modelo & & & Modelo 7 & & & Modelo o & & & Modelo 5 & & & Modelo 10 & & & Todelo 11 & & & Modelo 12 & & & Modelo 1 & \\
\hline Variáveis & B & & $t$ & B & & $t$ & B & & $t$ & B & & $t$ & B & & $t$ & B & & $t$ & B & & $t$ & B & & $t$ & B & & $t$ & B & & $t$ & B & & $t$ & B & & $t$ & B & & $t$ \\
\hline $1^{a}$ e $2^{a}$ Geração Familiar & 0,79 & & 1,34 & 0,88 & & 1,42 & 0,41 & & 0,64 & 0,08 & & 0,12 & 0,85 & & 1,43 & 0,97 & & 1,54 & 0,50 & & 0,76 & 0,30 & & 0,42 & 0,81 & & 1,32 & 0,90 & & 1,39 & 0,28 & & 0,39 & $-0,14$ & & $-0,17$ & 0,11 & & 0,15 \\
\hline $\begin{array}{c}\text { Familia na } \\
\text { Administração }\end{array}$ & 0,11 & & 0,24 & 0,11 & & 0,25 & 0,51 & & 0,71 & 0,60 & & 0,78 & 0,34 & & 0,84 & 0,36 & & 0,87 & 0,55 & & 0,86 & 0,58 & & 0,85 & 0,34 & & 0,84 & 0,39 & & 0,93 & 0,56 & & 0,93 & 0,67 & & 1,01 & 0,57 & & 0,76 \\
\hline Stake Controladores & & & & & & & & & & & & & & & & & & & & & & & & & & & & & & & & & & & & & $-0,02$ & & $-0,67$ \\
\hline $\begin{array}{c}\text { Propriedade } \\
\text { Concentrada }>50 \%\end{array}$ & $-0,87$ & * & $-1,75$ & $-0,98$ & ** & $-2,03$ & $-0,70$ & & $-1,27$ & $-1,06$ & & $-1,22$ & & & & & & & & & & & & & & & & & & & & & & & & & & & \\
\hline $\begin{array}{c}\text { Propriedade } \\
\text { Concentrada }>20 \%\end{array}$ & & & & & & & & & & & & & 0,20 & & 0,21 & 0,12 & & 0,13 & 0,00 & & 0,00 & $-0,05$ & & $-0,05$ & & & & & & & & & & & & & & & \\
\hline $\begin{array}{c}\text { Propriedade } \\
\text { Concentrada }>10 \%\end{array}$ & & & & & & & & & & & & & & & & & & & & & & & & & $-9,47$ & & $-1,40$ & $-9,64$ & & $-1,40$ & $-10,32$ & & $-1,55$ & $-10,63$ & & $-1,59$ & & & \\
\hline $\begin{array}{l}\text { Poder_Controladores_ } \\
\text { Conselho }\end{array}$ & & & & $-0,39$ & & $-0,49$ & $-0,13$ & & $-0,11$ & $-0,20$ & & $-0,17$ & & & & $-0,49$ & & $-0,57$ & $-0,08$ & & $-0,07$ & $-0,22$ & & $-0,18$ & & & & 0,24 & & 0,30 & 0,70 & & 0,74 & 0,68 & & 0,69 & $-0,33$ & & $-0,26$ \\
\hline $\begin{array}{l}\text { Índice_Stake_Control } \\
\text { adores/Blockholders } \\
\text { Indice_remuneração_vv }\end{array}$ & & & & & & & 0,00 & & $-0,11$ & 0,00 & & 0,02 & & & & & & & $-0,01$ & & $-0,44$ & $-0,01$ & & $-0,44$ & & & & & & & $-0,01$ & & $-0,33$ & 0,00 & & $-0,19$ & 0,01 & & 0,21 \\
\hline $\begin{array}{l}\text { ariável e por } \\
\text { ações/remuneração } \\
\text { total }\end{array}$ & & & & & & & & & & 0,85 & & 0,61 & & & & & & & & & & 0,01 & & 0,01 & & & & & & & & & & 0,68 & & 0,54 & 0,53 & & 0,37 \\
\hline Qde Tobin & $-0,20$ & & $-0,79$ & $-0,15$ & & $-0,62$ & $-0,26$ & & $-0,82$ & $-0,26$ & & $-0,78$ & $-0,25$ & & $-1,00$ & $-0,22$ & & $-0,86$ & $-0,29$ & & $-0,88$ & $-0,28$ & & $-0,79$ & $-0,19$ & & $-0,78$ & $-0,14$ & & $-0,59$ & $-0,25$ & & $-0,85$ & $-0,25$ & & $-0,81$ & $-0,30$ & & $-0,84$ \\
\hline $\begin{array}{c}\text { Indústria } \\
\text { Manufatureira }\end{array}$ & 0,23 & & 0,46 & 0,40 & & 0,81 & 0,81 & & 1,15 & 0,56 & & 0,66 & 0,29 & & 0,59 & 0,49 & & 0,96 & 0,85 & & 1,16 & 0,82 & & 0,98 & 0,09 & & 0,18 & 0,20 & & 0,40 & 0,27 & & 0,39 & $-0,16$ & & $-0,17$ & 0,68 & & 0,83 \\
\hline Idade & 0,02 & ${ }^{* * *}$ & 2,90 & 0,02 & **** & 2,94 & 0,02 & ${ }^{*}$ & 1,84 & 0,01 & & 0,87 & 0,02 & $* * *$ & 2,93 & 0,02 & ${ }^{* * *}$ & 2,98 & 0,02 & $* *$ & 2,05 & 0,02 & & 1,34 & 0,02 & $* * *$ & 3,34 & 0,03 & $* * *$ & 3,40 & 0,03 & **** & 3,07 & 0,02 & ** & 2,05 & 0,02 & & 0,92 \\
\hline $\begin{array}{c}\text { Tamanho_LN(Ativo } \\
\text { Total) }\end{array}$ & 0,12 & & 1,06 & 0,13 & & 1,04 & 0,17 & & 0,98 & 0,21 & & 1,02 & 0,09 & & 0,73 & 0,10 & & 0,76 & 0,19 & & 0,96 & 0,23 & & 1,00 & 0,13 & & 1,08 & 0,13 & & 1,06 & 0,34 & * & 1,72 & 0,39 & $*$ & 1,69 & 0,23 & & 1,13 \\
\hline $\begin{array}{l}\text { Investidores } \\
\text { Institucionais }\end{array}$ & $-0,44$ & & $-0,70$ & $-0,45$ & & $-0,68$ & $-0,88$ & & $-0,81$ & $-1,52$ & & $-1,33$ & $-0,12$ & & $-0,20$ & $-0,12$ & & $-0,19$ & $-0,78$ & & $-0,71$ & $-0,95$ & & $-0,81$ & $-0,41$ & & $-0,71$ & $-0,29$ & & $-0,45$ & $-0,89$ & & $-0,84$ & $-1,59$ & & $-1,35$ & $-1,57$ & & $-1,14$ \\
\hline $\begin{array}{l}\text { Alavancagem } \\
\text { Financeira }\end{array}$ & $-3,20$ & & $-1,48$ & $-2,93$ & & $-1,33$ & $-4,32$ & & $-1,18$ & $-4,23$ & & $-1,12$ & $-3,02$ & & $-1,50$ & $-2,76$ & & $-1,34$ & $-4,26$ & & $-1,20$ & $-4,40$ & & $-1,18$ & $-3,20$ & * & $-1,71$ & $-3,06$ & & $-1,56$ & $-4,70$ & & $-1,57$ & $-4,27$ & & $-1,44$ & $-4,09$ & & $-1,17$ \\
\hline $\begin{array}{l}\text { Folga Financeira } \\
\text { LN(CAPEX) }\end{array}$ & $\begin{array}{l}-0,16 \\
0,00\end{array}$ & ** & $\begin{array}{l}-2,39 \\
-0,11\end{array}$ & $\begin{array}{l}-0,17 \\
-0,01\end{array}$ & ** & $\begin{array}{l}-2,23 \\
-0,37\end{array}$ & $\begin{array}{l}-0,11 \\
-0,03\end{array}$ & & $\begin{array}{l}-1,25 \\
-0,81\end{array}$ & $\begin{array}{l}-0,10 \\
-0,04\end{array}$ & & $\begin{array}{l}-1,08 \\
-0,91\end{array}$ & $\begin{array}{c}-0,15 \\
0,01\end{array}$ & ** & $\begin{array}{l}-2,12 \\
0,23\end{array}$ & $\begin{array}{l}-0,16 \\
0,00\end{array}$ & ** & $\begin{array}{l}-2,14 \\
-0,02\end{array}$ & $\begin{array}{l}-0,10 \\
-0,02\end{array}$ & & $\begin{array}{l}-1,07 \\
-0,56\end{array}$ & $\begin{array}{l}-0,09 \\
-0,04\end{array}$ & & $\begin{array}{l}-0,86 \\
-0,75\end{array}$ & $\begin{array}{c}-0,15 \\
0,00\end{array}$ & *** & $\begin{array}{c}-2,21 \\
0,15\end{array}$ & $\begin{array}{c}-0,13 \\
0,00\end{array}$ & * & $\begin{array}{r}-1,67 \\
0,09\end{array}$ & $\begin{array}{l}-0,06 \\
-0,02\end{array}$ & & $\begin{array}{l}-0,62 \\
-0,65\end{array}$ & $\begin{array}{l}-0,04 \\
-0,02\end{array}$ & & $\begin{array}{l}-0,45 \\
-0,49\end{array}$ & $\begin{array}{l}-0,06 \\
-0,04\end{array}$ & & $\begin{array}{l}-0,52 \\
-0,80\end{array}$ \\
\hline $\begin{array}{l}\text { Novo Mercado e Nível } \\
2\end{array}$ & 0,28 & & 0,49 & 0,14 & & 0,24 & 0,26 & & 0,35 & 0,13 & & 0,13 & 0,66 & & 1,21 & 0,56 & & 1,01 & 0,60 & & 0,92 & 0,66 & & 0,87 & 0,45 & & 0,85 & 0,35 & & 0,65 & 0,25 & & 0,36 & 0,38 & & 0,48 & 0,41 & & 0,42 \\
\hline Adquirente Serial & $-0,59$ & & $-1,09$ & $-0,49$ & & $-0,86$ & $-0,65$ & & $-0,87$ & $-0,99$ & & $-0,96$ & $-0,57$ & & $-0,90$ & $-0,48$ & & $-0,75$ & $-0,71$ & & $-0,87$ & $-0,80$ & & $-0,77$ & $-0,21$ & & $-0,48$ & $-0,11$ & & $-0,24$ & $-0,02$ & & $-0,03$ & $-0,25$ & & $-0,39$ & $-0,94$ & & $-0,85$ \\
\hline $\begin{array}{l}\text { Aquisição } \\
\text { Internacional }\end{array}$ & $-1,13$ & ** & $-2,40$ & $-1,16$ & ** & $-2,47$ & $-1,58$ & ** & $-2,48$ & $-1,44$ & ** & $-2,07$ & $-1,03$ & ${ }^{* *}$ & $-2,17$ & $-1,04$ & ** & $-2,21$ & $-1,44$ & ** & $-2,26$ & $-1,39$ & ** & $-2,01$ & $-1,21$ & ** & $-2,35$ & $-1,21$ & ** & $-2,35$ & $-1,96$ & ${ }^{* * *}$ & $-2,63$ & $-1,77$ & ** & $-2,34$ & $-1,43$ & ${ }^{* *}$ & $-2,03$ \\
\hline $\begin{array}{l}\text {-cons } \\
\mathrm{N}\end{array}$ & $-0,62$ & 226 & $-0,24$ & $-0,60$ & 222 & $-0,22$ & $-0,04$ & 160 & $-0,01$ & 0,69 & 150 & 0,14 & $-1,59$ & 226 & $-0,63$ & $-1,69$ & 222 & $-0,63$ & $-1,10$ & 160 & $-0,27$ & $-1,02$ & 150 & $-0,24$ & 7,57 & 226 & 1,04 & 7,18 & 222 & 0,97 & 6,64 & 160 & 0,88 & 6,88 & 150 & 0,90 & 0,42 & 150 & 0,07 \\
\hline $\mathrm{F}$ & & 1,96 & & & 1,93 & & & 2,66 & & & 2,42 & & & 1,93 & & & 1,89 & & & 2,76 & & & 2,41 & & & 1,91 & & & 1,85 & & & 2,53 & & & 2,35 & & & 2,40 & \\
\hline $\mathrm{R}^{\wedge} 2$ & & 0,11 & & & 0,11 & & & 0,15 & & & 0,16 & & & 0,09 & & & 0,09 & & & 0,15 & & & 0,15 & & & 0,20 & & & 0,21 & & & 0,29 & & & 0,30 & & & 0,15 & \\
\hline
\end{tabular}

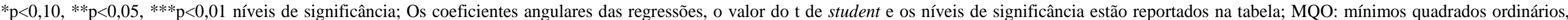

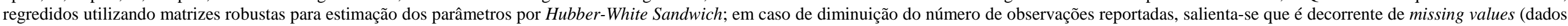
faltantes); CAR: cumulative abnormal return, em que o primeiro valor refere-se à janela de evento e a segunda nomenclatura ao benchmark de retorno de mercado utilizado.

Fonte: Elaborado pelo autor.

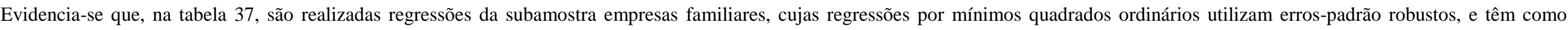
variável dependente o CAR_1_Ibovespa [cumulative abnormal return, da janela de evento de 1 dia (data do anúncio)], e, como benchmark de retorno de mercado, o Ibovespa.

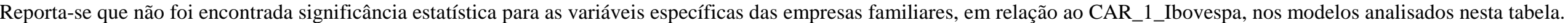

Quanto as demais variáveis, salienta-se que permanecem os mesmos achados relatados para CAR_1_Ibovespa quando regredido sobre toda a amostra.

A seguir, apresentam-se as regressões do CAR_1_Ibovespa sobre toda a amostra, entretanto, utilizando o teste de robustez da variável concentração acionária. 


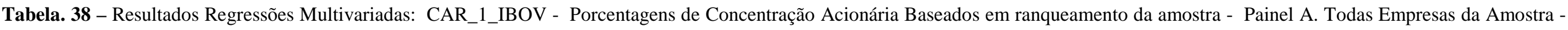
MQO com erros-padrão robustos

\begin{tabular}{|c|c|c|c|c|c|c|c|c|c|c|c|c|c|c|c|c|c|c|c|c|c|c|c|c|c|c|c|c|c|c|c|c|c|c|c|c|}
\hline & & Todelo 1 & & & Iodelo & & & Modelo & & & Sodelo & & & Modelo & & & Modelo & & & Modelo & & & Modelo & & & Modelo & & & Todelo & & & Todelo 1 & & & Todelo 1 & \\
\hline Variáveis & B & & $t$ & B & & $t$ & B & & $t$ & B & & $t$ & B & & $t$ & B & & $t$ & B & & $t$ & B & & $t$ & B & & $t$ & B & & $t$ & B & & $t$ & B & & $t$ \\
\hline Empresas Familiares & 0,34 & & 1,03 & 0,49 & & 1,11 & $-0,16$ & & $-0,28$ & $-0,16$ & & $-0,25$ & 0,39 & & 1,16 & 0,56 & & 1,27 & $-0,15$ & & $-0,25$ & $-0,12$ & & $-0,19$ & 0,46 & & 1,25 & 0,56 & & 1,28 & $-0,19$ & & $-0,32$ & $-0,13$ & & $-0,20$ \\
\hline $\begin{array}{c}\text { Propriedade } \\
\text { Concentrada Alta }\end{array}$ & & & & & & & & & & & & & & & & & & & & & & & & & $-1,00$ & * & $-1,91$ & $-0,99$ & * & $-1,64$ & $-0,27$ & & $-0,37$ & $-0,37$ & & $-0,42$ \\
\hline $\begin{array}{l}\text { Propriedade } \\
\text { Concentrada_Média }\end{array}$ & & & & & & & & & & & & & 0,26 & & 0,86 & 0,37 & & 1,17 & 0,12 & & 0,22 & 0,05 & & 0,07 & & & & & & & & & & & & \\
\hline $\begin{array}{l}\text { Concentrada_Média } \\
\text { Propriedade } \\
\text { Concentrada_Baixa }\end{array}$ & 0,16 & & 0,35 & 0,09 & & 0,16 & $-0,08$ & & $-0,11$ & 0,04 & & 0,06 & & & & & & & & & & & & & & & & & & & & & & & & \\
\hline $\begin{array}{l}\text { Poder_Controladores_ } \\
\text { Conselho }\end{array}$ & & & & 0,06 & & 0,08 & 0,24 & & 0,22 & $-0,01$ & & $-0,01$ & & & & 0,01 & & 0,02 & 0,24 & & 0,23 & 0,00 & & 0,00 & & & & $-0,15$ & & $-0,20$ & 0,22 & & 0,21 & $-0,03$ & & $-0,02$ \\
\hline $\begin{array}{l}\text { Índice_Stake_Control } \\
\text { adores/Blockholders } \\
\text { Índice_remuneração_v }\end{array}$ & & & & & & & $-0,01$ & & $-0,58$ & $-0,01$ & & $-0,45$ & & & & & & & $-0,01$ & & $-0,48$ & $-0,01$ & & $-0,42$ & & & & & & & $-0,01$ & & $-0,32$ & $-0,01$ & & $-0,20$ \\
\hline $\begin{array}{c}\text { aríávele por } \\
\text { açôes/remuneração } \\
\text { total }\end{array}$ & & & & & & & & & & 0,52 & & 0,54 & & & & & & & & & & 0,51 & & 0,53 & & & & & & & & & & 0,57 & & 0,61 \\
\hline Q de Tobin & $-0,02$ & & $-0,13$ & 0,06 & & 0,31 & $-0,08$ & & $-0,32$ & $-0,11$ & & $-0,41$ & $-0,04$ & & $-0,24$ & 0,06 & & 0,31 & $-0,08$ & & $-0,31$ & $-0,11$ & & $-0,40$ & $-0,05$ & & $-0,27$ & 0,05 & & 0,27 & $-0,09$ & & $-0,35$ & $-0,11$ & & $-0,44$ \\
\hline $\begin{array}{c}\text { Indústria } \\
\text { Manufatureira }\end{array}$ & 0,28 & & 0,88 & 0,51 & & 1,40 & 0,21 & & 0,41 & 0,00 & & 0,00 & 0,23 & & 0,74 & 0,44 & & 1,22 & 0,21 & & 0,41 & 0,01 & & 0,01 & 0,17 & & 0,54 & 0,39 & & 1,04 & 0,22 & & 0,43 & 0,02 & & 0,03 \\
\hline Idade & 0,01 & & 1,58 & 0,01 & * & 1,72 & 0,02 & $* * *$ & 2,58 & 0,02 & $* *$ & 2,17 & 0,01 & & 1,29 & 0,01 & & 1,47 & 0,02 & $* *$ & 2,52 & 0,02 & $* *$ & 2,14 & 0,01 & & 1,35 & 0,01 & & 1,60 & 0,02 & ${ }^{* *}$ & 2,46 & 0,02 & ** & 1,96 \\
\hline $\begin{array}{c}\text { Tamanho_LN(Ativo } \\
\text { Total) }\end{array}$ & 0,06 & & 0,72 & 0,03 & & 0,35 & 0,17 & & 1,04 & 0,23 & & 1,20 & 0,06 & & 0,71 & 0,03 & & 0,34 & 0,17 & & 1,03 & 0,23 & & 1,20 & 0,09 & & 0,96 & 0,06 & & 0,66 & 0,17 & & 1,08 & 0,23 & & 1,27 \\
\hline $\begin{array}{l}\text { Investidores } \\
\text { Institucionais }\end{array}$ & $-0,34$ & & $-0,61$ & $-0,14$ & & $-0,24$ & $-1,51$ & & $-1,57$ & $-1,87$ & * & $-1,87$ & $-0,28$ & & $-0,49$ & $-0,10$ & & $-0,16$ & $-1,51$ & & $-1,60$ & $-1,84$ & * & $-1,91$ & $-0,49$ & & $-0,91$ & $-0,36$ & & $-0,61$ & $-1,56$ & & $-1,66$ & $-1,91$ & $*$ & $-1,95$ \\
\hline $\begin{array}{l}\text { Alavancagem } \\
\text { Financeira }\end{array}$ & $-2,72$ & & $-1,59$ & $-2,98$ & $*$ & $-1,66$ & $-3,42$ & & $-1,01$ & $-3,27$ & & $-0,93$ & $-2,75$ & * & $-1,64$ & $-3,17$ & * & $-1,73$ & $-3,38$ & & $-0,99$ & $-3,24$ & & $-0,91$ & $-2,98$ & * & $-1,71$ & $-3,27$ & * & $-1,70$ & $-3,38$ & & $-1,05$ & $-3,18$ & & $-0,95$ \\
\hline $\begin{array}{l}\text { Folga Financeira } \\
\text { LN(CAPEX) }\end{array}$ & $\begin{array}{l}-0,14 \\
-0,02\end{array}$ & ** & $\begin{array}{l}-2,45 \\
-1,02\end{array}$ & $\begin{array}{l}-0,11 \\
-0,01\end{array}$ & ** & $\begin{array}{l}-2,08 \\
-0,31\end{array}$ & $\begin{array}{r}-0,13 \\
-0,02\end{array}$ & ** & $\begin{array}{l}-2,25 \\
-0,65\end{array}$ & $\begin{array}{l}-0,13 \\
-0,03\end{array}$ & *** & $\begin{array}{l}-2,26 \\
-0,62\end{array}$ & $\begin{array}{l}-0,15 \\
-0,02\end{array}$ & $* * *$ & $\begin{array}{l}-2,70 \\
-0,97\end{array}$ & $\begin{array}{c}-0,13 \\
0,00\end{array}$ & $* *$ & $\begin{array}{l}-2,26 \\
-0,23\end{array}$ & $\begin{array}{l}-0,13 \\
-0,02\end{array}$ & $* *$ & $\begin{array}{l}-2,29 \\
-0,63\end{array}$ & $\begin{array}{r}-0,13 \\
-0,02\end{array}$ & $* *$ & $\begin{array}{l}-2,37 \\
-0,57\end{array}$ & $\begin{array}{l}-0,13 \\
-0,03\end{array}$ & $* * *$ & $\begin{array}{l}-2,57 \\
-1,16\end{array}$ & $\begin{array}{l}-0,11 \\
-0,01\end{array}$ & $* *$ & $\begin{array}{l}-2,06 \\
-0,49\end{array}$ & $\begin{array}{l}-0,12 \\
-0,02\end{array}$ & $* *$ & $\begin{array}{l}-2,12 \\
-0,70\end{array}$ & $\begin{array}{l}-0,13 \\
-0,02\end{array}$ & $* *$ & $\begin{array}{l}-2,14 \\
-0,56\end{array}$ \\
\hline $\begin{array}{l}\text { Novo Mercado e Nível } \\
2\end{array}$ & 0,35 & & 0,97 & 0,28 & & 0,69 & 0,85 & & 1,46 & 0,87 & & 1,32 & 0,37 & & 1,03 & 0,23 & & 0,55 & 0,83 & & 1,50 & 0,87 & & 1,38 & 0,07 & & 0,19 & $-0,07$ & & $-0,16$ & 0,79 & & 1,33 & 0,81 & & 1,17 \\
\hline Adquirente Serial & $-0,32$ & & $-0,73$ & $-0,40$ & & $-0,85$ & $-0,73$ & & $-1,27$ & $-0,76$ & & $-1,11$ & $-0,36$ & & $-0,84$ & $-0,47$ & & $-1,00$ & $-0,75$ & & $-1,33$ & $-0,77$ & & $-1,18$ & $-0,48$ & & $-1,03$ & $-0,57$ & & $-1,09$ & $-0,76$ & & $-1,16$ & $-0,83$ & & $-1,05$ \\
\hline $\begin{array}{l}\text { Aquisição } \\
\text { Internacional }\end{array}$ & $-0,98$ & $* * *$ & $-2,60$ & $-0,86$ & ** & $-2,04$ & $-1,42$ & $* *$ & $-2,39$ & $-1,34$ & $* *$ & $-2,10$ & $-1,01$ & $* * *$ & $-2,72$ & $-0,87$ & $* *$ & $-2,11$ & $-1,43$ & $* *$ & $-2,35$ & $-1,35$ & $* *$ & $-2,07$ & $-0,99$ & $* * *$ & $-2,66$ & $-0,86$ & $* *$ & $-2,05$ & $-1,44$ & $* *$ & $-2,39$ & $-1,37$ & $* *$ & $-2,18$ \\
\hline _cons & 0,31 & & 0,19 & 0,17 & & 0,09 & 0,13 & & 0,04 & $-0,64$ & & $-0,17$ & 0,24 & & 0,15 & 0,14 & & 0,07 & 0,05 & & 0,01 & $-0,66$ & & $-0,17$ & 0,71 & & 0,45 & 0,67 & & 0,35 & 0,21 & & 0,06 & $-0,57$ & & $-0,15$ \\
\hline $\mathrm{N}$ & & 355 & & & 290 & & & 187 & & & 175 & & & 355 & & & 290 & & & 187 & & & 175 & & & 355 & & & 290 & & & 187 & & & 175 & \\
\hline $\mathrm{F}$ & & 1,76 & & & 1,70 & & & 2,89 & & & 2,54 & & & 1,91 & & & 1,92 & & & 2,85 & & & 2,51 & & & 2,20 & & & 1,99 & & & 2,90 & & & 2,53 & \\
\hline $\mathrm{R}^{\wedge} 2$ & & 0,05 & & & 0,05 & & & 0,14 & & & 0,14 & & & 0,05 & & & 0,05 & & & 0,14 & & & 0,14 & & & 0,06 & & & 0,06 & & & 0,14 & & & 0,14 & \\
\hline
\end{tabular}

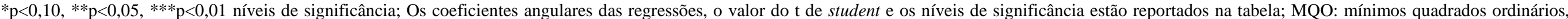

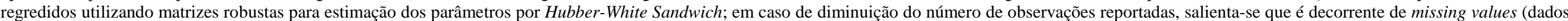
faltantes); CAR: cumulative abnormal return, em que o primeiro valor refere-se à janela de evento e a segunda nomenclatura ao benchmark de retorno de mercado utilizado.

Fonte: Elaborado pelo autor.

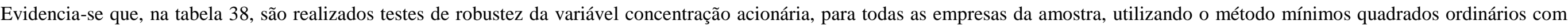

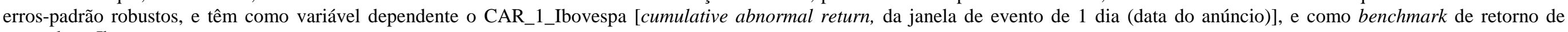
mercado, o Ibovespa.

Encontrou-se que a variável propriedade concentrada alta tem relação negativa com o CAR_1_Ibovespa, e significantes estatisticamente nos modelos 9 e 10 (ambos p<0.10).

Os resultados das demais variáveis coadunam com os achados já reportados anteriormente.

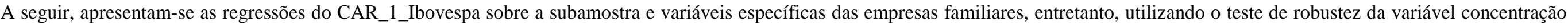
acionária. 


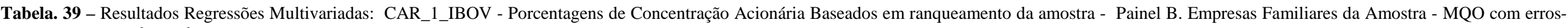
padrão robustos

\begin{tabular}{|c|c|c|c|c|c|c|c|c|c|c|c|c|c|c|c|c|c|c|c|c|c|c|c|c|c|c|c|c|c|c|c|c|c|c|c|c|}
\hline \multirow{2}{*}{ Variáveis } & \multirow{2}{*}{\multicolumn{3}{|c|}{ Modelo 1 }} & \multirow{2}{*}{\multicolumn{3}{|c|}{ Modelo 2 }} & \multicolumn{3}{|c|}{ Modelo 3} & \multicolumn{3}{|c|}{ Modelo 4} & \multicolumn{3}{|c|}{ Modelo 5} & \multicolumn{3}{|c|}{ Modelo 6} & \multicolumn{3}{|c|}{ Modelo 7} & \multicolumn{3}{|c|}{ Modelo 8} & \multicolumn{3}{|c|}{ Modelo 9 } & \multicolumn{3}{|c|}{ Modelo 10} & \multicolumn{3}{|c|}{ Modelo 11} & \multicolumn{3}{|c|}{ Modelo 12} \\
\hline & & & $t$ & & & $t$ & $B$ & & $t$ & $B$ & & $t$ & $B$ & & $t$ & $B$ & & $t$ & 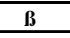 & & $\mathbf{t}$ & $B$ & & $t$ & $B$ & & $\mathrm{t}$ & $\mathbf{B}$ & & $t$ & B & & $t$ & B & & $t$ \\
\hline $1^{\mathrm{a}} \mathrm{e} 2^{\mathrm{a}}$ Geração Familiar & 0,84 & & 1,40 & 0,96 & & 1,52 & 0,49 & & 0,75 & 0,27 & & 0,36 & 0,79 & & 1,29 & 0,92 & & 1,45 & 0,50 & & 0,76 & 0,31 & & 0,42 & 0,65 & & 1,09 & 0,77 & & 1,23 & 0,41 & & 0,61 & 0,22 & & 0,29 \\
\hline $\begin{array}{c}\text { Familia na } \\
\text { Administração }\end{array}$ & 0,32 & & 0,73 & 0,34 & & 0,77 & 0,56 & & 0,75 & 0,61 & & 0,74 & 0,34 & & 0,78 & 0,37 & & 0,82 & 0,55 & & 0,78 & 0,59 & & 0,76 & 0,38 & & 0,83 & 0,40 & & 0,86 & 0,70 & & 0,84 & 0,77 & & 0,81 \\
\hline $\begin{array}{c}\text { Propriedade } \\
\text { Concentrada_Alta }\end{array}$ & & & & & & & & & & & & & & & & & & & & & & & & & $-0,76$ & & $-1,05$ & $-0,79$ & & $-0,98$ & $-0,92$ & & $-0,75$ & $-1,12$ & & $-0,72$ \\
\hline $\begin{array}{c}\text { Propriedade } \\
\text { Concentrada_Média }\end{array}$ & & & & & & & & & & & & & 0,18 & & 0,41 & 0,18 & & 0,42 & 0,00 & & 0,00 & $-0,03$ & & $-0,04$ & & & & & & & & & & & & \\
\hline $\begin{array}{c}\text { Propriedade } \\
\text { Concentrada_Baixa }\end{array}$ & 0,13 & & 0,21 & 0,15 & & 0,24 & 0,17 & & 0,23 & 0,23 & & 0,28 & & & & & & & & & & & & & & & & & & & & & & & & \\
\hline $\begin{array}{l}\text { Poder_Controladores_ } \\
\text { Conselho }\end{array}$ & & & & $-0,49$ & & $-0,60$ & $-0,11$ & & $-0,09$ & $-0,24$ & & $-0,20$ & & & & $-0,53$ & & $-0,66$ & $-0,08$ & & $-0,07$ & $-0,21$ & & $-0,18$ & & & & $-0,68$ & & $-0,76$ & $-0,21$ & & $-0,18$ & $-0,36$ & & $-0,29$ \\
\hline $\begin{array}{l}\text { Índice_Stake_Control } \\
\text { adores/Blockholders }\end{array}$ & & & & & & & $-0,01$ & & $-0,38$ & $-0,01$ & & $-0,35$ & & & & & & & $-0,01$ & & $-0,42$ & $-0,01$ & & $-0,43$ & & & & & & & 0,00 & & 0,12 & 0,01 & & 0,19 \\
\hline Índice_remuneração_v & & & & & & & & & & & & & & & & & & & & & & & & & & & & & & & & & & & & \\
\hline $\begin{array}{l}\text { ariávele por } \\
\text { ações/remuneração } \\
\text { total }\end{array}$ & & & & & & & & & & 0,05 & & 0,04 & & & & & & & & & & $-0,01$ & & $-0,01$ & & & & & & & & & & 0,25 & & 0,21 \\
\hline Q de Tobin & $-0,25$ & & $-0,98$ & $-0,22$ & & $-0,86$ & $-0,30$ & & $-0,87$ & $-0,29$ & & $-0,81$ & $-0,25$ & & $-0,98$ & $-0,21$ & & $-0,86$ & $-0,29$ & & $-0,87$ & $-0,28$ & & $-0,82$ & $-0,25$ & & $-0,99$ & $-0,22$ & & $-0,90$ & $-0,30$ & & $-0,92$ & $-0,30$ & & $-0,87$ \\
\hline $\begin{array}{l}\text { Indústria } \\
\text { Manufatureira }\end{array}$ & 0,32 & & 0,67 & 0,51 & & 1,04 & 0,87 & & 1,22 & 0,81 & & 0,97 & 0,29 & & 0,61 & 0,49 & & 1,00 & 0,85 & & 1,21 & 0,81 & & 0,97 & 0,25 & & 0,51 & 0,45 & & 0,91 & 0,92 & & 1,28 & 0,86 & & 1,02 \\
\hline Idade & 0,02 & **** & 2,94 & 0,02 & **** & 2,99 & 0,02 & $* *$ & 1,97 & 0,02 & & 1,24 & 0,02 & **** & 2,77 & 0,02 & $* * *$ & 2,79 & 0,02 & * & 1,94 & 0,02 & & 1,29 & 0,02 & $* * *$ & 2,61 & 0,02 & $* * *$ & 2,60 & 0,02 & & 1,56 & 0,01 & & 0,90 \\
\hline $\begin{array}{c}\text { Tamanho_LN(Ativo } \\
\text { Total) }\end{array}$ & 0,11 & & 0,92 & 0,11 & & 0,93 & 0,20 & & 1,08 & 0,24 & & 1,12 & 0,11 & & 0,93 & 0,11 & & 0,94 & 0,19 & & 1,05 & 0,23 & & 1,08 & 0,14 & & 1,13 & 0,15 & & 1,14 & 0,19 & & 1,08 & 0,22 & & 1,12 \\
\hline $\begin{array}{l}\text { Investidores } \\
\text { Institucionais }\end{array}$ & $-0,19$ & & $-0,31$ & $-0,19$ & & $-0,28$ & $-0,82$ & & $-0,74$ & $-1,04$ & & $-0,86$ & $-0,14$ & & $-0,22$ & $-0,14$ & & $-0,20$ & $-0,78$ & & $-0,70$ & $-0,94$ & & $-0,80$ & $-0,30$ & & $-0,51$ & $-0,34$ & & $-0,53$ & $-0,87$ & & $-0,76$ & $-1,14$ & & $-0,94$ \\
\hline $\begin{array}{l}\text { Alavancagem } \\
\text { Financeira }\end{array}$ & $-3,00$ & & $-1,39$ & $-2,73$ & & $-1,25$ & $-4,31$ & & $-1,14$ & $-4,45$ & & $-1,11$ & $-3,02$ & & $-1,43$ & $-2,77$ & & $-1,29$ & $-4,26$ & & $-1,12$ & $-4,43$ & & $-1,08$ & $-3,17$ & & $-1,44$ & $-2,90$ & & $-1,29$ & $-4,11$ & & $-1,15$ & $-4,14$ & & $-1,12$ \\
\hline $\begin{array}{l}\text { Folga Financeira } \\
\text { LN(CAPEX) }\end{array}$ & $\begin{array}{l}-0,14 \\
0,00\end{array}$ & *** & $\begin{array}{l}-2,10 \\
0,15\end{array}$ & $-0,15$ & *** & $-2,14$ & $\begin{array}{l}-0,09 \\
-0,03\end{array}$ & & $-0,97$ & $-0,08$ & & $-0,71$ & $-0,15$ & *** & $-2,30$ & $-0,16$ & ** & $-2,25$ & $-0,10$ & & $-1,12$ & $-0,09$ & & $-0,90$ & $-0,14$ & ** & $\begin{array}{r}-2,05 \\
018\end{array}$ & $\begin{array}{r}-0,15 \\
-000\end{array}$ & $* *$ & $-2,09$ & $\begin{array}{r}-0,08 \\
-008\end{array}$ & & $\begin{array}{r}-0,82 \\
-051\end{array}$ & $-0,06$ & & $-0,55$ \\
\hline $\begin{array}{c}\text { Novo Mercado e Nível } \\
2\end{array}$ & 0,63 & & 1,17 & $\begin{array}{l}0,00 \\
0,54\end{array}$ & & $\begin{array}{l}-0,09 \\
0,98\end{array}$ & $\begin{array}{l}-0,03 \\
0,57\end{array}$ & & $\begin{array}{l}-0,62 \\
0,80\end{array}$ & $\begin{array}{l}-0,04 \\
0,62\end{array}$ & & $\begin{array}{l}-0,79 \\
0,75\end{array}$ & $\begin{array}{l}0,01 \\
0,61\end{array}$ & & $\begin{array}{l}0,25 \\
1,07\end{array}$ & $\begin{array}{l}0,00 \\
0,52\end{array}$ & & $\begin{array}{l}0,00 \\
0,89\end{array}$ & $\begin{array}{l}-0,02 \\
0,60\end{array}$ & & $\begin{array}{l}-0,55 \\
0,92\end{array}$ & $\begin{array}{l}-0,04 \\
0,66\end{array}$ & & 0,87 & $\begin{array}{l}0,00 \\
0,36\end{array}$ & & $\begin{array}{l}0,18 \\
0,62\end{array}$ & $\begin{array}{l}0,00 \\
0,26\end{array}$ & & $\begin{array}{l}-0,09 \\
0,43\end{array}$ & $\begin{array}{c}-0,02 \\
0,41\end{array}$ & & 0,54 & $\begin{array}{l}-0,03 \\
0,39\end{array}$ & & $\begin{array}{r}-0,59 \\
0,40\end{array}$ \\
\hline Adquirente Serial & $-0,61$ & & $-1,10$ & $-0,50$ & & $-0,88$ & $-0,69$ & & $-0,94$ & $-0,79$ & & $-0,84$ & $-0,63$ & & $-1,19$ & $-0,52$ & & $-0,95$ & $-0,71$ & & $-0,98$ & $-0,79$ & & $-0,89$ & $-0,70$ & & $-1,21$ & $-0,60$ & & $-0,98$ & $-0,82$ & & $-0,95$ & $-1,01$ & & $-0,88$ \\
\hline $\begin{array}{c}\text { Aquisição } \\
\text { Internacional }\end{array}$ & $-1,02$ & *** & $-2,12$ & $-1,03$ & ** & $-2,16$ & $-1,44$ & ** & $-2,25$ & $-1,38$ & $*$ & $-1,92$ & $-1,04$ & *** & $-2,18$ & $-1,05$ & ** & $-2,22$ & $-1,44$ & ** & $-2,19$ & $-1,39$ & * & $-1,90$ & $-1,06$ & ** & $-2,24$ & $-1,08$ & *** & $-2,29$ & $-1,53$ & ** & $-2,30$ & $-1,47$ & ** & $-2,08$ \\
\hline _cons & $-1,61$ & & $-0,65$ & $-1,73$ & & $-0,66$ & $-1,14$ & & $-0,28$ & $-1,05$ & & $-0,24$ & $-1,60$ & & $-0,63$ & $-1,71$ & & $-0,64$ & $-1,10$ & & $-0,25$ & $-0,98$ & & $-0,22$ & $-1,32$ & & $-0,53$ & $-1,33$ & & $-0,50$ & $-0,78$ & & $-0,18$ & $-0,53$ & & $-0,11$ \\
\hline $\mathrm{N}$ & & 226 & & & 222 & & & 160 & & & 150 & & & 226 & & & 222 & & & 160 & & & 150 & & & 226 & & & 222 & & & 160 & & & 150 & \\
\hline $\mathrm{F}$ & & 1,87 & & & 1,84 & & & 2,76 & & & 2,45 & & & 1,90 & & & 1,85 & & & 2,76 & & & 2,42 & & & 1,90 & & & 1,85 & & & 2,76 & & & 2,44 & \\
\hline $\mathrm{R}^{\wedge} 2$ & & 0,09 & & & 0,09 & & & 0,15 & & & 0,15 & & & 0,09 & & & 0,09 & & & 0,15 & & & 0,15 & & & 0,10 & & & 0,10 & & & 0,15 & & & 0,15 & \\
\hline
\end{tabular}

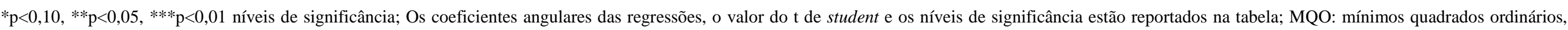

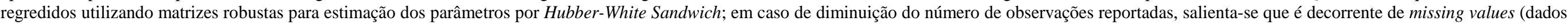
faltantes); CAR: cumulative abnormal return, em que o primeiro valor refere-se à janela de evento e a segunda nomenclatura ao benchmark de retorno de mercado utilizado.

Fonte: Elaborado pelo autor.

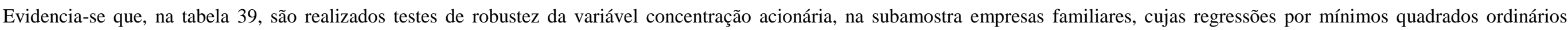

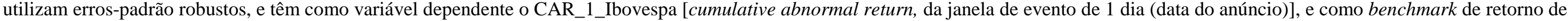
mercado, o Ibovespa.

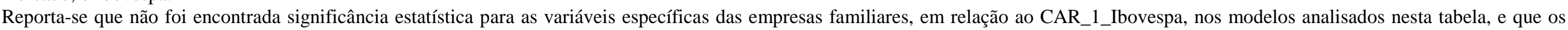
resultados das demais variáveis coadunam com os achados já reportados anteriormente.

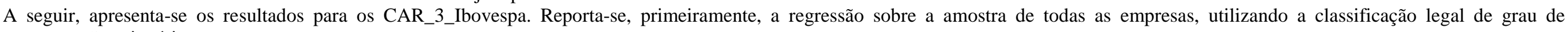
concentração acionária. 
Tabela. 40 - Resultados Regressões Multivariadas: CAR_3_IBOV - Porcentagens de Concentração Acionária Baseadas em legislação societária - Painel A. Todas Empresas da Amostra - MQO com erros-padrão robustos

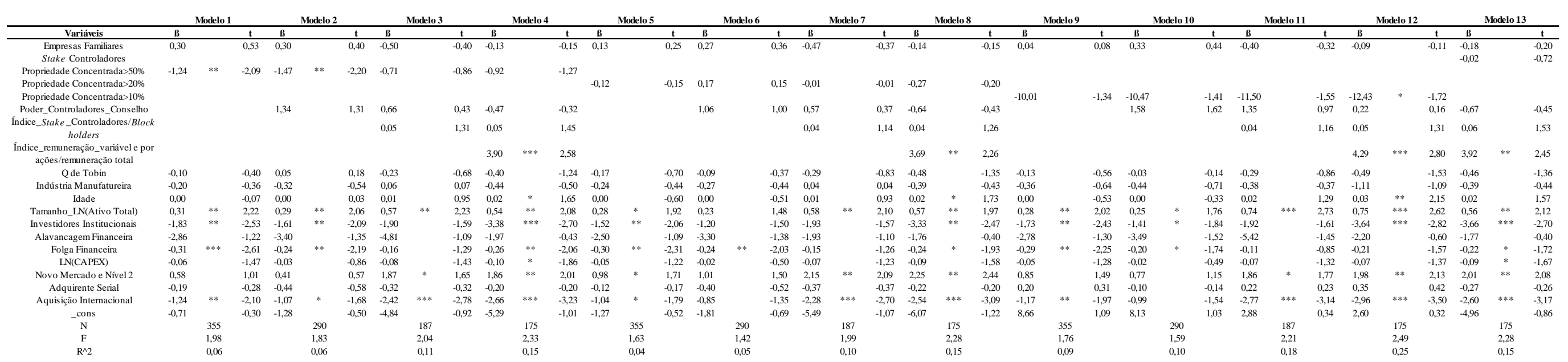

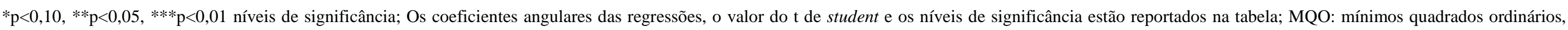

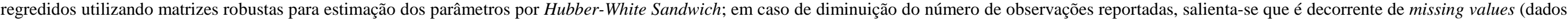
faltantes); CAR: cumulative abnormal return, em que o primeiro valor refere-se à janela de evento e a segunda nomenclatura ao benchmark de retorno de mercado utilizado.

Fonte: Elaborado pelo autor.

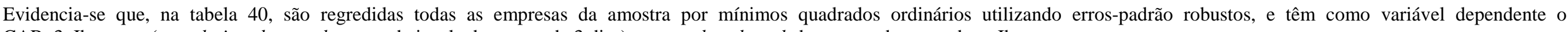
CAR_3_Ibovespa (cumulative abnormal return, da janela de evento de 3 dias), e como benchmark de retorno de mercado, o Ibovespa.

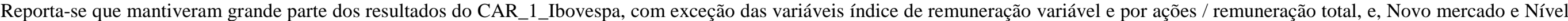
2 de governança corporativa, que tiveram relações positivas com o CAR_3_Ibovespa e significantes estatisticamente em modelos diversos.

Outrossim, evidencia-se que a variável CAPEX tem relação negativa com o CAR_3_Ibovespa, e significante estatisticamente em modelos diversos analisados.

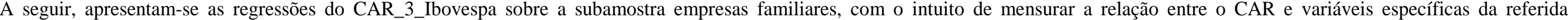
subamostra. 
Tabela. 41 - Resultados Regressões Multivariadas: CAR_3_IBOV - Porcentagens de Concentração Acionária Baseadas em legislação societária - Painel B. Empresas Familiares da Amostra MQO com erros-padrão robustos

\begin{tabular}{|c|c|c|c|c|c|c|c|c|c|c|c|c|c|c|c|c|c|c|c|c|c|c|c|c|c|c|c|c|c|c|c|c|c|c|c|c|c|c|c|}
\hline & & Modelo 1 & & & Modelo 22 & & & Modelo 3 & & & Modelo 4 & & & Modelo 5 & & & Modelo 6 & & & Modelo 7 & & & Modelo 8 & & & Modelo 9 & & & Modelo 10 & & & Modelo 11 & & & Modelo 12 & & & Modelo 1 . & \\
\hline 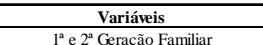 & $\frac{B}{0.16}$ & & $\frac{t}{0.14}$ & $\begin{array}{l}\boldsymbol{B} \\
0.32 \\
\end{array}$ & & $\frac{\mathbf{t}}{0.28}$ & $\frac{B}{-0.20}$ & & $\frac{\mathrm{t}}{-0.14}$ & $\begin{array}{c}\mathbf{B} \\
0.68\end{array}$ & & $\frac{\mathbf{t}}{0.42}$ & $\frac{B}{0.24}$ & & $\frac{\mathrm{t}}{0.22}$ & $\frac{\beta}{0.42}$ & & $\frac{t}{0.38}$ & $\frac{B}{-0.09}$ & & $\frac{\mathbf{t}}{-0.06}$ & $\frac{B}{0.81}$ & & $\frac{\mathbf{t}}{0.53}$ & $\frac{B}{0.16}$ & & $\frac{t}{0.15}$ & $\begin{array}{ll}\boldsymbol{B} \\
0.32\end{array}$ & & $\frac{\mathbf{t}}{0.29}$ & $\frac{\mathbf{B}}{-0.36}$ & & $\frac{t}{-0.26}$ & $\begin{array}{ll}\boldsymbol{B} \\
0.28\end{array}$ & & $\frac{\mathbf{t}}{0.18}$ & $\begin{array}{l}\mathbf{B} \\
0.67\end{array}$ & & $\frac{t}{0.41}$ \\
\hline Famlia na Administração & 1,37 & ** & 2,20 & 1,54 & *** & 2,40 & 1,89 & * & 1,91 & 1,06 & & 1,40 & $\begin{array}{l}1,66 \\
1,66\end{array}$ & $* * *$ & 2,72 & $\begin{array}{l}1,85 \\
1,85\end{array}$ & $* * *$ & $\begin{array}{l}2,38 \\
2,91\end{array}$ & $\begin{array}{l}-, 1,09 \\
1,97\end{array}$ & ** & 2,03 & $\begin{array}{l}1,81 \\
1,45\end{array}$ & & $\begin{array}{l}1,33 \\
1,47\end{array}$ & $\begin{array}{l}1,160 \\
1,61\end{array}$ & $* * *$ & 2,71 & 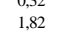 & $* * *$ & $\begin{array}{l}2,295 \\
295-19\end{array}$ & 1.,95 & ** & $\begin{array}{l}-2,10 \\
2,19\end{array}$ & $\begin{array}{l}0,152 \\
1,52\end{array}$ & * & $\begin{array}{l}1,167 \\
1,67\end{array}$ & $\begin{array}{l}0,42 \\
1,42\end{array}$ & & $\begin{array}{l}0,41 \\
1,40\end{array}$ \\
\hline $\begin{array}{c}\text { Stake Controladores } \\
\text { Propriedade Concentrada }>50 \%\end{array}$ & -0.87 & & $-1,22$ & -0.91 & & -128 & -078 & & -0.94 & .056 & & $-0.49 \quad>$ & & & & & & & & & & & & & & & & & & & & & & & & & $-0,01$ & & $-0,38$ \\
\hline 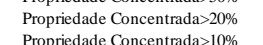 & & & & & & & & & & & & & 0,64 & & 0,53 & 0,67 & & 0,55 & 0,15 & & 0,12 & 0,10 & & 0,08 & & & & & & & & & & & & & & & \\
\hline 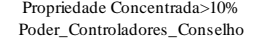 & & & & 1,25 & & 1,03 & 0.24 & & 0,15 & $-0,43$ & & -0.27 & & & & 1,20 & & 0,97 & 0,32 & & 0,19 & $-0,42$ & & $-0,25$ & $-10,35$ & & $-1,40$ & - $\begin{array}{l}-11,28 \\
2,02\end{array}$ & $*$ & $\begin{array}{l}-1,55 \\
1,69\end{array}$ & - $\begin{array}{c}-12,25 \\
1,23\end{array}$ & * & $\begin{array}{l}-1,74 \\
0,84\end{array}$ & $\begin{array}{l}-12,35 \\
0.60\end{array}$ & ${ }^{*}$ & $\begin{array}{l}-1,73 \\
0,41\end{array}$ & -0.52 & & $-0,31$ \\
\hline $\begin{array}{l}\text { Indice_Stake_Controladores/Block } \\
\text { holder }\end{array}$ & & & & & & & 0,05 & & 1,31 & 0,05 & & 1,38 & & & & & & & 0,04 & & 1,09 & 0,04 & & 1,23 & & & & & & & 0,04 & & 1,10 & 0,05 & & 1,34 & 0,06 & & 1,26 \\
\hline Índice_remuneração__variávele por & & & & & & & & & & 3,44 & * & 1,77 & & & & & & & & & & 2,96 & * & 1,65 & & & & & & & & & & 3,79 & *** & 2.07 & 3.36 & ${ }^{*}$ & 1,67 \\
\hline Q de Tobin & $-0,10$ & & $-0,33$ & 0.05 & & 0,17 & $-0,27$ & & -0.68 & -0.61 & & -1.61 & -0.15 & & -0.51 & 0.00 & & 0.00 & -0.29 & & $-0,72$ & -0.61 & & -1.53 & -0.08 & & -0.27 & 0.08 & & 0.28 & -0.25 & & -0.68 & -0.58 & * & $-1,66$ & -0.64 & & -1.55 \\
\hline Indústria Manufatureira & $-0,08$ & & $-0,11$ & 0,05 & & 0,07 & 0,79 & & 0,67 & 0,81 & & 0.59 & $-0,06$ & & $-0,09$ & 0,08 & & 0,10 & 0,83 & & 0,68 & 0.94 & & 0,71 & $-0,24$ & & $-0,32$ & $-0,20$ & & $-0,26$ & 0,15 & & 0,13 & $-0,20$ & & $-0,14$ & 0,85 & & 0,63 \\
\hline Idade & 0,01 & & 0,84 & 0,01 & & 0,79 & 0,02 & & 0,93 & 0,02 & & 1,01 & 0,01 & & 0,80 & 0,01 & & 0,73 & 0,02 & & 0,95 & 0,02 & & 1,26 & 0,01 & & 1,09 & 0,01 & & 1,07 & 0,02 & & 1,52 & 0,03 & ${ }^{*}$ & 1,69 & 0,02 & & 1,04 \\
\hline Tamanho_LN(Ativo Total) & 0,28 & & 1,52 & 0,30 & ${ }^{*}$ & 1,67 & 0.56 & ** & 2,00 & 0,47 & * & 1,66 & 0,22 & & 1,13 & 0,25 & & 1,25 & 0,56 & ${ }^{*}$ & 1,88 & 0,46 & & 1,54 & 0,28 & 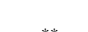 & 1,51 & 0,31 & * & 1,70 & 0,74 & $* * *$ & 2,67 & 0,66 & *** & 2,26 & 0,48 & * & 1,73 \\
\hline Investidores Institucionais & $-1,75$ & ** & $-2,17$ & $-1,40$ & * & $-1,70$ & $-0,86$ & & $-0,54$ & $-1,81$ & & $-1,00$ & $-1,37$ & * & & $-1,00$ & & $-1,21$ & $\begin{array}{l}-0,73 \\
537\end{array}$ & & $-0,45$ & $-1,47$ & & $-0,82$ & $-1,75$ & ${ }^{* *}$ & & $-1,28$ & & $-1,60$ & $\begin{array}{c}-0,88 \\
587\end{array}$ & & -0.56 & $-2,27$ & & $-1,27$ & $-1,94$ & & $-0,96$ \\
\hline $\begin{array}{l}\text { Alavancagem Financeira } \\
\text { Folga Financeira }\end{array}$ & $\begin{array}{l}-1,58 \\
-021\end{array}$ & $*$ & $\begin{array}{l}-0,57 \\
-1,67\end{array}$ & $\begin{array}{l}-2,14 \\
-0,14\end{array}$ & & $\begin{array}{l}-0,75 \\
-1,2 \\
-12\end{array}$ & $\begin{array}{r}-5,41 \\
-0,04\end{array}$ & & $\begin{array}{l}-1,17 \\
-0.28\end{array}$ & $\begin{array}{l}-3,09 \\
-0,16\end{array}$ & & $\begin{array}{l}-0,64 \\
-1,03 \\
-103\end{array}$ & $\begin{array}{l}-1,48 \\
-0.21\end{array}$ & & $\begin{array}{l}-0,57 \\
-1,57\end{array}$ & $\begin{array}{l}-2,110 \\
-0,14\end{array}$ & & $\begin{array}{l}-0,78 \\
-0,08\end{array}$ & $\begin{array}{l}-5,37 \\
-0.03 \\
-0.03\end{array}$ & & $\begin{array}{l}-1,18 \\
-022\end{array}$ & $\begin{array}{l}-3,22 \\
-0,15 \\
-12\end{array}$ & & $\begin{array}{l}-0,67 \\
-0.09\end{array}$ & $-1,59$ & & $-0,67$ & $-2,34$ & & $-0,95$ & $-5,87$ & & $-1,61$ & $-3,02$ & & $-0,80$ & $-2,96$ & & $-0,65$ \\
\hline $\begin{array}{l}\text { Fogga ananceria } \\
\text { LN(CAPEX) }\end{array}$ & $\begin{array}{l}-0,01 \\
-0,03\end{array}$ & & $\begin{array}{l}-1,61 \\
-0,74\end{array}$ & $\begin{array}{l}-0,14 \\
-0,02 \\
-0.4\end{array}$ & & $\begin{array}{l}-1,12 \\
-0,63\end{array}$ & $\begin{array}{l}-0,04 \\
-0,11\end{array}$ & * & $\begin{array}{l}-0,28 \\
-1,71\end{array}$ & $\begin{array}{l}-0,11 \\
-0,11\end{array}$ & * & $\begin{array}{l}-1,05 \\
-1,71 \\
-12\end{array}$ & $\begin{array}{l}-0,21 \\
-0,02\end{array}$ & & $\begin{array}{l}-1,71 \\
-0,48\end{array}$ & $\begin{array}{l}-0,014 \\
-0,01\end{array}$ & & $\begin{array}{l}-1,08 \\
-0,37\end{array}$ & $\begin{array}{l}-0,03 \\
-0,10\end{array}$ & & $\begin{array}{l}-0,22 \\
-1,51\end{array}$ & $\begin{array}{l}-0,13 \\
-0,11\end{array}$ & & $\begin{array}{l}-1,09 \\
-1,61\end{array}$ & $\begin{array}{l}-0,20 \\
-0,02\end{array}$ & & $\begin{array}{l}-1,45 \\
-0,56\end{array}$ & $\begin{array}{l}-0,10 \\
-0,01\end{array}$ & & $\begin{array}{l}-0,11 \\
-0,34\end{array}$ & - $0 ., 10$ & * & $\begin{array}{l}0,09 \\
-1,64\end{array}$ & $\begin{array}{l}-0,09 \\
-0,09\end{array}$ & & $\begin{array}{l}-0,63 \\
-1,43\end{array}$ & $\begin{array}{l}-0,13 \\
-0,11\end{array}$ & * & $\begin{array}{l}-0,80 \\
-1,65\end{array}$ \\
\hline Novo Mercado e Nível2 2 & 0,51 & & 0,57 & 0,36 & & & 0,98 & & $\begin{array}{l}-1,11 \\
0,85\end{array}$ & $\begin{array}{l}-0,81 \\
1,82\end{array}$ & & 37 & $0,0,02$ & & $\begin{array}{l}40 \\
01\end{array}$ & 0 & & & ${ }_{1,35}^{-1,10}$ & & $\begin{array}{l}-1,27 \\
1,27\end{array}$ & 2,09 & ${ }^{*}$ & & 0,66 & & & & & 0,57 & 0,95 & & & 1,77 & & & $\begin{array}{l}-0,11 \\
1,92 \\
-1\end{array}$ & & 1,54 \\
\hline Adquirente Serial & -0.04 & & -0.62 & -0.46 & & -0.08 & -0.013 & & - & $\begin{array}{l}-0.29 \\
-0.29\end{array}$ & & $\begin{array}{ll}-0.21 \\
-121\end{array}$ & - & & 47 & -0.38 & & -0.04 & $\begin{array}{lll}-0,18 & \end{array}$ & & 16 & $\begin{array}{l}-0,17 \\
-0.17\end{array}$ & & 13 & -0.06 & & 09 & 01 & & $02, \quad 2 \quad$ & 0,062 & & 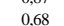 & 0.44 & & 0.44 & - & & $\begin{array}{l}1,04 \\
-0,21\end{array}$ \\
\hline qquisicãô Intermacional & $-1,59$ & *** & $-2,39$ & $-1,57$ & *** & $\begin{array}{l}-2,36 \\
-2,36\end{array}$ & $-2,66$ & **** & $\begin{array}{l}-3,05 \\
-3,05\end{array}$ & -2.59 & ${ }_{* * *}^{*}$ & $\begin{array}{ll}-2,91 \\
-2,93\end{array}$ & $-1,49$ & ** & $\begin{array}{ll}-2,25 \\
-1,25\end{array}$ & $\begin{array}{l}-1,40 \\
-1,47\end{array}$ & ** & $\begin{array}{lll}-2,23 \\
-1,23\end{array}$ & $\begin{array}{lll}-2,40 \\
-249\end{array}$ & ${ }_{* * *}^{*}$ & $-2,91$ & $-2,56$ & ${ }_{* * *}^{*}$ & $\begin{array}{ll}-2,91 \\
-191\end{array}$ & $\begin{array}{l}-1,69 \\
-1,69 \\
-10\end{array}$ & ** & $\begin{array}{l}-2,48 \\
-2,48\end{array}$ & $-1,66$ & $* *$ & $\begin{array}{l}-2,47 \\
-2,47\end{array}$ & $\begin{array}{l}0,062 \\
-3,12\end{array}$ & $* * *$ & $\begin{array}{l}-3,50 \\
-3,55 \\
0\end{array}$ & $\begin{array}{l}-3,00 \\
-3,40\end{array}$ & $* * *$ & $-3,33$ & $-2,59$ & **** & $\begin{array}{lll}-2,294 \\
-0,21\end{array}$ \\
\hline _cons & $\begin{array}{l}-1,99 \\
-1,99 \\
2\end{array}$ & & $-0,47$ & $-3,56$ & & 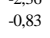 & $-5,84$ & & $-0,83$ & $\begin{array}{ccc}-2,51 \\
-6,19\end{array}$ & & $\begin{array}{l}-0,87 \\
-0,37\end{array}$ & 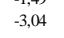 & & $-0,76$ & 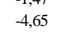 & & $\begin{array}{l}-1,16 \\
\end{array}$ & $\begin{array}{l}-2,9,9 \\
-6,4\end{array}$ & & $-1,09$ & $-7,33$ & & $-1,17$ & $\begin{array}{l}7,0,05 \\
7,05\end{array}$ & & $\begin{array}{l}0,460 \\
0,83\end{array}$ & 5,80 & & 0,70 & 2,17 & & 0,24 & 1,76 & & 0,20 & $-6,42$ & & $-0,81$ \\
\hline $\begin{array}{l}\mathrm{N} \\
\mathrm{F}\end{array}$ & & $\begin{array}{l}226 \\
1726\end{array}$ & & & $\begin{array}{l}2222 \\
1722\end{array}$ & & & $\begin{array}{l}160 \\
183\end{array}$ & & & $\begin{array}{l}150 \\
201\end{array}$ & & & $\begin{array}{l}226 \\
157\end{array}$ & & & $\begin{array}{l}222 \\
1.55\end{array}$ & & & $\begin{array}{l}160 \\
175\end{array}$ & & & $\begin{array}{l}150 \\
200\end{array}$ & & & 226 & & & 222 & & & $\begin{array}{l}160 \\
2160\end{array}$ & & & $\begin{array}{l}150 \\
227\end{array}$ & & & 1500 & \\
\hline $\begin{array}{c}F \\
\mathrm{R}^{\wedge} 2\end{array}$ & & $\begin{array}{l}1,72 \\
0,09\end{array}$ & & & $\begin{array}{l}1,72 \\
0,10\end{array}$ & & & $\begin{array}{l}1,83 \\
0.15\end{array}$ & & & $\begin{array}{l}2,01 \\
0,17\end{array}$ & & & 0.09 & & & 0,10 & & & $\begin{array}{l}1,15 \\
0.15\end{array}$ & & & $\begin{array}{l}2,00 \\
0,17\end{array}$ & & & 0,15 & & & $\begin{array}{l}1,10 \\
0,17\end{array}$ & & & $\begin{array}{l},, 10 \\
0,25\end{array}$ & & & $\begin{array}{l}2,27 \\
0,28\end{array}$ & & & $\begin{array}{l}2,00 \\
0,17\end{array}$ & \\
\hline
\end{tabular}

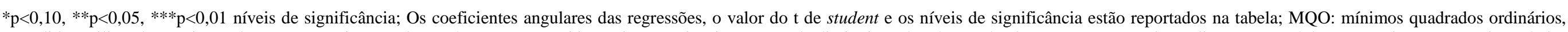

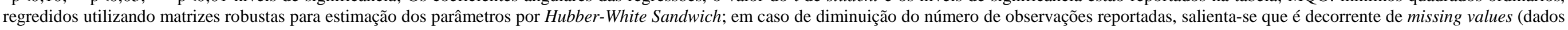
faltantes); CAR: cumulative abnormal return, em que o primeiro valor refere-se à janela de evento e a segunda nomenclatura ao benchmark de retorno de mercado utilizado.

Fonte: Elaborado pelo autor.

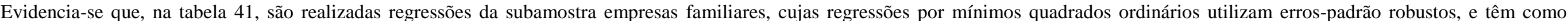
variável dependente o CAR_3_Ibovespa (cumulative abnormal return, da janela de evento de 3 dias), e como benchmark de retorno de mercado, o Ibovespa.

Encontrou-se que a variável família na administração tem relação positiva, e significante, reiteradamente, para modelos diversos analisados.

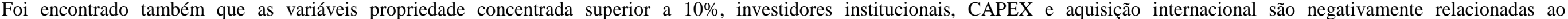
CAR_3_Ibovespa, e significantes estatisticamente para modelos diversos analisados.

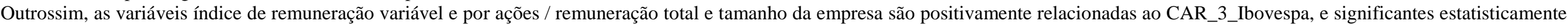
para modelos diversos analisados.

A seguir, apresentam-se as regressões do CAR_3_Ibovespa sobre toda a amostra, entretanto, utilizando o teste de robustez da variável concentração acionária. 
Tabela. 42 - Resultados Regressões Multivariadas: CAR_3_IBOV - Porcentagens de Concentração Acionária Baseados em ranqueamento da amostra - Painel A. Todas Empresas da Amostra MQO com erros-padrão robustos

\begin{tabular}{|c|c|c|c|c|c|c|c|c|c|c|c|c|c|c|c|c|c|c|c|c|c|c|c|c|c|c|c|c|c|c|c|c|c|c|c|c|}
\hline & & Modelo & & & Modelo 2 & & & Modelo 3 & & & Modelo 4 & & & Model 05 & & & Modelo 6 & & & Modelo 7 & & & Modelo 8 & & & Modelo 9 & & & Modelo 10 & & & Modelo 11 & & & Modelo 12 & \\
\hline $\begin{array}{l}\text { Variáveis } \\
\end{array}$ & $\mathbf{B}$ & & $t$ & B & & $t$ & $\bar{B}$ & & $t$ & $B$ & & $\mathrm{t}$ & B & & $\mathrm{t}$ & B & & $t$ & $B$ & & $t$ & B & & $t$ & B & & $\mathrm{t}$ & 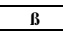 & & $\mathrm{t}$ & $\bar{B}$ & & $t$ & $\bar{B}$ & & $\mathrm{t}$ \\
\hline $\begin{array}{l}\text { Empresas Familiares } \\
\text { Propriedade Concentrads }\end{array}$ & 0,10 & & 0,19 & 0,27 & & 0,36 & $-0,45$ & & $-0,36$ & $-0,09$ & & $-0,09$ & 0,13 & & 0,24 & 0,33 & & 0,43 & $-0,39$ & & $-0,31$ & $-0,01$ & & $-0,01$ & $\begin{array}{c}0,22 \\
-088\end{array}$ & & 0,40 & 0,32 & & 0,42 & $-0,48$ & & $-0,38$ & $-0,05$ & & $-0,06$ \\
\hline Propriedade Concentrada_Média & & & & & & & & & & & & & 0,00 & & $-0,01$ & 0,33 & & 0,59 & 0,26 & & 0,29 & 0,18 & & 0,20 & & & & & & & & & & & & \\
\hline Propriedade Concentrada_Baixa & 0,48 & & 0,68 & 0,00 & & 0,00 & $-0,06$ & & $-0,06$ & 0,02 & & 0,02 & & & & & & & & & & & & & & & & & & & & & & & & \\
\hline Poder_Controladores_Consellho & & & & 1,04 & & 1,00 & 0,58 & & 0,36 & $-0,63$ & & $-0,41$ & & & & 0,99 & & 0,99 & 0,59 & & 0,38 & $-0,62$ & & $-0,41$ & & & & 0,87 & & 0,82 & 0,52 & & 0,34 & $-0,69$ & & $-0,48$ \\
\hline $\begin{array}{l}\text { Indice_Stake_Controladores/Block } \\
\text { holders }\end{array}$ & & & & & & & 0,04 & & 1,10 & 0,04 & & 1,23 & & & & & & & 0,04 & & 1,15 & 0,04 & & 1,21 & & & & & & & 0,05 & & 1,31 & 0,05 & & 1,37 \\
\hline $\begin{array}{l}\text { Índice_remuneracăão_variáavele por } \\
\text { acōes/remuneracăât total }\end{array}$ & & & & & & & & & & 3,59 & ** & 2,36 & & & & & & & & & & 3,58 & ** & 2,43 & & & & & & & & & & 3,73 & *** & 2,51 \\
\hline Q de Tobin & $-0,16$ & & $-0,65$ & $-0,09$ & & $-0,36$ & $-0,29$ & & $-0,79$ & $-0,47$ & & $-1,28$ & $-0,17$ & & $-0,70$ & $-0,09$ & & $-0,36$ & $-0,28$ & & $-0,78$ & $-0,46$ & & $-1,30$ & $-0,19$ & & $-0,76$ & $-0,10$ & & $-0,38$ & $-0,29$ & & $-0,84$ & $-0,48$ & & $-1,38$ \\
\hline Indústria Manufatureira & $-0,23$ & & $-0,43$ & $-0,25$ & & $-0,41$ & 0,03 & & 0,03 & $-0,41$ & & $-0,44$ & $-0,26$ & & $-0,48$ & $-0,30$ & & $-0,51$ & 0,03 & & 0,03 & $-0,39$ & & $-0,42$ & $-0,34$ & & $-0,60$ & $-0,33$ & & $-0,53$ & 0,06 & & 0,06 & $-0,37$ & & $-0,41$ \\
\hline Idade & 0,00 & & $-0,46$ & 0,00 & & $-0,46$ & 0,01 & & 0,90 & 0,02 & * & 1,66 & 0,00 & & $-0,60$ & 0,00 & & $-0,54$ & 0,01 & & 0,86 & 0,02 & & 1,62 & 0,00 & & $-0,68$ & 0,00 & & $-0,49$ & 0,01 & & 0,88 & 0,02 & & 1,54 \\
\hline Tamanho_LN(Ativo Total) & 0,28 & *** & 2,00 & 0,24 & * & 1,65 & 0,58 & *** & 2,19 & 0,54 & ** & 2,01 & 0,27 & * & 1,94 & 0,24 & * & 1,69 & 0,57 & *** & 2,19 & 0,53 & *** & 2,02 & 0,29 & *** & 2,10 & 0,27 & * & 1,80 & 0,58 & ** & 2,27 & 0,55 & $* *$ & 2,12 \\
\hline Investidores Institucionais & $-1,63$ & ** & $-2,18$ & $-1,23$ & & $-1,50$ & $-1,91$ & & $-1,51$ & $-3,28$ & ** & $-2,33$ & $-1,50$ & *** & $-2,02$ & $-1,21$ & & $-1,53$ & $-1,88$ & & $-1,52$ & $-3,23$ & *** & $-2,40$ & $-1,68$ & *** & $-2,35$ & $-1,42$ & * & $-1,84$ & $-2,04$ & $*$ & $-1,69$ & $-3,42$ & **** & $-2,65$ \\
\hline Alavancagem Financeira & $-2,57$ & & $-1,10$ & $-3,24$ & & $-1,31$ & $-4,68$ & & $-1,04$ & $-1,84$ & & $-0,39$ & $-2,51$ & & $-1,09$ & $-3,39$ & & $-1,35$ & $-4,57$ & & $-1,01$ & $-1,76$ & & $-0,37$ & $-2,75$ & & $-1,16$ & $-3,45$ & & $-1,33$ & $-4,51$ & & $-1,04$ & $-1,64$ & & $-0,36$ \\
\hline Folga Financeira & $-0,29$ & *** & $-2,25$ & $-0,23$ & *** & $-2,04$ & $-0,16$ & & $-1,34$ & $-0,25$ & *** & $-2,05$ & $-0,31$ & *** & $-2,36$ & $-0,24$ & *** & $-2,09$ & $-0,16$ & & $-1,37$ & $-0,25$ & *** & $-2,08$ & $-0,29$ & ** & $-2,41$ & $-0,23$ & $* *$ & $-2,03$ & $-0,15$ & & $-1,20$ & $-0,24$ & $*$ & $-1,90$ \\
\hline LN(CAPEX) & $-0,05$ & & $-1,25$ & $-0,02$ & & $-0,53$ & $-0,07$ & & $-1,21$ & $-0,09$ & . & $-1,56$ & $-0,05$ & 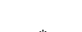 & $-1,20$ & $-0,02$ & & $-0,51$ & $-0,06$ & 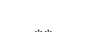 & $-1,15$ & $-0,08$ & 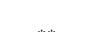 & $-1,46$ & $-0,05$ & & $-1,32$ & $-0,02$ & & $-0,65$ & $-0,07$ & & $-1,28$ & $-0,08$ & & $-1,51$ \\
\hline Novo Mercado e Nível 2 & 0,88 & & 1,50 & 1,00 & & 1,43 & 2,16 & *** & 2,05 & 2,25 & *** & 2,40 & 1,00 & * & 1,74 & 0,93 & & 1,38 & 2,15 & $* *$ & 2,10 & 2,24 & *** & 2,45 & 0,71 & & 1,18 & 0,71 & & 0,96 & 2,01 & $*$ & 1,92 & 2,10 & $* *$ & 2,18 \\
\hline $\begin{array}{l}\text { Adquirente Serial } \\
\text { a }\end{array}$ & $-0,11$ & * & $-0,16$ & $-0,42$ & & $-0,56$ & $-0,38$ & $* * *$ & $-0,39$ & $-0,18$ & $* * *$ & $-0,18$ & $-0,10$ & 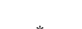 & $-0,15$ & $-0,48$ & & $-0,62$ & $-0,43$ & 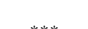 & $-0,43$ & $-0,22$ & 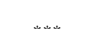 & $-0,23$ & $-0,25$ & 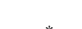 & $-0,34$ & $-0,55$ & & $-0,69$ & $-0,50$ & . & $-0,47$ & $-0,34$ & 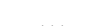 & $-0,32$ \\
\hline $\begin{array}{l}\text { Aquisiç̧ăo Intermacional } \\
\text { cons }\end{array}$ & $\begin{array}{l}-1,00 \\
-1,41\end{array}$ & & $\begin{array}{l}-1,71 \\
-0.59\end{array}$ & $\begin{array}{l}-0,85 \\
-1,79\end{array}$ & & $\begin{array}{l}-1,34 \\
-0,71\end{array}$ & $\begin{array}{r}-2,28 \\
-5,48\end{array}$ & F**** & $\begin{array}{l}-2,68 \\
-1,05\end{array}$ & $\begin{array}{l}-2,54 \\
-5,96\end{array}$ & F**** & $\begin{array}{l}-3,02 \\
-1,17 \\
-12\end{array}$ & $\begin{array}{r}-1,04 \\
-1,30\end{array}$ & & $\begin{array}{l}-1,78 \\
-0.54\end{array}$ & $\begin{array}{c}-0,86 \\
-1,85\end{array}$ & & $\begin{array}{l}-1,36 \\
-0.71\end{array}$ & $\begin{array}{l}-2,31 \\
-5,66 \\
\end{array}$ & & $\begin{array}{l}-2,65 \\
-1,05\end{array}$ & $\begin{array}{l}-2,56 \\
-6,06 \\
\end{array}$ & & $\begin{array}{l}-2,998 \\
-1,14\end{array}$ & $\begin{array}{l}-1,04 \\
-0.07\end{array}$ & & $\begin{array}{l}-1,79 \\
-0,41\end{array}$ & $\begin{array}{l}-0,85 \\
-1.42 \\
-142\end{array}$ & & $\begin{array}{l}-1,34 \\
-0.54\end{array}$ & $\begin{array}{l}-2,37 \\
-5,23\end{array}$ & ${ }^{* * * * *}$ & $\begin{array}{l}-2,700 \\
-1.00\end{array}$ & $\begin{array}{l}-2,61 \\
-5,80 \\
-\end{array}$ & ***** & $\begin{array}{l}-3,08 \\
-1,14 \\
-12\end{array}$ \\
\hline-1 & & 355 & & & 290 & & & 187 & & & 175 & & & 355 & & & 290 & & & 187 & & & 175 & & & 355 & & & 290 & & & 187 & & & 175 & \\
\hline $\mathrm{F}$ & & 1,64 & & & 1,42 & & & 1,99 & & & 2,30 & & & 1,65 & & & 1,45 & & & 2,00 & & & 2,33 & & & 1,74 & & & 1,46 & & & 1,97 & & & 2,29 & \\
\hline $\mathrm{R}^{\wedge} 2$ & & 0,05 & & & & & & & & & 0,15 & & & & & & & & & & & & & & & & & & & & & & & & 0,15 & \\
\hline
\end{tabular}

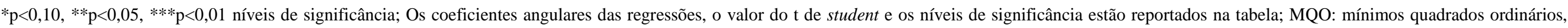

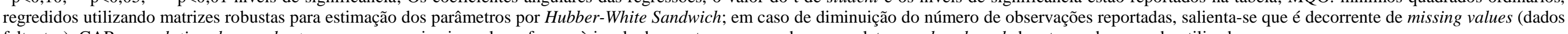
faltantes); CAR: cumulative abnormal return, em que o primeiro valor refere-se à janela de evento, e a segunda nomenclatura ao benchmark de retorno de mercado utilizado.

Fonte: Elaborado pelo autor.

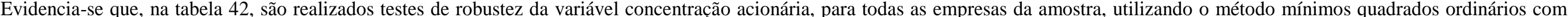

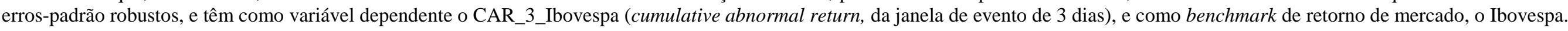
Informa-se que os resultados encontrados, nessa tabela, coadunam com os achados já reportados anteriormente.

A seguir, apresentam-se as regressões do CAR_3_Ibovespa sobre a subamostra empresas familiares, entretanto, utilizando o teste de robustez da variável concentração acionária. 
Tabela. 43 - Resultados Regressões Multivariadas: CAR_3_IBOV - Porcentagens de Concentração Acionária Baseadas em ranqueamento da amostra - Painel B. Empresas Familiares da Amostra - MQO com erros-padrão robustos

\begin{tabular}{|c|c|c|c|c|c|c|c|c|c|c|c|c|c|c|c|c|c|c|c|c|c|c|c|c|c|c|c|c|c|c|c|c|c|c|c|c|}
\hline & & Lodelo & & & Modelo 2 & & & Modelo3 & & & Modelo 4 & & & Modelo 5 & & & Modelo 6 & & & Model 7 & & & Modelo 8 & & & Modelo 9 & & & Modelo 10 & & & Modelo 11 & & & Modelo 12 & \\
\hline $\begin{array}{l}\text { Variáveis } \\
\end{array}$ & B & & $\mathrm{t}$ & B & & $t$ & B & & $t$ & B & & $\mathrm{t}$ & B & & $t$ & $\begin{array}{c}B \\
24\end{array}$ & & $t$ & $\begin{array}{l}B \\
B\end{array}$ & & $t$ & B & & $t$ & $B$ & & $t$ & $B$ & & $t$ & $\begin{array}{l}B \\
B 02\end{array}$ & & $t$ & $\begin{array}{ll}B \\
50\end{array}$ & & $t$ \\
\hline $1^{\mathrm{a} e} 2^{\mathrm{a}}$ Geração Familiar & $\overline{0,21}$ & & 0,19 & 0,39 & & 0,35 & $-0,12$ & & $-0,08$ & 0,74 & & 0,48 & 0,14 & & 0,13 & 0,34 & & 0,30 & $-0,10$ & & $-0,07$ & 0,81 & & 0,52 & $-0,07$ & & $-0,06$ & 0,20 & & 0,17 & $-0,32$ & & $-0,23$ & 0,59 & & 0,38 \\
\hline Família na Administração & 1,58 & $* *$ & 2,56 & 1,75 & **** & 2,77 & 1,97 & * & 1,93 & 1,47 & & 1,37 & 1,61 & **** & 2,62 & 1,78 & $* * *$ & 2,82 & 1,93 & *** & 1,97 & 1,44 & & 1,41 & 1,67 & $* * *$ & 2,68 & 1,81 & **** & 2,82 & 2,28 & ** & 2,09 & 1,85 & & 1,56 \\
\hline $\begin{array}{l}\text { Propriedade Concentrada_Alta } \\
\text { Propredade Concentrada Médie }\end{array}$ & & & & & & & & & & & & & 0.21 & & 031 & 020 & & 030 & -009 & & - & 012 & & 013 & $-1,07$ & & $-1,00$ & $-0,79$ & & $-0,69$ & $-2,23$ & & $-1,09$ & $-2,58$ & & $-1,16$ \\
\hline $\begin{array}{l}\text { Propredadec Concentrada_Media } \\
\text { Propriedade Concentrada_Baixa }\end{array}$ & 0,26 & & 0,30 & 0,12 & & 0,14 & 0,52 & & 0,51 & 0,32 & & 0.28 & & & & & & & & & & & & & & & & & & & & & & & & \\
\hline Poder_Controladores_Conselho & & & & 1,16 & & 0,96 & 0,21 & & 0,12 & $-0,48$ & & $-0,29$ & & & & 1,12 & & 0,94 & 0,30 & & 0,18 & $-0,44$ & & $-0,27$ & & & & 0,98 & & 0,77 & $-0,02$ & & $-0,01$ & $-0,79$ & & $-0,49$ \\
\hline $\begin{array}{l}\text { Indice_Stake_Controladores/Block } \\
\text { holders }\end{array}$ & & & & & & & 0,04 & & 1,17 & 0,05 & & 1,28 & & & & & & & 0,04 & & 1,05 & 0,04 & & 1,21 & & & & & & & 0,07 & & 1,46 & 0,08 & & 1,59 \\
\hline $\begin{array}{l}\text { Índice_remunneração_variávele por } \\
\text { acōes/remuneracão total }\end{array}$ & & & & & & & & & & 3,07 & * & 1,76 & & & & & & & & & & 2,99 & * & 1,78 & & & & & & & & & & 3,57 & ** & 2,02 \\
\hline Q de Tobin & $-0,15$ & & $-0,51$ & $-0,01$ & & $-0,05$ & $-0,34$ & & $-0,79$ & $-0,64$ & & $-1,52$ & $-0,14$ & & $-0,48$ & 0,00 & & $-0,01$ & $-0,30$ & & $-0,74$ & $-0,61$ & & $-1,55$ & $-0,14$ & & $-0,47$ & $-0,01$ & & $-0,03$ & $-0,32$ & & $-0,79$ & $-0,68$ & * & $-1,70$ \\
\hline Indústria Manufatureira & 0,02 & & 0,02 & 0,15 & & 0,20 & 0,89 & & 0,76 & 0,92 & & 0,69 & $-0,02$ & & $-0,03$ & 0,13 & & 0,17 & 0,84 & & 0,71 & 0,95 & & 0,71 & $-0,09$ & & $-0,12$ & 0,09 & & 0,12 & 1,01 & & 0,86 & 1,03 & & 0,78 \\
\hline Idade & 0,01 & & 0,87 & 0,01 & & 0,79 & 0,02 & & 1,01 & 0,02 & & 1,23 & 0,01 & & 0,76 & 0,01 & & 0,71 & 0,02 & & 0,97 & 0,02 & & 1,23 & 0,01 & & 0,67 & 0,01 & & 0,66 & 0,01 & & 0,71 & 0,02 & & 0,88 \\
\hline Tamanho_LN(Ativo Total) & 0,26 & & 1,44 & 0,29 & & 1,58 & 0,59 & *** & 2,11 & 0,49 & * & 1,72 & 0,26 & & 1,42 & 0,29 & & 1,59 & 0,57 & *** & 2,07 & 0,47 & * & 1,68 & 0,31 & & 1,62 & 0,33 & * & 1,68 & 0,58 & $* *$ & 2,18 & 0,47 & $*$ & 1,79 \\
\hline Investidores Instituciona & $-1,54$ & * & $-1,87$ & $-1,15$ & & $-1,34$ & $-0,88$ & & $-0,54$ & $-1,65$ & & $-0,89$ & $-1,45$ & * & $-1,77$ & $-1,11$ & & $-1,32$ & $-0,77$ & & $-0,46$ & $-1,46$ & & $-0,81$ & $-1,67$ & *** & $-2,12$ & $-1,31$ & & $-1,59$ & $-0,97$ & & $-0,61$ & $-1,98$ & & $-1,15$ \\
\hline Alavancagem Financeira & $-1,38$ & & $-0,51$ & $-1,95$ & & $-0,70$ & $-5,49$ & & $-1,16$ & $-3,24$ & & $-0,64$ & $-1,40$ & & $-0,52$ & $-1,99$ & & $-0,72$ & $-5,39$ & & $-1,12$ & $-3,14$ & & $-0,61$ & $-1,62$ & & $-0,58$ & $-2,12$ & & $-0,74$ & $-4,97$ & & $-1,10$ & $-2,56$ & & $-0,53$ \\
\hline Folga Financeira & $-0,19$ & & $-1,43$ & $-0,12$ & & $-0,98$ & $-0,01$ & & $-0,07$ & $-0,14$ & & $-0,86$ & $-0,20$ & & $-1,52$ & $-0,13$ & & $-1,02$ & $-0,03$ & & $-0,19$ & $-0,16$ & & $-1,00$ & $-0,18$ & & $-1,39$ & $-0,12$ & & $-0,94$ & 0,02 & & 0,10 & $-0,10$ & & $-0,57$ \\
\hline LN(CAPE & $-0,02$ & & $-0,60$ & $-0,02$ & & $-0,47$ & $-0,11$ & & $-1,61$ & $-0,11$ & ${ }^{*}$ & $-1,64$ & $-0,02$ & & $-0,51$ & $-0,02$ & & $-0,42$ & $-0,10$ & & $-1,52$ & $-0,11$ & & $-1,54$ & $-0,02$ & & $-0,57$ & $-0,02$ & & $-0,49$ & $-0,09$ & & $-1,48$ & $-0,09$ & & $-1,39$ \\
\hline Novo Mercado e & 0,84 & & 0,96 & 0,73 & & 0,82 & 1,26 & & 1,15 & 2,04 & * & 1,80 & 0,84 & & 0,92 & 0,70 & & 77 & 1,36 & & 1,27 & 2,08 & * & 1,92 & 0, & & 0,5 & 0 , & & 0,48 & 0,91 & & 0,78 & 1,48 & & 1,19 \\
\hline Adquirente Serial & $-0,49$ & & $-0,64$ & $-0,47$ & & $-0,59$ & $-0,15$ & & $-0,14$ & $-0,19$ & & $-0,15$ & $-0,51$ & & & $-0,50$ & & & $-0,18$ & & & $-0,21$ & & $-0,18$ & $-0,62$ & & & $-0,57$ & & $-0,66$ & $-0,46$ & & $-0,39$ & $-0,68$ & & $-0,47$ \\
\hline Aquisição Internacional & $-1,47$ & *** & $-2,20$ & $-1,45$ & *** & $-2,19$ & $-2,52$ & ${ }^{* * * *}$ & $-2,90$ & $-2,55$ & **** & $-2,81$ & $-1,50$ & $* *$ & $-2,24$ & $-1,48$ & $* *$ & $-2,22$ & $-2,49$ & ${ }^{* * *}$ & $-2,80$ & $-2,58$ & ***** & $-2,78$ & $-1,53$ & $* *$ & $-2,28$ & $-1,50$ & *** & $-2,25$ & $-2,74$ & ***** & $-2,92$ & $-2,75$ & ${ }^{* * * *}$ & $-2,94$ \\
\hline $\begin{array}{c}- \text { cons } \\
\mathrm{N}\end{array}$ & $-3,04$ & 226 & $-0,77$ & $-4,60$ & 222 & $-1,16$ & $-7,16$ & 160 & $-1,11$ & $-7,47$ & 150 & $-1,17$ & $-2,97$ & 226 & $-0,75$ & $-4,59$ & 222 & $-1,14$ & $-6,99$ & 160 & $-1,05$ & $-7,43$ & 150 & $-1,13$ & $-2,59$ & 226 & $-0,65$ & $-4,22$ & 222 & $-1,04$ & $-6,25$ & 160 & $-0,97$ & $-6,32$ & 150 & $-0,98$ \\
\hline $\mathrm{F}$ & & 1,56 & & & 1,55 & & & 1,74 & & & 2,00 & & & 1,57 & & & 1,56 & & & 1,74 & & & 2,04 & & & 1,64 & & & 1,62 & & & 1,75 & & & 2,01 & \\
\hline$R^{\wedge} \wedge 2$ & & 0,09 & & & 0,10 & & & 0,15 & & & 0,17 & & & 0,09 & & & 0,10 & & & 0,15 & & & 0,17 & & & 0,09 & & & 0,10 & & & 0,16 & & & 0,18 & \\
\hline
\end{tabular}

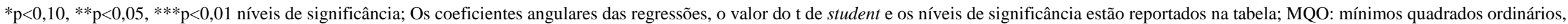

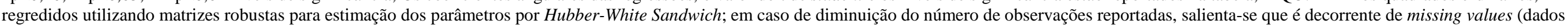
faltantes); CAR: cumulative abnormal return, em que o primeiro valor refere-se à janela de evento, e a segunda nomenclatura ao benchmark de retorno de mercado utilizado.

Fonte: Elaborado pelo autor.

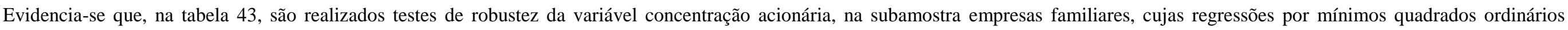

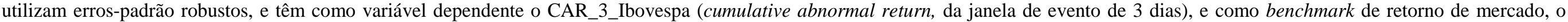
Ibovespa.

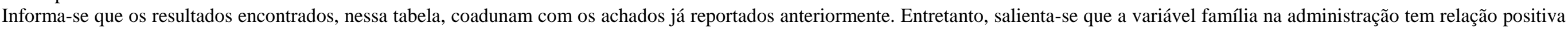
e significante ao CAR_3_Ibovespa, reiteradamente, em modelos diversos analisados.

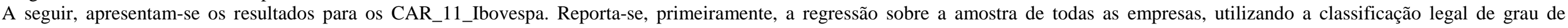
concentração acionária. 
Tabela. 44 - Resultados Regressões Multivariadas: CAR_11_IBOV - Porcentagens de Concentração Acionária Baseadas em legislação societária - Painel A. Todas Empresas da Amostra - MQO com erros-padrão robustos

\begin{tabular}{|c|c|c|c|c|c|c|c|c|c|c|c|c|c|c|c|c|c|c|c|c|c|c|c|c|c|c|c|c|c|c|c|c|c|c|c|c|c|c|}
\hline & & Modelo 1 & & & Modelo 2 & & & Modelo 3 & & & Model 04 & & Modelo 5 & & & Modelo 6 & & & Modelo 7 & & & Modelo 8 & & & Modelo9 & & & Modelo 10 & & & Modelo 11 & & & Modelo 12 & & & Modelo 1: & \\
\hline Variáreis & B & & $t$ & $B$ & & $t$ & B & & $t$ & $B$ & $\mathrm{t}$ & $B$ & & $t$ & $\mathrm{~B}$ & & $\mathrm{t}$ & 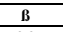 & & $\mathrm{t}$ & $B$ & & $\mathrm{t}$ & $B$ & & $\mathrm{t}$ & $B$ & & $t$ & $B$ & & $t$ & $B$ & & $t$ & B & & $\mathrm{t}$ \\
\hline $\begin{array}{l}\text { Empresas Familiares } \\
\text { Stake Controladores }\end{array}$ & $-0,07$ & & & & & & & & & 1,32 & & & & & & & & $-0,26$ & & & & & & & & & 1,02 & & & & & 0,08 & & & & 1,09 & & $\begin{array}{l}0,69 \\
-1.55\end{array}$ \\
\hline Propriedade Concentrada $>50 \%$ & $-1,62$ & & $-1,61$ & $-1,80$ & & $-1,62$ & $-2,09$ & & $-1,39$ & $-2,38$ & $-1,56$ & & & & & & & & & & & & & & & & & & & & & & & & & & & \\
\hline $\begin{array}{l}\text { Proppiridadde Concentradad }>20 \% \\
\text { Propriedade Concentrad }>0 \%\end{array}$ & & & & & & & & & & & & $-0,95$ & & $-0,74$ & $-1,67$ & & $-1,01$ & $-2,33$ & & $-1,20$ & $-1,86$ & & $-0,93$ & $-10,48$ & & $-1,08$ & $-11,27$ & & $-1,15$ & - 10.79 & & $-1,04$ & -10.74 & & $-1,01$ & & & \\
\hline Poder_Controladores_Conselho & & & & 3,52 & *** & 2,44 & 3,97 & * & 1,80 & 3,23 & 1,50 & & & & 2,98 & *** & 2,06 & 3,61 & & 1,62 & 2,75 & & 1,27 & & & & $\begin{array}{l}-1,7,7 \\
3,74\end{array}$ & $* * * *$ & 2,69 & 4,44 & ** & 2,13 & 3,56 & * & $\begin{array}{l}-1,101 \\
1,76\end{array}$ & 2,69 & & 1,25 \\
\hline Índice_Stake_Controladores/Blockholders & & & & & & & 0,06 & & 1,07 & 0,05 & 0,82 & & & & & & & 0,05 & & 0,84 & 0,03 & & 0.54 & & & & & & & 0,04 & & 0,77 & 0,03 & & 0,51 & 0,08 & & 1,32 \\
\hline 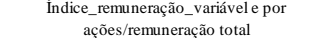 & & & & & & & & & & $-0,22$ & $-0,10$ & & & & & & & & & & $-0,32$ & & $-0,14$ & & & & & & & & & & $-0,42$ & & $-0,18$ & 0,18 & & 0,08 \\
\hline $\begin{array}{l}\text { açoestremuneracao total } \\
\text { Q de Tobin }\end{array}$ & 0,35 & & 0,80 & 0,43 & & 0,95 & 0,42 & & 0,72 & 0,47 & 0,82 & 0,29 & & 0,68 & 0,28 & & 0,64 & 0,23 & & 0,40 & 0,25 & & 0,44 & 0,29 & & 0.68 & 0,32 & & 0,73 & 0,25 & & 0,42 & 0,27 & & 0,47 & 0,33 & & 0.58 \\
\hline Indústria Manufatureira & $-1,01$ & & $-1,28$ & $-0,48$ & & $-0,56$ & 0,70 & & 0,50 & 0,63 & 0,46 & $-0,96$ & & $-1,16$ & $-0,17$ & & $-0,19$ & 0,90 & & 0,62 & 0,81 & & 0,58 & $-1,20$ & & $-1,48$ & $-0,60$ & & $-0,68$ & 0,22 & & 0,15 & 0,12 & & 0,08 & 0,77 & & 0,56 \\
\hline $\begin{array}{l}\text { Idade } \\
\text { IN }\end{array}$ & 0,00 & & 0,42 & 0,00 & & 0,29 & 0,01 & & 0,55 & 0,03 & 1,48 & 0,00 & & 0,12 & 0,00 & & 0,07 & 0,02 & & 0,68 & 0,04 & & 1,62 & 0,00 & & 0,04 & 0,00 & & $-0,01$ & 0,02 & & 0,68 & 0,04 & * & 1,73 & 0,03 & & 1,36 \\
\hline Tamanho_LN(Ativ & 0,15 & & 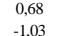 & 0,19 & & 0,81 & $-0,10$ & & $-0,25$ & $-0,25$ & - -0,60 -0. & 0,15 & & 0,62 & 0,22 & & 0.85 & 0,14 & & 0,32 & $-0,08$ & & $-0,18$ & 0,12 & & 0,54 & 0,14 & & 0,61 & 0,09 & & 0,22 & $-0,08$ & & -0,19 & $-0,20$ & & $-0,47$ \\
\hline $\begin{array}{l}\text { Investidores Institucionais } \\
\text { Alavanacagem Financeira }\end{array}$ & $\begin{array}{l}-1,13 \\
-2,89\end{array}$ & & - $-1,03$ & $\begin{array}{l}-0.32 \\
-3.36 \\
-\end{array}$ & & $\begin{array}{l}-0,27 \\
-1,06\end{array}$ & $\begin{array}{l}1,400 \\
-4,40\end{array}$ & & $\begin{array}{l}0.85 \\
-0.79\end{array}$ & $\begin{array}{l}1,98 \\
-3,38\end{array}$ & $\begin{array}{c}0.95 \\
-0.57\end{array}$ & $\begin{array}{l}-0,81 \\
-2,37\end{array}$ & & $\begin{array}{l}-0,78 \\
-0,76\end{array}$ & $\begin{array}{l}-0,13 \\
-2,73\end{array}$ & & 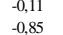 & $\begin{array}{l}1,422 \\
-3,81\end{array}$ & & $\begin{array}{l}0,74 \\
-0,70 \\
-10\end{array}$ & $\begin{array}{l}1,85 \\
-2.52 \\
\end{array}$ & & $\begin{array}{l}0.86 \\
-0.45\end{array}$ & $\begin{array}{l}-0,294 \\
-2,71\end{array}$ & & $\begin{array}{l}-0,93 \\
-0,09\end{array}$ & $\begin{array}{l}-0,04 \\
-0,62\end{array}$ & & $\begin{array}{l}-0,044 \\
-1,14\end{array}$ & $\begin{array}{l}1,55 \\
-4,75\end{array}$ & & $\begin{array}{l}0,82 \\
-0,91\end{array}$ & $\begin{array}{l}1,95 \\
-3,33\end{array}$ & & -0,63 0.03 & $\begin{array}{l}0,87 \\
-0,78\end{array}$ & & $\begin{array}{l}0,40 \\
-049\end{array}$ \\
\hline $\begin{array}{l}\text { Alavancegemfinarcerd } \\
\text { Folga Financeira }\end{array}$ & $\begin{array}{l}-2,89 \\
-0,07\end{array}$ & & $\begin{array}{l}-0.92 \\
-0.37\end{array}$ & $\begin{array}{l}-3,00 \\
0.16\end{array}$ & & $\begin{array}{l}-1,100 \\
0.96\end{array}-10$ & $\begin{array}{l}-4,22 \\
0.22\end{array}$ & & $\begin{array}{l}-0,19 \\
1.38 \\
\end{array}$ & $\begin{array}{l}-3,13 \\
0,13\end{array}$ & 0.85 & $\begin{array}{l}-2,0 / 7 \\
-0.04\end{array}$ & & $\begin{array}{l}-0,118 \\
-0,18\end{array}$ & 0,20 & & $\begin{array}{l}-0,05 \\
1.06\end{array}$ & $\begin{array}{l}-3,31 \\
0.30\end{array}$ & $*$ & $\begin{array}{l}-0,100 \\
1,67\end{array}$ & $\begin{array}{l}-2,52 \\
0.19\end{array}$ & & $\begin{array}{l}-0,45 \\
1,14\end{array}$ & $\begin{array}{l}-2,71 \\
-0.05 \\
-2\end{array}$ & & $\begin{array}{l}-0,090 \\
-0,23\end{array}$ & $\begin{array}{l}-3,32 \\
0,21 \\
0.21\end{array}$ & & $\begin{array}{l}-1,14 \\
1,15\end{array}$ & $\begin{array}{l}-4,75 \\
0,28\end{array}$ & $*$ & $\begin{array}{l}-0,01 \\
1,68\end{array}$ & $\begin{array}{l}-3,33 \\
0,18\end{array}$ & & 1.,17 & $\begin{array}{l}-2,78 \\
0.26\end{array}$ & & $\begin{array}{l}-0,49 \\
1,45\end{array}$ \\
\hline LN(CAPEX & $-0,08$ & & $-1,08$ & 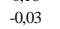 & & 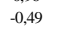 & -0,09 & & 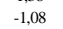 & $-0,16$ & $-1,75$ & $-0,06$ & & $-0,95$ & -0,02 & & $\begin{array}{l}1,00 \\
-0,38 \\
T\end{array}$ & $\begin{array}{l}0,00 \\
-0,08 \\
0\end{array}$ & & $\begin{array}{l}1,1,01 \\
-1,01\end{array}$ & $\begin{array}{l}0,19 \\
-0,13\end{array}$ & & $\begin{array}{l}1,14 \\
-1,55 \\
-15\end{array}$ & $\begin{array}{l}-0,06 \\
-0,06\end{array}$ & & $\begin{array}{l}-0,23 \\
-0,93\end{array}$ & $\begin{array}{l}0,01 \\
-0,01\end{array}$ & & . & $\begin{array}{l}0,28 \\
-0,06\end{array}$ & & $\begin{array}{l}1,08 \\
-0,77\end{array}$ & $\begin{array}{l}0,18 \\
-0,11\end{array}$ & & . & $\begin{array}{l}0,00 \\
-0,15\end{array}$ & ${ }^{*}$ & 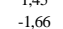 \\
\hline Novo Merca & $-1,98$ & *** & $-2,08$ & $-1,71$ & & $-1,54$ & $-0,13$ & & $-0,08$ & $-1,36$ & & $-1,55$ & * & $-1,76$ & $-1,13$ & & $-1,15$ & 0,62 & & 0,41 & $-0,35$ & & $-0,26$ & $-1,59$ & * & $-1,84$ & $-1,24$ & & $-1,29$ & 0,42 & & 0,27 & $-0,58$ & & $-0,41$ & $-1,20$ & & $-0,77$ \\
\hline Adquirente Serial & $-0,84$ & & $-0,85$ & $-1,35$ & & $-1,30$ & $-1,87$ & & $-1,36$ & $-1,19$ & $-0,88$ & $-0,84$ & & $-0,82$ & $-1,54$ & & -1,41 & $-2,21$ & & $-1,59$ & $-1,41$ & & $-0,98$ & $-0,411$ & & $-0,43$ & $-0,98$ & & $-1,00$ & $-1,49$ & & $-1,14$ & $-0,68$ & & $-0,57$ & $-1,48$ & & $-1,04$ \\
\hline Aquisição Internacional & 0,19 & & 0,21 & 0.38 & & 0,43 & 0,60 & & 0,44 & $-0,26$ & $-0,19$ & 0,48 & & 0,56 & 0,68 & & 0,77 & 0,88 & & 0,69 & 0,06 & & 0,04 & 0,31 & & 0,35 & 0,50 & & 0,56 & 0.54 & & 0,39 & $-0,31$ & & $-0,23$ & $-0,16$ & & $-0,12$ \\
\hline$\stackrel{- \text { cons }}{\mathrm{N}}$ & 2,99 & 355 & 0,72 & $-1,55$ & 290 & $-0,37$ & 0,79 & 187 & 0,10 & & 0,34 & & 355 & 0,59 & & & $-0,47$ & $-1,89$ & 187 & $-0,25$ & 0,20 & 175 & 0,03 & 12,63 & 355 & 1,19 & 8,51 & & 0,80 & 6,72 & 187 & 0,56 & 8,41 & 175 & 0,69 & 4,62 & 175 & 0,55 \\
\hline $\mathrm{F}$ & & 0,88 & & & 0,91 & & & 1,08 & & & 1,26 & & 0,73 & & & 0,82 & & & 1,07 & & & 1,19 & & & 0,81 & & & 0,92 & & & 1,15 & & & 1,27 & & & 1,14 & \\
\hline & & & & & & & & & & & & & 0,03 & & & & & & & & & & & & & & & & & & & & & 0,10 & & & & \\
\hline
\end{tabular}

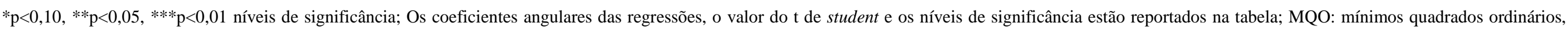

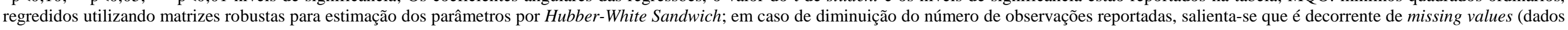
faltantes); CAR: cumulative abnormal return, em que o primeiro valor refere-se à janela de evento, e a segunda nomenclatura ao benchmark de retorno de mercado utilizado.

Fonte: Elaborado pelo autor.

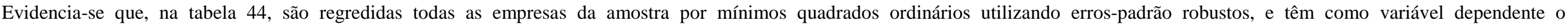
CAR_11_Ibovespa (cumulative abnormal return, da janela de evento de 11 dias), e como benchmark de retorno de mercado, o Ibovespa.

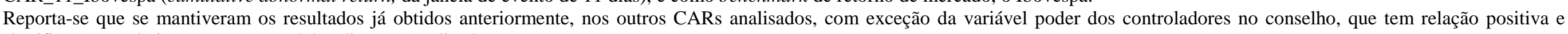
significante estatisticamente, em modelos diversos analisados.

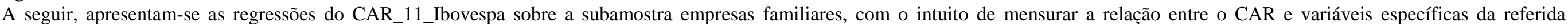
subamostra. 
Tabela. 45 - Resultados Regressões Multivariadas: CAR_11_IBOV - Porcentagens de Concentração Acionária Baseadas em legislação societária - Painel B. Empresas Familiares da Amostra MQO com erros-padrão robustos

\begin{tabular}{|c|c|c|c|c|c|c|c|c|c|c|c|c|c|c|c|c|c|c|c|c|c|c|c|c|c|c|c|c|c|c|c|c|c|c|c|c|c|c|}
\hline & & Modelo 1 & & Modelo 2 & & & Modelo 3 & & & Modelo4 & & & Modelo 5 & & & Modelo 6 & & & Modelo 7 & & & Modelo 8 & & & Modelo9 & & & Modelo 10 & & & Modelo 11 & & & Modelo 12 & & & Modelo 13 & \\
\hline 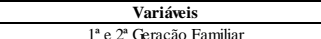 & B & $\frac{t}{t}$ & $\begin{array}{c}B \\
126\end{array}$ & & $\frac{t}{t-079}$ & $\begin{array}{c} \\
26\end{array}$ & & $t$ & $\frac{B}{B-58}$ & & $\frac{t}{t}$ & $\frac{B}{B}$ & & $\frac{t}{t}$ & B & & $\frac{t}{t}$ & B & & $\frac{t}{t}$ & $B$ & & $\frac{t}{t+1}$ & $\begin{array}{c}B \\
075\end{array}$ & & $t$ & $B$ & & $\frac{t}{t}$ & $\mathrm{~B}$ & & $t$ & $B$ & & $\frac{t}{t}$ & $B$ & & $\frac{t}{t}$ \\
\hline 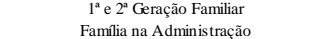 & $-0,80$ & -0.52 & $-1,26$ & & $-0,79$ & $-2,26$ & & $-1,12$ & $-0,58$ & & $-0,25$ & $-0,83$ & & -0.55 & $-1,18$ & & $-0,75$ & $-2,14$ & & $-1,09$ & $-0,46$ & & $-0,21$ & $-0,75$ & & $-0,50$ & $-1,19$ & & $-0,76$ & $-2,21$ & & $-1,14$ & $-0,71$ & & $-0,32$ & $-0,86$ & & $-0,37$ \\
\hline $\begin{array}{l}\text { Familua ana Administracaao } \\
\text { Stake Controladores }\end{array}$ & & & & & & & & & & & & & & & & & & & & & & & & & & & & & & & & & & & & $\begin{array}{l}0,06 \\
-0,05\end{array}$ & & $\begin{array}{l}0,47 \\
-1,09\end{array}$ \\
\hline 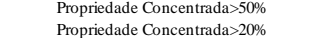 & $-1,52$ & $-1,20$ & $-1,81$ & & $-1,43$ & $-2,54$ & & $-1,57$ & $-1,59$ & & $-0,77$ & $-1,80$ & & -0.93 & $-1,79$ & & -0.92 & -2.42 & & $-1,13$ & $-1,79$ & & -0.81 & & & & & & & & & & & & & & & \\
\hline Propriedade Concentrada $>10 \%$ & & & & & & & & & & & & & & & & & & & & & & & & $-10,25$ & & $-1,02$ & $-12,28$ & & $-1,25$ & $-12,46$ & & $-1,26$ & $-11,18$ & & $-1,03$ & & & \\
\hline 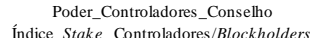 & & & 3,95 & ** & 2,36 & $\begin{array}{l}4,26 \\
0.07\end{array}$ & * & $\begin{array}{l}1,87 \\
1.26\end{array}$ & $\begin{array}{l}3,70 \\
0.05\end{array}$ & & $\begin{array}{l}1,63 \\
0.85\end{array}$ & & & & 3,67 & ** & 2,20 & $\begin{array}{l}4,10 \\
0.05\end{array}$ & * & $\begin{array}{l}1,73 \\
0.93\end{array}$ & $\begin{array}{l}3,46 \\
0.04\end{array}$ & & $\begin{array}{l}1,47 \\
0.69\end{array}$ & & & & 4,71 & **** & 2,84 & $\begin{array}{l}5,38 \\
0.05\end{array}$ & ** & $\begin{array}{l}2,50 \\
0,88\end{array}$ & $\begin{array}{l}4,62 \\
0.04\end{array}$ & ** & $\begin{array}{l}2,19 \\
0,11\end{array}$ & $\begin{array}{l}3,29 \\
0.99\end{array}$ & & $\begin{array}{l}1,40 \\
1,25\end{array}$ \\
\hline Indice_remuneração_varíavel e por & & & & & & & & & $-1,57$ & & -0.58 & & & & & & & & & & $-2,29$ & & $\begin{array}{l}-0,87 \\
-0,87\end{array}$ & & & & & & & & & & $-2,12$ & & $-0,73$ & $-1,12$ & & $\begin{array}{ll}-0,40 \\
-0,40\end{array}$ \\
\hline $\begin{array}{l}\text { açoessremunteracauo total } \\
\text { Q de Tobin }\end{array}$ & 0,33 & 0,65 & 0,38 & & 0,71 & 0,44 & & 0,63 & 0,22 & & 0,31 & 0,24 & & 0,48 & 0.24 & & 0.45 & 0,26 & & 0,37 & 0,12 & & 0,17 & 0,31 & & 0,61 & 0,36 & & 0,67 & 0,38 & & 0,54 & 0,22 & & & 0,11 & & 0,15 \\
\hline Indústria Manufatureira & $-1,02$ & $-1,04$ & $-1,53$ & & $-1,45$ & $-0,10$ & & $-0,07$ & 1,20 & & 0,66 & $-0,68$ & & $-0,666$ & $-1,15$ & & $-1,07$ & 0.26 & & 0,17 & 1,59 & & 0,87 & $-1,12$ & & $-1,11$ & $-1,72$ & & $-1,60$ & $-0,65$ & & $-0,45$ & 0,56 & & 0,29 & 1,15 & & 0,64 \\
\hline Idade & 0,02 & 1,13 & 0,02 & & 1,16 & 0,02 & & 0.92 & 0,04 & & 1,38 & 0,02 & & 1,23 & 0,02 & & 1,28 & 0,03 & & 1,24 & 0,05 & * & 1,83 & 0,02 & & 1,30 & 0,03 & & 1,38 & 0,03 & & 1,38 & 0,05 & ** & 2,00 & 0,04 & & 1,33 \\
\hline Tamanho_LN(Ati & $-0,12$ & $-0,41$ & $-0,17$ & & $-0,57$ & $-0,31$ & & -0.69 & $-0,36$ & & $-0,822$ & - -0.055 & & -0,16 & -0.09 & & -0,28 & 0,01 & & 0,022 & $-0,14$ & & $-0,28$ & $-0,13$ & & $-0,46$ & $-0,17$ & & $-0,60$ & $-0,08$ & & $-0,17$ & $-0,17$ & & & $-0,31$ & & $-0,70$ \\
\hline $\begin{array}{l}\text { Investidores Institucionais } \\
\text { Alayancagem Financeiratem }\end{array}$ & $\begin{array}{l}-1,58 \\
-032\end{array}$ & - $-1,212$ & $\begin{array}{l}-1,16 \\
-057\end{array}$ & & $-0,88$ & $\begin{array}{l}0,91 \\
-289\end{array}$ & & $\begin{array}{l}0,37 \\
-048\end{array}$ & $\begin{array}{l}3,03 \\
-383 \\
-38\end{array}$ & & 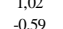 & $\begin{array}{l}-1,37 \\
0,37\end{array}$ & & - $-1,12$ & $-0,90$ & & $-0,72$ & $\begin{array}{l}0,94 \\
-235\end{array}$ & & $\begin{array}{l}0,39 \\
-040\end{array}$ & $\begin{array}{l}3,34 \\
-358\end{array}$ & & 1,20 & $-1,37$ & & $-1,18$ & -0, & & $-0,65$ & 1,15 & & 0,4 & $\begin{array}{l}3,22 \\
3.39\end{array}$ & & 1,16 & & & 0,58 \\
\hline $\begin{array}{l}\text { Alavancagem rmance } \\
\text { Folga Financeira }\end{array}$ & 0.07 & 0,41 & 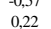 & & $\begin{array}{l}-0,19 \\
1,29\end{array}$ & $\begin{array}{l}-2,89 \\
0,31\end{array}$ & * & $\begin{array}{l}-0,48 \\
1,82\end{array}$ & $\begin{array}{l}-3.83 \\
0.20\end{array}$ & & $\begin{array}{l}-0,09 \\
1.09\end{array}$ & 0,14 & & 0.76 & $\begin{array}{l}0,28 \\
0.28\end{array}$ & & 1,54 & 0,39 & ${ }_{* *}^{*}$ & $\begin{array}{l}-, 090 \\
2,09\end{array}$ & $\begin{array}{l}-3,24 \\
0.38\end{array}$ & & $\begin{array}{l}-0,57 \\
124\end{array}$ & $-0,18$ & & $\begin{array}{l}-0,05 \\
0,56\end{array}$ & $\begin{array}{l}-0,63 \\
0,28\end{array}$ & & . & $\begin{array}{l}-3,21 \\
040\end{array}$ & $* *$ & $-0,61$ & & & $-0,70$ & -3,06 030 & & \\
\hline LN(CAPEX) & $-0,08$ & $-1,26$ & $-0,06$ & & $-0,93$ & $-0,17$ & * & - 1,95 & $-0,18$ & * & $-1,88$ & 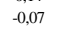 & & 作, & $-0,05$ & & -0,82 & $-0,16$ & * & $-1,83$ & -0,19 & * & $\begin{array}{l}1,24 \\
-1,87\end{array}$ & $\begin{array}{l}0,09 \\
-0,07\end{array}$ & & $\begin{array}{l}0.56 \\
-1,09 \\
-109\end{array}$ & $\begin{array}{l}0,28 \\
-0,04\end{array}$ & & 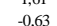 & $\begin{array}{l}0,40 \\
-0,13\end{array}$ & $*$ & $\begin{array}{l}2,21 \\
-1,68\end{array}$ & $\begin{array}{l}0,26 \\
-0,16\end{array}$ & $*$ & $\begin{array}{l}1,34 \\
-1,66\end{array}$ & . 0.30 & 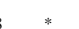 & $\begin{array}{l}1,36 \\
-1,84\end{array}$ \\
\hline Novo Mercado e Nível 2 & $-1,62$ & $-1,23$ & $-1,66$ & & $-1,28$ & $-0,58$ & & $-0,34$ & $-0,33$ & & $-0,17$ & $-1,00$ & & $-0,80$ & $-0,92$ & & $-0,74$ & 0,67 & & 0,43 & 0,52 & & 0,32 & $-1,18$ & & $-0,96$ & -1 , & & -0.94 & 0.22 & & 0,14 & $\begin{array}{l}-0,10 \\
0,17\end{array}$ & & $\begin{array}{l}-1,100 \\
0,10\end{array}$ & -0.32 & & $\begin{array}{l}-1,04 \\
-0,17\end{array}$ \\
\hline & $-1,25$ & $-1,18$ & $-1,34$ & & $-1,22$ & $-1,68$ & & $-1,14$ & -0.98 & & $-0,53$ & $-1,55$ & & $-1,29$ & $-1,61$ & & $-1,33$ & $-2,05$ & & $-1,34$ & $-0,96$ & & -0.033 & -0.85 & & -0.86 & -0 & & 87 & -1.05 & & & & & -0.08 & & & \\
\hline Aquisiçăo Intern & $-0,05$ & $-0,05$ & & & $-0,03$ & $-0,27$ & & & -0.86 & & & 0,16 & & 0,17 & 0,22 & & & 0,02 & & 0,02 & $-0,85$ & & $-0,60$ & $-0,06$ & & 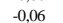 & & & -0.03 & $-0,38$ & & -0.027 & $-1,17$ & & $-0,79$ & -0.89 & & -0.062 \\
\hline _cons & 6 & $\begin{array}{l}-1,07 \\
1,07\end{array}$ & $\begin{array}{l}-, 0,03 \\
5,35\end{array}$ & & $\begin{array}{l}-, 0,03 \\
0,80\end{array}$ & $\begin{array}{l}-0,072 \\
6,36\end{array}$ & & $0,6,110$ & $\begin{array}{l}-, 0,06 \\
4,35\end{array}$ & & $\begin{array}{l}-0,39 \\
0,42\end{array}$ & $\begin{array}{l}5,10 \\
5,16\end{array}$ & & $\begin{array}{l}0,17 \\
0,88\end{array}$ & $\begin{array}{l}\text {, } 22 \\
3,62\end{array}$ & & $\begin{array}{l}0,52 \\
0,59\end{array}$ & $\begin{array}{l}1,022 \\
1,23\end{array}$ & & $\begin{array}{l}0,112 \\
0,1\end{array}$ & $\begin{array}{l}-0,0,08 \\
0,89\end{array}$ & & $\begin{array}{l}-, 0,010 \\
0,11\end{array}$ & $\begin{array}{l}-1,0,71 \\
14,1\end{array}$ & & $\begin{array}{l}-, 000 \\
1,26\end{array}$ & $\begin{array}{l}1,03 \\
14,64\end{array}$ & & $\begin{array}{l}-1,00 \\
1,28\end{array}$ & $\begin{array}{l}-, 018 \\
11,87\end{array}$ & & $\begin{array}{l}-2,21 \\
0,93\end{array}$ & $\begin{array}{l}-1,111 \\
10,11\end{array}$ & & $\begin{array}{l}-1,7) \\
0,76\end{array}$ & 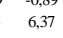 & & $\begin{array}{l}-0,022 \\
0,60\end{array}$ \\
\hline $\begin{array}{l}\mathrm{N} \\
\mathrm{F}\end{array}$ & & $\begin{array}{l}226 \\
0076\end{array}$ & & $\begin{array}{l}222 \\
107\end{array}$ & & & $\begin{array}{l}160 \\
1.40\end{array}$ & & & $\begin{array}{l}150 \\
132\end{array}$ & & & $\begin{array}{l}226 \\
0726\end{array}$ & & & $\begin{array}{l}2222 \\
103\end{array}$ & & & $\begin{array}{l}160 \\
1.39\end{array}$ & & & $\begin{array}{l}150 \\
128\end{array}$ & & & $\begin{array}{l}226 \\
0075\end{array}$ & & & $\begin{array}{r}222 \\
1,12\end{array}$ & & & $\begin{array}{l}0 \\
0 \\
2\end{array}$ & & & $\begin{array}{l}150 \\
146\end{array}$ & & & $\begin{array}{l}150 \\
117\end{array}$ & \\
\hline $\begin{array}{l}\mathrm{F} \\
\mathrm{R}^{\wedge} 2\end{array}$ & & $\begin{array}{l}0,10 \\
0,05\end{array}$ & & $\begin{array}{l}1,1 / 0 \\
0,07\end{array}$ & & & $\begin{array}{l}1,40 \\
0,11\end{array}$ & & & $\begin{array}{l}1,2,1 \\
0,10\end{array}$ & & & $\begin{array}{l}0,04 \\
0,04\end{array}$ & & & $\begin{array}{l}1,0,0 \\
0,06\end{array}$ & & & $\begin{array}{l}0,90 \\
0,10\end{array}$ & & & $\begin{array}{l}0,20 \\
0,10\end{array}$ & & & $\begin{array}{l}0,5 \\
0,07\end{array}$ & & & $\begin{array}{l}1,19 \\
0,10\end{array}$ & & & $\begin{array}{l}0,12 \\
0,13\end{array}$ & & & $\begin{array}{l}1,400 \\
0,13\end{array}$ & & & $\begin{array}{l}1,11 \\
0,11\end{array}$ & \\
\hline
\end{tabular}

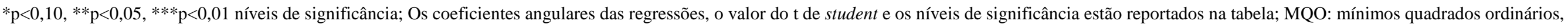

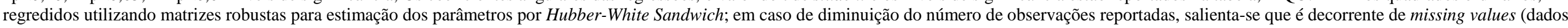
faltantes); CAR: cumulative abnormal return, em que o primeiro valor refere-se à janela de evento, e a segunda nomenclatura ao benchmark de retorno de mercado utilizado.

Fonte: Elaborado pelo autor.

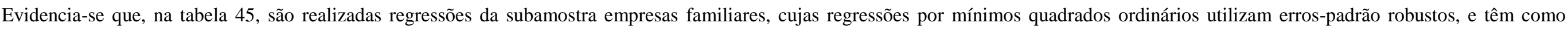
variável dependente o CAR_11_Ibovespa (cumulative abnormal return, da janela de evento de 11 dias), e como benchmark de retorno de mercado, o Ibovespa.

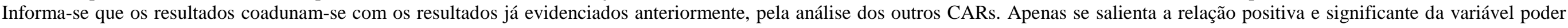
dos controladores no conselho com a variável CAR_11_Ibovespa.

A seguir, apresentam-se as regressões do CAR_11_Ibovespa sobre toda a amostra, entretanto, utilizando o teste de robustez da variável concentração acionária. 
Tabela. 46 - Resultados Regressões Multivariadas: CAR_11_IBOV - Porcentagens de Concentração Acionária Baseadas em ranqueamento da amostra - Painel A. Todas Empresas da Amostra MQO com erros-padrão robustos

\begin{tabular}{|c|c|c|c|c|c|c|c|c|c|c|c|c|c|c|c|c|c|c|c|c|c|c|c|c|c|c|c|c|c|c|c|c|c|c|c|c|}
\hline & & Modelo 1 - & & & Modelo2 2 & & & Modelo 3 & & & Modelo 4 & & & Modelo 5 & & & Modelo 6 & & & Modelo 7 & & & Modelo8 & & & Modelo 9 & & & Modelo 10 & & & Modelo 11 & & & Modelo 12 & \\
\hline $\begin{array}{l}\text { Variáveis } \\
\end{array}$ & B & & $t$ & B & & $t$ & $\begin{array}{ll}\text { B } \\
060\end{array}$ & & $t$ & $\bar{B}$ & & $t$ & $B$ & & $t$ & $\begin{array}{ll}\text { B } \\
\text { Bes }\end{array}$ & & $t$ & B & & $t$ & B & & $\frac{t}{t}$ & $\begin{array}{ll}B \\
009\end{array}$ & & $t$ & B & & $\mathrm{t}$ & $\begin{array}{c}B \\
007\end{array}$ & & $\mathrm{t}$ & $\begin{array}{ll}B \\
159\end{array}$ & & $\frac{t}{004}$ \\
\hline $\begin{array}{c}\text { Empresas Familiares } \\
\text { Ponpiedde Concentrat }\end{array}$ & $-0,37$ & & $-0,41$ & 0,76 & & 0,71 & $-0,60$ & & $-0,30$ & 0,74 & & 0,43 & $-0,31$ & & $-0,35$ & 0,84 & & 0,77 & $-0,25$ & & $-0,13$ & 0,98 & & 0,55 & $-0,09$ & & $-0,10$ & 1,01 & & 0,94 & 0,07 & & 0,04 & 1,51 & & 0,94 \\
\hline $\begin{array}{l}\text { Propriedade Concentrada_Alta } \\
\text { Propriedade Concentrada_Média }\end{array}$ & & & & & & & & & & & & & $-0,10$ & & $-0,12$ & $-0,61$ & & $-0,67$ & $-1,14$ & & -0.82 & $-1,12$ & & $-0,78$ & $-1,88$ & & $-1,61$ & $-1,01$ & & $-0,79$ & $-2,50$ & & $-1,27$ & $-1,88$ & & $-0,92$ \\
\hline Propriedade Concentrada_Baixa & 1,16 & & 1,07 & 1,61 & & 1,28 & 2,19 & & 1,42 & 1,85 & & 1,18 & & & & & & & & & & & & & & & & & & & & & & & & \\
\hline Poder_Controladores_Conselho & & & & 3,02 & ** & 2,13 & 3,43 & & 1,54 & 2,60 & & 1,20 & & & & 3,24 & ** & 2,28 & 3,63 & & & & & & & & & 2,94 & ** & 2,00 & 3,56 & * & 1,64 & & & \\
\hline Índice_Stake_Controladores/Blockholders & & & & & & & 0,06 & & 1,04 & 0,04 & & 0,74 & & & & 0,24 & & 2,20 & 0,03 & & 0,58 & 0,02 & & 0,31 & & & & 2,34 & 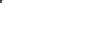 & $2, \infty$ & 0,08 & & 1,31 & 0,05 & & 0,93 \\
\hline $\begin{array}{l}\text { Índice_remuneração_varíável e por } \\
\text { acōes/remuneracaăo total }\end{array}$ & & & & & & & & & & $-0,68$ & & $-0,31$ & & & & & & & & & & $-0,99$ & & $-0,45$ & & & & & & & & & & $-0,73$ & & $-0,32$ \\
\hline $\begin{array}{l}\text { Q de Tobin } \\
\text { Thal }\end{array}$ & 0,29 & & 0,67 & 0,25 & & 0,58 & 0,14 & & 0,24 & 0,19 & & 0,33 & 0,25 & & 0,59 & 0,26 & & 0,60 & 0,19 & & 0,32 & 0,25 & & 0,42 & 0,21 & & 0,48 & 0,25 & & 0,56 & 0,23 & & 0,40 & 0,28 & & 0,47 \\
\hline Indústria Manufatureira & $-1,04$ & & $-1,30$ & $-0,29$ & & $-0,34$ & 0,74 & & 0,53 & 0,64 & & 0,46 & $-1,08$ & & $-1,33$ & $-0,28$ & & $-0,32$ & 0,64 & & 0,46 & 0,63 & & 0,46 & $-1,27$ & & $-1,53$ & $-0,50$ & & $-0,56$ & 0,69 & & 0,49 & 0,80 & & 0,58 \\
\hline Idade & 0,00 & & 0,21 & 0,00 & & 0,13 & 0,01 & & 0,63 & 0,03 & & 1,57 & 0,00 & & 0,00 & 0,00 & & $-0,01$ & 0,01 & & 0,56 & 0,03 & & 1,55 & 0,00 & & $-0,11$ & 0,00 & & $-0,13$ & 0,01 & & 0,40 & 0,03 & & 1,33 \\
\hline Tamanho_LN(Ativ & 0,13 & & 0,57 & 0,18 & & 0,76 & 0,02 & & 0,04 & $-0,16$ & & $-0,36$ & 0,11 & & 0,47 & 0,13 & & 0,55 & $-0,02$ & & $-0,06$ & $-0,20$ & & $-0,47$ & 0,16 & & 0,69 & & & 0,68 & $-0,06$ & & $-0,15$ & $-0,25$ & & $-0,62$ \\
\hline Investidores Institucionais & $-1,00$ & & $-0,94$ & $-0,34$ & & $-0,29$ & 0,92 & & 0,47 & 1,50 & & 0,69 & $-0,70$ & & & 0,11 & & & & & & 1,98 & & 0,91 & $-1,07$ & & $-1,07$ & $-0,10$ & & $-0,09$ & 1,23 & & 0,67 & 1,96 & & 0,94 \\
\hline Alavancagem Financeira & $-2,57$ & & $-0,81$ & $-3,03$ & & $-0,92$ & $-4,64$ & & $-0,82$ & $-3,38$ & & $-0,57$ & $-2,42$ & & $-0,77$ & $-3,06$ & & $-0,91$ & $-4,60$ & & $-0,80$ & $-3,48$ & & $-0,57$ & $-2,95$ & & $-0,93$ & $-3,63$ & & $-1,05$ & $-3,56$ & & $-0,64$ & $-2,62$ & & $-0,45$ \\
\hline Folga Financeira & $-0,02$ & & $-0,09$ & 0,22 & & 1,19 & 0,31 & * & 1,77 & 0,21 & & 1,23 & $-0,06$ & & $-0,28$ & 0,19 & & 1,01 & 0,27 & & 1,54 & 0,17 & & 1,04 & $-0,03$ & & $-0,18$ & 0,17 & & 0,97 & 0,26 & & 1,54 & 0,17 & & 1,10 \\
\hline LN(CAPEX) & $-0,06$ & & $-0,93$ & $-0,03$ & & $-0,46$ & $-0,09$ & & $-1,13$ & $-0,15$ & * & $-1,66$ & $-0,06$ & & $-0,87$ & $-0,022$ & & $-0,29$ & $-0,08$ & & $-0,92$ & $-0,14$ & & $-1,56$ & $-0,07$ & & $-1,02$ & $-0,02$ & & $-0,35$ & $-0,06$ & & $-0,75$ & $-0,11$ & & $-1,30$ \\
\hline Novo Mercado e Nível 2 & $-1,71$ & ${ }^{*}$ & $-1,89$ & $-1,29$ & & $-1,28$ & 0,36 & & 0,23 & $-0,58$ & & $-0,41$ & $-1,43$ & & $-1,63$ & $-0,89$ & & $-0,90$ & 0,69 & & 0,46 & $-0,30$ & & $-0,22$ & $-2,04$ & *** & $-2,21$ & $-1,37$ & & $-1,31$ & 0,30 & & 0,20 & $-0,66$ & & $-0,44$ \\
\hline Adquirente Serial & $-0,75$ & & $-0,75$ & $-1,32$ & & $-1,28$ & $-1,83$ & & $-1,36$ & $-1,03$ & & $-0,78$ & $-0,711$ & & $-0,72$ & $-1,23$ & & $-1,18$ & $-1,77$ & & $-1,30$ & $-0,87$ & & $-0,67$ & $-1,04$ & & $-0,98$ & $-1,50$ & & $-1,36$ & $-2,38$ & ${ }^{*}$ & $-1,64$ & $-1,48$ & & $-1,01$ \\
\hline Aquisição Internacional & 0,54 & & 0,61 & 0,72 & & 0,80 & 0,98 & & 0,75 & 0,15 & & 0,11 & 0,45 & & 0,52 & 0,68 & & 0,77 & 1,10 & & 0,83 & 0,20 & & 0,15 & 0,44 & & 0,51 & 0,65 & & 0,75 & 0,76 & & 0,58 & $-0,10$ & & $-0,08$ \\
\hline$-{ }_{\mathrm{N}}^{\text {cons }}$ & 1,95 & 355 & 0,47 & $-2,74$ & 290 & $-0,66$ & $-1,24$ & 187 & $-0,16$ & 0,56 & 175 & 0,07 & 2,25 & & 0,54 & $-2,07$ & & $-0,49$ & $-0,37$ & 187 & $-0,05$ & 1,67 & 175 & 0,21 & 2,91 & 355 & 0,72 & $-1,69$ & & $-0,41$ & $-0,42$ & 187 & $-0,06$ & 1,34 & 175 & 0,18 \\
\hline $\mathrm{F}$ & & 0,74 & & & 0,81 & & & $\begin{array}{l}1,08 \\
\end{array}$ & & & $\begin{array}{l}1,17 \\
\text { S }\end{array}$ & & & 0,73 & & & 0,78 & & & 1,14 & & & $\begin{array}{l}1,19 \\
\end{array}$ & & & 0,87 & & & 0,82 & & & 1,17 & & & $\begin{array}{l}1,31 \\
\end{array}$ & \\
\hline $\mathrm{R}^{\wedge} 2$ & & 0,03 & & & 0,04 & & & 0,07 & & & 0,08 & & & 0,02 & & & 0,04 & & & 0,06 & & & 0,07 & & & 0,03 & & & 0,04 & & & 0,06 & & & 0,07 & \\
\hline
\end{tabular}

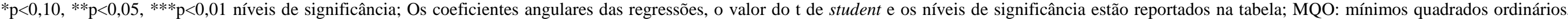

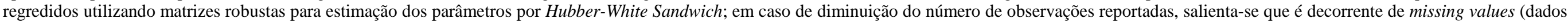
faltantes); CAR: cumulative abnormal return, em que o primeiro valor refere-se à janela de evento, e a segunda nomenclatura ao benchmark de retorno de mercado utilizado.

Fonte: Elaborado pelo autor.

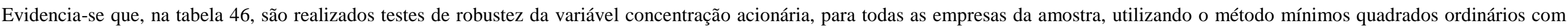

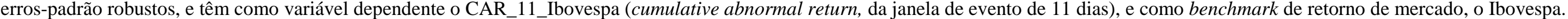
Informa-se que os resultados encontrados, nessa tabela, coadunam com os achados já reportados anteriormente.

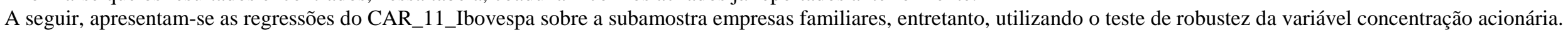


Tabela. 47 - Resultados Regressões Multivariadas: CAR_11_IBOV - Porcentagens de Concentração Acionária Baseadas em ranqueamento da amostra - Painel B. Empresas Familiares da Amostra - MQO com erros-padrão robustos

\begin{tabular}{|c|c|c|c|c|c|c|c|c|c|c|c|c|c|c|c|c|c|c|c|c|c|c|c|c|c|c|c|c|c|c|c|c|c|c|}
\hline & & Modelo 1 & & Modelo 2 & & & Modelo 3 & & & Modelo 4 & & & Modelo 5 & & Modelo 6 & & & Modelo 7 & & & Modelo 8 & & & Modelo9 9 & & & Modelo 10 & & & Modelo 11 & & & Modelo 12 & \\
\hline $\begin{array}{l}\text { Variáveis } \\
\end{array}$ & B & $\mathrm{t}$ & B & & $t$ & $\begin{array}{l}\mathbf{B} \\
20\end{array}$ & & $\mathrm{t}$ & $B$ & & $t$ & B & $\frac{t}{0}$ & $\mathbf{B}$ & & $t$ & $\begin{array}{ll}B \\
177\end{array}$ & & $\mathrm{t}$ & $\begin{array}{ll}B \\
039\end{array}$ & & $\mathrm{t}$ & B & & $t$ & $\begin{array}{c}B \\
B\end{array}$ & & $t$ & $\mathrm{~B}$ & & $\mathrm{t}$ & $B$ & & $\mathrm{t}$ \\
\hline 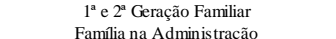 & $-0,67$ & $\begin{array}{l}-0,44 \\
079\end{array}$ & $-1,09$ & & $-0,70$ & $-2,02$ & & $\begin{array}{l}-1,06 \\
-1,3\end{array}$ & $-0,62$ & & $-0,29$ & $-0,40$ & $\begin{array}{l}-0,27 \\
071\end{array}$ & $-0,70$ & & $-0,45$ & $\begin{array}{c}-1,79 \\
133\end{array}$ & & $-0,92$ & $-0,38$ & & $-0,18$ & $\begin{array}{ll}-0,94 \\
055\end{array}$ & & $\begin{array}{l}-0,61 \\
091\end{array}$ & $\begin{array}{cc}-1,12 \\
084\end{array}$ & & $\begin{array}{ccc}-0,71 \\
089\end{array}$ & $\begin{array}{l}-2,17 \\
101\end{array}$ & & $-1,12$ & $-0,38$ & & $-0,18$ \\
\hline $\begin{array}{l}\text { Familia na Administrtracăo } \\
\text { Proporiedade Concentrada Alta }\end{array}$ & 0,73 & & 0,74 & & & 1,70 & & 1,23 & & & & 0,66 & 0,71 & 0,66 & & 0,70 & 1,33 & & 0,97 & 0,62 & & & $\begin{array}{l}0,85 \\
-0.86\end{array}$ & & -0,01 0.03 & $\begin{array}{l}0,84 \\
-0.4\end{array}$ & & $\begin{array}{l}0,89 \\
-0.03\end{array}$ & $\begin{array}{l}1,91 \\
-232\end{array}$ & & $\begin{array}{l}1,24 \\
-0.06\end{array}$ & 1,00 & & $\begin{array}{l}0,60 \\
-0.07\end{array}$ \\
\hline $\begin{array}{l}\text { Propriceadec Concentrada_Aita } \\
\text { Propriedade Concentrada_Média }\end{array}$ & & & & & & & & & & & & $-1,13$ & $-1,01$ & $-1,61$ & & $-1,41$ & $-2,15$ & & $-1,46$ & $-1,57$ & & $-1,00$ & & & & & & & & & & & & \\
\hline Propriedade Concentrada_Baixa & 1,97 & 1,45 & 2,17 & & 1,59 & 2,98 & * & 1,89 & 2,19 & & 1,29 & & & & & & & & & & & & & & & & & & & & & & & \\
\hline Poder_Controladores_Conselho & & & 3,77 & *** & 2,29 & 3,93 & * & 1,71 & 3,38 & & 1,46 & & & 4,14 & *** & 2,48 & 4,37 & ${ }^{*}$ & 1,93 & 3,68 & & 1,63 & & & & 3,76 & *** & 2,19 & 4,10 & ${ }^{*}$ & 1,77 & 3,44 & & 1,49 \\
\hline Índice_Stake_Controladores/Blockholders & & & & & & 0,07 & & 1,25 & 0,06 & & 0,95 & & & & & & 0,03 & & 0,59 & 0,03 & & 0,48 & & & & & & & 0,08 & & 1,26 & 0,06 & & 0,90 \\
\hline $\begin{array}{l}\text { Índice_remuneração_variávele por } \\
\text { açōes/remuneraçăo total }\end{array}$ & & & & & & & & & $-2,34$ & & $-0,89$ & & & & & & & & & $-2,84$ & & $-1,07$ & & & & & & & & & & $-2,44$ & & $-0,82$ \\
\hline Qde Tobin & 0,21 & & 0,18 & & 0,34 & 0,10 & & 0,13 & 0,04 & & 0,05 & 0,21 & 0,42 & 0,20 & & 0,38 & 0,19 & & 0,26 & 0,12 & & 0,17 & 0,25 & & 0,48 & 0,26 & & 0,49 & 0,31 & & 0,43 & 0,15 & & 0,20 \\
\hline Indústria Manufatureira & -0,78 & - 0.80 & $\begin{array}{l}-1,30 \\
-1,30\end{array}$ & & $-1,26$ & 0,33 & & 0.23 & 1,48 & & 0,84 & $\begin{array}{l}-, 0,72 \\
-0,2\end{array}$ & . & & & & & & & & & 0.82 & & & & & & -1.1727 & 0,22 & & 0.16 & ${ }_{1.105}^{10}$ & & 0,09 \\
\hline Idade & 0,02 & 1,31 & 0,03 & & 1,37 & 0,03 & & 1,21 & 0,05 & * & 1,69 & & 1,31 & 0,03 & & 1,45 & 0,03 & & 1,28 & 0,05 & ${ }^{*}$ & 1,82 & 0,02 & & 1,02 & 0,02 & & 1,14 & 0,02 & & 0,80 & 0,04 & & 1,46 \\
\hline Tamanho_LN(Ativo Total) & $-0,09$ & $-0,29$ & $-0,13$ & & $-0,44$ & $-0,15$ & & $\begin{array}{l}-, 21 \\
-0,34\end{array}$ & $-0,24$ & & $-0,51$ & $-0,17$ & $-0,59$ & $-0,23$ & & $\begin{array}{l}-0,77 \\
-0,1\end{array}$ & $-0,18$ & & 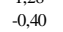 & $-0,26$ & & $-0,57$ & $-0,11$ & & $-0,37$ & $-0,20$ & & $-0,63$ & $-0,25$ & & -0,59 & $-0,34$ & & $\begin{array}{l}-0,82 \\
-1,0\end{array}$ \\
\hline Investidores Institucionais & $-1,63$ & -1,30 & $-1,23$ & & $-0,96$ & 0,52 & & 0,21 & 2,85 & & 1,00 & $-1,18$ & $-0,96$ & $-0,67$ & & $-0,55$ & 0,94 & & 0,37 & 3,44 & & 1,20 & $-1,25$ & & $-1,10$ & $-0,60$ & & $-0,53$ & 1,06 & & 0,45 & 3,58 & & 1,29 \\
\hline Alavancagem Financeira & $-0,09$ & $-0,02$ & $-0,18$ & & $-0,05$ & $-3,49$ & & $-0,57$ & $-4,44$ & & $-0,67$ & 0,23 & 0,06 & 0,15 & & 0,04 & $-3,63$ & & $-0,58$ & $-4,73$ & & $-0,69$ & $-0,16$ & & $-0,04$ & $-0,21$ & & $-0,05$ & $-2,29$ & & $-0,39$ & $-3,67$ & & $-0,57$ \\
\hline Folga Financeira & 0,17 & 0,95 & 0,31 & * & 1,77 & 0,46 & ** & 2,35 & 0,31 & & 1,44 & 0,12 & 0,68 & 0,28 & & 1,59 & 0,39 & ** & 2,04 & 0,25 & & 1,25 & 0,11 & & 0,68 & 0,24 & & 1,43 & 0,40 & ** & 2,21 & 0,25 & & 1,29 \\
\hline LN(CAPEX) & $-0,08$ & $-1,28$ & $-0,06$ & & $-0,94$ & $-0,18$ & $* *$ & $-2,03$ & $-0,20$ & * & $-1,95$ & $-0,08$ & $-1,17$ & $-0,05$ & & $-0,83$ & $-0,18$ & * & $-1,92$ & $-0,21$ & ${ }^{*}$ & $-1,91$ & $-0,07$ & & $-1,10$ & $-0,04$ & & $-0,72$ & $-0,13$ & & $-1,59$ & $-0,16$ & ${ }^{*}$ & $-1,64$ \\
\hline Novo Mercado e Nivel2 & $-1,28$ & $-1,04$ & $-1,21$ & & $-0,99$ & 0,09 & & 0,05 & 0,12 & & 0,07 & $-0,71$ & $-0,54$ & $-0,51$ & & $-0,40$ & 0,67 & & 0,43 & 0,59 & & 0,36 & $-1,30$ & & $-0,94$ & $-0,90$ & & $-0,68$ & 0,17 & & 0,10 & 0,04 & & 0,02 \\
\hline Adquirente Serial & $-1,28$ & $-1,21$ & $-1,35$ & & $-1,25$ & $-1,60$ & & $-1,12$ & $-0,68$ & & $-0,41$ & $-1,14$ & $-1,10$ & $-1,15$ & & $-1,08$ & $-1,43$ & & $-0,99$ & $-0,39$ & & $-0,23$ & $-1,38$ & & $-1,25$ & $-1,37$ & & $-1,18$ & $-2,16$ & & $-1,39$ & $-1,03$ & & $-0,53$ \\
\hline Aquisiç̧ă Internacional & 0,23 & 0,23 & 0,29 & & 0,29 & 0,14 & & 0,10 & $-0,68$ & & $-0,47$ & 0,24 & 0,24 & 0,35 & & 0,36 & 0,40 & & 0,29 & $-0,59$ & & $-0,40$ & 0,10 & & 0,10 & 0,19 & & 0,19 & 0,01 & & 0,00 & $-0,911$ & & -0,63 \\
\hline -cons & 3,96 & 0,67 & 2,55 & 222 & 0,42 & 1,74 & 160 & 0,19 & 1,26 & 150 & 0,14 & 5,12 & 0,87 & 3,67 & 222 & 0,60 & 3,37 & 160 & 0,35 & 2,35 & 150 & 0,26 & 5,10 & 226 & 0,89 & 3,38 & 222 & 0,57 & 3,32 & 160 & 0,38 & 2,57 & 150 & 0,30 \\
\hline $\mathrm{F}$ & & 0,77 & & 1,06 & & & 1,42 & & & 1,25 & & & 0,69 & & 1,00 & & & 1,50 & & & 1,33 & & & 0,77 & & & 0,99 & & & 1,40 & & & 1,31 & \\
\hline $\mathrm{R}^{\wedge} 2$ & & 0,05 & & 0,07 & & & 0,12 & & & 0,11 & & & 0,04 & & 0,07 & & & 0,11 & & & 0,11 & & & 0,04 & & & 0,06 & & & 0,09 & & & 0,10 & \\
\hline
\end{tabular}

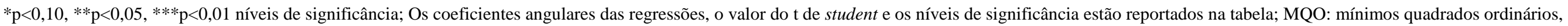

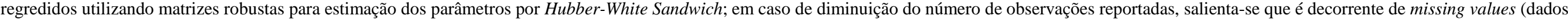
faltantes); CAR: cumulative abnormal return, em que o primeiro valor refere-se à janela de evento, e a segunda nomenclatura ao benchmark de retorno de mercado utilizado.

Fonte: Elaborado pelo autor.

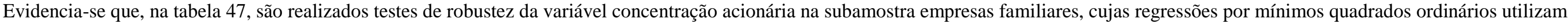

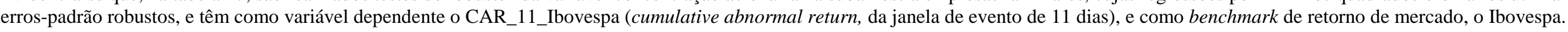
Informa-se que os resultados encontrados, nessa tabela, coadunam com os achados já reportados anteriormente.

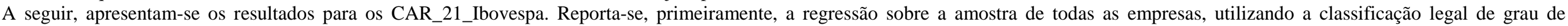
concentração acionária. 
Tabela. 48 - Resultados Regressões Multivariadas: CAR_21_IBOV - Porcentagens de Concentração Acionária Baseadas em legislação societária - Painel A. Todas Empresas da Amostra - MQO com erros-padrão robustos

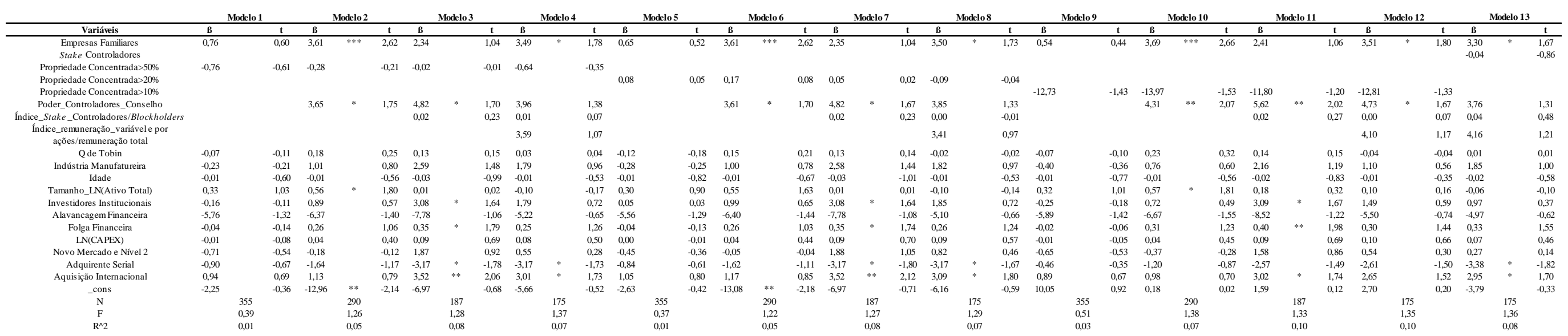

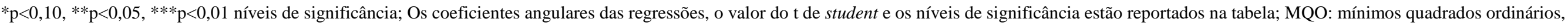

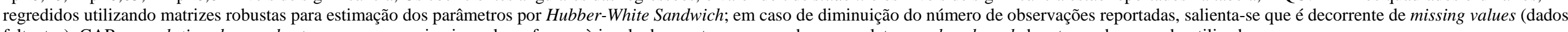
faltantes); CAR: cumulative abnormal return, em que o primeiro valor refere-se à janela de evento, e a segunda nomenclatura ao benchmark de retorno de mercado utilizado.

Fonte: Elaborado pelo autor.

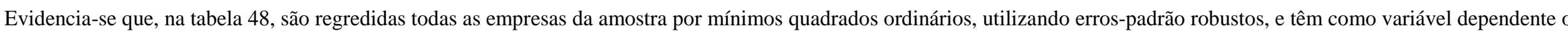

CAR_21_Ibovespa (cumulative abnormal return, da janela de evento de 21 dias), e como benchmark de retorno de mercado, o Ibovespa.

Reporta-se que a variável empresas familiares tem relação positiva e significante estatisticamente ao CAR_21_Ibovespa, reiteradamente, em modelos diversos analisados.

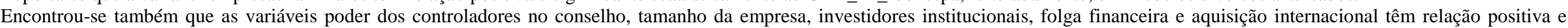
significante ao CAR_21_Ibovespa.

Outrossim, que a variável adquirente serial tem relação negativa e significante ao CAR_21_Ibovespa.

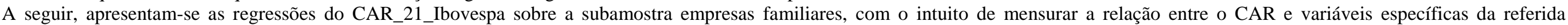
subamostra. 
Tabela. 49 - Resultados Regressões Multivariadas: CAR_21_IBOV - Porcentagens de Concentração Acionária Baseadas em legislação societária - Painel B. Empresas Familiares da Amostra MQO com erros-padrão robustos

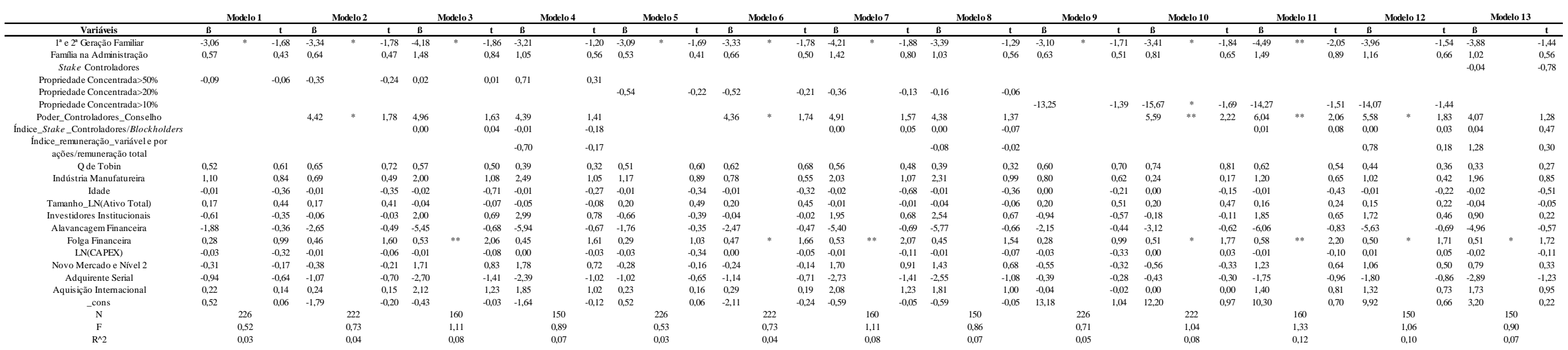

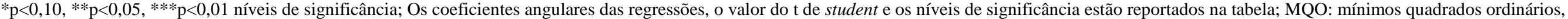

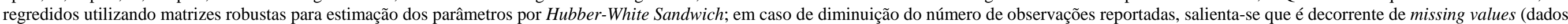
faltantes); CAR: cumulative abnormal return, em que o primeiro valor refere-se à janela de evento, e a segunda nomenclatura ao benchmark de retorno de mercado utilizado.

Fonte: Elaborado pelo autor.

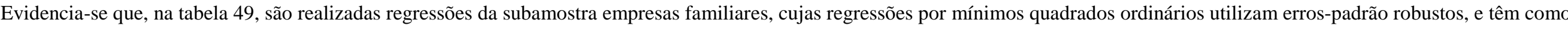
variável dependente o CAR_21_Ibovespa (cumulative abnormal return, da janela de evento de 21 dias), e como benchmark de retorno de mercado, o Ibovespa.

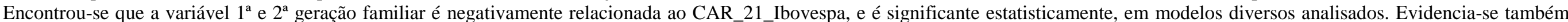
que as variáveis poder dos controladores no conselho e folga financeira têm relação positiva e significante com o CAR_21_Ibovespa, em modelos diversos analisados.

A seguir, apresentam-se as regressões do CAR_21_Ibovespa sobre toda a amostra, entretanto, utilizando o teste de robustez da variável concentração acionária. 
Tabela. 50 - Resultados Regressões Multivariadas: CAR_21_IBOV - Porcentagens de Concentração Acionária Baseadas em ranqueamento da amostra - Painel A. Todas Empresas da Amostra MQO com erros-padrão robustos

\begin{tabular}{|c|c|c|c|c|c|c|c|c|c|c|c|c|c|c|c|c|c|c|c|c|c|c|c|c|c|c|c|c|c|c|c|c|c|c|c|c|}
\hline & & Modelo 1 & & & Modelo 2 & & & Modelo 3 & & & Modelo 4 & & & Modelo 5 & & & Modelo 6 & & & Model 107 & & & Modelo 8 & & & Modelo9 & & & Modelo 10 & & & Modelo 11 & & & Modelo 1 & \\
\hline $\begin{array}{c}\text { Variáveis } \\
\end{array}$ & $B$ & & $t$ & $B$ & & $t$ & B & & $t$ & $B$ & & $t$ & B & & $\mathrm{t}$ & $B$ & & $t$ & $B$ & & $\mathrm{t}$ & $B$ & & $\mathrm{t}$ & B & & $t$ & $B$ & & $t$ & $B$ & & $t$ & & & \\
\hline $\begin{array}{l}\text { Empresas Familiares } \\
\text { Propriedade Concentrada Alta }\end{array}$ & 0,64 & & 0,53 & 3,58 & $* * *$ & 2,60 & 2,30 & & 1,00 & 3,48 & ${ }^{*}$ & 1,66 & 0,75 & & 0,62 & 3,66 & ${ }^{* * * *}$ & 2,65 & 2,55 & & 1,12 & 3,83 & $*$ & 1,81 & 0,86 & & 0,68 & 3,67 & ${ }^{* * * *}$ & 2,65 & 2,30 & & 1,03 & 3,67 & * & 1,87 \\
\hline $\begin{array}{l}\text { Propriedade Concentrada_Alta } \\
\text { Propriedade Concentrada_Média }\end{array}$ & & & & & & & & & & & & & 0.58 & & 0,53 & 0.31 & & 0.26 & 0.68 & & 039 & (2) & & 040 & $-1,90$ & & $-1,17$ & $-1,00$ & & $-0,58$ & $-3,38$ & & $-1,33$ & $-3,82$ & & $-1,28$ \\
\hline Propriedade Concentrada_Baixa & 0,18 & & 0,13 & 0,19 & & 0,12 & 0,13 & & 0,07 & 0,10 & & 0,05 & & & & & & & 0,00 & & 0,39 & 0,10 & & & & & & & & & & & & & & \\
\hline Poder_Controladores_Conselho & & & & 3,57 & * & 1,69 & 4,81 & & 1,64 & 3,84 & & 1,31 & & & & 3,55 & $*$ & 1,70 & 4,87 & $*$ & 1,67 & 3,90 & & 1,34 & & & & 3,37 & & 1,58 & 4,62 & $*$ & 1,64 & 3,59 & & \\
\hline İndice_Stake_Controladores/Blockholders & & & & & & & 0,02 & & 0,24 & 0,00 & & 0,00 & & & & & & & 0,02 & & 0,29 & 0,00 & & 0,04 & & & & & & & 0,07 & & 0,81 & 0,05 & & 0,66 \\
\hline 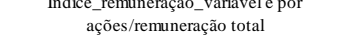 & & & & & & & & & & 3,40 & & 1,01 & & & & & & & & & & 3,36 & & 0,99 & & & & & & & & & & 3,98 & & 1,14 \\
\hline Qde Tobin & $-0,11$ & & $-0,17$ & 0,15 & & 0,21 & 0,12 & & 0,13 & $-0,02$ & & $-0,02$ & $-0,15$ & & $-0,22$ & 0,15 & & 0,21 & 0,16 & & 0,18 & 0,02 & & 0,02 & $-0,16$ & & $-0,24$ & 0,14 & & 0,20 & 0,12 & & 0,14 & $-0,05$ & & $-0,06$ \\
\hline Indústria Manufatureira & $-0,26$ & & $-0,24$ & 1,03 & & 0,83 & 2,59 & & 1,49 & 1,81 & & 0,97 & $-0,36$ & & $-0,32$ & 0,97 & & 0,77 & 2,57 & & 1,47 & 1,88 & & 1,00 & $-0,45$ & & $-0,40$ & 0,91 & & 0,71 & 2,69 & & 1,55 & 1,97 & & 1,07 \\
\hline Idade & $-0,01$ & & $-0,77$ & $-0,01$ & & $-0,62$ & $-0,03$ & & $-0,99$ & $-0,01$ & & $-0,53$ & $-0,01$ & & $-0,90$ & $-0,01$ & & $-0,69$ & $-0,03$ & & $-1,04$ & $-0,02$ & & $-0,59$ & $-0,01$ & & $-0,90$ & $-0,01$ & & $-0,68$ & $-0,03$ & & $-1,07$ & $-0,02$ & & $-0,68$ \\
\hline Tamanho_LN(Ativo Total) & 0,31 & & 0,96 & 0,56 & * & 1,77 & 0,02 & & 0,03 & $-0,10$ & & $-0,16$ & 0,31 & & 0,98 & 0,56 & * & 1,76 & $-0,01$ & & $-0,02$ & $-0,14$ & & $-0,23$ & 0,36 & & 1,11 & 0,59 & * & 1,82 & 0,02 & & 0,03 & $-0,09$ & & $-0,15$ \\
\hline Investidores Institucionais & $-0,01$ & & $-0,01$ & 0,90 & & 0,57 & 3,04 & & 1,55 & 1,83 & & 0,70 & 0,08 & & 0,05 & 0,98 & & 0,65 & 3,19 & ${ }^{*}$ & 1,69 & 2,06 & & 0,81 & $-0,33$ & & $-0,25$ & 0,72 & & 0,50 & 2,66 & & 1,45 & 1,25 & & 0,50 \\
\hline Alavancagem Financeira & $-5,57$ & & $-1,28$ & $-6,30$ & & $-1,40$ & $\begin{aligned}-7,81 \\
0.83\end{aligned}$ & $*$ & $-1,05$ & $-5,15$ & & $-0,63$ & $-5,64$ & & $-1,31$ & $-6,48$ & & $-1,44$ & $\begin{array}{l}-7,46 \\
034\end{array}$ & $*$ & $-0,99$ & $-4,82$ & & $-0,59$ & $-6,07$ & & $-1,40$ & $-6,61$ & & $-1,46$ & $-7,08$ & $*$ & $-0,97$ & $-4,31$ & & $-0,54$ \\
\hline $\begin{array}{l}\text { Folga Financeira } \\
\text { LN(CAPEX) }\end{array}$ & $\begin{array}{l}-0,03 \\
0,00\end{array}$ & & $\begin{array}{c}-0,10 \\
-0,02\end{array}$ & 0,27 & & $\begin{array}{l}1,08 \\
041\end{array}$ & $\begin{array}{l}0,36 \\
0.99\end{array}$ & * & 1,84 & 0,26 & & $\begin{array}{l}1,28 \\
0.56\end{array}$ & $\begin{array}{l}-0,05 \\
0.00\end{array}$ & & $-0,17$ & $\begin{array}{l}0,26 \\
0.4\end{array}$ & & $\begin{array}{l}1,03 \\
044\end{array}$ & $\begin{array}{l}0,34 \\
0.10\end{array}$ & * & $\begin{array}{l}1,74 \\
079\end{array}$ & 0,25 & & $\begin{array}{l}1,21 \\
0,67\end{array}$ & $\begin{array}{l}-0,01 \\
-001 \\
-0.1\end{array}$ & & $\begin{array}{l}-0,02 \\
-0.09\end{array}$ & 0,27 & & 1,08 & 0,38 & ${ }^{*}$ & 1,93 & 0,31 & & 1,49 \\
\hline $\begin{array}{l}\text { LN(CAPEX) } \\
\text { Novo Mercado e Nivel } 2\end{array}$ & $\begin{array}{l}0,000 \\
-0.50\end{array}$ & & $\begin{array}{l}-0,02 \\
-0,39 \\
-10\end{array}$ & $\begin{array}{l}0,04 \\
-0,10\end{array}$ & & $\begin{array}{l}0,41 \\
-0,07\end{array}$ & $\begin{array}{l}0,09 \\
1.86\end{array}$ & & $\begin{array}{l}0,68 \\
1.01\end{array}$ & 0.08 & & $0.0,06$ & $\begin{array}{l}0,000 \\
-0.51\end{array}$ & & 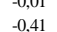 & 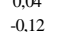 & & . 0.09 & $\begin{array}{l}0,100 \\
1.88\end{array}$ & & $\begin{array}{l}0,9 \\
1,05\end{array}$ & $\begin{array}{l}0,110 \\
0,79\end{array}$ & & 0,06 & $\begin{array}{l}-0,01 \\
-1,07 \\
-107\end{array}$ & & $\begin{array}{l}-0,09 \\
-0.81\end{array}$ & $\begin{array}{l}0,03 \\
-0.43\end{array}$ & & $\begin{array}{l}0,08 \\
-0,30\end{array}$ & $\begin{array}{l}0,09 \\
1.36\end{array}$ & & $0,0,8$ & $\begin{array}{l}0,11 \\
0,18\end{array}$ & & 0,77 \\
\hline Adquirente Serial & $-0,85$ & & $\begin{array}{l}-0,63 \\
-0,63\end{array}$ & $-1,64$ & & $-1,16$ & $-3,16$ & * & $\begin{array}{l}1,1,80 \\
-1,00\end{array}$ & 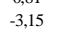 & $*$ & $-1,72$ & $\begin{array}{l}-0,94 \\
-0,14\end{array}$ & & $\begin{array}{l}-0,69 \\
-0,49 \\
-10\end{array}$ & $\begin{array}{l}-1,69 \\
-1,69\end{array}$ & & $\begin{array}{l}-1,19 \\
-1,19\end{array}$ & $\begin{array}{l}-, 000 \\
-3,33\end{array}$ & $*$ & 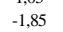 & $-3,34$ & * & $-1,78$ & 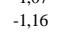 & & $\begin{array}{l}-0,82 \\
-0,12 \\
-10\end{array}$ & $-1,81$ & & $-1,25$ & 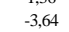 & $* *$ & $-1,98$ & $\begin{array}{l}-3,84 \\
-3,84\end{array}$ & $*$ & $-1,95$ \\
\hline Aquisição Internacional & 1,07 & & 0,81 & 1,18 & & 0,85 & 3,52 & *** & 2,11 & 3,10 & * & 1,79 & 1,01 & & 0,76 & 1,16 & & 0,84 & 3,46 & ** & 2,07 & 2,99 & $*$ & 1,72 & 1,05 & & 0,80 & 1,17 & & 0,85 & 3,20 & $*$ & 1,88 & 2,78 & & 1,59 \\
\hline -cons & $-2,65$ & & $-0,42$ & $-13,12$ & ** & $-2,20$ & $-7,00$ & & $-0,71$ & $-6,15$ & & $-0,58$ & $-2,85$ & & $-0,46$ & $-13,11$ & $* *$ & $-2,18$ & $-7,44$ & & $-0,75$ & $-6,57$ & & $-0,62$ & $-1,92$ & & $-0,31$ & $-12,58$ & $* *$ & $-2,11$ & $-6,03$ & & $-0,63$ & $-5,47$ & & $-0,54$ \\
\hline & & $\begin{array}{l}355 \\
0.36\end{array}$ & & & $\begin{array}{l}290 \\
1,22\end{array}$ & & & $\begin{array}{l}187 \\
1,25\end{array}$ & & & $\begin{array}{l}175 \\
1,30\end{array}$ & & & 0.41 & & & $\begin{array}{l}290 \\
1,24\end{array}$ & & & $\begin{array}{l}187 \\
1,28\end{array}$ & & & $\begin{array}{l}175 \\
1,30\end{array}$ & & & 0 & & & $\begin{array}{l}290 \\
1,34\end{array}$ & & & $\begin{array}{l}187 \\
1.56\end{array}$ & & & $\begin{array}{l}175 \\
1.37\end{array}$ & \\
\hline $\mathrm{R}^{\wedge} 2$ & & 0,01 & & & 0,05 & & & 0,08 & & & 0,07 & & & 0,01 & & & 0,05 & & & 0,08 & & & 0,08 & & & 0,02 & & & 0,05 & & & 0,09 & & & 0,08 & \\
\hline
\end{tabular}

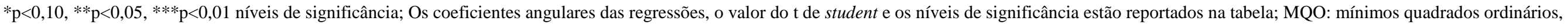

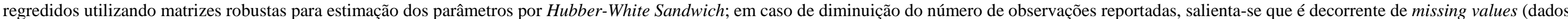
faltantes); CAR: cumulative abnormal return, em que o primeiro valor refere-se à janela de evento, e a segunda nomenclatura ao benchmark de retorno de mercado utilizado.

Fonte: Elaborado pelo autor.

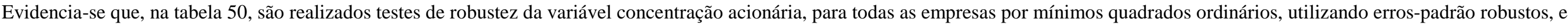
têm como variável dependente o CAR_21_Ibovespa (cumulative abnormal return, da janela de evento de 21 dias), e como benchmark de retorno de mercado, o Ibovespa.

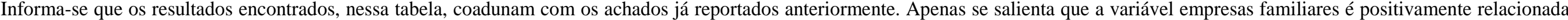
ao CAR_21_Ibovespa, e significante estatisticamente, em modelos diversos analisados.

A seguir, apresentam-se as regressões do CAR_21_Ibovespa sobre a subamostra empresas familiares, entretanto, utilizando o teste de robustez da variável concentração acionária. 
Tabela. 51 - Resultados Regressões Multivariadas: CAR_21_IBOV - Porcentagens de Concentração Acionária Baseadas em ranqueamento da amostra - Painel B. Empresas Familiares da Amostra - MQO com erros-padrão robustos

\begin{tabular}{|c|c|c|c|c|c|c|c|c|c|c|c|c|c|c|c|c|c|c|c|c|c|c|c|c|c|c|c|c|c|c|c|c|c|c|}
\hline & & Modelo 1 & & & Modelo 2 & & & Modelo 3 & & & Modelo 4 & & Modelo 5 & & & Modelo 6 & & & Modelo 7 & & & Modelo 8 & & Modelo 9 & & & Modelo 10 & & & Modelo 11 & & & Modelo 12 & \\
\hline $\begin{array}{c}\text { Variáveis } \\
1^{\mathrm{a}} \mathrm{e} 2^{\mathrm{a}} \text { Geracão Familiar }\end{array}$ & $\begin{array}{l}\mathbf{B} \\
-3.03\end{array}$ & * & $\begin{array}{c}t \\
-1,67 \\
\end{array}$ & $\begin{array}{l}\boldsymbol{B} \\
-3,30\end{array}$ & 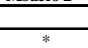 & $\frac{\mathrm{t}}{-1.17}$ & $\begin{array}{ll}\mathrm{B} \\
-421\end{array}$ & 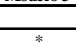 & $\frac{\mathbf{t}}{-189}$ & $\begin{array}{l}\mathbf{B} \\
-347\end{array}$ & $\frac{\mathbf{t}}{-131}$ & $\begin{array}{l}\text { B } \\
-325\end{array}$ & $*$ & $\frac{\mathbf{t}}{-181}$ & $\begin{array}{l}\boldsymbol{B} \\
-340\end{array}$ & 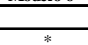 & $\begin{array}{c}\mathbf{t} \\
-1.83\end{array}$ & $\begin{array}{l}\text { B } \\
-420\end{array}$ & 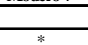 & $\begin{array}{c}\mathbf{t} \\
-1.89 \\
\end{array}$ & $\begin{array}{l}\beta \\
-330\end{array}$ & $\frac{\mathbf{t}}{-125}$ & $\begin{array}{l}\text { B } \\
-399\end{array}$ & ** & $t$ & B & ** & $\mathrm{t}$ & $\frac{B}{484}$ & nuron & $\mathrm{t}$ & $\frac{B}{409}$ & $*$ & $\frac{t}{166}$ \\
\hline 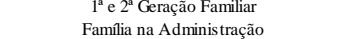 & $\begin{array}{l}-3,03 \\
0.57\end{array}$ & & $\begin{array}{l}-1,6 / 7 \\
0,46\end{array}$ & $\begin{array}{l}-3,30 \\
0,69\end{array}$ & & $\begin{array}{l}-1,7 / 7 \\
0,54\end{array}$ & $\begin{array}{l}-4,21 \\
1.53 \\
\end{array}$ & & $\begin{array}{l}-1,199 \\
0.86\end{array}$ & $\begin{array}{l}-3,47 \\
1,12 \\
-12\end{array}$ & $\begin{array}{l}-1,131 \\
0.58\end{array}$ & (-,67, 0 & & $\begin{array}{l}-1,58 \\
0.54\end{array}$ & $\begin{array}{l}-3,40 \\
0,77\end{array}$ & & $\begin{array}{c}-1,83 \\
0,60\end{array}$ & $\begin{array}{l}-4,420 \\
1,51\end{array}$ & & $\begin{array}{c}-1,89 \\
0,86\end{array}$ & $\begin{array}{l}-3,30 \\
1,10\end{array}$ & $\begin{array}{l}-1,2,2 \\
0,60\end{array}$ & $\begin{array}{l}-3,99 \\
0,89\end{array}$ & & $\begin{array}{c}-2,23 \\
0,71\end{array}$ & $\begin{array}{l}-4,03 \\
0.92\end{array}$ & & $\begin{array}{c}-2,20 \\
0,73\end{array}$ & $\begin{array}{l}-4,44 \\
2,51\end{array}$ & & $\begin{array}{l}-2,33 \\
1,35\end{array}$ & & & $\begin{array}{l}-1,1,6 \\
1,17\end{array}$ \\
\hline Propriedade Concentrada_Alta & & & & & & & & & & & & & & & & & & & & & & & $-3,70$ & $*$ & $-1,67$ & $-2,95$ & & $-1,29$ & $\begin{array}{l}-6,71 \\
-6,11\end{array}$ & ** & $\begin{array}{l}-2,05 \\
1,05\end{array}$ & 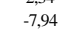 & ** & $\begin{array}{l}1,217 \\
-2,03\end{array}$ \\
\hline Propriedade Concentrada_Média & & & & & & & & & & & & 0,70 & & 0,47 & 0,35 & & 0,23 & 0,24 & & 0,13 & 0,69 & 0,34 & & & & & & & & & & & & \\
\hline Propriedade Concentrada_Baixa & 0,91 & & 0,53 & 0,96 & & 0,56 & 0,97 & & 0,48 & 0,60 & 0,28 & & & & & & & & & & & & & & & & & & & & & & & \\
\hline Poder_Controladores_Conselho & & & & 4,39 & * & 1,77 & 4,80 & & 1,55 & 4,31 & 1,36 & & & & 4,31 & * & 1,72 & 4,97 & & 1,63 & 4,40 & 1,41 & & & & 3,71 & & 1,43 & 4,00 & & 1,34 & 3,31 & & 1,09 \\
\hline İndice_Stake_Controladores/Blockholders & & & & & & & 0,01 & & 0,17 & 0,00 & 0,01 & & & & & & & 0,00 & & 0,06 & 0,00 & $-0,03$ & & & & & & & 0,10 & & 1,31 & 0,11 & & 1,30 \\
\hline 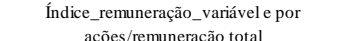 & & & & & & & & & & 0,01 & 0,00 & & & & & & & & & & $-0,13$ & $-0,03$ & & & & & & & & & & 1,66 & & 0,37 \\
\hline Q de Tobin & 0,49 & & 0.58 & 0,59 & & 0,64 & 0,50 & & 0,42 & 0,35 & 0,29 & 0,53 & & 0,61 & 0,64 & & 0,69 & 0,59 & & 0,50 & 0,43 & 0,35 & 0,54 & & 0,63 & 0,63 & & 0,69 & 0,51 & & 0,44 & 0,20 & & 0,17 \\
\hline Indústria Manufatureira & 1,15 & & 0,91 & 0,75 & & 0,54 & 2,10 & & 1,13 & 2,28 & 0.99 & 1,01 & & 0,78 & 0,70 & & 0,50 & 2,00 & & 1,07 & 2,37 & 1,02 & 0,79 & & 0,61 & 0,51 & & 0,37 & 2,50 & & 1,41 & 2,59 & & 1,17 \\
\hline Idade & $-0,01$ & & $-0,30$ & $-0,01$ & & $-0,27$ & $-0,02$ & & $-0,65$ & $-0,01$ & $-0,36$ & $-0,01$ & & $-0,45$ & $-0,01$ & & $-0,39$ & $-0,02$ & & $-0,72$ & $-0,01$ & $-0,40$ & $-0,02$ & & $-0,64$ & $-0,01$ & & $-0,58$ & $-0,03$ & & $-1,11$ & $-0,03$ & & $-0,84$ \\
\hline Tamanho_LN(Ativo Total) & 0,20 & & 0,51 & 0,19 & & 0,47 & $-0,01$ & & $-0,02$ & $-0,03$ & $-0,05$ & 0,18 & & 0,46 & 0,17 & & 0,41 & $-0,05$ & & $-0,08$ & $-0,09$ & $-0,14$ & 0,35 & & 0,82 & 0,31 & & 0,70 & $-0,03$ & & $-0,05$ & $-0,07$ & & $-0,11$ \\
\hline Investidores Institucionais & $-0,83$ & & $-0,47$ & $-0,23$ & & $-0,13$ & 1,75 & & 0,60 & 2,30 & 0,60 & $-0,52$ & & $-0,30$ & 0,07 & & 0,04 & 2,04 & & 0,70 & 2,80 & 0,74 & $-1,29$ & & $-0,83$ & $-0,66$ & & $-0,42$ & 1,36 & & 0,52 & 1,10 & & 0,31 \\
\hline Alavancagem Financeira & $-1,92$ & & $-0,37$ & $-2,57$ & & $-0,47$ & $-5,72$ & & $-0,70$ & $-5,91$ & $-0,65$ & $-1,98$ & & $-0,39$ & $-2,66$ & & $-0,50$ & $-5,34$ & & $-0,65$ & $-5,55$ & $-0,60$ & $-2,73$ & & $-0,53$ & $-3,19$ & & $-0,60$ & $-4,32$ & & $-0,55$ & $-3,88$ & & $-0,44$ \\
\hline $\begin{array}{l}\text { Folga Financeira } \\
\text { IN(SAPE) }\end{array}$ & 0,31 & & 1,11 & 0,50 & * & 1,76 & 0,56 & ** & 2,16 & 0,47 & 1,55 & 0,27 & & 0,96 & 0,45 & & 1,61 & 0,52 & *** & 2,05 & 0,43 & 1,48 & 0,34 & & 1,27 & 0,48 & * & 1,74 & 0,66 & ${ }^{* * *}$ & 2,62 & 0,62 & ** & 2,15 \\
\hline $\begin{array}{c}\text { LN(CAPEX) } \\
\text { (1) }\end{array}$ & $-0,03$ & & $-0,39$ & $-0,01$ & & $-0,11$ & $-0,03$ & & -0,20 0 & -0,02 & - $-0,11$ & $-0,02$ & & $-0,25$ & 0,00 & & 0,00 & $-0,01$ & & $\begin{array}{l}-0,05 \\
0.09\end{array}$ & 0,01 & 0,03 & $-0,03$ & & -0,33 & $-0,01$ & & $-0,08$ & 0,01 & & 0,09 & 0,05 & & 0,31 \\
\hline $\begin{array}{l}\text { Novo Mercadoe e Nivev } 2 \\
\text { Adquirente Serial }\end{array}$ & $\begin{array}{l}-0,41 \\
-0,94\end{array}$ & & $\begin{array}{l}-0,24 \\
-0,64\end{array}$ & $\begin{array}{l}-1,07 \\
-1,06\end{array}$ & & $\begin{array}{l}-0,21 \\
-0,070\end{array}$ & $\begin{array}{l}1,52,2 \\
-2.61\end{array}$ & & $\begin{array}{l}0,79 \\
-1,38\end{array}$ & $\begin{array}{l}1,33 \\
-252\end{array}$ & 0.622 & $\begin{array}{l}-0,43 \\
-1,02\end{array}$ & & $\begin{array}{l}-0,24 \\
-0,71\end{array}$ & $\begin{array}{l}-0,31 \\
-1,12\end{array}$ & & $\begin{array}{l}-0,17 \\
-074\end{array}$ & $\begin{array}{l}1,70 \\
-275\end{array}$ & & 0,91 & $\begin{array}{l}1,36 \\
-265\end{array}$ & 0,66 & $\begin{array}{l}-1,71 \\
-1,40\end{array}$ & & $\begin{array}{l}-0,88 \\
-0.05\end{array}$ & $\begin{array}{l}-1,35 \\
-145\end{array}$ & & $\begin{array}{l}-0,72 \\
-0.94\end{array}$ & $\begin{array}{l}0,35 \\
-3,49 \\
-1\end{array}$ & * & $\begin{array}{l}0,16 \\
-1,84\end{array}$ & $\begin{array}{l}-0,46 \\
-0,02\end{array}$ & $*$ & $-0,18$ \\
\hline $\begin{array}{l}\text { Aquurente senal } \\
\text { Aquisiçâo Intermacional }\end{array}$ & $\begin{array}{l}-0,24 \\
0,27\end{array}$ & & $\begin{array}{l}-0,04 \\
0,18\end{array}$ & $\begin{array}{l}-1,060 \\
0,33\end{array}$ & & $\begin{array}{l}-0,70 \\
0,21\end{array}$ & $\begin{array}{l}-2,61 \\
2,08\end{array}$ & & $\begin{array}{l}-1,38 \\
1,22 \\
-\end{array}$ & $\begin{array}{l}-2,32 \\
1,84\end{array}$ & $\begin{array}{l}-1,11 \\
1,00 \\
1\end{array}$ & $\begin{array}{l}-1,02 \\
0,16\end{array}$ & & $\begin{array}{l}-0,11 \\
0,11\end{array}$ & $\begin{array}{l}-1,22 \\
0,25\end{array}$ & & 0 & $\begin{array}{l}-2,1 / 1 \\
2,10\end{array}$ & & $\begin{array}{l}-1,1,5 \\
1,24\end{array}$ & $\begin{array}{l}-2,25 \\
1,74 \\
24\end{array}$ & $\begin{array}{l}-1,17 \\
0,95\end{array}$ & $\begin{array}{l}-1,100 \\
0,05\end{array}$ & & 0,03 & $\begin{array}{l}-1,45 \\
0,12\end{array}$ & & 0 & $\begin{array}{l}-0,49 \\
1,41\end{array}$ & & $\begin{array}{l}-1,144 \\
0,82\end{array}$ & $\begin{array}{l}-4,02 \\
1,24\end{array}$ & & $\begin{array}{l}-1,15 \\
0,67\end{array}$ \\
\hline _cons & 0,02 & & 0,00 & $-2,54$ & & $-0,29$ & $-0,65$ & & $-0,05$ & $-0,66$ & $-0,05$ & 0,25 & & 0,03 & $-2,25$ & & $-0,26$ & $-0,49$ & & $-0,04$ & $-0,73$ & $-0,06$ & 1,55 & & 0,19 & $-0,91$ & & $-0,11$ & 1,91 & & 0,17 & 2,78 & & 0,24 \\
\hline $\mathrm{N}$ & & 226 & & & 222 & & & 160 & & & 150 & & 22 & & & 222 & & & 160 & & & & & 226 & & & 222 & & & 160 & & & 150 & \\
\hline $\begin{array}{c}\mathrm{F} \\
\mathrm{B} / 2\end{array}$ & & 0,55 & & & 0,77 & & & 1,14 & & & 0,87 & & 0,55 & & & 0,71 & & & 1,11 & & & 0.07 & & 0,87 & & & 0,96 & & & 1,95 & & & 1,57 & \\
\hline $\mathrm{R}^{\wedge 2}$ & & 0,03 & & & 0,04 & & & 0,08 & & & 0,07 & & 0,03 & & & 0,04 & & & 0,08 & & & 0,07 & & 0,04 & & & 0,05 & & & 0,09 & & & 0,09 & \\
\hline
\end{tabular}

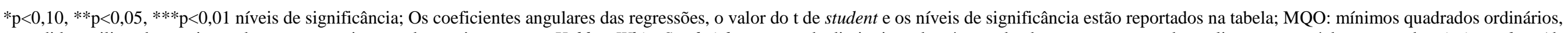

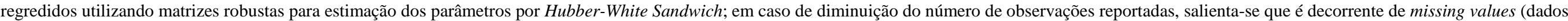
faltantes); CAR: cumulative abnormal return, em que o primeiro valor refere-se à janela de evento, e a segunda nomenclatura ao benchmark de retorno de mercado utilizado.

Fonte: Elaborado pelo autor.

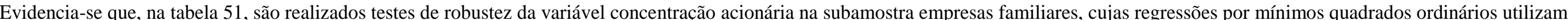

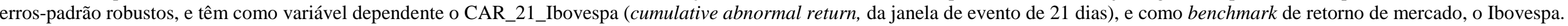

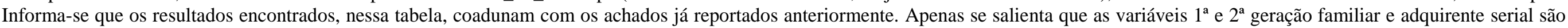
negativamente relacionadas ao CAR 21_Ibovespa, e são significantes estatisticamente em modelos diversos analisados.

Outrossim, que as variáveis poder dos controladores no conselho e folga financeira têm relação positiva e significante com o CAR_21_Ibovespa, em modelos diversos analisados.

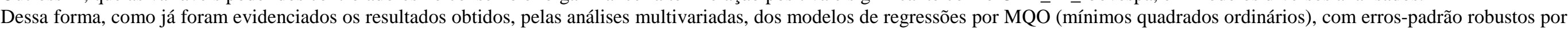
Hubber-White Sandwich, por meio das tabelas reportadas anteriormente, já se torna possível responder às hipóteses faltantes da pesquisa.

Logo, seguem. 
Hipótese 3. Retornos anormais em aquisições de empresas estão relacionados positivamente às empresas familiares cujo gestor é membro da familia controladora.

Foram encontrados para os modelos analisados, que os retornos anormais estão relacionados positivamente à empresa familiar, cujo gestor é membro da família controladora. Entretanto, evidencia-se que, somente para o CAR_3 (três dias - janela de eventos), encontrou-se que é altamente significante a referida relação. Portanto, existem evidências de que há relação positiva entre o retorno anormal em eventos de aquisições e empresas familiares, quando o gestor é membro da família controladora.

Hipótese 4. Retornos anormais em aquisições de empresas estão relacionados positivamente às empresas familiares de primeira e segunda gerações.

Foram encontrados, para os modelos estatisticamente significantes, neste trabalho analisados, que os retornos anormais em eventos de aquisições de empresas estão relacionados negativamente à variável empresas familiares de primeira e segunda gerações. Portanto, podese afirmar que não há evidências de relação positiva entre o retorno anormal em eventos de aquisições de empresas familiares, e empresas de primeira e segunda gerações familiares.

É importante ressaltar que não se encontraram diferenças significativas, nos resultados do teste de robustez para o benchmark de retorno de mercado - IBRX50, para ambas técnicas estatísticas utilizadas, MQO com erros-padrão robustos e Bootstrap.

Igualmente, evidencia-se que não houve diferenças significativas, aos resultados dos modelos, e que estes, se coadunam, ao utilizar a técnica estatística de resampling Bootstrap. Dessa forma, não se reportarão os resultados obtidos pelo teste de robustez para o benchmark de retorno de mercado - IBRX50, no corpo de desenvolvimento do texto dessa dissertação, bem como os resultados obtidos pela técnica estatística de resampling, Bootstrap. Entretanto, informa-se que serão inseridos como apêndice no presente trabalho. 


\section{CONSIDERAÇÕES FINAIS}

Este trabalho teve como objetivo geral investigar os impactos oriundos da variável propriedade familiar sobre os retornos anormais em eventos de aquisições de empresas. Analisou-se ainda a relação entre variáveis específicas pertinentes à propriedade familiar em relação aos retornos anormais mensurados.

Reporta-se também que foram comparados os retornos anormais entre empresas familiares e empresas não familiares em eventos de aquisições de empresas, a fim de verificar e analisar a existência de possível diferença de desempenho em aquisições de empresas entre as referidas classificações de empresas mensuradas pelos retornos anormais acumulados (CAR cumulative abnormal return).

Esta pesquisa, em conformidade com a literatura apresentada, no capítulo Fundamentação Teórica, estabeleceu ainda as seguintes hipóteses testadas pela presente pesquisa:

Hipótese 1. Empresas familiares geram valor em eventos de aquisições de empresas.

Hipótese 2. Empresas familiares têm maiores retornos anormais em aquisições de empresas do que empresas não familiares;

Hipótese 3. Retornos anormais em aquisições de empresas estão relacionados positivamente às empresas familiares cujo gestor é membro da familia controladora;

Hipótese 4. Retornos anormais em aquisições de empresas estão relacionados positivamente às empresas familiares de primeira e segunda gerações;

Hipótese 5. Retornos anormais em aquisições de empresas estão relacionados positivamente ao grau de concentração acionária detido pela família controladora.

Como conclusão final do trabalho, reportam-se sucintamente os principais achados globais da pesquisa, respondendo novamente às hipóteses e arguições estabelecidas, para atingir o objetivo desta pesquisa.

Dessa forma, evidencia-se que foram realizadas análises univariadas, bivariadas e multivariadas, com a utilização dos devidos instrumentais estatísticos informados em seção própria, a fim de testar as hipóteses de pesquisa. Como fechamento global da hipótese 1, conclue-se que há evidências de que empresas familiares geram valor em eventos de 
aquisições de empresas, pois em análise univariada do CAR (cumulative abnormal return), foi encontrado que, no dia dos anúncios dos eventos de aquisições de empresas (CAR_1), resultaram retornos anormais positivos e significantes estatisticamente $(p<0.10)$. Corroboramse a essa conclusão mencionada os resultados encontrados nas análises multivariadas, em que empresas familiares têm relação positiva e significante reiteradamente em técnicas estatísticas e modelos diversos, utilizados e analisados para o (CAR_21).

Como conclusão global da hipótese 2, reporta-se que, quando analisados apenas univariadamente, os CAR das subamostras empresas familiares e não familiares, a tendência pode ser aceitar a referida hipótese, pois apesar de, em geral, ambas subamostras terem ACAR positivos, empresas familiares têm maiores ACARs e, em (CAR_1), é significante estatisticamente. Entretanto, quando analisadas estatisticamente as diferenças entre as médias dos CARs, das empresas familiares e não familiares, há evidências de que não se confirma a referida hipótese, segundo reportado na tabela 15. Portanto, a conclusão final da hipótese 2 é que não há evidências de que empresas familiares tenham maiores retornos anormais positivos do que empresas não familiares.

As hipóteses 3, 4 e 5 são oriundas da literatura de empresas familiares, fundamentadas em capítulo próprio, onde se visou mensurar o impacto dessas características específicas em eventos de aquisições de empresas. Dessa forma, quanto à hipótese 3 , foram encontrados, para todos os modelos e CARs analisados, que o retorno anormal está relacionado positivamente à empresa familiar, cujo gestor é membro da família controladora. Entretanto, evidencia-se que somente para o CAR_3 (três dias - janela de eventos), encontrou-se que é altamente significante a referida relação. Portanto, existem evidências de que há relação positiva entre o retorno anormal em eventos de aquisições de empresas familiares, quando o gestor é membro da família controladora.

Por outro lado, quanto à hipótese 4, não existem evidências de que os retornos anormais em aquisições de empresas estão relacionados positivamente às empresas familiares de primeira e segunda gerações.

Referente à última hipótese desta pesquisa, reporta-se que, em análise parcial e univariada, encontrou-se que para o grau de concentração acionária média e superior a $20 \%$ de stake detido pela família controladora, há evidências de que retornos anormais estão relacionados positivamente e significantemente aos graus de concentração acionária mencionados. Entretanto, como conclusão final, tendo como base também as análises bivariadas e multivariadas, conclue-se que não se pode afirmar a existência de relação positiva entre o grau 
de concentração acionária detido pela família controladora, e retornos anormais em aquisições de empresas. Desse modo, para a hipótese 5 de pesquisa, não se confirma que os retornos anormais em aquisições de empresas estão positivamente relacionados ao grau de concentração acionária detido pela família controladora.

Logo, o presente trabalho atendeu plenamente aos objetivos, às arguições, e às hipóteses de pesquisa aqui estabelecidos. Foram testadas as hipóteses, que resultaram nas respostas das arguições e objetivos da pesquisa anteriormente estabelecidos, a saber: i) há evidências de que a propriedade familiar possa resultar em retornos anormais, e que há variáveis que podem influenciar seu desempenho, como por exemplo, família atuante na gestão da empresa, entre outras variáveis; ii) não há evidências de que os retornos anormais sejam distintas entre empresas familiares e empresas não familiares.

Quanto à sugestão para trabalhos futuros, sugere-se o desdobramento da análise da relação entre retornos anormais em eventos de aquisições de empresas e a variável concentração acionária, em que pode ser interessante a investigação mais profunda e exaustiva sobre os efeitos dos retornos anormais e a variável concentração acionária. Outrossim, recomenda-se a extensão do período amostral para verificação dos resultados com um período mais longo, e/ou análise de outro corte no tempo. Por fim, sugere-se ainda a utilização de outras métricas de desempenho para maior robustez na comparação entre resultados de empresas familiares e não familiares. 


\section{REFERÊNCIAS}

ADAMS, R.B.; ALMEIDA, H.; FERREIRA, D. Understanding the relationship between founder-CEOs and firm performance. Journal of Empirical Finance. [S.1.], v.16, p.136-150, 2009.

AGRAWAL, A.; JAFFE, J. F.; MANDELKER, G. N. The post-merger performance of acquiring firms: A reexamination of an anomaly. The Journal of Finance. [S.1.], v.47, p.1605-1621, 1992.

ALCHIAN, A.; DEMSETZ, H. Production, information cost and economic organization. The American Economic Review. [S.1.], v. 62, n.5, p.777-795, 12/1972.

ALVAREZ, S. A.; BUSENITZ, L. W. The entrepreneurship of resource-based theory. Journal of Management, [S.1.], v.27, n.6, p.755-775, 12/2001.

ANBID. Associação Brasileira das Entidades dos Mercados Financeiro e de Capitais. Merger \& Acquisition Report. Disponível em: $<$ http://www.anbid.com.br/institucional/CalandraRedirect/?temp $=3 \& p r o j=A N B I D \& p u b=T$ \&nome=sec_ESTATISTICAS_FINANCAS_fusoes\&db>. Acesso em 29/112012 às 09:00h.

ANDERSON, R. C.; REEB, D. M. e ZHAO, W. Family-controlled firms and informed trading: Evidence from short sales. The Journal of Finance. [S.1.], v.67, n.1, 02/2012.

ANDRADE, W. R. A. Efeitos da diversificação no valor das empresas do mercado de telecomunicações: teste do modelo de Berger e Ofek. Dissertação de mestrado. Universidade de São Paulo, São Paulo, SP, Brasil, 2002.

ASQUITH, P. Merger bids, uncertainty, and stockholder returns. Journal of Financial Economics. [S.1.], v.11, p.51-83, 1983

ASQUITH, P.; KIM, E. H. The impact of merger bids on the participating firms' security holders. The Journal of Finance. [S.1.], v.37, p.1209-1228, 1982

ASSOCIAÇÃO DAS EMPRESAS FAMILIARES. O que é uma Empresa Familiar? Disponível em: <http://www.empresasfamiliares.pt/o-que-e-uma-empresafamiliar?article=287-o-que-e-uma-ef > . Acesso em 10/11/2013 às 09:00h.

ASTRACHAN, J. H. Welcome from the Editor. Journal of Family Business Strategy. [S.1.], v.1, 2010.

AYBAR, B.; FICICI, A. Cross-border acquisitions and firm value: An analysis of emergingmarket multinationals. Journal of International Business Studies. [S.1.], v.40, p.1317-1338, 2009.

BAHGAT, S.; MALHOTRA, S. \& ZHU, P. Emerging country cross-border acquisitions: Characteristics, acquirer returns and cross-sectional determinants. Emerging Markets Review. [S.1.], v.12, p.250-271, 2011. 
BARRETO, A. V. P.; HONORATO, C. de F. Manual de sobrevivência na Selva Acadêmica. Rio de Janeiro: Objeto Direto, 1998.

BAZERMAN, M. H.; MOORE, D. A. Judgment in managerial decision making. New York: John Wiley \& Sons, Inc. New York, 2010.

BERKOVITCH, E., \& NARAYARANAN, M. P. Motives for takeovers: an empirical investigation. Journal of Financial and Quantitative Analysis. [S.1.], v.28, n.3, p.347-363, 1993.

BERNHOEFT, R. Empresa familiar: sucessão profissionalizada ou sobrevivência comprometida. São Paulo: Ibecon (Instituto Brasileiro de Educação Continuada), 1987.

BERTRAND, J. Theorie Mathematique de la Richesse Sociale. Journal des Savants. [S.1.], pp. 499-508, 1883.

BERTRAND, M.; MULLAINATHAN, S. Agents with and without principals. American Economic Review. v.90, p.203-208, 2000.

BESANKO, D; DRANOVE, D.; SHANLEY, M.; SCHAEFER, S. A Economia da Estratégia. $3^{a}$ Edição. Porto Alegre, Bookman, 2006.

BLANCO-MAZAGATOS, V.; de QUEVEDO-PUENTE, E.; CASTRILLO, L. A. The tradeoff between financial resources and agency costs in the family business: An exploratory study. Family Business Review. [S.1.], v.20, n.3, p.199-213, 2007.

BLOOMBERG®. Disponível em: 〈http://www.bloomberg.com/>. Acesso em: $1^{\circ}$ semestre de 2013.

BOVESPA - Bolsa de Valores de São Paulo. Disponível em: <http://www.bmfbovespa.com.br/home.aspx?idioma=pt-br>. Acesso em: 15.05 .2013 às 07:00h.

BRADLEY, M.; DESAI, A.; KIM, E. H. Synergistic gains from corporate acquisitions and their division between the stockholders of target and acquiring firms. Journal of Financial Economics. [S.1.], 21: 3-40, 1988.

BRASIL. Lei 6.404, de 15 de Dezembro de 1976. Disponível em: <http://www.planalto.gov.br/ccivil_03/leis/16404consol.htm〉. Acesso em 10/12/2012 às 09:00h.

BRASIL. Lei 11.638, de 28 de Dezembro de 2007. Disponível em: $<$ http://www.planalto.gov.br/ccivil_03/_ato2007-2010/2007/lei/111638.htm . Acesso em 10/12/2012 às 08:00h.

BROWN, S. J.; WARNER, J. B. Using daily stock returns: The case of event studies. Journal of Financial Economics. [S.1.], v.14, n.1, p.3-31, 1985.

BRUNER, R. F. The use of excess cash and debt capacity as a motive for merger. Journal of Financial and Quantitative Analysis. [S.1.], v.23, p.199-217, 1988. 
CAMARGOS, M. A., \& BARBOSA, F. V. Análise empírica do retorno acionário anormal e da reação do mercado de capitais brasileiro aos anúncios de fusões e aquisições ocorridos entre 1994 e 2001. Anais do Encontro Nacional da Associação Nacional de PósGraduação e Pesquisa em Administração, Brasília, DF, Brasil, 29. Setembro, 2005.

CAMARGOS, M. A.; COUTINHO, E. S. A teoria da firma e a fundamentação teórica para fusões e aquisições: um análise de suas interfaces. RAC-Eletrônica, Curitiba, v.2, n.2, art. 7, p. 273-295, Maio/Ago, 2008.

CAMPBELL, J. Y.; LO, A. W.; MACKINLAY, A. C. The econometrics of financial markets. 2.ed. New Jersey: Princeton University Press, 1997.

CANO, L. O recente processo de fusões e aquisições na economia brasileira. Dissertação de mestrado. Universidade Estadual de Campinas, Campinas, SP, Brasil, 2002.

CAROW, K.; HERON, R.; SAXTON, T. Do early birds get the returns? An empirical investigation of early-mover advantages in acquisitions. Strategic Management Journal. [S.1.], v.25, p.563-585, 2004.

CERVO, A. L.; BERVIAN, P. A.. Metodologia Científica. 5.ed. São Paulo: Prentice Hall, 2002.

CHANDLER, A. D. Scale and Scope. Cambridge: Havard University Press, 1990.

CHATTERJEE, S. Sources of value in takeovers: Synergy or restructuring implications for target and bidder firms. Strategic Management Journal. [S.1.], v.13, p.267-286, 1992.

CHUA, J. H.; CHRISMAN, J. J. e SHARMA, P. Defining the Family business by behavior. Entrepreneurship Theory and Practice. v.23, n.4, p.19-39, 1999.

CLAESSENS, S.; DJANKOV, S.; LANG, L. H. P. The Separation of Ownership and Control in East Asian Corporations. Journal of Financial Economics. [S.1.], n.58, p.81-112, 2000.

CNBC. Asia's Richest Families. Disponível em: <www.cnbc.com>. Acessado em: 29/04/2013 às 18:00h.

COASE, R. The nature of the firm. Economica. [S.1.], v.4, p. 386-405, 1937.

COSTA JR., J. V. da. Retornos anormais versus performances operacionais anormais de firmas brasileiras envolvidas em fusões e aquisições no período de 2002 a 2006 . Tese de Doutorado. Universidade de São Paulo. São Paulo, 2008.

COURNOT, A. (1838). Researches into the mathematical principles of the theory of wealth. London: Macmillan \& Co., Ltd., 1897. Disponibilizado gratuitamente no sítio: <http://www.archive.org/stream/researchesintom00fishgoog\#page/n8/mode/2up>. Acessado em: 18.10.2012 às 19:00hs.

CREMERS, M.; NAIR, V. B. Governance mechanisms and equity prices. The Journal of Finance. [S.1.], v.60, p.2859-2894, 2005. 
CUERVO-CAZURRA, A.; MALONEY, M. M.; MANRAKHAN, S. Causes of the difficulties in internationalization. Journal of International Business Studies. [S.1.], v.38, n.5, p.709-725, 2007.

CVM - Comissão de Valores Mobiliários. Disponível em: 〈www.cvm.gov.br〉. Acesso em: 26.05.2013 às 05:30h.

DATASTREAM DATABASE. Acesso em: FEA USP Biblioteca no $2^{\circ}$ semestre de 2012.

DATTA, D. K.; PINCHES, G. E.; NARAYANAN, V. K. Factors influencing wealth creation from mergers and acquisitions $-A$ meta-analysis. Strategic Management Journal. [S.1.], v.13, p.67-84, 1992.

DAWAR, N.; FROST, T. Competing with giants: Survival strategies for local companies in emerging markets. Harvard Business Review. [S.1.], v.77, n.2, p.119-132, 1999.

DEMSETZ, H. Toward a theory of property rights. American Economic Review. [S.1.], v.62, n.2, p.347-359, 1967.

DODD, P. Merger proposals, management discretion and stockholder wealth. Journal of Financial Economics. [S.1.], v.8, p.105-137, 1980.

DONALDSON, T.; PRESTON, L. E. The stakeholder theory of the Corporation: concepts, evidence, and implications. Academy of Management Review. [S.1.], v.20,n.1, p.65-91, 1995.

DONNELlEY, R. G. A empresa familiar. Revista de Administração de Empresas - RAE. Fundação Getúlio Vargas. São Paulo, v. 7, n. 23, p.161-198, 06/1967.

ECONOMÁTICA® SECURITIES FINANCIAL DATA. Acesso em: FEA USP Biblioteca $1^{\circ}$ semestre de 2013.

EDMANS, A. Blockholder trading, market efficiency, and managerial myopia. The Journal of Finance. [S.1.], v.64, p.2481-2514, 2009.

EDMANS, A.; MANSO, G. Governance through trading and intervention: a theory of multiple blockholders. Review of Financial Studies. [S.1.], v.24, n.7, p.2395-2428, 2011.

FAHLENBRACH, R. Founder-CEOs, investment decidions, and stock market performance. Journal of Financial and Quantitative Analysis. [S.1.], v.44, p.439-466, 2009.

FERNANDEZ, Z. \& NIETO, M. J. Internationalization strategy of small and medium-sized family businesses: some influential factors. Family Business Review. [S.1.], v.18, n.1, p.7789, 2005.

FORBES. America's richest: America's biggest billionaire moneymakers of 2009. Disponível em: <www.forbes.com>. Acessado em: 29.04.2013 às 18:00h.

FORBES. Asia's 20 richest 2012. Disponível em: <www.forbes.com>. Acessado em: 29.04.2013 às 18:00h. 
FORBES. The richest people in Brazil. Disponível em: 〈www.forbes.com>. Acessado em: 29.04.2013 às 18:00h.

FORBES, D. P. Are some entrepreneurs more overconfident than others? Journal of Business Venturing. [S.1.], v.20, p.623-640, 2005.

FREEMAN, R. E. Strategic Management: A stakeholder approach. Marshfield, MA: Pitman Books Limited, 1984.

FREIRE, P. S.; NAKAYAMA, K. M.; SPANHOL, F. J.; TOSTA, K. C. B. T.; TOSTA, H. T.; AMARAL, R. Profissionalização de empresas familiares brasileiras: uma transformação paradigmática. In: INTERNATIONAL METTING OF THE IBEROAMERICAN ACADEMY OF MANAGEMENT, 2009, Buenos Aires. Anais. INTERNATIONAL METTING OF IBEROAMERICAN ACADEMY OF MANAGEMENT, Buenos Aires: 2009b.

FRUGIS, L. F. As empresas familiares e a continuidade na gestão das terceiras gerações. São Paulo: EDUC, 2007.

GALLO, M. A.; VILASECA, A. A financial perspective on structure, conduct and performance in the family firm: an empirical study. Family Business Review. [S.1.], v.11, n1, p.35-47, 1998.

GERA (GLOBAL ENTREPRENEURSHIP RESEARCH ASSOCIATION). Global entrepreneurship monitor 2010: Global report. Londres, 2011. Disponível em: <http://www.gemconsortium.org>. Acessado em: 18.08.2012 às 8:00hs.

GERSICK, K. E.; DAVIS, J. A.; HAMPTON, M,; LANSBERG, I. De geração para geração: ciclos de vida das empresas familiares. São Paulo: Negócios, 1997.

GORGATI, V. Os determinantes da estrutura de capital de empresas familiares brasileiras durante os processos sucessórios: Contribuições da Teoria da Firma. Dissertação de Mestrado. Universidade de São Paulo. São Paulo, 2000.

GUARITA, S. Fusões e aquisições no Brasil. Revista FAE Business. [S.1.], n.3, p. 24-26, $09 / 2002$.

GUBBI, S.R. et al. Do international acquisitions by emerging-economy firms create shareholder value? The case of Indian firms. Journal of International Business Studies. [S.1.], v.41, n.397-418, 2010.

GUIMARÃES, E. A. A decisão de investir na firma. Rio de Janeiro, Zahar, 1982a.

GUIMARÃES, E. A. A decisão de investir na firma. Rio de Janeiro, IEI/UFRJ, 1982b.

HALEBLIAN, J. et al. Taking Stock of What We Know About Mergers and Acquisitions: A Review and Research Agenda. Journal of Management. [S.1.], v. 35 n.3, p.469-502, 06/2009. 
HALEBLIAN, J.; FINKELSTEIN, S, The influence of organizational acquisition experience on acquisition performance. Administrative Science Quarterly. [S.1.], v.44, p.29-56, 1999.

HANSEN, R. G.; LOTT, J. R. Externalities and corporate objectives in a world with diversified shareholder consumers. Journal of Financial and Quantitative Analysis. [S.1.], v.31, p.43-68, 1996.

HART, O. An economist's perspective on the theory of the firm. In: BUCKLEY, P. J., MICHIE, J. Firms, organizations and contracts. 1 ed. Oxford University Press, 1996.

HARTZELL, J.; STARKS, L. Institutional investors and executive compensation. The Journal of Finance. [S.1.], v.58, p.2351-2374, 2003.

HEALY, P. M.; PALEPU, K. G.; RUBACK, R. S. Does corporate performance improve after mergers. Journal of Financial Economics. [S.1.], v.31, p.135-175, 1992

HÉAU, D. (2001). Mania de fusões. In: B. T. Barros (Org.). Fusões, aquisições e parcerias. São Paulo: Atlas, 2001.

HOUSTON, J. F.; JAMES, C. M.; RYNGAERT, M. D. Where do merger gains come from? Bank mergers from the perspective of insiders and outsiders. Journal of Financial Economics. v.60, p.285-331, 2001.

JARRELL, G. A.; POULSEN, A. B. The returns to acquiring firms in tender offers: Evidence from 3 decades. Financial Management. [S.1.], v.18, n.3, p.12-19, 1989.

JENSEN, M. Value maximization, stakeholder, theory, and the corporate objective function. European Financial Management. [S.1.], v.7, n.3, p.207-317, 2001a.

JENSEN, M.; MECKLING, W. Theory of the firm: managerial behavior, agency cost and ownership structure. Journal of Financial Economics. [S.1.], v.3, p.305-360, 10/1976.

KAHNEMAN, D.; TVERSKY, A. Prospect theory: an analysis of decision under risk. Econometrica. [S.1.], v. 47, n. 2, p. 263-292, 03/1979.

KAYO, E. K. A Estrutura de capital e o risco das empresas tangível e intangívelintensivas: uma contribuição ao estudo da valoração de empresas. Tese de Doutorado. Universidade de São Paulo. São Paulo, 2002.

KAYO, E. K.; FAMA, R. Teoria da agência e crescimento: evidências empíricas dos efeitos positivos e negativos do endividamento. Caderno de Pesquisa em Administração. v.2, n.5, p. $1-8,2^{\circ}$. Sem/1997.

KAYO, E.K.; PATROCINIO, M.R.; MARTIN, D. M. L. Intangibilidade e criação de valor em aquisições. Revista de Administração da Universidade de São Paulo, São Paulo, p. 5969, 2009.

KELLERMANNS, F.W.; EDDLESTON, K.A. Feuding families: When conflict does a family firm good. Entrepreneurship Theory and Practice. [S.1.], v.28, n.3, p. 209-228, 2004. 
KETS DE VRIES, M. F. The dynamics of family controlled firms: The good and the bad news. Organizational Dynamics. [S.1.], v.21, n.3, p. 59-71, 1993.

KIM, E. H., LU. Y. CEO ownership, external governance, and risk-taking. Journal of Financial Economics. [S.1.], v.102, p. 272-292, 2011.

KING, D. R.; DALTON, D. R.; DAILY, C. M.; COVIN, J. G. Meta-analyses of postacquisition performance: Indications of unidentified moderators. Strategic Management Journal, v.25, p. 187-200, 2004.

KLEIN, B.; CRAWFORD, R.; ALCHIAN, A. Vertical integration, appropriable rents, and the competitive contracting process. Journal of Law and Economics. [S.1.], v. 28, p. 297326, 1978.

KNIGHT, F. Risk, uncertainty and profit. 1.ed. Boston, MA: Hart, Schaffner \& Marx; Houghton Mifflin Co., 1921. Livro disponível gratuitamente em: < http://www.econlib.org/library/Knight/knRUP.html>. Acesso em: 12.06.2012 às 18:00hs.

KOZAN, M. K.; OKSOY, D.; OZSOY, O. Owner sacrifice and small business growth. Journal of World Business. [S.1.], v.47, p. 409-419, 2012.

KPMG. Merger and Acquisitions 2012 - 20 quarter. São Paulo, 07/2012a. Disponível em: $<$ http://www.kpmg.com>. Acessado em: 21.10.2012 às 09:00h.

KPMG. Merger and Acquisitions 2012 - 4⿳0 quarter. São Paulo, 11/2012b. Disponível em: <http://www.kpmg.com>. Acessado em: 10.02.2013 às 17:00h.

LANZANA, A.; COSTANZI, R. As empresas familiares brasileiras diante do atual panorama econômico mundial. In. MARTINS, I. G. S.; MENEZES, P. L. e BERNHOEFT, R. (Org.) Empresas familiares brasileiras: perfil e perspectivas. São Paulo: Negócio Editora, 1999.

LANSBERG, I. et al. Editor's notes. Family Business Review, v.1, n.1, 1988.

LA PORTA, R. F.; LÓPEZ, de S. e SHLEIFER, A. Corporate Ownership Around the World. The Journal of Finance. [S.1.], v.54, p. 471-517, 1999.

LEETH, J. D.; BORG, J. R. The impact of takeovers on shareholder wealth during the 1920s merger wave. Journal of Financial and Quantitative Analysis, v. 35, p. 217-238, 2000.

LEMELIN, A. Relatedness in the patterns of interindustry diversification. The Review of Economics and Statistics. [S.1.], v.64, p. 645-657, 1982.

LI, F.; SRINIVASAN, S. Corporate governance when founders are directors. Journal of Financial Economics. [S.1.], v.102, p. 454-469, 2011.

LODERER, C., \& MARTIN, K. Postacquisition performance of acquiring firms. Financial Management. [S.1.], v.21, n.3, p. 69-79, 1992.

LODI, J. B. A Empresa familiar. 5. ed. São Paulo: Pioneira, 1998. 
MACDONALD, J.M. Research \& Development and the directions of diversification. The Review of Economics and Statistics. [S.1.], v.4, p. 351-374, 1985.

MACKINLAY, A. C. Event studies in economics and finance. Journal of Economic Literature. [S.1.], v. 35, n. 1, 03/1997.

MALATESTA, P. H. The wealth effect of merger activity and the objective functions of merging firms. Journal of Financial Economics, v.11, p. 155-181, 1983.

MANNE, H. G. Mergers and the market for corporate control. Journal of Political Economy. [S.1.], v.73, n.2, p. 110-120, 1965.

MARKIDES, C. C., \& ITTNER, C. D. Shareholder benefits from corporate international diversification: Evidence from US international acquisitions. Journal of International Business Studies. [S.1.], v.25, n.2, p. 343-366, 1994.

MARSHALL, A. Princípios de economia: tratado introdutório. São Paulo: Abril Cultural, 1982.

MARTINS, I. G. S.; MENEZES, P. L. e BERNHOEFT, R. (Org.) Empresas familiares brasileiras: perfil e perspectivas. São Paulo: Negócio Editora, 1999.

MATTAR, F. N. Pesquisa de Marketing. 3.ed. São Paulo: Atlas, 2001.

MAURY, B. Family ownership and firm performance: Empirical evidence from Western European corporations. Journal of Corporate Finance. [S.1.], v.12, p. 321-341, 2006.

MAZZON, J. A. Formulação de um modelo de avalição e comparação de modelos em marketing. Dissertação de Mestrado. Universidade de São Paulo. São Paulo, 1978.

MCCONAUGHY, D.L.; MATTHEWS, C.H.; FIALKO, A.S. Founding family controlled firms: Performance, risk, and value. Journal of Small Business Management. [S.1.], v.39, n.1, p. 21-49, 2001.

MCCONAUGHY, D. L.; PHILLIPS, G. M. Founders versus descendants: The profitability, efficiency, growth characteristics and financing in large, public founding-family-controlled firms. Family Business Review. [S.1.], v.12, n.2, p. 123-131, 1999.

MCCONAUGHY, D. L.; WALKER, M. C.; HENDERSON, G. V.; MISHRA, C. S. Founding family controlled firms: efficiency and value. Review of Financial Economics. [S.1.], v.7, p. 1-19, 1998.

MCNAMARA, G. M.; HALEBLIAN, J. J.; DYKES, B. J. The Performance Implications of Participating in an Acquitition Wave. Academy of Management Journal. [S.1.], v.51, n.1, p.113-130, 2008.

MCWILLIAMS, A.; SIEGEL, D. Event studies in management research: Theoretical and empirical issues. Academy of Management Journal. [S.1.], v.40, n.3, p. 626-657, 1997. 
MELlO, C. M. de; NEVES, H. L.; BRUNEAU, J.; MATTIELlO, K. Do que estamos falando quando falamos sobre empreendedorismo no Brasil? In: Encontro de estudos sobre empreendedorismo e gestão de pequenas empresas. Anais. São Paulo: EGEPE, 2008. CDROM.

MILMAN, C. D., D'MELLO, J. P., AYBAR, B., \& ARBELAEZ, H. A note using mergers and acquisitions to gain competitive advantage in the United States in the case of Latin American MNCs. International Review of Financial Analysis. [S.1.], v.10, n.3, p. 323-332, 2001.

MIRANDA, J. C., MARTINS, L.. Fusões e aquisições de empresas no Brasil. Revista Economia e Sociedade. Campinas, p. 67-88, 06/2000.

MOELlER, S. B.; SCHLINGEMANN, F. P.; STULZ, R. M. Do shareholders of acquiring firms gain from acquisitions? Research Technology Management. [S.1.], v.46, n.6, 2003.

MOLLY, V.; LAVEREN, E.; JORISSEN, A. Intergenerational diferences in family firms: Impact on capital structure and growth behavior. Entrepreneurship Theory and Practice ET\&P. [S.1.], v.36, n.4, pp. 703-725. 07/2012.

MORCK, R.; SHLEIFER, A.; VISHNY, R. Management ownership and market valuation: an empirical analysis. Journal of Financial Economics. [S.1.], 20, 293-315, 1988.

MUNOZ-BULLON, F.; SANCHEZ-BUENO, M. J. Do family ties shape the performance consequences of diversification? Evidence from the European Union. Journal of World Business. [S.1.], v.47, p. 469-477, 2012.

MUSSNICH, F. A. M. A utilização desleal de informações privilegiadas - insider trading - no Brasil e nos Estados Unidos. Revista de Direito Mercantil, Industrial, Econômico e Financeiro. [S.1.], v.18, n34, p. 31-51, 1979.

NARDI, R. Y. S. Criação de valor em fusões e aquisições - A Influência do sentimento de mercado. Dissertação de Mestrado. Universidade de São Paulo. São Paulo, 2012.

NASH, J. F. Equilibrium Points in n Person Games. PNAS (Proceedings of the National Academy of Sciences). [S.1.], v. 36, n.1, p. 48-49, 1950.

NEUBAUER, F.; LANK, A.G. The Family business: its governance for sustainability. New York: Routledge, 1998.

NORTH, D. Structure and performance: the task of economic history. Journal of Economic Literature. [S.1.], v.16, p. 963-978, 1978.

PALIA, D.; RAVID, S. A. The Role of Founders in Large Companies: Entrenchment or Valuable Human Capital? Working Paper. Rutgers University, 2003.

PATROCÍNIO, M. R., KAYO, E. K., \& KIMURA, H. Intangibilidade e criação de valor nos eventos de fusão e aquisição: uma análise dos retornos anormais do período de 1994 a 2004. Anais do Encontro Nacional da Associação Nacional de Pós-Graduação e Pesquisa em Administração, Brasília, DF, Brasil, 29, setembro, 2005. 
PENROSE, E. The Theory of the Growth of the Firm. Oxford University Press:

New York, 1959.

PÉREZ-GONZÁLEZ, F. Inherited Control and Firm Performance. The American Economic Review. [S.1.], v. 96, n. 5, p. 1559-1588, 12/2006.

PFIFFER, E. A. Adequação estratégica dos processos de fusões e aquisições no setor de minério de ferro: estudo de caso da Companhia Vale do Rio Doce. Dissertação de mestrado. Pontifícia Universidade Católica do Rio de Janeiro, Rio de Janeiro, RJ, Brasil, 2004.

PHILLIPS, R. Stakeholder Theory and Organizational Ethics. San Francisco, CA: BerrettKoehler Publishers, 2003.

PINDYCK, R. S.; RUBINFELD, D. L. Microeconomia. 6. ed. São Paulo: Pearson Education do Brasil Ltda, 2006.

PRICEWATERHOUSECOOPERS (PWC). Empresas familiares no Brasil: Cenários e desafios, 2011. Disponível em: 〈http://www.pwc.com.br>. Acesso em: 29.04.2013 às 18:00h.

RASMUSSEN, U. W. Aquisições, fusões e incorporações empresariais. $1^{a}$ ed. São Paulo: Ed. Aduaneiras, 1989.

RICHARDSON, R. J. et al. Pesquisa social: métodos e técnicas. 3.ed. São Paulo: Atlas, 2007.

ROBBINS, L. An essay on the nature and significance of economic science. 2nd. ed. London: Macmillan and Co., 1945.

ROCHA, F.; IOOTTY, M.; FERRAZ, J.C. Desempenho das fusões e aquisições e rentabilidade na indústria brasileira na década de 90: A ótica das empresas adquiridas. Revista de Economia Contemporânea, v.5, p. 69-72, 2001.

ROCHA, T. A. R. da. Efeitos da propriedade familiar sobre os eventos de fusão e aquisição. Dissertação de Mestrado. Universidade de São Paulo. São Paulo, 2012.

ROLL, R. The hypothesis of corporate takeovers. Journal of Business. [S.1.], v.59, p. 197216, 1986.

ROSENBLATT, P. C.; de MIK, L.; ANDERSON, R. M.; JOHNSON, P. A. The family in business: Understanding and dealing with the challenges entrepreneurial families face. San Francisco: Jossey-Bass, 1985.

ROSSETTI, J. P. Fusões e aquisições no Brasil: as razões e os impactos. In: BARROS, B. T. (Org.). Fusões, aquisições e parcerias. São Paulo: Atlas, 2001.

RUSSO, J. E.; SCHOEMAKER, P. J. H. Decision Traps and How To Avoid Them. Chemical Engineering. [S.1.], pp. 181-185, 05/1991.

RUSSO, J. E.; SCHOEMAKER, P. J. H. Managing Overconfidence. Sloan Management Review. Winter. [S.1.], pp. 7-18, 1992. 
SAITO, R.; SILVEIRA, A. di M. Governança Corporativa: Custos de Agência e Estrutura de Propriedade. RAE. Revista de Administração de Empresas. [S.1.], v. 48, p. 1-20, 2008.

SANTOS, A. R. Metodologia científica: a construção do conhecimento. Rio de Janeiro: DP\&A, 1999.

SCHUMAN, A.; STUTZ, S; WARD, J. L. Family business as paradox. $1^{\text {a }}$ ed. New York: Palgrave Macmillan, 2010.

SCHUMPETER, J. A. Teoria do desenvolvimento econômico: uma investigação sobre lucros, capital, crédito, juro e o ciclo econômico. São Paulo: Abril Cultural, 1982. (Os Economistas).

SCOTT, J.T. Purposive diversification and economic performance. Cambridge; Cambridge University Press. 1983.

SEBRAE. Serviço Brasileiro de Apoio às Micro e Pequenas Empresas. Disponível em: <http://www.sebrae.com.br/momento/quero-abrir-um-negocio/que-negocioabrir/tipos/empresa-familiar>. Acesso em: 10/11/2013 às 16:00h.

SETH, A.. Value creation in acquisitions: a reexamination of performance issues. Strategic Management Journal, v.11, p. 99-115, 1990a.

SETH, A. Sources of value creation in acquisitions: an empirical investigation. Strategic Management Journal, v.11, n.6, p. 431-446, 1990 b.

SETH, A., SONG, K. P., \& PETTIT, R. R. Value creation and destruction in cross-border acquisitions: An empirical analysis of foreign acquisitions of US firms. Strategic Management Journal. [S.1.], v.23, n.10, p. 921-940, 2002.

SHAN, W., \& SONG, J.. Foreign direct investment and the sourcing of technological advantage: Evidence from the biotechnology industry. Journal of International Business Studies. [S.1.], v.28, n.2, p. 267-284, 1997.

SHARMA, P. An overview of the field of business studies: current status and directions for the future. Family Business Review. [S.1.], v.17, n.1, 2004.

SHARMA, P. et al. Strategic management of the family business: past research and future challenges. Family Business Review. [S.1.], v. 10, n.1, 1997.

SHLEIFER, A.; Vishny, R. W. Large shareholders and corporate control. Journal of Political Economy. [S.1.], v.94, n.3, parte 1, p. 461-488, 06/1986.

SILVEIRA, A. D. M. da. Governança corporativa e estrutura de propriedade: determinantes e relação com o desempenho das empresas no Brasil, Saint Paul Editora. São Paulo, 2006. 
SILVEIRA, A. D. M. da; BARROS, L. A. B. de C. Concentration of Power and Corporate Performance Variability. In: 21th European Financial Management Association - EFMA, 2012, Barcelona. 21th Annual Meeting of the European Financial Management Association - EFMA, 2012.

SIMON, H. A. Models of Man. John Wiley and Sons. New York, 1957.

SRAER, D.; THESMAR. D. Performance and behavior of Family firms:Evidence from the french stock market. Journal of the European Economic Association. [S.1.], v.5, n.4, p.709$751,06 / 2007$.

STIGLER, G. J. Monopoly and oligopoly by merger. The American Economic Review. [S.1.], V.40, n.1, p. 23-34, 1950.

TAPIES, J.; WARD, J. L. Family Values and Value Creation: The fostering of enduring values within Family-owned businesses. New York: Palgrave Macmillan, July 2008.

TEECE, D. Na economic theory of multiproduct firms. Journal of Economic Behavior and Organization. [S.1.], v.3, p. 39-63, 1982.

THOMSON REUTERS PLATINUM FINANCIAL SECURITIES DATA - Base de dados obtido no dia 27.10.2011 às 16:39h.

THOMSON REUTERS EIKON FINANCIAL DATA - Base de dados obtido em Janeiro de 2013.

THOMSON REUTERS. Acesso em: FEA USP Biblioteca $1^{\circ}$ semestre de 2012.

TOFFLER, A. Criando uma nova civilização - a política da terceira onda. São Paulo: Record, 1998.

TOFFLER, A. A terceira onda. 16 ed. Rio de Janeiro: Record, 1980.

TSANG, E. W. K. Learnig from overseas venturing experience. Journal of Business Venturing. [S.1.], v. 17, 2002.

TVERSKY, A.; KAHNEMAN D.; Judgment under uncertainty: Heuristics and biases. Science. [S.1.], v.185, n.4157, p. 1124-1131, 27.09/1974.

UHLENBRUCK, K.; HITT, M.A.; SEMADENI, M. Market value effects of acquisitions involving internet firms: a resource-based analysis. Strategic Management Journal. [S.1.], v.27, n.10, p. 899-913, 2006.

VEBLEN, T. B. Absentee ownership business enterprise in recente times: the case of America. Boston: Beacon Press, 1967.

VERGARA, S. C. Projetos e Relatórios de Pesquisa em Administração. 13 ${ }^{\text {a }}$ Ed. São Paulo: Atlas, 2011. 
VERMEULEN, F., \& BARKEMA, H. Learning through acquisitions. Academy of Management Journal. [S.1.], v.44, n.3, p. 457-476, 2001.

VIEIRA, E. Nova Geração. Revista Indústria Brasileira. São Paulo, v. 85, p. 16-21, 03/2008.

VILLALONGA, B.; AMIT, R. How do family ownership, control and management affect firm value? Journal of Financial Economics. [S.1.], v.80, p. 385-417, 2006.

VILLALONGA, B.; AMIT, R. Family control of firms and industries. Financial Management. [S.1.], v.39, p. 863-904, 2010.

VILLALONGA, B.; MCGAHAM, A.M. The choice among acquisitions, alliances, and divestitures. Strategic Management Journal. [S.1.], v.26, n.13, 2005.

VISSCHER, F. M. de ; ARONOFF, C. E. ; WARD, J. L. Financing transitions: managing capital and liquidity in the family business. Marietta, GA: Family Enterprise Publishers, 1995.

VON NEUMANN, J.; MORGENSTERN, O. Theory of games and economic behavior. Princeton, NJ : Princeton University Press, 1944.

WERNER, R. A. Família e negócios: um caminho para o sucesso. Barueri: Manole, 2004.

WILLIAMSON, O. Markets and hierarchies: Analysis and antitrust implications. 1 ed. New York: The Free Press, 1975.

WINTER, M; FITZGERALD, M. A.; HECK, R. K. Z.; HAYNES, G. W. e DANES, S. M. Revisiting the study of family businesses: Methodological Challenges, Dilemmas, and Alternative Approaches. Family Business Review. [S.1.], v.11, n.3, p. 239-252, 1998.

WOOD, A. Diversification, merger and research expenditure. Londres, Macmillan, 1971.

WRIGHT, P.; KROLL, M.; LADO, A.; VAN NESS, B. The structure of ownership and corporate acquisition strategies. Strategic Management Journal. [S.1.], v.23, p.41-53, 2002.

ZAHRA, S. A. Entrepreneurial risk taking in Family firms. Family Business Review. [S.1.], v.18, n.1, p. 23-40, 2005.

ZAHRA, S. A.; SHARMA, P. Family business research: a strategic reflection. Family Business Review. [S.1.], v.17, n.4, 2004. 
APÊNDICES 
Reportam-se, conforme abordado anteriormente, os resultados encontrados que fundamentaram os testes das hipóteses de pesquisa e consideração final.

Apêndice 1 - Resultados das Regressões Multivariadas obtidos com a técnica estatística não paramétrica de resampling Bootstrap utilizando os Benchmark de retorno de mercado

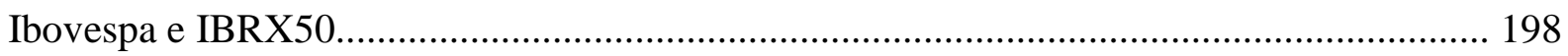
Apêndice 2 - Resultados das Regressões Multivariadas obtidos com o método mínimos quadrados ordinários (MQO) com erros-padrão robustos utilizando o teste de robustez de Benchmark de retorno de mercado: IBRX50. 230 
Apêndice 1 - Resultados das Regressões Multivariadas obtidos com a técnica estatística não paramétrica de resampling Bootstrap utilizando os Benchmark de retorno de mercado Ibovespa e IBRX50.

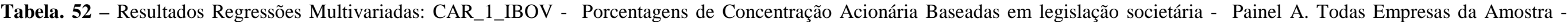
Bootstrap

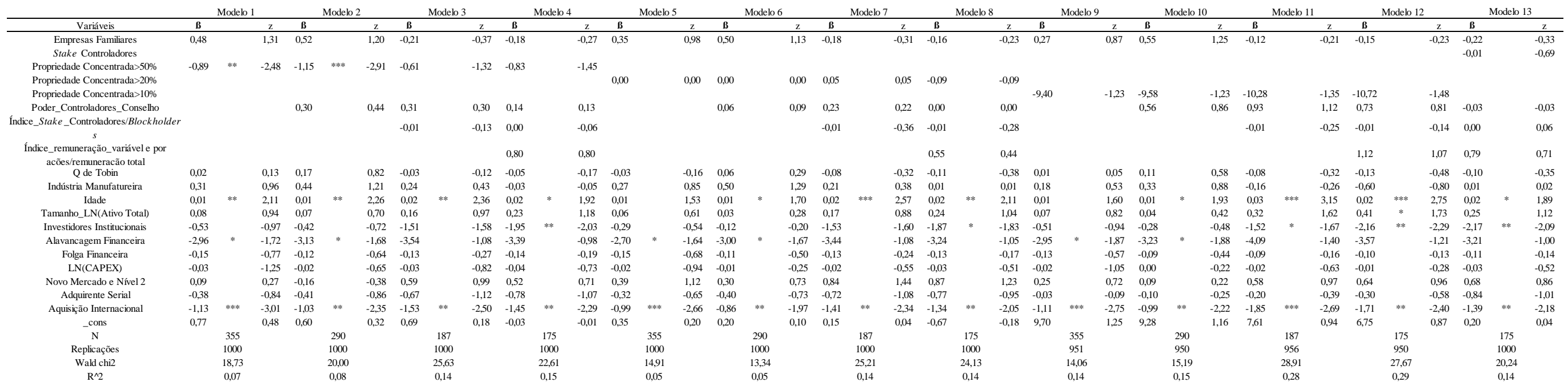

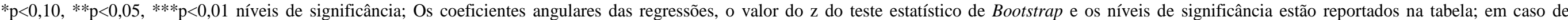

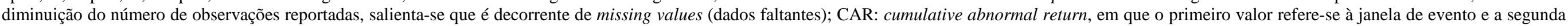
nomenclatura ao benchmark de retorno de mercado utilizado.

Fonte: Elaborado pelo autor. 
Tabela. 53 - Resultados Regressões Multivariadas: CAR_1_IBOV - Porcentagens de Concentração Acionária Baseadas em legislação societária - Painel B. Empresas Familiares da Amostra Bootstrap

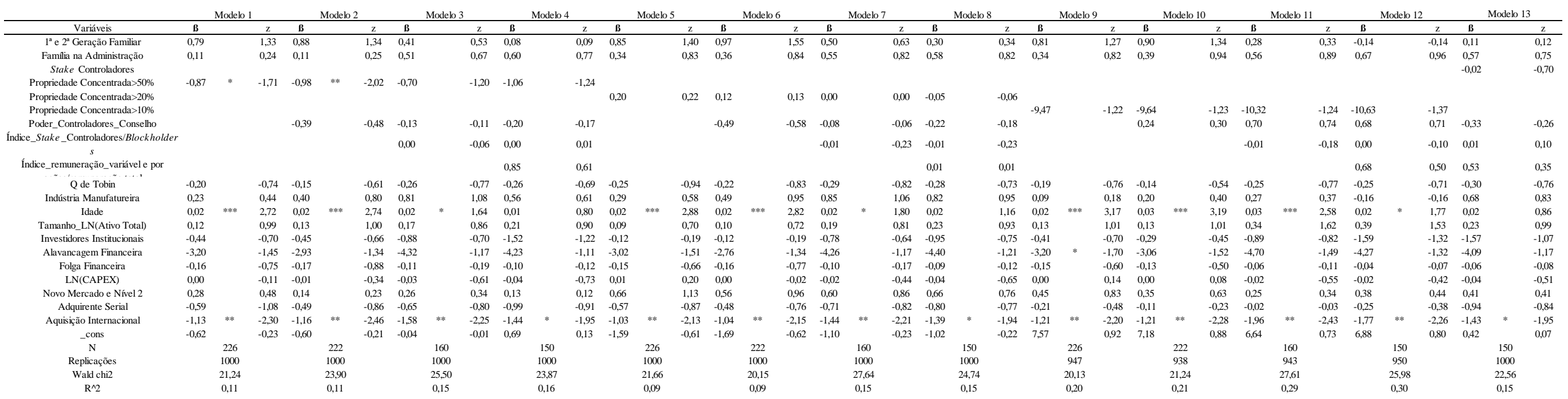

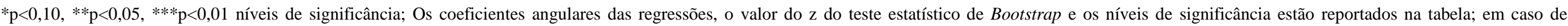

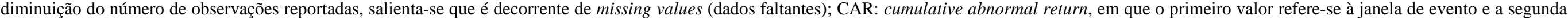
nomenclatura ao benchmark de retorno de mercado utilizado.

Fonte: Elaborado pelo autor. 


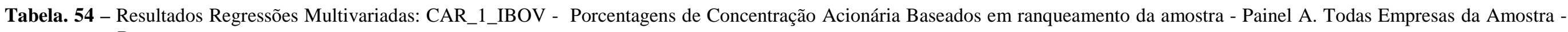
Bootstrap

\begin{tabular}{|c|c|c|c|c|c|c|c|c|c|c|c|c|c|c|c|c|c|c|c|c|c|c|c|c|c|c|c|c|c|c|c|c|c|c|c|c|}
\hline & & Modelo & & & Modelo 2 & & & Modelo & & & Modelo. & & & Modelo & & & Modelo 6 & & & Modelo 7 & & & Modelo 8 & & & Modelo 9 & & & Modelo 1 & & & Modelo 11 & & & Modelo 1 & \\
\hline Variáveis & $B$ & & $\mathrm{z}$ & $B$ & & $\mathrm{z}$ & B & & $z$ & $B$ & & $\mathrm{z}$ & B & & $z$ & B & & $\mathrm{z}$ & B & & $\mathrm{z}$ & B & & $\mathrm{z}$ & B & & $\mathrm{z}$ & $B$ & & $\mathrm{z}$ & $B$ & & $\mathrm{z}$ & B & & $\mathrm{z}$ \\
\hline Empresas Familiares & 0,34 & & 0,98 & 0,49 & & 1,09 & $-0,16$ & & $-0,27$ & $-0,16$ & & $-0,24$ & 0,39 & & 1,14 & 0,56 & & 1,26 & $-0,15$ & & $-0,26$ & $-0,12$ & & $-0,18$ & & & & & & & $-0,19$ & & & $-0,13$ & & $-0,19$ \\
\hline Propriedade Concentrada_Alta & 0,34 & & $0, \%$ & $0,+\infty$ & & $1,0 \%$ & $-0,10$ & & $-0,27$ & $-0,110$ & & $-0,24$ & (3) & & 1,14 & 0 & & 1,20 & $-0,1$ & & $-0,20$ & $-0,12$ & & $-0,10$ & $-1,00$ & $*$ & $\begin{array}{l}-1,91 \\
-1,251\end{array}$ & 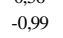 & $*$ & 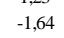 & $\begin{array}{l}-0,27 \\
-0,27\end{array}$ & & $\begin{array}{l}-0,31 \\
-0,31\end{array}$ & $-0,37$ & & $\begin{array}{l}-0,37 \\
-0,37\end{array}$ \\
\hline Propriedade Concentrada_Média & & & & & & & & & & & & & 0,26 & & 0,84 & 0,37 & & 1,16 & 0,12 & & 0,22 & 0,05 & & 0,07 & & & & & & & & & & & & \\
\hline Propriedade Concentrada_Baixa & 0,16 & & 0,35 & 0,09 & & 0,16 & $-0,08$ & & $-0,11$ & 0,04 & & 0,06 & & & & & & & & & & & & & & & & & & & & & & & & \\
\hline Poder_Controladores_Consellho & & & & 0,06 & & 0,08 & 0,24 & & 0,21 & $-0,01$ & & $-0,01$ & & & & 0,01 & & 0,02 & 0,24 & & 0,23 & 0,00 & & 0,00 & & & & $-0,15$ & & $-0,20$ & 0,22 & & 0,21 & $-0,03$ & & $-0,02$ \\
\hline Índice_Stake_Controladores/Blockholder & & & & & & & $-0,01$ & & $-0,36$ & $-0,01$ & & $-0,29$ & & & & & & & $-0,01$ & & $-0,32$ & $-0,01$ & & $-0,28$ & & & & & & & $-0,01$ & & $-0,18$ & $-0,01$ & & $-0,11$ \\
\hline Índice_remuneração_variável e por & & & & & & & & & & 0,52 & & 0,49 & & & & & & & & & & 0,51 & & 0,48 & & & & & & & & & & 0,57 & & 0,55 \\
\hline Q de Tobin $\cdots$ & $-0,02$ & & $-0,13$ & 0,06 & & 0,29 & $-0,08$ & & $-0,30$ & $-0,11$ & & $-0,38$ & $-0,04$ & & $-0,23$ & 0,06 & & 0,30 & $-0,08$ & & $-0,28$ & $-0,11$ & & $-0,37$ & $-0,05$ & & $-0,25$ & 0,05 & & 0,25 & $-0,09$ & & $-0,32$ & $-0,11$ & & $-0,41$ \\
\hline Indústria Manufatureira & 0,28 & & 0,85 & 0,51 & & 1,40 & 0,21 & & 0,38 & 0,00 & & 0,00 & 0,23 & & 0,75 & 0,44 & & 1,18 & 0,21 & & 0,40 & 0,01 & & 0,01 & 0,17 & & 0,54 & 0,39 & & 1,06 & 0,22 & & 0,41 & 0,02 & & 0,03 \\
\hline Idade & 0,01 & & 1,56 & 0,01 & $*$ & 1,74 & 0,02 & $* *$ & 2,39 & 0,02 & $* *$ & 2,02 & 0,01 & & 1,27 & 0,01 & & 1,40 & 0,02 & $* *$ & 2.42 & 0,02 & * & 1.92 & 0,01 & & 1,32 & 0,01 & & 1,46 & 0,02 & $* *$ & 2,28 & 0,02 & $*$ & 1.84 \\
\hline Tamanho_LN(Ativo Total) & 0,06 & & 0,67 & 0,03 & & 0,34 & 0,17 & & 0,96 & 0,23 & & 1,13 & 0,06 & & 0,69 & 0,03 & & 0,33 & 0,17 & & 0,94 & 0,23 & & 1,06 & 0,09 & & 0,93 & 0,06 & & 0,63 & 0,17 & & 1,00 & 0,23 & & 1,13 \\
\hline Investidores Institucionais & $-0,34$ & & $-0,62$ & $-0,14$ & & $-0,25$ & $-1,51$ & & $-1,56$ & $-1,87$ & * & $-1,85$ & $-0,28$ & & $-0,47$ & $-0,10$ & & $-0,16$ & $-1,51$ & & $-1,51$ & $-1,84$ & $*$ & $-1,82$ & $-0,49$ & & $-0,94$ & $-0,36$ & & $-0,60$ & $-1,56$ & & $-1,52$ & $-1,91$ & $*$ & $-1,79$ \\
\hline Alavancagem Financeira & $\begin{array}{l}-2,72 \\
-2,72\end{array}$ & & $\begin{array}{l}-1,62 \\
-1,63\end{array}$ & $\begin{array}{l}-2,14 \\
-2,98\end{array}$ & $*$ & $\begin{array}{l}-1,225 \\
-1,65\end{array}$ & $\begin{array}{l}-3,11 \\
-3,42\end{array}$ & & $\begin{array}{l}-1,00 \\
-1,04\end{array}$ & $\begin{array}{l}-1,0 / 1 \\
-3,27\end{array}$ & & $\begin{array}{l}-1, \infty) \\
-0,93\end{array}$ & $\begin{array}{l}-2,28 \\
-2,75\end{array}$ & $*$ & $\begin{array}{l}-1,047 \\
-1,65\end{array}$ & $\begin{array}{l}-0,10 \\
-3,17\end{array}$ & * & $\begin{array}{l}-1,010 \\
-1,76\end{array}$ & $\begin{array}{l}-3,38 \\
-3,38\end{array}$ & & $\begin{array}{l}-1,01 \\
-0,98\end{array}$ & $\begin{array}{l}-1,044 \\
-3,24\end{array}$ & & $\begin{array}{l}-1,82 \\
-0,92\end{array}$ & $\begin{array}{l}-2,49 \\
-2,98\end{array}$ & * & $\begin{array}{l}-1,73 \\
-1,73\end{array}$ & $\begin{array}{l}-3,00 \\
-3,27\end{array}$ & * & $\begin{array}{l}-0,00 \\
-1,76\end{array}$ & $\begin{array}{l}-3,30 \\
-3,38\end{array}$ & & $\begin{array}{l}-1,03 \\
-1,22\end{array}$ & $\begin{array}{l}-3,18 \\
-3,18\end{array}$ & & $\begin{array}{l}-1,79 \\
-0,96\end{array}$ \\
\hline Folga Financeira & $-0,14$ & & $-0,66$ & $-0,11$ & & $-0,51$ & $-0,13$ & & $-0,28$ & $-0,13$ & & $-0,16$ & $-0,15$ & & $-0,69$ & $-0,13$ & & $-0,70$ & $-0,13$ & & $-0,25$ & $-0,13$ & & $-0,17$ & $-0,13$ & & $-0,63$ & $-0,11$ & & $-0,56$ & $-0,12$ & & $-0,23$ & $-0,13$ & & $-0,15$ \\
\hline LN(CAPEX) & $-0,02$ & & $-0,98$ & $-0,01$ & & $-0,28$ & $-0,02$ & & $-0,53$ & $-0,03$ & & $-0,52$ & $-0,02$ & & $-0,93$ & 0,00 & & $-0,21$ & $-0,02$ & & $-0,49$ & $-0,02$ & & $-0,42$ & $-0,03$ & & $-1,08$ & $-0,01$ & & $-0,44$ & $-0,02$ & & $-0,57$ & $-0,02$ & & $-0,48$ \\
\hline Novo Mercado e Nível 2 & 0,35 & & 0,93 & 0,28 & & 0,68 & 0,85 & & 1,35 & 0,87 & & 1,23 & 0,37 & & 1,05 & 0,23 & & 0,55 & 0,83 & & 1,50 & 0,87 & & 1,23 & 0,07 & & 0,19 & $-0,07$ & & $-0,16$ & 0,79 & & 1,29 & 0,81 & & 1,11 \\
\hline Adquirente Seri & $-0,32$ & & $-0,73$ & $-0,40$ & & $-0,80$ & $-0,73$ & & $-1,26$ & $-0,76$ & & $\begin{array}{l}-1,07 \\
\end{array}$ & $-0,36$ & & 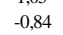 & $-0,47$ & & $-0,99$ & $-0,75$ & & $-1,28$ & $-0,77$ & & $-1,16$ & $-0,48$ & & $-1,02$ & $-0,57$ & & $-1,09$ & $-0,76$ & & $-1,12$ & $-0,83$ & & $-1,05$ \\
\hline Aquisição Internacional & $\begin{array}{l}-0,98 \\
-0,18 \\
-1\end{array}$ & **** & $-2,58$ & $-0,86$ & *** & $\begin{array}{l}-1,98 \\
-1,10 \\
\end{array}$ & $-1,42$ & ** & $-2,24$ & $-1,34$ & ** & $\begin{array}{l}-1,99 \\
\end{array}$ & $-1,01$ & $* * *$ & $-2,63$ & $\begin{array}{l}-0,87 \\
-0,77\end{array}$ & ** & $-2,01$ & $-1,43$ & ** & $-2,25$ & $-1,35$ & * & $\begin{array}{l}-1,95 \\
-105\end{array}$ & 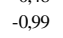 & **** & $-2,66$ & $-0,86$ & *** & $-2,00$ & $-1,44$ & ** & 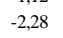 & $-1,37$ & *** & $-2,13$ \\
\hline _cons & 0,31 & & 0,19 & 0,17 & & 0,09 & $\begin{array}{l}1,13 \\
0,13\end{array}$ & & 0,04 & $-0,64$ & & $-0,16$ & 0,24 & & 0,15 & 0,14 & & 0,07 & 0,05 & & 0,01 & $-0,66$ & & $-0,15$ & 0,71 & & 0,45 & 0,67 & & 0,35 & 0,21 & & 0,05 & -0,57 & & $-0,13$ \\
\hline $\mathrm{N}$ & & 355 & & & 290 & & & 187 & & & 175 & & & 355 & & & 290 & & & & & & & & & 35 & & & & & & & & & & \\
\hline Replicações & & 1000 & & & 10 & & & 1000 & & & 10 & & & 1000 & & & & & & 1000 & & & 1000 & & & 1000 & & & & & & 1000 & & & 1000 & \\
\hline Wald chi2 & & 13,96 & & & 12,84 & & & 25,69 & & & 24,26 & & & 15,51 & & & 14,36 & & & 25,35 & & & 22,54 & & & 17,03 & & & 16,78 & & & 23,24 & & & 21,87 & \\
\hline $\mathrm{R}^{\wedge} 2$ & & 0,05 & & & 0,05 & & & 0,14 & & & 0,14 & & & 0,05 & & & 0,05 & & & 0,14 & & & 0,14 & & & 0,06 & & & 0,06 & & & 0,14 & & & $\begin{array}{l}0,14 \\
0,14\end{array}$ & \\
\hline
\end{tabular}

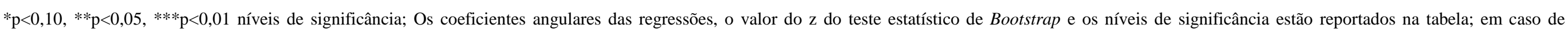

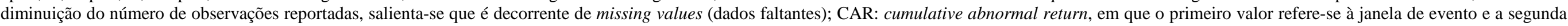
nomenclatura ao benchmark de retorno de mercado utilizado.

Fonte: Elaborado pelo autor. 


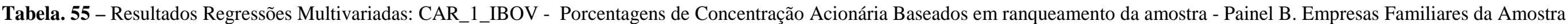
- Bootstrap

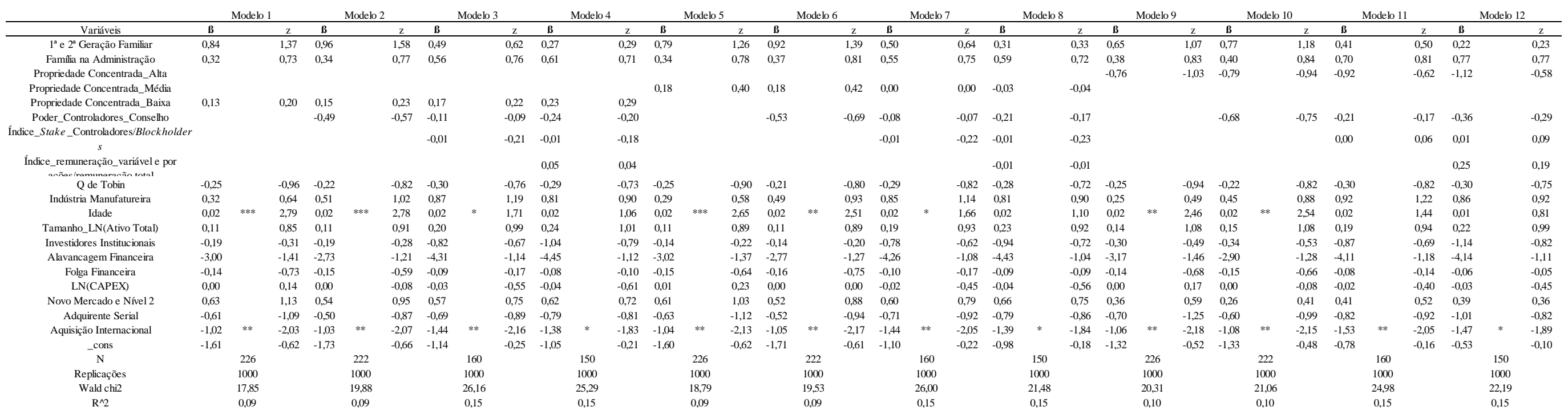

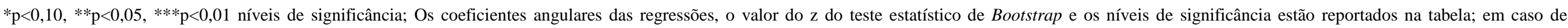

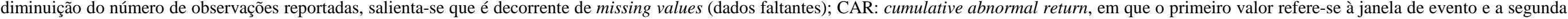
nomenclatura ao benchmark de retorno de mercado utilizado.

Fonte: Elaborado pelo autor. 
Tabela 56 - Resultados Regressões Multivariadas: CAR_1_IBRX50 - Porcentagens de Concentração Acionária Baseadas em legislação societária - Painel A. Todas Empresas da Amostra Bootstrap

\begin{tabular}{|c|c|c|c|c|c|c|c|c|c|c|c|c|c|c|c|c|c|c|c|c|c|c|c|c|c|c|c|c|c|c|c|c|}
\hline & & Modelo 1 & & & Modelo 2 & & & Modelo 3 & & Modelo 4 & & Modelo 5 & & Modelo 6 & & Modelo 7 & & Modelo 8 & & Modelo 9 & & Modelo 10 & & & Modelo 11 & & & Modelo 12 & & & Modelo 13 & \\
\hline Variáveis & $B$ & & $\mathrm{z}$ & $B$ & & $\mathrm{z}$ & $B$ & $z$ & $B$ & $z$ & $B$ & $z$ & B & N & B & $z$ & $B$ & $z$ & $B$ & $z$ & $B$ & & $\mathrm{z}$ & $B$ & & $\mathrm{z}$ & $\bar{B}$ & & $\mathrm{z}$ & $B$ & & \\
\hline $\begin{array}{l}\text { Empresas Familiares } \\
\text { Stake Controladores }\end{array}$ & 0,37 & & 1,01 & 0,41 & & 0,95 & $-0,22$ & $-0,38$ & $-0,22$ & $-0,31$ & 0,26 & 0,75 & 0,39 & 0,89 & $-0,18$ & $-0,31$ & $-0,19$ & $-0,28$ & 0,17 & 0,57 & 0,44 & & 0,97 & $-0,13$ & & $-0,22$ & $-0,18$ & & $-0,29$ & $-0,25$ & & $-0,38$ \\
\hline $\begin{array}{l}\text { Stake Controlodores } \\
\text { Propiedade Concentrad }>50 \%\end{array}$ & $-0,83$ & & $-2,25$ & $-1,08$ & & $-2,67$ & $-0,60$ & $-1,19$ & -0.82 & $-1,49$ & & & & & & & & & & & & & & & & & & & & & & \\
\hline Propriedade Concentrada $20 \%$ & & & & & & & & & & & 0,02 & 0,03 & 0,06 & 0,08 & 0,08 & 0,08 & $-0,07$ & $-0,06$ & $e_{0}$ & & & & & & & & & & & & & \\
\hline $\begin{array}{l}\text { Propriedadad Concentradad }>10 \% \\
\text { Poder Contraldores Conselhe }\end{array}$ & & & & 035 & & 048 & (4) & 039 & 075 & 023 & & & 014 & 0,19 & 0.34 & 031 & 0.11 & 0.09 & $-9,38$ & $-1,18$ & $\begin{array}{l}-9,98 \\
0,63\end{array}$ & & $\begin{array}{l}-1,24 \\
094\end{array}$ & $\begin{array}{l}-10,30 \\
103\end{array}$ & & $\begin{array}{l}-1,27 \\
1,16\end{array}$ & $\begin{array}{l}-10,76 \\
0,84\end{array}$ & & $\begin{array}{l}-1,41 \\
0.88\end{array}$ & 0.08 & & 007 \\
\hline Índice_Stake_Controladores/Blockholder & & & & & & & $0.0,1$ & -0.14 & 0,000 & -0.05 & & & & & -001 & -0.035 & $-0,0.1$ & - & & & & & & . & & $\begin{array}{l}1,023 \\
-0.02\end{array}$ & 0.04 & & -0.14 & 0,000 & & 0,05 \\
\hline $\begin{array}{c}s \\
\text { Índice_remuneração_varíável e por }\end{array}$ & & & & & & & & & 0,80 & 0,76 & & & & & & & 0,54 & 0,45 & & & & & & & & & 1,13 & & 1.04 & 0.78 & & 0.69 \\
\hline $\begin{array}{l}\text { açōes/remununaçăōototal } \\
\text { Q de Tobin }\end{array}$ & 0,02 & & 0.08 & 0.16 & & 0.74 & -0.02 & -0.08 & $-0,04$ & $-0,13$ & -0.04 & $-0,19$ & 0.05 & 0.28 & -0.07 & -0.27 & -0.10 & $-0,33$ & 0.00 & 0.01 & 0,11 & & 0.56 & -0.07 & & -0.26 & $-0,12$ & & -0.42 & $-0,09$ & & $-0,31$ \\
\hline Indústria Manufatureira & 0,38 & & 1,16 & 0,48 & & 1,30 & 0,29 & 0,56 & 0,01 & 0,02 & 0,33 & 1,00 & 0,53 & 1,33 & 0,26 & 0,47 & 0,05 & 0,08 & 0,24 & 0,73 & 0,36 & & 0,90 & $-0,11$ & & $-0,17$ & $-0,56$ & & $-0,73$ & 0,06 & & 0,09 \\
\hline Idade & 0,01 & & 2,38 & 0,01 & & 2,44 & 0,02 & 2,31 & 0,02 & 1,88 & 0,01 & 1,70 & 0,01 & 1,84 & 0,02 & 2,49 & 0,02 & 1,95 & 0,01 & 1,97 & 0,01 & & 2,17 & 0,03 & & 3,10 & 0,02 & & 2,77 & 0,02 & & 1,88 \\
\hline Tamanho_LN(Ativo Total) & 0,06 & & 0,66 & 0,04 & & 0,37 & 0,15 & 0,86 & 0,22 & 1,09 & 0,03 & 0,36 & 0,00 & $-0,03$ & 0,15 & 0,79 & 0,22 & 0,89 & 0,05 & 0,54 & 0,01 & & 0,11 & 0,30 & & 1,53 & 0,39 & & 1,64 & 0,23 & & 1,10 \\
\hline Investidores Institucionais & $-0,49$ & & $-0,89$ & $-0,37$ & & $-0,59$ & $-1,47$ & 55 & $-1,91$ & $-1,89$ & $-0,27$ & $-0,45$ & $-0,08$ & $-0,12$ & $-1,48$ & $-1,48$ & $-1,83$ & $-1,72$ & $-0,48$ & $-0,87$ & $-0,25$ & & $-0,40$ & $-1,48$ & & $-1,51$ & $-2,13$ & & $-2,34$ & $-2,12$ & & $-1,97$ \\
\hline Alavancagem Financeira & $-2,79$ & & $-1,62$ & $-2,96$ & & $-1,59$ & $-3,61$ & $-1,06$ & $-3,43$ & $-1,01$ & $-2,56$ & $-1,59$ & $-2,86$ & $-1,75$ & $-3,53$ & $-1,11$ & $-3,29$ & $-1,01$ & $-2,80$ & $-1,75$ & $-3,07$ & & $-1,71$ & $-4,17$ & & $-1,41$ & $-3,62$ & & $-1,22$ & $-3,26$ & & $-1,00$ \\
\hline Folga Financeira & $-0,17$ & & $-0,87$ & $-0,13$ & & $-0,65$ & $-0,14$ & $-0,28$ & $-0,15$ & $-0,22$ & $-0,16$ & $-0,64$ & $-0,13$ & $-0,62$ & $-0,14$ & $-0,29$ & $-0,14$ & $-0,22$ & $-0,15$ & $-0,71$ & $-0,10$ & & $-0,44$ & $-0,10$ & & $-0,17$ & $-0,11$ & & $-0,16$ & $-0,12$ & & $-0,15$ \\
\hline LN(CAPEX) & $-0,03$ & & $-1,40$ & $-0,02$ & & $-0,64$ & $-0,03$ & $-0,87$ & $-0,04$ & $-0,76$ & $-0,03$ & $-0,98$ & $-0,01$ & $-0,27$ & $-0,02$ & $-0,58$ & $-0,03$ & $-0,49$ & $-0,03$ & $-1,14$ & $-0,01$ & & $-0,25$ & $-0,03$ & & $-0,68$ & $-0,02$ & & $-0,33$ & $-0,03$ & & $-0,57$ \\
\hline Novo Mercado e Nível 2 & 0,15 & & 0,43 & $-0,10$ & & $-0,24$ & 0,60 & 0,93 & 0,54 & 0,76 & 0,43 & 1,23 & 0,33 & 0,83 & 0,84 & 1,39 & 0,89 & 1,28 & 0,28 & 0,80 & 0,12 & & 0,29 & 0,58 & & 0,95 & 0,66 & & 0,92 & 0,70 & & 0,89 \\
\hline Adquirente Serial & $-0,30$ & & $-0,69$ & $-0,35$ & & $-0,72$ & $-0,64$ & $-1,05$ & $-0,74$ & $-0,99$ & $-0,24$ & $-0,51$ & $-0,33$ & $-0,62$ & $-0,68$ & $-1,03$ & $-0,73$ & $-0,89$ & 0,04 & 0,11 & $-0,04$ & & $-0,10$ & $-0,16$ & & $-0,33$ & $-0,27$ & & $-0,48$ & $-0,80$ & & $-0,98$ \\
\hline $\begin{array}{l}\text { Aquisişắo Internacional } \\
\text { cons }\end{array}$ & $-1,16$ & & $\begin{array}{l}-3,04 \\
0,07\end{array}$ & $\begin{array}{l}-1,07 \\
0.06\end{array}$ & & $-2,61$ & $\begin{array}{l}-1,52 \\
0,80\end{array}$ & $-2,41$ & $-1,44$ & $-2,19$ & $\begin{array}{l}-1,03 \\
065\end{array}$ & $-2,74$ & $-0,91$ & $\begin{array}{l}-2,05 \\
030\end{array}$ & $\begin{array}{l}-1,40 \\
028\end{array}$ & $\begin{array}{l}-2,27 \\
0008\end{array}$ & $\begin{array}{l}-1,33 \\
-0,3\end{array}$ & $-1,94$ & - & $-2,84$ & $\begin{array}{l}-1,04 \\
0,66\end{array}$ & & $-2,23$ & $\begin{array}{l}-1,85 \\
775\end{array}$ & & $\begin{array}{l}-2,60 \\
090\end{array}$ & $\begin{array}{l}-1,70 \\
691\end{array}$ & & $\begin{array}{l}-2,34 \\
086\end{array}$ & $\begin{array}{l}-1,37 \\
029\end{array}$ & & $\begin{array}{l}-2,02 \\
0,06\end{array}$ \\
\hline$-{ }^{-c o n s}$ & & 355 & & & 290 & & & 187 & & 175 & & 355 & & 290 & & 187 & & 175 & & 355 & & 290 & & & 187 & & & 175 & & & 175 & \\
\hline Replicações & & 1000 & & & 1000 & & & 1000 & & 1000 & & 1000 & & 1000 & & 1000 & & 1000 & & 950 & & 946 & & & 951 & & & 964 & & & 1000 & \\
\hline Wald chi2 2 & & 19,87 & & & 20,25 & & & 25,77 & & 22,12 & & 15,59 & & 13,40 & & 23,64 & & 20,28 & & 15,35 & & 15,81 & & & 26,34 & & & 26,63 & & & 20,75 & \\
\hline $\mathrm{R}^{\wedge} 2$ & & 0,07 & & & 0,08 & & & 0,14 & & 0,14 & & & & 0.05 & & 0,14 & & 0,13 & & 0,14 & & & & & & & & 0,29 & & & 0,14 & \\
\hline
\end{tabular}

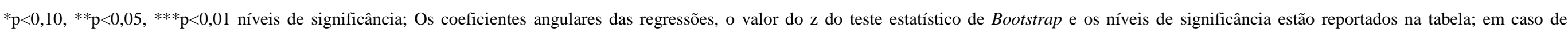

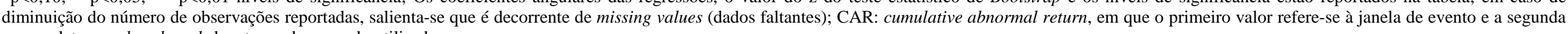
nomenclatura ao benchmark de retorno de mercado utilizado.

Fonte: Elaborado pelo autor. 


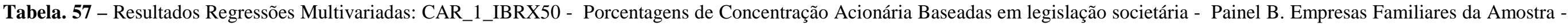
Bootstrap

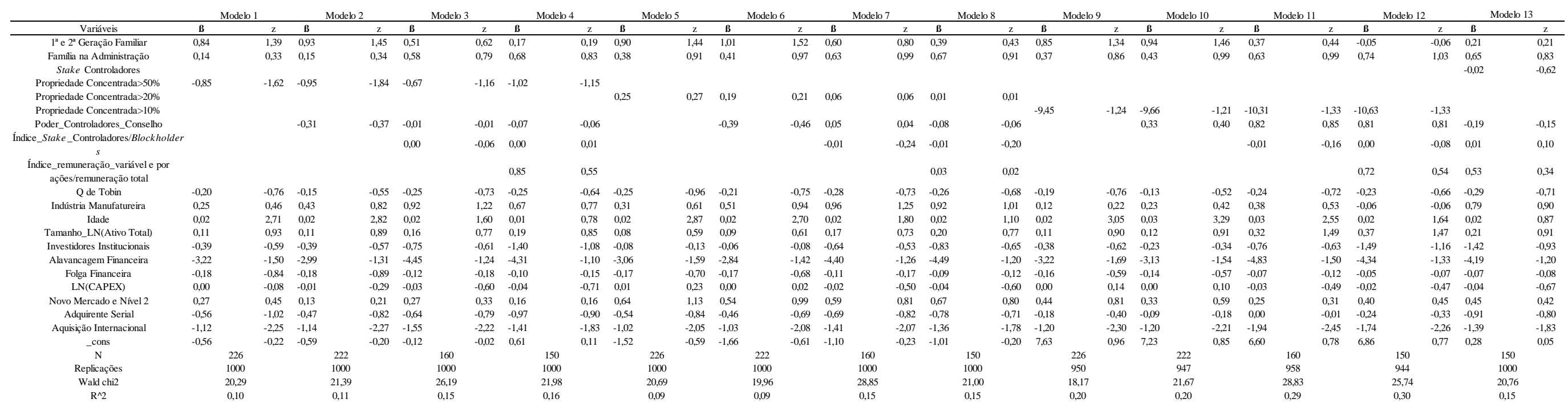

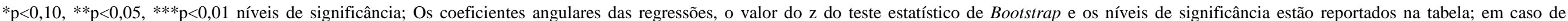

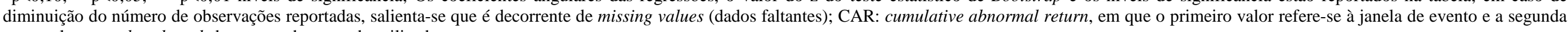
nomenclatura ao benchmark de retorno de mercado utilizado.

Fonte: Elaborado pelo autor. 


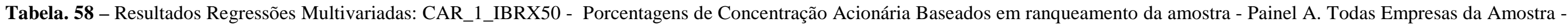
Bootstrap

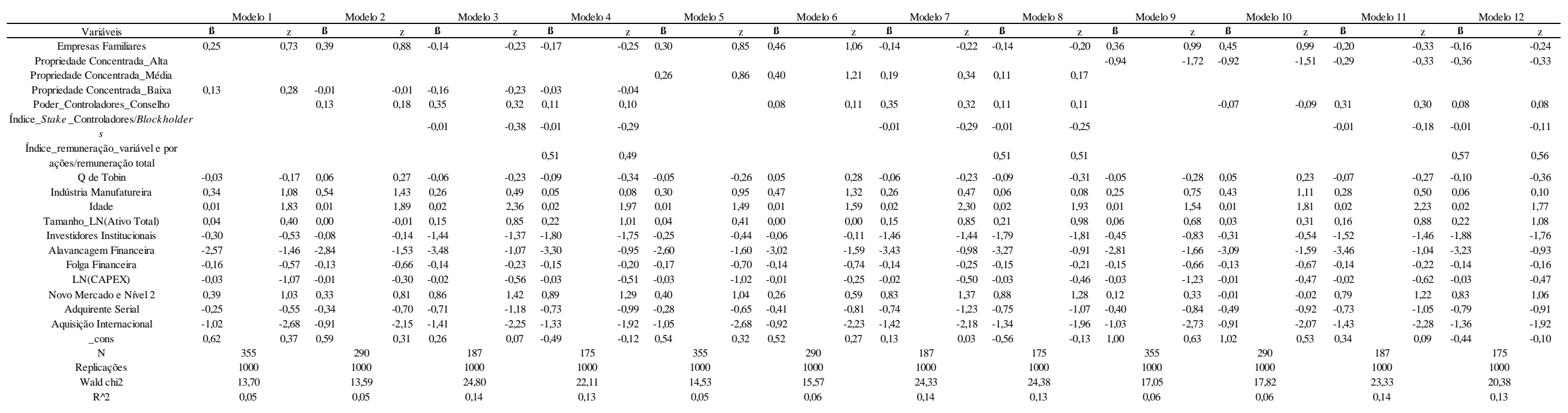

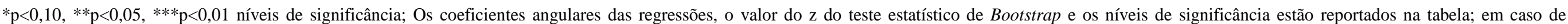

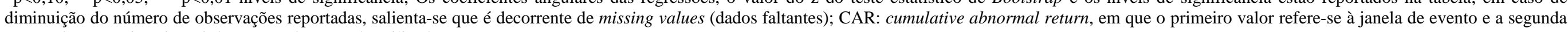
nomenclatura ao benchmark de retorno de mercado utilizado.

Fonte: Elaborado pelo autor. 


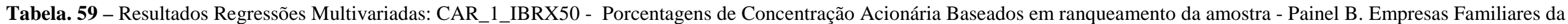
Amostra - Bootstrap

\begin{tabular}{|c|c|c|c|c|c|c|c|c|c|c|c|c|c|c|c|c|c|c|c|c|c|c|c|c|c|c|c|c|}
\hline & & Modelo 1 & & & Modelo 2 & & Modelo 3 & & Modelo 4 & & Modelo 5 & & Modelo 6 & & Modelo 7 & & Modelo 8 & & Modelo 9 & & & Modelo 10 & & & Modelo 11 & & & Modelo 12 \\
\hline Variáveis & 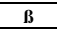 & & $z$ & B & $\mathrm{z}$ & B & 2 & B & & B & $\mathrm{z}$ & B & +2 & B & 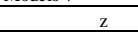 & $B$ & (n) $>0$ & B & & & B & & & B & & & B & \\
\hline $1^{a} \mathrm{e} 2^{\mathrm{a}}$ Geração Familiar & 0,89 & & 1,45 & 1,00 & 1,49 & 0,59 & 0,74 & 0,36 & 0,39 & 0,82 & 1,32 & 0,94 & 1,42 & 0,59 & 0,77 & 0,40 & 0,43 & 0,70 & & 1,09 & 0,82 & & 1,22 & 0,50 & & 0,60 & 0,30 & 0,29 \\
\hline Familia na Administração & 0,35 & & 0,80 & 0,38 & 0,88 & 0,63 & 0,79 & 0,68 & 0,76 & 0,37 & 0,85 & 0,41 & 0,89 & 0,63 & 0,90 & 0,67 & 0,83 & 0,41 & & 0,84 & 0,44 & & 0,87 & 0,77 & & 0,88 & 0,85 & 0,84 \\
\hline Propriedade Concentrada_Alta & & & & & & & & & & & & & & & & & & $-0,75$ & & $-0,97$ & $-0,76$ & & $-0,87$ & $-0,98$ & & $-0,62$ & $-1,16$ & $-0,61$ \\
\hline $\begin{array}{l}\text { Proppriedade Concentrada_Média } \\
\text { Propriedade Concentrada Baiax }\end{array}$ & & & & & & & & & & 0,23 & 0,54 & 0,23 & 0,53 & 0,08 & 0,13 & 0,04 & 0,07 & & & & & & & & & & & \\
\hline $\begin{array}{l}\text { Propriedade Concentrada_Baixa } \\
\text { Poder Controladores Conselho }\end{array}$ & 0,06 & & 0,09 & 0,06 & 0,10 & 0,09 & 0,12 & 0,16 & 0,18 & & & & & & & & & & & & & & & & & & & \\
\hline $\begin{array}{l}\text { Poder_Controladores_COnselho } \\
\text { Indice Stake Controladdres/Black kolder }\end{array}$ & & & & $-0,40$ & $-0,49$ & 0,02 & 0,02 & $-0,10$ & $-0,08$ & & & $-0,46$ & $-0,53$ & 0,04 & 0,04 & $-0,08$ & $-0,07$ & & & & $-0,58$ & & $-0,61$ & $-0,10$ & & $-0,09$ & $-0,24$ & $-0,19$ \\
\hline $\begin{array}{c}\text { Índice_Stake_Controladores/Blockholder } \\
s\end{array}$ & & & & & & $-0,01$ & $-0,21$ & $-0,01$ & $-0,17$ & & & & & $-0,01$ & $-0,22$ & $-0,01$ & $-0,22$ & & & & & & & 0,00 & & 0,07 & 0,01 & 0,11 \\
\hline $\begin{array}{l}\text { Índice_remuneraçã̃o_variável e por } \\
\text { aç̧ōes/remuneração total }\end{array}$ & & & & & & & & 0,07 & 0,05 & & & & & & & 0,03 & 0,02 & & & & & & & & & & 0,29 & 0,23 \\
\hline Q de Tobin & $-0,25$ & & $-0,96$ & $-0,21$ & $-0,75$ & $-0,29$ & $-0,76$ & $-0,27$ & $-0,68$ & $-0,25$ & $-0,90$ & $-0,20$ & $-0,78$ & $-0,27$ & $-0,76$ & $-0,26$ & $-0,66$ & $-0,25$ & & $-0,93$ & $-0,21$ & & $-0,79$ & $-0,29$ & & $-0,80$ & $-0,29$ & $-0,71$ \\
\hline Indústria Manufatureira & 0,34 & & 0,68 & 0,53 & 1,02 & 0,97 & 1,28 & 0,91 & 1,00 & 0,31 & 0,64 & 0,51 & 0,98 & 0,96 & 1,26 & 0,92 & 1,00 & 0,27 & & 0,54 & 0,47 & & 0,91 & 1,03 & & 1,25 & 0,96 & 1,01 \\
\hline Idade & 0,02 & & 2,83 & 0,02 & 2,69 & 0,02 & 1,64 & 0,02 & 1,07 & 0,02 & 2,59 & 0,02 & 2,53 & 0,02 & 1,62 & 0,02 & 1,09 & 0,02 & & 2,39 & 0,02 & & 2,30 & 0,02 & & 1,32 & 0,01 & 0,79 \\
\hline Tamanho_LN(Ativo Total) & 0,09 & & 0,75 & 0,10 & 0,75 & 0,18 & 0,88 & 0,21 & 0,93 & 0,10 & 0,79 & 0,10 & 0,78 & 0,17 & 0,85 & 0,20 & 0,84 & 0,13 & & 0,98 & 0,13 & & 0,99 & 0,17 & & 0,83 & 0,20 & 0,91 \\
\hline Investidores Institucionais & $-0,13$ & & $-0,21$ & $-0,11$ & $-0,15$ & $-0,67$ & $-0,58$ & $-0,91$ & $-0,67$ & $-0,10$ & $-0,15$ & $-0,07$ & $-0,10$ & $-0,64$ & $-0,54$ & $-0,82$ & $-0,61$ & $-0,26$ & & $-0,44$ & $-0,27$ & & $-0,39$ & $-0,75$ & & $-0,58$ & $-1,05$ & $-0,73$ \\
\hline Alavancagem Financeira & $-3,022$ & & $-1,36$ & $-2,79$ & $-1,26$ & $-4,42$ & $-1,16$ & $-4,51$ & $-1,09$ & $-3,05$ & $-1,45$ & $-2,85$ & $-1,26$ & $-4,36$ & $-1,16$ & $-4,47$ & $-1,09$ & $-3,19$ & & $-1,40$ & $-2,95$ & & $-1,23$ & $-4,23$ & & $-1,14$ & $-4,20$ & $-1,10$ \\
\hline Folga Financeira & $-0,16$ & & $-0,79$ & $-0,16$ & $-0,78$ & $-0,10$ & $-0,18$ & $-0,09$ & $-0,11$ & $-0,17$ & $-0,73$ & $-0,17$ & $-0,78$ & $-0,11$ & $-0,16$ & $-0,09$ & $-0,12$ & $-0,15$ & & $-0,56$ & $-0,16$ & & $-0,70$ & $-0,09$ & & $-0,11$ & $-0,07$ & $-0,06$ \\
\hline LN(CAPEX) & 0,00 & & 0,17 & 0,00 & $-0,03$ & $-0,03$ & $-0,50$ & $-0,04$ & $-0,64$ & 0,01 & 0,25 & 0,00 & 0,04 & $-0,02$ & $-0,46$ & $-0,04$ & $-0,58$ & 0,00 & & 0,18 & 0,00 & & $-0,05$ & $-0,02$ & & $-0,44$ & $-0,03$ & $-0,49$ \\
\hline Novo Mercado e Nível 2 & 0,63 & & 1,14 & 0,53 & 0,92 & 0,58 & 0,78 & 0,65 & 0,70 & 0,58 & 0,99 & 0,48 & 0,80 & 0,59 & 0,82 & 0,67 & 0,79 & 0,3 & & 0,56 & 0,2 & & 0,39 & 0,40 & & 0,47 & & 0,38 \\
\hline Adquirente Serial & $-0,58$ & & $-1,01$ & $-0,48$ & $-0,84$ & $-0,68$ & $-0,87$ & $-0,78$ & $-0,78$ & $-0,60$ & $-1,10$ & $-0,51$ & $-0,88$ & $-0,71$ & $-0,95$ & $-0,79$ & $-0,84$ & $-0,67$ & & $-1,13$ & $-0,58$ & & $-0,93$ & $-0,81$ & & $-0,84$ & $-1,00$ & $-0,85$ \\
\hline Aquisição Internacional & $-1,01$ & & $-1,97$ & $-1,02$ & $-2,06$ & $-1,42$ & $-2,08$ & $-1,36$ & $-1,72$ & $-1,04$ & $-2,07$ & $-1,05$ & $-2,07$ & $-1,42$ & $-2,04$ & $-1,37$ & $-1,72$ & $-1,05$ & & $-2,06$ & $-1,07$ & & $-2,19$ & $-1,52$ & & $-2,10$ & $-1,45$ & $-1,85$ \\
\hline cons & $-1,50$ & & $-0,59$ & $-1,66$ & $-0,60$ & $-1,15$ & $-0,25$ & $-1,05$ & $-0,21$ & $-1,53$ & $-0,60$ & $-1,68$ & $-0,61$ & $-1,16$ & $-0,24$ & $-1,03$ & $-0,20$ & $-1,25$ & & $-0,47$ & $-1,31$ & & $-0,47$ & $-0,79$ & & $-0,15$ & $-0,53$ & $-0,10$ \\
\hline $\mathrm{N}$ & & 226 & & & 222 & & 160 & & 150 & & 226 & & 222 & & 160 & & 150 & & 226 & & & 222 & & & 160 & & & 150 \\
\hline Replicações & & 1000 & & & 100 & & 10 & & 1000 & & 10 & & 10 & & 1000 & & 1000 & & 1000 & & & & & & 1000 & & & 1000 \\
\hline Wald chi2 & & 20,18 & & & 18,42 & & 26,04 & & 22,63 & & 18,55 & & 20,12 & & 25,84 & & 21,42 & & 17,35 & & & 18,36 & & & 25,42 & & & 21,40 \\
\hline $\mathrm{R}^{\wedge} 2$ & & 0,09 & & & 0,09 & & 0,15 & & 0,15 & & 0,09 & & 0,09 & & 0,15 & & 0,15 & & 0,09 & & & 0,10 & & & 0,15 & & & 0,15 \\
\hline
\end{tabular}

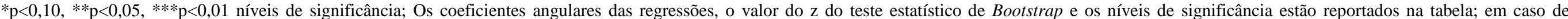

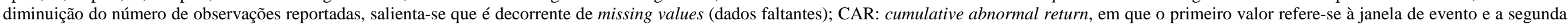
nomenclatura ao benchmark de retorno de mercado utilizado.

Fonte: Elaborado pelo autor. 


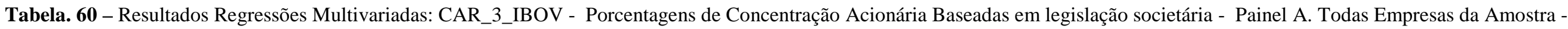
Bootstrap

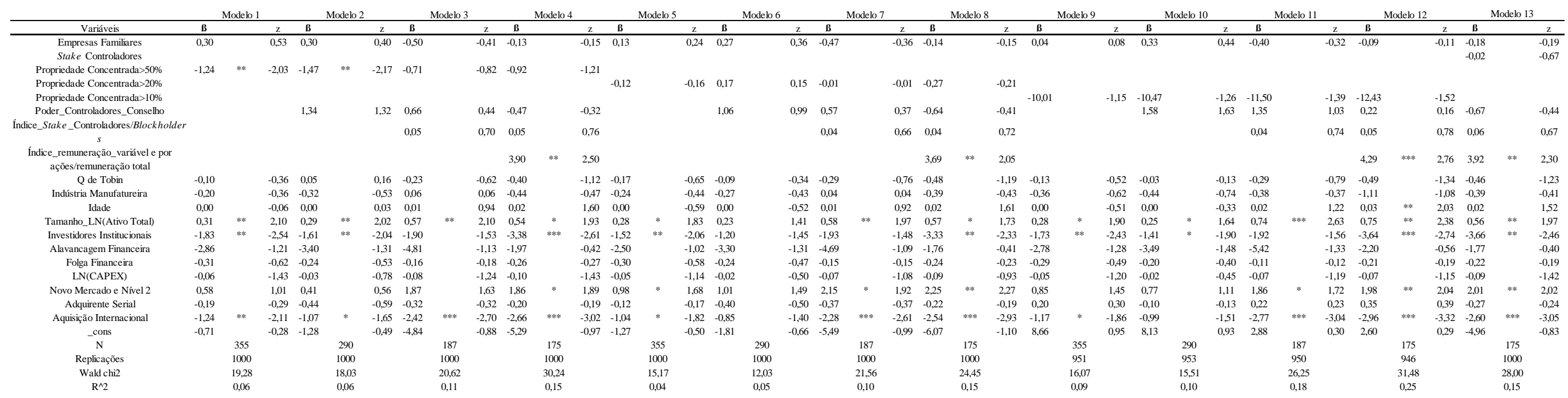

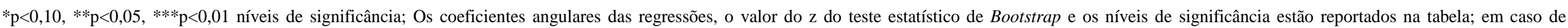

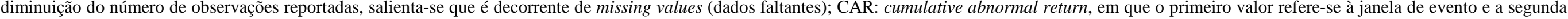
nomenclatura ao benchmark de retorno de mercado utilizado.

Fonte: Elaborado pelo autor. 


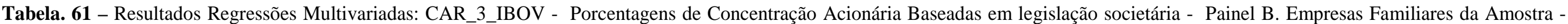
Bootstrap

\begin{tabular}{|c|c|c|c|c|c|c|c|c|c|c|c|c|c|c|c|c|c|c|c|c|c|c|c|c|c|c|c|c|c|c|c|c|c|c|c|c|c|c|c|}
\hline & & Modelo 1 & & & Modelo 2 & & & Modelo 3 & & & Modelo 4 & & & Modelo 5 & & & Modelo 6 & & & Modelo 7 & & & Modelo 8 & & & Modelo 9 & & & Modelo 10 & & & Modelo 11 & & & Modelo 12 & & & Modelo $1:$ & \\
\hline 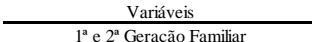 & $\frac{B}{0.16}$ & & $\frac{z}{0.14}$ & $\frac{\mathrm{B}}{0.32}$ & & $\frac{z}{0.28}$ & $\frac{B}{-020}$ & & $\frac{z}{-0.13}$ & $\frac{B}{068}$ & & $\frac{z}{036}$ & $\frac{B}{0.24}$ & & $\frac{z}{0.22}$ & $\frac{B}{042}$ & & $\begin{array}{c}\mathrm{z} \\
0.35 \\
\end{array}$ & $\begin{array}{ll}\mathbf{B} \\
-0.09\end{array}$ & & $\begin{array}{c}z \\
-0.06 \\
z\end{array}$ & $\begin{array}{l}\boldsymbol{B} \\
0.81\end{array}$ & & $\frac{\mathrm{z}}{0.46}$ & $\begin{array}{ll}\text { B } \\
0,16\end{array}$ & & $\frac{z}{0.15}$ & $\begin{array}{l}\boldsymbol{B} \\
0.32\end{array}$ & & $\frac{\mathrm{z}}{0.30}$ & $\begin{array}{ll}\mathbf{B} \\
-0.36\end{array}$ & & $\frac{z}{-0.24}$ & $\begin{array}{ll}\boldsymbol{B} \\
028\end{array}$ & & $\frac{z}{0.16}$ & $\begin{array}{c}\text { B } \\
0,67\end{array}$ & & $\frac{\mathrm{z}}{0.37}$ \\
\hline Fammia na Administração & 1,37 & *** & 2,09 & 1,54 & $* *$ & 2,25 & 1,89 & $*$ & 1,89 & $\begin{array}{l}1,06 \\
1,44\end{array}$ & & 1,35 & $\begin{array}{l}1,66 \\
1,66\end{array}$ & $* * *$ & $\begin{array}{l}2,62 \\
2,62\end{array}$ & $\begin{array}{l}1,42 \\
1,85\end{array}$ & $* * * *$ & 3,06 & 1,97 & *** & 2,07 & $\begin{array}{l}1,45 \\
1,45\end{array}$ & & 1,38 & $\begin{array}{l}1,61 \\
1,61\end{array}$ & $* * *$ & 2,60 & 1,82 & $* * *$ & 2,94 & 1,95 & ** & 2,18 & 1,52 & & 1,60 & 1,42 & & 1,39 \\
\hline $\begin{array}{c}\text { Stake Controladores } \\
\text { Propriedade Concentrada }>50 \%\end{array}$ & -0.87 & & -1.21 & -0.91 & & -1.25 & -0.78 & & -0.93 & -0.56 & & -0.50 & & & & & & & & & & & & & & & & & & & & & & & & & $-0,01$ & & $-0,37$ \\
\hline Propriedade Concentrada $20 \%$ & & & & & & & & & & & & & 0,64 & & 0,53 & 0,67 & & 0,55 & 0,15 & & 0,12 & 0,10 & & 0,08 & & & & & & & & & & & & & & & \\
\hline $\begin{array}{l}\text { Propriedade Concentrada } 10 \% \\
\text { Poder Controladores Consellho }\end{array}$ & & & & & & & & & & & & & & & & & & & & & & & & & $-10,35$ & & $-1,24$ & $-11,28$ & & $-1,38$ & $-12,25$ & & $-1,51$ & $-12,35$ & & $-1,52$ & & & \\
\hline 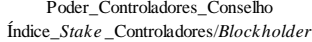 & & & & 1,25 & & 1,01 & 0,24 & & 0,14 & $-0,43$ & & $-0,26$ & & & & 1,20 & & 0,97 & 0,32 & & 0,18 & $-0,42$ & & $-0,26$ & & & & 2,02 & ${ }^{*}$ & & & & & 0,60 & & & $-0,52$ & & $-0,31$ \\
\hline $\begin{array}{c}\text { iice_Stake_Controladores/Blockholder } \\
s\end{array}$ & & & & & & & 0,05 & & 0,64 & 0,05 & & 0,59 & & & & & & & 0,04 & & 0,51 & 0,04 & & 0,56 & & & & & & & 0,04 & & 0,61 & 0,05 & & 0,65 & 0,06 & & 0,54 \\
\hline $\begin{array}{l}\text { İndice_remuneraçăo_variávele por } \\
\text { aačesstremuneraçototal }\end{array}$ & & & & & & & & & & 3,44 & & 1,59 & & & & & & & & & & 2,96 & & 1,52 & & & & & & & & & & 3,79 & $*$ & 1,94 & 3,36 & & 1,55 \\
\hline Q de Tobin & $-0,10$ & & $-0,31$ & 0.05 & & 0,15 & $-0,27$ & & $-0,59$ & $-0,61$ & & $-1,37$ & $-0,15$ & & $-0,44$ & 0,00 & & 0.00 & $-0,29$ & & $-0,62$ & $-0,61$ & & $-1,37$ & $-0,08$ & & $-0,24$ & 0,08 & & 0,25 & $-0,25$ & & $-0,59$ & $-0,58$ & & $-1,31$ & $-0,64$ & & $-1,38$ \\
\hline Indústria Manufatureira & $-0,08$ & & $-0,11$ & 0,05 & & 0,06 & 0,79 & & 0,64 & 0,81 & & 0,59 & $-0,06$ & & $-0,09$ & 0,08 & & 0,10 & 0,83 & & 0,67 & 0,94 & & 0,68 & $-0,24$ & & $-0,33$ & $-0,20$ & & $-0,26$ & 0,15 & & 0,13 & $-0,20$ & & $-0,13$ & 0,85 & & 0,59 \\
\hline Idade & 0,01 & & 0,83 & 0,01 & & 0,76 & 0,02 & & 0,78 & 0,02 & & 22 & 0,01 & & 0,78 & 0,01 & & 0,74 & 0,02 & & 0,82 & 0,0 & & 10 & 0,01 & & 1,06 & 0,01 & & 1,05 & & & 1,38 & 0,03 & & 1,47 & & & 0,93 \\
\hline Tamanho_LN(Ati & 0,28 & & 1,49 & 0,30 & & 1,52 & 0,56 & * & 1,74 & 0,47 & & 1,45 & 0,22 & & 1,01 & 0,25 & & 1,14 & 0,56 & * & 1,69 & 0,4 & & 33 & 0,28 & & 1,43 & 0,31 & * & 1,66 & 0,74 & *** & 2,50 & 0,66 & *** & 2,05 & & & 47 \\
\hline Investidores Institucionais & $-1,75$ & *** & $-2,14$ & $-1,40$ & & $-1,57$ & $-0,86$ & & $-0,48$ & $-1,81$ & & $-0,90$ & $-1,37$ & * & $-1,69$ & $-1,00$ & & $-1,16$ & $-0,73$ & & $-0,41$ & $-1,47$ & & $-0,73$ & $-1,75$ & *** & $-2,26$ & $-1,28$ & & $-1,62$ & $-0,88$ & & $-0,53$ & $-2,27$ & & $-1,13$ & $-1,94$ & & $-0,91$ \\
\hline Alavanc & $-1,58$ & & $-0,58$ & $-2,14$ & & $-0,74$ & $-5,41$ & & $-1,17$ & $-3,09$ & & $-0,64$ & $-1,48$ & & $-0,57$ & $-2,10$ & & $-0,79$ & $-5,37$ & & $-1,18$ & $-3,22$ & & $-0,67$ & $-1,59$ & & 66 & $-2,34$ & & $-0,89$ & $-5,87$ & & $-1,50$ & $-3,02$ & & 75 & $-2,96$ & & $-0,63$ \\
\hline Folg & $-0,21$ & & $-0,42$ & $-0,14$ & & $-0,29$ & $-0,04$ & & $-0,05$ & $-0,16$ & & $-0,14$ & $-0,21$ & & $-0,35$ & $-0,14$ & & $-0,25$ & $-0,03$ & & $-0,04$ & $-0,15$ & & 12 & $-0,20$ & & 31 & $-0,10$ & & $-0,17$ & & & 0,02 & $-0,10$ & & $-0,09$ & & &, 11 \\
\hline LN(CA & $-0,03$ & & $-0,73$ & $-0,02$ & & $-0,59$ & $-0,11$ & & $-1,45$ & $-0,11$ & & $-1,37$ & $-0,02$ & & $-0,42$ & $-0,01$ & & $-0,34$ & $-0,10$ & & $-1,29$ & $-0,11$ & & $-1,34$ & $-0,02$ & & $-0,52$ & $-0,01$ & & $-0,30$ & $-0,10$ & & $-1,40$ & $-0,09$ & & $-1,17$ & -0 , & & $-1,32$ \\
\hline Novo Mercado e Nível 2 & 0,51 & & 0,54 & 0,36 & & 0,38 & 0.98 & & 0,81 & 1,82 & & 1,33 & 0,90 & & 1,04 & 0,76 & & 0,78 & 1,35 & & 1,23 & 2,09 & * & 67 & 0,66 & & 74 & 0,50 & & & & & 0,82 & 1, & & 1,45 & & & 39 \\
\hline $\begin{array}{l}\text { Adquirente Serial } \\
\text { a }\end{array}$ & $-0,47$ & & $-0,63$ & $-0,46$ & $* *$ & - -0,56 & $-0,13$ & & $-0,12$ & $-0,29$ & & $-0,21$ & $-0,39$ & & $-0,47$ & $-0,38$ & & $-0,43$ & $-0,18$ & & $-0,16$ & & & & $-0,06$ & $* * *$ & & $-0,01$ & & $-0,02$ & & & 0,67 & 0,44 & 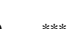 & 0,40 & $-0,29$ & & $-0,20$ \\
\hline $\begin{array}{l}\text { Aquisiçấo Internacional } \\
\text { cons }\end{array}$ & $\begin{array}{l}-1,59 \\
-1,99\end{array}$ & ${ }^{* *}$ & $\begin{array}{l}-2,33 \\
-0.47\end{array}$ & $\begin{array}{l}-1,57 \\
-3.56\end{array}$ & ${ }^{* *}$ & $\begin{array}{l}-2,26 \\
-2,79\end{array}$ & $\begin{array}{l}-2,66 \\
-5,84\end{array}$ & **** & $\begin{array}{l}-2,81 \\
-0,71\end{array}$ & $\begin{array}{r}-2,59 \\
-6,51\end{array}$ & * & $\begin{array}{l}-2,62 \\
-2,79\end{array}$ & $\begin{array}{l}-1,49 \\
-3,04\end{array}$ & ** & $\begin{array}{l}-2,16 \\
-0,71\end{array}$ & $\begin{array}{l}-1,47 \\
-4,65\end{array}$ & ${ }^{* *}$ & $\begin{array}{l}-2,25 \\
-1,04\end{array}$ & $\begin{array}{r}-2,49 \\
-6,94\end{array}$ & ${ }^{* * * *}$ & $\begin{array}{l}-2,66 \\
-0,95\end{array}$ & $\begin{array}{r}-2,56 \\
-7,33\end{array}$ & & $\begin{array}{l}-2,63 \\
-2,97\end{array}$ & $\begin{array}{l}-1,69 \\
7.05\end{array}$ & **** & $\begin{array}{l}-2,30 \\
0,76\end{array}$ & $\begin{array}{r}-1,66 \\
5,80\end{array}$ & ${ }^{* * *}$ & $\begin{array}{c}-2,40 \\
0,64\end{array}$ & $\begin{array}{l}-3,212 \\
2,17\end{array}$ & **** & $\begin{array}{l}-3,35 \\
0,21\end{array}$ & $\begin{array}{c}-3,300 \\
1,76\end{array}$ & **** & $\begin{array}{c}-2,98 \\
0,17\end{array}$ & $\begin{array}{r}-2,59 \\
-6,42\end{array}$ & **** & $\begin{array}{l}-2,71 \\
-0,75 \\
\end{array}$ \\
\hline $\mathrm{N}$ & & 226 & & & 222 & & & 160 & & & 150 & & & 226 & & & 222 & & & 160 & & & 150 & & & 226 & & & 222 & & & 160 & & & 150 & & & 150 & \\
\hline Replic. & & 1000 & & & 1000 & & & 1000 & & & 1000 & & & 1000 & & & 1000 & & & 1000 & & & 1000 & & & 943 & & & 933 & & & & & & 954 & & & 1000 & \\
\hline & & 18,29 & & & 18,97 & & & 20,25 & & & 24, & & & 16,54 & & & 19,52 & & & 21,8 & & & 22, & & & 18,22 & & & 21,65 & & & 29,25 & & & & & & 23,52 & \\
\hline $\mathrm{R}^{\wedge} 2$ & & 0,09 & & & 0,10 & & & 0,15 & & & 0,17 & & & 0,09 & & & 0,10 & & & 0,15 & & & 0,17 & & & 0,15 & & & 0,17 & & & 0,25 & & & 0,28 & & & 0,17 & \\
\hline
\end{tabular}

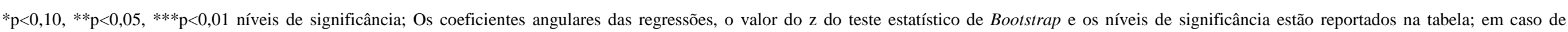

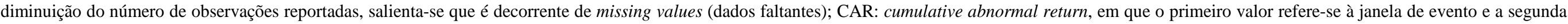
nomenclatura ao benchmark de retorno de mercado utilizado.

Fonte: Elaborado pelo autor. 


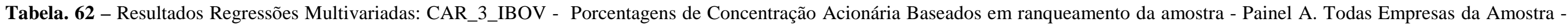
Bootstrap

\begin{tabular}{|c|c|c|c|c|c|c|c|c|c|c|c|c|c|c|c|c|c|c|c|c|c|c|c|c|c|c|c|c|c|c|c|c|c|c|c|c|}
\hline & & Modelo 1 & & & Modelo 2 & & & Modelo 3 & & & Modelo 4 & & & Modelo 5 & & & Modelo 6 & & & Modelo 7 & & & Modelo 8 & & & Modelo 9 & & & Modelo 10 & & & Modelo 11 & & & Modelo 12 & \\
\hline $\begin{array}{l}\text { Variáveis } \\
\end{array}$ & B & & $\mathrm{z}$ & B & & $\mathrm{z}$ & B & & $\frac{z}{z}$ & B & & $\mathrm{z}$ & B & & $\mathrm{z}$ & B & & $\mathrm{z}$ & $\begin{array}{l}B \\
\end{array}$ & & $\mathrm{z}$ & $\mathbf{B}$ & & 2 & B & & $\mathrm{z}$ & $\begin{array}{l}B \\
022\end{array}$ & & $\mathrm{z}$ & B & & $\mathrm{z}$ & B & & $\frac{z}{-006}$ \\
\hline Empresas Familiares & 0,10 & & 0,18 & 0,27 & & 0,35 & $-0,45$ & & $-0,35$ & $-0,09$ & & $-0,09$ & 0,13 & & 0,24 & 0,33 & & 0,43 & $-0,39$ & & $-0,31$ & $-0,01$ & & $-0,01$ & 0,22 & & 0,40 & 0,32 & & 0,40 & $-0,48$ & & $-0,37$ & $-0,05$ & & $-0,06$ \\
\hline Propriedade Concentrada_Alta & & & & & & & & & & & & & & & & & & & & & & & & & $-0,88$ & & $-1,06$ & $-0,78$ & & $-0,84$ & $-0,91$ & & $-0,56$ & $-0,90$ & & $-0,51$ \\
\hline Propriedade Concentrada_Média & & & & & & & & & & & & & 0,00 & & $-0,01$ & 0,33 & & 0,60 & 0,26 & & 0,28 & 0,18 & & 0,20 & & & & & & & & & & & & \\
\hline Propriedade Concentrada_Baixa & 0,48 & & 0,69 & 0,00 & & 0,00 & $-0,06$ & & $-0,06$ & 0,02 & & 0,02 & & & & & & & & & & & & & & & & & & & & & & & & \\
\hline Poder_Controladores_Conselho & & & & 1,04 & & 1,00 & 0,58 & & 0,36 & $-0,63$ & & $-0,41$ & & & & 0,99 & & 0,97 & 0,59 & & 0,36 & $-0,62$ & & $-0,41$ & & & & 0,87 & & 0,80 & 0,52 & & 0,34 & $-0,69$ & & $-0,48$ \\
\hline $\begin{array}{c}\text { Índice_Stake_Controladores/Blockholder } \\
s\end{array}$ & & & & & & & 0,04 & & 0,68 & 0,04 & & 0,70 & & & & & & & 0,04 & & 0,71 & 0,04 & & 0,73 & & & & & & & 0,05 & & 0,71 & 0,05 & & 0,75 \\
\hline $\begin{array}{l}\text { Índice_remuneracăãovvaraívele por } \\
\text { açõess/remuneração total }\end{array}$ & & & & & & & & & & 3,59 & $* *$ & 2,21 & & & & & & & & & & 3,58 & ** & 2,34 & & & & & & & & & & 3,73 & *** & 2,40 \\
\hline Q de Tobin & $-0,16$ & & $-0,65$ & $-0,09$ & & $-0,33$ & $-0,29$ & & $-0,72$ & $-0,47$ & & $-1,22$ & $-0,17$ & & $-0,69$ & $-0,09$ & & $-0,36$ & $-0,28$ & & $-0,72$ & $-0,46$ & & $-1,14$ & $-0,19$ & & $-0,75$ & $-0,10$ & & $-0,36$ & $-0,29$ & & $-0,82$ & $-0,48$ & & $-1,30$ \\
\hline Indústria Manufatureira & $-0,23$ & & $-0,42$ & $-0,25$ & & $-0,40$ & 0,03 & & 0,03 & $-0,41$ & & $-0,43$ & $-0,26$ & & $-0,47$ & $-0,30$ & & $-0,49$ & 0,03 & & 0,03 & $-0,39$ & & $-0,40$ & $-0,34$ & & $-0,59$ & $-0,33$ & & $-0,54$ & 0,06 & & 0,06 & $-0,37$ & & $-0,41$ \\
\hline Idade & 0,00 & & $-0,46$ & 0,00 & & $-0,45$ & 0,01 & & 0,86 & 0,02 & & 1,58 & 0,00 & & $-0,58$ & 0,00 & & $-0,52$ & 0,01 & & 0,86 & 0,02 & & 1,55 & 0,00 & & $-0,68$ & 0,00 & & $-0,50$ & 0,01 & & 0,87 & 0,02 & & 1,51 \\
\hline Tamanho_LN(Ativo Total) & 0,28 & $*$ & 1,88 & 0,24 & & 1,56 & 0,58 & ** & 2,01 & 0,54 & * & 1,81 & 0,27 & * & 1,87 & 0,24 & & 1,56 & 0,57 & ** & 2,07 & 0,53 & $*$ & 1,80 & 0,29 & ** & 2,08 & 0,27 & $*$ & 1,77 & 0,58 & ** & 2,18 & 0,55 & * & 1,89 \\
\hline Investidores Institucionais & $-1,63$ & *** & $-2,18$ & $-1,23$ & & $-1,44$ & $-1,91$ & & $-1,45$ & $-3,28$ & *** & $-2,22$ & $-1,50$ & *** & $-1,99$ & $-1,21$ & & $-1,55$ & $-1,88$ & & $-1,48$ & $-3,23$ & $* *$ & $-2,28$ & $-1,68$ & ** & $-2,27$ & $-1,42$ & * & $-1,77$ & $-2,04$ & & $-1,56$ & $-3,42$ & *** & $-2,43$ \\
\hline Alavancagem Financeira & $-2,57$ & & $-1,08$ & $-3,24$ & & $-1,25$ & $-4,68$ & & $-1,04$ & $-1,84$ & & $-0,39$ & $-2,51$ & & $-1,05$ & $-3,39$ & & $-1,37$ & $-4,57$ & & $-0,97$ & $-1,76$ & & $-0,37$ & $\begin{array}{l}-2,75 \\
\end{array}$ & & $-1,16$ & $\begin{array}{l}-3,475 \\
-3,451\end{array}$ & & $-1,28$ & $-4,51$ & & $-1,03$ & $-1,64$ & & $-0,35$ \\
\hline Folga Financeira & $-0,29$ & & $\begin{array}{l}-1,0, \\
-0,49\end{array}$ & $\begin{array}{l}-0,23 \\
-0,23\end{array}$ & & $\begin{array}{l}-0,45 \\
-0,45\end{array}$ & $-0,16$ & & $\begin{array}{l}-1,07 \\
-0,19\end{array}$ & $\begin{array}{l}-1,04 \\
-0,25\end{array}$ & & $\begin{array}{l}-0,22 \\
-0,22\end{array}$ & $-0,31$ & & $\begin{array}{l}-1,0,54 \\
-0,1\end{array}$ & $-0,24$ & & $\begin{array}{l}-0,55 \\
-0,71\end{array}$ & $-0,16$ & & $\begin{array}{l}-0,18 \\
-0,18\end{array}$ & $\begin{array}{l}-1,25 \\
-0,25\end{array}$ & & $\begin{array}{l}-0,3) \\
-0,23\end{array}$ & $\begin{array}{l}-0,29 \\
-0,29\end{array}$ & & $\begin{array}{l}-0,110 \\
-0,55\end{array}$ & $\begin{array}{l}-0,23 \\
-0,23\end{array}$ & & $-0,48$ & $-0,15$ & & $\begin{array}{l}-1,0,14 \\
-0,14\end{array}$ & $-0,24$ & & $\begin{array}{l}-0,20 \\
-0,0 \\
-10\end{array}$ \\
\hline LN(CAPEX) & $-0,05$ & & $-1,16$ & $-0,02$ & & $-0,49$ & $-0,07$ & & $-1,07$ & $-0,09$ & & $-1,19$ & $-0,05$ & & $-1,18$ & $-0,02$ & & $-0,46$ & $-0,06$ & & $-1,01$ & $-0,08$ & & $-1,20$ & $-0,05$ & & $-1,26$ & $-0,02$ & & $-0,61$ & $-0,07$ & & $-1,12$ & $-0,08$ & & $-1,14$ \\
\hline Novo Mercado e Nível & 0,88 & & 1,46 & 1,00 & & 1,40 & 2,16 & *** & 2,00 & 2,25 & ** & 2,27 & 1,00 & * & 1,71 & 0,93 & & 1,37 & 2,15 & ** & 2,01 & 2,24 & ** & 2,31 & 0,71 & & & & & 0,95 & 2,01 & $*$ & 1,87 & 2,10 & ** & 2,13 \\
\hline & $-0,1$ & & $-0,16$ & $-0,42$ & & $-0,55$ & $-0,38$ & & $-0,38$ & $-0,1$ & & $-0,17$ & $-0,1$ & & $-0,15$ & $-0,48$ & & $\begin{array}{c}-0,64 \\
\end{array}$ & $-0,43$ & & $-0,41$ & $-0,22$ & & $-0,22$ & $-0,25$ & & $-0,33$ & & & $-0,67$ & $-0,50$ & & 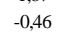 & $\begin{aligned}-0,34 \\
\end{aligned}$ & & $-0,31$ \\
\hline Aquisição Internacional & $\begin{array}{l}-1,00 \\
-1,12\end{array}$ & $*$ & $-1,66$ & 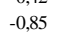 & & $-1,29$ & $-2,28$ & $* *$ & $-2,56$ & $-2,54$ & **** & $-2,85$ & $-1,04$ & * & $-1,79$ & $-0,86$ & & $-1,33$ & $-2,31$ & $* *$ & -2,54 & $-2,56$ & **** & $-2,84$ & $-1,04$ & $*$ & $-1,80$ & -0 & & $-1,30$ & $-2,37$ & **** & $\begin{array}{l}-2,57 \\
-157\end{array}$ & $-2,61$ & $* * * *$ & $-2,88$ \\
\hline _cons & $-1,41$ & & $-0,57$ & $-1,79$ & & $-0,69$ & $-5,48$ & & $-1,01$ & $-5,96$ & & $-1,08$ & $-1,30$ & & $-0,54$ & $-1,85$ & & $-0,68$ & $-5,66$ & & $-1,01$ & $-6,06$ & & $-1,06$ & $-0,97$ & & $-0,42$ & $-1,42$ & & $-0,52$ & $-5,23$ & & $-1,00$ & $-5,80$ & & $-1,04$ \\
\hline $\mathrm{N}$ & & 355 & & & 290 & & & 187 & & & 175 & & & 355 & & & & & & 187 & & & 175 & & & 355 & & & & & & 187 & & & 175 & \\
\hline Replicą̧ões & & 1000 & & & 10 & & & 1000 & & & 1000 & & & 1000 & & & 10 & & & 1000 & & & 1000 & & & 1000 & & & 1000 & & & 1000 & & & 1000 & \\
\hline Wald chi2 & & 14,72 & & & 12,43 & & & 20,84 & & & 27,58 & & & 15,33 & & & 12,02 & & & 21,95 & & & 28,62 & & & 16,05 & & & 13,44 & & & 20,16 & & & 26,25 & \\
\hline $\mathrm{R}^{\wedge 2}$ & & 0,05 & & & 0,05 & & & 0,10 & & & 0,15 & & & 0,04 & & & 0,05 & & & 0,10 & & & 0,15 & & & 0,05 & & & 0,05 & & & 0,11 & & & 0,15 & \\
\hline
\end{tabular}

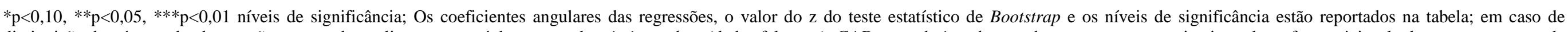

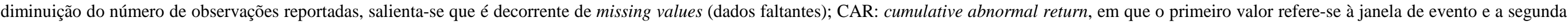
nomenclatura ao benchmark de retorno de mercado utilizado.

Fonte: Elaborado pelo autor. 


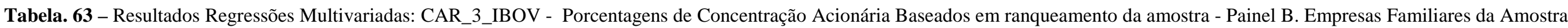
- Bootstrap

\begin{tabular}{|c|c|c|c|c|c|c|c|c|c|c|c|c|c|c|c|c|c|c|c|c|c|c|c|c|c|c|c|c|c|c|c|c|c|c|c|c|}
\hline & & Modelo 1 & & & Modelo 2 & & & Modelo 3 & & & Modelo 4 & & & Modelo 5 & & & Modelo 6 & & & Modelo 7 & & & Modelo 8 & & & Modelo 9 & & & Modelo 10 & & & Modelo 11 & & & Iodelo 12 & \\
\hline Variáveis & B & & $\mathrm{z}$ & B & & $\mathrm{z}$ & B & & $\mathrm{z}$ & B & & $\mathrm{z}$ & B & & $\mathrm{z}$ & B & & $\mathrm{z}$ & B & & $\mathrm{z}$ & B & & $\frac{1}{0}$ & B & & $\mathrm{z}$ & B & & $\mathrm{z}$ & B & & $\mathrm{z}$ & B & & \\
\hline $1^{\mathrm{a} e} 2^{\mathrm{a}}$ Geração Familiar & 0,21 & & 0,19 & 0,39 & & 0,34 & $-0,12$ & & $-0,07$ & 0,74 & & 0,41 & 0,14 & & 0,13 & 0,34 & & 0,29 & $-0,10$ & & $-0,06$ & 0,81 & & 0,47 & $-0,07$ & & $-0,06$ & 0,20 & & 0,17 & $-0,32$ & & $-0,21$ & 0,59 & & 0,33 \\
\hline Familia na Administração & 1,58 & *** & 2,56 & 1,75 & $* * *$ & 2,77 & 1,97 & * & 1,94 & 1,47 & & 1,25 & 1,61 & $* * *$ & 2,61 & 1,78 & ***** & 2,82 & 1,93 & * & 1,79 & 1,44 & & 1,34 & 1,67 & **** & 2,62 & 1,81 & $* * *$ & 2,88 & 2,28 & ** & 2,00 & 1,85 & & 1,46 \\
\hline Propriedade Concentrada_Alta & & & & & & & & & & & & & & & & & & & & & & & & & $-1,07$ & & -0,98 & 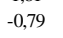 & & $-0,69$ & $-2,23$ & & $-0,90$ & $-2,58$ & & $-0,87$ \\
\hline Propriedade Concentrada_Média & & & & & & & & & & & & & 0,21 & & 0,29 & 0,20 & & 0,29 & $-0,09$ & & $-0,09$ & 0,12 & & 0,13 & & & & & & & & & & & & \\
\hline Propriedade Concentrada_Baixa & 0,26 & & 0,30 & 0,12 & & 0,14 & 0,52 & & 0,51 & 0,32 & & 0,29 & & & & & & & & & & & & & & & & & & & & & & & & \\
\hline Poder_Controladores_Conselho & & & & 1,16 & & 0,94 & 0,21 & & 0,12 & $-0,48$ & & $-0,28$ & & & & 1,12 & & 0,92 & 0,30 & & 0,18 & $-0,44$ & & $-0,25$ & & & & 0,98 & & 0,75 & $-0,02$ & & $-0,01$ & $-0,79$ & & $-0,46$ \\
\hline $\begin{array}{l}\text { Índice_Stake_Controladores/Blockholder } \\
s\end{array}$ & & & & & & & 0,04 & & 0,60 & 0,05 & & 0,57 & & & & & & & 0,04 & & 0,53 & 0,04 & & 0,57 & & & & & & & 0,07 & & 0,72 & 0,08 & & 0,71 \\
\hline $\begin{array}{c}\text { Índice_remuneraçãa_variável e por } \\
\text { ações/remuneração total }\end{array}$ & & & & & & & & & & 3,07 & * & 1,67 & & & & & & & & & & 2,99 & $*$ & 1,65 & & & & & & & & & & 3,57 & * & 1,76 \\
\hline Q de Tobin & $-0,15$ & & $-0,46$ & $-0,01$ & & $-0,04$ & $-0,34$ & & $-0,72$ & $-0,64$ & & $-1,32$ & $-0,14$ & & $-0,43$ & 0,00 & & 0,00 & $-0,30$ & & $-0,66$ & $-0,61$ & & $-1,36$ & $-0,14$ & & $-0,46$ & $-0,01$ & & $-0,03$ & $-0,32$ & & $-0,72$ & $-0,68$ & & $-1,53$ \\
\hline Indústria Manufatureira & 0,02 & & 0,02 & 0,15 & & 0,19 & 0,89 & & 0,76 & 0,92 & & 0,65 & $-0,02$ & & $-0,03$ & 0,13 & & 0,17 & 0,84 & & 0,67 & 0,95 & & 0,70 & $-0,09$ & & $-0,11$ & 0,09 & & 0,12 & 1,01 & & 0,83 & 1,03 & & 0,75 \\
\hline Idade & 0,01 & & 0,82 & 0,01 & & 0,74 & 0,02 & & 0,89 & 0,02 & & 1,06 & 0,01 & & 0,74 & 0,01 & & 0,69 & 0,02 & & 0,83 & 0,02 & & 1,08 & 0,01 & & 0,65 & 0,01 & & 0,62 & 0,01 & & 0,64 & 0,02 & & 0,80 \\
\hline Tamanho_LN(Ativo Total) & 0,26 & & 1,35 & 0,29 & & 1,48 & 0,59 & * & 1,84 & 0,49 & & 1,48 & 0,26 & & 1,29 & 0,29 & & 1,54 & 0,57 & * & 1,78 & 0,47 & & 1,45 & 0,31 & & 1,47 & 0,33 & & 1,59 & 0,58 & * & 1,90 & 0,47 & & 1,53 \\
\hline Investidores Institucionais & $-1,54$ & * & $-1,86$ & $-1,15$ & & $-1,34$ & $-0,88$ & & $-0,49$ & $-1,65$ & & $-0,80$ & $-1,45$ & * & $-1,70$ & $-1,11$ & & $-1,30$ & $-0,77$ & & $-0,41$ & $-1,46$ & & $-0,75$ & $-1,67$ & ** & $-2,00$ & $-1,31$ & & $-1,51$ & $-0,97$ & & $-0,56$ & $-1,98$ & & $-1,01$ \\
\hline Alavancagem Financeira & $-1,38$ & & $-0,49$ & $-1,95$ & & $-0,69$ & $-5,49$ & & $-1,19$ & $-3,24$ & & $-0,63$ & $-1,40$ & & $-0,52$ & $-1,99$ & & $-0,74$ & $-5,39$ & & $-1,07$ & $-3,14$ & & $-0,60$ & $-1,62$ & & $-0,59$ & $-2,12$ & & $-0,75$ & $-4,97$ & & $-1,09$ & $-2,56$ & & $-0,52$ \\
\hline Folga Fin & $-0,19$ & & $-0,33$ & $-0,12$ & & $-0,26$ & $-0,01$ & & $-0,01$ & $-0,14$ & & $-0,13$ & $-0,20$ & & $-0,35$ & $-0,13$ & & $-0,25$ & $-0,03$ & & $-0,03$ & $-0,16$ & & $-0,14$ & $-0,18$ & & $-0,32$ & $-0,12$ & & $-0,22$ & 0,02 & & 0,02 & $-0,10$ & & $-0,08$ \\
\hline LN(CAPEX) & $-0,02$ & & $-0,55$ & $-0,02$ & & $-0,44$ & $-0,11$ & & $-1,40$ & $-0,11$ & & $-1,37$ & $-0,02$ & & $-0,48$ & $-0,02$ & & $-0,38$ & $-0,10$ & & $-1,34$ & $-0,11$ & & $-1,24$ & $-0,02$ & & $-0,51$ & $-0,02$ & & $-0,43$ & $-0,09$ & & $-1,28$ & $-0,09$ & & $-1,02$ \\
\hline Novo Mercado e Nível 2 & 0,84 & & 0,90 & 0,73 & & 0,81 & 1,26 & & 1,08 & 2,04 & & 1,59 & 0,84 & & 0,89 & 0,70 & & 0,78 & 1,36 & & 1,19 & 2,08 & $*$ & 1,74 & & & 0,49 & & & 0,47 & 0,9 & & 0,77 & 1,48 & & 1,10 \\
\hline Adquirente Ser & $-0,49$ & & $-0,67$ & $-0,47$ & & -0,58 & $\begin{array}{l}-0,15 \\
-0,15 \\
-15\end{array}$ & & $\begin{array}{l}-0,13 \\
-13\end{array}$ & $-0,19$ & & $-0,14$ & $-0,51$ & & $-0,68$ & $-0,50$ & & $-0,62$ & $-0,18$ & & 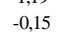 & $\begin{array}{l}-0,21 \\
-0,1\end{array}$ & & $\begin{array}{l}-0,17 \\
-0,17 \\
-1\end{array}$ & $-0,62$ & & $-0,73$ & $-0,57$ & & $-0,67$ & $-0,46$ & & $-0,38$ & $-0,68$ & & $-0,44$ \\
\hline Aquisição Internacional & $-1,47$ & *** & $-2,13$ & $-1,45$ & *** & $-2,11$ & $-2,52$ & **** & $-2,64$ & $-2,55$ & ***** & $-2,67$ & $-1,50$ & *** & $-2,23$ & $-1,48$ & *** & $-2,13$ & $-2,49$ & **** & $-2,65$ & $-2,58$ & **** & $-2,67$ & $-1,53$ & ** & $-2,24$ & $-1,50$ & ** & $-2,19$ & $-2,74$ & **** & $-2,84$ & $-2,75$ & **** & $-2,81$ \\
\hline _cons & $-3,04$ & & $-0,75$ & $-4,60$ & & $-1,10$ & $-7,16$ & & $-0,95$ & $-7,47$ & & $-1,00$ & $-2,97$ & & $-0,71$ & $-4,59$ & & $-1,13$ & $-6,99$ & & $-0,90$ & $-7,43$ & & $-0,98$ & $-2,59$ & & $-0,63$ & $-4,22$ & & $-1,01$ & $-6,25$ & & $-0,83$ & $-6,32$ & & $-0,84$ \\
\hline $\mathrm{N}$ & & 226 & & & 222 & & & 160 & & & 150 & & & 226 & & & 222 & & & 160 & & & 150 & & & 226 & & & 222 & & & 160 & & & 150 & \\
\hline Replicaçōes & & 1000 & & & 1000 & & & 1000 & & & 1000 & & & 1000 & & & 1000 & & & 1000 & & & 1000 & & & 1000 & & & 1000 & & & 1000 & & & 1000 & \\
\hline Wald chi2 & & 15,87 & & & 19,48 & & & 19,76 & & & 24,51 & & & 16,76 & & & 18,26 & & & 20,10 & & & 28,29 & & & 17,08 & & & 18,70 & & & 23,05 & & & 25,81 & \\
\hline $\mathrm{R}^{\wedge} 2$ & & 0,09 & & & 0,10 & & & 0,15 & & & 0,17 & & & 0,09 & & & 0,10 & & & 0,15 & & & 0,17 & & & 0,09 & & & 0,10 & & & 0,16 & & & 0,18 & \\
\hline
\end{tabular}

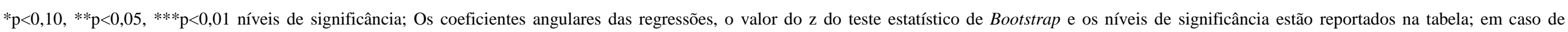

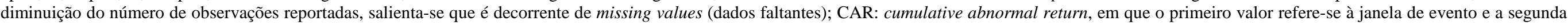
nomenclatura ao benchmark de retorno de mercado utilizado.

Fonte: Elaborado pelo autor. 
Tabela. 64 - Resultados Regressões Multivariadas: CAR_3_IBRX50 - Porcentagens de Concentração Acionária Baseadas em legislação societária - Painel A. Todas Empresas da Amostra Bootstrap

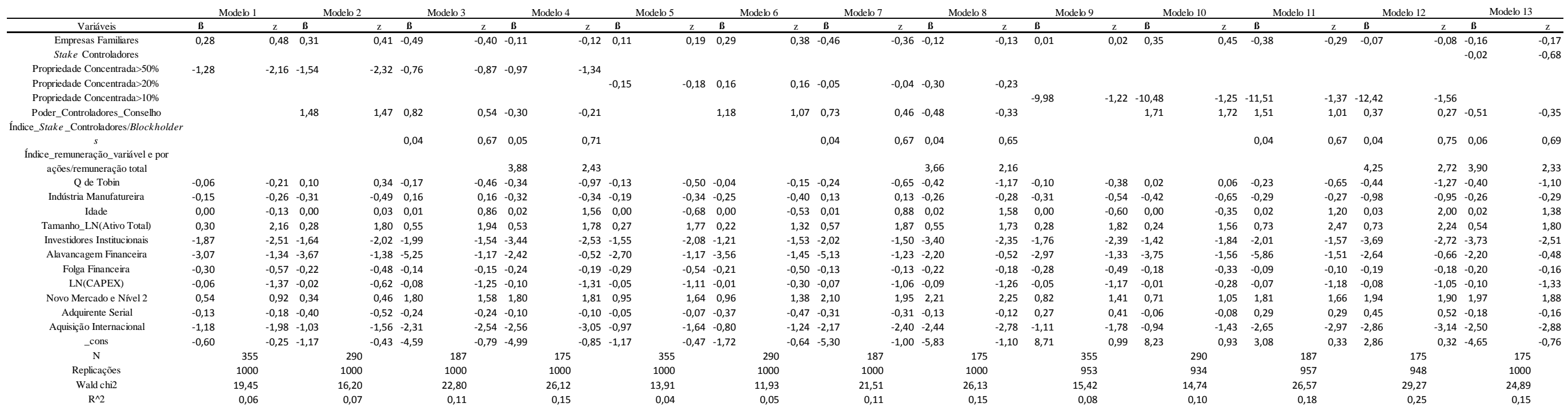

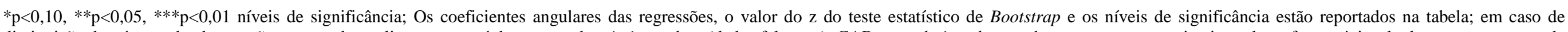

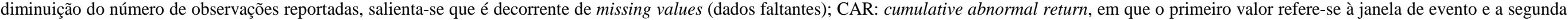
nomenclatura ao benchmark de retorno de mercado utilizado.

Fonte: Elaborado pelo autor. 


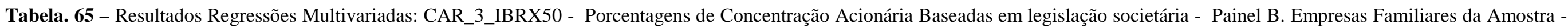
Bootstrap

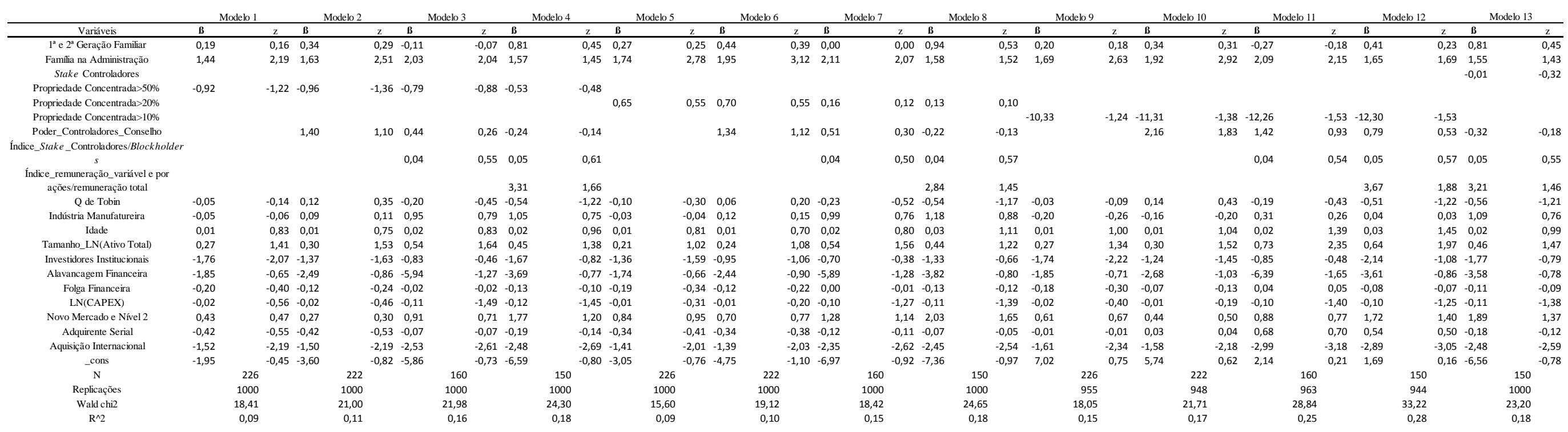

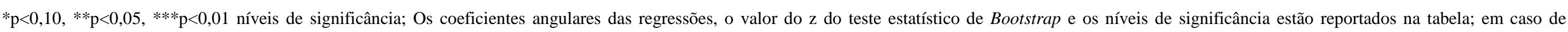

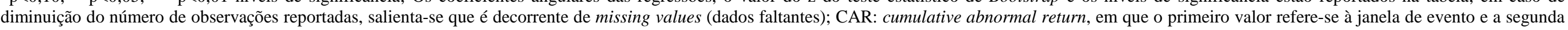
nomenclatura ao benchmark de retorno de mercado utilizado.

Fonte: Elaborado pelo autor. 


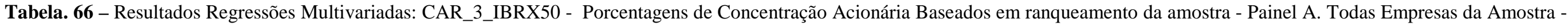
Bootstrap

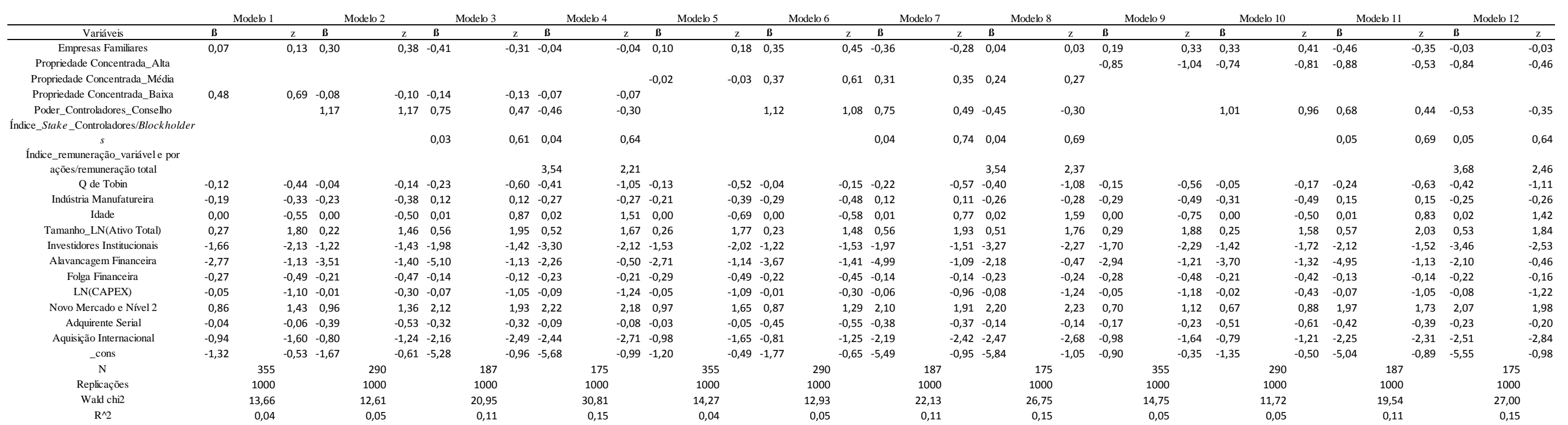

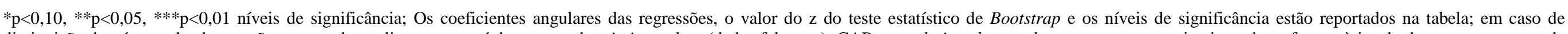

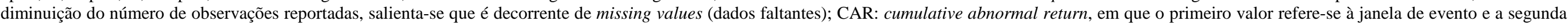
nomenclatura ao benchmark de retorno de mercado utilizado.

Fonte: Elaborado pelo autor. 


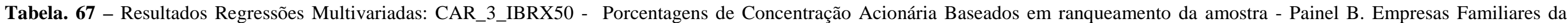
Amostra - Bootstrap

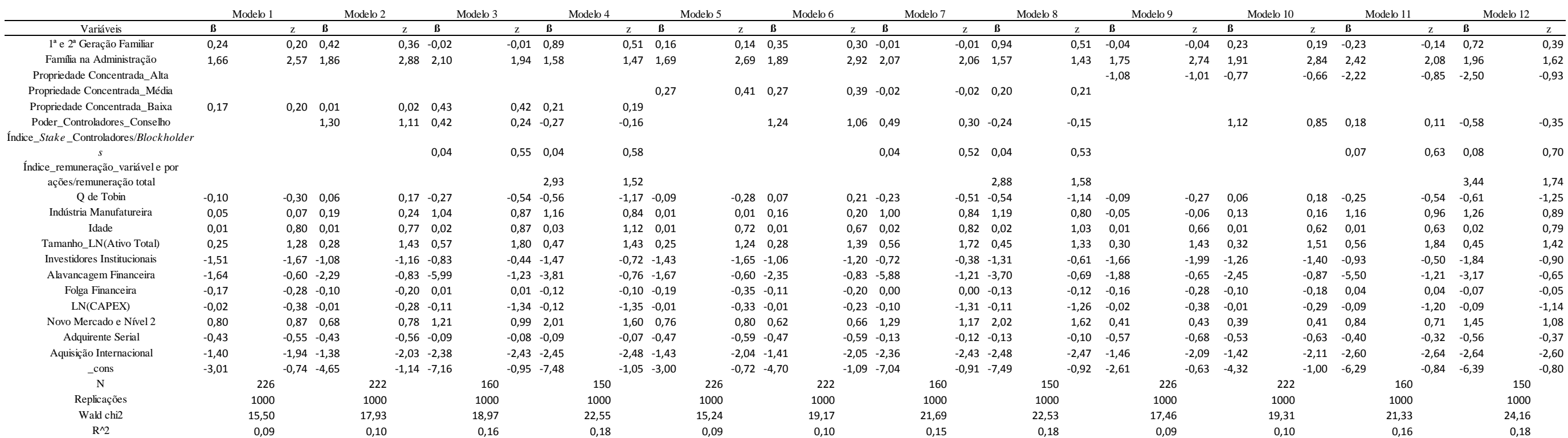

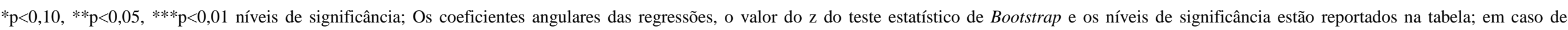

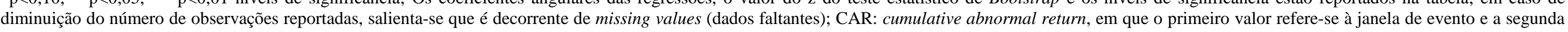
nomenclatura ao benchmark de retorno de mercado utilizado.

Fonte: Elaborado pelo autor. 
Tabela. 68 - Resultados Regressões Multivariadas: CAR_11_IBOV - Porcentagens de Concentração Acionária Baseadas em legislação societária - Painel A. Todas Empresas da Amostra Bootstrap

\begin{tabular}{|c|c|c|c|c|c|c|c|c|c|c|c|c|c|c|c|c|c|c|c|c|c|c|c|c|c|c|c|c|c|c|c|c|c|c|c|c|c|c|}
\hline & & Modelo 1 & & & Modelo 2 & & & Modelo 3 & & & Modelo 4 & & Modelo 5 & & & Modelo 6 & & & Modelo 7 & & & Modelo 8 & & & Modelo 9 & & & Modelo 10 & & & Iodelo 11 & & & Modelo 12 & & & Modelo 13 & \\
\hline Variáveis & $\begin{array}{l}B \\
\end{array}$ & & $\mathrm{z}$ & $B$ & & $\mathrm{z}$ & $B$ & & $z$ & B & $\mathrm{z}$ & $\bar{B}$ & & $\mathrm{z}$ & $\bar{B}$ & & $\mathrm{z}$ & $B$ & & $z$ & $B$ & & $z$ & $B$ & & & $B$ & & & $B$ & & & $B$ & & $\mathrm{z}$ & B & & \\
\hline $\begin{array}{l}\text { Empresas Familiares } \\
\text { Stake Controladores }\end{array}$ & $-0,07$ & & $-0,08$ & 0,98 & & 0,90 & 0,00 & & 0,00 & 1,32 & 0,84 & $-0,26$ & & $-0,30$ & 0,93 & & 0,89 & $-0,26$ & & $-0,13$ & 1,06 & & 0,62 & $-0,39$ & & $-0,45$ & 1,02 & & 0,89 & 0,16 & & 0,08 & 1,43 & & 0,89 & $\begin{array}{c}1,09 \\
-0,06\end{array}$ & & $\begin{array}{l}0,66 \\
-1,36\end{array}$ \\
\hline Propriedade Concentrada $>50 \%$ & $-1,62$ & & $-1,63$ & $-1,80$ & & $-1,62$ & $-2,09$ & & $-1,34$ & $-2,38$ & $-1,49$ & & & & & & & & & & & & & & & & & & & & & & & & & & & \\
\hline $\begin{array}{l}\text { Propriedade Concentrada }>20 \% \\
\text { Propiedade Concentrada }>10 \%\end{array}$ & & & & & & & & & & & & $-0,95$ & & $-0,77$ & $-1,67$ & & $-1,04$ & $-2,33$ & & $-1,26$ & $-1,86$ & & $-0,94$ & $-10,48$ & & $-0,92$ & $-11,27$ & & $-1,04$ & $-10,79$ & & $-0,92$ & $-10,74$ & & $-0,90$ & & & \\
\hline Pode__Controladores_Conselho & & & & 3,52 & ** & 2,39 & 3,97 & * & 1,79 & 3,23 & 1,45 & & & & 2,98 & ** & 2,04 & 3,61 & & 1,63 & 2,75 & & 1,27 & & & & 3,74 & **** & 2,61 & 4,44 & *** & 2,10 & 3,56 & * & 1,71 & 2,69 & & 1,26 \\
\hline $\begin{array}{c}\text { Índice_Stake_Controladores/Blockholder } \\
s\end{array}$ & & & & & & & 0,06 & & 0,67 & 0,05 & 0,47 & & & & & & & 0,05 & & 0,52 & 0,03 & & 0,33 & & & & & & & 0,04 & & 0,50 & 0,03 & & 0,33 & 0,08 & & 0,58 \\
\hline $\begin{array}{l}\text { Índice_remuneraçăo_varíavele por } \\
\text { aç̧össremuneraçăo total }\end{array}$ & & & & & & & & & & $-0,22$ & $-0,10$ & & & & & & & & & & $-0,32$ & & $-0,13$ & & & & & & & & & & $-0,42$ & & $-0,17$ & 0,18 & & 0,08 \\
\hline Q de Tobin & 0,35 & & 0,80 & 0,43 & & 0,90 & 0,42 & & 0,67 & 0,47 & 0,74 & 0,29 & & 0,66 & 0,28 & & 0,62 & 0,23 & & 0,37 & 0,25 & & 0,41 & 0,29 & & 0,67 & 0,32 & & 0,71 & 0,25 & & 0,41 & 0,27 & & 0,44 & 0,33 & & 0,52 \\
\hline Indústria Manufatureira & $-1,01$ & & $-1,30$ & $-0,48$ & & $-0,55$ & 0,70 & & 0,48 & 0,63 & 0,43 & $-0,96$ & & $-1,15$ & $-0,17$ & & $-0,19$ & 0,90 & & 0,63 & 0,81 & & 0,57 & $-1,20$ & & $-1,43$ & $-0,60$ & & $-0,67$ & 0,22 & & 0,15 & 0,12 & & 0,07 & 0,77 & & 0,53 \\
\hline Idade & 0,00 & & 0,41 & 0,00 & & 0,29 & 0,01 & & 0,52 & 0,03 & 1,39 & 0,00 & & 0,12 & 0,00 & & 0,07 & 0,02 & & 0,65 & 0,04 & & 1,49 & 0,00 & & 0,04 & 0,00 & & $-0,01$ & 0,02 & & 0,64 & 0,04 & * & 1,66 & 0,03 & & 1,29 \\
\hline Tamanho_LN(Ativo Total) & 0,15 & & 0,68 & 0,19 & & 0,78 & $-0,10$ & & $-0,24$ & $-0,25$ & $-0,55$ & 0,15 & & 0.59 & 0,22 & & 0,86 & 0,14 & & 0,30 & $-0,08$ & & $-0,17$ & 0,12 & & 0,51 & 0,14 & & 0,57 & 0,09 & & 0,21 & $-0,08$ & & $-0,17$ & $-0,20$ & & $-0,39$ \\
\hline Investidores Institucionais & $-1,13$ & & $-1,06$ & $-0,32$ & & $-0,27$ & 1,60 & & 0,84 & 1,98 & 0,92 & $-0,81$ & & $-0,76$ & $-0,13$ & & $-0,11$ & 1,42 & & 0,72 & 1,85 & & 0,82 & $-0,94$ & & $-0,92$ & $-0,04$ & & $-0,04$ & 1,55 & & 0,78 & 1,95 & & 0,87 & 0,87 & & 0,39 \\
\hline Alavancagem Financeira & $-2,89$ & & $-0,91$ & $-3,56$ & & $-1,07$ & $-4,40$ & & $-0,77$ & $-3,38$ & $-0,58$ & $-2,37$ & & $-0,75$ & $-2,73$ & & $-0,82$ & $-3,81$ & & $-0,70$ & $-2,52$ & & $-0,43$ & $-2,71$ & & $-0,87$ & $-3,62$ & & $-1,15$ & $-4,75$ & & $-0,86$ & $-3,33$ & & $-0,60$ & $-2,78$ & & $-0,49$ \\
\hline Folga Financeira & $-0,07$ & & $-0,08$ & 0,16 & & 0,26 & 0,22 & & 0,17 & 0,13 & 0,07 & $-0,04$ & & $-0,04$ & 0,20 & & 0,28 & 0,30 & & 0,20 & 0,19 & & 0,11 & $-0,05$ & & $-0,05$ & 0,21 & & 0,29 & 0,28 & & 0,19 & 0,18 & & 0,10 & 0,26 & & 0,14 \\
\hline $\begin{array}{l}\text { LN(CAPEX) } \\
\text { (1) }\end{array}$ & $-0,08$ & & $-1,06$ & $-0,03$ & & $-0,45$ & $-0,09$ & & $-0,95$ & $-0,16$ & $-1,41$ & $-0,06$ & & $-0,91$ & $-0,02$ & & $-0,35$ & $-0,08$ & & $-0,87$ & $-0,13$ & & $-1,31$ & $-0,06$ & & $-0,92$ & $-0,01$ & & $-0,22$ & $-0,06$ & & -0,67 0707 & $\begin{array}{r}-0,11 \\
058\end{array}$ & & $-1,12$ & $-0,15$ & & $-1,36$ \\
\hline $\begin{array}{l}\text { Novo Mercadoe e Nível } 2 \\
\text { Adquirente Serial }\end{array}$ & $\begin{array}{l}-1,98 \\
-0.04\end{array}$ & ** & $\begin{array}{l}-2,10 \\
-0,04\end{array}$ & $\begin{array}{l}-1,71 \\
-1,35\end{array}$ & & $\begin{array}{l}-1,15 \\
-1,30\end{array}$ & $\begin{array}{l}-0,13 \\
-1.187 \\
\end{array}$ & & $\begin{array}{l}-0,08 \\
-1,33\end{array}$ & $\begin{array}{l}-1,36 \\
-1,19\end{array}$ & $\begin{array}{l}-0,84 \\
-0.86\end{array}$ & $\begin{array}{l}-1,55 \\
-0,84\end{array}$ & * & $\begin{array}{l}-1,76 \\
-0.82\end{array}$ & $\begin{array}{l}-1,13 \\
-1.54\end{array}$ & & $\begin{array}{l}-1,11 \\
-1,38\end{array}$ & $\begin{array}{r}0,62 \\
-2,21\end{array}$ & * & $\begin{array}{l}0,39 \\
-1,69\end{array}$ & $\begin{array}{l}-0,35 \\
-1.41 \\
\end{array}$ & & $\begin{array}{l}-0,24 \\
-0.99\end{array}$ & $\begin{array}{l}-1,59 \\
-0,41\end{array}$ & * & $\begin{array}{l}-1,90 \\
-0,44\end{array}$ & $\begin{array}{l}-1,24 \\
-0.09\end{array}$ & & $\begin{array}{l}-1,28 \\
-1,00\end{array}$ & $\begin{array}{l}0,42 \\
-1,49\end{array}$ & & $\begin{array}{l}0,27 \\
-1,09\end{array}$ & $\begin{array}{l}-0,58 \\
-0,68\end{array}$ & & $\begin{array}{l}-0,41 \\
-0.55\end{array}$ & $\begin{array}{l}-1,20 \\
-1,48\end{array}$ & & $\begin{array}{l}-0,70 \\
-0,99\end{array}$ \\
\hline Aquisição Internacional & 0,19 & & 0,21 & 0,38 & & 0,42 & 0,60 & & 0,42 & $-0,26$ & $-0,18$ & 0,48 & & 0,56 & 0,68 & & 0,75 & 0,88 & & 0,64 & 0,06 & & 0,04 & 0,31 & & 0,35 & 0,50 & & 0,55 & 0,54 & & 0,37 & $-0,31$ & & $-0,21$ & $\begin{array}{l}-1,88 \\
-0,16\end{array}$ & & $\begin{array}{l}-0,11 \\
-0,11\end{array}$ \\
\hline _cons & 2,99 & & 0,73 & $-1,55$ & & $-0,37$ & 0,79 & & 0,10 & 2,73 & 0,32 & 2,45 & & 0,57 & $-1,96$ & & $-0,46$ & $-1,89$ & & $-0,22$ & 0,20 & & 0,03 & 12,63 & & 1,03 & 8,51 & & 0,74 & 6,72 & & 0,51 & 8,41 & & 0,61 & 4,62 & & 0,51 \\
\hline $\mathrm{N}$ & & 355 & & & 290 & & & 187 & & & 175 & & 355 & & & 290 & & & 187 & & & 175 & & & 355 & & & 290 & & & 187 & & & 175 & & & 175 & \\
\hline Replicações & & 1000 & & & 1000 & & & 1000 & & & 1000 & & 1000 & & & 1000 & & & 1000 & & & 1000 & & & 944 & & & 942 & & & 957 & & & 956 & & & 1000 & \\
\hline Wald chi2 & & 11,87 & & & 12,77 & & & 10,76 & & & 12,93 & & 9,85 & & & 11,37 & & & 9,67 & & & 12,59 & & & 10,86 & & & 12,20 & & & 10,65 & & & 13,31 & & & 12,07 & \\
\hline $\mathrm{R}^{\wedge} 2$ & & 0,03 & & & 0,05 & & & 0,07 & & & 0,08 & & 0,03 & & & 0,04 & & & 0,07 & & & 0,07 & & & 0,04 & & & 0,06 & & & 0,09 & & & 0,10 & & & 0,09 & \\
\hline
\end{tabular}

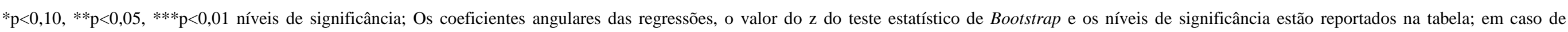

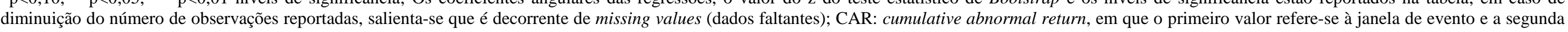
nomenclatura ao benchmark de retorno de mercado utilizado.

Fonte: Elaborado pelo autor. 
Tabela. 69 - Resultados Regressões Multivariadas: CAR_11_IBOV - Porcentagens de Concentração Acionária Baseadas em legislação societária - Painel B. Empresas Familiares da Amostra Bootstrap

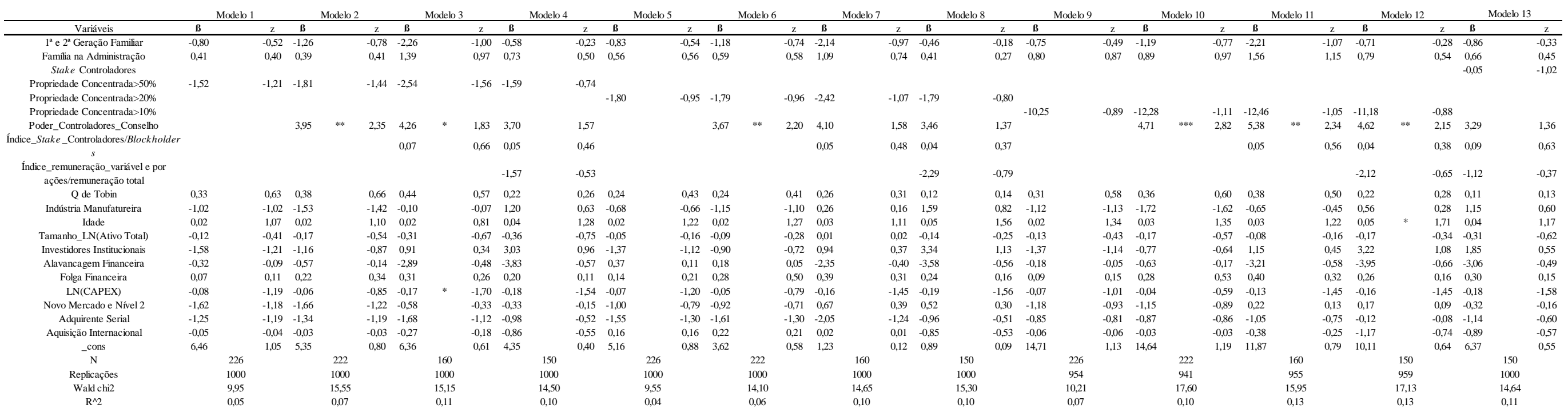

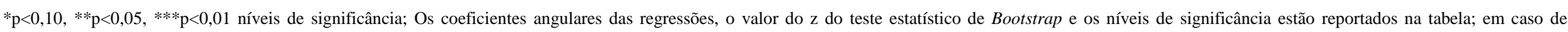

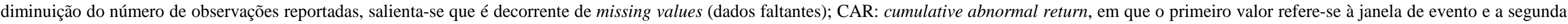
nomenclatura ao benchmark de retorno de mercado utilizado.

Fonte: Elaborado pelo autor. 
Tabela.70 - Resultados Regressões Multivariadas: CAR_11_IBOV - Porcentagens de Concentração Acionária Baseados em ranqueamento da amostra - Painel A. Todas Empresas da Amostra Bootstrap

\begin{tabular}{|c|c|c|c|c|c|c|c|c|c|c|c|c|c|c|c|c|c|c|c|c|c|c|c|c|c|c|c|c|c|c|c|c|c|c|c|}
\hline & & Modelo 1 & & & Modelo 2 & & & Modelo 3 & & & Modelo 4 & & Modelo 5 & & & Modelo 6 & & & Modelo 7 & & & Modelo 8 & & & Modelo 9 & & & Modelo 10 & & & Modelo 11 & & & Modelo 12 & \\
\hline Variáveis & B & & $\mathrm{z}$ & $\mathbf{B}$ & & $\mathrm{z}$ & B & & $\mathrm{z}$ & $\mathbf{B}$ & $\mathrm{z}$ & B & & $\mathrm{z}$ & B & & $\mathrm{z}$ & B & & $\mathrm{z}$ & B & & $\mathrm{z}$ & B & & $\mathrm{z}$ & B & & $\mathrm{z}$ & B & & $\mathrm{z}$ & B & & $\mathrm{z}$ \\
\hline Empresas Familiares & $-0,37$ & & $-0,41$ & 0,76 & & 0,69 & $-0,60$ & & $-0,30$ & 0,74 & 0,42 & $-0,31$ & & $-0,34$ & 0,84 & & 0,76 & $-0,25$ & & $-0,13$ & 0,98 & & 0,53 & $-0,09$ & & $-0,10$ & 1,01 & & 0,90 & 0,07 & & 0,04 & 1,51 & & 0,87 \\
\hline Propriedade Concentrada_Alta & & & & & & & & & & & & & & & & & & & & & & & & $-1,88$ & & $-1,56$ & $-1,01$ & & $-0,75$ & $-2,50$ & & $-1,11$ & $-1,88$ & & $-0,80$ \\
\hline Propriedade Concentrada_Média & & & & & & & & & & & & $-0,10$ & & $-0,12$ & $-0,61$ & & $-0,68$ & $-1,14$ & & $-0,83$ & $-1,12$ & & $-0,78$ & & & & & & & & & & & & \\
\hline Propriedade Concentrada_Baixa & 1,16 & & 1,08 & 1,61 & & 1,24 & 2,19 & & 1,41 & 1,85 & 1,15 & & & & & & & & & & & & & & & & & & & & & & & & \\
\hline Poder_Controladores_Conselho & & & & 3,02 & ** & 2,16 & 3,43 & & 1,47 & 2,60 & 1,17 & & & & 3,24 & ** & 2,27 & 3,63 & & 1,58 & 2,77 & & 1,25 & & & & 2,94 & ** & 1,99 & 3,56 & & 1,63 & 2,70 & & 1,27 \\
\hline $\begin{array}{l}\text { Índice_Stake_Controladores/Blockholder } \\
s\end{array}$ & & & & & & & 0,06 & & 0,59 & 0,04 & 0,42 & & & & & & & 0,03 & & 0,36 & 0,02 & & 0,20 & & & & & & & 0,08 & & 0,77 & 0,05 & & 0,52 \\
\hline $\begin{array}{l}\text { Índice_remuneraçãa_varíavele por } \\
\text { acōes/remuneracãa total }\end{array}$ & & & & & & & & & & $-0,68$ & $-0,29$ & & & & & & & & & & $-0,99$ & & $-0,42$ & & & & & & & & & & $-0,73$ & & $-0,32$ \\
\hline Q de Tobin & 0,29 & & 0,66 & 0,25 & & 0.56 & 0,14 & & 0,23 & 0,19 & 0,30 & 0,25 & & 0.56 & 0,26 & & 0.57 & 0,19 & & 0.31 & 0.25 & & 0.38 & 0.21 & & 0.44 & 0.25 & & 0,55 & 0.23 & & 0.38 & 0.28 & & 0,44 \\
\hline Indústria Manufatureira & $\begin{array}{l}-1,04 \\
-29\end{array}$ & & $\begin{array}{l}-1,22 \\
-1,2\end{array}$ & $\begin{array}{l}-0,29 \\
-0,29\end{array}$ & & 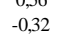 & 0,74 & & 0,52 & 0,64 & 0,45 & $\begin{array}{l}-1,08 \\
-1,08\end{array}$ & & $\begin{array}{l}-1,31 \\
-1,31\end{array}$ & $\begin{array}{l}0,20 \\
-0,28\end{array}$ & & -0,32 & 0,64 & & 0,47 & 0,63 & & 0,43 & $\begin{array}{l}0,21 \\
-1,27\end{array}$ & & $\begin{array}{l}-1,50 \\
-1,50\end{array}$ & -0,50 & & -0,55 & 0,69 & & 0 & 0 & & 0,56 \\
\hline Idade & 0,00 & & 0,21 & 0,00 & & 0,12 & 0,01 & & 0,61 & 0,03 & 1,51 & 0,00 & & 0,00 & 0,00 & & $-0,01$ & 0,01 & & 0,53 & 0,03 & & 1,44 & 0,00 & & $-0,11$ & 0,00 & & $-0,13$ & 0,01 & & 0,38 & 0,03 & & 1,23 \\
\hline Tamanho_LN(Ativo Total) & 0,13 & & 0,55 & 0,18 & & 0,73 & 0,02 & & 0,04 & $-0,16$ & $-0,33$ & 0,11 & & 0,45 & 0,13 & & 0,53 & $-0,02$ & & $-0,06$ & $-0,20$ & & $-0,44$ & 0,16 & & 0,64 & 0,16 & & 0,65 & $-0,06$ & & $-0,14$ & $-0,25$ & & $-0,55$ \\
\hline Investidores Institucionais & $-1,00$ & & $-0,94$ & $-0,34$ & & $-0,29$ & 0,92 & & 0,47 & 1,50 & 0,67 & $-0,70$ & & $-0,69$ & 0,11 & & 0,10 & 1,36 & & 0,71 & 1,98 & & 0,91 & $-1,07$ & & $-1,00$ & $-0,10$ & & $-0,09$ & 1,23 & & 0,65 & 1,96 & & 0,92 \\
\hline Alavancagem Financeira & $-2,57$ & & $-0,77$ & $-3,03$ & & $-0,92$ & $-4,64$ & & $-0,83$ & $-3,38$ & $-0,54$ & $-2,42$ & & $-0,75$ & $-3,06$ & & $-0,94$ & $-4,60$ & & $-0,82$ & $-3,48$ & & $-0,55$ & $-2,95$ & & $-0,89$ & $-3,63$ & & $-1,01$ & $-3,56$ & & $-0,65$ & $-2,62$ & & $-0,45$ \\
\hline Folga Financeira & $-0,02$ & & $-0,02$ & 0,22 & & 0,32 & 0,31 & & 0,22 & 0,21 & 0,11 & $-0,06$ & & $-0,07$ & 0,19 & & 0,28 & 0,27 & & 0,17 & 0,17 & & 0,09 & $-0,03$ & & $-0,04$ & 0,17 & & 0,26 & 0,26 & & 0,18 & 0,17 & & 0,08 \\
\hline LN(CAPEX) & $-0,06$ & & $-0,88$ & $-0,03$ & & $-0,43$ & $-0,09$ & & $-1,02$ & $-0,15$ & $-1,30$ & $-0,06$ & & $-0,81$ & $-0,02$ & & $-0,28$ & $-0,08$ & & $-0,78$ & $-0,14$ & & $-1,29$ & $-0,07$ & & $-0,98$ & $-0,02$ & & $-0,34$ & $-0,06$ & & $-0,61$ & $-0,11$ & & $-1,03$ \\
\hline Novo Mercado e Nível 2 & $-1,71$ & * & $-1,84$ & $-1,29$ & & $-1,19$ & 0,36 & & 0,23 & $-0,58$ & $-0,38$ & $-1,43$ & & $-1,59$ & $-0,89$ & & $-0,90$ & 0,69 & & 0,47 & $-0,30$ & & $-0,19$ & $-2,04$ & $* *$ & $-2,20$ & $-1,37$ & & $-1,27$ & 0,30 & & 0,20 & $-0,66$ & & $-0,41$ \\
\hline Adquirent & $-0,75$ & & $-0,74$ & $-1,32$ & & $-1,23$ & $-1,83$ & & $-1,32$ & $-1,03$ & $-0,76$ & $-0,71$ & & $-0,71$ & $-1,23$ & & $-1,19$ & $-1,77$ & & $-1,36$ & $-0,87$ & & $-0,64$ & $-1,04$ & & $\begin{array}{l}-0,99 \\
-0.69\end{array}$ & $-1,5$ & & $-1,31$ & $-2,2$ & & $-1,57$ & $-1,48$ & & $-0,96$ \\
\hline Aquisição Internacional & 0,54 & & 0,59 & 0,72 & & 0,80 & 0,98 & & 0,74 & 0,15 & 0,10 & 0,45 & & 0,51 & 0,68 & & 0,76 & $\begin{array}{l}1,10 \\
1,10\end{array}$ & & 0,77 & 0,20 & & 0,14 & 0,44 & & 0,47 & 0,65 & & 0,74 & 0,76 & & 0,54 & $-0,10$ & & $-0,07$ \\
\hline _cons & 1,95 & & 0,47 & $-2,74$ & & $-0,64$ & $-1,24$ & & $-0,15$ & 0,56 & 0,07 & 2,25 & & 0,53 & $-2,07$ & & $-0,47$ & $-0,37$ & & $-0,04$ & $\begin{array}{l}1,67 \\
1,67\end{array}$ & & 0,19 & 2,91 & & 0,68 & $-1,69$ & & $\begin{array}{l}-0,44 \\
-0,41\end{array}$ & $-0,42$ & & $\begin{array}{l}-0,05 \\
-0,5\end{array}$ & 1,34 & & 0,16 \\
\hline $\mathrm{N}$ & & 355 & & & 290 & & & 187 & & & 175 & & 355 & & & 29 & & & 1 & & & 1 & & & 355 & & & & & & & & & & \\
\hline Replicą̧ōes & & 1000 & & & 10 & & & 1000 & & & 1000 & & 1000 & & & 10 & & & 10 & & & 1000 & & & 1000 & & & 1000 & & & 1000 & & & 1000 & \\
\hline Wald chi2 & & 9,31 & & & 10,94 & & & 9,73 & & & 12,17 & & 9,83 & & & 10,68 & & & 10,47 & & & 12,52 & & & 10,87 & & & 11,72 & & & 10,16 & & & 12,93 & \\
\hline $\mathrm{R}^{\wedge 2}$ & & 0,03 & & & 0,04 & & & 0,07 & & & 0,08 & & 0,02 & & & 0,04 & & & 0,06 & & & 0,07 & & & 0,03 & & & 0,04 & & & 0,06 & & & 0,07 & \\
\hline
\end{tabular}

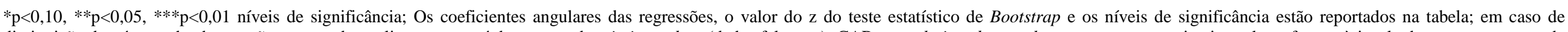

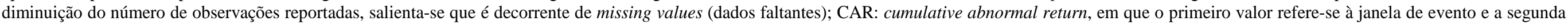
nomenclatura ao benchmark de retorno de mercado utilizado.

Fonte: Elaborado pelo autor. 


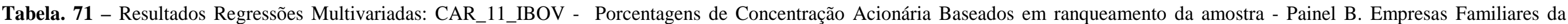
Amostra - Bootstrap

\begin{tabular}{|c|c|c|c|c|c|c|c|c|c|c|c|c|c|c|c|c|c|c|c|c|c|c|c|c|c|c|c|c|c|c|c|c|c|c|c|c|}
\hline & & Modelo 1 & & & Modelo 2 & & & Modelo 3 & & & Modelo 4 & & & Modelo 5 & & & Modelo 6 & & & Modelo 7 & & & Modelo 8 & & & Modelo 9 & & & Modelo 10 & & & Modelo 11 & & & Modelo 12 & \\
\hline Variáveis & B & & $\mathrm{z}$ & $B$ & & $\mathrm{z}$ & $\mathbf{B}$ & & $\mathrm{z}$ & B & & $\mathrm{z}$ & B & & $\mathrm{z}$ & B & & $\mathrm{z}$ & $\begin{array}{l}B \\
170\end{array}$ & & $\frac{z}{z}$ & $B$ & & 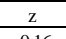 & B & & $\mathrm{z}$ & $B$ & & $\mathrm{z}$ & $\begin{array}{l} \\
\end{array}$ & & $\mathrm{z}$ & $B$ & & \\
\hline $1^{\mathrm{a}} \mathrm{e} 2^{\mathrm{a}}$ Geração Familiar & $-0,67$ & & $-0,42$ & $-1,09$ & & $-0,68$ & $-2,02$ & & $-0,95$ & $-0,62$ & & $-0,27$ & $-0,40$ & & $-0,27$ & $-0,0,70$ & & $-0,46$ & $-1,79$ & & $-0,82$ & $-0,38$ & & $-0,16$ & $-0,94$ & & $-0,61$ & $-1,12$ & & $-0,69$ & $-2,17$ & & $-0,99$ & $-0,38$ & & $-0,15$ \\
\hline Familia na Administração & 0,73 & & 0,78 & 0,74 & & 0,79 & 1,70 & & 1,17 & 0,94 & & 0,61 & 0,66 & & 0,68 & 0,66 & & 0,72 & 1,33 & & 0,94 & 0,62 & & 0,43 & 0,85 & & 0,90 & 0,84 & & 0,87 & 1,91 & & 1,16 & 1,00 & & 0,58 \\
\hline Propriedade Concentrada_Alta & & & & & & & & & & & & & & & & & & & & & & & & & $-0,86$ & & $-0,51$ & $-0,04$ & & $-0,03$ & $-2,32$ & & $-0,73$ & $-1,78$ & & $-0,49$ \\
\hline Propriedade Concentrada_Média & & & & & & & & & & & & & $-1,13$ & & $-1,03$ & $-1,61$ & & $-1,37$ & $-2,15$ & & $-1,46$ & $-1,57$ & & $-0,92$ & & & & & & & & & & & & \\
\hline Propriedade Concentrada_Baixa & 1,97 & & 1,41 & 2,17 & & 1,62 & 2,98 & $*$ & 1,91 & 2,19 & & 1,31 & & & & & & & & & & & & & & & & & & & & & & & & \\
\hline Poder_Controladores_Conselho & & & & 3,77 & ** & 2,18 & 3,93 & * & 1,65 & 3,38 & & 1,39 & & & & 4,14 & ** & 2,42 & 4,37 & * & 1,85 & 3,68 & & 1,56 & & & & 3,76 & ** & 2,12 & 4,10 & * & 1,71 & 3,44 & & 1,48 \\
\hline $\begin{array}{c}\text { Índice_Stake_Controladores/Block holder } \\
s\end{array}$ & & & & & & & 0,07 & & 0,67 & 0,06 & & 0,47 & & & & & & & 0,03 & & 0,33 & 0,03 & & 0,28 & & & & & & & 0,08 & & 0,63 & 0,06 & & 0,45 \\
\hline $\begin{array}{l}\text { Índice_remuneração_variávele por } \\
\text { ações/remuneração total }\end{array}$ & & & & & & & & & & $-2,34$ & & $-0,85$ & & & & & & & & & & $-2,84$ & & $-1,01$ & & & & & & & & & & $-2,44$ & & $-0,80$ \\
\hline Q de Tobin & 0,21 & & 0,39 & 0,18 & & 0,30 & 0,10 & & 0,12 & 0,04 & & 0,04 & 0,21 & & 0,39 & 0,20 & & 0,33 & 0,19 & & 0,23 & 0,12 & & 0,14 & 0,25 & & 0,47 & 0,26 & & 0,46 & 0,31 & & 0,40 & 0,15 & & 0,17 \\
\hline Indústria Manufatureira & $-0,78$ & & $-0,73$ & $-1,30$ & & $-1,20$ & 0,33 & & 0,22 & 1,48 & & 0,77 & $-0,72$ & & $-0,71$ & $-1,19$ & & $-1,09$ & 0,09 & & 0,06 & 1,45 & & 0,78 & $-0,95$ & & $-0,89$ & $-1,34$ & & $-1,24$ & 0,22 & & 0,15 & 1,65 & & 0,85 \\
\hline Idade & 0,02 & & 1,21 & 0,03 & & 1,31 & 0,03 & & 1,06 & 0,05 & & 1,47 & 0,02 & & 1,24 & 0,03 & & 1,42 & 0,03 & & 1,13 & 0,05 & * & 1,65 & 0,02 & & 0,98 & 0,02 & & 1,13 & 0,02 & & 0,69 & 0,04 & & 1,37 \\
\hline Tamanho_LN(Ativo Total) & $-0,09$ & & $-0,27$ & $-0,13$ & & $-0,42$ & $-0,15$ & & $-0,31$ & $-0,24$ & & $-0,47$ & $-0,17$ & & $-0,54$ & $-0,23$ & & $-0,73$ & $-0,18$ & & $-0,37$ & $-0,26$ & & $-0,49$ & $-0,11$ & & $-0,35$ & $-0,20$ & & $-0,60$ & $-0,25$ & & $-0,54$ & $-0,34$ & & $-0,70$ \\
\hline Investidores Institucionais & $-1,63$ & & $-1,30$ & $-1,23$ & & $-0,93$ & 0,52 & & 0,20 & 2,85 & & 0,96 & $-1,18$ & & $-0,95$ & $-0,67$ & & $-0,54$ & 0,94 & & 0,36 & 3,44 & & 1,14 & $-1,25$ & & $-1,07$ & $-0,60$ & & $-0,51$ & 1,06 & & 0,42 & 3.58 & & 1,16 \\
\hline Alavancagem Financeira & $-0,09$ & & $-0,02$ & $-0,18$ & & $-0,04$ & $-3,49$ & & $-0,56$ & $-4,44$ & & $-0,64$ & 0,23 & & 0,06 & 0,15 & & 0,04 & $-3,63$ & & $-0,56$ & $-4,73$ & & $-0,67$ & $-0,16$ & & $-0,04$ & $-0,21$ & & $-0,05$ & $-2,29$ & & $-0,38$ & $-3,67$ & & $-0,57$ \\
\hline Folga Financeira & 0,17 & & 0,22 & 0,31 & & 0,61 & 0,46 & & 0,36 & 0,31 & & 0,17 & 0,12 & & 0,17 & 0,28 & & 0,60 & 0,39 & & 0,31 & 0,25 & & 0,14 & 0,11 & & 0,19 & 0,24 & & 0,43 & 0,40 & & 0,30 & 0,25 & & 0,14 \\
\hline LN(CAPEX) & $-0,08$ & & $-1,20$ & $-0,06$ & & $-0,88$ & $-0,18$ & $*$ & $-1,79$ & $-0,20$ & & $-1,41$ & $-0,08$ & & $-1,08$ & $-0,05$ & & $-0,79$ & $-0,18$ & $*$ & $-1,66$ & $-0,21$ & & $-1,58$ & $-0,07$ & & $-1,00$ & $-0,04$ & & $-0,66$ & $-0,13$ & & $-1,28$ & $-0,16$ & & $-1,08$ \\
\hline Novo Mercado e Nível 2 & $-1,28$ & & $-0,98$ & $-1,21$ & & $-0,98$ & 0,09 & & 0,05 & 0,12 & & 0,07 & $-0,71$ & & $-0,53$ & $-0,51$ & & $-0,38$ & 0,67 & & 0,40 & 0,59 & & 0,32 & $-1,30$ & & $-0,90$ & $-0,90$ & & $-0,63$ & 0,17 & & 0,09 & 0,04 & & 0,02 \\
\hline Adquirente Serial & $-1,28$ & & $-1,13$ & $\begin{array}{l}-1,35 \\
\end{array}$ & & $-1,26$ & $-1,60$ & & $-1,09$ & $-0,68$ & & $-0,39$ & $-1,14$ & & $-1,09$ & $-1,15$ & & $-1,08$ & $-1,43$ & & $-0,95$ & $-0,39$ & & $-0,22$ & $\begin{array}{l}-1,38 \\
-12 y\end{array}$ & & $-1,28$ & $-1,37$ & & $-1,20$ & $-2,16$ & & $-1,35$ & $-1,03$ & & $-0,51$ \\
\hline Aquisição Internacional & 0,23 & & 0,22 & 0,29 & & 0,29 & 0,14 & & 0,10 & $-0,68$ & & $-0,44$ & 0,24 & & 0,25 & 0,35 & & 0,35 & 0,40 & & 0,28 & $-0,59$ & & $-0,39$ & 0,10 & & 0,09 & 0,19 & & 0,18 & 0,01 & & 0,00 & $-0,91$ & & $-0,61$ \\
\hline _cons & 3,96 & & 0,65 & 2,55 & & 0,40 & 1,74 & & 0,17 & 1,26 & & 0,13 & 5,12 & & 0,83 & 3,67 & & 0,55 & 3,37 & & 0,32 & 2,35 & & 0,22 & 5,10 & & 0,86 & 3,38 & & 0,53 & 3,32 & & 0,32 & 2,57 & & 0,25 \\
\hline $\mathrm{N}$ & & 226 & & & 222 & & & 160 & & & 150 & & & 226 & & & 222 & & & 160 & & & 150 & & & 226 & & & 222 & & & 160 & & & 150 & \\
\hline Replicaçōes & & 1000 & & & 1000 & & & 1000 & & & 1000 & & & 1000 & & & 1000 & & & 1000 & & & 1000 & & & 1000 & & & 1000 & & & 1000 & & & 1000 & \\
\hline Wald chi2 & & 8,97 & & & 14,84 & & & 15,69 & & & 14,25 & & & 8,70 & & & 13,23 & & & 14,81 & & & 14,84 & & & 9,33 & & & 13,38 & & & 14,03 & & & 13,34 & \\
\hline $\mathrm{R}^{\wedge} 2$ & & 0,05 & & & 0,07 & & & 0.12 & & & 0,11 & & & 0,04 & & & 0.07 & & & 0,11 & & & 0,11 & & & 0,04 & & & 0.06 & & & 0.09 & & & 0,10 & \\
\hline
\end{tabular}

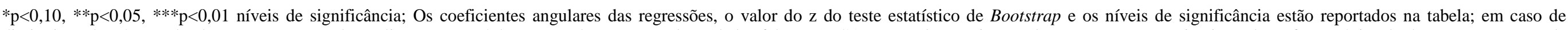

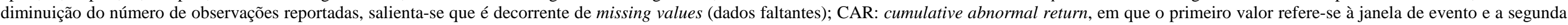
nomenclatura ao benchmark de retorno de mercado utilizado.

Fonte: Elaborado pelo autor. 
Tabela. 72 - Resultados Regressões Multivariadas: CAR_11_IBRX50 - Porcentagens de Concentração Acionária Baseadas em legislação societária - Painel A. Todas Empresas da Amostra Bootstrap

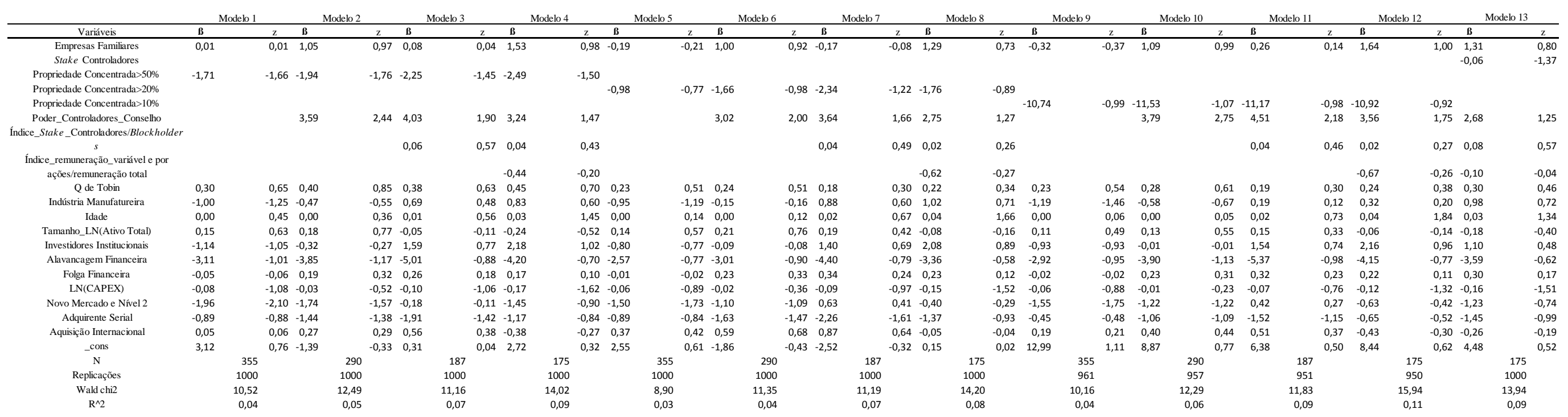

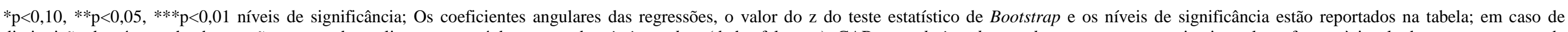

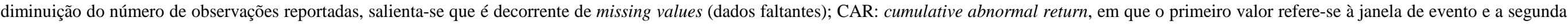
nomenclatura ao benchmark de retorno de mercado utilizado.

Fonte: Elaborado pelo autor. 


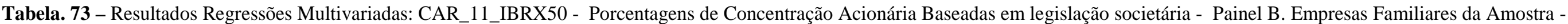
Bootstrap

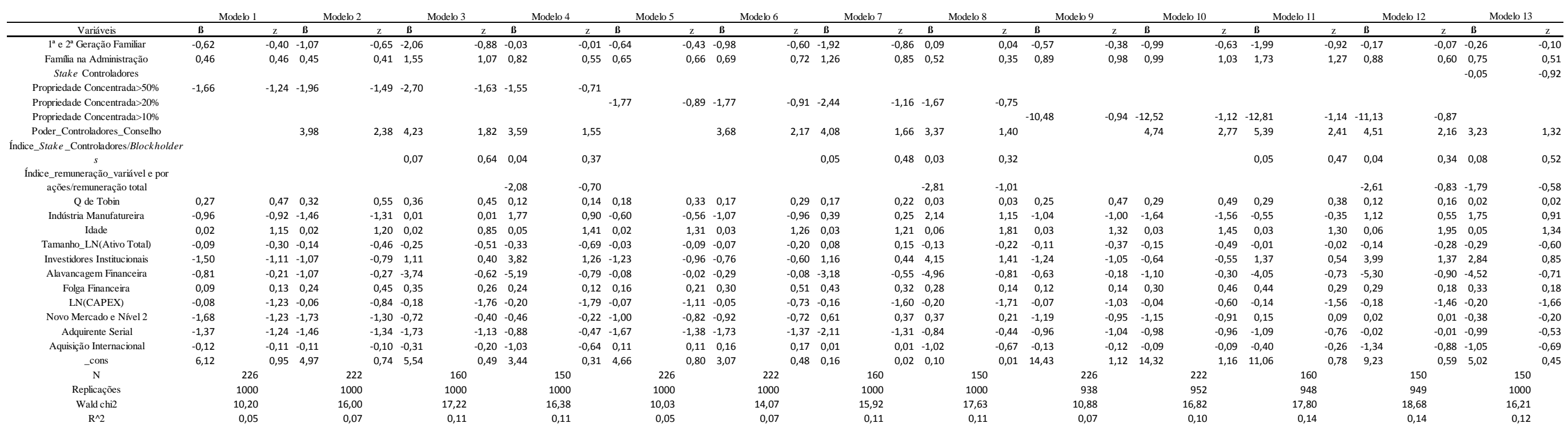

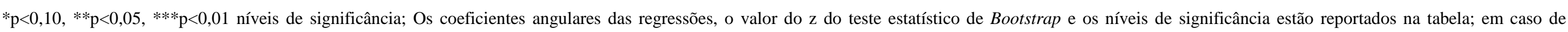

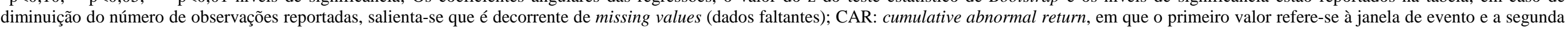
nomenclatura ao benchmark de retorno de mercado utilizado.

Fonte: Elaborado pelo autor. 


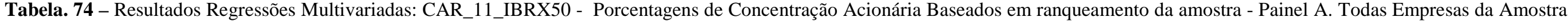
- Bootstrap

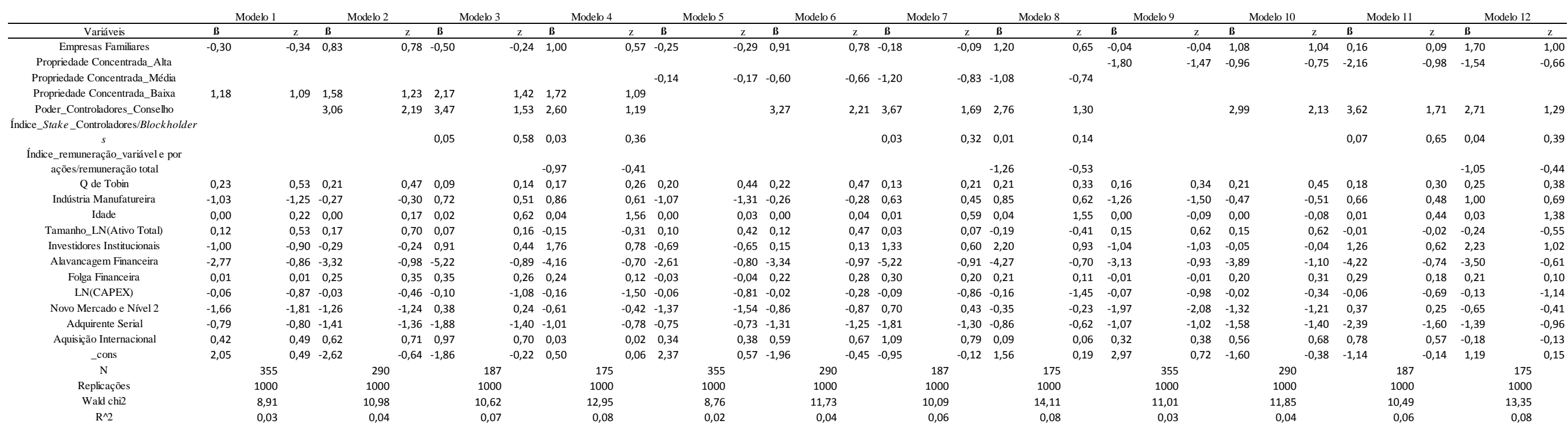

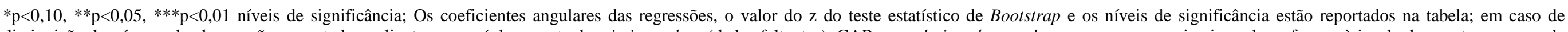

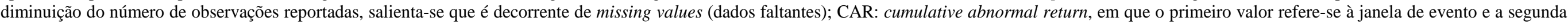
nomenclatura ao benchmark de retorno de mercado utilizado.

Fonte: Elaborado pelo autor. 


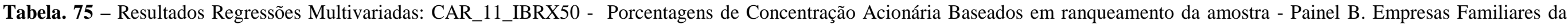
Amostra - Bootstrap

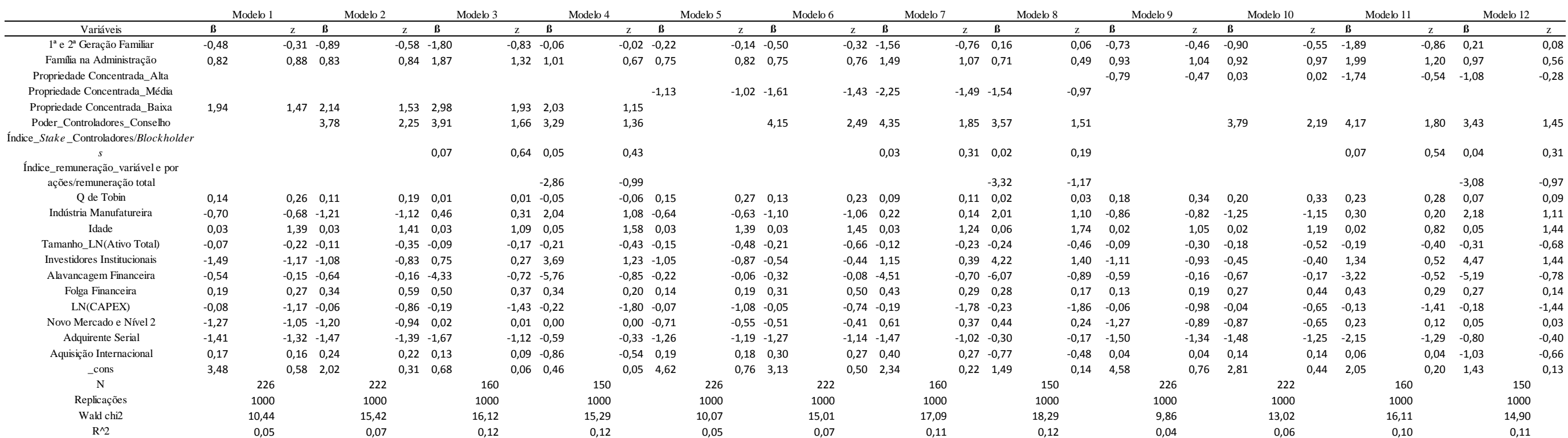

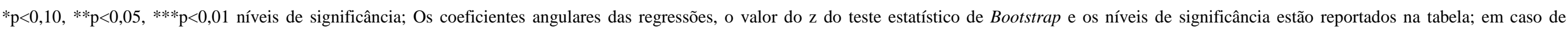

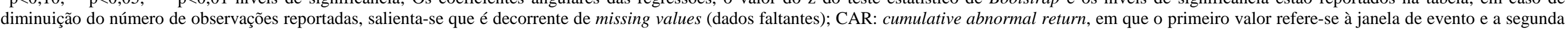
nomenclatura ao benchmark de retorno de mercado utilizado.

Fonte: Elaborado pelo autor. 
Tabela. 76 - Resultados Regressões Multivariadas: CAR_21_IBOV - Porcentagens de Concentração Acionária Baseadas em legislação societária - Painel A. Todas Empresas da Amostra Bootstrap

\begin{tabular}{|c|c|c|c|c|c|c|c|c|c|c|c|c|c|c|c|c|c|c|c|c|c|c|c|c|c|c|c|c|c|c|c|c|c|c|c|c|c|c|}
\hline & & Modelo 1 & & & Modelo 2 & & & Modelo 3 & & & Modelo 4 & & & Modelo 5 & & Modelo 6 & & & Modelo 7 & & & Modelo 8 & & & Modelo 9 & & & Modelo 10 & & & Modelo 11 & & & Modelo 12 & & & Modelo 1 : & \\
\hline Variáveis & $\bar{B}$ & & $z$ & B & & $\mathrm{z}$ & B & & $\mathrm{z}$ & $B$ & & $\mathrm{z}$ & $B$ & $z$ & $B$ & & $\mathrm{z}$ & $\mathbf{B}$ & & $z$ & $B$ & & $\mathrm{z}$ & $B$ & & $\mathrm{z}$ & $B$ & & $z$ & $B$ & & $\mathrm{z}$ & B & & $\mathrm{z}$ & B & & $z$ \\
\hline $\begin{array}{l}\text { Empresas Familiares } \\
\text { Stake Controlaldores }\end{array}$ & 0,76 & & 0,61 & 3,61 & *** & 2,54 & 2,34 & & 1,02 & 3,49 & ${ }^{*}$ & 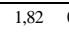 & 0,65 & 0,51 & 3,61 & *** & 2,50 & 2,35 & & $\begin{array}{ll}1,00 \quad 3 \\
3\end{array}$ & 3,50 & * & 1,66 & 0,54 & & 0,44 & 3,69 & **** & 2,65 & 2,41 & & 1,04 & 3,51 & * & 1,66 & 3,30 & & 1,59 \\
\hline $\begin{array}{l}\text { STatak Controlodorose } \\
\text { Propiedade Concentrada }>0 \%\end{array}$ & $-0,76$ & & $-0,59$ & $-0,28$ & & $-0,20$ & -0.02 & & -0.01 & -0.64 & & $-0,35$ & & & & & & & & & & & & & & & & & & & & & & & & & & \\
\hline Propriedade Concentrada $>20 \%$ & & & & & & & & & & & & & 0,08 & 0,05 & 0,17 & & 0,08 & 0,05 & & $0,02-1$ & $-0,09$ & & $-0,04$ & & & & & & & & & & & & & & & \\
\hline Propriedade Concentrada $>10 \%$ & & & & & & & & & & & & & & & & & & & & & & & & $-12,73$ & & $-1,24$ & $-13,97$ & & $-1,35$ & $-11,80$ & & $-1,02$ & $-12,81$ & & $-1,15$ & & & \\
\hline Poder_Controladores_Conselho & & & & 3,65 & * & 1,67 & 4,82 & * & 1,71 & 3,96 & & 1,42 & & & 3,61 & * & 1,64 & 4,82 & & $1,59 \quad 3$ & 3,85 & & 1,32 & & & & 4,31 & ** & 2,01 & 5,62 & *** & 2,04 & 4,73 & & 1,60 & 3,76 & & 1,29 \\
\hline $\begin{array}{l}\text { Índice_Stake_Controladores/Blockholder } \\
s\end{array}$ & & & & & & & 0,02 & & 0,14 & 0,01 & & 0,04 & & & & & & 0,02 & & 0,14 & 0,00 & & $-0,01$ & & & & & & & 0,02 & & 0,17 & 0,00 & & 0,04 & 0,04 & & 0,24 \\
\hline 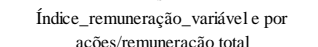 & & & & & & & & & & 3,59 & & 1,02 & & & & & & & & & 3,41 & & 0,93 & & & & & & & & & & 4,10 & & 1,14 & 4,16 & & 1,15 \\
\hline Q de Tobin & $-0,07$ & & $-0,11$ & 0,18 & & 0.24 & 0,13 & & 0.13 & 0.03 & & 0,03 & $-0,12$ & -0.18 & 0.15 & & 0.21 & 0,13 & & $0,13-1$ & -0.02 & & -0.02 & -0.07 & & $-0,10$ & 0.23 & & 0.30 & 0.14 & & 0.14 & $-0,04$ & & -0.04 & 0.01 & & 0,01 \\
\hline Indústria Manufatureira & $-0,23$ & & $-0,21$ & 1,01 & & 0,81 & 2,59 & & 1,49 & 1,79 & & 0,91 . & $-0,28$ & $-0,24$ & 1,00 & & 0,77 & 2,58 & & 1,44 & 1,82 & & 0,93 & 然 $-0,40$ & & $\begin{array}{l}-0,36 \\
-0,10\end{array}$ & 0,76 & & 0,60 & $\begin{array}{l}2,16 \\
2,16\end{array}$ & & $\begin{array}{l}0,17 \\
1,17\end{array}$ & 1,10 & & 0,53 & & & 0.94 \\
\hline Idade & $-0,01$ & & $-0,59$ & $\begin{array}{l}-0,01 \\
-0,1\end{array}$ & & . & - & & $-0,94$ & - & & $-0,49$ & $-0,01$ & . & $\begin{array}{l}-0,01 \\
-0,01\end{array}$ & & -0,65 & - & & - & $\begin{array}{l}-0,01 \\
-0,01\end{array}$ & & $-0,51$ & 然, 0101 & & 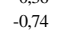 & $-0,01$ & & $-0,56$ & $-0,02$ & & 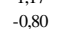 & - & & -0.33 & $\begin{array}{l}1,0,02 \\
-0.02\end{array}$ & & $-0,54$ \\
\hline Tamanho_LN(Ativo Total) & 0,33 & & 1,02 & 0,56 & * & 1,75 & 0,01 & & 0,02 & $-0,10$ & & $-0,15$ & 0,30 & 0,86 & 0,55 & & 1,55 & 0,01 & & $0,01-1$ & $-0,10$ & & $-0,14$ & 0,32 & & 0,96 & 0,57 & * & 1,76 & 0,18 & & 0,31 & 0,10 & & 0,16 & $-0,06$ & & $-0,10$ \\
\hline Investidores Institucionais & $-0,16$ & & $-0,11$ & 0,89 & & 0,56 & 3,08 & & 1,62 & 1,79 & & 0,70 & 0,05 & 0,03 & 0,99 & & 0,64 & 3,08 & & 1,63 & 1,85 & & 0,71 & $-0,25$ & & $-0,18$ & 0,72 & & 0,50 & 3,09 & & 1,60 & 1,49 & & 0,59 & 0,97 & & 0,35 \\
\hline Alavancagem Financeira & $-5,76$ & & $-1,32$ & $-6,37$ & & $-1,40$ & $-7,78$ & & $-1,07$ & $-5,22$ & & $-0,64$ & $-5,56$ & $-1,30$ & $-6,40$ & & $-1,40$ & $-7,78$ & & $-1,11$ & $-5,10$ & & $-0,65$ & $-5,89$ & & $-1,34$ & $-6,67$ & & $-1,53$ & $-8,52$ & & $-1,22$ & $-5,50$ & & $-0,72$ & & & $-0,60$ \\
\hline Folga Financeira & $-0,04$ & & $-0,04$ & 0,26 & & 0,30 & 0,35 & & 0,17 & 0,25 & & 0,09 & $-0,04$ & $-0,03$ & 0,26 & & 0,29 & 0,35 & & 0,210 & 0,26 & & 0,09 & $-0,02$ & & $-0,02$ & 0,31 & & 0,38 & 0,40 & & 0,20 & 0,30 & & 0,10 & 0,33 & & 0,12 \\
\hline LN(CAPEX) & $-0,01$ & & $-0,07$ & 0,04 & & 0,39 & 0,09 & & 0,62 & 0,08 & & 0,40 & 0,00 & $-0,01$ & 0,04 & & 0,42 & 0,09 & & 0,61 & 0,09 & & 0,49 & $-0,01$ & & $-0,05$ & & & 0,43 & 0,09 & & & & & 0,56 & 07 & & 0,37 \\
\hline Novo Mercad & $-0,71$ & & $-0,55$ & $-0,18$ & & $-0,12$ & 1,87 & & 0,91 & 0,55 & & 0,26 & $-0,45$ & 37 & $-0,05$ & & $-0,04$ & 1,88 & & 1,01 & 0,82 & & 0,45 & $-0,6$ & & $-0,52$ & -0 & & $-0,27$ & 1,58 & & & 0,54 & & 0,30 & 27 & & 0,13 \\
\hline Adquirente Sc & $-0,90$ & & $-0,67$ & $-1,64$ & & $-1,17$ & $-3,17$ & * & $-1,75$ & $-3,17$ & * & $-1,65$ & $-0,84$ & $-0,60$ & $-1,62$ & & $-1,10$ & $-3,17$ & * & $-1,74$ & $-3,17$ & & $-1,61$ & $-0,4$ & & $-0,33$ & -1 & & $-0,88$ & & & $-1,49$ & $-2,61$ & & $-1,46$ & 38 & * & $-1,73$ \\
\hline Aquisição Internacional & 0,94 & & 0,67 & 1,13 & & 0,79 & 3,52 & $* *$ & 2,00 & 3,01 & & 1,63 & 1,05 & 79 & 1,17 & & 0,82 & 3,52 & * & 1,953 & 3,09 & ${ }^{*}$ & 1,69 & 0,89 & & 0,67 & & & 0,66 & 3,02 & * & 1,72 & 2,65 & & 1,44 & 2,95 & $*$ & 1,64 \\
\hline _cons & $-2,25$ & 355 & $-0,36$ & $-12,96$ & ${ }^{* * *}$ & $-2,06$ & $-6,97$ & 187 & $-0,68$ & $-5,66$ & 175 & $-0,48$ & $-2,63$ & $-0,42$ & $-13,08$ & ${ }^{* * *}$ & $-2,12$ & $-6,97$ & 187 & $-0,66$ & & 175 & $-0,57$ & 10,05 & & 0,81 & & & 0,01 & 1,59 & 187 & 0,11 & 2,70 & & 0,19 & $-3,79$ & 175 & $-0,31$ \\
\hline Replicacões & & 1000 & & & $\begin{array}{l}19000 \\
1000\end{array}$ & & & $\begin{array}{l}107 \\
1000\end{array}$ & & & 1000 & & & 1000 & & $\begin{array}{l}290 \\
1000\end{array}$ & & & 1000 & & & 1000 & & & 951 & & & 954 & & & 950 & & & 949 & & & 1000 & \\
\hline & & 4,92 & & & 16,38 & & & 15,82 & & & 19,63 & & & 4,51 & & 15,18 & & & 15,01 & & & 16,80 & & & 5,75 & & & 18,56 & & & 17,26 & & & 16,72 & & & 18,33 & \\
\hline $\mathrm{R}^{\wedge} 2$ & & 0,01 & & & 0.05 & & & 0.08 & & & 0,07 & & & 0,01 & & 0,05 & & & 0,08 & & & 0.07 & & & 0,03 & & & 0,07 & & & 0,10 & & & 0,10 & & & 0.08 & \\
\hline
\end{tabular}

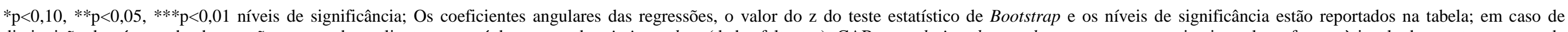

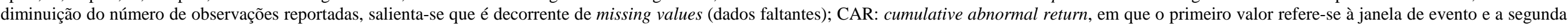
nomenclatura ao benchmark de retorno de mercado utilizado.

Fonte: Elaborado pelo autor. 
Tabela. 77 - Resultados Regressões Multivariadas: CAR_21_IBOV - Porcentagens de Concentração Acionária Baseadas em legislação societária - Painel B. Empresas Familiares da Amostra Bootstrap

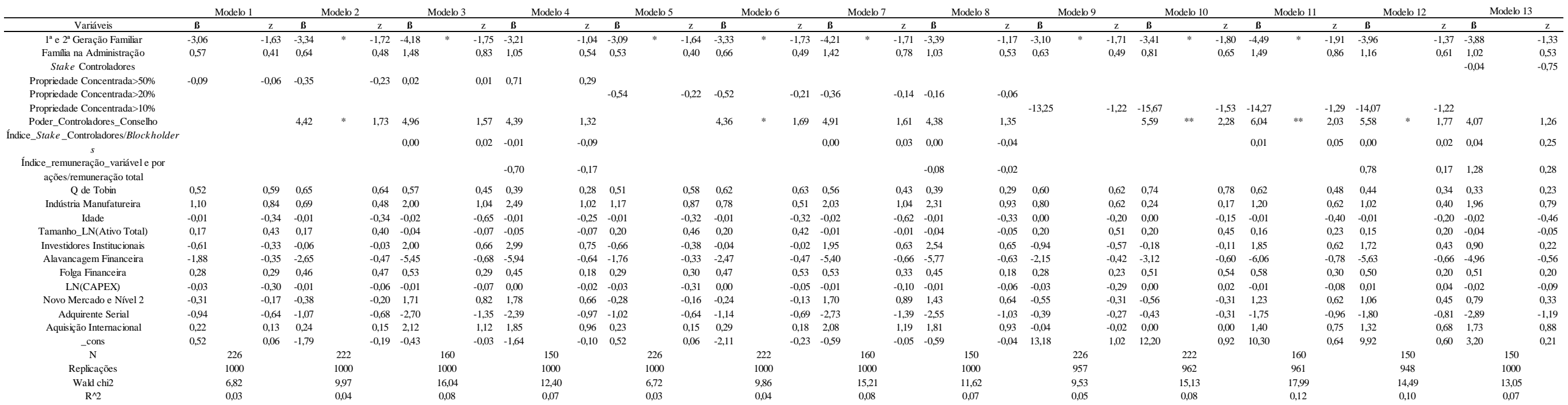

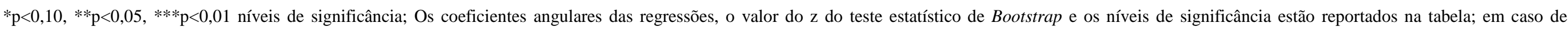

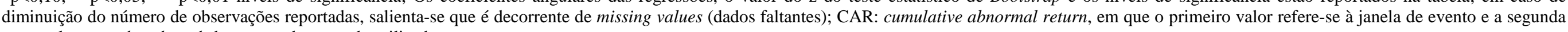
nomenclatura ao benchmark de retorno de mercado utilizado.

Fonte: Elaborado pelo autor. 


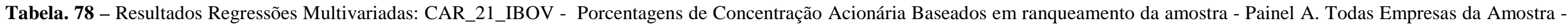
Bootstrap

\begin{tabular}{|c|c|c|c|c|c|c|c|c|c|c|c|c|c|c|c|c|c|c|c|c|c|c|c|c|c|c|c|c|c|c|c|c|c|c|c|c|}
\hline & & Modelo 1 & & & Modelo 2 & & & Modelo 3 & & & Modelo 4 & & & Modelo 5 & & & Modelo 6 & & & Modelo 7 & & & Modelo 8 & & & Modelo 9 & & & Modelo 10 & & & Modelo 11 & & & Modelo 12 & \\
\hline Variáveis & B & & $\mathrm{z}$ & $B$ & & $\mathrm{z}$ & 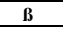 & & $\mathrm{z}$ & $B$ & & $\mathrm{z}$ & $\bar{B}$ & & $\mathrm{z}$ & B & & $\mathrm{z}$ & $B$ & & $\mathrm{z}$ & $B$ & & $\mathrm{z}$ & B & & $\mathrm{z}$ & $\mathbf{B}$ & & $\mathrm{z}$ & B & & $\mathrm{z}$ & B & & $\mathrm{z}$ \\
\hline Empresas Familiares & 0,64 & & 0,52 & 3,58 & ** & 2,54 & 2,30 & & 0,97 & 3,48 & & 1,55 & 0,75 & & 0,64 & 3,66 & **** & 2,67 & 2,55 & & 1,14 & 3,83 & * & 1,73 & 0,86 & & 0,65 & 3,67 & *** & 2,52 & 2,30 & & 1,02 & 3,67 & * & 1,85 \\
\hline Propriedade Concentrada_Alta & & & & & & & & & & & & & & & & & & & & & & & & & $-1,90$ & & $-1,12$ & $-1,00$ & & $-0,56$ & $-3,38$ & & $-1,18$ & $-3,82$ & & $-1,13$ \\
\hline Propriedade Concentrada_Média & & & & & & & & & & & & & 0,58 & & 0,53 & 0,31 & & 0,25 & 0,68 & & 0,38 & 0,76 & & 0,42 & & & & & & & & & & & & \\
\hline Propriedade Concentrada_Baixa & 0,18 & & 0,13 & 0,19 & & 0,12 & 0,13 & & 0,07 & 0,10 & & 0,05 & & & & & & & & & & & & & & & & & & & & & & & & \\
\hline Poder_Controladores_Conselho & & & & 3,57 & * & 1,68 & 4,81 & * & 1,65 & 3,84 & & 1,27 & & & & 3,55 & * & 1,71 & 4,87 & * & 1,74 & 3,90 & & 1,36 & & & & 3,37 & & 1,59 & 4,62 & & 1,58 & 3,59 & & 1,29 \\
\hline $\begin{array}{l}\text { Índice_Stake_Controladores/Blockholder } \\
s\end{array}$ & & & & & & & 0,02 & & 0,15 & 0,00 & & 0,00 & & & & & & & 0,02 & & 0,19 & 0,00 & & 0,03 & & & & & & & 0,07 & & 0,48 & 0,05 & & 0,34 \\
\hline $\begin{array}{l}\text { Índice_remuneracăãovaraíavele por } \\
\text { açốes/remuneração total }\end{array}$ & & & & & & & & & & 3,40 & & 0,98 & & & & & & & & & & 3,36 & & 0,91 & & & & & & & & & & 3,98 & & 1,10 \\
\hline Q de Tobin & $-0,11$ & & $-0,16$ & 0,15 & & 0,20 & 0,12 & & 0,12 & $-0,02$ & & $-0,02$ & $-0,15$ & & $-0,22$ & 0,15 & & 0,20 & 0,16 & & 0,16 & 0,02 & & 0,02 & $-0,16$ & & $-0,23$ & 0,14 & & 0,19 & 0,12 & & 0,12 & $-0,05$ & & $-0,05$ \\
\hline Indústria Manufatureira & $-0,26$ & & $-0,25$ & 1,03 & & 0,84 & 2,59 & & 1,45 & 1,81 & & 0,94 & $-0,36$ & & $-0,31$ & 0,97 & & 0,78 & 2,57 & & 1,40 & 1,88 & & 0,99 & $-0,45$ & & $-0,39$ & 0,91 & & 0,71 & 2,69 & & 1,51 & 1,97 & & 1,03 \\
\hline Idade & $-0,01$ & & $-0,74$ & $-0,01$ & & $-0,59$ & $-0,03$ & & $-0,97$ & $-0,01$ & & $-0,49$ & $-0,01$ & & $-0,87$ & $-0,01$ & & $-0,66$ & $-0,03$ & & $-0,99$ & $-0,02$ & & $-0,54$ & $-0,01$ & & $-0,89$ & $-0,01$ & & $-0,66$ & $-0,03$ & & $-1,05$ & $-0,02$ & & $-0,64$ \\
\hline Tamanho_LN(Ativo Total) & 0,31 & & 0,93 & 0,56 & $*$ & 1,68 & 0,02 & & 0,03 & $-0,10$ & & $-0,15$ & 0,31 & & 0,96 & 0,56 & * & 1,70 & $-0,01$ & & $-0,02$ & $-0,14$ & & $-0,21$ & 0,36 & & 1,06 & 0,59 & * & 1,77 & 0,02 & & 0,03 & $-0,09$ & & $-0,14$ \\
\hline Investidores Institucionais & $-0,01$ & & $-0,01$ & 0,90 & & 0,58 & 3,04 & & 1,52 & 1,83 & & 0,69 & 0,08 & & 0,06 & 0,98 & & 0,65 & 3,19 & $*$ & 1,65 & 2,06 & & 0,76 & $-0,33$ & & $-0,25$ & 0,72 & & 0,47 & 2,66 & & 1,42 & 1,25 & & 0,50 \\
\hline Alavancagem Financeira & $\begin{array}{l}-5,57 \\
-0,07\end{array}$ & & $\begin{array}{ll}-1,28 \\
-1,01\end{array}$ & $-6,30$ & & $\begin{array}{l}-1,41 \\
-1,1\end{array}$ & $-7,81$ & & $\begin{array}{l}-1,01 \\
-1,01\end{array}$ & $\begin{array}{l}-5,15 \\
-5,15\end{array}$ & & $\begin{array}{l}-0,60 \\
-0,60\end{array}$ & $\begin{array}{l}-5,64 \\
\end{array}$ & & $\begin{array}{l}-1,29 \\
-1,2\end{array}$ & $\begin{array}{r}-6,48 \\
-6,48\end{array}$ & & $\begin{array}{l}-1,38 \\
-1,30\end{array}$ & $-7,46$ & & 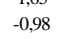 & $-4,82$ & & $-0,61$ & $\begin{array}{l}-6,07 \\
-6,07\end{array}$ & & 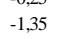 & $\begin{array}{l}-6,61 \\
-6,12\end{array}$ & & $\begin{array}{l}0,472 \\
-1,42\end{array}$ & $\begin{array}{l}2,00 \\
-7,08\end{array}$ & & $\begin{array}{l}1,72 \\
-0,96\end{array}$ & $\begin{array}{l}-4,31 \\
-431\end{array}$ & & $-0,52$ \\
\hline Folga Financeira & $-0,03$ & & $-0,02$ & 0,27 & & 0,28 & 0,36 & & 0,19 & 0,26 & & 0,11 & $-0,05$ & & $-0,05$ & 0,26 & & 0,31 & 0,34 & & 0,20 & 0,25 & & 0,08 & $-0,01$ & & 0,00 & 0,27 & & 0,33 & 0,38 & & 0,19 & 0,31 & & 0,12 \\
\hline LN(CAPEX) & 0,00 & & $-0,02$ & 0,04 & & 0,37 & 0,09 & & 0,60 & 0,08 & & 0,48 & 0,00 & & $-0,01$ & 0,04 & & 0,43 & 0,10 & & 0,69 & 0,10 & & 0,55 & $-0,01$ & & $-0,09$ & 0,03 & & 0,36 & 0,09 & & 0,68 & 0,11 & & 0,63 \\
\hline Novo Mercado e Nível 2 & $-0,50$ & & $-0,38$ & $-0,10$ & & $-0,07$ & 1,86 & & 0,99 & 0,81 & & 0,41 & $-0,51$ & & $-0,40$ & $-0,12$ & & $-0,09$ & 1,88 & & 1,02 & 0,79 & & 0,41 & $-1,07$ & & $-0,79$ & $-0,43$ & & $-0,30$ & 1,36 & & 0,68 & 0,18 & & 0,09 \\
\hline Adquirente Serial & $-0,85$ & & $-0,62$ & $-1,64$ & & $-1,14$ & $-3,16$ & * & $-1,76$ & $-3,15$ & * & $-1,67$ & $-0,94$ & & $-0,68$ & $-1,69$ & & $-1,19$ & $-3,33$ & * & $-1,84$ & $-3,34$ & * & $-1,75$ & $-1,16$ & & $-0,84$ & $-1,81$ & & $-1,21$ & $-3,64$ & * & $-1,89$ & $-3,84$ & $*$ & $-1,91$ \\
\hline Aquisição Internacional & 1,07 & & 0,78 & 1,18 & & 0,83 & 3,52 & * & 1,92 & 3,10 & * & 1,74 & 1,01 & & 0,75 & 1,16 & & 0,82 & 3,46 & * & 1,95 & 2,99 & * & 1,66 & 1,05 & & 0,79 & 1,17 & & 0,85 & 3,20 & * & 1,79 & 2,78 & & 1,50 \\
\hline _cons & $-2,65$ & & $-0,41$ & $-13,12$ & $* *$ & $-2,19$ & $-7,00$ & & $-0,69$ & $-6,15$ & & $-0,54$ & $-2,85$ & & $-0,45$ & $-13,11$ & $* *$ & $-2,15$ & $-7,44$ & & $\begin{array}{c}-0,69 \\
\end{array}$ & $-6,57$ & & $-0,58$ & $-1,92$ & & $-0,31$ & $-12,58$ & & $-2,07$ & $-6,03$ & & $-0,61$ & $-5,47$ & & $-0,49$ \\
\hline $\mathrm{N}$ & & 355 & & & 290 & & & 187 & & & 175 & & & 355 & & & 290 & & & 187 & & & 175 & & & 355 & & & 290 & & & 187 & & & 175 & \\
\hline $\begin{array}{l}\text { Repplicaçōes } \\
\text { Waldchho }\end{array}$ & & 1000 & & & 1000 & & & $\begin{array}{l}1000 \\
1532\end{array}$ & & & 1000 & & & 1000 & & & $\begin{array}{l}1000 \\
1589\end{array}$ & & & 1000 & & & $\begin{array}{l}1000 \\
1700\end{array}$ & & & 1000 & & & 1000 & & & 1000 & & & 1000 & \\
\hline $\begin{array}{l}\text { Wald ch12 } \\
\mathrm{R}^{\wedge} 22\end{array}$ & & $\begin{array}{l}4,43 \\
0,01\end{array}$ & & & $\begin{array}{l}1,1,13 \\
0,05\end{array}$ & & & $\begin{array}{l}1,32 \\
0,08\end{array}$ & & & $\begin{array}{l}1,27 \\
0,07\end{array}$ & & & $\begin{array}{l}5,12 \\
0,01\end{array}$ & & & $\begin{array}{l}1,8,81 \\
0,05\end{array}$ & & & $\begin{array}{l}16,57 \\
0,08\end{array}$ & & & $\begin{array}{l}1,90 \\
0.08\end{array}$ & & & $\begin{array}{l}5,30 \\
0,02\end{array}$ & & & $\begin{array}{l}1,99 \\
0.05\end{array}$ & & & $\begin{array}{l}18,17 \\
0.09\end{array}$ & & & $\begin{array}{l}1,8,26 \\
0.08\end{array}$ & \\
\hline
\end{tabular}

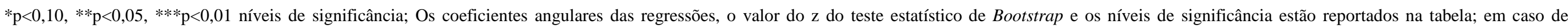

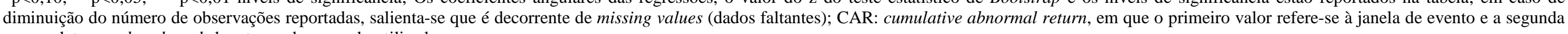
nomenclatura ao benchmark de retorno de mercado utilizado.

Fonte: Elaborado pelo autor. 


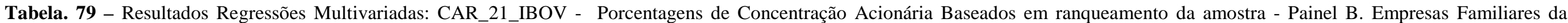
Amostra - Bootstrap

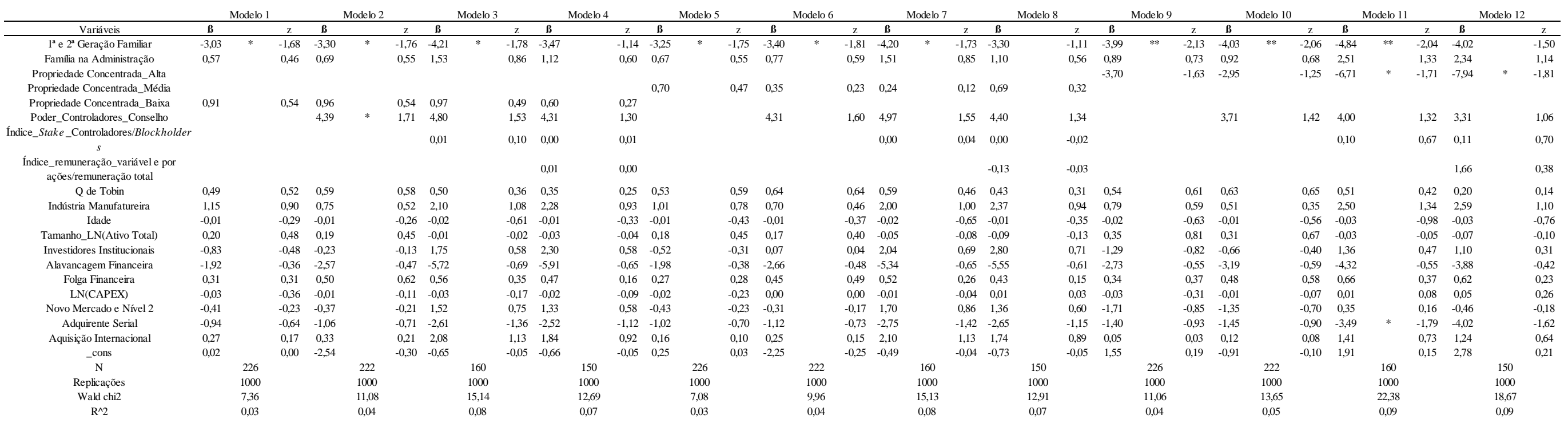

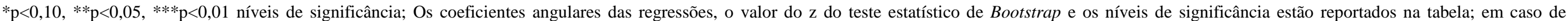

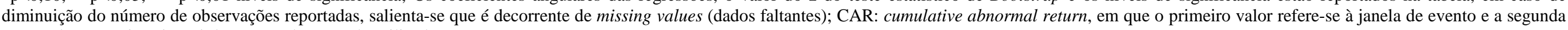
nomenclatura ao benchmark de retorno de mercado utilizado.

Fonte: Elaborado pelo autor. 
Tabela. 80 - Resultados Regressões Multivariadas: CAR_21_IBRX50 - Porcentagens de Concentração Acionária Baseadas em legislação societária - Painel A. Todas Empresas da Amostra Bootstrap

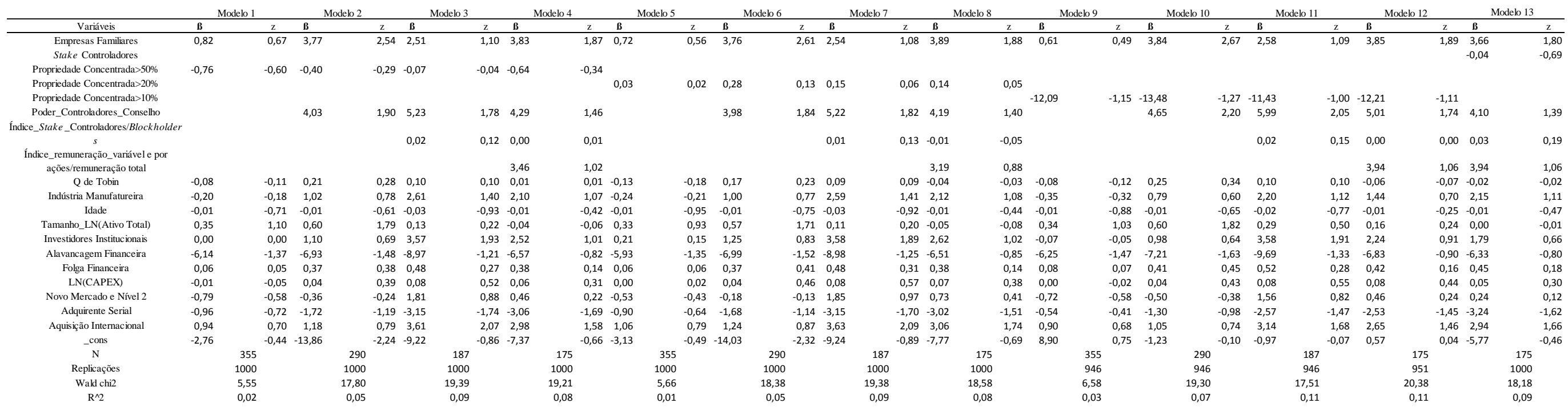

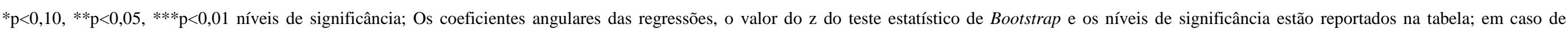

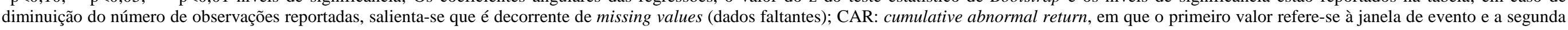
nomenclatura ao benchmark de retorno de mercado utilizado.

Fonte: Elaborado pelo autor. 


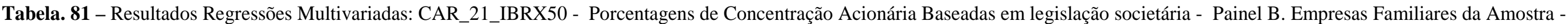
Bootstrap

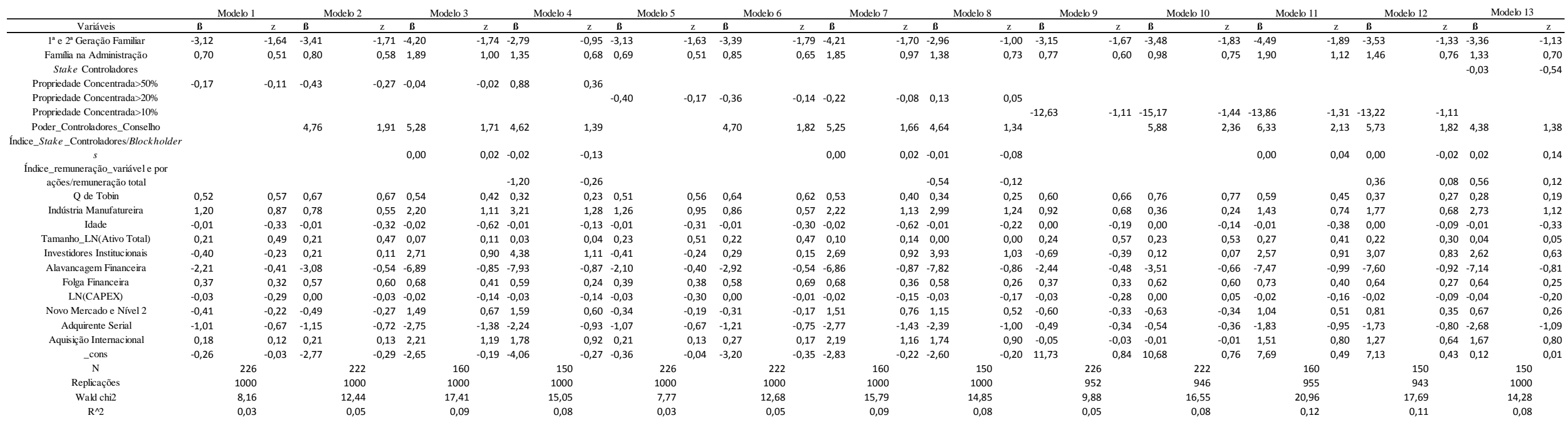

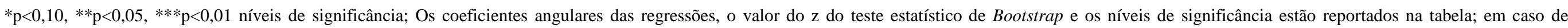

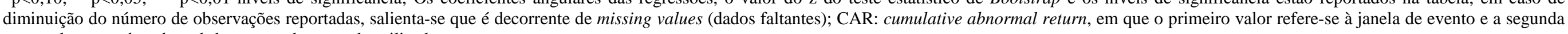
nomenclatura ao benchmark de retorno de mercado utilizado.

Fonte: Elaborado pelo autor. 


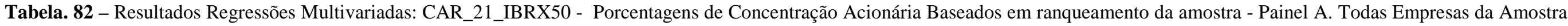
- Bootstrap

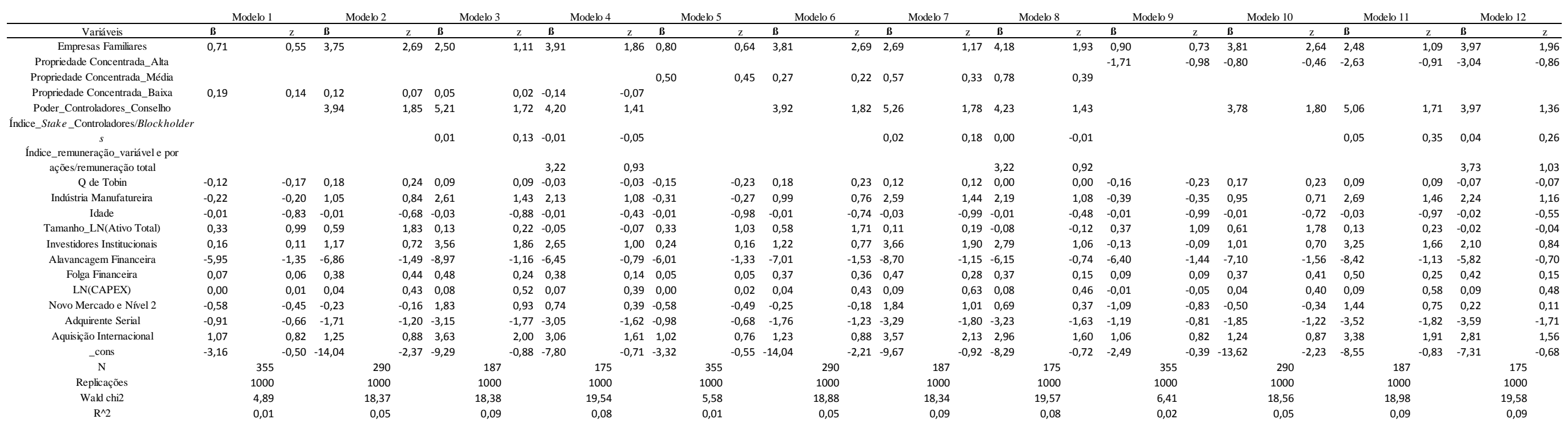

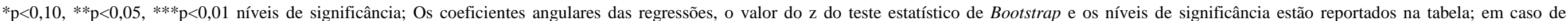

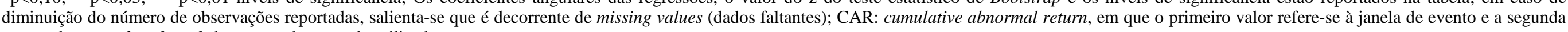
nomenclatura ao benchmark de retorno de mercado utilizado.

Fonte: Elaborado pelo autor. 


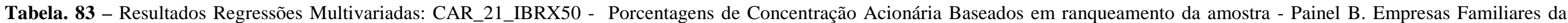
Amostra - Bootstrap

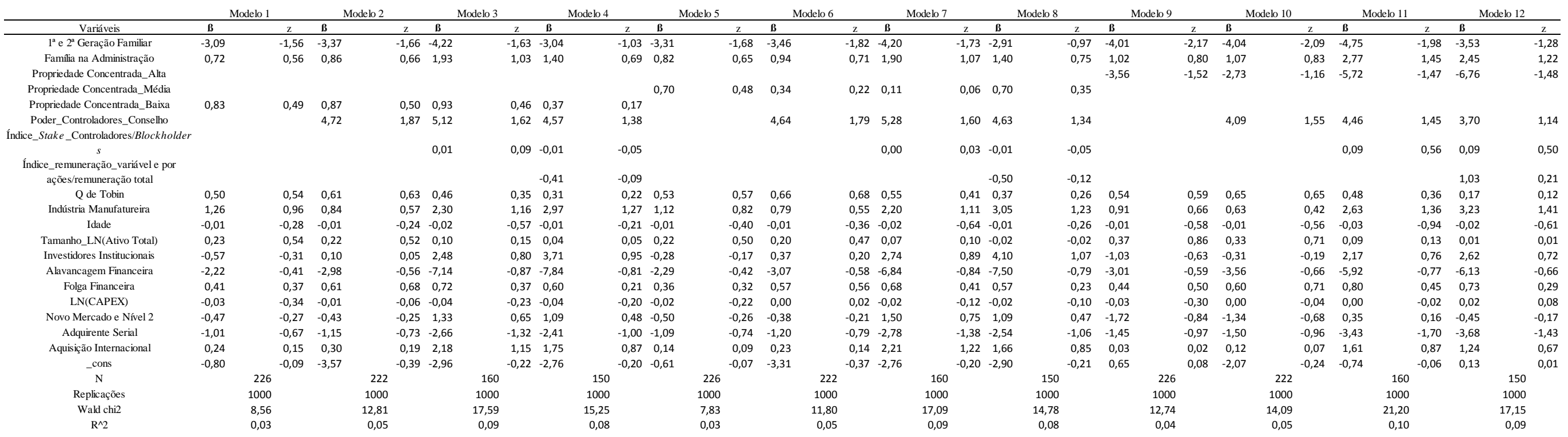

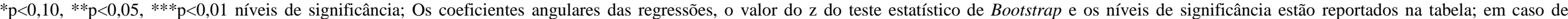

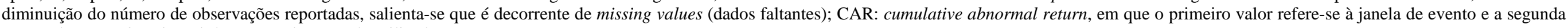
nomenclatura ao benchmark de retorno de mercado utilizado.

Fonte: Elaborado pelo autor 
Apêndice 2 - Resultados das Regressões Multivariadas obtidos com o método mínimos quadrados ordinários (MQO) com erros-padrão robustos utilizando o teste de robustez de Benchmark de retorno de mercado: IBRX50.

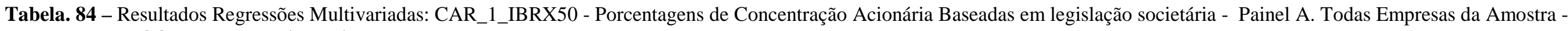
MQO com erros-padrão robustos

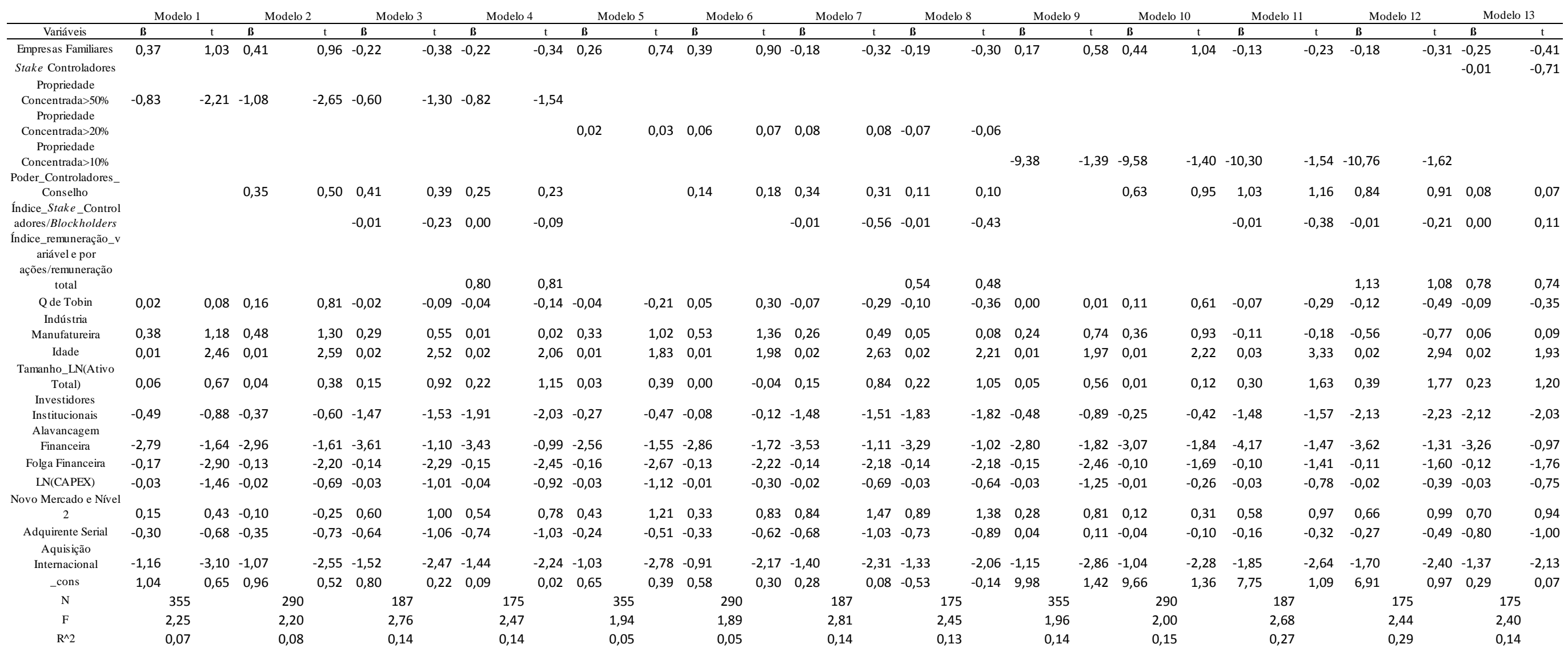

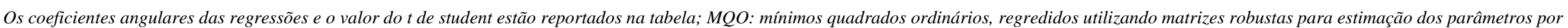

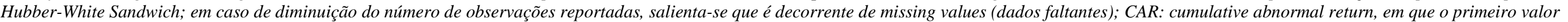
refere-se à janela de evento, e a segunda nomenclatura ao benchmark de retorno de mercado utilizado.

Fonte: Elaborado pelo autor. 


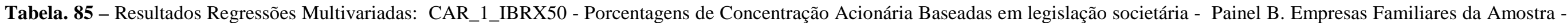
MQO com erros-padrão robustos

\begin{tabular}{|c|c|c|c|c|c|c|c|c|c|c|c|c|c|c|c|c|c|c|c|c|c|c|c|c|c|c|}
\hline & \multicolumn{2}{|c|}{ Modelo 1} & \multicolumn{2}{|c|}{ Modelo 2} & \multicolumn{2}{|c|}{ Modelo 3} & \multicolumn{2}{|c|}{ Modelo 4} & \multicolumn{2}{|c|}{ Modelo 5} & \multicolumn{2}{|c|}{ Modelo 6} & \multicolumn{2}{|c|}{ Modelo 7} & \multicolumn{2}{|c|}{ Modelo 8} & \multicolumn{2}{|c|}{ Modelo 9} & \multicolumn{2}{|c|}{ Modelo 10} & \multicolumn{2}{|c|}{ Modelo 11} & \multicolumn{2}{|c|}{ Modelo 12} & \multicolumn{2}{|c|}{ Modelo 13} \\
\hline Variáveis & $B$ & $\mathrm{t}$ & B & $\mathrm{t}$ & B & $\mathrm{t}$ & B & $\mathrm{t}$ & $B$ & $\mathrm{t}$ & $B$ & $\mathrm{t}$ & $B$ & $\mathrm{t}$ & B & $\mathrm{t}$ & B & $\mathrm{t}$ & $B$ & $\mathrm{t}$ & $B$ & $\mathrm{t}$ & B & $\mathrm{t}$ & B & $\mathrm{t}$ \\
\hline $1^{a} \mathrm{e} 2^{2^{a}}$ Geração Familiar & 0,84 & 1,41 & 0,93 & 1,47 & 0,51 & 0,78 & 0,17 & 0,24 & 0,90 & 1,50 & 1,01 & 1,59 & 0,60 & 0,90 & 0,39 & 0,53 & 0,85 & 1,38 & 0,94 & 1,44 & 0,37 & 0,52 & $-0,05$ & $-0,07$ & 0,21 & 0,27 \\
\hline $\begin{array}{c}\text { Familia na } \\
\text { Administraçã̃o }\end{array}$ & 0,14 & 0,32 & 0,15 & 0,35 & 0,58 & 0,80 & 0,68 & 0,86 & 0,38 & 0,91 & 0,41 & 0,97 & 0,63 & 0,97 & 0,67 & 0,95 & 0,37 & 0,89 & 0,43 & 1,01 & 0,63 & 1,03 & 0,74 & 1,11 & 0,65 & 0,85 \\
\hline $\begin{array}{l}\text { Stake Controladores } \\
\text { Propriedade }\end{array}$ & & & & & & & & & & & & & & & & & & & & & & & & & $-0,02$ & $-0,61$ \\
\hline $\begin{array}{l}\text { Concentrada }>50 \% \\
\text { Propriedade }\end{array}$ & $-0,85$ & $-1,66$ & $-0,95$ & $-1,93$ & $-0,67$ & $-1,19$ & $-1,02$ & $-1,16$ & & & & & & & & & & & & & & & & & & \\
\hline $\begin{array}{c}\text { Concentrada }>20 \% \\
\text { Propriedade }\end{array}$ & & & & & & & & & 0,25 & 0,26 & 0,19 & 0,20 & 0,06 & 0,06 & 0,01 & 0,01 & & & & & & & & & & \\
\hline Concentrada $>10 \%$ & & & & & & & & & & & & & & & & & $-9,45$ & $-1,40$ & $-9,66$ & $-1,41$ & $-10,31$ & $-1,55$ & $-10,63$ & $-1,59$ & & \\
\hline $\begin{array}{c}\text { Poder_Controladores_ } \\
\text { Conselho } \\
\text { Índice_Stake_Control }\end{array}$ & & & $-0,31$ & $-0,38$ & $-0,01$ & $-0,01$ & $-0,07$ & $-0,06$ & & & $-0,39$ & $-0,46$ & 0,05 & 0,04 & $-0,08$ & $-0,06$ & & & 0,33 & 0,41 & 0,82 & 0,85 & 0,81 & 0,80 & $-0,19$ & $-0,15$ \\
\hline $\begin{array}{l}\text { adores/Blockholders } \\
\text { Îndice_remuneraçẫo_v } \\
\text { ariáavel e por } \\
\text { acões/remuneracão }\end{array}$ & & & & & 0,00 & $-0,11$ & 0,00 & 0,03 & & & & & $-0,01$ & $-0,43$ & $-0,01$ & $-0,41$ & & & & & $-0,01$ & $-0,31$ & 0,00 & $-0,16$ & 0,01 & 0,19 \\
\hline total & & & & & & & 0,85 & 0,61 & & & & & & & 0,03 & 0,02 & & & & & & & 0,72 & 0,57 & 0,53 & 0,36 \\
\hline $\begin{array}{l}\text { Q de Tobin } \\
\text { Indústria }\end{array}$ & $-0,20$ & $-0,80$ & $-0,15$ & $-0,60$ & $-0,25$ & $-0,78$ & $-0,25$ & $-0,74$ & $-0,25$ & $-1,01$ & $-0,21$ & $-0,84$ & $-0,28$ & $-0,84$ & $-0,26$ & $-0,75$ & $-0,19$ & $-0,79$ & $-0,13$ & $-0,56$ & $-0,24$ & $-0,81$ & $-0,23$ & $-0,76$ & $-0,29$ & $-0,80$ \\
\hline Manufatureira & 0,25 & 0,51 & 0,43 & 0,85 & 0,92 & 1,29 & 0,67 & 0,77 & 0,31 & 0,61 & 0,51 & 0,98 & 0,96 & 1,29 & 0,92 & 1,08 & 0,12 & 0,23 & 0,23 & 0,44 & 0,38 & 0,54 & $-0,06$ & $-0,06$ & 0,79 & 0,94 \\
\hline $\begin{array}{c}\text { Idade } \\
\text { Tamanho LN(Ativo }\end{array}$ & 0,02 & 2,85 & 0,02 & 2,88 & 0,02 & 1,81 & 0,01 & 0,86 & 0,02 & 2,88 & 0,02 & 2,91 & 0,02 & 1,99 & 0,02 & 1,30 & 0,02 & 3,28 & 0,03 & 3,32 & 0,03 & 3,00 & 0,02 & 2,00 & 0,02 & 0,91 \\
\hline $\begin{array}{c}\text { Total) } \\
\text { Investidores }\end{array}$ & 0,11 & 0,95 & 0,11 & 0,93 & 0,16 & 0,88 & 0,19 & 0,92 & 0,08 & 0,61 & 0,09 & 0,63 & 0,17 & 0,83 & 0,20 & 0,88 & 0,11 & 0,97 & 0,12 & 0,96 & 0,32 & 1,62 & 0,37 & 1,59 & 0,21 & 1,02 \\
\hline $\begin{array}{l}\text { Institucionais } \\
\text { Alavancagem }\end{array}$ & $-0,39$ & $-0,62$ & $-0,39$ & $-0,57$ & $-0,75$ & $-0,67$ & $-1,40$ & $-1,20$ & $-0,08$ & $-0,13$ & $-0,06$ & $-0,08$ & $-0,64$ & $-0,56$ & $-0,83$ & $-0,68$ & $-0,38$ & $-0,63$ & $-0,23$ & $-0,35$ & $-0,76$ & $-0,69$ & $-1,49$ & $-1,23$ & $-1,42$ & $-1,00$ \\
\hline Financeira & $-3,22$ & $-1,49$ & $-2,99$ & $-1,36$ & $-4,45$ & $-1,21$ & $-4,31$ & $-1,13$ & $-3,06$ & $-1,52$ & $-2,84$ & $-1,38$ & $-4,40$ & $-1,23$ & $-4,49$ & $-1,20$ & $-3,22$ & $-1,73$ & $-3,13$ & $-1,59$ & $-4,83$ & $-1,61$ & $-4,34$ & $-1,46$ & $-4,19$ & $-1,19$ \\
\hline Folga Financeira & $-0,18$ & $-2,49$ & $-0,18$ & $-2,26$ & $-0,12$ & $-1,29$ & $-0,10$ & $-1,11$ & $-0,17$ & $-2,27$ & $-0,17$ & $-2,22$ & $-0,11$ & $-1,14$ & $-0,09$ & $-0,91$ & $-0,16$ & $-2,33$ & $-0,14$ & $-1,74$ & $-0,07$ & $-0,68$ & $-0,05$ & $-0,50$ & $-0,07$ & $-0,58$ \\
\hline LN(CAPEX) & 0,00 & $-0,09$ & $-0,01$ & $-0,32$ & $-0,03$ & $-0,84$ & $-0,04$ & $-0,92$ & 0,01 & 0,24 & 0,00 & 0,02 & $-0,02$ & $-0,59$ & $-0,04$ & $-0,76$ & 0,00 & 0,15 & 0,00 & 0,11 & $-0,03$ & $-0,69$ & $-0,02$ & $-0,52$ & $-0,04$ & $-0,81$ \\
\hline $\begin{array}{c}\text { Novo Mercado e Nível } \\
2\end{array}$ & 0,27 & 0,47 & 0,13 & 0,22 & 0,27 & 0,35 & 0,16 & 0,16 & 0,64 & 1,16 & 0,54 & 0,96 & 0,59 & 0,90 & 0,67 & 0,88 & 0,44 & 0,81 & 0,33 & 0,60 & 0,25 & 0,35 & 0,40 & 0,50 & 0,45 & 0,45 \\
\hline $\begin{array}{l}\text { Adquirente Serial } \\
\text { Aquisicão }\end{array}$ & $-0,56$ & $-1,02$ & $-0,47$ & $-0,82$ & $-0,64$ & $-0,84$ & $-0,97$ & $-0,92$ & $-0,54$ & $-0,84$ & $-0,46$ & $-0,69$ & $-0,69$ & $-0,83$ & $-0,78$ & $-0,73$ & $-0,18$ & $-0,41$ & $-0,09$ & $-0,19$ & 0,00 & $-0,01$ & $-0,24$ & $-0,36$ & $-0,91$ & $-0,82$ \\
\hline $\begin{array}{l}\text { Aquisçao } \\
\text { Internacional }\end{array}$ & $-1,12$ & $-2,32$ & $-1,14$ & $-2,38$ & $-1,55$ & $-2,37$ & $-1,41$ & $-1,97$ & $-1,02$ & $-2,11$ & $-1,03$ & $-2,14$ & $-1,41$ & $-2,16$ & $-1,36$ & $-1,91$ & $-1,20$ & $-2,29$ & $-1,20$ & $-2,29$ & $-1,94$ & $-2,56$ & $-1,74$ & $-2,26$ & $-1,39$ & $-1,94$ \\
\hline _cons & $-0,56$ & $-0,22$ & $-0,59$ & $-0,21$ & $-0,12$ & $-0,03$ & 0,61 & 0,12 & $-1,52$ & $-0,60$ & $-1,66$ & $-0,61$ & $-1,10$ & $-0,27$ & $-1,01$ & $-0,23$ & 7,63 & 1,04 & 7,23 & 0,98 & 6,60 & 0,87 & 6,86 & 0,90 & 0,28 & 0,05 \\
\hline $\mathrm{N}$ & & & & & & & & & & & & & & & & & & & & & & & & & & \\
\hline $\mathrm{F}$ & & & & & & & & & & & & & & & & & 1, & & 1, & & & & & & & \\
\hline $\mathrm{R}^{\wedge} 2$ & & & & & & & & & & & & & & & & & 0 & & 0 , & & & & & & & \\
\hline
\end{tabular}

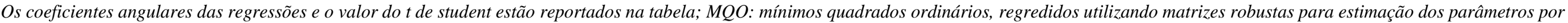

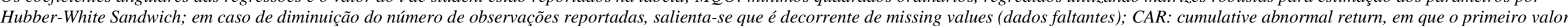
refere-se à janela de evento, e a segunda nomenclatura a benchmark de retorno de mercado utilizado.

Fonte: Elaborado pelo autor. 
Tabela. 86 - Resultados Regressões Multivariadas: CAR_1_IBRX50 - Porcentagens de Concentração Acionária Baseados em ranqueamento da amostra - Painel A. Todas Empresas da Amostra - MQO com erros-padrão robustos

\begin{tabular}{|c|c|c|c|c|c|c|c|c|c|c|c|c|c|c|c|c|c|c|c|c|c|c|c|c|}
\hline & \multicolumn{2}{|c|}{ Modelo 1} & \multicolumn{2}{|c|}{ Modelo 2} & \multicolumn{2}{|c|}{ Modelo 3} & \multicolumn{2}{|c|}{ Modelo 4} & \multicolumn{2}{|c|}{ Modelo 5} & \multicolumn{2}{|c|}{ Modelo 6} & \multicolumn{2}{|c|}{ Modelo 7} & \multicolumn{2}{|c|}{ Modelo 8} & \multicolumn{2}{|c|}{ Modelo 9} & \multicolumn{2}{|c|}{ Modelo 10} & \multicolumn{2}{|c|}{ Modelo 11} & \multicolumn{2}{|c|}{ Modelo 12} \\
\hline Variáveis & B & $\mathrm{t}$ & B & $\mathrm{t}$ & B & $\mathrm{t}$ & $B$ & $\mathrm{t}$ & B & $\mathrm{t}$ & $B$ & $\mathrm{t}$ & $B$ & $t$ & $B$ & $\mathrm{t}$ & 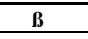 & $\mathrm{t}$ & B & $\mathrm{t}$ & $B$ & $\mathrm{t}$ & B & $\mathrm{t}$ \\
\hline Empresas Familiares & 0,25 & 0,76 & 0,39 & 0,90 & $-0,14$ & $-0,25$ & $-0,17$ & $-0,26$ & 0,30 & 0,89 & 0,46 & 1,06 & $-0,14$ & $-0,23$ & $-0,14$ & $-0,21$ & 0,36 & 0,99 & 0,45 & 1,04 & $-0,20$ & $-0,34$ & $-0,16$ & $-0,26$ \\
\hline $\begin{array}{l}\text { Stake Controladores } \\
\text { Propriedade }\end{array}$ & & & & & & & & & & & & & & & & & & & & & & & & \\
\hline $\begin{array}{l}\text { Concentrada_Alta } \\
\text { Propriedade }\end{array}$ & & & & & & & & & & & & & & & & & $-0,94$ & $-1,81$ & $-0,92$ & $-1,51$ & $-0,29$ & $-0,39$ & $-0,36$ & $-0,40$ \\
\hline $\begin{array}{l}\text { Concentrada_Média } \\
\text { Propriedade }\end{array}$ & & & & & & & & & 0,26 & 0,86 & 0,40 & 1,24 & 0,19 & 0,34 & 0,11 & 0,17 & & & & & & & & \\
\hline Concentrada_Baixa & 0,13 & 0,28 & $-0,01$ & $-0,01$ & $-0,16$ & $-0,23$ & $-0,03$ & $-0,04$ & & & & & & & & & & & & & & & & \\
\hline $\begin{array}{l}\text { Poder_Controladores_ } \\
\text { Conselho } \\
\text { Índice_Stake_Control }\end{array}$ & & & 0,13 & 0,18 & 0,35 & 0,32 & 0,11 & 0,10 & & & 0,08 & 0,11 & 0,35 & 0,32 & 0,11 & 0,10 & & & $-0,07$ & $-0,09$ & 0,31 & 0,30 & 0,08 & 0,08 \\
\hline $\begin{array}{c}\text { Índice_remuneração_v } \\
\text { ariável e por } \\
\text { acões/remuneracão }\end{array}$ & & & & & $-0,01$ & $-0,63$ & $-0,01$ & $-0,47$ & & & & & $-0,01$ & $-0,46$ & $-0,01$ & $-0,39$ & & & & & $-0,01$ & $-0,32$ & $-0,01$ & $-0,20$ \\
\hline total & & & & & & & 0,51 & 0,52 & & & & & & & 0,51 & 0,53 & & & & & & & 0,57 & 0,60 \\
\hline $\begin{array}{l}\text { Qde Tobin } \\
\text { Indústria }\end{array}$ & $-0,03$ & $-0,17$ & 0,06 & 0,29 & $-0,06$ & $-0,25$ & $-0,09$ & $-0,35$ & $-0,05$ & $-0,27$ & 0,05 & 0,29 & $-0,06$ & $-0,25$ & $-0,09$ & $-0,35$ & $-0,05$ & $-0,29$ & 0,05 & 0,25 & $-0,07$ & $-0,30$ & $-0,10$ & $-0,39$ \\
\hline Manufatureira & 0,34 & 1,08 & 0,54 & 1,46 & 0,26 & 0,50 & 0,05 & 0,08 & 0,30 & 0,96 & 0,47 & 1,29 & 0,26 & 0,50 & 0,06 & 0,09 & 0,25 & 0,76 & 0,43 & 1,15 & 0,28 & 0,53 & 0,06 & 0,10 \\
\hline Idade & 0,01 & 1,86 & 0,01 & 1,93 & 0,02 & 2,51 & 0,02 & 2,12 & 0,01 & 1,56 & 0,01 & 1,70 & 0,02 & 2,45 & 0,02 & 2,08 & 0,01 & 1,63 & 0,01 & 1,84 & 0,02 & 2,40 & 0,02 & 1,91 \\
\hline $\begin{array}{c}\text { Tamanho_LN(Ativo } \\
\text { Total) } \\
\text { Investidores }\end{array}$ & 0,04 & 0,45 & 0,00 & $-0,01$ & 0,15 & 0,93 & 0,22 & 1,10 & 0,04 & 0,44 & 0,00 & 0,00 & 0,15 & 0,93 & 0,21 & 1,10 & 0,06 & 0,69 & 0,03 & 0,32 & 0,16 & 0,98 & 0,22 & 1,18 \\
\hline $\begin{array}{l}\text { Institucionais } \\
\text { Alavancagem }\end{array}$ & $-0,30$ & $-0,54$ & $-0,08$ & $-0,13$ & $-1,44$ & $-1,45$ & $-1,80$ & $-1,76$ & $-0,25$ & $-0,44$ & $-0,06$ & $-0,10$ & $-1,46$ & $-1,49$ & $-1,79$ & $-1,81$ & $-0,45$ & $-0,83$ & $-0,31$ & $-0,51$ & $-1,52$ & $-1,52$ & $-1,88$ & $-1,86$ \\
\hline Financeira & $-2,57$ & $-1,51$ & $-2,84$ & $-1,58$ & $-3,48$ & $-1,02$ & $-3,30$ & $-0,93$ & $-2,60$ & $-1,56$ & $-3,02$ & $-1,66$ & $-3,43$ & $-1,00$ & $-3,27$ & $-0,91$ & $-2,81$ & $-1,62$ & $-3,09$ & $-1,61$ & $-3,46$ & $-1,06$ & $-3,23$ & $-0,96$ \\
\hline Folga Financeira & $-0,16$ & $-2,66$ & $-0,13$ & $-2,32$ & $-0,14$ & $-2,39$ & $-0,15$ & $-2,39$ & $-0,17$ & $-2,88$ & $-0,14$ & $-2,46$ & $-0,14$ & $-2,41$ & $-0,15$ & $-2,47$ & $-0,15$ & $-2,77$ & $-0,13$ & $-2,24$ & $-0,14$ & $-2,20$ & $-0,14$ & $-2,23$ \\
\hline LN(CAPEX) & $-0,03$ & $-1,14$ & $-0,01$ & $-0,31$ & $-0,02$ & $-0,65$ & $-0,03$ & $-0,62$ & $-0,03$ & $-1,10$ & $-0,01$ & $-0,26$ & $-0,02$ & $-0,64$ & $-0,03$ & $-0,57$ & $-0,03$ & $-1,28$ & $-0,01$ & $-0,50$ & $-0,02$ & $-0,74$ & $-0,03$ & $-0,59$ \\
\hline $\begin{array}{l}\text { Novo Mercado e Nível } \\
2\end{array}$ & 0,39 & 1.08 & 0,33 & 0,80 & 0,86 & 1.46 & 0,89 & 1,33 & 0.40 & 112 & 0.26 & 0,61 & 0,83 & 1,48 & 0,88 & 139 & 0,12 & 0,33 & $-0,01$ & $-0,02$ & 0,79 & 131 & 083 & 1,17 \\
\hline Adquirente Serial & $-0,25$ & $-0,56$ & $-0,34$ & $-0,71$ & $-0,71$ & $-1,20$ & $-0,73$ & $-1,04$ & $-0,28$ & $-0,66$ & $-0,41$ & $-0,87$ & $-0,74$ & $-1,27$ & $-0,75$ & $-1,12$ & $-0,40$ & $-0,84$ & $-0,49$ & $-0,93$ & $-0,73$ & $-1,10$ & $-0,79$ & $-0,98$ \\
\hline $\begin{array}{l}\text { Aquisição } \\
\text { Internacional }\end{array}$ & $-1,02$ & $-2,70$ & $-0,91$ & $-2,15$ & $-1,41$ & $-2,31$ & $-1,33$ & $-2,03$ & $-1,05$ & $-2,82$ & $-0,92$ & $-2,21$ & $-1,42$ & $-2,28$ & $-1,34$ & $-2,00$ & $-1,03$ & $-2,76$ & $-0,91$ & $-2,15$ & $-1,43$ & $-2,31$ & $-1,36$ & $-2,09$ \\
\hline _cons & 0,62 & 0,39 & 0,59 & 0,32 & 0,26 & 0,07 & $-0,49$ & $-0,13$ & 0,54 & 0,33 & 0,52 & 0,27 & 0,13 & 0,03 & $-0,56$ & $-0,14$ & 1,00 & 0,63 & 1,02 & 0,54 & 0,34 & 0,09 & $-0,44$ & $-0,11$ \\
\hline $\mathrm{N}$ & & & & & & & & & & & & & & & & & & & & & & & & \\
\hline $\mathrm{F}$ & & & & & & & & & & & & & & & & & & & & & & & & \\
\hline $\mathrm{R}^{\wedge} 2$ & & & & & & & & & & & & & & & & & & & & & & & & \\
\hline
\end{tabular}

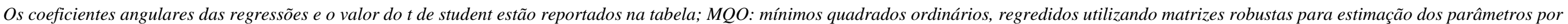

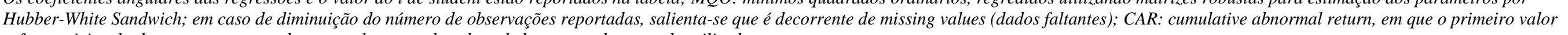
refere-se à janela de evento, e a segunda nomenclatura ao benchmark de retorno de mercado utilizado.

Fonte: Elaborado pelo autor 


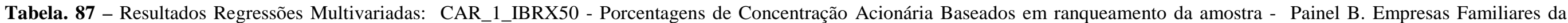
Amostra - MQO com erros-padrão robustos

\begin{tabular}{|c|c|c|c|c|c|c|c|c|c|c|c|c|c|c|c|c|c|c|c|c|c|c|c|c|}
\hline & \multicolumn{2}{|c|}{ Modelo 1} & \multicolumn{2}{|c|}{ Modelo 2} & \multicolumn{2}{|c|}{ Modelo 3} & \multicolumn{2}{|c|}{ Modelo 4} & \multicolumn{2}{|c|}{ Modelo 5} & \multicolumn{2}{|c|}{ Modelo 6} & \multicolumn{2}{|c|}{ Modelo 7} & \multicolumn{2}{|c|}{ Modelo 8} & \multicolumn{2}{|c|}{ Modelo 9} & \multicolumn{2}{|c|}{ Modelo 10} & \multicolumn{2}{|c|}{ Modelo 11} & \multicolumn{2}{|c|}{ Modelo 12} \\
\hline Variáveis & B & $\mathrm{t}$ & B & $t$ & B & $\mathrm{t}$ & B & $\mathrm{t}$ & B & $t$ & B & $\mathrm{t}$ & B & $\mathrm{t}$ & B & $\mathrm{t}$ & B & $\mathrm{t}$ & B & $\mathrm{t}$ & B & $\mathrm{t}$ & $B$ & $\mathrm{t}$ \\
\hline $1^{\mathrm{a}} \mathrm{e} 2^{\mathrm{a}}$ Geração Familiar & 0,89 & 1,45 & 1,00 & 1,57 & 0,59 & 0,88 & 0,36 & 0,48 & 0,82 & 1,33 & 0,94 & 1,48 & 0,59 & 0,88 & 0,40 & 0,54 & 0,70 & 1,16 & 0,82 & 1,30 & 0,50 & 0,74 & 0,30 & 0,40 \\
\hline $\begin{array}{l}\text { Família na } \\
\text { Administração } \\
\text { Propriedade }\end{array}$ & 0,35 & 0,78 & 0,38 & 0,86 & 0,63 & 0,83 & 0,68 & 0,81 & 0,37 & 0,84 & 0,41 & 0,91 & 0,63 & 0,88 & 0,67 & 0,86 & 0,41 & 0,88 & 0,44 & 0,92 & 0,77 & 0,92 & 0,85 & 0,89 \\
\hline $\begin{array}{l}\text { Concentrada_Alta } \\
\text { Propriedade }\end{array}$ & & & & & & & & & & & & & & & & & $-0,75$ & $-1,02$ & $-0,76$ & $-0,93$ & $-0,98$ & $-0,78$ & $-1,16$ & $-0,74$ \\
\hline $\begin{array}{l}\text { Concentrada_Média } \\
\text { Propriedade }\end{array}$ & & & & & & & & & 0,23 & 0,53 & 0,23 & 0,55 & 0,08 & 0,13 & 0,04 & 0,07 & & & & & & & & \\
\hline $\begin{array}{l}\text { Concentrada_Baixa } \\
\text { Poder_Controladores }\end{array}$ & 0,06 & 0,09 & 0,06 & 0,10 & 0,09 & 0,12 & 0,16 & 0,19 & & & & & & & & & & & & & & & & \\
\hline $\begin{array}{l}\text { Conselho } \\
\text { Índice_Stake Control }\end{array}$ & & & $-0,40$ & $-0,48$ & 0,02 & 0,02 & $-0,10$ & $-0,08$ & & & $-0,46$ & $-0,56$ & 0,04 & 0,04 & $-0,08$ & $-0,07$ & & & $-0,58$ & $-0,64$ & $-0,10$ & $-0,08$ & $-0,24$ & $-0,19$ \\
\hline $\begin{array}{c}\text { adores/Blockholders } \\
\text { Índice_remuneração_v } \\
\text { ariávele e por } \\
\text { acões/remuneracão }\end{array}$ & & & & & $-0,01$ & $-0,39$ & $-0,01$ & $-0,35$ & & & & & $-0,01$ & $-0,38$ & $-0,01$ & $-0,37$ & & & & & 0,00 & 0,15 & 0,01 & 0,23 \\
\hline total & & & & & & & 0,07 & 0,06 & & & & & & & 0,03 & 0,03 & & & & & & & 0,29 & 0,25 \\
\hline $\begin{array}{l}\text { Q de Tobin } \\
\text { Indústria }\end{array}$ & $-0,25$ & $-0,98$ & $-0,21$ & $-0,83$ & $-0,29$ & $-0,82$ & $-0,27$ & $-0,76$ & $-0,25$ & $-0,98$ & $-0,20$ & $-0,83$ & $-0,27$ & $-0,82$ & $-0,26$ & $-0,77$ & $-0,25$ & $-1,00$ & $-0,21$ & $-0,87$ & $-0,29$ & $-0,89$ & $-0,29$ & $-0,84$ \\
\hline Manufatureira & 0,34 & 0,70 & 0,53 & 1,06 & 0,97 & 1,34 & 0,91 & 1,07 & 0,31 & 0,63 & 0,51 & 1,03 & 0,96 & 1,34 & 0,92 & 1,08 & 0,27 & 0,55 & 0,47 & 0,95 & 1,03 & 1,41 & 0,96 & 1,12 \\
\hline Idade & 0,02 & 2,88 & 0,02 & 2,90 & 0,02 & 1,92 & 0,02 & 1,21 & 0,02 & 2,70 & 0,02 & 2,71 & 0,02 & 1,87 & 0,02 & 1,25 & 0,02 & 2,56 & 0,02 & 2,54 & 0,02 & 1,52 & 0,01 & 0,87 \\
\hline $\begin{array}{c}\text { Tamanho_LN(Ativo } \\
\text { Total) } \\
\text { Investidores }\end{array}$ & 0,09 & 0,80 & 0,10 & 0,80 & 0,18 & 0,96 & 0,21 & 1,00 & 0,10 & 0,83 & 0,10 & 0,84 & 0,17 & 0,93 & 0,20 & 0,97 & 0,13 & 1,02 & 0,13 & 1,02 & 0,17 & 0,98 & 0,20 & 1,01 \\
\hline Institucionais & $-0,13$ & $-0,21$ & $-0,11$ & $-0,15$ & $-0,67$ & $-0,58$ & $-0,91$ & $-0,72$ & $-0,10$ & $-0,15$ & $-0,07$ & $-0,11$ & $-0,64$ & $-0,55$ & $-0,82$ & $-0,67$ & $-0,26$ & $-0,43$ & $-0,27$ & $-0,41$ & $-0,75$ & $-0,63$ & $-1,05$ & $-0,84$ \\
\hline $\begin{array}{l}\text { Alavancagem } \\
\text { Financeira }\end{array}$ & $-3,02$ & $-1,40$ & $-2,79$ & $-1,28$ & $-4,42$ & $-1,16$ & $-4,51$ & $-1,12$ & $-3,05$ & $-1,45$ & $-2,85$ & $-1,32$ & $-4,36$ & $-1,14$ & $-4,47$ & $-1,09$ & $-3,19$ & $-1,45$ & $-2,95$ & $-1,31$ & $-4,23$ & $-1,19$ & $-4,20$ & $-1,13$ \\
\hline Folga Financeira & $-0,16$ & $-2,27$ & $-0,16$ & $-2,24$ & $-0,10$ & $-1,06$ & $-0,09$ & $-0,78$ & $-0,17$ & $-2,44$ & $-0,17$ & $-2,33$ & $-0,11$ & $-1,19$ & $-0,09$ & $-0,96$ & $-0,15$ & $-2,18$ & $-0,16$ & $-2,14$ & $-0,09$ & $-0,87$ & $-0,07$ & $-0,59$ \\
\hline LN(CAPEX) & 0,00 & 0,18 & 0,00 & $-0,03$ & $-0,03$ & $-0,63$ & $-0,04$ & $-0,79$ & 0,01 & 0,27 & 0,00 & 0,05 & $-0,02$ & $-0,56$ & $-0,04$ & $-0,72$ & 0,00 & 0,18 & 0,00 & $-0,06$ & $-0,02$ & $-0,56$ & $-0,03$ & $-0,61$ \\
\hline $\begin{array}{c}\text { Novo Mercado e Nível } \\
2\end{array}$ & 0,63 & 1,15 & 0,53 & 0,95 & 0,58 & 0,81 & 0,65 & 0,78 & 0,58 & 1,01 & 0,48 & 0,83 & 0,59 & 0,90 & 0,67 & 0,88 & 0,35 & 0,58 & 0,25 & 0,40 & 0,40 & 0,52 & 0,40 & 0,40 \\
\hline $\begin{array}{l}\text { Adquirente Serial } \\
\text { Aquisicão }\end{array}$ & $-0,58$ & $-1,04$ & $-0,48$ & $-0,83$ & $-0,68$ & $-0,91$ & $-0,78$ & $-0,82$ & $-0,60$ & $-1,13$ & $-0,51$ & $-0,91$ & $-0,71$ & $-0,96$ & $-0,79$ & $-0,88$ & $-0,67$ & $-1,14$ & $-0,58$ & $-0,93$ & $-0,81$ & $-0,92$ & $-1,00$ & $-0,86$ \\
\hline Internacional & $-1,01$ & $-2,06$ & $-1,02$ & $-2,10$ & $-1,42$ & $-2,15$ & $-1,36$ & $-1,84$ & $-1,04$ & $-2,12$ & $-1,05$ & $-2,16$ & $-1,42$ & $-2,11$ & $-1,37$ & $-1,83$ & $-1,05$ & $-2,17$ & $-1,07$ & $-2,22$ & $-1,52$ & $-2,22$ & $-1,45$ & $-1,99$ \\
\hline _cons & $-1,50$ & $-0,60$ & $-1,66$ & $-0,63$ & $-1,15$ & $-0,27$ & $-1,05$ & $-0,24$ & $-1,53$ & $-0,61$ & $-1,68$ & $-0,62$ & $-1,16$ & $-0,26$ & $-1,03$ & $-0,22$ & $-1,25$ & $-0,50$ & $-1,31$ & $-0,48$ & $-0,79$ & $-0,18$ & $-0,53$ & $-0,11$ \\
\hline $\mathrm{N}$ & & & & & & & & & & & & & & & & & & & & & & & & \\
\hline $\mathrm{F}$ & & & & & & & & & & & & & & & & & & & & & & & & \\
\hline $\mathrm{R}^{\wedge} 2$ & & & & & & & & & & & & & & & & & & & & & & & & \\
\hline
\end{tabular}

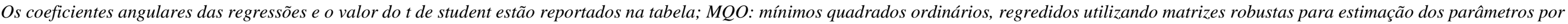

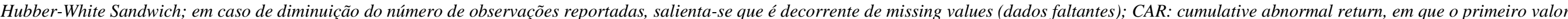
refere-se à janela de evento, e a segunda nomenclatura ao benchmark de retorno de mercado utilizado.

Fonte: Elaborado pelo autor. 
Tabela. 88 - Resultados Regressões Multivariadas: CAR_3_IBRX50 - Porcentagens de Concentração Acionária Baseadas em legislação societária - Painel A. Todas Empresas da Amostra MQO com erros-padrão robustos

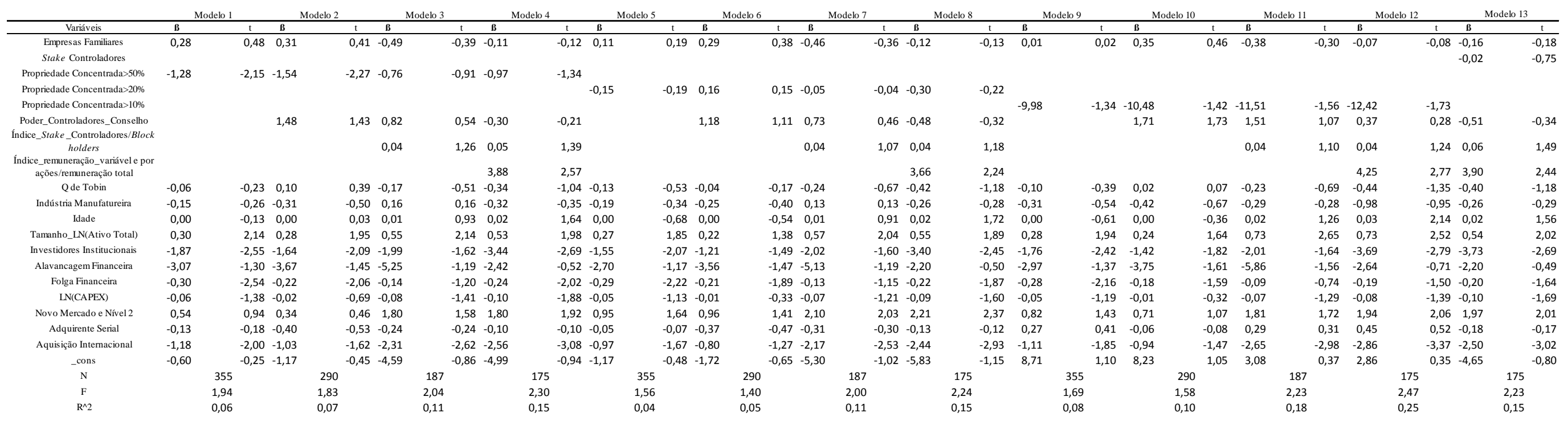

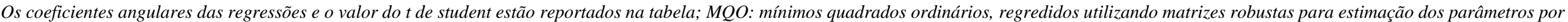

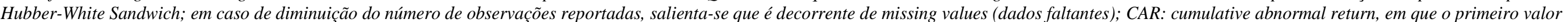
refere-se à janela de evento, e a segunda nomenclatura ao benchmark de retorno de mercado utilizado.

Fonte: Elaborado pelo autor. 


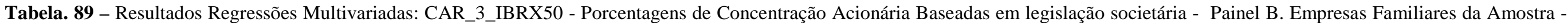
MQO com erros-padrão robustos

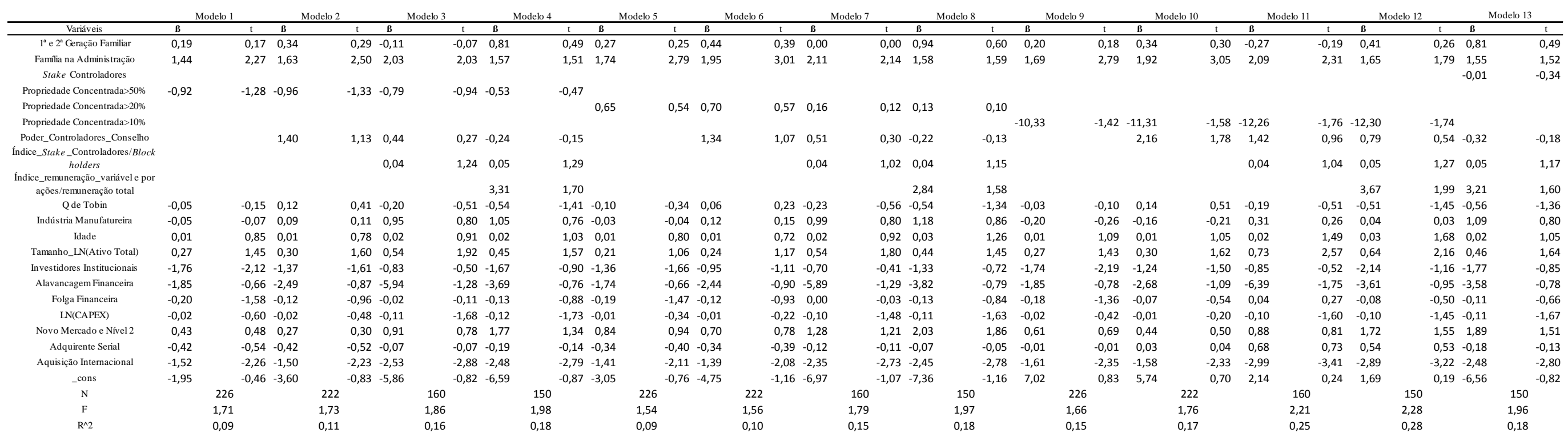

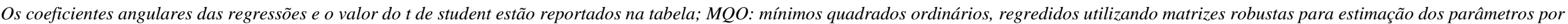

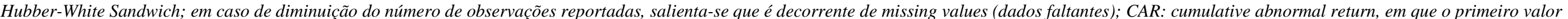
refere-se à janela de evento, e a segunda nomenclatura ao benchmark de retorno de mercado utilizado.

Fonte: Elaborado pelo autor. 
Tabela. 90 - Resultados Regressões Multivariadas: CAR_3_IBRX50 - Porcentagens de Concentração Acionária Baseados em ranqueamento da amostra - Painel A. Todas Empresas da Amostra - MQO com erros-padrão robustos

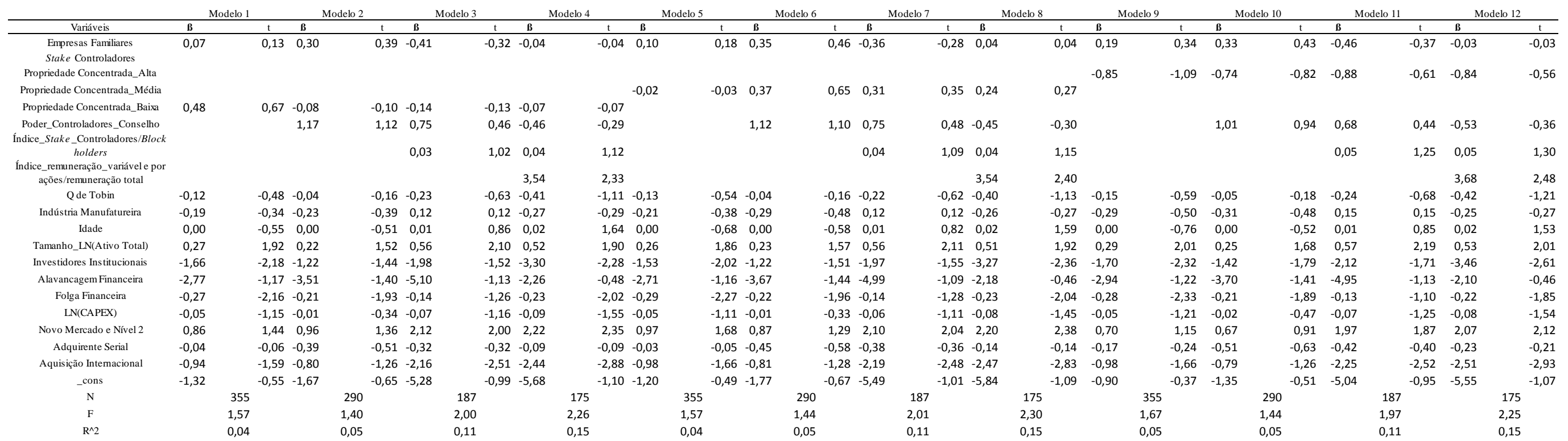

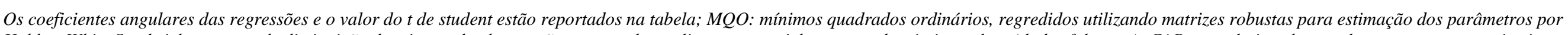

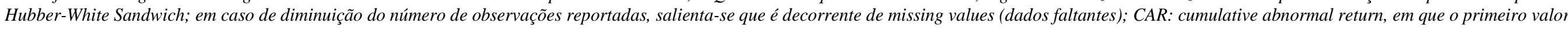
refere-se à janela de evento, e a segunda nomenclatura ao benchmark de retorno de mercado utilizado.

Fonte: Elaborado pelo autor. 
Tabela. 91 - Resultados Regressões Multivariadas: CAR_3_IBRX50 - Porcentagens de Concentração Acionária Baseadas em ranqueamento da amostra - Painel B. Empresas Familiares da Amostra - MQO com erros-padrão robustos

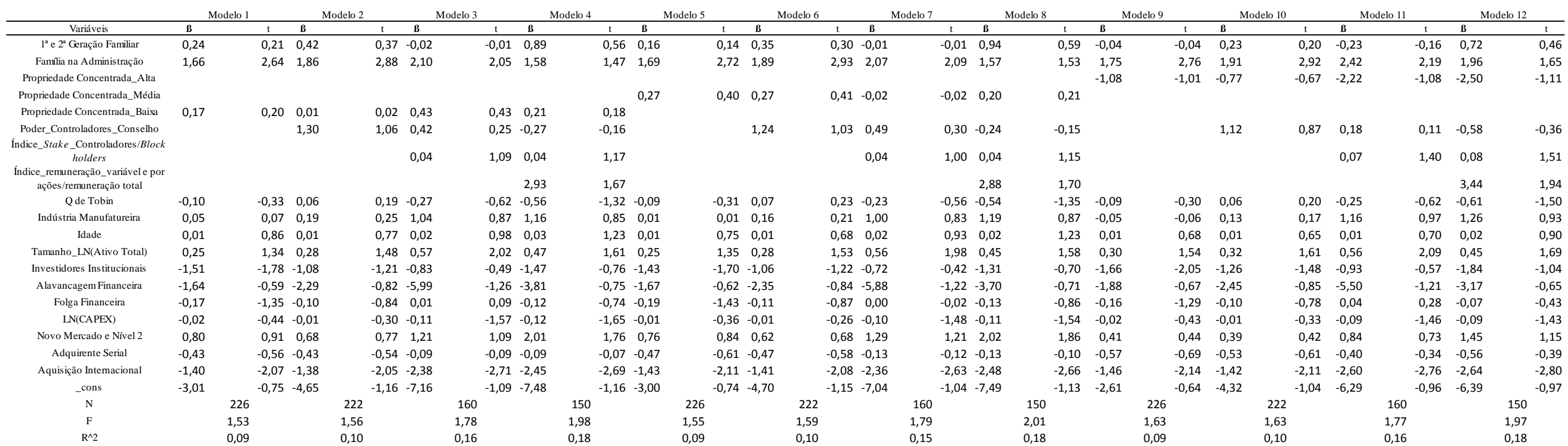

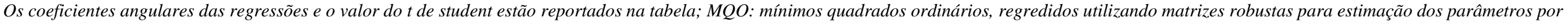

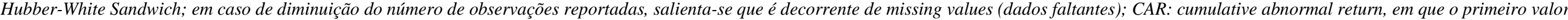

refere-se à janela de evento, e a segunda nomenclatura ao benchmark de retorno de mercado utilizado.

Fonte: Elaborado pelo autor. 
Tabela. 92 - Resultados Regressões Multivariadas: CAR_11_IBRX50 - Porcentagens de Concentração Acionária Baseadas em legislação societária - Painel A. Todas Empresas da Amostra MQO com erros-padrão robustos

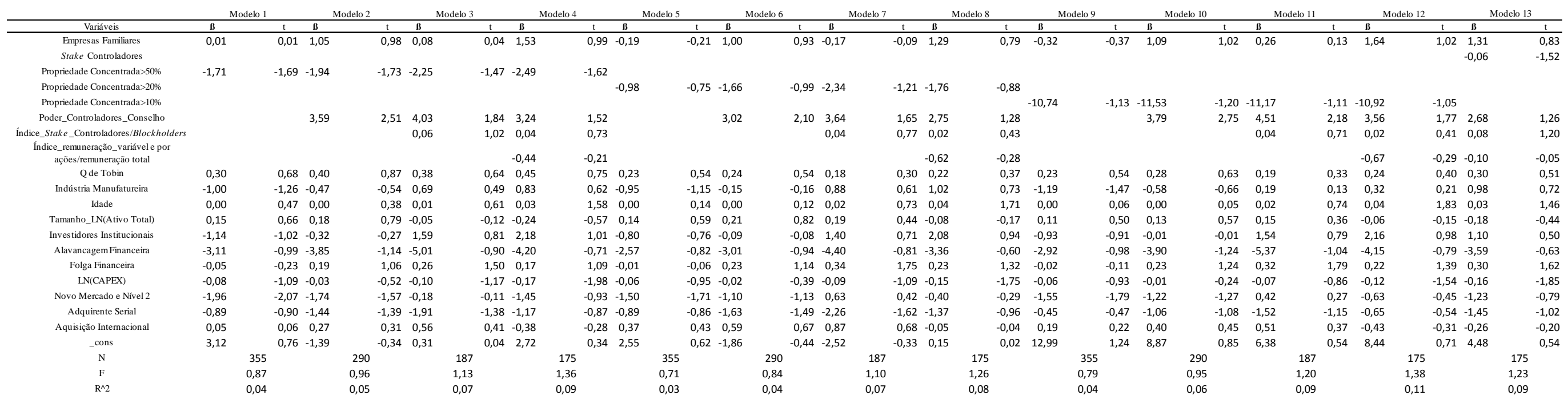

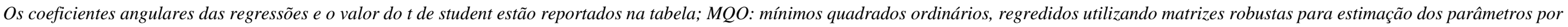

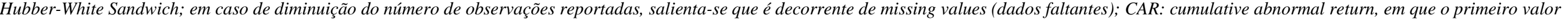

refere-se à janela de evento, e a segunda nomenclatura ao benchmark de retorno de mercado utilizado.

Fonte: Elaborado pelo autor. 


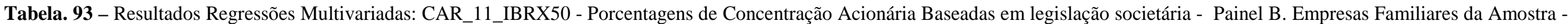
MQO com erros-padrão robustos

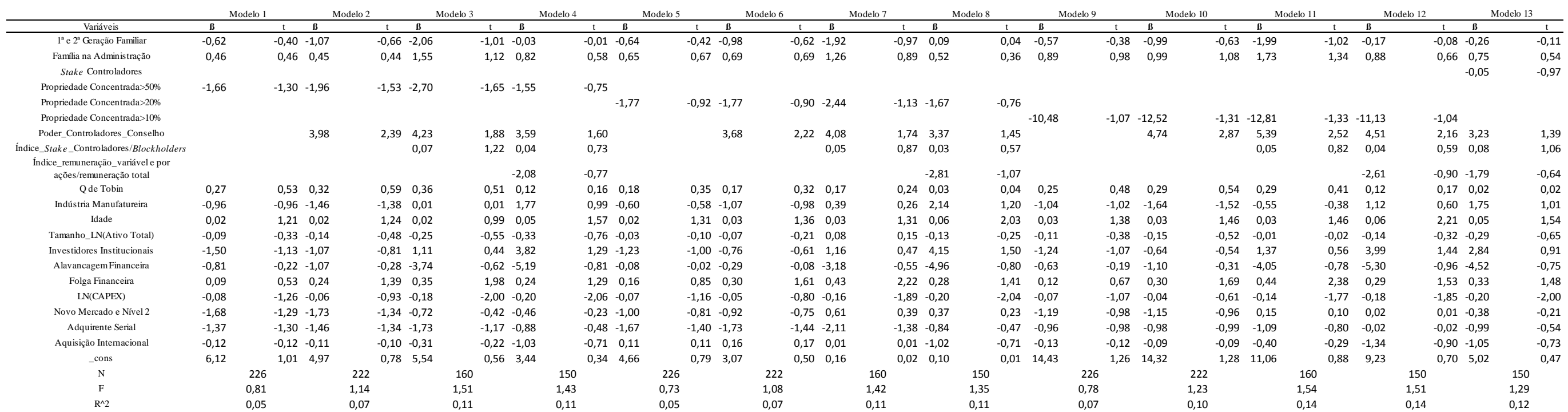

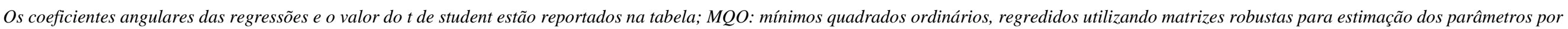

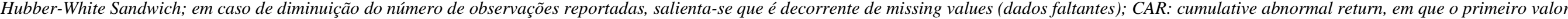

refere-se à janela de evento, e a segunda nomenclatura ao benchmark de retorno de mercado utilizado.

Fonte: Elaborado pelo autor. 


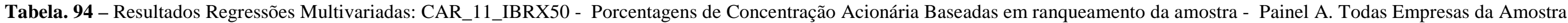
- MQO com erros-padrão robustos

\begin{tabular}{|c|c|c|c|c|c|c|c|c|c|c|c|c|c|c|c|c|c|c|c|c|c|c|c|c|}
\hline & \multicolumn{2}{|c|}{ Modelo 1} & \multicolumn{2}{|c|}{ Modelo 2} & \multicolumn{2}{|c|}{ Modelo 3} & \multicolumn{2}{|c|}{ Modelo 4} & \multicolumn{2}{|c|}{ Modelo 5} & \multicolumn{2}{|c|}{ Modelo 6} & \multicolumn{2}{|c|}{ Modelo 7} & \multicolumn{2}{|c|}{ Modelo 8} & \multicolumn{2}{|c|}{ Modelo 9} & \multicolumn{2}{|c|}{ Modelo 10} & \multicolumn{2}{|c|}{ Modelo 11} & \multicolumn{2}{|c|}{ Modelo 12} \\
\hline Variáveis & $B$ & $\mathrm{t}$ & B & $\mathrm{t}$ & B & $\mathrm{t}$ & $B$ & $\mathrm{t}$ & $B$ & $\mathrm{t}$ & $B$ & $\mathrm{t}$ & $B$ & $\mathrm{t}$ & $B$ & $\mathrm{t}$ & $B$ & $\mathrm{t}$ & $B$ & . & & $\mathrm{t}$ & $B$ & $\mathrm{t}$ \\
\hline $\begin{array}{l}\text { Empresas Familiares } \\
\text { Stake Controladores }\end{array}$ & $-0,30$ & $-0,34$ & 0,83 & 0,78 & $-0,50$ & $-0,25$ & 1,00 & 0,58 & $-0,25$ & $-0,28$ & 0,91 & 0,84 & $-0,18$ & $-0,09$ & 1,20 & 0,68 & $-0,04$ & $-0,04$ & 1,08 & 1,01 & 0,16 & 0,09 & 1,70 & 1,06 \\
\hline Propriedade Concentrada_Alta & & & & & & & & & & & & & & & & & $-1,80$ & $-1,56$ & $-0,96$ & $-0,76$ & $-2,16$ & $-1,08$ & $-1,54$ & $-0,75$ \\
\hline Propriedade Concentrada_Média & & & & & & & & & $-0,14$ & $-0,17$ & $-0,60$ & $-0,67$ & $-1,20$ & $-0,87$ & $-1,08$ & $-0,76$ & & & & & & & & \\
\hline Propriedade Concentrada_Baixa & 1,18 & 1,08 & 1,58 & 1,25 & 2,17 & 1,41 & 1,72 & 1,10 & & & & & & & & & & & & & & & & \\
\hline Poder_Controladores_Conselho & & & 3,06 & 2,18 & 3,47 & 1,57 & 2,60 & 1,22 & & & 3,27 & 2,32 & 3,67 & 1,66 & 2,76 & 1,29 & & & 2,99 & 2,05 & 3,62 & 1,68 & 2,71 & 1,29 \\
\hline Índice_Stake_Controladores/Blockholders & & & & & 0,05 & 0,97 & 0,03 & 0,62 & & & & & 0,03 & 0,51 & 0,01 & 0,22 & & & & & 0,07 & 1,14 & 0,04 & 0,73 \\
\hline $\begin{array}{l}\text { Índice_remuneraçăo_varíável e por } \\
\text { açōes/remuneração total }\end{array}$ & & & & & & & $-0,97$ & $-0,43$ & & & & & & & $-1,26$ & $-0,56$ & & & & & & & $-1,05$ & $-0,46$ \\
\hline Q de Tobin & 0,23 & 0,54 & 0,21 & 0,48 & 0,09 & 0,15 & 0,17 & 0,28 & 0,20 & 0,45 & 0,22 & 0,50 & 0,13 & 0,23 & 0,21 & 0,36 & 0,16 & 0,35 & 0,21 & 0,46 & 0,18 & 0,31 & 0,25 & 0,41 \\
\hline Indústria Manufatureira & $-1,03$ & $-1,29$ & $-0,27$ & $-0,31$ & 0,72 & 0,52 & 0,86 & 0,63 & $-1,07$ & $-1,31$ & $-0,26$ & $-0,30$ & 0,63 & 0,45 & 0,85 & 0,62 & $-1,26$ & $-1,51$ & $-0,47$ & $-0,52$ & 0,66 & 0,47 & 1,00 & 0,73 \\
\hline Idade & 0,00 & 0,24 & 0,00 & 0,18 & 0,02 & 0,68 & 0,04 & 1,66 & 0,00 & 0,03 & 0,00 & 0,04 & 0,01 & 0,61 & 0,04 & 1,65 & 0,00 & $-0,09$ & 0,00 & $-0,08$ & 0,01 & 0,45 & 0,03 & 1,44 \\
\hline Tamanho_LN(Ativo Total) & 0,12 & 0,54 & 0,17 & 0,72 & 0,07 & 0,17 & $-0,15$ & $-0,35$ & 0,10 & 0,43 & 0,12 & 0,51 & 0,03 & 0,07 & $-0,19$ & $-0,45$ & 0,15 & 0,65 & 0,15 & 0,63 & $-0,01$ & $-0,02$ & $-0,24$ & $-0,58$ \\
\hline Investidores Institucionais & $-1,00$ & $-0,92$ & $-0,29$ & $-0,25$ & 0,91 & 0,45 & 1,76 & 0,79 & $-0,69$ & $-0,66$ & 0,15 & 0,14 & 1,33 & 0,66 & 2,20 & 0,98 & $-1,04$ & $-1,02$ & $-0,05$ & $-0,04$ & 1,26 & 0,65 & 2,23 & 1,03 \\
\hline Alavancagem Financeira & $-2,77$ & $-0,88$ & $-3,32$ & $-1,01$ & $-5,22$ & $-0,92$ & $-4,16$ & $-0,70$ & $-2,61$ & $-0,83$ & $-3,34$ & $-1,00$ & $-5,22$ & $-0,90$ & $-4,27$ & $-0,70$ & $-3,13$ & $-0,98$ & $-3,89$ & $-1,13$ & $-4,22$ & $-0,76$ & $-3,50$ & $-0,60$ \\
\hline Folga Financeira & 0,01 & 0,03 & 0,25 & 1,26 & 0,35 & 1,84 & 0,24 & 1,39 & $-0,03$ & $-0,15$ & 0,22 & 1,10 & 0,30 & 1,64 & 0,21 & 1,24 & $-0,01$ & $-0,05$ & 0,20 & 1,06 & 0,29 & 1,61 & 0,21 & 1,28 \\
\hline LN(CAPEX) & $-0,06$ & $-0,93$ & $-0,03$ & $-0,47$ & $-0,10$ & $-1,20$ & $-0,16$ & $-1,85$ & $-0,06$ & $-0,87$ & $-0,02$ & $-0,30$ & $-0,09$ & $-1,01$ & $-0,16$ & $-1,77$ & $-0,07$ & $-1,02$ & $-0,02$ & $-0,35$ & $-0,06$ & $-0,82$ & $-0,13$ & $-1,53$ \\
\hline Novo Mercado e Nível 2 & $-1,66$ & $-1,85$ & $-1,26$ & $-1,25$ & 0,38 & 0,24 & $-0,61$ & $-0,43$ & $-1,37$ & $-1,57$ & $-0,86$ & $-0,88$ & 0,70 & 0,47 & $-0,35$ & $-0,25$ & $-1,97$ & $-2,16$ & $-1,32$ & $-1,28$ & 0,37 & 0,24 & $-0,65$ & $-0,44$ \\
\hline Adquirente Serial & $-0,79$ & $-0,79$ & $-1,41$ & $-1,37$ & $-1,88$ & $-1,39$ & $-1,01$ & $-0,77$ & $-0,75$ & $-0,75$ & $-1,31$ & $-1,27$ & $-1,81$ & $-1,32$ & $-0,86$ & $-0,65$ & $-1,07$ & $-1,01$ & $-1,58$ & $-1,43$ & $-2,39$ & $-1,63$ & $-1,39$ & $-0,95$ \\
\hline Aquisição Internacional & 0,42 & 0,48 & 0,62 & 0,70 & 0,97 & 0,74 & 0,03 & 0,02 & 0,34 & 0,39 & 0,59 & 0,67 & 1,09 & 0,82 & 0,09 & 0,07 & 0,32 & 0,38 & 0,56 & 0,65 & 0,78 & 0,59 & $-0,18$ & $-0,14$ \\
\hline cons & 2,05 & 0,49 & $-2,62$ & $-0,63$ & $-1,86$ & $-0,24$ & 0,50 & 0,07 & 2,37 & 0,57 & $-1,96$ & $-0,47$ & $-0,95$ & $-0,12$ & 1,56 & 0,19 & 2,97 & 0,74 & $-1,60$ & $-0,39$ & $-1,14$ & $-0,15$ & 1,19 & 0,16 \\
\hline $\mathrm{N}$ & & & & 290 & & 187 & & 175 & & 355 & & 290 & & 187 & & 175 & & & & 290 & & 187 & & 175 \\
\hline $\mathrm{F}$ & & & & 0,84 & & 1,11 & & 1,25 & & 0,70 & & 0,82 & & 1,17 & & 1,28 & & & & 0,84 & & 1,16 & & 1,36 \\
\hline $\mathrm{R}^{\wedge} 2$ & & & & 0,04 & & 0,07 & & 0,08 & & 0,02 & & 0,04 & & 0,06 & & 0,08 & & & & 0,04 & & 0,06 & & 0,08 \\
\hline
\end{tabular}

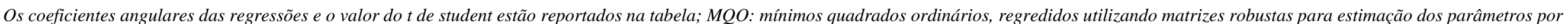

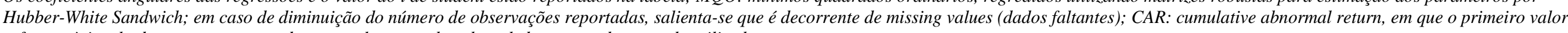
refere-se à janela de evento, e a segunda nomenclatura ao benchmark de retorno de mercado utilizado.

Fonte: Elaborado pelo autor. 


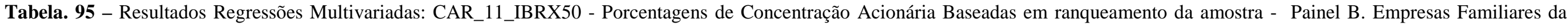
Amostra - MQO com erros-padrão robustos

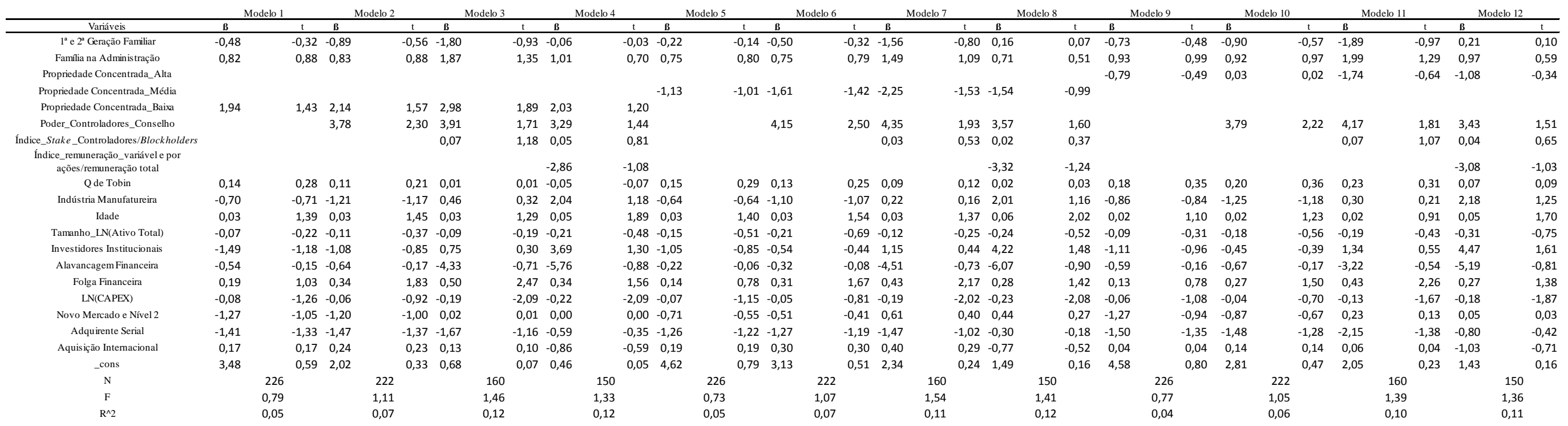

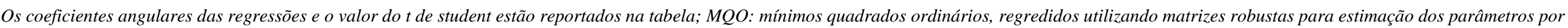

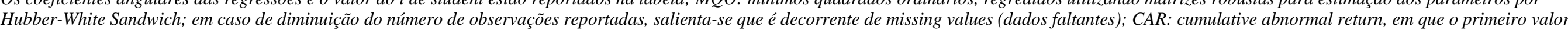
refere-se à janela de evento, e a segunda nomenclatura ao benchmark de retorno de mercado utilizado.

Fonte: Elaborado pelo autor. 
Tabela. 96 - Resultados Regressões Multivariadas: CAR_21_IBRX50 - Porcentagens de Concentração Acionária Baseadas em legislação societária - Painel A. Todas Empresas da Amostra MQO com erros-padrão robustos

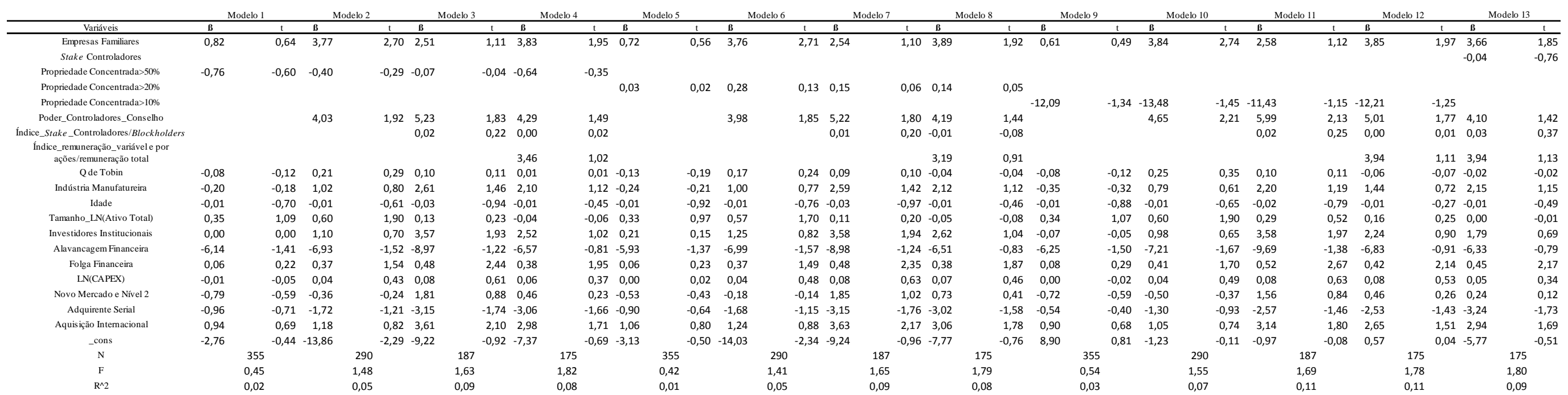

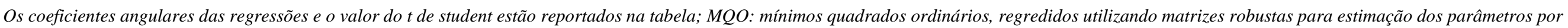

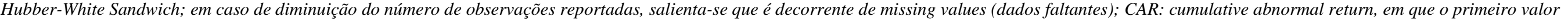
refere-se à janela de evento, e a segunda nomenclatura ao benchmark de retorno de mercado utilizado.

Fonte: Elaborado pelo autor. 


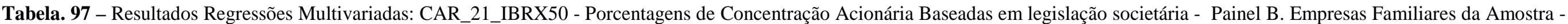
MQO com erros-padrão robustos

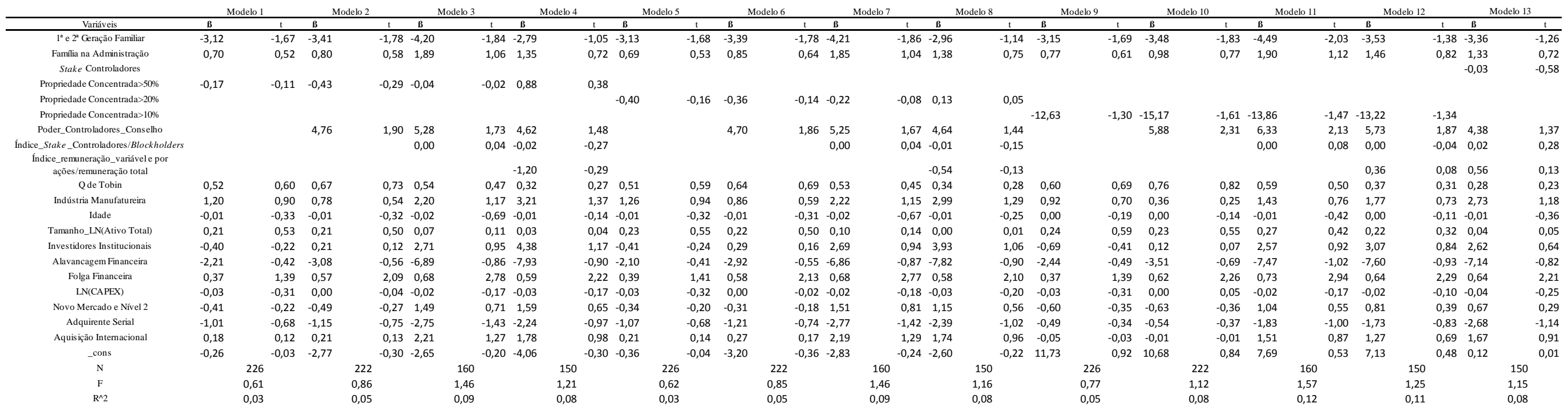

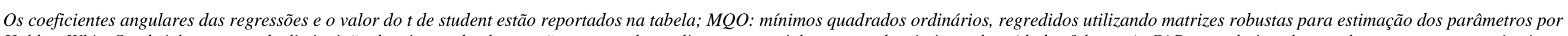

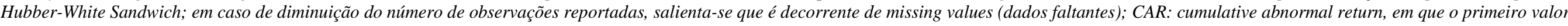

refere-se à janela de evento, e a segunda nomenclatura ao benchmark de retorno de mercado utilizado.

Fonte: Elaborado pelo autor. 


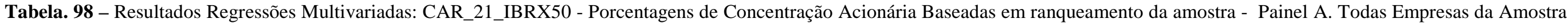
- MQO com erros-padrão robustos

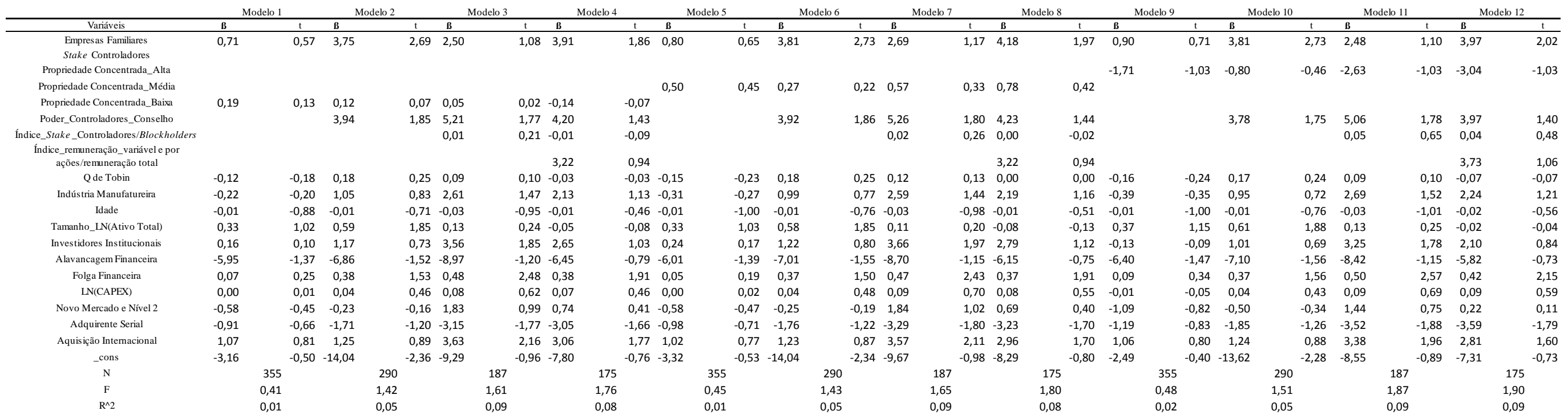

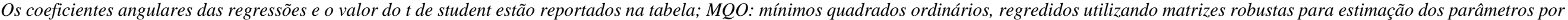

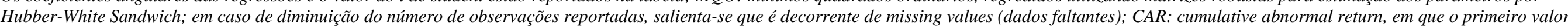
refere-se à janela de evento, e a segunda nomenclatura ao benchmark de retorno de mercado utilizado.

Fonte: Elaborado pelo autor. 


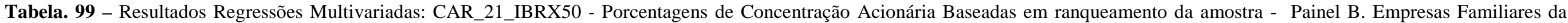
Amostra - MQO com erros-padrão robustos

\begin{tabular}{|c|c|c|c|c|c|c|c|c|c|c|c|c|c|c|c|c|c|c|c|c|c|c|c|c|}
\hline & \multicolumn{2}{|c|}{ Modelo 1} & \multicolumn{2}{|c|}{ Modelo 2} & \multicolumn{2}{|c|}{ Modelo 3} & \multicolumn{2}{|c|}{ Modelo 4} & \multicolumn{2}{|c|}{ Modelo 5} & \multicolumn{2}{|c|}{ Modelo 6} & \multicolumn{2}{|c|}{ Modelo 7} & \multicolumn{2}{|c|}{ Modelo 8} & \multicolumn{2}{|c|}{ Modelo 9} & \multicolumn{2}{|c|}{ Modelo 10} & \multicolumn{2}{|c|}{ Modelo 11} & \multicolumn{2}{|c|}{ Modelo 12} \\
\hline Variáveis & B & $\mathrm{t}$ & $B$ & $\mathrm{t}$ & B & $\mathrm{t}$ & 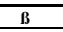 & $t$ & $B$ & $\mathrm{t}$ & $B$ & $\mathrm{t}$ & $B$ & $\mathrm{t}$ & $B$ & 100170 & $B$ & $\mathrm{t}$ & B & $\mathrm{t}$ & & $\mathrm{t}$ & & $t$ \\
\hline $1^{\mathrm{a}}$ e $2^{\mathrm{a}}$ Geração Familiar & $-3,09$ & $-1,66$ & $-3,37$ & $-1,76$ & $-4,22$ & $-1,87$ & $-3,04$ & $-1,15$ & $-3,31$ & $-1,79$ & $-3,46$ & $-1,82$ & $-4,20$ & $-1,87$ & $-2,91$ & $-1,11$ & $-4,01$ & $-2,20$ & $-4,04$ & $-2,16$ & $-4,75$ & $-2,24$ & $-3,53$ & $-1,45$ \\
\hline Familia na Administração & 0,72 & 0,56 & 0,86 & 0,67 & 1,93 & 1,07 & 1,40 & 0,73 & 0,82 & 0,64 & 0,94 & 0,73 & 1,90 & 1,08 & 1,40 & 0,76 & 1,02 & 0,81 & 1,07 & 0,84 & 2,77 & 1,47 & 2,45 & 1,22 \\
\hline Propriedade Concentrada_Alta & & & & & & & & & & & & & & & & & $-3,56$ & $-1,58$ & $-2,73$ & $-1,17$ & $-5,72$ & $-1,75$ & $-6,76$ & $-1,74$ \\
\hline Propriedade Concentrada_Média & & & & & & & & & 0,70 & 0,47 & 0,34 & 0,22 & 0,11 & 0,06 & 0,70 & 0,35 & & & & & & & & \\
\hline Propriedade Concentrada_Baixa & 0,83 & 0,48 & 0,87 & 0,50 & 0,93 & 0,46 & 0,37 & 0,17 & & & & & & & & & & & & & & & & \\
\hline Poder_Controladores_Conselho & & & 4,72 & 1,88 & 5,12 & 1,65 & 4,57 & 1,43 & & & 4,64 & 1,84 & 5,28 & 1,73 & 4,63 & 1,48 & & & 4,09 & 1,57 & 4,46 & 1,49 & 3,70 & 1,22 \\
\hline Índice_Stake_Controladores/Blockholders & & & & & 0,01 & 0,16 & $-0,01$ & $-0,09$ & & & & & 0,00 & 0,05 & $-0,01$ & $-0,10$ & & & & & 0,09 & 1,10 & 0,09 & 1,02 \\
\hline 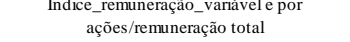 & & & & & & & $-0,41$ & $-0,10$ & & & & & & & $-0,50$ & $-0,12$ & & & & & & & 1,03 & 0,23 \\
\hline Qde Tobin & 0,50 & 0,57 & 0,61 & 0,66 & 0,46 & 0,38 & 0,31 & 0,25 & 0,53 & 0,61 & 0,66 & 0,71 & 0,55 & 0,46 & 0,37 & 0,30 & 0,54 & 0,62 & 0,65 & 0,70 & 0,48 & 0,41 & 0,17 & 0,14 \\
\hline Indústria Manufatureira & 1,26 & 0,97 & 0,84 & 0,60 & 2,30 & 1,22 & 2,97 & 1,29 & 1,12 & 0,85 & 0,79 & 0,56 & 2,20 & 1,17 & 3,05 & 1,32 & 0,91 & 0,68 & 0,63 & 0,43 & 2,63 & 1,44 & 3,23 & 1,45 \\
\hline Idade & $-0,01$ & $-0,28$ & $-0,01$ & $-0,25$ & $-0,02$ & $-0,64$ & $-0,01$ & $-0,24$ & $-0,01$ & $-0,43$ & $-0,01$ & $-0,37$ & $-0,02$ & $-0,69$ & $-0,01$ & $-0,28$ & $-0,01$ & $-0,60$ & $-0,01$ & $-0,53$ & $-0,03$ & $-1,02$ & $-0,02$ & $-0,65$ \\
\hline Tamanho_LN(Ativo Total) & 0,23 & 0,58 & 0,22 & 0,54 & 0,10 & 0,17 & 0,04 & 0,05 & 0,22 & 0,54 & 0,20 & 0,48 & 0,07 & 0,11 & $-0,02$ & $-0,03$ & 0,37 & 0,88 & 0,33 & 0,74 & 0,09 & 0,14 & 0,01 & 0,01 \\
\hline Investidores Institucionais & $-0,57$ & $-0,32$ & 0,10 & 0,05 & 2,48 & 0,86 & 3,71 & 0,98 & $-0,28$ & $-0,16$ & 0,37 & 0,21 & 2,74 & 0,95 & 4,10 & 1,11 & $-1,03$ & $-0,64$ & $-0,31$ & $-0,19$ & 2,17 & 0,83 & 2,62 & 0,74 \\
\hline Alavancagem Financeira & $-2,22$ & $-0,42$ & $-2,98$ & $-0,55$ & $-7,14$ & $-0,88$ & $-7,84$ & $-0,87$ & $-2,29$ & $-0,44$ & $-3,07$ & $-0,57$ & $-6,84$ & $-0,84$ & $-7,50$ & $-0,82$ & $-3,01$ & $-0,58$ & $-3,56$ & $-0,66$ & $-5,92$ & $-0,76$ & $-6,13$ & $-0,69$ \\
\hline Folga Financeira & 0,41 & 1,50 & 0,61 & 2,24 & 0,72 & 2,86 & 0,60 & 2,06 & 0,36 & 1,36 & 0,57 & 2,10 & 0,68 & 2,77 & 0,57 & 2,04 & 0,44 & 1,69 & 0,60 & 2,23 & 0,80 & 3,31 & 0,73 & 2,67 \\
\hline LN(CAPEX) & $-0,03$ & $-0,37$ & $-0,01$ & $\begin{array}{l}-0,07 \\
-0,17\end{array}$ & $-0,04$ & $-0,27$ & $-0,04$ & $-0,24$ & $-0,02$ & $-0,24$ & 0,00 & 0,02 & $-0,02$ & $-0,14$ & $-0,02$ & $-0,11$ & $-0,03$ & $-0,32$ & 0,00 & $-0,04$ & 0,00 & $-0,02$ & 0,02 & 0,10 \\
\hline Novo Mercado e Nível 2 & $-0,47$ & $-0,27$ & $-0,43$ & $-0,25$ & 1,33 & 0,70 & 1,09 & 0,52 & $-0,50$ & $-0,27$ & $-0,38$ & $-0,21$ & 1,50 & 0,81 & 1,09 & 0,53 & $-1,72$ & $-0,88$ & $-1,34$ & $-0,71$ & 0,35 & 0,16 & $-0,45$ & $-0,18$ \\
\hline Adquirente Serial & $-1,01$ & $-0,69$ & $-1,15$ & $-0,75$ & $-2,66$ & $-1,40$ & $-2,41$ & $-1,06$ & $-1,09$ & $-0,75$ & $-1,20$ & $-0,79$ & $-2,78$ & $-1,45$ & $-2,54$ & $-1,12$ & $-1,45$ & $-0,98$ & $-1,50$ & $-0,97$ & $-3,43$ & $-1,79$ & $-3,68$ & $-1,50$ \\
\hline Aquisição Intermacional & 0,24 & 0,16 & 0,30 & 0,19 & 2,18 & 1,27 & 1,75 & 0,96 & 0,14 & 0,09 & 0,23 & 0,14 & 2,21 & 1,29 & 1,66 & 0,90 & 0,03 & 0,02 & 0,12 & 0,07 & 1,61 & 0,92 & 1,24 & 0,67 \\
\hline _cons & $-0,80$ & $-0,10$ & $-3,57$ & $-0,41$ & $-2,96$ & $-0,24$ & $-2,76$ & $-0,23$ & $-0,61$ & $-0,07$ & $-3,31$ & $-0,38$ & $-2,76$ & $-0,22$ & $-2,90$ & $-0,24$ & 0,65 & 0,08 & $-2,07$ & $-0,24$ & $-0,74$ & $-0,06$ & 0,13 & 0,01 \\
\hline $\mathrm{N}$ & & & & 222 & & 160 & & 150 & & 226 & & 222 & & 160 & & 150 & & 226 & & 222 & & & & 150 \\
\hline $\mathrm{F}$ & & & & 0,90 & & 1,49 & & 1,15 & & 0,64 & & 0,83 & & 1,46 & & 1,17 & & 0,92 & & 1,04 & & & & 1,63 \\
\hline $\mathrm{R}^{\wedge} 2$ & & & & 0,05 & & 0,09 & & 0,08 & & 0,03 & & 0,05 & & 0,09 & & 0,08 & & 0,04 & & 0,05 & & & & م0م \\
\hline
\end{tabular}

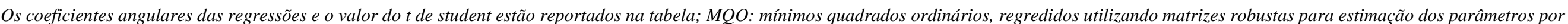

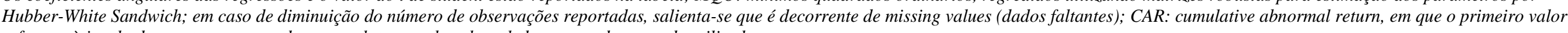
refere-se à janela de evento, e a segunda nomenclatura ao benchmark de retorno de mercado utilizado.

Fonte: Elaborado pelo autor. 
ANEXOS 
Reportam-se, conforme abordado anteriormente, os anexos que fundamentaram as análises na seção pertinente.

Anexo 1 - Histórico setorial acumulado das transações de aquisições de empresas, no período de 1994-2012.

Anexo 2 - Aquisições de empresas, em 2012, no Brasil, discriminadas por setor, origem e destino do capital. 
Anexo 1 - Histórico setorial acumulado das transações de aquisições de empresas, no período de 1994-2012

\begin{tabular}{|c|c|c|c|c|c|c|c|c|c|c|c|c|c|c|c|c|c|c|c|c|}
\hline \#SStor & 12 & 11 & 10 & 9 & 8 & 7 & 6 & 5 & 4 & 3 & 2 & 1 & 0 & 99 & 98 & 97 & 96 & 95 & 94 & \begin{tabular}{|l|} 
Total \\
\end{tabular} \\
\hline $1^{\circ}$ & 104 & 90 & 85 & 58 & 73 & 56 & 46 & 49 & 22 & 28 & 13 & 36 & 57 & 28 & 8 & 8 & 11 & 7 & 8 & 73 \\
\hline $2^{\circ}$ & 46 & 44 & 42 & 39 & 54 & 66 & 43 & 36 & 36 & 22 & 29 & 32 & 36 & 25 & 36 & 49 & 38 & 24 & 21 & 69 \\
\hline $3^{\circ}$ & 27 & 34 & 28 & 23 & 19 & 27 & 28 & 21 & 32 & 21 & 22 & 27 & 26 & 47 & 31 & 14 & 5 & 8 & 5 & 43 \\
\hline $4^{\circ}$ & 24 & 35 & 28 & 22 & 23 & 19 & 21 & 19 & 19 & 16 & 20 & 17 & 18 & 16 & 28 & 36 & 31 & 20 & 15 & 41 \\
\hline $5^{\circ}$ & 30 & 42 & 36 & 19 & 24 & 25 & 61 & 16 & 12 & 17 & 16 & 36 & 20 & 10 & 11 & 17 & 9 & 1 & 0 & 392 \\
\hline $6^{\circ}$ & 24 & 29 & 26 & 22 & 26 & 35 & 19 & 19 & 17 & 12 & 12 & 19 & 23 & 17 & 19 & 9 & 5 & 2 & 3 & 32 \\
\hline $7^{\circ}$ & 4 & 15 & 14 & 6 & 20 & 31 & 38 & 25 & 19 & 14 & 13 & 15 & 11 & 9 & 23 & 18 & 17 & 9 & 11 & 31 \\
\hline $8^{\circ}$ & 65 & 41 & 30 & 18 & 18 & 35 & 17 & 5 & 9 & 9 & 7 & 9 & 5 & 8 & 13 & 6 & 8 & 1 & 2 & 27. \\
\hline $9^{\circ}$ & 18 & 16 & 19 & 9 & 17 & 39 & 21 & 18 & 7 & 5 & 4 & 7 & 12 & 6 & 25 & 22 & 18 & 13 & 14 & 28 \\
\hline $10^{\circ}$ & 19 & 29 & 34 & 8 & 19 & 6 & 8 & 14 & 16 & 7 & 26 & 40 & 28 & 6 & 1 & 3 & 4 & 4 & 2 & 26 \\
\hline $11^{\circ}$ & 16 & 31 & 16 & 24 & 27 & 4 & 6 & 16 & 10 & 10 & 5 & 7 & 6 & 9 & 15 & 24 & 16 & 9 & 8 & 25 \\
\hline $12^{\circ}$ & 33 & 46 & 41 & 23 & 41 & 51 & \multicolumn{13}{|c|}{ Em 2007 foi determinada uma categoria para esse setor. } & 215 \\
\hline $13^{\circ}$ & 17 & 19 & 11 & 15 & 8 & 18 & 14 & 9 & 3 & 1 & 4 & 2 & 5 & 5 & 9 & 19 & 15 & 14 & 5 & $18 \mathrm{~s}$ \\
\hline $14^{\circ}$ & 25 & 21 & 18 & 12 & 9 & 12 & 15 & 13 & 10 & 4 & 4 & 4 & 6 & 6 & 4 & 4 & 10 & 11 & 4 & 18 \\
\hline $15^{\circ}$ & 11 & 13 & 12 & 9 & 9 & 10 & 10 & 5 & 4 & 1 & 4 & 7 & 6 & 13 & 20 & 16 & 11 & 11 & 4 & 17 \\
\hline \multirow[t]{2}{*}{$16^{\circ}$} & 36 & 26 & 16 & 8 & 13 & 17 & 11 & 9 & 11 & 4 & 4 & 8 & 5 & 1 & 11 & 7 & 6 & 4 & 1 & 168 \\
\hline & 10 & 20 & 20 & 2 & 17 & 51 & 5 & 1 & 1 & 1 & 4 & 2 & 2 & 1 & 2 & 4 & 2 & 0 & 1 & 15 \\
\hline $18^{\circ}$ & 23 & 16 & 15 & 11 & 8 & 4 & 15 & 9 & 1 & 2 & 2 & 6 & 5 & 7 & 6 & 8 & 7 & 2 & 1 & 13 \\
\hline $19^{\circ}$ & 16 & 20 & 24 & 9 & 27 & 13 & 9 & 2 & 2 & 1 & 5 & 4 & 6 & 1 & 0 & 0 & 0 & 0 & 0 & 13 \\
\hline $20^{\circ}$ & 13 & 14 & 15 & 2 & 13 & 12 & 1 & 0 & 2 & 4 & 7 & 4 & 7 & 6 & 7 & 9 & 9 & 5 & 2 & 12 \\
\hline $21^{\circ}$ & 19 & 8 & 15 & 0 & 6 & 3 & 7 & 11 & 2 & 3 & 2 & 2 & 5 & 13 & 10 & 8 & 15 & 2 & 3 & 12. \\
\hline $22^{\circ}$ & 13 & 27 & 20 & 12 & 53 & \multicolumn{14}{|c|}{ Em 2008 foi determinada uma categoria para esse setor. } & 126 \\
\hline \multirow[t]{2}{*}{$23^{\circ}$} & 4 & 4 & 9 & 6 & 4 & 7 & 8 & 2 & 3 & 4 & 1 & 9 & 7 & 5 & 9 & 14 & 4 & 7 & 7 & 11 \\
\hline & 5 & 5 & 5 & 5 & 2 & 6 & 0 & 6 & 3 & 5 & 4 & 8 & 10 & 24 & 13 & 9 & 2 & 0 & 2 & 111 \\
\hline $25^{\circ}$ & 10 & 15 & 26 & 13 & 14 & 25 & \multicolumn{13}{|c|}{ Em 2007 foi determinada uma categoria para esse setor. } & 9 \\
\hline $26^{\circ}$ & 14 & 12 & 12 & 7 & 15 & 12 & 6 & 2 & 2 & 1 & 0 & 1 & 1 & 1 & 2 & 0 & 4 & 2 & 4 & 9 \\
\hline $27^{\circ}$ & 14 & 12 & 13 & 8 & 21 & 12 & 5 & 0 & 1 & 1 & 2 & 0 & 2 & 1 & 1 & 0 & 4 & 0 & 0 & 88 \\
\hline $28^{\circ}$ & 14 & 14 & 13 & 8 & 6 & 2 & 6 & 3 & 3 & 2 & 1 & 4 & 1 & 2 & 2 & 2 & 4 & 2 & 2 & 9 \\
\hline $29^{\circ}$ & 3 & 12 & 16 & 11 & 6 & 1 & 4 & 4 & 7 & 1 & 3 & 7 & 1 & 1 & 2 & 4 & 4 & 1 & 1 & 88 \\
\hline $30^{\circ}$ & 56 & 25 & \multicolumn{17}{|c|}{ Em 2011 foi determinada uma categoria para esse setor. } & 5 \\
\hline $31^{\circ}$ & 9 & 5 & 10 & 7 & 2 & 3 & 11 & 6 & 3 & 2 & 1 & 2 & 1 & 1 & 1 & 2 & 2 & 5 & 3 & 7 \\
\hline $32^{\circ}$ & 5 & 2 & 10 & 3 & 7 & 4 & 4 & 2 & 4 & 1 & 3 & 3 & 3 & 6 & 1 & 6 & 5 & 5 & 0 & 7 \\
\hline $33^{\circ}$ & 2 & 1 & 3 & 1 & 1 & 4 & 2 & 5 & 3 & 6 & 0 & 0 & 0 & 6 & 8 & 8 & 4 & 8 & 7 & 6 \\
\hline $34^{\circ}$ & 9 & 13 & 7 & 1 & 11 & 12 & 3 & 2 & 0 & 1 & 0 & 1 & 5 & 0 & 0 & 1 & 0 & 0 & 0 & 5 \\
\hline $35^{\circ}$ & 4 & 9 & 7 & 2 & 1 & 4 & 1 & 1 & 2 & 2 & 1 & 0 & 4 & 3 & 3 & 4 & 4 & 8 & 1 & 6 \\
\hline $36^{\circ}$ & 8 & 7 & 1 & 7 & 5 & 4 & 0 & 0 & 2 & 0 & 0 & 2 & 0 & 2 & 3 & 0 & 6 & 4 & 8 & 5 \\
\hline $37^{\circ}$ & 8 & 3 & 8 & 1 & 7 & 1 & 0 & 5 & 0 & 0 & 0 & 0 & 1 & 5 & 2 & 1 & 4 & 1 & 0 & 4. \\
\hline $38^{\circ}$ & 7 & 7 & 7 & 0 & 1 & 0 & 1 & 2 & 1 & 1 & 0 & 2 & 5 & 1 & 4 & 0 & 0 & 0 & 1 & 3 \\
\hline $39^{\circ}$ & 0 & 1 & 2 & 1 & 0 & 0 & 0 & 2 & 0 & 3 & 0 & 1 & 1 & 1 & 0 & 4 & 5 & 9 & 3 & 3. \\
\hline $40^{\circ}$ & 1 & 2 & 0 & 0 & 0 & 1 & 1 & 0 & 0 & 0 & 1 & 1 & 1 & 0 & 1 & 5 & 2 & 0 & 0 & $1 t$ \\
\hline $41^{\circ}$ & 0 & 0 & 1 & 0 & 1 & 0 & 0 & 0 & 0 & 0 & 1 & 0 & 2 & 2 & 0 & 0 & 7 & 1 & 0 & 13 \\
\hline $42^{\circ}$ & 1 & 3 & \multicolumn{17}{|c|}{ Em 2011 foi determinada uma categoria para esse setor. } & s. \\
\hline $43^{\circ}$ & 49 & 29 & 11 & 22 & 35 & 67 & 26 & 24 & 30 & 18 & 6 & 15 & 19 & 14 & 20 & 31 & 30 & 12 & 26 & 45 \\
\hline Total geral & 816 & 817 & 726 & 454 & 663 & 699 & 473 & 363 & 299 & 230 & 227 & 340 & 353 & 309 & 351 & 372 & 328 & 212 & 175 & 7824 \\
\hline
\end{tabular}

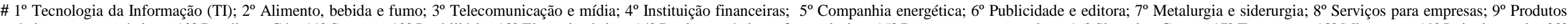

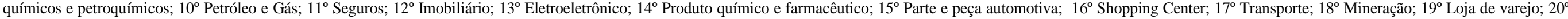

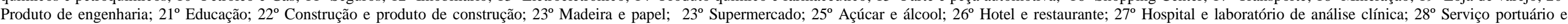

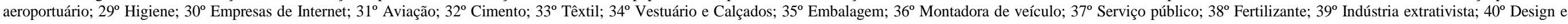
projeto gráfico; $41^{\circ}$ Ferroviário; $42^{\circ}$ Revenda de veículo; $43^{\circ}$ Outros.Fonte: KPMG (2012b). Acesso em: 24 de Abril de 2013 às 08:00. 
Anexo 2 - Aquisições de empresas, em 2012, no Brasil, discriminadas por setor, origem e destino do capital

\begin{tabular}{|c|c|c|c|c|c|c|c|c|c|}
\hline$\#$ & Setor & d & cb1 & cb2 & cb3 & $\mathrm{cb} 4$ & cb5 & $\begin{array}{c}\text { subtotal } \\
\text { (cb) }\end{array}$ & $\begin{array}{r}\text { Total } \\
(\mathrm{d}+\mathrm{c} \text { ) }\end{array}$ \\
\hline 1 & Tecnologia de Informaçăo (TI) & 38 & 37 & 4 & 1 & 24 & 0 & 66 & 104 \\
\hline 2 & Servicos para empresas & 19 & 37 & 3 & 0 & 6 & 0 & 46 & 65 \\
\hline 3 & Empresas de internet & 12 & 31 & 2 & 0 & 10 & 1 & 44 & 56 \\
\hline 4 & Alimentos, bebidas e fumo & 18 & 16 & 3 & 3 & 5 & 1 & 28 & 46 \\
\hline 5 & Shopping centers & 24 & 6 & 0 & 1 & 5 & 0 & 12 & 36 \\
\hline 6 & Imobiliário & 22 & 7 & 1 & 3 & 0 & 0 & 11 & 33 \\
\hline 7 & Companhias energéticas & 20 & 4 & 0 & 5 & 1 & 0 & 10 & 30 \\
\hline 8 & Telecomunicą̧óes & 10 & 9 & 1 & 0 & 5 & 2 & 17 & 27 \\
\hline 9 & Produtos químicos e farmacêuticos & 5 & 12 & 2 & 2 & 4 & 0 & 20 & 25 \\
\hline 10 & Instituiçōes financeiras & 12 & 5 & 1 & 1 & 4 & 1 & 12 & 24 \\
\hline 11 & $\begin{array}{l}\text { Publicidade e Editoras } \\
\end{array}$ & 11 & 9 & 1 & 3 & 0 & 0 & 13 & 24 \\
\hline 12 & Minerąăa & 6 & 8 & 1 & 0 & 5 & 3 & 17 & 23 \\
\hline 13 & Educação & 12 & 7 & 0 & 0 & 0 & 0 & 7 & 19 \\
\hline 14 & Petrolifero & 6 & 3 & 2 & 4 & 4 & 0 & 13 & 19 \\
\hline 15 & Produtos químicos e petroquímicos & 3 & 9 & 4 & 0 & 2 & 0 & 15 & 18 \\
\hline 16 & Eletroeletrônicos & 3 & 10 & 0 & 0 & 4 & 0 & 14 & 17 \\
\hline \multirow[t]{2}{*}{17} & Lojas de Varejo & 12 & 4 & 0 & 0 & 0 & 0 & 4 & 16 \\
\hline & Seguros & 10 & 3 & 1 & 1 & 1 & 0 & 6 & 16 \\
\hline \multirow[t]{3}{*}{19} & Hospitais e laboratórios clínicos & 12 & 1 & 0 & 0 & 1 & 0 & 2 & 14 \\
\hline & Hotéis e restaurantes & 10 & 3 & 0 & 0 & 1 & 0 & 4 & 14 \\
\hline & Serviços portuários e aeroviários & 11 & 3 & 0 & 0 & 0 & 0 & 3 & 14 \\
\hline \multirow[t]{2}{*}{22} & Construção e produtos de construção & 7 & 6 & 0 & 0 & 0 & 0 & 6 & 13 \\
\hline & Produtos de engenharia & 1 & 7 & 1 & 1 & 3 & 0 & 12 & 13 \\
\hline 24 & $\begin{array}{l}\text { Partes e peças automotivas } \\
\end{array}$ & 1 & 4 & 2 & 0 & 4 & 0 & 10 & 11 \\
\hline \multirow[t]{2}{*}{25} & Açúcar e Álcool & 5 & 2 & 0 & 1 & 2 & 0 & 5 & 10 \\
\hline & Transportes & 7 & 3 & 0 & 0 & 0 & 0 & 3 & 10 \\
\hline \multirow[t]{2}{*}{27} & Aviação & 1 & 6 & 1 & 0 & 1 & 0 & 8 & 9 \\
\hline & Vestuário & 6 & 3 & 0 & 0 & 0 & 0 & 3 & 9 \\
\hline \multirow[t]{2}{*}{29} & Montadoras de veículos & 0 & 2 & 1 & 2 & 3 & 0 & 8 & 8 \\
\hline & Serviços públicos & 4 & 1 & 1 & 1 & 1 & 0 & 4 & 8 \\
\hline 31 & Fertilizantes & 2 & 5 & 0 & 0 & 0 & 0 & 5 & 7 \\
\hline \multirow[t]{2}{*}{32} & Cimento & 2 & 1 & 2 & 0 & 0 & 0 & 3 & 5 \\
\hline & Supermercados & 4 & 1 & 0 & 0 & 0 & 0 & 1 & 5 \\
\hline \multirow[t]{3}{*}{34} & Embalagens & 0 & 4 & 0 & 0 & 0 & 0 & 4 & 4 \\
\hline & Madeira e papel & 1 & 1 & 1 & 0 & 1 & 0 & 3 & 4 \\
\hline & Metalurgia e siderurgia & 2 & 2 & 0 & 0 & 0 & 0 & 2 & 4 \\
\hline 37 & Higiene & 1 & 1 & 1 & 0 & 0 & 0 & 2 & 3 \\
\hline 38 & Têxteis & 1 & 0 & 0 & 0 & 0 & 1 & 1 & 2 \\
\hline \multirow[t]{2}{*}{39} & Design e projetos gráficos & 1 & 0 & 0 & 0 & 0 & 0 & 0 & 1 \\
\hline & Revenda de veículos & 1 & 0 & 0 & 0 & 0 & 0 & 0 & 1 \\
\hline 41 & Outros & 19 & 23 & 1 & 1 & 5 & 0 & 30 & 49 \\
\hline rotal & Geral & 342 & 296 & 37 & 30 & 102 & 9 & 474 & 816 \\
\hline
\end{tabular}


Continuação do Anexo 2 - Aquisições de empresas, em 2012, no Brasil, discriminadas por setor, origem e destino do capital

\begin{tabular}{cl}
\hline $\begin{array}{c}\text { Cross border } 1 \\
(\text { cb1): }\end{array}$ & Empresa estrangeira adquirindo empresa brasileira estabelecida no Brasil. \\
\hline $\begin{array}{c}\text { Cross border } 2 \\
(\text { cb2): }\end{array}$ & Empresa brasileira adquirindo empresa estrangeira estabelecida no exterior. \\
\hline $\begin{array}{c}\text { Cross border } 3 \\
(\text { cb3): }\end{array}$ & Empresa brasileira adquirindo empresa estrangeira estabelecida no Brasil. \\
\hline $\begin{array}{c}\text { Cross border } 4 \\
(\text { cb4): }\end{array}$ & $\begin{array}{l}\text { Empresa estrangeira adquirindo empresa de capital majoritário estrangeiro estabelecida } \\
\text { no Brasil. }\end{array}$ \\
\hline $\begin{array}{c}\text { Cross border } 5 \\
(\text { cb 5): }\end{array}$ & Empresa estrangeira adquirindo empresa brasileira estabelecida no exterior. \\
\hline Doméstico $(d):$ & Empresa brasileira adquirindo empresa de capital majoritário brasileiro no próprio país. \\
\hline
\end{tabular}

Fonte: KPMG (2012b). Acesso em: 24 de Abril de 2013 às 08:00h 